UNIVERSIDADE DE SÃO PAULO

FACULDADE DE ECONOMIA, ADMINISTRAÇÃO E CONTABILIDADE DEPARTAMENTO DE CONTABILIDADE E ATUÁRIA PROGRAMA DE PÓS-GRADUAÇÃO EM ADMINISTRAÇÃO

DETERMINANTES DA TRANSFERÊNCIA REVERSA DE CONHECIMENTO TECNOLÓGICO NAS EMPRESAS MULTINACIONAIS BRASILEIRAS

Franciane Freitas Silveira

Orientador: Prof. Dr. Roberto Sbragia

SÃO PAULO 
Prof. Dr. Marco Antonio Zago

Reitor da Universidade de São Paulo

Profa. Dr. Reinaldo Guerreiro

Diretora da Faculdade de Economia, Administração e Contabilidade

Prof. Dr. Adalberto Américo Fischmann

Chefe do Departamento de Administração

Prof. Dr. Lindolfo Galvão de Albuquerque Coordenador do Programa de Pós-Graduação em Administração 

FRANCIANE FREITAS SILVEIRA

\section{DETERMINANTES DA TRANSFERÊNCIA REVERSA DE CONHECIMENTO TECNOLÓGICO NAS EMPRESAS MULTINACIONAIS BRASILEIRAS}

Tese apresentada ao Departamento de Administração da Faculdade de Economia, Administração e Contabilidade da Universidade de São Paulo como requisito para a obtenção do título de doutor em Ciências.

Orientador: Prof. Dr. Roberto Sbragia

\section{Versão corrigida}

(Versão original disponível na Faculdade de Economia, Administração e Contabildiade)

SÃO PAULO

2013 


\section{FICHA CATALOGRÁFICA}

Elaborada pela Seção de Processamento Técnico do SBD/FEA/USP

Silveira, Franciane Freitas

Determinantes da transferência reversa de conhecimento tecnológico nas empresas multinacionais brasileiras / Franciane Freitas Silveira - São Paulo, 2013.

$306 \mathrm{p}$.

Tese (doutorado) - Universidade de São Paulo, 2013.

Orientador: Roberto Sbragia.

1. Empresas multinacionais - Brasil 2. Transferência de conhecimento tecnológico 2. Transferência reversa de conhecimento 4. Empresas multinacionais emergentes 

Decido este trabalho a mais pura e singela representação de amor: minhas crianças, Pedro e Gabriel. 


\section{AGRADECIMENTOS}

Agradeço em primeiro lugar ao meu marido, Paulo Lopes, que sempre me incentivou e apoiou nessa grande empreitada de vida e que tantas horas brincou com as crianças enquanto eu me debruçava sobre este trabalho.

Agradeço imensamente ao meu mestre e orientador professor Roberto Sbragia, pelo longo tempo de valiosas orientações e agradeço também pelo carinho que me dedicou desde o período do mestrado. Foi uma honra conviver todos esses anos com alguém tão sábio e tão íntegro.

Agradeço imensamente ao professor e amigo Felipe Borini que em todos os momentos de meu doutorado concedeu valiosos comentários e orientações, seja na orientação para artigos ou nas recomendações para a elaboração da tese.

Agradeço aos professores Afonso Fleury e Moacir de Miranda Oliveira Junior pela oportunidade de participar de uma coleta de dados em empresas multinacionais. Foi a partir deste trabalho que surgiu a ideia de elaboração desta tese.

Agradeço a todos os amigos que comigo estiveram todos esses anos. Seguramente pude aprender muito com as nossas trocas e compartilhamento de conhecimento e pude rir e me alegrar com as brincadeiras do dia a dia.

Agradeço em especial, à amiga Rosária Russo que mais do que acompanhar o passo a passo desse trabalho, acompanhou o passo a passo de minha vida, tornando a caminhada mais leve e alegre. Agradeço também à querida Mari Gonçalves (secretária de meu orientador) que sempre me ajudou com as questões burocráticas e me deu força com as pessoais.

Agradeço ao amigo Marcos Piscopo que muito me ensinou, não apenas por meio do seu conhecimento, mas principalmente por meio de seu exemplo de integridade e lealdade.

Agradeço aos amigos Ivete Rodrigues e Marcos Garcez, colegas de trabalho e de orientador, pelas orientações e boas conversas ao longo de todo esse tempo. 
Agradeço também aos colegas da Uninove, em especial à professora Cristina Martens e ao professor Emerson Maccari, que muitas vezes compreenderam minha ausência em função da dedicação para finalizar este trabalho.

Não posso deixar de agradeço às minhas duas queridas secretárias Lú e Graça que mantiveram o nosso lar e que cuidaram de nossas crianças durante esse período de trabalho árduo.

Agradeço aos respondentes das setenta e oito subsidiárias as quais tive acesso para realizar o estudo de campo. Agradeço também ao Observatório de Multinacionais Brasileiras da ESPM, pelo apoio financeiro e operacional na fase da coleta de dados. Agradeço especialmente ao Gabriel Vouga que acompanhou de perto a etapa da coleta dos dados.

Agradeço também o excelente trabalho realizado pelos membros da equipe da coleta de dados, entre eles Maitê, Kelly e Louisse. Sem essas pessoas a operacionalização da pesquisa seria impossível.

Agradeço também ao apoio da CAPES que, por meio da bolsa de estudos, concedida nos últimos dois anos da pesquisa, me deu tranquilidade financeira para conduzir este trabalho. 
"Aqueles que embarcam numa vida de diálogo com a experiência humana deveriam abandonar todos os sonhos de um fim tranquilo de viagem. Toda a felicidade se encontra na própria jornada.” Zygmund Bauman 


\section{RESUMO}

A transferência de conhecimento internacional é fonte fundamental de vantagem competitiva das empresas multinacionais. Em razão do pressuposto tradicional de que a matriz da multinacional é a principal fonte de conhecimento, a maioria dos estudos tem-se centrado na transferência de conhecimento da matriz para as subsidiárias. Entretanto, a importância estratégica da subsidiária tem crescido nas últimas dédadas, em razão de seus recursos e de suas capacidades que podem contribuir ativamente para a geração de valor e o subsequente ganho de vantagem competitiva para toda a corporação multinacional. Este estudo investiga os fatores determinantes da transferência de conhecimento tecnológico que parte da subsidiária para a matriz (transferência reversa), em empresas multinacionais brasileiras, procurado integrar as contribuições da visão baseada no conhecimento e da teoria das redes. Para testar os pressupostos, foi conduzido um survey eletrônico com 78 subsidiárias, de um universo de 240 subsidiárias no exterior em 63 empresas multinacionais brasileiras. O método para a análise dos dados foi a modelagem de equações estruturais com estimação partial least esquare. Os resultados mostram que, ainda que em média extensão, as subsidiárias brasileiras transferem conhecimento tecnológico para a matriz, sobretudo os relacionados a produtos. Com relação aos fatores determinantes da transferência reversa de conhecimento tecnológico, os associados positivamente foram: características do conhecimento (complexidade), características das subsidiárias (ambiente institucional, autonomia e integração externa com os fornecedores) e características da interação matriz/subsidiárias (integração interna com a matriz e mecanismos de socialização via comunicação pessoal). O único fator associado negativamente foi a integração externa com instituições de C\&T. Conclui-se que a matriz precisa elaborar uma estratégia de compartilhamento de conhecimento interno, a fim de motivar e incentivar, de forma deliberada, o fluxo do conhecimento gerado nas subsidiárias. Por sua vez, as subsidiárias devem tornar claro aos seus funcionários, os benefícios de melhorar a eficácia da transferência de conhecimento para, inclusive, melhorar seu posicionamento estratégico dentro da rede corporativa.

Palavras-chave: Empresas multinacionais brasileiras; Transferência de conhecimento tecnológico; Transferência reversa de conhecimento; Empresas multinacionais emergentes. 


\begin{abstract}
Knowledge transfer is key source of international competitive advantage of multinational companies. Due to the traditional assumption that the headquarter of the multinational is the main source of knowledge, most studies have focused on the transfer of knowledge from headquarters to subsidiaries. However, it has grown considerably in recent times the strategic importance of subsidiary, due to their resources and capabilities that can actively contribute to the generation of value and the subsequent gain of competitive advantage for the entire multinational corporation. This study investigates the determinants of technological knowledge transfer from the subsidiary to the parent company in Brazilian multinational companies, and sought to integrate the contributions of vision of the knowledge-based and networks theory. To test the assumptions we carried out an electronic survey with 78 subsidiaries, of a universe of 240 overseas subsidiaries from 63 Brazilian multinationals. The method of data analysis was the structural equation modeling with Partial Least Esquare Estimation. The results show that the Brazilian subsidiaries knowledge transfer to the headquarter, although in medium extent. Regarding the determinants of technological knowledge reverse transfer, the positive factors: characteristics of knowledge (complexity), characteristics of subsidiaries (location-specific factors, external integration with the supplier's chain and autonomy) and characteristics of the interaction headquarter/subsidiaries (headquarter integration and socialization mechanisms). The only negative factor was the external integration with Science and Technology Research. We conclude that the headquarter may need to develop a strategy for internal knowledge sharing, in order to motivate and encourage deliberately knowledge flow generated at the subsidiaries. In the order hand, the subsidiaries should make clear the benefits of improving the effectiveness of knowledge transfer improve its strategic position within the corporate network.
\end{abstract}

Keywords: Brazilian Multinationals; technological knowledge transfer; knowledge reverse transfer; Emerging Multinationals. 




\section{SUMÁRIO}

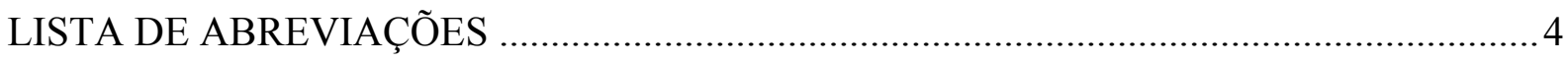

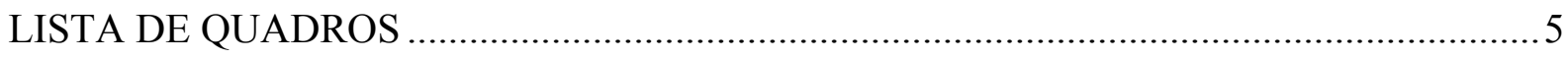

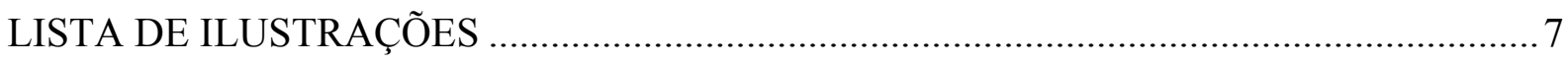

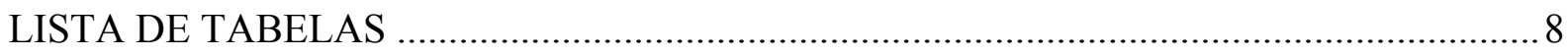

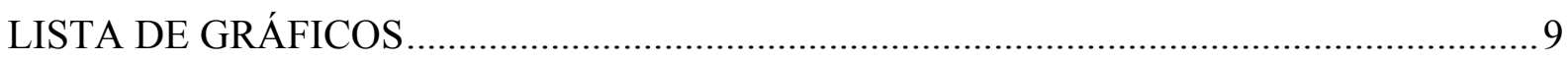

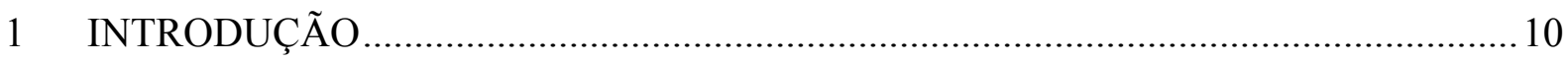

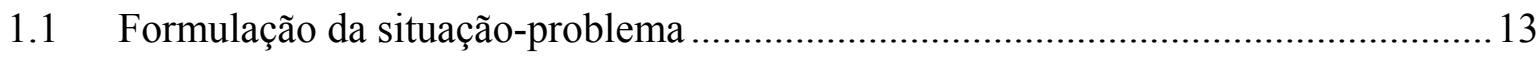

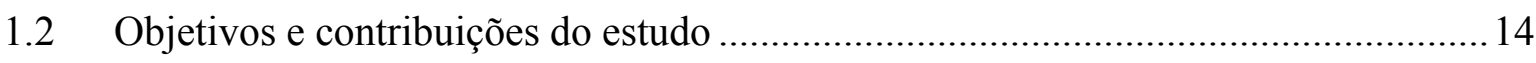

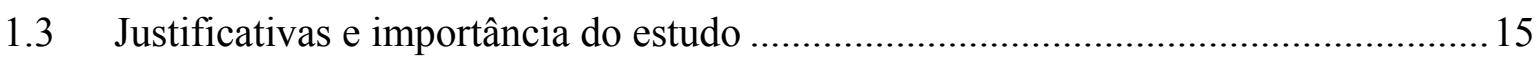

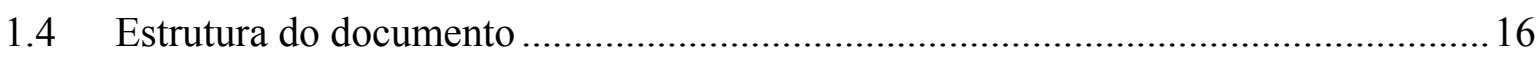

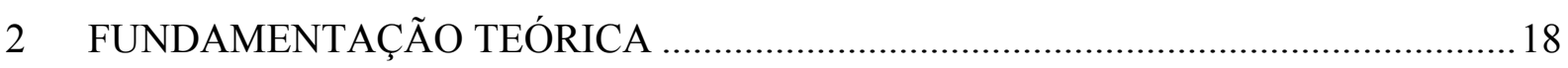

2.1 A expansão das multinacionais emergentes...................................................... 18

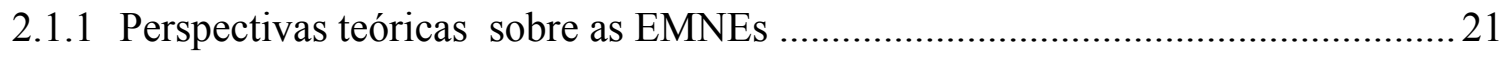

2.1.2 Motivações e padrões da internacionalização de EMNEs ......................................2 23

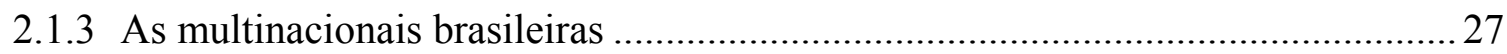

2.2 O papel das subsidiárias e sua relação com a transferência de conhecimento............32

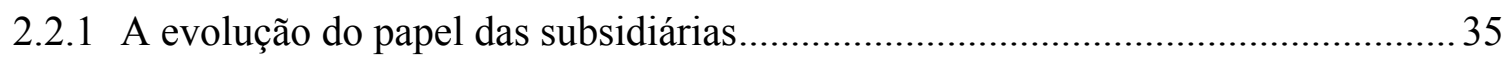

2.2.2 Inovação nas subsidiárias e o desenvolvimento de suas capacidades

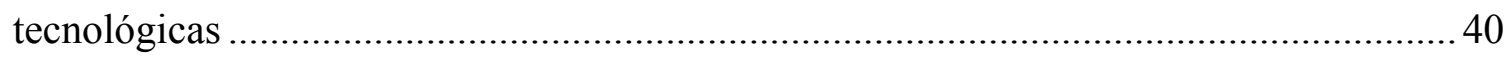

2.3 Perspectivas teóricas da transferência reversa de conhecimento.............................44

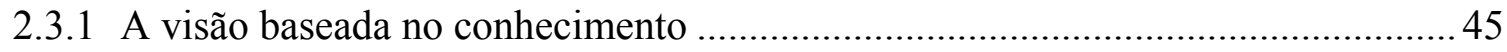

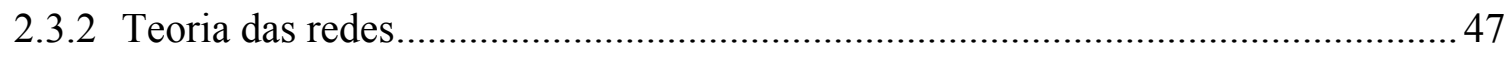

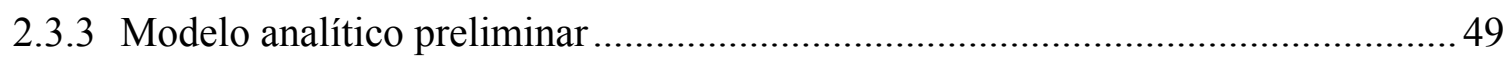

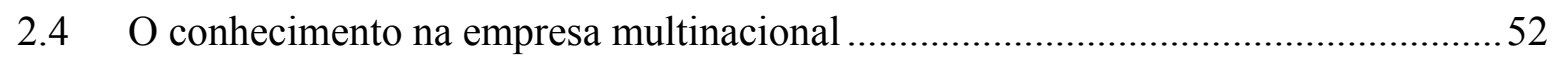

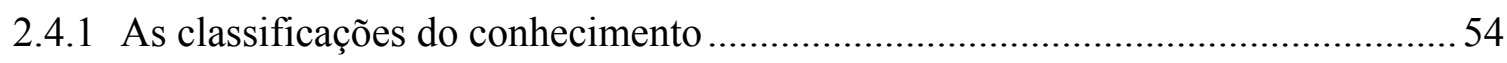

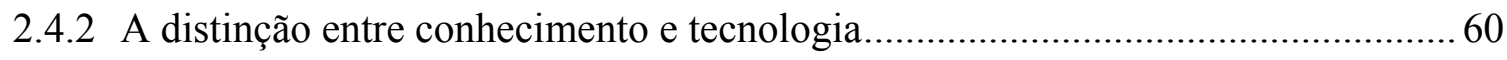

2.4.3 Transferência de conhecimento tecnológico na EMN ........................................... 63

2.4.4 As barreiras para a transferência do conhecimento............................................ 73 
2.4.5 Transferência reversa do conhecimento na EMN. .75

2.4.6 Identificação dos fatores determinantes da transferência reversa de conhecimento na EMN . .78

3 ESTRUTURA CONCEITUAL E HIPÓTESES 86

3.1 Fatores determinantes da transferência reversa do conhecimento em EMNs ...........86

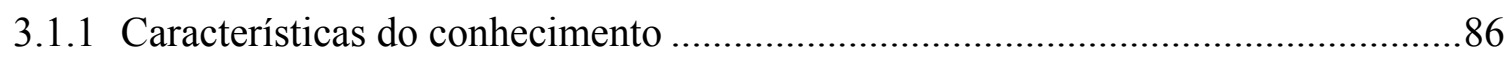

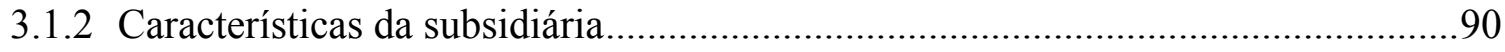

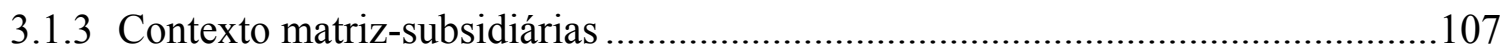

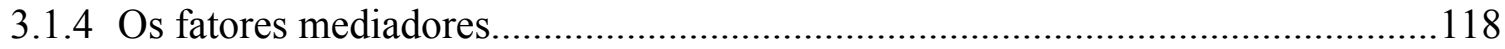

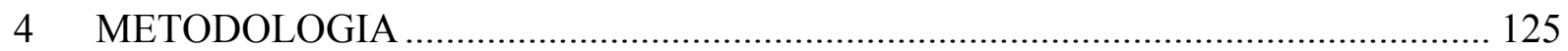

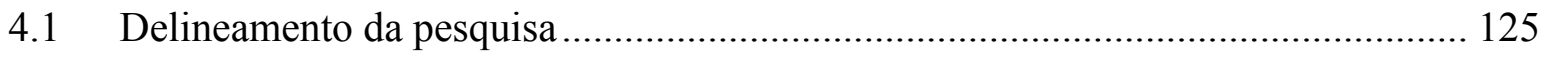

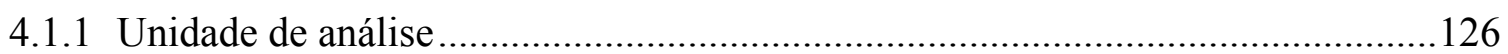

4.2 Modelo conceitual e operacionalização das variáveis.......................................... 127

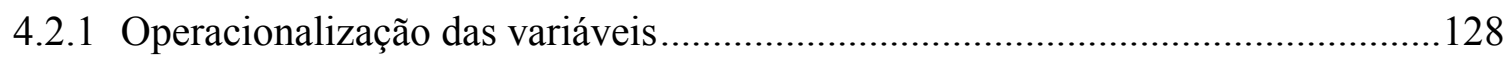

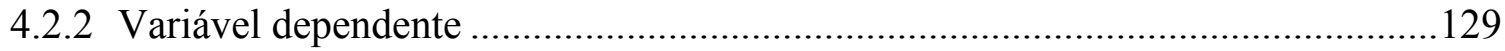

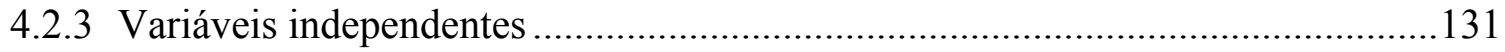

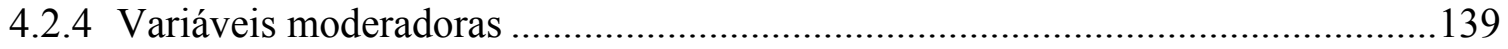

4.3 Caracterização do universo e seleção da amostra .................................................. 144

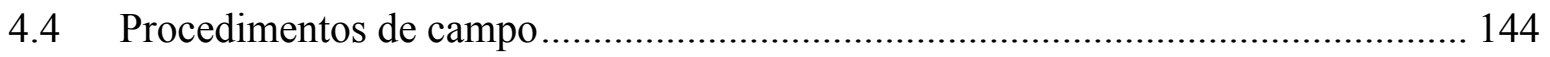

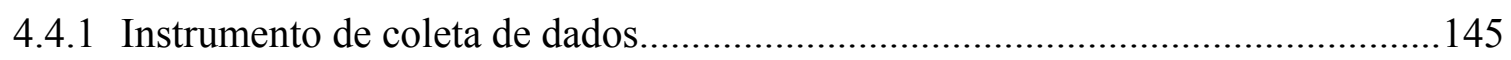

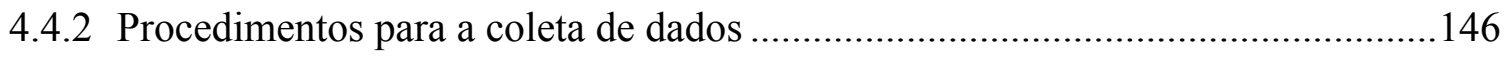

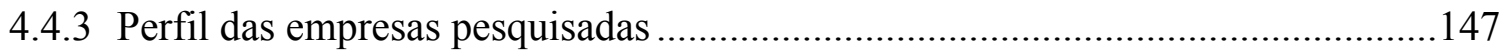

4.4.4 Localização das subsidiárias respondentes ......................................................... 151

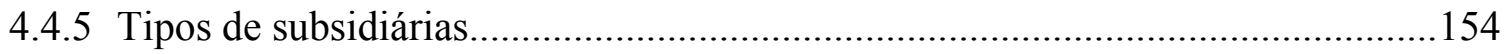

4.5 Seleção da técnica e do modelo da análise de dados............................................ 154

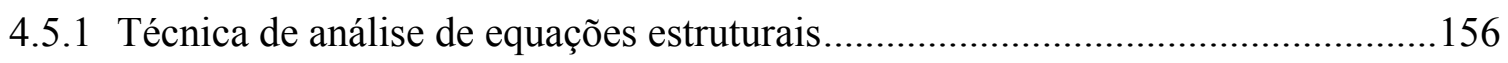

4.5.2 Avaliação da qualidade do modelo estimado via técnica PLS ............................160

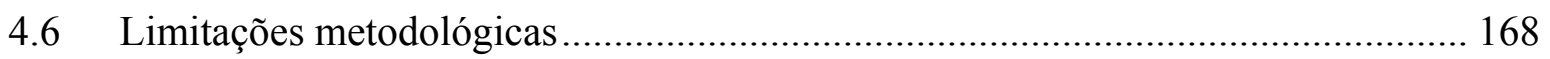

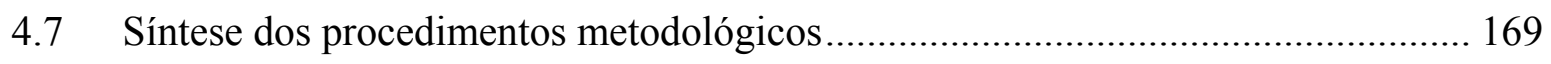

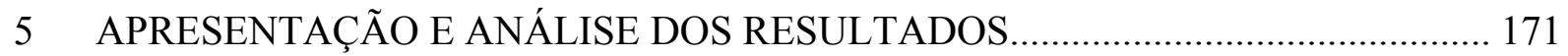

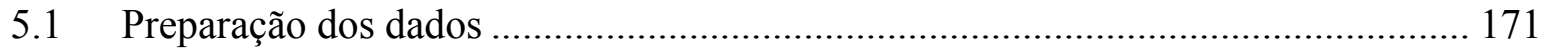

5.2 Verificação do tamanho do efeito (effect-size)..................................................... 172 
5.3 Análise univariada 173

5.3.1 Transferência reversa de conhecimento tecnológico 174

5.3.2 Determinantes da transferência reversa de conhecimento tecnológico. 176

5.3.3 Síntese da análise descritiva dos constructos do estudo 190

5.4 Análise multivariada 192

5.4.1 Análise Fatorial Combinatória (AFC) 192

5.4.2 Modelagem de equações estruturais - partial least square (MEEPL) 201

5.4.3 Teste de hipóteses

5.4.4 A influência das variáveis moderadoras: idade, modo de entrada e importância estratégica das subsidiárias.

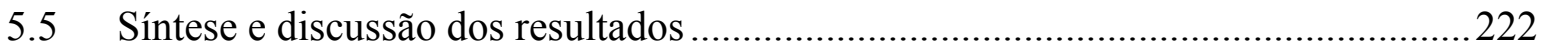

5.5.1 Transferência reversa do conhecimento e características do conhecimento .........222

5.5.2 Transferência reversa do conhecimento e características das subsidiárias 224

5.5.3 Transferência reversa do conhecimento e características da interação subsidiárias/matriz. 231

5.5.4 Visão integrada da transferência reversa de conhecimento tecnológico. 235

6 CONCLUSÕES E RECOMENDAÇÕES 236

6.1 Conclusões 236

6.2 Contribuições teóricas e práticas 245

6.3 Limitações e recomendações para futuros estudos 250

REFERÊNCIAS 252

APÊNDICE I 276

APÊNDICE II 285

APÊNDICE III 290

APÊNDICE IV 291 


\section{LISTA DE ABREVIAÇÕES}

AFC: Análise Fatorial Combinatória

BRIC: Brasil, Rússia, Índia e China

C\&T: Ciência e Tecnologia

EMN: Empresa Multinacional

EMNBR: Empresa Multinacional Brasileira

EMNE: Empresa Multinacional Emergente

GINEBRA: Gestão Empresarial para Internacionalização das Empresas Brasileiras

IDE: Investimento Direto Estrangeiro

KBV: Knowledge-Based View (visão baseada no conhecimento).

MEEPLS: Modelagem de Equações Estruturais com Estimação Partial Least Square

OLI: Ownership, Location e Internalization (propriedade, localização e internacionalização)

P\&D: Pesquisa e Desenvolvimento

PLS: Partial Least Square

RBV: Resource-Based View (visão baseada em recursos) 


\section{LISTA DE QUADROS}

Quadro 1: Capacidade tecnológica do desenvolvimento de produto e processo.....................43

Quadro 2: Correntes teóricas para a análise da transferência de conhecimento....................... 45

Quadro 3: Taxonomia e exemplos do conhecimento ...............................................................57

Quadro 4: Diferentes conteúdos do conhecimento utilizados como base para os estudos da área

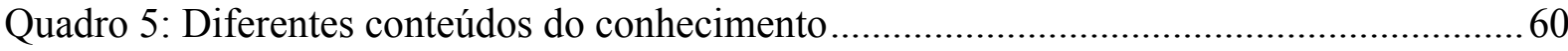

Quadro 6: Distinções entre tecnologia e conhecimento ............................................................ 61

Quadro 7: Possíveis classificações das transferências internacionais de conhecimento

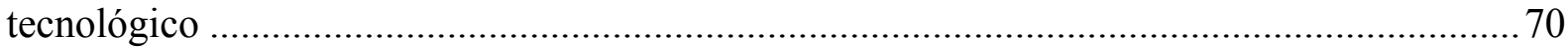

Quadro 8: Classificações de transferência de conhecimento utilizadas por este estudo ...........72

Quadro 9: Fatores culturais inibidores e soluções da transferência de conhecimento .............74

Quadro 10: Modelos de determinantes da transferência de conhecimento ............................... 80

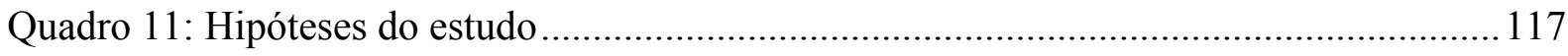

Quadro 12: Tipologias dos papéis desempenhados pelas subsidiárias .................................. 121

Quadro 13: Taxonomia do conhecimento segundo o papel da subsidiária ........................... 123

Quadro 14: Detalhamento dos tipos de conhecimento tecnológico com base no nível das

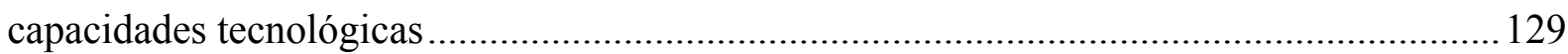

Quadro 15: Definição operacional da variável dependente................................................ 140

Quadro 16: Definição operacional das variáveis independentes ........................................ 141

Quadro 17: Definição operacional das variáveis moderadoras ........................................... 143

Quadro 18: Multinacionais que participaram da pesquisa e as subsidiárias respondentes..... 147

Quadro 19: Diferenças entre MEEPLS e MEEBC (LISREL)............................................. 159

Quadro 20: Critérios para avaliação do modelo de mensuração (outer model) ...................... 163

Quadro 21: Critérios de avaliação do modelo estrutural ....................................................... 166

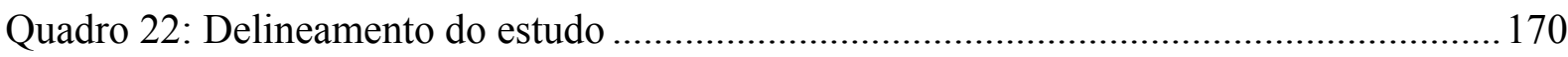

Quadro 23: Síntese dos resultados da análise descritiva ................................................... 192

Quadro 24: Indicadores que apresentaram problemas de cargas cruzadas...........................205

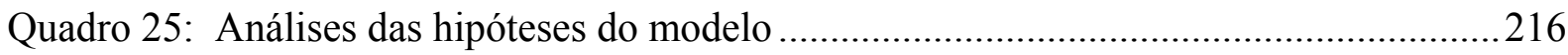

Quadro 26: Conclusões sobre a associação entre às características do conhecimento e a

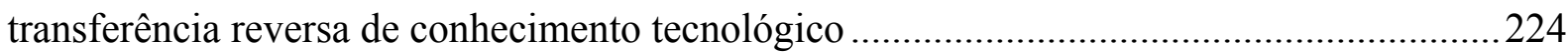


Quadro 27: Conclusões sobre a associação entre às características das subsidiárias e a transferência reversa de conhecimento tecnológico........................................................... 230

Quadro 28: Conclusões sobre a associação entre às características da interação entre matriz/subsidiárias e a transferência reversa de conhecimento tecnológico. 235 


\section{LISTA DE ILUSTRAÇÕES}

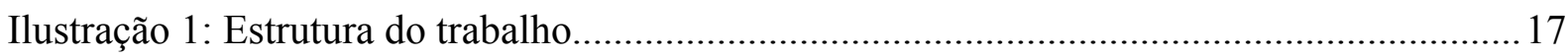

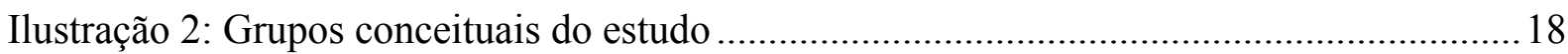

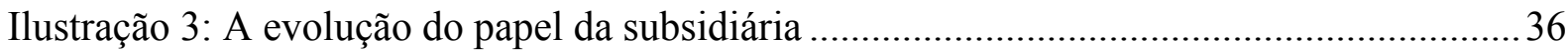

Ilustração 4: Modelo esquemático da transferência de conhecimento .....................................50

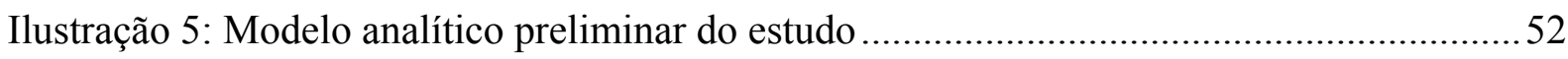

Ilustração 6: Contínuo dados - informação - conhecimento .................................................53

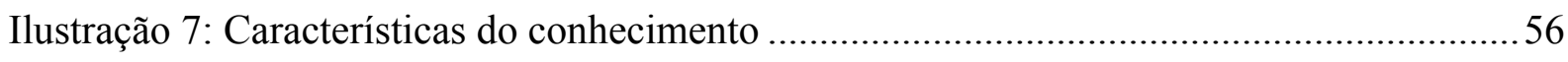

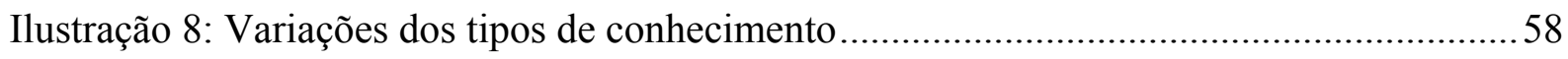

Ilustração 9: Nove tipos de transferência de conhecimento .....................................................69

Ilustração 10: Determinantes da transferência classificados por grupos de influência .............83

Ilustração 11: Síntese dos principais temas analisados no referencial teórico .........................85

Ilustração 12: classificação da transferência de conhecimento ............................................... 88

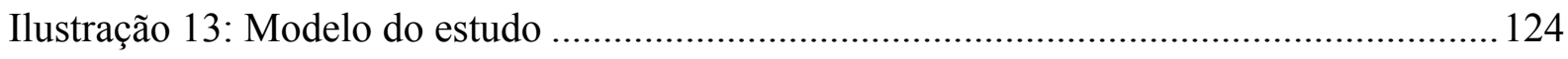

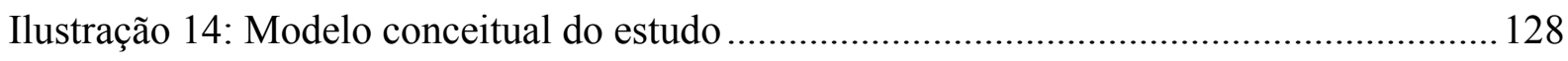

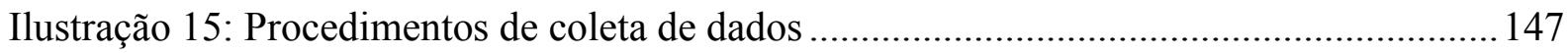

Ilustração 16: Universo das Multinacionais - Comparação por setor entre as matrizes

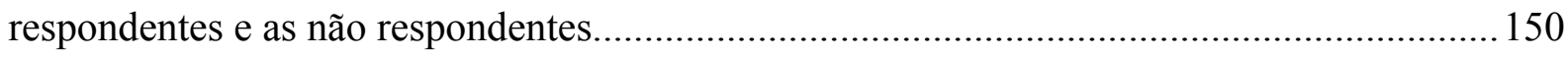

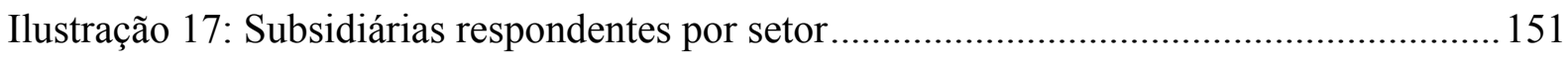

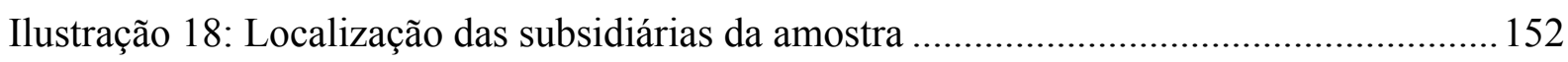

Ilustração 19: Número de Funcionários por subsidiárias ................................................... 153

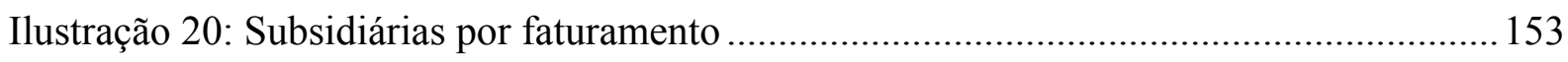

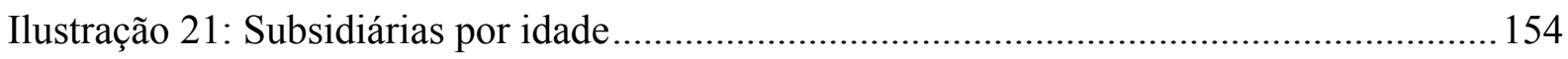

Ilustração 22: Subsidiárias por modo de entrada no exterior ............................................... 154

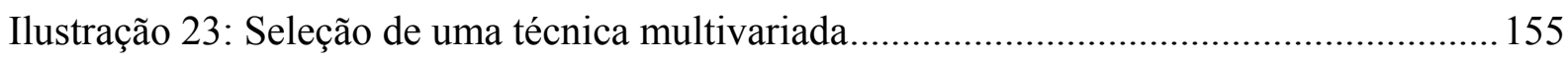

Ilustração 24: Análise de sensibilidade da amostra ............................................................ 173

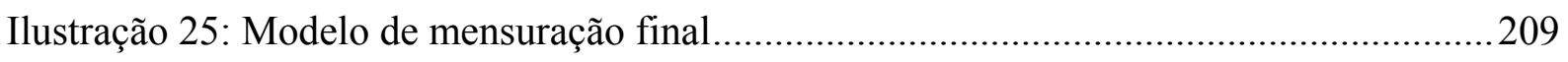

Ilustração 26: Resultado do teste de hipóteses ....................................................................213

Ilustração 27: Facilitadores e dificultadores da transferência reversa de conhecimento

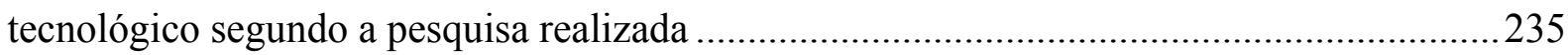




\section{LISTA DE TABELAS}

Tabela 1: Localização regional das atividades das multinacionais brasileiras 28

Tabela 2: Distribuição de frequências da transferência reversa de conhecimento tecnológico

Tabela 3: Distribuição de frequências das características do conhecimento tecnológico....... 177

Tabela 4: Distribuição de frequências das características das subsidiárias respondentes...... 179

Tabela 5: Distribuição de frequências das características da interação subsidiária/matriz.... 186

Tabela 6: Modelo de mensuração da AFC - Cargas fatoriais dos constructos e códigos dos

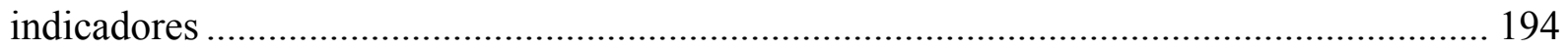

Tabela 7: Modelo de mensuração global para todos os constructos ..................................... 199

Tabela 8: Indicadores excluídos do modelo por apresentarem carga fatorial menor que 0,7 202

Tabela 9: Avaliação do modelo de mensuração.................................................................... 204

Tabela 10: Resultado da análise de cargas cruzadas (cross loading) .................................. 206

Tabela 11: Análise de Fornell-Larker ............................................................................. 208

Tabela 12: Análise dos coeficientes de determinação das variáveis endógenas.................... 210

Tabela 13: Análise dos coeficientes do caminho e significâncias ......................................... 212

Tabela 14: Comparação do grupo Tipo de empresa .............................................................. 218

Tabela 15: Comparação do grupo Idade da empresa ........................................................... 219

Tabela 16: Comparação do grupo Importância estratégica da subsidiária............................ 220 


\section{LISTA DE GRÁFICOS}

Gráfico 1: Distribuição da frequência de respostas ao constructo transferência reversa de conhecimento tecnológico 176

Gráfico 2: Distribuição da frequência de resposta ao constructo tacitividade 178

Gráfico 3: Distribuição da frequência de resposta ao constructo complexidade. 178

Gráfico 4: Distribuição da frequência de resposta ao constructo Ambiente Institucional ..... 181

Gráfico 5: Distribuição da frequência de resposta ao constructo Ambiente competitivo ...... 181

Gráfico 6: Distribuição da frequência de resposta aos constructos de rede externa................ 183

Gráfico 7: Distribuição da frequência de resposta ao constructo autonomia ......................... 185

Gráfico 8: Distribuição da frequência de resposta ao constructo motivação .......................... 185

Gráfico 9: Distribuição da frequência de resposta do constructo rede interna (matriz) .......... 187

Gráfico 10: Distribuição da frequência de resposta ao constructo semelhança organizacional 188

Gráfico 11: Distribuição da frequência de resposta do constructo semelhança cultural 189

Gráfico 12: Distribuição da frequência de resposta do constructo mecanismos de socialização - comunicação eletrônica 190

Gráfico 13: Distribuição da frequência de resposta do constructo mecanismos de socialização - comunicação pessoal 190 


\section{INTRODUÇÃo}

A atividade de exploração, produção e transferência do conhecimento tem sido relatada na literatura como uma das principais motivações para o investimento direto estrangeiro (IDE) realizado pelas empresas multinacionais (EMNs) (GUPTA; GOVINDARAJAN, 1994). Isso se dá pela suposição de que EMNs são mais hábeis em gerar e transferir internamente novos conhecimentos (processo e tecnologia de produto, capacidade de gestão, ativos intangíveis, entre outros) do que os mecanismos tradicionais de mercado, tais como exportação e licenciamento (KOGUT; ZANDER, 1992, 1993; BIRKISNHAW; HOOD, 1998; FOSS; PEDERSEN, 2002). A eficiência da EMN é relacionada tto aos custos (TEECE, 1977) quanto à velocidade (ZANDER; KOGUT, 1995) da transferência. Em decorrência disso, o conhecimento tem sido relatado como um dos recursos estratégicos mais importantes da EMN (GRANT, 1996; SZULANSKI, 1996), e a habilidade de compartilhá-lo tem sido vista como uma importante fonte de vantagem competitiva da empresa (NONAKA; TAKEUCHI, 1995).

A princípio, essa imagem - das EMNs como exploradoras, criadoras e transferidoras de conhecimento - sugere uma transferência de sentido único, tanto no que se refere à matriz que transfere conhecimento à subsidiária, quanto aos países desenvolvidos, que transferem conhecimento para as nações menos desenvolvidas. No entanto, observa-se uma mudança de paradigma, pois, ainda que a matriz continue desempenhando um papel significativo na rede corporativa no que tange à determinação das estratégias, políticas e criação de novos conhecimentos, nota-se um aumento considerável da importância e do papel estratégico da subsidiária dentro da rede corporativa. Como consequência, a geração do conhecimento deixa de se restringir à matriz e passa a ocorrer em diversas unidades da rede multinacional, podendo seguir, dessa forma, diversas direções - matriz-subsidiária, subsidiária-matriz, subsidiáriasubsidiária (BARTLETT; GOSHAL, 1998; NOHRIA; GHOSHAL, 1997).

A ideia subjacente é a necessidade de a EMN explorar com primazia todos os recursos a que as subsidiárias possam ter acesso, e é nesse contexto que as subsidiárias passam a ter uma importância crescente dentro da rede corporativa, superando suas atribuições iniciais relacionadas apenas às questões de adaptação da oferta às necessidades e preferências dos mercados receptores (GHOSHAL; BARTLETT, 1988; BIRKINSHAW, 1997; NOHRIA; GHOSHAL, 1997; FROST; BIRKINSHAW; ENSIGN, 2002; CANTWELL; MUDAMBI, 2005; MUDAMBI; MUDAMBI; NAVARRA, 2007). 
Como resultado, a transferência de conhecimento no sentido inverso, ou seja, das subsidiárias para a sede da multinacional tem emergido como um tema proeminente nos estudos dos negócios internacionais (AMBOS; AMBOS; SCHLEGELMILCH, 2006; GUPTA; GOVINDARAJAN, 2000; HAKANSON; NOBEL; 2001; CRISCUOLO et al., 2005; FROST; ZOU, 2005; YANG, MUDAMBI; MEYER, 2008; RABIOSI, 2008, 2011; RABIOSI; SANTANGELO, 2011). Tais estudos chamam a atenção para a compreensão das subsidiárias que são incorporadas em diferentes ambientes e, portanto, são capazes de contribuir para a competitividade global das EMNs de diferentes formas. Os estudos reconhecem que a absorção do conhecimento criado no nível da subsidiária pode aumentar a inovação (HAKANSON; NOBEL, 2001) e a competitividade de toda a rede da multinacional (ANDERSSON; FORSGREN; HOLM, 2001).

A suposição de que o fluxo de conhecimento dentro da rede multinacional é benéfico tem sido explicitada em diversos estudos (GUPTA; GOVINDARAJAN, 2000; KOGUT; ZANDER, 1993; TSAI, 2001). No entanto, não se pode assumir que todo o fluxo de transferência seja igualmente benéfico para o destinatário (AMBOS; AMBOS; SCHLEGELMILCH, 2006). Benefícios à parte, faz-se importante registrar as inúmeras barreiras a serem transpostas para viabilizar o processo de difusão interna de conhecimento, ligadas à dispersão geográfica das unidades, à distância organizacional e cultural, à distância tecnológica e à disposição motivacional, tanto do emissor quanto do receptor (GUPTA; GOVINDARAJAN, 2000; KOGUT; ZANDER, 1993; SZULANSKI, 1996). Sendo assim, se por um lado as multinacionais desejam colher os benefícios de uma organização com recursos geograficamente dispersos, por outro devem garantir que o conhecimento gerado em diferentes unidades da rede seja transferido com sucesso para o resto da organização.

Se as competências geradas pela transferência reversa do conhecimento são fundamentais para a competitividade das multinacionais tradicionais, parece ser ainda mais crucial para a competitividade das multinacionais emergentes (EMNEs). Isso porque, as EMNs emergentes, ao contrário de se internacionalizarem para explorar vantagens preexistentes, internacionalizam-se em busca da aquisição de novas vantagens e capacidades (MATHEWS 2006; RAMAMURTI; SINGH, 2009; GUILLEN; GARCIA-CANAL, 2009). Em outras palavras, as EMNEs não só precisam buscar e desenvolver competências fora do seu país de 
origem, mas também precisam fazê-lo de forma muito mais rápida do que fizeram as multinacionais tradicionais em suas trajetórias de expansão (MATHEWS, 2006).

Quando se trata de multinacionais brasileiras (EMNs), a realidade não é diferente. Para que possam superar a competitividade, precisam do conhecimento adquirido em suas subsidiárias. Contudo, um estudo recente realizado em 65 subsidiárias brasileiras concluiu que as subsidiárias possuíam orientação etnocêntrica, tímida inovação e poucas parcerias com institutos e universidades em seus países de atuação. Tal situação, mesmo considerada padrão para jovens multinacionais como as brasileiras, não se sustentará por muito tempo, caso as subsidiárias brasileiras desejem continuar crescendo nos mercados internacionais (BORINI; OLIVEIRA JÚNIOR, 2010), pois como já dito, as subsidiárias funcionam hoje como forma de potencializar as vantagens competitivas das multinacionais.

A literatura já consegue listar alguns fatores determinantes para viabilizar a capacidade das EMNs em aprender por meio de suas subsidiárias. Estudos sugerem que a criação e transferência do conhecimento nas EMNs estão relacionadas a diversos fatores, entre eles:

- A natureza do conhecimento - tacitividade, complexidade, especificidade e disponibilidade (WINTER, 1987; KOGUT; ZANDER, 1992; MINBAEVA, 2007);

- Os Ambiente Institucional (CANTWELL; MUDAMBI, 2005; FROST 2001; YANG; MUDAMBI; MEYER, 2008).

- Os Ambiente competitivo (AMBOS; AMBOS; SCHLEGELMILCH, 1996; FROST; BIRKINSHAW; ENSIGN, 2002; KUEMMERLE, 1999);

- O envolvimento com a rede externa - rede de negócios local (HAKANSON; NOBEL, 2001; ANDERSSON; FORGREN; HOLM, 2001; ANDERSSON; BJORKMAN; FORGREN, 2005);

- O envolvimento com a rede interna - outras subsidiárias da multinacional (ANDERSON; FORSGREN, 1996; ANDERSON; FORSGREN; HOLM, 2001, 2007; TAVANI, 2010);

- A importância estratégica da subsidiária (AMBOS; AMBOS; SCHLEGELMILCH, 2006);

- A autonomia da subsidiária (GHOSHAL; NOHRIA, 1989; BIRKINSHAW; HOOD; JONSSON, 1998; RABIOSI, 2008); 
- A motivação para a transferência (GUPTA; GOVINDARAJAN, 2000; SZULANSKI, 1996; TAVANI, 2010);

- As semelhanças do contexto - cultural e organizacional (AMBOS; AMBOS; SCHLEGELMILCH, 2006);

- Os mecanismos de interação social entre matriz e subsidiárias (HAKANSON; NOBEL, 2001).

Todos esses e outros fatores serão explorados detalhadamente no capítulo da fundamentação teórica.

\subsection{Formulação da situação-problema}

Grande parte dos trabalhos que tratam da gestão de negócios internacionais é proveniente de centros de investigação e de universidades situadas em países desenvolvidos e, por isso, volta suas análises às EMNs que já possuem maior grau de internacionalização, com foco predominante em empresas cuja origem são os países que compõem a tríade (América do Norte, União Europeia e Japão) (KUEMMERLE, 2001). Essa literatura é de extrema importância para a visão futura da gestão e para a compreensão da dinâmica das empresas globais de países desenvolvidos, contudo é limitada no que diz respeito às questões e aos dilemas por que passam as EMNEs durante seu processo de expansão internacional (RAMAMURTI, 2009b).

Da mesma forma, o estudo sobre as subsidiárias tem sido pouco explorado se comparado ao estudo da corporação multinacional como um todo. Como sugere Porter (1986), pesquisas sobre EMNs precisam apresentar ambos os níveis: uma visão sistêmica de toda a corporação e uma visão individual das subsidiárias. Contudo, apesar de se reconhecer que a atividade inovativa nas subsidiárias é crescente, ainda não se tem uma ideia completa do conteúdo e das influências dessas atividades na rede da corporação, sobretudo quando se trata do universo das EMNs emergentes, e mais especificamente, das EMNs brasileiras.

Diversos são os estudos no sentido contrário, ou seja, que tratam do entendimento das atividades das subsidiárias de EMNs instaladas no Brasil. Alguns exemplos de estudos qualitativos são os focados em setores específicos, como o da indústria de equipamentos de telecomunicações (GALINA, 2004; GOMES, 2006), da indústria de equipamentos mecânicos e elétricos 
(AVELLAR, 2004) e da indústria automotiva (DIAS, 2003; CONSONI; QUADROS, 2005; AMATUCCI; BERNARDES, 2007). O conteúdo de tais estudos circunscreve-se à definição das estratégias das subsidiárias dentro da rede corporativa, tentando identificar o conteúdo das atividades tecnológicas já realizadas pelas subsidiárias instaladas no Brasil. Apesar de ocorrerem em menor escala, identificam-se também alguns estudos quantitativos que versam sobre as capacidades desenvolvidas pelas estratégias próprias das subsidiárias instaladas no Brasil e sua relevância estratégica na corporação multinacional (BOEHE, 2007; BORINI, FLEURY; FLEURY, 2009; GOMES, 2010).

Apenas nos últimos cinco anos é que se tem podido observar estudos cuja preocupação é a estratégia de atuação das subsidiárias brasileiras no exterior. Os que se circunscrevem a esse objeto enfocam as estratégias gerais das subsidiárias, bem como os fatores condicionantes para que obtenham uma maior importância dentro da rede multinacional (MOURA, 2007; PORTO et al., 2010; OLIVEIRA JÚNIOR; BORINI, 2010; BORINI; FLEURY; FLEURY, 2010), contudo, poucos têm analisado as subsidiárias sob a perspectiva específica dos condicionantes para a criação e transferência de conhecimento.

A partir da identificação dessa lacuna, o presente estudo procura responder à seguinte questãochave: Quais os fatores determinantes da transferência reversa de conhecimento tecnológico nas multinacionais brasileiras? O universo analisado será o das subsidiárias das multinacionais brasileiras que atuam no exterior por meio de subsidiárias com atividades de manufatura ou de laboratórios de pesquisa e desenvolvimento.

\subsection{Objetivos e contribuições do estudo}

Em face dessa discussão, o objetivo geral deste estudo é discutir como as subsidiárias das EMNs brasileiras desenvolvem novos conhecimentos e como contribuem para a difusão desse conhecimento para a matriz da corporação. Os objetivos específicos são:

- Identificar quais os tipos de conhecimento tecnológico são transferidos com mais frequência e intensidade pela subsidiária para a matriz; 
- Identificar quais fatores são determinantes para a transferência reversa de conhecimento tecnológico nas EMNs brasileiras, relacionados à (s):

- Características do conhecimento;

- Características das subsidiárias;

- Características da interação matriz/subsidiária.

- Verificar se fatores moderadores como idade, modo de entrada e importância estratégica das subsidiárias interferem na relação entre os determinantes e a transferência reversa de conhecimento tecnológico.

\subsection{Justificativas e importância do estudo}

A relevância deste trabalho está associada às potenciais contribuições que ele pode oferecer tanto no campo teórico como no campo prático. Tais contribuições relacionam-se ao entendimento sobre o papel das subsidiárias brasileiras no que tange ao seu potencial de criar e transferir novos conhecimentos dentro da rede multinacional. A contribuição esperada para o campo teórico é a integração e o entendimento de duas áreas que, juntas, ainda são pouco exploradas na literatura das EMNs: as subsidiárias de multinacionais brasileiras e a transferência reversa de conhecimento (subsidiárias-matriz).

O interesse sobre a investigação a respeito das subsidiárias está calcado na perspectiva de que as subsidiárias são detentoras de conhecimento que podem alavancar vantagens competitivas para toda a rede da empresa multinacional (BIRKINSHAW, 1997; GUPTA; GOVINDARAJAN, 2000; DOZ et al., 2001). Sobre esse aspecto, a principal contribuição do estudo é identificar o papel das subsidiárias de empresas multinacionais brasileiras na geração de valor para a rede multinacional por meio da transferência de conhecimento tecnológico para suas matrizes. No que se refere à transferência reversa de conhecimento tecnológico a principal contribuição teórica deste estudo é fornecer uma taxonomia abrangente sobre os fatores que influenciam a transferência reversa de conhecimento em multinacionais emergentes. O estudo abrangerá três grupos de fatores influenciadores: as características do conhecimento que está sendo transferido, as características da fonte (subsidiária) e as características da interação subsidiária/matriz (fonte/receptora). A literatura existente já investiga os impactos de cada um desses determinantes, porém, na sua grande maioria, de forma separada, tanto nos casos de 
transferência de conhecimento tradicional como nos casos de transferência reversa. Investigações que analisam o conjunto desses fatores influenciadores são raras (SZULANKSI, 1996; GUPTA; GOVINDARAJAN, 2000; MINBAEVA, 2007; TAVANI, GIROUD, SINKOVICS, 2010).

Outra contribuição importante do estudo refere-se à investigação da transferência reversa de conhecimento tecnológico no contexto das empresas multinacionais brasileiras. Prévios estudos

sobre subsidiárias de empresas multinacionais brasileiras centraram-se nas competências das subsidiárias (BORINI, FLEURY, 2011; BORINI et al., 2010) e até mesmo nas transferências de conhecimento desenvolvidos nas subsidiaras (SILVIA, FLEURY, 2012), mas nenhum deles analisou um conjunto de influenciadores tão abrangente quanto este estudo. Portanto, esta pesquisa contribui para a literatura, identificando um conjunto de influenciadores da transferência reversa de conhecimento em subsidiárias de empresas multinacionais brasileiras.

No plano gerencial, os resultados implicam a elaboração de recomendações que possam subsidiar as decisões dos gestores das subsidiárias e da matriz em prol de uma maior capacidade de criar e de transferir o conhecimento para as outras unidades da rede. O estudo elabora um conjunto de sugestões com o objetivo de que os gestores de EMNs brasileiras elaborem estratégias eficazes para desfrutar dos efeitos benéficos da transferência interna de conhecimento tecnológico.

\subsection{Estrutura do documento}

Este documento está estruturado em capítulos. O presente capítulo apresentou o tema escolhido, seu contexto, situação-problema, justificativas e contribuições esperadas. Em seguida, apresenta-se o capítulo de fundamentação teórica, no qual estão contemplados os temas sobre a empresa multinacional (emergente e brasileira), as principais perspectivas teóricas para o entendimento do processo de transferência reversa de conhecimento, as definições-chaves do termo conhecimento e os fatores condicionantes para a transferência reversa de conhecimento tecnológico. O terceiro capítulo detalha a parte central do estudo que são os determinantes da transferência reversa de conhecimento e na sequência firma as hipóteses para cada um desses determinantes. O quarto capítulo apresenta a metodologia aplicada, o tipo e a natureza da pesquisa adotada, o modelo conceitual e a operacionalização das variáveis, os critérios 
utilizados para a definição da população e seleção da amostra, a descrição dos procedimentos de coleta, o tratamento e análise dos dados e as possíveis limitações do estudo no tocante à metodologia. No quinto capítulo, são apresentados, analisados e discutidos os resultados alcançados. Finalmente, o sexto capítulo apresenta as conclusões do estudo e as contribuições teóricas e práticas. O capítulo é encerrado com sugestões de novos estudos, ressaltando-se, ainda, suas limitações. A Ilustração 1 apresenta a visão geral da estrutura do trabalho.

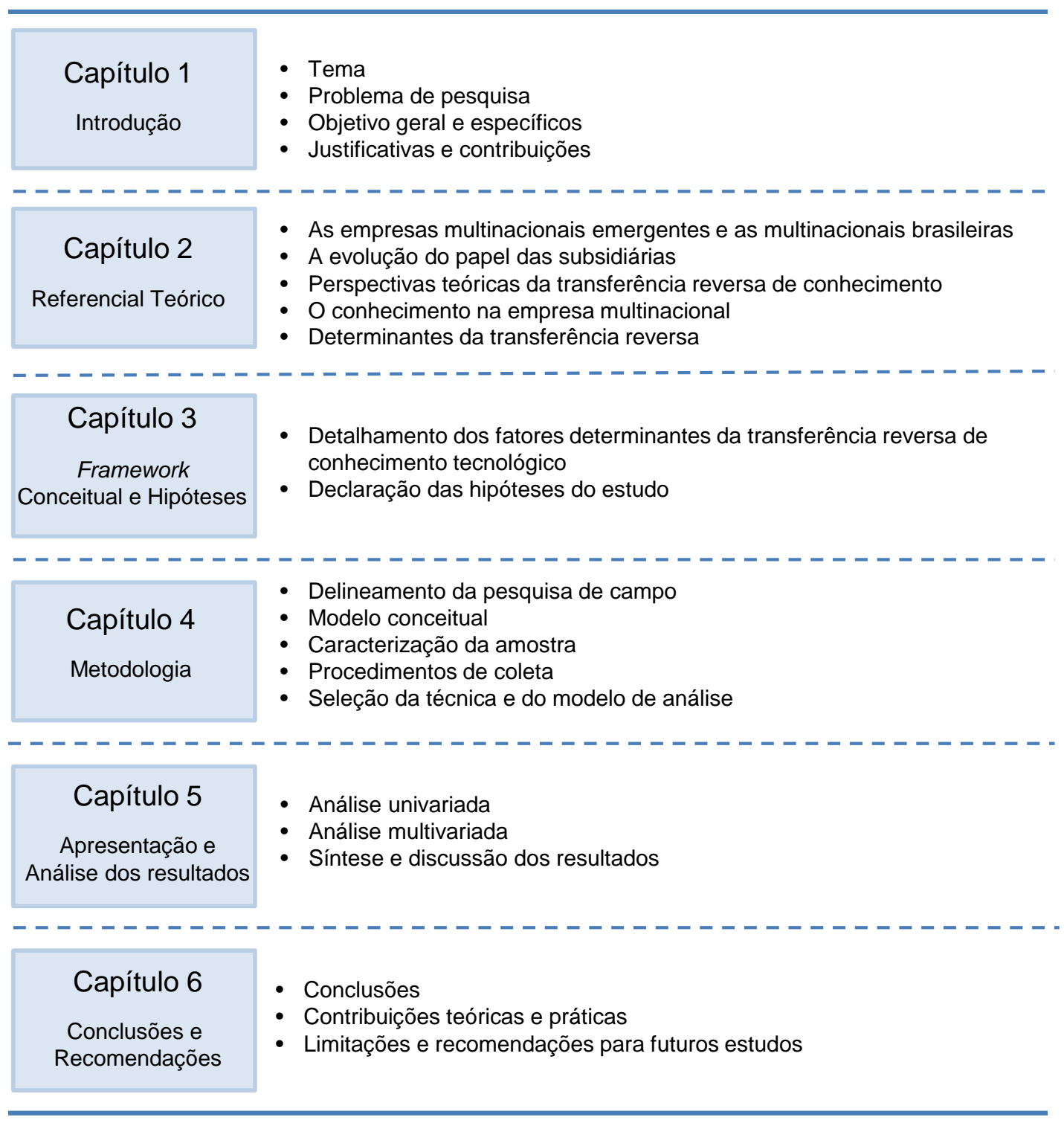

Ilustração 1: Estrutura do trabalho 


\section{FUNDAMENTAÇÃO TEÓRICA}

Este capítulo é estruturado em quatro seções. Inicialmente apresenta-se o contexto que se pretende estudar, a multinacional emergente, as especificidades das multinacionais brasileiras. Na segunda seção o papel das subsidiárias é apresentado e também são traçados os primeiros argumentos sobre a importância do conhecimento para a EMN. A terceira seção prossegue discorrendo sobre as teorias-chave que dão subsídio à cooperação transfronteiriça do conhecimento dentro da firma multinacional - apresenta-se então a visão baseada em conhecimento e teoria das redes de negócios. A intenção é apresentar uma fundamentação inicial que subsidie o desenvolvimento dos tópicos seguintes. A quarta parte do capítulo provê as definições-chave do conhecimento, definindo, portanto, o conhecimento, suas tipologias e classificações; depois, aborda a transferência de conhecimento e o contexto em que esse processo pode vigorar dentro da EMN e, finalmente, apresenta os fundamentos da transferência reversa de conhecimento, seus benefícios e barreiras. O capítulo é concluído com a síntese da bibliografia estudada que apresenta os principais temas comentados, o recorte e as escolhas teóricas que formaram as bases para a construção do modelo conceitual utilizado na análise do estudo. A Ilustração 2 apresenta os principais assuntos que permearão este capítulo.

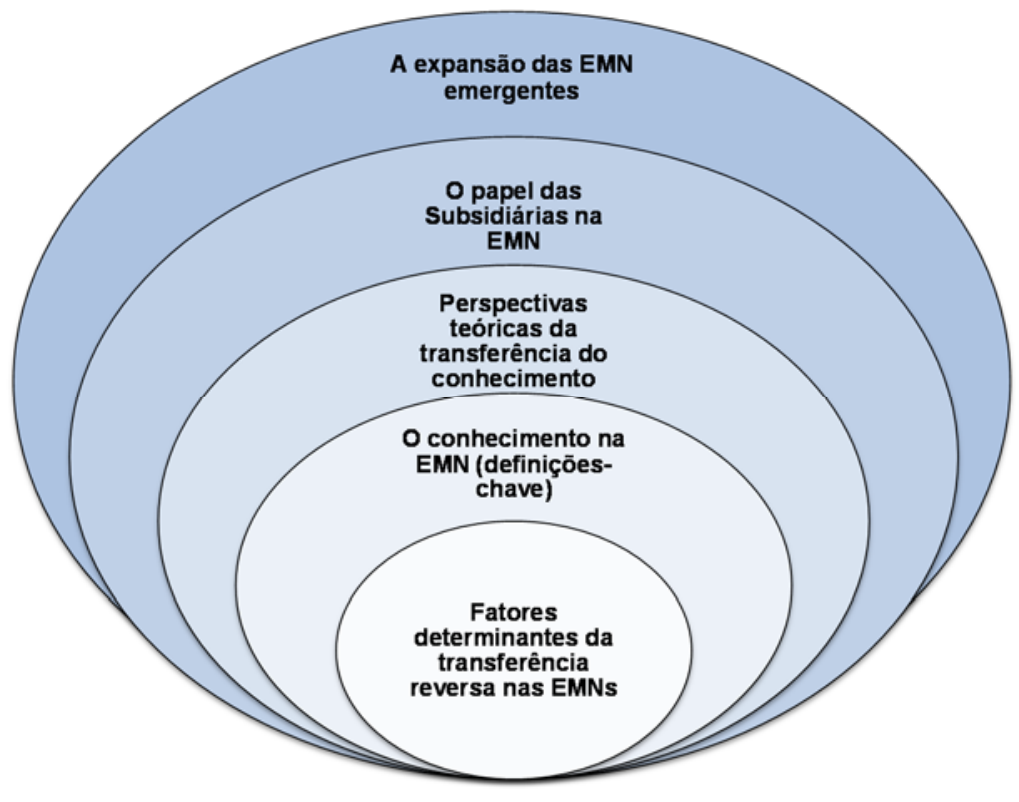

Ilustração 2: Grupos conceituais do estudo

\subsection{A expansão das multinacionais emergentes}


Diversas são as fontes que evidenciam a importância crescente das EMNEs na economia global. Uma delas são seus fluxos de saída de IDE (investimento direto estrangeiro), que têm aumentado de forma muito mais significativa do que o fluxo de saída de IDE dos países desenvolvidos. Em 2008, as economias emergentes foram responsáveis por 18\% de todo o fluxo de IDE do mundo, enquanto em 1990 elas eram responsáveis por apenas 5\% do total (GAMMELTOFT et al., 2010a). Ressalta-se, que em números absolutos, as economias desenvolvidas têm aumentado seus investimentos ano a ano, no entanto, elas vêm perdendo participação em termos porcentuais para as economias emergentes. No que se refere à entrada de IDE, percebe-se também um aumento na movimentação do fluxo entre os países emergentes. Do total de investimentos que se originam de países emergentes, pelo menos dois terços estão sendo investidos em outras economias emergentes por meio de aquisições ou investimentos do tipo greenfield - configurando o que se tem chamado de cooperação Sul-Sul ${ }^{1}$ (RAMAMURTI, 2009b; GAMMELTOFT et al., 2010a). Uma das explicações para o aumento dos investimentos Sul-Sul seriam as vantagens que as empresas advindas de países emergentes teriam em países similares, pois já estariam acostumadas a ambientes com condições de operação que partilham deficiências institucionais semelhantes (CUERVO- CAZURRA, 2008).

A internacionalização produtiva das EMNs tem seu início no começo do século $\mathrm{XX}$, quando as empresas americanas começaram a se sentir motivadas a internacionalizar sua produção, processo que foi seguido por outras empresas, notadamente da Europa central. Na década de 1980, foi a vez de as empresas japonesas internacionalizarem fortemente sua produção, sendo seguidas pelas empresas sul-coreanas. Atualmente, impulsionadas pelas melhorias nas circunstâncias macroeconômicas dos países emergentes - aumento do poder de compra da população, melhorias no nível de educação e urbanização, entre outros vários indicadores -, empresas provenientes dos mercados emergentes têm se agigantado no mercado interno. Como consequência, tais empresas, sobretudo as que conseguiram a posição de campeãs nacionais, começam a formar as bases para competir no mercado internacional como forma de se expandir e de manter suas vantagens competitivas. Inicia-se assim o processo de internacionalização das empresas de países emergentes (FLEURY, A.; FLEURY, M. 2011).

\footnotetext{
${ }^{1}$ A expressão sul-sul remete-se à divisão econômica feita no mapa-múndi.
} 
A internacionalização das EMNEs pode ser dividida em algumas etapas. A primeira teve início na década de 1970, predominantemente nos países da América Latina - Argentina, México, Chile, Brasil, Colômbia e Venezuela (GAMMELTOFT, 2007). Nessa época, o contexto dos países era caracterizado por leis que protegiam as indústrias nacionais e por fortes políticas de substituição das importações. A internacionalização das empresas advindas da América Latina objetivava a proximidade com os clientes, ajustes de produtos, assistência técnica e facilidades logísticas. $\mathrm{O}$ destino dos produtos, em geral, ficava também restrito aos países da América Latina (STAL; CAMPANÁRIO, 2010).

A segunda etapa da internacionalização das emergentes foi dominada pelos países dos Tigres Asiáticos - Coréia do Sul, Taiwan, Hong-Kong e Singapura - seguidos por empresas da Malásia, Tailândia, China, Índia e Filipinas (MINDA, 2008 apud STAL; CAMPANÁRIO, 2010). Os motivos desta etapa de internacionalização diferiram dos da primeira etapa, já que o objetivo principal dessas empresas era obter ativos estratégicos no exterior. Os investimentos no exterior foram mais expressivos e o conteúdo da internacionalização relacionava-se mais a setores sofisticados tecnologicamente (CHUDNOVSKY; LÓPEZ, 2000 apud STAL; CAMPANÁRIO, 2010).

A terceira etapa da internacionalização das emergentes foi marcada pela internacionalização de EMNs de países como Brasil, China, Rússia, Egito e África do Sul, e se deu no início dos anos 1990, estimulada pela liberalização da economia e pelas privatizações de grandes empresas públicas. Essas medidas propiciaram modificações profundas nas condições ambientais dos países, aumentando a competitividade local e estimulando as empresas a concorrer em mercados externos em busca de acesso à tecnologia e a novas fontes de financiamento, de superação de barreiras tarifárias e não tarifárias, dentre outras razões. Atualmente, a terceira geração de EMNEs é constituída por empresas que conseguem se destacar num ambiente de competição global, concorrendo não só com seus pares também emergentes, mas também com multinacionais tradicionais advindas de países desenvolvidos (STAL; CAMPANÁRIO, 2010).

Segundo Stal e Campanário (2010), as multilatinas ficam em desvantagem em relação às asiáticas, pois não possuem as vantagens específicas relacionadas às indústrias de alta tecnologia ou aos setores intensivos em capital. Isso se deve "ao modelo inicial de desenvolvimento industrial, à baixa taxa de acumulação de capital físico e humano e também à falta de visão das políticas públicas, especialmente aquelas voltadas para a educação, indústria, 
e pesquisa e desenvolvimento" (Ibid., p. 61). Esse conjunto de fatores resultou, para as multilatinas, em baixo nível de produtividade dos fatores de produção e em menor capacidade de inovação. Ainda segundo Stal e Campanário (2010), essa talvez seja uma das razões da maior parte das pesquisas sobre as multinacionais de países emergentes voltar-se para o entendimento das empresas asiáticas, em detrimento do entendimento das multilatinas. De fato, "estudos sobre IDE dos países BRIC têm crescido, mas Índia e China têm sido os focos preferenciais" (Ibid., 2010, p. 62).

\subsubsection{Perspectivas teóricas sobre as EMNEs}

Várias ciências sociais têm contribuído para o estudo das empresas multinacionais em economias emergentes. Um dos primeiros estudos sobre esse novo fenômeno foi o trabalho de Wells (1983). A partir daí surgiram inúmeras nomenclarturas a fim de referenciar as multinacionais emergentes. Entre elas, “as multinacionais do terceiro mundo” por Wells (1983), “as empresas retardatárias" por Mathews (2002), "multinacionais não convencionais" por Li (2003), “desafiadoras” pela BCG (2008), “novas multinacionais” por Guillén e García-Canal (2009) e “empresas multinacionais de mercados emergentes" por Luo e Rui (2009).

O trabalho de Wright et al. (2005) fez um apanhado das várias correntes teóricas utilizadas como arcabouço para analisar as pesquisas realizadas sobre os movimentos de empresas nacionais e estrangeiras em países emergentes. Na conclusão desse trabalho é estabelecido que a teoria institucional é, inesperadamente, o ponto de vista mais utilizado na pesquisa de mercados emergentes, seguido pela visão baseada em recursos, teoria da agência e a teoria dos custos de transação. Naturalmente, cada teoria levanta questões únicas ligadas ao contexto de mercados emergentes, mas o que Wright et al. (2005) afirmam insistentemente é a utilização de uma combinação de perspectivas teóricas em trabalhos futuros, em vez de depender de abordagens singulares.

Em concordância com essa advertência, vários estudos têm lançado mão de dois ou mais arcabouços teóricos para analisar determinando aspecto sobre o fenômeno das EMNs, como por exemplo: o estudo de Gammeltoft e Hobdari (2012) relacionou duas abordagens teóricas (visão baseada em recursos e literatura sobre aquisições) para analisar o impacto de experiências passadas em atividades futuras de fusões e aquisições internacionais de empresas multinacionais brasileiras. Gubbi et al. (2010) integraram as percepções da visão baseada em recursos e da literatura sobre internacionalização para investigar se as aquisições internacionais 
feitas por empresas indianas são capazes de criar valor adicionado. A contribuição do trabalho de Wang (2012) foi a integração da teoria institucional, economia das organizações industriais e visão baseada em recursos para investigar os propulsores dos fluxos de investimentos estrangeiros das empresas chinesas. Outro exemplo que será explorado mais adiante vem do estudo de Tavani, Giroud e Sinkovics (2010) que utilizou as perspectivas da visão baseada em valor e das teorias das redes para analisar a transferência reversa de conhecimento entre unidades de multinacionais do setor de serviços provenientes do Reino Unido.

Adicionalmente às teorias tradicionais utilizadas na pesquisa de negócios internacionais, alguns autores estudam especificamente as multinacionais de mercados emergentes e, em decorrência, elaboram teorias e perspectivas especializadas que podem servir para melhorar a compreensão das EMNEs. Luo e Tung (2007) instituíram a "perspectiva de trampolim" que explica como as EMNEs utilizam as aquisições estrangeiras para reduzir os constrangimentos institucionais que podem ser encontrados em seus mercados domésticos. Khanna e Palepu (2006) discutem a existência de "vazios institucionais" e sua relevância para as empresas de mercados emergentes. Os autores argumentam que a habilidade das EMNEs em superar essas dificuldades institucionais podem ser entendidas como vantagens competitivas em contraste com empresas estrangeiras de países desenvolvidos, que têm menos experiências com esse tipo de ambiente marcado por instabilidades estruturais e econômicas.

A corrente que tem por base o "escapismo institucional" argumenta que as empresas multinacionais tentam evitar arranjos institucionais e ambientes competitivos menos desenvolvidos por meio da internacionalização (CUERVO-CAZURRA; GENGC, 2008; YAMAKAWA; PENG; DEEDS, 2008). As empresas podem ter diferentes arranjos institucionais e ambientes, no entanto empresas que têm ambientes domésticos limitados institucionalmente podem estar mais dispostos a procurar melhores oportunidades no exterior.

A "perspectiva ambidestra" argumenta que as empresas multinacionais são organizações ambidestras perseguindo a realização simultânea de dois objetivos simultaneamente que são, muitas vezes, conflitantes (LUO; RUI, 2009, p. 50). Essa perspectiva sugere que as EMNEs possuem quatro dimensões de ambidestralidade: co-orientação, co-competência, co-opetição e co-evolução. Eles acreditam que empresas de países em desenvolvimento, como a China, têm motivos mais fortes e habilidades para construir e alavancar tais ambidestralidades com vistas em compensar suas desvantagens de falta de pioneirismo. Tais empresas se comportariam "co- 
evolutivamente" para lidar com o ambiente externo que enfrentam no país de sua sede e no exterior; alavancam sua "co-competência" (transacionais e relacionais) para competir com os seus rivais globais; desenvolvem laços de "co-opetição" (cooperação e competição simultaneamente) com seus stakeholders, e mantém co-orientação (aproveitando vantagens competitivas para reforçar sua sobrevivência a curto prazo e compensar as desvantagens competitivas para o crescimento a longo prazo) (Ibid.).

\subsubsection{Motivações e padrões da internacionalização de EMNEs}

Estudos recentes tem se debruçado nos motivos e padrões da internacionalização de EMNEs para avaliar a adequação das teorias das multinacionais existentes, sobretudo no que concerne ao paradigma $\mathrm{OLI}^{2}$ e à teoria da internalização (por exemplo, CHILD; RODRIGUEZ 2005, LUO; TUNG 2007).

Apesar de generalizações não serem facilmente aplicadas, pois se trata de um grupo bastante heterogêneo (RAMAMURTI; SINGH, 2009), algumas características comuns podem ser observadas no grupo das EMNEs, quais sejam: são empresas maduras e integradas que cresceram em mercados protegidos da competição internacional; utilizam intensamente recursos naturais e mão de obra barata; não possuem competência tecnológica avançada; são atrasadas em termos de capacitação gerencial; e operam em ambientes extremamente turbulentos (FLEURY, A. FLEURY, M. 2007, p. 4).

Análises recentes sobre os fluxos de saída de IDE de cada mercado emergente, sobretudo os mercados do grupo BRICs, têm indicado grandes idiossincrasias das multinacionais com seu contexto específico. Por conseguinte, tais especificidades acabam ocasionando grande diversidade nas tendências e estratégias de internacionalização dessas empresas (GAMMELTOFT et al., 2010a). Isso reforça o que já é reconhecido de longa data na literatura (VERNON, 1966; CHANDLER, 1977 apud GAMMELTOFT et al., 2010a): o contexto de origem em que a multinacional está envolvida acaba implicando fortes especificidades nas características e estratégias adotadas pelas multinacionais.

\footnotetext{
${ }^{2}$ O Paradigma OLI (também designado Teoria Eclética) é uma abordagem desenvolvida por J. H. Dunning que procura explicar o processo de internacionalização da empresas com base no investimento estrangeiro. Segundo esta abordagem, um investimento de sucesso deve respeitar três condições (paradigma O.L.I: Ownership-Location, Internalization).
} 
No tocante às motivações, estudos indica que a internacionalização dessas empresas é motivada, sobretudo, pela perspectiva de buscar acesso aos recursos estratégicos no exterior, tais como know-how tecnológico, capacidades de P\&D. habilidades gerenciais e marcas globais em busca de competir com sucesso com suas concorrentes de mercados desenvolvidos (GUILLÉN; GARCÍA-CANAL, 2009). Em sua maioria, os estudos dão destaque aos rápidos e pouco convencionais caminhos de tais expansões internacionais (ALMEIDA, 1996; LUO; TUNG, 2007; MATHEWS, 2006). O que parece incontestável é que empresas de mercados emergentes, diferentemente daquelas dos países desenvolvidos, prosseguem a internacionalização de forma rápida, e em muitos casos o fazem por meio de aquisições.

A lógica subjacente é que os mercados internacionais servem como laboratórios de aprendizagem e como canais que permitem que empresas tenham acesso as diversas ideias incorporadas localmente e conhecimento baseados nas capacidades dispersas pelo mundo (ALMEIDA, 1996; DOZ; SANTOS; WILLIAMSON, 2001).

Mathews (2006) argumenta que, como as emergentes não possuem vantagens monopolísticas, elas tentam buscá-las por meio da internacionalização acelerada, com vistas em superar sua posição de retardatárias; para isso, usam um processo apelidado de linkage, leverage e learning. Esse framework, proposto como uma alternativa ao paradigma OLI ${ }^{3}$ de Dunning (1988), sugere que as EMNEs são mais adaptáveis e, por isso, têm mais facilidade de se interligar à nova economia global (linkage) para alavancar suas estratégias (leverage) e utilizar os recursos disponíveis além-fronteiras, preferindo então as estratégias de alianças e aquisições. Essa expansão internacional acelerada facilita o decorrente processo de aprendizagem (learning), comparativamente com as multinacionais tradicionais.

Em outras palavras, as EMNEs, mais do que explorar vantagens preexistentes, se internacionalizam para adquirir novas vantagens e capacidades (MATHEWS, 2006; LUO; TUNG, 2007), ou seja, ao contrário das multinacionais tradicionais, as emergentes têm muito a ganhar com as alianças e aquisições internacionais e pouco a perder, já que não são detentoras

\footnotetext{
${ }^{3}$ Também conhecido como paradigma eclético, pretende ser um framework para analisar as vantagens da empresa multinacional no exterior. O (vantagens específicas proprietárias); L (vatagens de localização específicas) e I (vantagens específicas de internalização).
} 
de recursos, tais como os citados anteriormente. Essa nova configuração possibilitaria às retardatárias alcançar uma internacionalização de forma acelerada, não por meio de inovações tecnológicas, mas por meio de inovações organizacionais, remodelando assim o negócio ou os setores em que atuam. Mas para que isso seja possível, é necessária uma participação ativa das subsidiárias, no sentido de adquirir competências no exterior e transferi-las para toda a corporação (Ibid.).

Assim, a clássica perspectiva do paradigma eclético de Dunning (1988), que estende as estratégias competitivas das multinacionais tradicionais para os mercados, estrangeiros tratando as estratégias das subsidiárias como braços seguidores das estratégias da matriz, parece não se adequar à realidade das EMNEs. A partir dessa nova ótica, a necessidade de as subsidiárias explorarem e transferirem novas competências é condição sine qua non para assegurar sua competitividade, muito embora elas continuem ainda com o papel tradicional de construir e transferir competências para a matriz (BORINI, 2008). O fato de as emergentes precisarem buscar competências no exterior, "as tornaria dependentes de competências não locais criadas nas subsidiárias estrangeiras, invertendo a tradicional ordem de valor das fontes de vantagens competitivas de empresas multinacionais" (BORINI, 2008, p. 29).

Em consonância com essa perspectiva, vários autores da área têm feito uso do delineamento do contexto institucional de tais países como subsídio para investigar as atividades das EMNEs. Segundo Gammeltoft et al. (2010b), as diferenças no contexto institucional decorrem principalmente dos seguintes aspectos:

i) O governo local desempenha um papel mais ativo nesse tipo de economia, encorajando suas empresas a atuar em sintonia com suas prioridades e preferências. Seus mecanismos em geral são a disponibilização de acesso privilegiado a certos insumos, financiamentos especiais, subsídios e outros apoios;

ii) $\mathrm{O}$ ambiente econômico/institucional das EMNEs tende a ser menos sofisticado, o que implica especificidades de estrutura organizacional e de governança. Para compensar a escassez de recursos físicos, tecnológicos e de gestão, entre outros, as empresas acabam diversificando seu grupo de negócios, tornando-se mais verticalizadas e horizontalizadas. Se, por um lado, isso implica vantagens competitivas relacionadas à eficiência no país de origem, por outro, implica desenvolvimento de vantagens que são 
de difícil duplicação em outros mercados. Ademais, a estrutura societária do grupo de negócios acaba influenciando sua forma de entrar e de atuar nos mercados internacionais;

iii) As EMNEs são, em geral, muito dependentes de redes locais apoiadas em afinidades étnicas, linguísticas ou culturais. Tal fator permite a essas empresas reduzir os riscos associados com o IDE em mercados emergentes, pois elas acessam informações vitais e recursos complementares nesses países emergentes (FILATOCHEV et al., 2007); por isso, tendem a operar em redes mais fechadas e por meio de um sistema de governança mais controlado e centralizado (por exemplo, investidores familiares e/ou investidores institucionais domésticos), o que torna suas decisões estratégicas, fortemente dependentes do interesse do grupo controlador e de sua rede de negócios;

iv) As economias emergentes possuem níveis muito mais baixos de desenvolvimento e sofisticação tecnológicos se comparadas com países desenvolvidos (CUERVOCAZURRA, 2007), e tendem a operar com tecnologias mais maduras, tais como as dos setores de commodities como aço e cimento, linha branca, etc., em razão da natureza dos seus ambientes domésticos.

Nesse sentido, para Ramamurti (2009a), uma das vantagens específicas das novas multinacionais é a adversidade. As empresas aprenderam a operar em condições difíceis relacionadas às características dos mercados emergentes, como infraestrutura pouco desenvolvida, portos e estradas congestionadas, burocracias corruptas, instituições educacionais fracas e governos instáveis. Enquanto as multinacionais tradicionais muitas vezes foram desencorajadas a se internacionalizar em razão de tais desafios, as emergentes evoluíram copiando estratégias e tendo de lidar com tais restrições desde seu nascimento.

Segundo Ramamurti (2009a), as vantagens específicas mais comuns das multinacionais tradicionais podem ser divididas em tangíveis (tecnologia, marca forte, capital financeiro, capacidades gerenciais) e intangíveis (capacidade de criar, processar e aplicar conhecimento).

Para Mathews (2006), as estratégias das EMNEs são definidas por três aspectos:

- Busca por recursos no exterior, por meio de aquisições, parcerias ou inserção nas redes de negócios internacionais; 
- Aproveitamento dos recursos adquiridos e desenvolvidos no exterior para alavancar os negócios de toda corporação; e

- Desenvolvimento de uma extraordinária capacidade de aprendizagem contínua, tanto para perceber as novas oportunidades quanto para integrar novos recursos à rede de negócios.

Outros autores defendem que as EMNEs procuram se expandir internacionalmente, não apenas para explorar os recursos existentes no exterior, mas, a fim de adquirir e melhorar suas próprias capacidades pré-existentes (DENG, 2007, 2009; GUBBI et al., 2010). Analisando o caso de aquisições estrangeiras por três empresas chinesas, Deng (2009) constatou que, apesar de terem adquirido recursos valiosos, isso não criou oportunidades para que se tornassem empresas globalmente competitivas. Em outras palavras, a posse de ativos estratégicos por si só, apesar de ser uma condição necessária, não é suficiente para as empresas criarem vantagens competitivas sustentáveis. Isso se dá porque além da aquisição de recursos, as empresas tem que se deparar com os desafios de integrar esses ativos de modo a melhorá-los após a aquisição.

Dessa forma, fica claro que os aspectos que condicionam a exploração de recursos pelas multinacionais tradicionais (sobretudo pelas subsidiárias) podem ser bastante diferentes dos fatores que condicionam a busca de recursos pelas multinacionais emergentes. Por isso a importância de investigar como as subsidiárias brasileiras buscam se diferenciar no exterior com o objetivo de elevar as capacidades de toda a corporação.

\subsubsection{As multinacionais brasileiras}

Apenas a partir da década de 1970 as empresas brasileiras iniciaram sua atuação no mercado internacional, intensificada na década de 1990 pela a abertura do mercado brasileiro. Com o aumento da competição no mercado doméstico, influenciado pela entrada de produtos estrangeiros, algumas empresas nacionais iniciaram sua busca por mercados estrangeiros, tanto por meio de exportações como por investimento em subsidiárias comerciais ou de produção. No entanto, a busca pela internacionalização, mais do que uma opção consciente e intencional, foi uma forma defensiva e compensatória. A internacionalização como opção estratégica surgiu, para as empresas brasileiras, de modo geral, apenas em estágios posteriores (CYRINO; 
BARCELLOS, 2006). As principais características da internacionalização das multinacionais brasileiras são as seguintes:

- A decisão para internacionalizar levou um longo tempo para acontecer e só teve lugar após décadas de sua criação, como a grande maioria das empresas latino-americanas (CUERVO-CAZURRA, 2008).

- Suas estratégias focaram inicialmente em países latino-americanos, muito provavelmente para se beneficiar da proximidade geográfica e reduzir e as diferenças culturais e institucionais. No entanto, essa preferência por instalação em países próximos mudou ao longo do tempo e desde os anos recentes (2006), os relatórios anuais da Fundação Dom Cabral, por exemplo, começam a indicar uma dispersão espacial das atividades das multinacionais brasileiras. Observa-se, a partir da Tabela 1, que é crescente importância de novos mercados criados pela globalização, como os da Ásia, África e Oceania, para as multinacionais brasileiras.

Tabela 1: Localização regional das atividades das multinacionais brasileiras

\begin{tabular}{lcccccc}
\hline & $\begin{array}{c}\text { América } \\
\text { Latina }\end{array}$ & $\begin{array}{c}\text { América do } \\
\text { Norte }\end{array}$ & Europa & África & Ásia & Oceania \\
\hline $\mathbf{2 0 0 6}$ & 46,91 & 11,34 & 20,62 & 6,87 & 14,43 & 0 \\
$\mathbf{2 0 0 7}$ & 40,38 & 14,72 & 20,00 & 8,3 & 16,60 & 0 \\
$\mathbf{2 0 0 8}$ & 46,23 & 17,31 & 20,61 & 10,75 & 10,75 & 0,43 \\
$\mathbf{2 0 0 9}$ & 52,95 & 9,18 & 16,89 & 5,43 & 14,66 & 0,89 \\
\hline
\end{tabular}

FONTE: FUNDAÇÃO DOM CABRAL com base em FLEURY, A.; FLEURY, M., 2013.

Cyrino e Barcellos (2006) consideram que as EMNBRs são ainda os "pontos fora da curva" no universo de empresas do país. Em sua maioria, são empresas líderes de mercado que já atuavam com um desempenho diferenciado desde a década de 1970, por meio da exportação de seus produtos, e foram as pioneiras também em incluir as estratégias de internacionalização em suas pautas desde o final dos anos 1980 e início dos anos 1990. Essas empresas, no entanto, operam ainda com desvantagens significativas em relação aos grandes concorrentes globais, dentre as quais: os valores de vendas e de ativos das EMNBRs são inferiores tanto em relação aos concorrentes de países desenvolvidos quanto em relação aos de países em desenvolvimento; o aprendizado das empresas dá-se de forma lenta, porque na maioria dos casos as empresas adotaram uma estratégia incremental de internacionalização tanto quanto à forma escolhida 
(exportação) como quanto à escolha dos mercados-alvo (países com menor distância psíquica em relação ao Brasil); as vantagens competitivas ainda se referem, em grande parte, a estruturas de custo não facilmente replicáveis em outros mercados, como, por exemplo, mão de obra e acesso privilegiado a recursos naturais; estruturas organizacionais bastante hierarquizadas, com uma comunicação unidirecional entre matriz e subsidiárias; e, finalmente, dificuldades causadas pelo chamado "custo Brasil" - ou seja, estrutura tributária, elevada taxação interna, infraestrutura deficiente de logística e de transportes.

Dentre os motivos para a expansão internacional, pesquisas indicam que os principais são: aumento da competitividade; redução da dependência do mercado interno; economia de escala; demanda mundial; estabelecimento de plataformas de exportação; acompanhar concorrentes; acompanhar clientes; saturação do mercado interno; incentivos fiscais; acesso a matériasprimas, canais de distribuição, tecnologia, capitais baratos e deficiências institucionais no país de origem (SOBEET/VALOR ECONÔMICO, 2011; ROCHA; SILVA; CARNEIRO, 2007).

Um estudo realizado pelo grupo GINEBRA em 2011 concluiu que a maior parte das multinacionais brasileiras é constituída por empresas manufatureiras de grande porte. Chama a atenção, entretanto, o fato de que a participação de pequenas e médias empresas, especialmente operadoras de serviços, está crescendo significativamente, indicando uma inflexão no processo de internacionalização das empresas brasileiras. Outra conclusão foi de que a América Latina, em primeiro lugar, e a América do Norte, em segundo, são os principais destinos dos investimentos diretos das multinacionais brasileiras. As evidências sugerem ainda uma crescente orientação para outros países emergentes e a África. "Isto decorreria de uma crescente capacitação em gestão, que permitiria superar os critérios de proximidade geográfica e cultural para localização de subsidiárias, e sustentaria o avanço em regiões ainda não dominadas pelas multinacionais dos países desenvolvidos" (GINEBRA, 2011, p. 2). O estudo concluiu ainda que as subsidiárias são empresas de pequeno porte em seus países de atuação; cerca de $75 \%$ possuem menos de 500 funcionários. Outra conclusão refere-se ao nível de autonomia versus integração. Grande parte das multinacionais brasileiras (46\%) combina baixa autonomia e alta integração na gestão de suas subsidiárias. Isso significa que o controle ainda é a principal preocupação na gestão das operações no estrangeiro. A transferência de competências organizacionais é prioritariamente da matriz para as subsidiárias, em especial as competências de produção e comercialização, o que indica que ainda há muito a explorar em termos do potencial aberto pelas operações internacionais (Ibid.). 
Como resultado de um survey eletrônico envolvendo 76 subsidiárias de 36 matrizes de multinacionais brasileiras, conduzido entre 2010 e 2011, Fleury A., Fleury M. e Borini (2013), desenvolvem uma análise geral do comportamento das multinacionais brasileiras no tocante a três principais aspectos: (i) escolha da região geográfica; (ii) estágio de desenvolvimento do país de acolhimento, e (iii) condições de competição dos países de acolhimento.

No tocante à escolha da região geográfica, as subsidiárias que realizam o conjunto completo de atividades são preferencialmente estabelecidas na América Latina. A América Latina também é priorizada nos casos em que a subsidiária executa basicamente atividades de marketing e desenvolvimento de produtos com a produção permanecendo no Brasil. Regiões mais desenvolvidas como as da Europa, América do Norte e Ásia são preferidos quando a subsidiária executa atividades relacionadas ao marketing.

No que diz respeito à fase de desenvolvimento dos países de acolhimento, as multinacionais brasileiras, uma preferem localizar a sua produção em países em desenvolvimento. "Os investimentos brasileiros na África e sua perseverança em operar em países instáveis latinoamericanos, como Venezuela e Bolívia, exemplificam essa tendência" (FLEURY, A.; FLEURY, M.; BORINI, 2013, p. 112). Por outro lado, quando a atividade núcleo é a comercialização, as multinacionais brasileiras preferem se estabelecer em países desenvolvidos para explorar mercados mais ricos.

Quanto à competitividade do ambiente externo fatores como os de infraestrutura, condições da demanda e disponibilidade de mão de obra especializada, pareceu influenciar a escolha do local em que a subsidiária executa as atividades de produção no exterior. E fatores como condições de mercado (alta demanda e forte concorrência), influenciam multinacionais que vão para o exterior em busca de realizar atividades de produção e marketing.

O estudo também apresenta os resultados no tocante às transferências de competências de conhecimento da matriz para a subsidiária e vice-versa, fazendo um comparativo com o levantamento feito em 2006 e 2010/2011. Como já era de se esperar, os resultados de 2006 indicavam que a matriz brasileira priorizava transferência de competências relacionadas a produção e finanças, seguido por competências de marketing e de gestão de recursos humanos. As transferências sobre desenvolvimento de produto e serviços eram feitas em uma intensidade 
muito menor do que as primeiras quatro citadas. Já com relação à transferência reversa (subsidiárias para a matriz) constatava-se uma baixíssima intensidade para os cinco tipos de competências analisadas. Já os resultados do segundo levantamento - 2010/2011 indicaram atuações mais arrojadas tanto por parte da matriz como das subsidiárias. Os novos resultados indicaram que a transferência referente às competências de marketing, finanças e desenvolvimento do produto/serviço, da matriz para as subsidiárias, aumentou significativamente, ao passo que as transferências relativas à produção diminuíram significativamente. Com relação à transferência reversa, os resultados indicaram os fluxos referentes à produção aumentaram significativamente, enquanto os referentes às quatro outras competências (gestão de finanças, marketing e recursos humanos e desenvolvimento de produtos/serviços) permaneceram baixos (FLEURY, A.; FLEURY, M.; BORINI, 2013).

A partir desses resultados, os autores concluem que a principal mudança relaciona-se à competência de produção, no sentido de que as subsidiárias parecem ter aumentado as suas competências na produção até um ponto em que a matriz parece não considerar mais necessário realizar transferências desse tipo para elas. Outra conclusão refere-se ao status crescente das subsidiárias revelada pelo crescente fluxo de competências de marketing e finanças e desenvolvimento de produtos e serviços da matriz para a subsidiária. Por outro lado, a transferência reversa aumentou apenas para a produção (Ibid.). Isso indica que as subsidiárias de multinacionais brasileiras ainda têm um papel longe de ser inovador - classificação firmada por Ambos e Schlegelmilch (2007) para subsidiárias que aumentam ou criam novas competências tecnológica no exterior.

No que tange ao papel das subsidiárias brasileiras, outro estudo recente de Oliveira Júnior e Borini (2010) analisou 65 subsidiárias de 29 matrizes de EMNBRs e concluiu que é desejo das multinacionais brasileiras tornarem suas subsidiárias estrategicamente relevantes para a rede da corporação multinacional. Os resultados apontaram uma forte tendência de iniciativas com vistas em desenvolver os mercados locais e, em um nível secundário, em desenvolver soluções para os mercados globais. No entanto, as conclusões também apontam que as EMNBRs ainda estão longe de ser organizadas como uma rede diferenciada no âmbito de uma estratégia transnacional. Para concorrerem em pé de igualdade com outras multinacionais tradicionais, é preciso que sejam capazes de pular estágios e chegar com mais velocidade a uma estratégia em que cada subsidiária consiga se diferenciar e aproveitar todo o seu potencial dentro da rede 
corporativa de forma coordenada pela matriz. Para que isso se concretize, o estudo fez algumas recomendações às multinacionais brasileiras, quais sejam:

- Incentivar a criação de conhecimento no exterior;

- Localizar as subsidiárias em países e setores que têm contextos dinâmicos e competitivos;

- Incentivar o envolvimento com diversas redes de negócios no exterior;

- Procurar desenvolver conhecimentos nos países estrangeiros alinhados com as expectativas estratégicas da matriz no Brasil;

- Alinhar estrategicamente cada uma de suas operações internacionais por meio da integração, utilizando mecanismos de transferência de conhecimentos e promoção de atividades empresariais em determinados países estrangeiros, tendo como ponto de partida uma estratégia bem planejada e bem implantada globalmente.

Na busca de superação de todos os desafios citados, as empresas brasileiras, mesmo que tardiamente, têm empreendido esforços na direção de uma estratégia mais firme de expansão internacional que possibilite, sobretudo, a transferência das vantagens competitivas adquiridas no seu país de origem para os mercados globais. É provável que os resultados não sejam percebidos em curto prazo, mas certamente serão compensadores. Independentemente da forma escolhida de atuação, parece inevitável que o sucesso da estratégia de internacionalização exigirá não só um esforço mais direcionado, mas também comprometimento por parte das empresas, o que, consequentemente, poderá exigir mudanças estruturais e ajustes em seus sistemas e procedimentos do modelo de gestão (GINEBRA, 2011).

Após essa visão geral sobre a EMN e o contexto que se pretende estudar, o capítulo segue com a seção que introduz as teorias que formam as bases para o entendimento da transferência de conhecimento na EMN.

\subsection{O papel das subsidiárias e sua relação com a transferência de conhecimento}

A empresa multinacional é definida como "um grupo geográfico disperso, com objetivos organizacionais díspares, que inclui a sede e as subsidiárias situadas em diferentes nacionalidades" (GHOSHAL; BARTLETT, 1990, p. 603). Já a subsidiária de uma EMN pode 
ser definida como "qualquer unidade operacional controlada pela multinacional que esteja situada fora do país de origem" (BIRKINSHAW, 1997, p. 2007).

Estudos recentes têm afirmado que o desenvolvimento das capacidades da EMN não ocorre somente em sua sede ou em seu país de origem. Pelo contrário, as subsidiárias estão sendo identificadas como atores-chave dentro da EMN, independentemente de sua conceituação: corporação multinacional multifocal (PRAHALAD; DOZ, 1987), que busca aperfeiçoar as pressões pela integração global e pela responsabilidade local; empresa transnacional (BARTLETT; GHOSHAL, 1989), que combina responsabilidade local com eficiência global; empresa metanacional (DOZ, SANTOS E WILLIAMSON, 2001), que identifica, acessa e alavanca o conhecimento a partir de várias localizações internacionais; heterarquia (HEDLUND, 1986), em que as redes organizacionais são altamente flexíveis, com atividades dispersas e centros de conhecimento caracterizado pela comunicação aberta e relações não hierárquicas. A grande vantagem das subsidiárias são suas operações dispersas, as quais possibilitam realizar atividades de criação de valor nos países de acolhimento, muitas vezes por meio de sua inserção na rede de negócios locais. No caso específico do desenvolvimento de conhecimento, a rede de negócios local pode fornecer à EMN novos conhecimentos, ideias e oportunidades. Consequentemente, a inserção das subsidiárias em redes de negócios pode ser benéfica para o desenvolvimento do conhecimento (ANDERSSON; FORSGREN; HOLM, 2002).

Os primeiros trabalhos que ressaltam a importância da subsidiária tomam por base os custos de transação (BUCKLEY; CASSON, 1976) para defender que a razão da existência de uma EMN reside em sua capacidade de internalizar as externalidades, ou seja, de compensar as falhas de mercado - o fracasso do mercado em transacionar bens intermediários -, unindo recursos e atividades de uma forma mais eficiente do que se contassem com os atores dos mercados externos. Surge aí o argumento de que as empresas criam valor por meio das subsidiárias que podem combinar o conhecimento disperso, sobretudo quando se reconhece que os mercados muitas vezes não conseguem transferir esse conhecimento a um custo de transação compensatório (AMBOS, T.; AMBOS, B.; SCHLEGELMILCH, 2006). Além disso, “a existência de princípios organizacionais, tais como compartilhamento de valor, linguagens e códigos, facilitam a integração da organização como um todo" (KOGUT; ZANDER, 1992, p. 389). 
De acordo com a teoria de custos de transação, o processo de transferência de conhecimento e, mais especificamente, a transferência de tecnologia está dentro de um mercado considerado imperfeito, tanto porque nem todo o conhecimento existente no mercado está à venda; quanto porque vendedores e compradores não possuem as mesmas informações sobre o conhecimento em questão e sua aplicação; e ainda porque se espera que esses atores ajam de maneira oportunista. O oportunismo sugere que os agentes não são confiáveis, porque eles tendem a tomar decisões com base no auto interesse, tornando os contratos difíceis de serem cumpridos (WILLIAMSON, 1975 apud WAHAD et al., 2010). Dessa forma, cabe à EMN decidir se dependerá do mercado para determinar o preço e o conteúdo de suas ofertas, optando assim pela operação no exterior via exportações e licenciamento, ou se a empresa optará por internalizar suas atividades operando por intermédio de subsidiárias próprias no exterior.

Mais recentemente, Gupta e Govindarajan (2000, p. 473-474) reiteraram que, apesar da evidente sofisticação das transações dos mercados externos ao longo do tempo - seja pelo crescente aumento da abertura dos mercados internacionais, seja pela diminuição dos custos e da velocidade das transações, entre outras razões -,

\footnotetext{
seus mecanismos permanecem relativamente ineficientes no que tange à transferência do conhecimento, por duas razões: a primeira se dá porque o arcabouço do conhecimento especializado de qualquer empresa é tácito e, dessa forma, não comercializável; segundo, porque a transferência de conhecimento baseada em transações de mercado é frequentemente associada à externalidades negativas, tais como expropriação involuntária e risco de desenvolver novos competidores (GUPTA; GOVINDARAJAN, 2000, p. 473-474).
}

Contudo, os autores deixam claro que, a despeito de todas as evidências das vantagens superiores da EMN em lidar com o ativo conhecimento, isso não implica necessariamente que a transferência intrafirma seja uma ação realizada de modo trivial no que tange à efetividade e eficiência do processo. A razão disso é que há muitas barreiras que impactam negativamente o processo de transferência, entre elas os custos e as incertezas do processo, que impactam sobremaneira no sucesso das transferências intrafirma. Teece (1981, p. 4 apud GUPTA; GOVINDARAJAN, 2000) constatou que os custos de transferir a capacidade de fabricar um produto ou um processo entre unidades internacionais podem chegar, em média, a 19\% dos custos totais de manufatura desse projeto. Tais custos chegaram a representar $59 \%$ dos custos 
totais em um dos 26 projetos investigados pelo autor ${ }^{4}$. Em outro estudo, Mansfield et al. (1983) constatou que os custos de transferência tecnológica em projetos de implantação de help desk chegam a uma média de $20 \%$ dos custos totais do projeto.

No tópico seguinte, será apresentada a evolução das pesquisas sobre a crescente importância do papel da subsidiária na rede da EMN.

\subsubsection{A evolução do papel das subsidiárias}

Este tópico parte do pressuposto de que os diferentes aspectos que permeiam os papéis das subsidiárias, tais como escopo geográfico, autonomia, importância estratégica, ambiente local no qual estão inseridas, entre outros, influenciam o tipo e o grau de inovação em processo e produto que venha a ser desenvolvida pela subsidiária (FROST; BIRKSHAWN; ENSIGN, 2002). Outro pressuposto assumido é que os papéis das subsidiárias se modificam ao longo do tempo (PATERSON; BROCK, 2002).

As pesquisas das últimas três décadas indicam que as subsidiárias têm expandido seu papel na rede da corporação, saindo de atividades downstream - atividades a jusante na cadeia de valor -, tais como marketing, vendas e distribuição, e passando a se responsabilizarem por atividades upstream - a montante na cadeia de valor -, tais como pesquisa e desenvolvimento, produção e estabelecimento de estratégias (MUDAMBI; NAVARRA, 2004). Com efeito, estudos recentes têm reconhecido que a subsidiária pode atuar como fonte de inovações (BIRKINSHAW; HOOD; JONSSON, 1998; PEARCE; PAPANASTASSIOU, 1999) que podem ser transferidas e utilizadas por suas sedes, contribuindo assim para a vantagem competitiva de toda a corporação (AMBOS, T.; AMBOS, B.; SCHLEGELMILCH, 2006). A constatação da importância crescente do papel da subsidiária ao longo do tempo é representada, essencialmente, pelas tendências de aumento das responsabilidades operacionais da subsidiária e criação de conhecimento de forma dispersa na rede multinacional (Ibid.).

\footnotetext{
${ }^{4}$ Teece (1976, p. 36) “[...] define custo de transferência tecnológica como sendo o custo de transferir e absorver conhecimento na medida necessária para que o processo seja realizado de forma efetiva. Os custos totais para a implantação de um projeto de fabricação no exterior, nos estudos de Teece, incluem adicionalmente aos custos de transferir, os custos de todas as atividades envolvidas para o estabelecimento de uma planta num país estrangeiro."
} 
O estudo de Paterson e Brock (2002) clarifica essa nova perspectiva na medida em que desenvolve uma visão sistemática, a partir da literatura da área, sobre a evolução da gestão das subsidiárias. Os autores identificaram quatro grandes correntes de pesquisa, que foram se desenvolvendo ao longo do tempo, com diferentes perspectivas de análise do papel da subsidiária, a saber: i) corrente estratégia-estrutura; ii) corrente relacionamento matrizsubsidiárias; iii) corrente papel das subsidiárias; iv) corrente evolução das subsidiárias.

A primeira corrente de estudos teve início na década de 1970 e focalizou o tema estratégia e estrutura da EMN. Nesta corrente, analisa-se a gestão das subsidiárias a partir de uma perspectiva estática cujo objetivo era investigar a relação entre a estratégia e a estrutura da EMN, destinando-se pouca atenção ao entendimento das características da subsidiária. A preocupação era encontrar estruturas mais flexíveis para gerenciar a rede multinacional, mas sempre na perspectiva de que as estratégias partiriam das deliberações da matriz (PATERSON; BROCK, 2002). Surgem novas configurações para as empresas multinacionais, como, por exemplo, o conceito de transnacionais.

A segunda corrente discute o relacionamento matriz-subsidiária e teve início no final da década de 1970. Essa corrente focalizou a centralização e a tomada de decisão pela matriz, bem como a integração das atividades das subsidiárias, com vistas em maximizar os resultados para a matriz. A novidade é que esses estudos passaram a considerar a possibilidade de a subsidiária ter alguma autonomia ou influência na rede da corporação (PATERSON; BROCK, 2002).

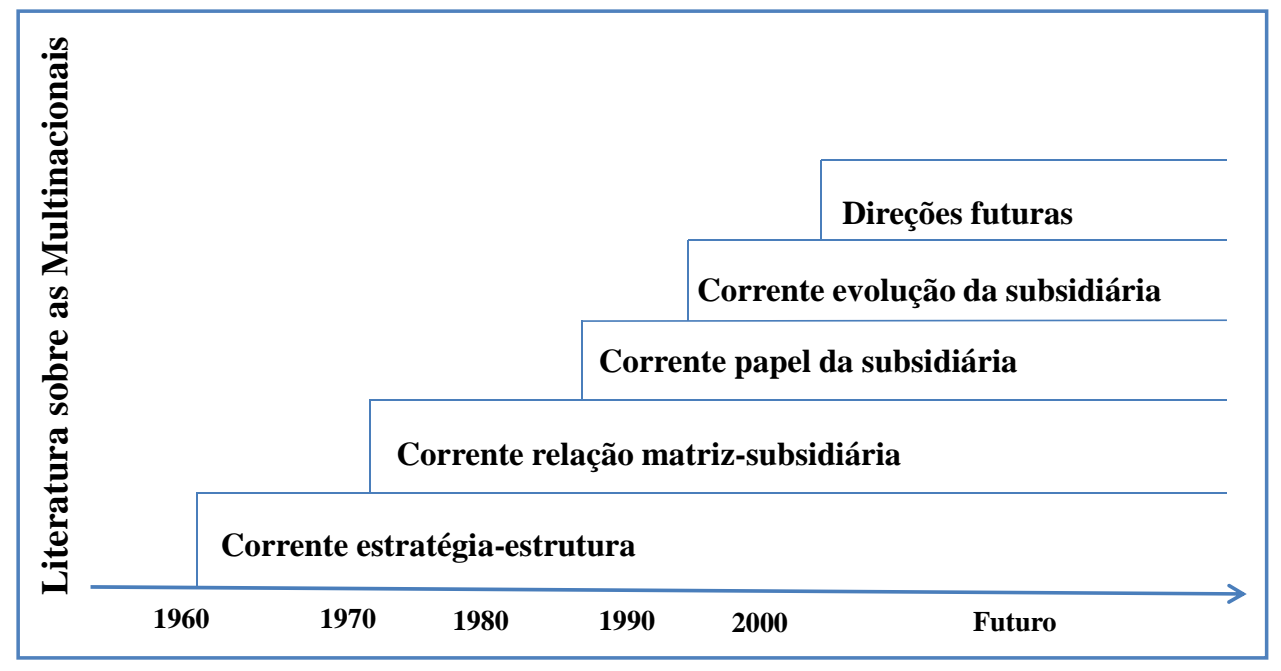

Ilustração 3: A evolução do papel da subsidiária

FONTE: PATERSON; BROCK, 2002, p. 140. 
A terceira corrente surgiu no final da década de 1980 e a sua preocupação foi compreender o papel das subsidiárias. Ela mudou o enfoque dado até então pelas pesquisas anteriores e passou a considerar a subsidiária como a principal unidade de análise e, por conseguinte, sua influência em toda a corporação. Esta corrente identificou que cada subsidiária poderia assumir papéis diferenciados dentro de uma mesma corporação, o que significa que cada subsidiária pode variar sistematicamente em sua propensão para criar novas capacidades ou recursos, ou para utilizar os recursos desenvolvidos em outras unidades da EMN. Aqui, a literatura volta sua atenção a assuntos como: papéis estratégicos das subsidiárias, mandatos de produtos globais, tipologias dos papéis da subsidiária e centros de excelência. Esses trabalhos identificaram diferentes tipologias, que classificaram as subsidiárias segundo seu papel dentro da rede (por exemplo, BARTLETT; GHOSHAL, 1986, 1989; HEDLUND, 1986; GUPTA; GOVINDARAJAN, 1991; PRAHALAD; DOZ, 1981). Todas essas tipologias são resumidas no estudo de Paterson e Brock (2002). Contudo, a definição dos papéis, segundo esses estudos, decorria das decisões da matriz (PATERSON; BROCK, 2002; BIRKINSHAW; PEDERSEN, 2009).

A quarta corrente, evolução do papel das subsidiárias, configurou-se, a partir de meados da década de 1990, quando surge o pressuposto de desenvolvimento da subsidiária com base em suas próprias decisões estratégicas (PRAHALAD; DOZ, 1981). Tais estudos apontam para a importância estratégica das subsidiárias, ou seja, o quanto a filial pode desenvolver sua importância e suas decisões estratégicas - particularmente em seu ambiente local ou em suas relações com a rede de negócios local -, bem como contribuir diretamente para a construção das vantagens competitivas de toda a corporação. De modo geral, os estudos procuram verificar quais fatores podem favorecer o desenvolvimento das estratégias nas subsidiárias, as quase teriam a responsabilidade de desenvolver e transferir o conhecimento de forma regional ou global dentro da corporação. Os fatores mais destacados como condicionantes do papel das subsidiárias costumam estar relacionados ao desenvolvimento e/ou à combinação dos seguintes aspectos: disponibilidade de recursos, mudanças de competição no ambiente local, pressões do governo local, iniciativa (ou escolhas da subsidiária), entre outros fatores (PATERSON; BROCK, 2002; FROST; BIRKINSHAW; ENSIGN, 2002).

A despeito de se constatar uma grande evolução na compreensão sobre os fatores determinantes do desenvolvimento e transferência de conhecimento, pela subsidiária, de forma global ou regional dentro da rede, muito ainda há para ser explorado (FROST; BIRKINSHAW; ENSIGN, 
2002; BIRKINSHAW; HOOD; JONSSON, 1998), porque os conceitos e a própria gestão da corporação multinacional estão em constante evolução (FROST; BIRKINSHAW; ENSIGN, 2002). Ademais, quando se trata de subsidiárias de EMNEs, o entendimento do papel das subsidiárias parece ser primordial tendo em vista que a captura de novos conhecimentos pode se configurar nelas de forma diferenciada das EMNs tradicionais. Outro aspecto importante é que a posterior transferência de conhecimento para a rede é um forte condicionante da busca de competitividade com os players tradicionais (MATHEWS, 2006).

Birkinshaw e Hood (1998b), ao discorrer sobre a corrente da evolução das subsidiárias, entendem essa evolução como o aumento ou a atrofia de suas capacidades que desencadearam o estabelecimento ou perda de suas responsabilidades no tempo. Como essa corrente visa estabelecer um equilíbrio entre as correntes anteriores, Birkinshaw e Hood (1998b) utilizam uma abordagem integrativa para apresentar a ideia da evolução da subsidiária relacionada às suas capacidades e consideram tanto os fatores ligados à matriz quanto os ligados à subsidiária e ao ambiente local para explicar como ocorre a evolução das subsidiárias. Sendo assim, a evolução da subsidiária é tida como resultante da combinação de três conjuntos de fatores: determinantes da matriz, determinantes das subsidiárias e determinantes do ambiente local, conforme segue:

- Determinantes da EMN (perspectiva da matriz): decisões tomadas pelos gerentes da matriz sobre a alocação das atividades para as subsidiárias;

- Determinantes da subsidiária (escolha da subsidiária, capacidade de decisão autônoma): decisões tomadas pelos gerentes das subsidiárias sobre as atividades assumidas pelas subsidiárias;

- Determinantes do ambiente local (oportunidades e ameaças do ambiente local): influência dos fatores ambientais sobre as decisões tomadas pelos gerentes da matriz e das subsidiárias considerando as atividades empreendidas pelas subsidiárias.

O processo de delegar responsabilidades às subsidiárias é um reconhecimento explícito pela matriz de que as capacidades da subsidiária são valiosas. Se as capacidades não são valiosas para a corporação, não há mudança positiva nas responsabilidades e, consequentemente, não há desenvolvimento da filial. As responsabilidades são móveis e as subsidiárias competem por responsabilidades no ambiente EMN; sendo assim, com o passar do tempo e pela combinação desses determinantes, a subsidiária vai alterando seu papel por meio da aquisição ou perda de 
responsabilidades e pelo aumento ou atrofia de suas capacidades. É desse processo de ganhos/perdas de responsabilidades e capacidades que surge a evolução da subsidiária (BIRKINSHAW; HOOD, 1998b).

No tocante à relação do papel da subsidiária com o conhecimento, estudos sugerem que o fluxo de conhecimento intraempresa multinacional é um determinante-chave do poder de barganha da subsidiária (MUDAMBI; NAVARRA, 2004). Dessa maneira, a criação do conhecimento pelas subsidiárias da EMN tem sido mapeada de diversas formas, dentre elas (MUDAMBI; NAVARRA, 2004):

- Subsidiárias com mandato mundial de produtos - esses estudos indicam que um papel importante da subsidiária pode ser sua responsabilidade por uma capacidade específica de desenvolver produtos que se ajustem não apenas às necessidades locais ou regionais, mas às necessidades globais (BIRKINSHAW; MORRISON, 1995);

- Subsidiárias com centros de excelência - esses estudos deixam de considerar a subsidiária como tendo um único papel dentro da rede e passam a considerar que ela pode assumir diversos papéis, de acordo com suas áreas funcionais. Sendo assim, ao mesmo tempo em que a área de pesquisa e desenvolvimento (P\&D) de uma subsidiária pode assumir o papel de centro de excelência, tendo em vista o reconhecimento de suas capacidades por toda a rede, a área de manufatura da mesma subsidiária pode desempenhar uma função apenas local (HOLM; PERDERSEN, 2000; FROST; BIRKINSHAW; ENSIGN, 2000). Isso indica que nem todas as capacidades desenvolvidas pelas áreas funcionais da subsidiária podem garantir-lhe o status de centro de excelência, a menos que tais capacidades sejam também relevantes para o contexto das outras unidades da empresa, pois uma capacidade, mesmo que melhore a competitividade da subsidiária em particular, pode ser neutra para as outras filiais e a matriz.

- Subsidiárias que criam conhecimento (home-base augmenting) ${ }^{5}$ - subsidiárias que possuem esta característica procuram absorver as competências especializadas

\footnotetext{
${ }^{5}$ De acordo com Cantwell e Mudambi (2005), as subsidiárias podem ser categorizadas em dois grupos principais: as que possuem competência de criar e adquirir novos conhecimentos (exploration) e as que possuem competência de adaptar os conhecimentos existentes em outras unidades (exploitation). Enquanto as subsidiárias do segundo
} 
(pesquisadores e pesquisas) dos países onde atuam, com vistas em desenvolver a capacidade de criar e adquirir novos conhecimentos considerados importantes para o desenvolvimento de novas tecnologias e produtos relevantes para a corporação (KUEMMERLE, 1999).

Essa diversidade de visões sobre o papel das subsidiárias indica que grande parte dos ativos da EMN está sob o controle da subsidiária, que, sabendo disso, barganha seu poder dentro da empresa (MUDAMBI; NAVARRA, 2004).

\subsubsection{Inovação nas subsidiárias e o desenvolvimento de suas capacidades tecnológicas}

O escopo da inovação é amplo e pode incluir inovações tecnológicas (novas tecnologias, produtos e serviços) e inovações organizacionais (novos procedimentos, políticas e formas de organização) (VAN DE VEN, 1986). Este estudo está particularmente interessado na análise das inovações do tipo tecnológica que se restringe a implantação de produtos e/ou processos tecnológicos novos ou substancialmente aprimorados. Uma inovação de produto é considerada implantada ao ser introduzida no mercado, e uma inovação de processo é considerada implantada ao ser utilizada para a produção de bens ou serviços ou ao se destinar a aumentar a eficiência da produção e da entrega de produtos já existentes. Essa definição está ligada à exigência mínima de que o produto ou processo seja novo (ou substancialmente melhorado) para a empresa, e não necessariamente para o mercado/mundo (OCDE, 2005, p. 54).

A inovação é percebida como importante para a EMN porque esta é particularmente hábil em combinar o conhecimento de diferentes tecnologias e locais, exatamente devido a sua facilidade de disseminação interna do conhecimento. $\mathrm{O}$ desenvolvimento da inovação na subsidiária é conceituado como um processo no qual a subsidiária desenvolve uma ideia de forma completa e que é adotada por subsidiárias pares, fornecedores e/ou clientes (VAN DE VEN, 1986;

grupo são engajadas principalmente na implantação das competências desenvolvidas em outras unidades da corporação, as subsidiárias do primeiro grupo são cada vez mais capazes de desenvolver, elas mesmas, novos conhecimentos. No entanto, March (1991) argui que deve haver um equilíbrio entre a criação e a adaptação dos conhecimentos na empresa, pois aquelas unidades que focalizam fortemente as atividades de criação, vendo-as como alternativas para as necessidades futuras, podem sofrer com incertezas e ideias imaturas. Em contraposição, aquelas que focalizam fortemente as atividades de adaptação estão em busca de alternativas para as necessidades presentes, o que pode limitar suas possibilidades futuras (MARCH, 1991, p. 71). 
CIABUSCHI, DELLESTRAND; MARTÍN, 2011). Muitos autores reforçam que a criação de valor pelas subsidiárias depende em grande parte de sua capacidade inovar em produtos, produção e processos e serviços organizacionais (BARTLETT; GHOSHAL, 1990; ANDERSSON; FORSGREN; HOLM, 2002).

Segundo Ciabuschi e Martín (2012), analisar o impacto de certa inovação no desenvolvimento e no desempenho da subsidiária é útil porque prediz o potencial impacto que a transferência de conhecimento relacionado terá sobre o desempenho dos receptores. Um dos aspectos centrais que permeiam a inovação, é que sua difusão não se dá pela simples adoção de novos conhecimentos e tecnologias, ao contrário, perpassa pela forma como as empresas adotam e aprendem a construir novos conhecimentos e tecnologias. $\mathrm{O}$ acesso ao conhecimento e à tecnologia pode depender, em grande medida, das conexões entre empresas e organizações, seja porque o conhecimento tem uma característica tácita, que se configura nas mentes das pessoas, ou porque está imbricado nas rotinas das organizações. Sendo assim, para ter acesso a conhecimentos e tecnologias de outras empresas, é necessária a interação direta com as pessoas que detêm conhecimentos tácitos ou ter acesso a rotinas organizacionais (OCDE, 2005).

Os benefícios trazidos pela inovação às subsidiárias são inúmeros. Eles podem conduzir a subsidiária ao sucesso no mercado, aumentando as vendas e o volume de negócios, podem melhorar a eficiência de produção e a redução de custos ou contribuir para a vantagem competitiva de toda a EMN (CIABUSCHI; DELLESTRAND; MARTÍN, 2011). Além disso, uma inovação pode influenciar novas decisões de investimentos em P\&D, e, uma vez transferindo suas inovações para as subsidiárias pares, a subsidiária pode alcançar uma posição de destaque dentro da rede da EMN. Em resumo, o impacto do desenvolvimento da inovação na subsidiária pode ser conceituado como um conjunto de efeitos ao longo de diferentes dimensões da subsidiária, que se conectam em atividades de curto, médio e longo prazo (ANDERSSON, HOLM; PEDERSEN, 2000, 2007; FORSGREN et al., 2000; CIABUSCHI, DELLESTRAND; MARTÍN, 2011).

Andersson, Holm e Pedersen (2002) advertem que, para melhor entender por que algumas subsidiárias atingem um nível superior de desempenho em mercados locais e globais, é importante explicar como essa capacidade é construída dentro da subsidiária. A capacidade tecnológica de uma organização é definida como o acúmulo de conhecimentos, habilidades, experiências e base organizacional que habilitam a empresa a realizar a produção e diferentes 
graus de atividade de inovação. Esses conhecimentos e capacidades são acumulados, pela aprendizagem, por indivíduos (habilidades, conhecimento e experiência) e sistemas organizacionais (BELL; PAVITT, 1995; IAMMARINO; PADILLA-PÉREZ; TUNZELMANN, 2008). Tal conhecimento refere-se às técnicas "know-how" e "know-why" sobre as atividades de adaptação, melhoria, experimentação, desenvolvimento, design e também de $\mathrm{P} \& \mathrm{D}$ em produtos e processos. Essas capacidades são acumuladas nos recursos humanos e nos sistemas organizacionais que existem dentro e fora da empresa. Esses autores indicam haver dois tipos de capacidades em uma empresa. Capacidades tecnológicas são também definidas como o resultado do aprendizado tecnológico em que uma empresa adquire conhecimento codificado (ex. máquinas, equipamentos, manuais). Combina conhecimento codificado com conhecimento tácito e constrói um estoque de conhecimento tácito específico. Para trabalhar o conceito de capacidades tecnológicas de um modo mais específico, Bell e Pavitt (1995) fazem uma diferenciação entre capacidade de produção e capacidade tecnológica. Segundo os autores, capacidades produtivas estão associadas à produção com certo nível de eficiência e com dados recursos (equipamentos, pessoal, conhecimento, métodos, etc.), já as capacidades tecnológicas referem-se aos recursos necessários para gerar e gerenciar mudanças técnicas, incluindo habilidades, conhecimento, experiência e estruturas e relações institucionais (FIGUEIREDO; BRITO, 2011).

Para Figueiredo e Brito (2011), em vez de identificar níveis de capacidade de inovação em termos de quantidades específicas e qualidades de bases de conhecimento, como, por exemplo, citações de patentes e despesas em P\&D, o melhor a fazer é identificar os níveis de capacidade que são necessários para aumentar a atividade de inovação. A abordagem desenvolvida inicialmente por Lall (1992, p. 167) e sucessivamente ampliada por outros autores, como Bell e Pavitt (1995), Figueiredo (2002), Iammarino, Padilla-Pérez e Tunzelmann (2008) e Figueiredo e Brito (2011), faz a diferenciação do nível de capacidade da empresa, de acordo com os diferentes graus de novidade de inovação, em termos de processos, produtos, serviços e organização. Essa abordagem sugere que capacidades tecnológicas podem evoluir de um baixo grau de complexidade, como atividades de rotina e pequenas adaptações, para um alto grau de complexidade e maior risco, como inovação baseada em pesquisas científicas.

De acordo de Lall (1992), é possível distinguir as capacidades de desenvolvimento de produto e processo em três categorias: básica, intermediária e avançada. As capacidades tecnológicas básicas são acumuladas por meio dos processos básicos das atividades de produção; as 
intermediárias, a partir de atividades ou esforços conduzidos em base mais específica; e as avançadas são desenvolvidas por meio de atividades de P\&D. O estudo traça a relação do grau de complexidade com as diversas funções que representam as capacidades tecnológicas na empresa, tais como: capacidade de investimento (pré-investimento e execução do projeto), de produção (engenharia de processo e de produto, engenharia industrial) e de ligação com outros agentes da economia. Destaca-se ainda que essas funções não são exaustivas nem precisam ser desempenhadas por todos os setores da indústria (Ibid.). O Quadro 1 a seguir apresenta o detalhamento do nível de produção da classificação de Lall (1992), deixando de fora o nível de pré-investimento e execução do projeto.

Quadro 1: Capacidade tecnológica do desenvolvimento de produto e processo

\begin{tabular}{lll}
\hline & \multicolumn{2}{c}{ Capacidade Tecnológica } \\
\hline Grau de Complexidade & \multicolumn{1}{c}{ Produto } & \multicolumn{1}{c}{ Processo } \\
\hline $\begin{array}{l}\text { Básica } \\
\text { (rotinas, baseada em experiência) }\end{array}$ & $\begin{array}{l}\text { Assimilação da tecnologia de } \\
\text { produtos importados à } \\
\text { necessidade do mercado local }\end{array}$ & $\begin{array}{l}\text { Assimilação da tecnologia de } \\
\text { processos }\end{array}$ \\
\hline $\begin{array}{l}\text { Intermediária } \\
\text { (adaptativa, baseada em pesquisa }\end{array}$ & $\begin{array}{l}\text { Melhoria da qualidade do produto, } \\
\text { assimilação da tecnologia de } \\
\text { novos produtos importados }\end{array}$ & $\begin{array}{l}\text { Adaptação de processos, } \\
\text { economia de custos, } \\
\text { licenciamento de novas } \\
\text { tecnologias }\end{array}$ \\
\hline $\begin{array}{l}\text { Avançada } \\
\text { (inovação, baseada em pesquisa e } \\
\text { riscos) }\end{array}$ & $\begin{array}{l}\text { Inovação de produto “in-house" - } \\
\text { pesquisa básica }\end{array}$ & $\begin{array}{l}\text { Inovação de processo "in- } \\
\text { house", pesquisa básica }\end{array}$ \\
\hline
\end{tabular}

FONTE: LALL, 1992.

Aplicando essas categorias às áreas de desenvolvimento de produto em subsidiárias de multinacionais, é possível trabalhar com três papéis estratégicos essencialmente distintos:

- A subsidiária que adapta (tropicaliza) produtos existentes, desenvolvidos em outras unidades da multinacional, às necessidades específicas do mercado onde atua;

- A subsidiária que melhora significativamente produtos existentes;

- A subsidiária que cria produtos novos.

Importante notar, que essa tipologia destaca as capacidades que são internas à subsidiária, mas também reconhece o fato de que uma parte substancial de suas capacidades encontra-se na rede corporativa e em organizações locais, por exemplo, universidades, institutos de pesquisa, empresas de consultoria, fornecedores e clientes (FIGUEIREDO; BRITO, 2011). 
Cabe ressaltar que, como reforça Figueiredo e Brito (2012), a literatura sobre capacidades tecnológicas em empresas multinacionais emergentes difere significativamente da literatura sobre capacidades tecnológicas de empresas de fronteira tecnológica, uma vez que as multinacionais emergentes geralmente importam sua tecnologia do exterior e muitas vezes carecem até de capacidades tecnológicas básicas (FIGUEIREDO, 2002; FIGUEIREDO; BRITO, 2012; LALL, 1992). Isso implica que, nos mercados emergentes, a definição de inovação pode incluir todos os tipos de pesquisa e aperfeiçoamento do desenvolvimento de produtos e processos, pois ignorar as capacidades tecnológicas das subsidiárias mais básicas poderia levar a uma conclusão errônea de que esforços tecnológicos em países retardatários são inexistentes (LALL, 1992, p. 166). O autor defende ainda que capacidades tecnológicas básicas podem facilmente evoluir no sentido de se transformar em capacidades tecnológicas mais complexas (Ibid.).

\subsection{Perspectivas teóricas da transferência reversa de conhecimento}

Diversas são as correntes teóricas que formam as bases do conhecimento sobre o tema transferência de conhecimento em EMNs e que, portanto, viabilizam sua análise. Ensign (2000) sugere a análise de três correntes teóricas a) teoria evolucionária; b) visão baseada em recursos; c) visão baseada no conhecimento. Tavani, Giroud e Andersson (2013) sugerem a análise das correntes: visão baseada em recursos, visão baseada em conhecimento e teoria das redes. $\mathrm{O}$ recorte teórico apresentado por Rabiosi (2006) relaciona a teoria econômica representada pela teoria dos custos de transação fundada por Hymer (1976), a teoria de cluster (PORTER, 2000, por exemplo) e a teoria racional representada pela visão baseada no conhecimento (KOGUT; ZANDER, 1992, 1993, por exemplo), a teoria de redes (BARTLETT; GHOSHAL, 1989, por exemplo) e a teoria de aprendizagem organizacional (HEDLUND, 1986, por exemplo), que estão ligadas entre si pela ideia de que a EMN é um repositório de conhecimento e uma forma superior de organizar a transferência de conhecimento para toda a sua rede internacional, por meio de relações verticais e laterais (Ibid.). O Quadro 2 apresenta as principais correntes teóricas que tratam da transferência de conhecimento da EMN. 
Quadro 2: Correntes teóricas para a análise da transferência de conhecimento

\begin{tabular}{|c|c|c|c|}
\hline & $\begin{array}{c}\text { Fluxo de conhecimento } \\
\text { Hierárquico }\end{array}$ & $\begin{array}{c}\text { Fluxo de conhecimento } \\
\text { Externo }\end{array}$ & Fluxo de conhecimento em Rede \\
\hline Teoria & - Custos de transação & - Teoria de cluster & $\begin{array}{l}\text { - Visão baseada em } \\
\text { conhecimento } \\
\text { - Teoria de redes } \\
\text { - Teoria de aprendizagem } \\
\text { organizacional }\end{array}$ \\
\hline $\begin{array}{l}\text { Fluxo de } \\
\text { conhecimento }\end{array}$ & $\begin{array}{l}\text { Única direção } \\
\text { (da matriz para a } \\
\text { subsidiária) }\end{array}$ & $\begin{array}{l}\text { Direção dupla } \\
\text { (integração local: da } \\
\text { subsidiária para o seu } \\
\text { mercado local e vice- } \\
\text { versa) }\end{array}$ & $\begin{array}{l}\text { Múltiplas direções } \\
\text { (da matriz para a subsidiária e da } \\
\text { subsidiária para a matriz) }\end{array}$ \\
\hline Foco & $\begin{array}{l}\text { Exploração de vantagens } \\
\text { no mercado externo }\end{array}$ & $\begin{array}{l}\text { Aproveitamento do } \\
\text { conhecimento local pela } \\
\text { subsidiária }\end{array}$ & Rede como fonte de ativos \\
\hline $\begin{array}{l}\text { Fonte do } \\
\text { conhecimento }\end{array}$ & Matriz & $\begin{array}{l}\text { Ambiente local da } \\
\text { subsidiária }\end{array}$ & Relações com a rede de negócios \\
\hline $\begin{array}{l}\text { Unidade de } \\
\text { análise }\end{array}$ & Matriz & Subsidiária & Rede Multinacional \\
\hline P\&D & Centralizado & Dispersa & Integrada (em rede) \\
\hline
\end{tabular}

FONTE: Adaptado de Rabiosi (2006).

Para os fins deste estudo, entende-se que as teorias mais apropriadas para formar as bases teóricas do estudo devem partir da categoria de fluxo de conhecimento em rede. Das três teorias apresentadas nessa categoria por Rabiosi (2006), utiliza-se a visão baseada em recursos e a teoria de redes. Ressalta-se que a teoria da aprendizagem organizacional não será utilizada no estudo porque não é seu foco investigar os mecanismos de aprendizagem da subsidiária.

Nos tópicos seguintes serão apresentadas com mais detalhes a visão baseada em conhecimento e a teoria de redes.

\subsubsection{A visão baseada no conhecimento}

A visão baseada em conhecimento (em inglês, knowledge-based view - KBV) surgiu no final da década de 1980 e início da década de 1990 com o pressuposto subjacente de que as empresas, diferentemente dos mercados, são capazes de criar e utilizar o conhecimento para elevar a criação de valor (KOGUT; ZANDER, 1992; NONAKA, 1994). A perspectiva da KBV foi originalmente desenvolvida a partir de visão baseada em recursos empresa (resource-based view - RBV) (BARNEY, 1991). Os pesquisadores ampliaram a definição de "recurso" para incluir, além do capital físico e financeiro, o capital humano e o conhecimento; a partir daí, desenvolveram uma teoria segundo a qual a criação e transferência de conhecimento são igualmente obtidas e desenvolvidas, e o conhecimento, como os outros recursos, também é um 
ativo estratégico e por isso contribui para se obter e sustentar uma vantagem competitiva. Nessa perspectiva, a KBV é fundamental para explicar como as empresas gradualmente crescem e alcançam vantagens competitivas sustentáveis por meio da aprendizagem e da criação do conhecimento (KOGUT; ZANDER, 1992, 1993).

Pesquisadores que adotam uma perspectiva baseada no conhecimento enfatizam que o conhecimento da empresa, bem como sua capacidade de gerar conhecimento, está no cerne da empresa. Assim, a empresa pode ser vista como um repositório de conhecimento (GRANT, 1996; TSOUKAS, 1996) e, nessa perspectiva, sua principal tarefa é integrar e desenvolver o conhecimento especializado residente na empresa (GRANT, 1996). Como repositório de conhecimento, as empresas constroem e acumulam ao logo do tempo seu conhecimento específico, o que costuma torna-las especializadas em determinado produto ou serviço (KOGUT; ZANDER, 1993). EMNs transferem a suas subsidiárias conhecimentos específicos que são tidos como "vantagens de propriedade"6 superiores, tais como produção, marketing e conhecimento técnico; tais vantagens devem ser superiores as da concorrência por causa da desvantagem inerente de operar no ambiente do país anfitrião (HYMER, 1976). Partindo-se desse pressuposto, o entendimento dos mecanismos e estruturas apropriados para transferir esse conhecimento internamente na rede multinacional passou a ser uma das grandes preocupações da literatura da área (KOGUT; ZANDER, 1993).

No entanto, estudos recentes têm argumentado que as empresas não são mais vistas como repositório de conhecimento, mas sim como um instrumento de transferência de conhecimento entre subsidiárias com vistas em contribuir para o desenvolvimento conhecimento para toda a rede da EMN (GUPTA; GOVINDARAJAN, 2000; HOLM; PEDERSEN, 2000). Em suas obras subsequentes, Kogut e Zander (1995) desafiam a teoria dos custos de transação ao afirmar que a EMN cresce não porque existam falhas de mercado, mas porque ela possui uma eficiência superior em transferir internamente o conhecimento. Os autores defendem que a empresa irá se especializar na comunicação do conhecimento de difícil entendimento e codificação, transferindo-o para suas filiais porque pode fazê-lo de modo mais rápido e com menor custo. Contudo, Kogut e Zander (1993) ressaltam que, mesmo que de forma intraorganizacional, nem sempre o conhecimento é facilmente transferível, pois em muitos casos ele possui

\footnotetext{
${ }^{6}$ Termo específico representa o "o" de ownership (vantagem de propriedade) do paradigma eclético (OLI) de Dunning (2001).
} 
características tácitas e idiossincráticas. E sendo tácito, não é fácil de ser comunicado e compartilhado, pois é altamente pessoal e profundamente enraizado na ação e de um indivíduo envolvido num contexto específico (NONAKA, 1994). Corroborando isso, Gupta e Govindarajan (1993, p. 330) afirmam que "as transações de conhecimento interfirma são suscetíveis a várias imperfeições de mercado, incluindo problemas de reconhecimento, de divulgação, e de externalidades negativas”. Desta forma, o conhecimento e seu posterior compartilhamento intrafirma tornam-se aspectos fundamentais para sustentar o processo de internacionalização.

Sendo assim, de acordo com a KBV, as EMNs, mais do que repositórios de conhecimento (KOGUT; ZANDER, 1992), são vistas como instrumentos de transferência do conhecimento por meio de subsidiárias que contribuem para o desenvolvimento do conhecimento (GUPTA; GOVINDARAJAN, 2000).

\subsubsection{Teoria das redes}

Uma vez que uma empresa não pode deter todos os recursos e conhecimentos necessários para se manter, em razão de sua interdependência de recursos, sua inserção em uma rede de relações torna-se importante para a aquisição de capacidades competitivas (ANDERSSON; FORSGREN, 2000). Assim, a conduta e o desempenho das empresas são influenciados de forma importante pelas redes estratégicas em que estão inseridas (Ibid.), pois um dos aspectos que viabilizam as trocas de recursos e a transferência de conhecimento intraorganizacional são os vínculos sociais criados pelas unidades da multinacional. Tais vínculos são estudados pela teoria das redes - uma corrente de estudos que se tem mostrado fundamental como pano de fundo para as discussões sobre a transferência de conhecimento. As bases da teoria das redes são formadas pela visão baseada em recursos (em inglês, resource based review - RBV), uma vez que essa teoria defende que as subsidiárias possuem capacidades diferenciadas de acordo com seus recursos (ENRIGHT; SUBRAMANIAN, 2007), bem como pela KBV, que sugere que os laços sociais facilitam a criação de novos conhecimentos organizacionais (KOGUT; ZANDER, 1992; TSAI, 2000).

Para a teoria das redes, a EMN é uma rede de negócios com unidades diferenciadas onde o conhecimento é criado por vários atores da rede e transferido para unidades inter-relacionadas (HELDLUND, 1994; BARTLETT; GOSHAL, 1989; GUPTA, GOVINDARAJAN, 2000). A rede de negócios tem como pré-requisito os laços relacionais que unem as unidades dispersas e 
formam o arranjo da EMN (NOHRIA; GHOSHAL, 1997). A diferenciação refere-se ao argumento de que o comportamento, as decisões e, consequentemente, o desempenho dos atores da rede são afetados pelo contexto social e pelas relações formadas nesse ambiente (GRANOVETTER, 1985).

A diversificação das unidades dispersas é tida como vantajosa porque sugere que pode haver benefícios de sinergia para a troca de recursos ou transferência de conhecimentos entre as unidades relacionadas dentro da mesma organização (RUMELT 1974, apud TSAI, 2000). Em outros termos, a teoria das redes examina o papel das unidades da EMN de criar, disseminar e alavancar o conhecimento em uma base mundial (GHOSHAL; BARTLETT, 1990; NOHRIA; GHOSHAL, 1997; TSAI, 2000).

Dessa forma, o conhecimento e, mais especificamente, as atividades de inovação de uma unidade da EMN dependem do tipo e do nível de envolvimento da unidade com a rede de negócios - interna e externa - (ANDERSSON; FORSGREN; HOLM, 2002). Ou seja, quanto mais fortes os laços com os outros atores da rede, maiores as possibilidades de aprendizado (Ibid.) e, por conseguinte, de criação de valor para a corporação. Sendo assim, a vantagem competitiva das EMNs reside em sua habilidade de explorar localmente o conhecimento disponível via sua rede de negócios e de, posteriormente, transferi-lo para as outras unidades da rede intraorganizacional (BIRKINSHAW; HOOD; JONSSON, 1998; KOGUT; ZANDER, 1993).

Relações interunidades são consideradas, portanto, uma importante parte do processo de aprendizagem organizacional porque "possibilitam às unidades descobrir novas oportunidades e obter novos conhecimentos através da interação com o agente" (TSAI, 2000). Tais relações "podem ser formais ou informais, fortes ou fracas, e podem resultar em fluxo unidirecional do conhecimento, quando o conhecimento é adquirido apenas por uma filial ou em um fluxo bidirecional, quando há partilha recíproca ou desenvolvimento de novos conhecimentos" (GNYAWALI; SINGAL; MU, 2009).

As relações se configuram pela instituição de laços voluntários, com consentimento mútuo; e no caso de laços intersubsidiárias, podem ser formados com ou sem o apoio da matriz. Contudo, a formação dos laços "não é um evento espontâneo, nem exógeno. Em vez disso, é uma ação deliberada, que requer um compromisso mútuo de longo prazo entre as unidades e que prescinde de um contexto composto por estratégia e infraestrutura básica de suporte" (ZHAO; 
LUO, 2005, p 75). Os laços entre as unidades podem objetivar a realização de pesquisas para criar um corpo comum de conhecimento e/ou a introdução de novos produtos. As unidades podem colaborar com conhecimentos especializados e sinérgicos.

É importante notar que a troca de conhecimentos e recursos intraorganizacional parece ser uma alternativa atraente, se comparada às trocas via atores do mercado, porque as unidades da EMN normalmente compartilham valores semelhantes e linguagem corporativa comum que podem facilitar a comunicação no processo de troca (TSAI, 2000). Contudo, apesar dos benefícios relatados, reitera-se que a criação de tais laços não é uma tarefa fácil, pois desenvolver relações com novos atores leva tempo e envolve incerteza, tanto pela falta de informação sobre as competências como pela falta de informação sobre a confiabilidade dos potenciais parceiros. Dessa forma, a noção sobre as EMNs como redes de negócios sugere que os laços sociais são elementos básicos da rede, e, portanto, entender e examinar tais laços é um passo fundamental para aumentar o entendimento sobre como ocorre a transferência do conhecimento (GNYAWALI; SINGAL; MU, 2009).

Assume-se neste estudo, portanto, que o desenvolvimento do conhecimento e sua posterior transferência intrarede, além de serem influenciados pelas idiossincrasias das relações formadas a partir do contexto local de negócios, também o são pelo grau de envolvimento (laços fortes) com a matriz e as subsidiárias pares (GNYAWALI; SINGAL; MU, 2009; TAVANI, 2010).

\subsubsection{Modelo analítico preliminar}

A literatura tem sugerido que os elementos básicos da transferência de conhecimento podem ser classificados analogamente aos elementos básicos que compõem o processo de comunicação: emissor, mensagem, canal, destinatário e contexto (GUPTA; GOVINDARAJAN, 2000; SZULANSKI, 1996, 2003; MINBAEVA， 2007; NOORDEHARVEN; HARZING, 2009). Com base nessa metáfora, os estudos especificam quatro conjuntos de fatores considerados determinantes para a transferência reversa de conhecimento nas EMNs: fatores relacionados à subsidiária (emissor), às características do conhecimento (mensagem), à matriz (receptor) e à interação matriz-subsidiária (contexto). A Ilustração 4 abaixo, apresenta um modelo esquemático dos fatores influenciadores da transferência de conhecimento. 


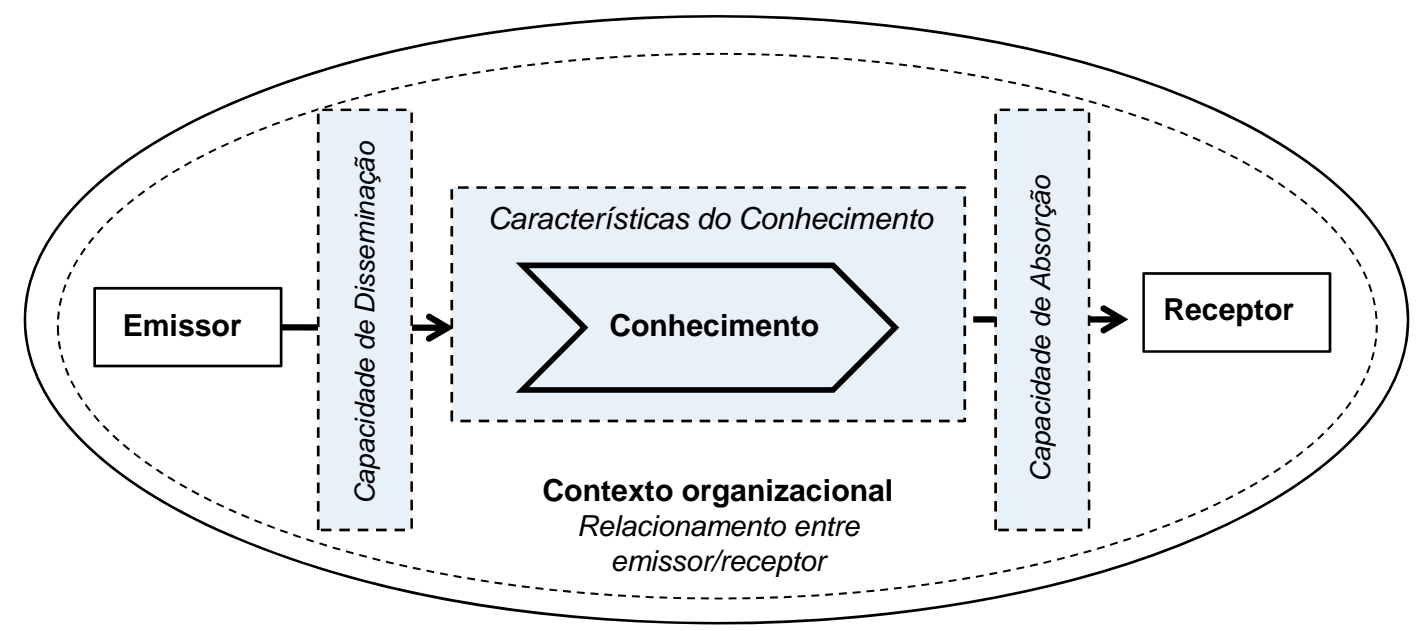

Em negrito: elementos da transferência do conhecimento

Em itálico: determinantes e barreiras associados aos quatro elementos da transferência do conhecimento

\section{Ilustração 4: Modelo esquemático da transferência de conhecimento}

FONTE: MINBAEVA (2007)

As características e natureza do conhecimento impactam em sua transferência porque conhecimento codificável é fácil de transferir, ao passo que conhecimento tácito é de difícil transferência por causa de sua dependência de pessoas (ZANDER; KOGUT, 2005). Adicionalmente, a ambiguidade causal do conhecimento faz com que as características das duas partes envolvidas e seu relacionamento também sejam importantes na análise da transferência. A fonte do conhecimento é importante não só porque determina as características do conhecimento a ser transferido, mas também porque de sua motivação depende a transferência. Já analisar a parte que recebe o conhecimento é importante porque ela precisa estar preparada, ou seja, é preciso que tenha um conhecimento prévio que lhe dê capacidade de absorção do novo conhecimento (GUPTA; GOVINDARAJAN, 2000). Por fim, o relacionamento entre as partes também é importante, porque facilita a transferência.

Poucos estudos incluem a análise conjunta dos quatro fatores do processo de transferência de conhecimento em razão das dificuldades de trabalhar com tantas variáveis em um único estudo (SZULANSKI 1996, 2003; GUPTA; GOVINDARAJAN, 2000; MINBAEVA, 2007). Este estudo focalizará o processo de transferência a partir da perspectiva do emissor e, portanto, analisará apenas três conjuntos de fatores relacionados às características do conhecimento, da subsidiária e da interação matriz-subsidiária. 
Como base teórica para a análise dos elementos do processo de transferência, este estudo combina a utilização das teorias sobre a visão baseada em conhecimento (KBV) e teoria das redes. O objetivo é fundamentar cada elemento (ou fator) da transferência a partir dessas duas teorias, como segue:

- Fatores relacionados à natureza e às características do conhecimento: de acordo com a $\mathrm{KBV}$, o conhecimento é um dos ativos estratégicos mais importantes para a organização, e sua transferência entre as unidades da EMN, um fator decisivo para a competitividade (KOGUT; ZANDER, 1996). As características do conhecimento, como sua ambiguidade, tacitividade, complexidade, especificidade, disponibilidade, entre outros aspectos, influenciam tanto na efetividade quanto nos custos e na velocidade (eficiência) associados à transferência do conhecimento (ENSIGN, 2000; MINBAEVA, 2007).

- Fatores relacionados à subsidiária: de acordo com a teoria de redes, assume-se que os recursos são criados no nível da subsidiária e, por conseguinte, ajudam a formar a vantagem competitiva da EMN. Esses recursos incluem tanto o estoque de conhecimento quanto as redes de relacionamento externa (mercado local) e interna (outras unidades da rede) da subsidiária (TAVANI, 2010).

- Fatores relacionados à interação matriz-subsidiária: a teoria das redes analisa a criação do conhecimento como sendo condicionada pelo relacionamento dual que se dá pela configuração de laços fortes entre as unidades da rede; tais laços facilitam a transferência de conhecimento, sobretudo quando se trata de um conhecimento de natureza tácita e complexa (ANDERSSON; FORSGREN; HOLM, 2002; FORSGREN; HOLM; JOHANSON, 2006; TAVANI, 2010).

Com base nessas definições, a Ilustração 5 apresenta o modelo analítico preliminar do estudo. 


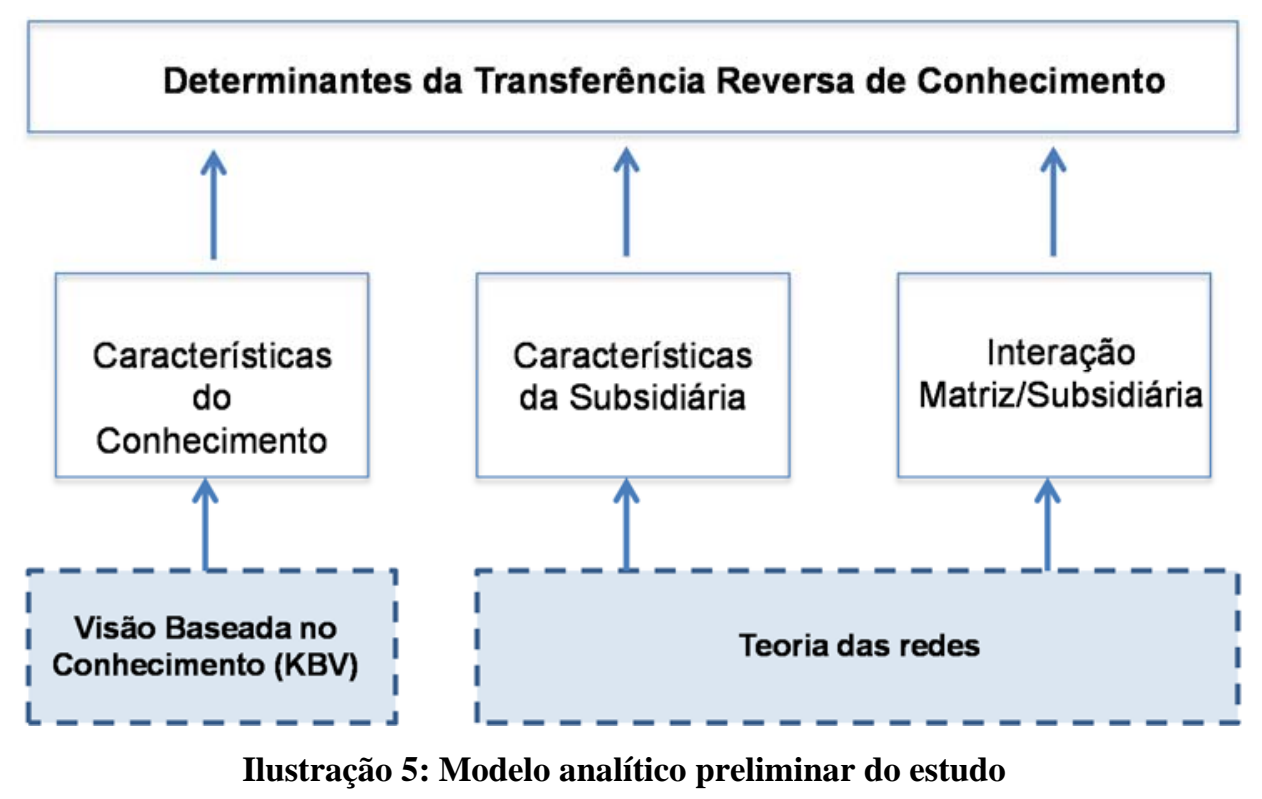

FONTE: Adaptado de Ensign (2000) e Tavani, Giroud e Andersson (2013) e Rabiosi (2006).

\subsection{O conhecimento na empresa multinacional}

A literatura afirma constantemente que o termo "conhecimento" não é fácil de definir. Uma das razões disso é a variedade de possibilidades de classificação e definição. Para fins deste estudo, o conhecimento é definido como informações e know-how (KOGUT; ZANDER, 1992) incorporados na tecnologia de produtos e processo. Utiliza-se conhecimento como sinônimo de “capacidades", definida por Amit e Schoemaker (1993, p. 35) como o "um conjunto de knowhow e capacidades que se referem à habilidade de uma empresa para implantar recursos, geralmente em combinação com os processos organizacionais, para efetuar um fim desejado".

Parte da dificuldade para definir o conhecimento reside no fato de ser necessário distinguir as diferenças entre dados, informação e conhecimento. Dado é a informação bruta, "é o registro estruturado de informações [...] descreve apenas parte daquilo que aconteceu, não fornece julgamento e nem interpretação [...] e não pode indicar o que fazer; dados nada dizem sobre a própria importância ou irrelevância." Informação é o dado adicionado de análise, significado e propósito, "tem por finalidade mudar o modo como o destinatário vê algo, exercer algum impacto sobre o seu julgamento e comportamento." Conhecimento permite fazer predições ou tomar decisões prescritivas sobre o que fazer (BOHN, 1994), é mais amplo, profundo e mais rico do que o dado e a informação. Segundo Davenport e Prusak (1998), conhecimento é: 
[...] uma mistura fluida de experiência condensada, valores, informação contextual e insight experimentado, a qual proporciona uma estrutura para a avaliação e incorporação de novas experiências e informações. Ele tem origem e é aplicado na mente dos conhecedores. Nas organizações, ele costuma estar embutido não só em documentos ou em repositórios, mas também em rotinas, processos, práticas e normas organizacionais (Ibid., p. 5).

Essa definição chama a atenção porque considera a coexistência do conhecimento que está ligado à experiência do indivíduo com o conhecimento organizacional que pode ser codificado em documentos, rotinas, processos, etc. (NOORDERHAVEN; HARZING, 2009).

A Ilustração 6 apresenta a transição, como um contínuo, dos dados, para a informação e o conhecimento.

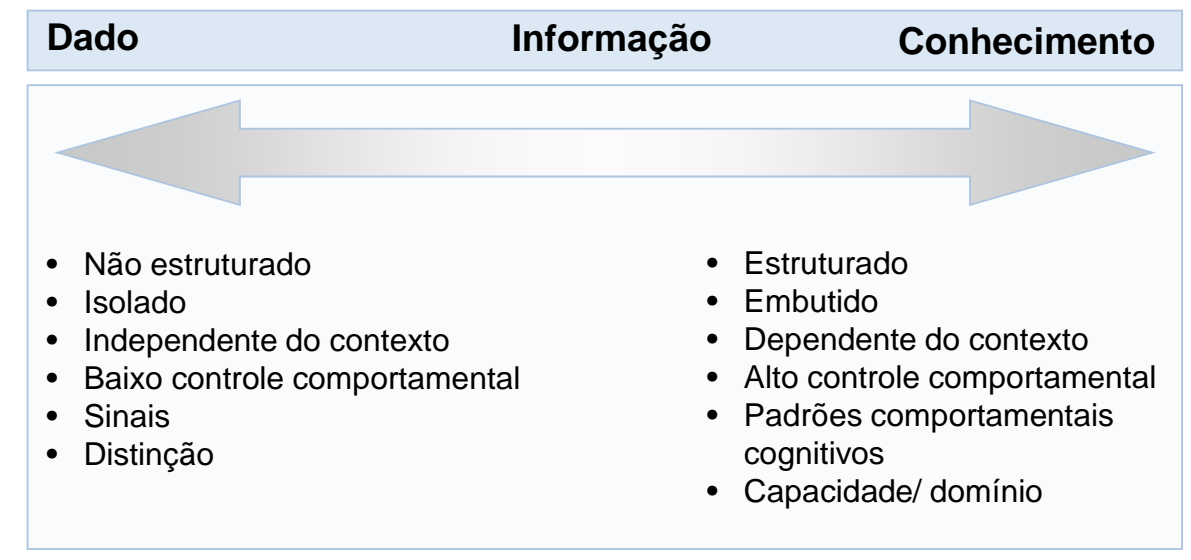

Ilustração 6: Contínuo dados - informação - conhecimento

FONTE: PROBST; RAUB, ROMHARDT (1999, p. 38 apud CHINI, 2004).

Conhecimento, ao mesmo tempo em que é fluido, é formalmente estruturado; é de difícil compreensão, entendimento lógico, identificação, representação e mensuração (DAVENPORT; PRUSAK, 1998; HOWELLS, 2000). Normalmente, é classificado como o mais valioso entre os três tipos citados, porque é o que está mais próximo da ação; em outros termos, "o conhecimento pode ser avaliado pelas decisões ou tomadas de ação às quais ele leva" (DAVENPORT; PRUSAK, 1998, p. 7).

O conhecimento pode ser retido na organização de diversas formas, entre elas, por procedimentos operacionais-padrão, rotinas, regras ou por estar contido na mente dos integrantes das organizações (SCHULZ, 2003). Do ponto de vista gerencial, reconhece-se ser difícil modificar as características do conhecimento. Entretanto, ações gerenciais parecem ser 
capazes de modificar a forma pelo qual o conhecimento é adquirido na empresa (FOSS; PEDERSEN, 2002).

\subsubsection{As classificações do conhecimento}

Uma das principais classificações do conhecimento é quanto a sua dimensão tácita e explícita (POLANYI, 1962, 1967). A dimensão explícita do conhecimento é articulada, codificada e fácil de comunicar. Essa forma de conhecimento é capaz de ser facilmente articulada de tal modo que um indivíduo pode extrair o conhecimento dos meios de armazenamento e utilizá-lo (POLANYI, 1962). Kogut e Zander (1992) definem o conhecimento explícito ou codificado, como o conhecimento que envolve "as informações que podem ser transmitidas sem perda da integridade, já que as regras sintáticas para decifrá-las são conhecidas." Esse tipo de conhecimento pode ser transmitido por meio de mecanismos formais e linguagem sistemática porque não requer experiência direta com o conhecimento que está sendo adquirido. Por conhecimento tácito entende-se "aquilo que é frequentemente usado, mas raramente definido [...] são as habilidades práticas ou expertises acumuladas que permitem a alguém fazer algo de maneira fácil e eficiente.” (KOGUT; ZANDER, 1992, p. 386). A dimensão tácita do conhecimento foi referida pela primeira vez nos estudos de Polanyi $(1962,1967)$ e representa as formas de conhecimento que são difíceis de articular e transferir porque são enraizadas na ação, experiência e envolvimento em um contexto específico, é, portanto, composta por elementos cognitivos e técnicos Nonaka (1994). O componente cognitivo refere-se aos modelos mentais de um indivíduo que consistem em mapas mentais, crenças, paradigmas e pontos de vista. O componente técnico consiste no know-how e habilidades que se aplicam a um contexto específico.

Essa dicotomia entre as características do conhecimento tem sido motivo de inúmeras pesquisas. A primeira delas diz respeito à existência de um relacionamento entre os custos (financeiros e outros) associados com a transferência de conhecimento e sua capacidade de ser codificada (TEECE, 1998, HANSEN; NOHRIA; TIERNEY, 1999). O conhecimento que é passível de ser documentado pode ser armazenado para utilização futura a custos baixos para a organização, ao passo que o conhecimento tácito é disseminado na organização por meio de atividades de socialização e experiências (HANSEN, NOHRIA; TIERNEY, 1999) que, naturalmente, incorrem em custos mais elevados e geralmente não são escaláveis como a transferência de conhecimento explícito pode ser. Quanto maior os custos incorridos pela transferência, mais lentamente ela ocorrerá. Contudo, a característica tácita do conhecimento, 
tem suas vantagens porque o torna difícil de ser imitado pelos concorrentes, podendo então, ser fonte de vantagem competitiva para a empresa (KOGUT; ZANDER, 1993). Bonache e Zárraga (2008) seguem a classificação do conhecimento entre tácito e explícito, mas sua contribuição está na criação de subcategorias para o conhecimento tácito, classificando-o de acordo com a natureza, escopo e dependência. Quanto à natureza do conhecimento, os autores propõem que pode ser individual ou de grupo. O conhecimento individual é detido por uma única pessoa e, portanto, só precisa de sua interação para transmiti-lo a outras pessoas na empresa. $\mathrm{O}$ conhecimento de grupo é o produto dos esforços coordenados de muitos especialistas individuais que possuem diferentes, mas complementares, habilidades. Um exemplo deste último seria a definição de uma equipe multidisciplinar para a implantação de um produto que deve ser composta por conhecimentos de marketing, finanças, cadeia de fornecimento e fabricação. Só a partir do conhecimento combinado de todas essas áreas é que o produto poderia ser viabilizado ao mercado.

A característica de "escopo" é relacionada ao volume do conhecimento a ser transferido. Alguns tipos de conhecimento são muito restritos em seu escopo e envolvem a realização de uma determinada tarefa específica dentro de uma área funcional mais ampla, geralmente são pouco complexos e pouco demandantes de tempo. Outros tipos de conhecimento são mais amplos, mais complexos, menos codificável e mais difícil de ensinar do que as capacidades técnicas. Os autores exemplificam essa classificação contrastando o conhecimento limitado necessário para a utilização de um novo software de previsão de tempo (que exigiria um curto período de interação para transferi-lo aos envolvidos) versus o desenvolvimento de uma estrutura de melhores práticas da organização (que exigiria um grande período de interação para transferilo aos indivíduos envolvidos).

A característica de "dependência" refere-se ao fato de o conhecimento ser de natureza específica para a organização, ou de ser uma prática genérica comum em uma indústria. Conhecimento organizacionalmente específico possui uma natureza idiossincrática e refere-se à maneira como as coisas são feitas em uma determinada empresa e só pode ser adquirido por meio da observação. Conhecimento organizacionalmente genérico, ao contrário, pode ser transmitido por meios contratuais, por exemplo, com uma entidade externa que se especializou na divulgação desta forma de conhecimento. 


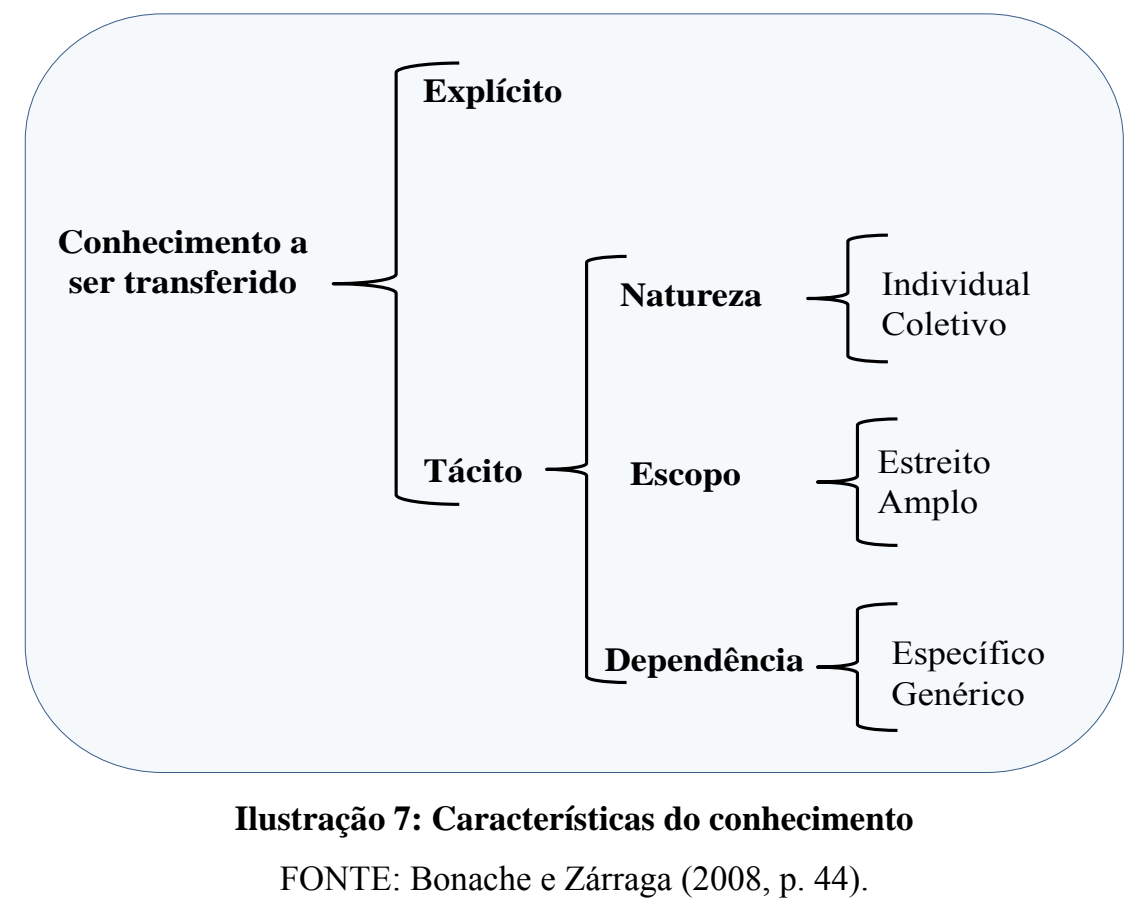

Apesar de ser umas das classificações mais importantes e utilizadas, a classificação do conhecimento que o distingue entre as dimensões tácita e explícita não é a única. Kogut e Zander (1992), por exemplo, classifica o conhecimento em:

- Conhecimento processual: (relativo ao saber como - know-how), que pode ser definido como as habilidades ou expertises práticas acumuladas que permitem fazer algo de forma eficiente. É o conhecimento sobre como fazer alguma atividade. É também relacionado a um processo ou desempenho de tarefas e, por isso, possui uma dimensão tácita (ANDERSON, 1983 apud NORDEHAVEN; HARZING, 2009). É relativo ao know-how de desenvolvimento de produtos, distribuição, marketing, etc. (GUPTA; GOVINDARAJAN, 2000);

- Conhecimento declarativo (relativo ao saber o que - know-what), que é relacionado à organização formal, podendo ser visto como o fluxo dos dados operacionais compartilhados entre as unidades, tais como rotinas, relatórios operacionais, informações empacotadas, conteúdos, fatos, entre outros (HARVEY; ANDERSON, 1996 apud NORDEHAVEN; HARZING, 2009). É o conhecimento sobre informações operacionais caso, por exemplo, dos dados financeiros mensais (GUPTA; GOVINDARAJAN, 2000). 
Adicionalmente, Zack (1998; 1999) e Alavi e Leidner (2001) destacam outros três tipos de conhecimento:

- Conhecimento causal (relativo ao saber por que - know-why), que é relacionado às experiências sobre as relações de causa e efeito (sobre como algo ocorre);

- Conhecimento condicional (relativo ao saber quando - know-when), que se refere a reconhecer que o problema em questão é similar a outro que já ocorreu anteriormente e a identificar quando aplicar determinado procedimento;

- Conhecimento relacional (relativo ao saber com - know-with), que é a capacidade de refletir sobre o que fazer, de questionar os modelos mentais e procedimentos vigentes e, se necessário, estabelecer uma nova maneira de fazer as coisas.

A compreensão sobre as diferentes perspectivas de classificação do conhecimento é importante porque influenciam as abordagens teóricas na área (ALAVI; LEIDNER, 2001). O Quadro 3 apresenta um resumo das tipologias discutidas.

Quadro 3: Taxonomia e exemplos do conhecimento

\begin{tabular}{|l|l|l|}
\hline \multicolumn{1}{|c|}{$\begin{array}{c}\text { Tipo de } \\
\text { conhecimento }\end{array}$} & \multicolumn{1}{|c|}{ Definições } & \multicolumn{1}{c|}{ Exemplos } \\
\hline Tácito Cognitivo & Modelo mental & $\begin{array}{l}\text { Indivíduos que acreditam nas relações de } \\
\text { causa e efeito }\end{array}$ \\
Explícito & $\begin{array}{l}\text { Know-how aplicado a um trabalho } \\
\text { específico } \\
\text { Conhecimento articulável e } \\
\text { generalizável } \\
\text { Criado por um indivíduo, inerente ao } \\
\text { indivíduo } \\
\text { Criado por um grupo, inerente às } \\
\text { ações de um grupo } \\
\text { know-what }\end{array}$ & $\begin{array}{l}\text { Habilidades de um cirurgião } \\
\text { Conhecimento sobre os principais } \\
\text { clientes e/ou região } \\
\text { Conhecimento gerado por um projeto } \\
\text { realizado por ele }\end{array}$ \\
Sormas de comunicação dos grupos \\
Declarativo & $\begin{array}{l}\text { Know-how } \\
\text { Know-why }\end{array}$ & $\begin{array}{l}\text { Quais medicamente são apropriados para } \\
\text { quais doenças } \\
\text { Como administrar um remédio específico } \\
\text { Entendimento sobre como } \\
\text { medicamentos agem }\end{array}$ \\
\hline Causal & Know-when \\
Condicional & Know-with & $\begin{array}{l}\text { Entendimento sobre quando prescrever } \\
\text { um medicamento } \\
\text { Entendimento sobre como } \\
\text { medicamente interage com outros }\end{array}$ \\
\hline
\end{tabular}

FONTE: Adaptado de Alavi e Leidner (2001). 
Outra classificação importante é feita por Heldlund e Nonaka (1993), que distinguem três aspectos do conhecimento: conhecimento como estoque (armazenamento do conhecimento), conhecimento como fluxo (transferência do conhecimento), conhecimento como interação (transformação do conhecimento). O armazenamento refere-se ao estoque de conhecimento apropriado por uma pessoa específica; a transmissão refere-se ao conhecimento que é comunicado de uma pessoa/grupo para outra pessoa/grupo; a transformação refere-se ao processo pelo qual um conhecimento é adicionado, recontextualizado, reinterpretado e reconfigurando com o objetivo de gerar novos conhecimentos, ou, em outros termos, de gerar inovações (HELDLUND; NONAKA, 1993 apud ENSIGN, 2000).

Winter (1987) desenvolveu uma terminologia para distinguir os diferentes tipos de conhecimento: tácito/articulável, complexo/simples, um elemento de sistema/independente e não observável/observável. A Ilustração 8 apresenta as dimensões especificadas por Winter (1987).

\begin{tabular}{|c|}
\hline Tácito........................... \\
\hline 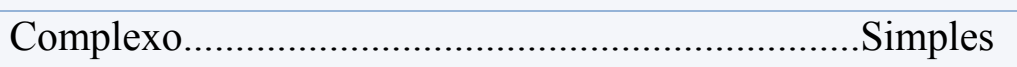 \\
\hline Elemento de um sistema...................................Independente \\
\hline Não observável..... \\
\hline
\end{tabular}

\section{Ilustração 8: Variações dos tipos de conhecimento}

FONTE: Adaptado de Winter (1987)

Inspirados no trabalho de Winter, os autores Zander e Kogut (1995) defendem que os principais atributos para mensurar a qualidade e natureza do conhecimento são: a "codificabilidade", a “ensinabilidade", a "complexidade", a "dependência do sistema" e a "observabilidade." Por codificabilidade os autores entendem a extensão pela qual o conhecimento pode ser especificado em documentos. Por ensinabilidade, a facilidade com que o know-how pode ser ensinado a novos trabalhadores. Por complexidade, o número de elementos críticos e interagentes envolvidos em uma dada atividade ou criação, onde um menor número de elementos está relacionado a maior simplicidade e maior facilidade de transferência. Por dependência do sistema, entende-se o quanto um conhecimento está embutido em outro(s) tipo(s) de conhecimento(s) ou o quanto está disponível para ser utilizado de forma isolada. Winter (1987) utiliza os exemplos de um componente de computador e de uma máquina de calcular para caracterizar os dois extremos dessa dimensão. Por observabilidade, entende-se o 
grau de facilidade de captação do conhecimento para replicar seu uso (imitação) em outras circunstâncias.

Especificamente no contexto da EMN, o conhecimento é classificado por Ensign (2000) como output - resultados de esforços de diversos especialistas - ou como input - um ativo estratégico que servirá de base para outros resultados. O Quadro 4 apresenta um resumo com as principais classificações do conhecimento apresentados nessa seção.

Quadro 4: Diferentes conteúdos do conhecimento utilizados como base para os estudos da área

\begin{tabular}{|c|c|}
\hline Autores & Classificações do conhecimento \\
\hline Polany $(1962,1967)$ & - Tácito e explícito \\
\hline $\begin{array}{l}\text { Bonache e Zárraga } \\
\text { (2008) }\end{array}$ & $\begin{array}{ll}\text { - } & \text { Explícito } \\
\text { - } & \text { Tácito } \\
- & \text { Natureza (individual/coletivo) } \\
- & \text { Escopo(estreito/amplo) } \\
- & \text { Dependência(específico/genérico) }\end{array}$ \\
\hline $\begin{array}{l}\text { Kogut e Zander (1992) } \\
\text { Zack (1998, 1999) } \\
\text { Alavi e Leidner (2001) }\end{array}$ & $\begin{array}{ll}\text { - } & \text { Declarativo (know-what) } \\
\text { - } & \text { Processual (know-how) } \\
\text { - } & \text { Julgamento (know-when) } \\
\text { - } & \text { Habilidade e expertises (who) }\end{array}$ \\
\hline $\begin{array}{l}\text { Heldlund e Nonaka } \\
\text { (1993) }\end{array}$ & $\begin{array}{ll}\text { - } & \text { Estoque } \\
\text { - } & \text { Fluxo } \\
\text { - } & \text { Interação } \\
\end{array}$ \\
\hline Winter (1983) & $\begin{array}{l}\text { - } \quad \text { Tácito - articulável } \\
\text { - } \quad \text { Elemplexo - simples } \\
\text { - } \quad \text { Não observável - observável } \\
\end{array}$ \\
\hline Zander e Kogut (1995) & $\begin{array}{ll}\text { - } & \text { Codificabilidade } \\
\text { - } & \text { Ensinabilidade } \\
\text { - } & \text { Complexidade } \\
\text { - } & \text { Dependência do sistema } \\
\end{array}$ \\
\hline Ensign (2000) & $\begin{array}{ll}\text { - } & \text { Input } \\
\text { - } & \text { Output }\end{array}$ \\
\hline
\end{tabular}

FONTE: Adaptado pela autora

Este estudo focaliza o conhecimento do tipo processual, que é identificado na forma de knowhow ou como desempenhar alguma atividade, e que, portanto, possui um grau tácito em sua dimensão (GUPTA; GOVINDARAJAN, 2000).

No que tange ao conteúdo do conhecimento, Tavani (2010) elaborou um resumo das principais tipologias existentes na literatura. Segundo o autor, as contribuições podem ser classificadas em dois grupos principais: os estudos que se concentram em apenas um tipo de conteúdo e os 
estudos que empregam vários tipos de conteúdo. O Quadro 5, a seguir, resume as tipologias identificadas por Tavani (2010, p. 91), com alguns acréscimos do autor deste estudo.

Quadro 5: Diferentes conteúdos do conhecimento

\begin{tabular}{|c|c|}
\hline Artigos-chave & Conteúdo do Conhecimento \\
\hline Zander e Kogut (1995) & - Capacidade de manufatura \\
\hline Tsang (2002) & $\begin{array}{l}\text { - Habilidades e competências } \\
\text { - Conhecimento para supervisionar e gerenciar sozinho } \\
\text { uma joint venture } \\
\text { - Conhecimento de fazer negócios }\end{array}$ \\
\hline Håkanson e Nobel $(2000,2001)$ & - Conhecimento tecnológico \\
\hline Schulz (2001) & $\begin{array}{l}\text { - Conhecimento organizacional: } \\
-\quad \text { Conhecimento tecnológico } \\
-\quad \text { Conhecimento de vendas e marketing } \\
-\quad \text { Conhecimento estratégico }\end{array}$ \\
\hline Gupta e Govindarajan (2000) & $\begin{array}{l}\text { - Conhecimento de marketing } \\
\text { - Conhecimento de distribuição } \\
\text { - Conhecimento de design/tecnologia de embalagem } \\
\text { - Conhecimento de design de produtos } \\
\text { - Conhecimento de design de processo } \\
\text { - Conhecimento de compras } \\
\text { - Conhecimento de sistemas e práticas de gestão }\end{array}$ \\
\hline $\begin{array}{l}\text { Bresman, Birkinshaw e Nobel } \\
\text { (1999) }\end{array}$ & - Conhecimento tecnológico \\
\hline Lord e Ranft (2000) & - Conhecimento do mercado local \\
\hline Simonin (1999b) & - Conhecimento de marketing \\
\hline Lyles e Salk (1996) & $\begin{array}{l}\text { - Conhecimento sobre: } \\
-\quad \text { Desenvolvimento de produtos } \\
-\quad \text { Culturas estrangeiras }\end{array}$ \\
\hline
\end{tabular}

Fonte: Adaptado de Tavani (2010)

\subsubsection{A distinção entre conhecimento e tecnologia}

A palavra tecnologia é bastante utilizada em inúmeras disciplinas acadêmicas e em diversas instituições profissionais ao redor do mundo, com diversos significados, dependendo do contexto organizacional (MALIK, 2002). Essa multiplicidade é devida ao fato de, ao longo dos anos, ter havido mudanças históricas no conteúdo do termo e no caráter das atividades consideradas como tecnológicas (LIN; BERG, 2002 apud MALIK, 2004). De uma maneira mais ampla, tecnologia é definida como um conhecimento ou como uma combinação de informações (ENSIGN, 2000) que pode variar de acordo com o grau em que possa ser articulada ou codificada (HAKANSON; NOBEL, 2000). Alguns autores se preocupam em fazer uma distinção clara entre os termos tecnologia e conhecimento. Segundo Gopalakrishnan e Santoro (2004): 
[...] a tecnologia e o conhecimento são constructos distintos que incorporam diferentes atividades na organização [...] Tecnologia diz respeito a saber mais sobre como as coisas são feitas, ao passo que o conhecimento diz respeito a saber mais sobre por que as coisas ocorrem [...] Sendo assim, o conhecimento tende a ser menos codificado, mais tácito e mais sujeito a interpretações do que a tecnologia [...] por outro lado, a tecnologia tende a ser mais específica em seu foco, mais tangível e menos sujeita a interpretações subjetivas. [...] a tecnologia se refere a novas ferramentas, metodologias, processos e produtos, sendo geralmente utilizada para gerar mudanças no ambiente. O conhecimento, ao contrário, incorpora um sentido mais amplo de aprendizagem que pode ser evidenciado em mudanças do pensamento estratégico, da cultura e da resolução de problemas técnicos na empresa [...] Em termos práticos, o conhecimento é o know-how necessário para comercializar e gerenciar um produto ou processo, enquanto o produto ou processo atual representam a tecnologia.

O Quadro 6 resume a diferenciação entre os dois termos, feita por Gopalakrishnan e Santoro (2004).

Quadro 6: Distinções entre tecnologia e conhecimento

\begin{tabular}{|l|l|}
\hline \multicolumn{1}{|c|}{ Tecnologia } & \multicolumn{1}{|c|}{ Conhecimento } \\
\hline Saber mais sobre como as coisas são feitas & Saber mais sobre por que as coisas ocorrem \\
\hline $\begin{array}{l}\text { Tende a ser mais específica em seu foco, mais } \\
\text { tangível e menos sujeita a interpretações } \\
\text { subjetivas }\end{array}$ & $\begin{array}{l}\text { Menos codificado, mais tácito e mais sujeito a } \\
\text { interpretações }\end{array}$ \\
\hline $\begin{array}{l}\text { Refere-se a novas ferramentas, metodologias, } \\
\text { processos e produtos, e geralmente é utilizada para } \\
\text { gerar mudanças no ambiente }\end{array}$ & $\begin{array}{l}\text { Incorpora um sentido mais amplo de } \\
\text { aprendizagem, que pode ser evidenciado em } \\
\text { mudanças do pensamento estratégico, na } \\
\text { cultura e na resolução de problemas técnicos } \\
\text { utilizadas por uma empresa }\end{array}$ \\
\hline Produto ou processo & $\begin{array}{l}\text { Know-how necessário para comercializar e } \\
\text { gerenciar um produto ou processo }\end{array}$ \\
\hline
\end{tabular}

FONTE: Gopalakrishnan e Santoro (2004).

Dadas todas as considerações já feitas, essa última distinção entre os termos "tecnologia" e “conhecimento" é crucial para este estudo uma vez que Shin, Holden e Schmidt (2001) sugerem que se deve distinguir entre uma escola de pensamento que considera o conhecimento como um objeto (cf. ZACK, 1999) e outra que define o conhecimento como um processo que contém atividades e aplicações relacionadas (cf. KOGUT; ZANDER, 1993). Nesse sentido, o conceito de conhecimento que será tratado neste estudo, embora tenha o conteúdo tecnológico, deve ser tratado de uma forma mais ampla do que o conceito de tecnologia (ou de transferência tecnológica). 
O conhecimento tecnológico "[...] surge, e é incorporado na atividade humana, em contraste com o conhecimento científico, por exemplo, que é uma expressão do mundo físico e de seus fenómenos. [...] "Embora o conhecimento tecnológico tenha seus próprios conceitos abstratos, teorias e regras, bem como a sua própria estrutura e dinâmica da mudança, estes são essencialmente aplicações a situações reais." (HERSCHBACH, 1995). O cohecimento tecnológico consiste num processo de "aquisição e aplicação de um corpo de conhecimento sobre a técnica, ou seja, maneiras de fazer as coisas" (LANDIES, 1980, p. 111 apud HERSCHBACH, 1995). Devido a sua ligação com uma atividade específica, o conhecimento tecnológico não pode ser facilmente categorizados e/ou como o é o conhecimento científico, por exemplo. "Tecnologia melhor se exprime através da aplicação específica do conhecimento e técnica para determinadas atividades tecnológicas. Por esta razão, não é considerada uma disciplina como por exemplo a matemática ou a física" (HERSCHBACH, 1995).

O conhecimento tecnológico pode ser intangível (por exemplo, habilidades, conhecimento tácito) ou tangível (por exemplo, patentes, informações armazenadas em bancos de dados, etc.). Tal conhecimento pode ser tanto utilizado como acumulado pela empresa (ENSIGN, 1999). No contexto da EMN, o conhecimento tecnológico pode ser visto tanto como uma saída como uma entrada. O conhecimento tecnológico é uma saída (por exemplo, quando uma empresa produz subprodutos a partir de conhecimento específicos). Na perspectiva da visão baseada em recursos, o conhecimento é visto como uma entrada (ou recurso crítico) (Ibid.).

A partir da visão baseada em recursos, o conhecimento tecnológico é um ativo que depende de habilidades especializadas de indivíduos e grupos. Quando tais ativos possuem características tácita e complexa, são menos passíveis de imitação pela concorrência (WINTER, 1987; ENSIGN, 1999) e, por isso, podem ser uma fonte de vantagem sustentável. Logo, pode-se concluir que para empresas que competem por ativos intelectuais, o compartilhamento do conhecimento tecnológico entre suas unidades pode ser de grande importância (ENSIGN, 1999). Por isso, requer arranjos ou mecanismos intrafirma que possam facilitar o compartilhamento Interunidade de conhecimento tecnológico. "O estoque de ativos de conhecimento tecnológico pode ser descrito como conhecimento declarativo". [...] "É a essência do conhecimento sobre "saber o quê"." (ENSIGN, 1999, p. 215). 


\subsubsection{Transferência de conhecimento tecnológico na EMN}

Em uma revisão da literatura, realizada por Wahab Rose e Osman (2012) revela que estudos anteriores não fizeram muitas tentativas para explicar as diferenças entre a transferência de conhecimento e transferência de tecnologia, pois a maioria dos estudos tem aplicado o termo indistintamente.

Kogut e Zander (1992,1993), por exemplo, utilizam os dois termos como sinônimos para estabelecer uma estreita associação entre a transferência de tecnologia. Isso sugere que a transferência de tecnologia dentro de EMNs pode ser explicada pelos atributos do conhecimento, como tacitividade, codificabilidade e possibilidade de ensinar.

Outros estudos como os de Sahal (1981, 1982 apud WAHAB; ROSE; OSMAN, 2012) sugeriram que a transferência de tecnologia e de conhecimento são inseparáveis. A justificativa reside no fato de que quando um produto tecnológico é transferido ou difundido o conhecimento sobre sua composição também é transferido (BOZEMAN, 2000 apud WAHAB; ROSE; OSMAN, 2012). Contudo, embora os termos "transferência de tecnologia" e "transferência de conhecimento" "tenham sido regularmente utilizados alternadamente em muitas literaturas, uma vez que são altamente interativos, servem a propósitos diferentes. Gopalakrishnan e Santoro (2004) apud Wahab, Rose e Osman (2012), argumentam que o foco da transferência de conhecimento é mais amplo e direciona-se a entender o "porquê" da mudança, enquanto o foco da transferência de tecnologia é mais estreito e mais orientado, e incorpora certas ferramentas para alterar o ambiente. Apesar da existência de distinções entre a finalidade dos dois termos, a maioria dos pesquisadores concorda que o conhecimento é o elemento crítico que sustenta a transferência de tecnologia (WAHAB; ROSE; OSMAN, 2012).

Do ponto de vista mais prático, a transferência tecnológica se dá pela transferência de tecnologias incorporadas, tais como: plantas, equipamentos, desenhos técnicos e outros documentos, como manuais de operação. Já a transferência de conhecimento tecnológico é um pacote mais amplo que inclui a compreensão e o aprendizado do processo de inovação em si, e, nesses termos, a transferência de conhecimento, ao mesmo tempo em que cria, também exige do receptor uma construção de competências tecnológicas de longo prazo (HOWELLS, 2000). Sendo assim, o conhecimento (tecnológico) tem um importante aspecto tecnológico que é tácito por natureza e, portanto, mais difícil de transferir.

Igualmente à conceituação do conhecimento, o conceito de transferência é algo difícil de capturar (BRESMAN; BIRKINSHAW; NOBEL, 1999). De acordo com Foss (2006), ainda há 
pouca compreensão sobre como os diferentes mecanismos e estruturas organizacionais podem influenciar no processo de transferência de conhecimento. Os resultados mais comuns indicam que a transferência de conhecimento, ao mesmo tempo em que é vantajosa, é um processo problemático e custoso (TEECE, 1977; SZULANSKI 1996; SIMONIN, 1999; GUPTA; GOVINDARAJAN, 2000).

Como se pode definir a transferência de conhecimento na EMN? Kumar e Ganeshi (2009) desenvolvem uma perspectiva interessante para explicar o conceito. Segundo os autores, um agente (indivíduo, grupo ou unidade organizacional) pode aprender com suas próprias experiências ou a partir das experiências dos outros (GRAY; MEISTER, 2004 apud KUMAR; GANESHI, 2009). A aprendizagem trazida pela transferência de conhecimento pertence à última categoria. Dessa forma, é consenso na literatura definir transferência de conhecimento como sendo um processo por meio do qual um agente é afetado pela experiência de outro. Essa perspectiva reforça que a ideia de que a transferência de conhecimento é distinta do conhecimento meramente relacionado aos dados e informações.

Szulanski (1996, 2003) define a transferência de conhecimento como um processo de trocas mútuas entre o remetente e o receptor, no qual a eficácia da transferência depende, em certa medida, de alguns fatores, tais como: a disposição e habilidade do emissor e do receptor, a qualidade dos vínculos entre os agentes e as características do conhecimento que está sendo transferido (2003). Ainda de acordo com Szulanski (1996, p. 28), a transferência de conhecimento "tem a conotação de replicação de uma prática interna que é realizada de forma superior em alguma parte da organização e é considerada superior a práticas alternativas internas e a alternativas conhecidas fora da empresa".

Para Ensign e Hébert (2009), o compartilhamento do conhecimento deve ser entendido como um processo que inclui:

[...] o reconhecimento de uma necessidade ou oportunidade; uma busca por uma fonte que pode ajudar a atender essa necessidade ou oportunidade, e uma troca envolvendo uma fonte e um destinatário facilitada por decisões de gestão e adequada coordenação/e mecanismos de integração (ENSIGN; HÉBERT, 2009, p. 76). 
A transferência pode ocorrer por meio da transferência de produtos, processos ou pessoas. Na literatura, a ênfase das investigações tem sido direcionada às transferências incorporadas em processos e pessoas (AGMON; GLINOW, 1991). Kumar e Ganeshi (2009) esclarecem ainda que o resultado pretendido com a transferência de conhecimento é a aprendizagem, já que o conhecimento é tido como um evento por meio do qual uma entidade aprende a partir da experiência do outro. Para Lane, Salk e Lyles (2001), a transferência de conhecimento é estabelecida sobre quatro pilares: a transferência tem base na percepção das pessoas; o conhecimento explícito pode ser conquistado e codificado; a aprendizagem depende de modelos mentais compartilhados; e, finalmente, todos os envolvidos devem ter participação ativa no processo.

As transferências intraempresa "permitem que os atores utilizem melhor os ativos da organização combinando e recombinando diferentes elementos do conhecimento, replicando práticas e rotinas e estimulando a criação de novos conhecimentos que contribuam para as inovações na corporação" (ANDERSEN; MUDAMBI; PERSSON, 2009, p. 6). As transferências contribuem para o desenvolvimento de capacidades organizacionais difíceis de imitar e, consequentemente, levam a um melhor desempenho organizacional (SZULANSKI, 1996).

Apesar dessas definições iniciais, o termo "transferência de conhecimento" ainda não é definido de forma consensual na literatura. Uma das razões que gera a dificuldade de entendimento do conceito de transferência de conhecimento é a falta de clareza ou de precisão das distinções entre o que é transferência e o que é criação de novos conhecimentos. Isso se dá porque, na maioria das vezes, as combinações, adaptações e modificações do conhecimento transferido são consideradas parte integrante do processo de transferência. Procurando dar luz a essa questão, Hayami e Ruttan (1971 apud BRESMAN; BIRKINSHAW; NOBEL, 1999) propuseram uma distinção entre os tipos de transferência de acordo com o grau de modificação a que o conhecimento está sujeito durante o processo de transferência. Já Foss e Pedersen (2002) sugeriram que a transferência de conhecimento não pode ser considerada uma replicação completa do conhecimento em um novo local; ao contrário, envolve a modificação do conhecimento existente para que seja adaptado ao contexto específico do receptor -“o que é transferido não é (geralmente) um conhecimento subjacente, mas sim aplicações desse conhecimento na forma de soluções para problemas específicos” (Ibid., p. 54). 
$\mathrm{Na}$ literatura podem-se encontrar diversos termos que são utilizados como sinônimos ou não do processo de transferência de conhecimento: "transferência de conhecimento", "compartilhamento de conhecimento" e "fluxo de conhecimento" (MAJCHRZAK; COOPER; NEECE, 2004). Para Majchrzak, Cooper e Neece (2004, p. 174), o termo transferência de conhecimento deve ser considerado distinto dos termos "compartilhamento" e "fluxo" de conhecimento. Na visão do autor, a transferência de conhecimento pode ser subdividida em compartilhamento de conhecimento e reutilização do conhecimento. O compartilhamento refere-se "ao processo pelo qual um conhecimento do emissor é capturado". Nessa definição, o compartilhamento possui a conotação de dar ou de contribuir, e está incluído no âmbito da transferência, mas não compreende os aspectos de recebimento e reutilização da transferência. Para Zhou e Luo (2005), a transferência de conhecimento é vista como um processo unidirecional no qual o conhecimento flui de um emissor para um receptor e, portanto, é distinta do compartilhamento ou do fluxo de conhecimento, que pode ser multidirecional.

A despeito disso, autores como Renzl (2008) e Bresman, Birkinshaw e Nobel (1999) concluem que os termos "compartilhamento do conhecimento" e "transferência do conhecimento" são utilizados de forma intercambiável na literatura. Como observam Kumar e Ganeshi, (2009), o termo "fluxo de conhecimento" tem sido utilizado com um significado muito semelhante ao da "transferência de conhecimento", o que pode ser visto no trabalho de Gupta e Govindarajan (2000). Para Nissen (2005-2006, p. 226 apud KUMAR; GANESHI, 2009), a definição de fluxo de conhecimento "congrega conceitos similares tais como conversão, transferência, compartilhamento, reutilização, integração e outros que retratam as mudanças, movimentos e aplicações de conhecimento ao longo do tempo.”

Conclui-se, portanto, que a interação nos significados implícitos de "transferência", "compartilhamento" e "fluxo de conhecimento" parece sugerir que a tentativa de uma definição exata e sem sobreposição dos três termos pode ser impraticável. Em vez disso, parece mais sensato assumir considerar que a "transferência de conhecimento", o "compartilhamento de conhecimentos" e o "fluxo de conhecimento" possuem traços comuns representados pela troca de conhecimento (KUMAR; GANESHI, 2009).

Por essa razão, este estudo utilizará o termo transferência de conhecimento sem fazer distinções quanto ao fluxo e ao grau de adaptação que o referido conhecimento sofre ao ser transferido. Com base na discussão acima, transferência de conhecimento é definida como: 
[...] um processo de troca de conhecimento explícito ou tácito entre dois agentes, durante o qual um agente propositadamente recebe e utiliza os conhecimentos fornecidos por outro. Agente pode se referir a um indivíduo, uma equipe, uma unidade organizacional, à própria organização, ou a um conjunto de organizações. O processo de troca envolve dois atos complementares: o ato de dar ou fornecer conhecimentos por um agente (a origem), complementado pelo ato de recebimento e uso do conhecimento por outro agente - o destinatário (KUMAR; GANESHI, 2009, p. 163-164).

Especificamente, esse movimento pode ocorrer por meio da EMN em pelo menos de cinco formas diferentes: (i) os fluxos da matriz para as subsidiárias, (ii) os fluxos das subsidiárias para a matriz (iii) os fluxos do ambiente local para as subsidiárias, (iv) fluxo das subsidiárias para o ambiente local, (v) o fluxo entre as subsidiárias (GUPTA; GOVINDARAJAN, 1991).

\subsubsection{Tipos de transferência de conhecimento}

Encontram-se na literatura muitas formas de classificação da transferência de conhecimento. Tais classificações são importantes porque ajudam a definir os parâmetros de cooperação entre emissores e receptores (AGMON; GLINOW, 1991).

Cusumano e Elenkov (1992), por exemplo, fazem uma distinção entre os tipos direto e indireto. O tipo direto é operacionalizado pelos contratos de licenciamento ou compra de tecnologias; já o tipo indireto refere-se às trocas de conhecimento entre os membros das unidades dispersas de uma corporação multinacional. Menzler-Hokkanen (1995) classifica a transferência de conhecimento (neste caso, de cunho tecnológico) em ativos tangíveis, tais como novos produtos, plantas ou equipamentos, e intangíveis, transferidos por meio de mecanismos formais tais como patentes e licenças, ou informais, como fluxo de informação e compartilhamento de conhecimento.

De uma forma mais ampla, Agmon e Glinow (1991) classificam as transferências internacionais de conhecimento em dois tipos principais: "macroveículos" e "canais micro organizacionais". O tipo de transferência via macroveículos trata das transferências de conhecimento que acontecem de forma mais abrangente nos mercados, preocupando-se, por exemplo, com os fatores relacionados ao sistema de educação. Já a abordagem dos canais micro organizacionais trata de aspectos mais restritos, relacionados, por exemplo, com o processo de transferência de conhecimento que se dá dentro de uma organização específica ou entre várias organizações (Ibid.). A partir dessa abordagem, os autores elaboram uma classificação mais específica considerando cinco tipos de transferência internacional de conhecimento, a saber: 
i) Transferência via mercado externo por meio de fornecedores e compradores independentes;

ii) Transferência intrafirma por meio de joint ventures ou subsidiárias de propriedade integral;

iii) Transferência via acordos ou trocas realizados diretamente pelos governos na qual as contrapartes podem ser atores público e/ou privados;

iv) Transferência via educação, treinamentos e conferências na qual a disseminação da informação é feita de forma pública;

v) Transferência via engenharia reversa ou pirataria. É um tipo de transferência obtido enquanto recurso de mercado e só pode ser evitado à custa de direito de propriedade.

Em uma tentativa similar, Sveiby (2001) identificou nove mecanismos básicos para a transferência de conhecimento entre dois agentes (Ibid., p. 348): entre indivíduos; de indivíduos para a estrutura externa; da estrutura externa para os indivíduos; da competência individual para a estrutura interna; da estrutura interna para a competência individual; entre a estrutura externa; da estrutura externa para a estrutura interna; da estrutura interna para a estrutura externa; e na estrutura interna. Detalhes dos tipos podem ser visualizados na Ilustração 9.

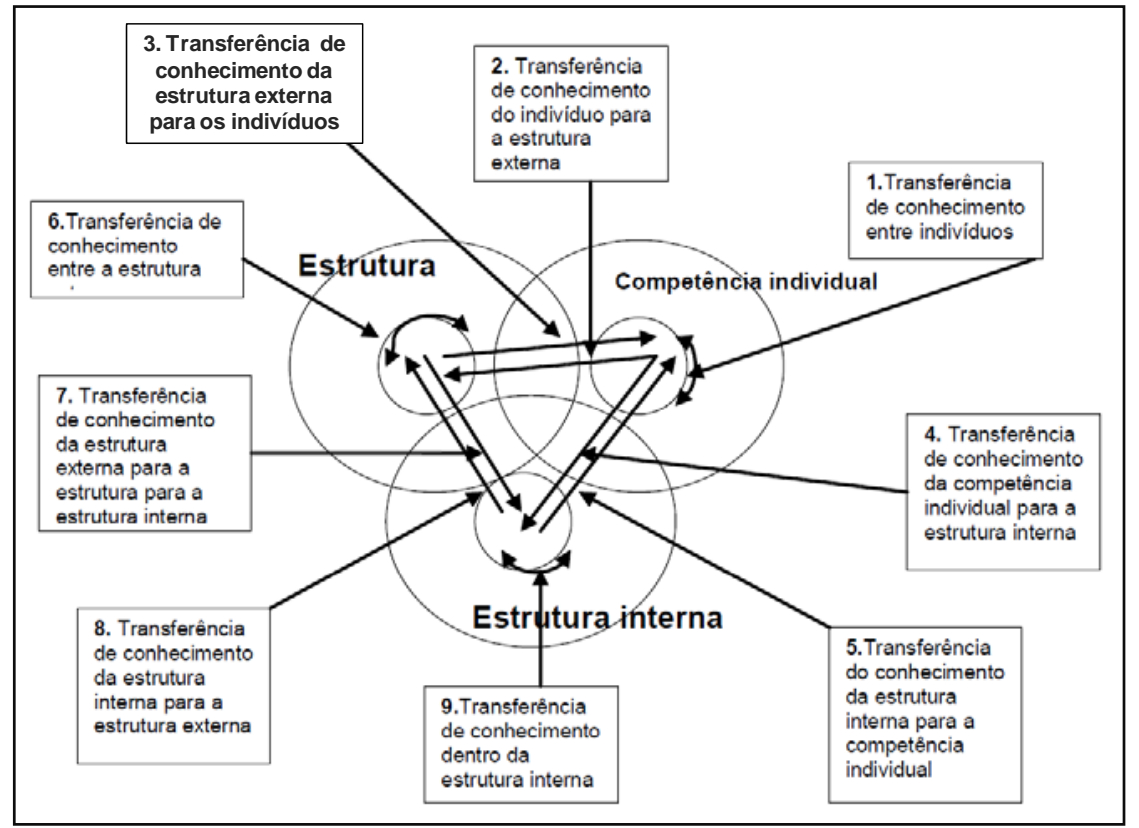




\section{Ilustração 9: Nove tipos de transferência de conhecimento}

FONTE: SVEIBY (2001, p. 349).

Para este estudo, todos os processos de transferência envolvendo remetentes ou receptores interorganizacionais serão excluídos da análise.

Tratando-se das transferências que ocorrem entre as unidades dispersas da EMN, a distinção pode ser feita quanto ao fluxo ou à direção em que o conhecimento é transferido. O tipo mais usual de transferência é o tradicional, que implica a transferência matriz-subsidiária, mas há também os tipos de transferência lateral, que implica a transferência subsidiária-subsidiária, reversa, que implica a transferência subsidiária-matriz, e, finalmente, recíproca, caso de transferências conjuntas feitas via projetos globais realizados simultaneamente por duas ou mais unidades da multinacional (BRESMAN; BIRKINSHAW; NOBEL, 1999).

De acordo com Simon (1991 apud AGMON; GLINOW, 1991; CUSSOMANO; ELENKOV, 1992), a transferência de tecnologia também pode ser classificada conforme os seus objetivos, que podem ser divididos em três tipos. O primeiro é a transferência de material, que consiste na transferência de materiais, produtos finais, componentes, equipamentos e até plantas turnkey (plantas entregues em funcionamento). A classificação desse tipo como tendo natureza de transferência de conhecimento é questionada por alguns autores sob a justificativa de que, nesses casos, não há a transferência de conhecimento propriamente dita, ou seja, não há transferência de know-how, mas apenas de show-how. O principal objetivo é suprir de capacidade física o receptor para que ele consiga produzir os bens requeridos. $\mathrm{O}$ segundo tipo é a transferência de design, que envolve a transferência de design, desenhos técnicos ou outros tipos de informações necessárias para fabricar produtos ou facilidades de produção. Nesse tipo de transferência, o principal objetivo é transmitir dados, informações básicas e diretrizes necessárias ao receptor para provê-lo da capacidade desejada. O terceiro tipo é a transferência de capacidade, tida como a mais difícil de identificar e de avaliar, porque envolve a construção de competências de longo prazo (HOWELLS, 2000) refere-se à educação e ao treinamento (know-how) não apenas para operar plantas existentes, mas também para desenvolver inovações em produtos e processos. O objetivo é prover o receptor, da capacidade de inovar e de adaptar as tecnologias existentes e os produtos, e, até mesmo, de conceber novos produtos. 
Em suma, de acordo com o que é proposto pelos dos autores citados, a transferência de conhecimento pode ser classificada das seguintes formas, conforme o Quadro 7.

Quadro 7: Possíveis classificações das transferências internacionais de conhecimento tecnológico

\begin{tabular}{|c|c|c|}
\hline Classificação & Tipologias & Autor \\
\hline \multirow{3}{*}{$\begin{array}{l}\text { Quanto ao } \\
\text { tipo }\end{array}$} & $\begin{array}{l}\text { Direto - operacionalizado pelos contratos de licenciamento } \\
\text { ou compra de tecnologias; } \\
\text { Indireto - refere-se às trocas de conhecimento entre os } \\
\text { membros das unidades dispersas de uma corporação } \\
\text { multinacional. }\end{array}$ & $\begin{array}{l}\text { Cusumano e } \\
\text { Elenkov (1992) }\end{array}$ \\
\hline & $\begin{array}{l}\text { - Ativos tangíveis } \\
-\quad \text { Novos produtos, plantas ou equipamentos; } \\
\text { Ativos intangíveis } \\
\text { - Transferidos por meio de mecanismos formais, tais } \\
\text { como patentes e licenças; } \\
\text { - Transferidos por meio de mecanismos informais, como } \\
\text { fluxo de informação e compartilhamento de } \\
\text { conhecimento. }\end{array}$ & $\begin{array}{l}\text { Menzler-Hokkanen } \\
\text { (1995) }\end{array}$ \\
\hline & $\begin{array}{l}\text { - Transferência via mercado; } \\
\text { - Transferência intrafirma multinacional; } \\
\text { - Transferência via acordos com o governo; } \\
\text { - Transferência via mecanismos de educação e informação } \\
\text { pública; } \\
\text { - Transferência via engenharia reversa ou pirataria. }\end{array}$ & $\begin{array}{l}\text { Agmon e Glinow } \\
\text { (1991) }\end{array}$ \\
\hline $\begin{array}{l}\text { Quanto aos } \\
\text { mecanismos }\end{array}$ & $\begin{array}{l}\text { - Entre indivíduos; } \\
\text { - De indivíduos para a estrutura externa; } \\
\text { - Da estrutura externa para os indivíduos; } \\
\text { - Da competência individual para a estrutura interna; } \\
\text { - Da estrutura interna para a competência individual; } \\
\text { - Na estrutura externa; } \\
\text { - Da estrutura externa para a estrutura interna; } \\
\text { - Da estrutura interna para a estrutura externa; } \\
\text { - Na estrutura interna. }\end{array}$ & Sveiby (2001) \\
\hline $\begin{array}{l}\text { Quanto à } \\
\text { direção do } \\
\text { conhecimento }\end{array}$ & $\begin{array}{l}\text { - } \quad \text { Tradicional - transferência matriz-subsidiária; } \\
\text { - } \quad \text { Lateral - transferência subsidiária-subsidiária; } \\
\text { - } \quad \text { Reversa - transferência subsidiária-matriz; } \\
\text { - Recíproca - transferências conjuntas feitas por meio de } \\
\text { projetos globais desenvolvidos simultaneamente por duas ou } \\
\text { mais unidades da multinacional. }\end{array}$ & $\begin{array}{l}\text { Bresman, } \\
\text { Birkinshaw e } \\
\text { Nobel, (1999) }\end{array}$ \\
\hline $\begin{array}{l}\text { Quanto aos } \\
\text { objetivos }\end{array}$ & $\begin{array}{l}\text { - Transferência de material (transferência de artefatos físicos) } \\
\text { - Transferência de design (transferência de informações } \\
\text { necessárias para a fabricação de um produto); } \\
\text { - Transferência de capacidade (refere-se à educação e } \\
\text { treinamento (know-how) com o objetivo de prover o receptor } \\
\text { da capacidade de inovar e de adaptar as tecnologias existentes } \\
\text { e produtos). }\end{array}$ & Simon (1991) \\
\hline
\end{tabular}

FONTE: Adaptado pela autora.

Para o presente trabalho, optou-se pelas seguintes classificações de transferência de conhecimento: 


\section{- Quanto ao tipo:}

o Indireto e intangível - porque serão consideradas as trocas via mecanismos menos formais (ao contrário de patentes) entre os membros das unidades dispersas da EMN (CUSSOMANO, 1992; MENZLER-HOKKANEN, 1995);

o Intrafirma - porque o estudo analisará a transferência que ocorre entre as unidades da matriz e as subsidiárias da EMN (AGMON; GLINOW, 1991)

- Quanto aos mecanismos - os participantes externos à organização serão excluídos do estudo. Portanto, para este estudo, apenas quatro dos nove modelos apresentados por Sveiby (2001) são relevantes:

o Transferências entre indivíduos (Ilustração 9 - item 1): este tipo corre na comunicação entre funcionários da organização e pode ser representado pelo modelo simplificado de comunicação. Questões como a confiança entre os membros e a exposição a diferentes tipos de expertise da empresa são importantes para a realização desse processo;

o Transferências da competência individual para a estrutura interna (Ilustração 9 item 4): este tipo representa a conversão da competência individual para os sistemas, ferramentas e modelos organizacionais. Quando o conhecimento das competências individuais é armazenado em repositórios, torna-se acessível na organização e pode ser compartilhado por todos. Esta definição de 'transferência' compreende apenas a primeira metade do modelo de comunicação, ou seja, do emissor para a mídia (sistemas de informação);

o Transferências da estrutura interna para a competência individual (Ilustração 9 item 5): realizadas por meio da interface entre os indivíduos e o conhecimento armazenado nos sistemas, ferramentas e modelos organizacionais. Neste tipo ocorre a interface entre humanos e o conhecimento armazenado nos sistemas. Aqui, a segunda metade do processo de comunicação é descrita, a transição da mídia para o destinatário; 
o Transferências no âmbito da estrutura interna (Ilustração 9 - item 9): representam a forma pelo qual como os sistemas das organizações, ferramentas e processos podem ser integrados de forma eficaz.

Reitera-se que os processos mais relevantes são os da transferência que envolve "competência individual à estrutura interna" e o "da estrutura interna à competência individual". Os dois processos restantes "entre os indivíduos" e "na estrutura interna", não serão destacados, mas, pelo fato de serem fases necessárias à transferência, serão analisados. O primeiro deixa de ser destaque nas organizações globais que são caracterizadas por interações à distância entre os membros que ainda têm que lidar com fusos horário diferenciados; dessa forma, na maioria dos casos será necessário que o conhecimento seja armazenado em um meio (mesmo que por um curto espaço de tempo). O último explica apenas a gestão do conhecimento dentro dos sistemas de armazenamento e, portanto, excede o foco desta investigação.

- Quanto à direção do conhecimento - a direção do fluxo de conhecimento relevante para este estudo é a reversa, que implica a transferência da subsidiária para a matriz (BRESMAN; BIRKINSHAW; NOBEL, 1999);

- Quanto aos objetivos - para que se consiga capturar todos os aspectos importantes que facilitam ou dificultam a transferência do conhecimento, entende-se que é preciso considerar a classificação mais ampla de Simon (1991), ou seja, a transferência de capacidades.

Em síntese, a classificação utilizada para este estudo é apresentada no Quadro 8.

Quadro 8: Classificações de transferência de conhecimento utilizadas por este estudo

\begin{tabular}{|l|ll|}
\hline \multicolumn{1}{|c|}{ Classificação } & \multicolumn{1}{c|}{ Descrição } \\
\hline \multirow{2}{*}{ Quanto ao tipo } & $\bullet$ & Indireta \\
& - Intangível \\
& - Intrafirma \\
Quanto aos mecanismos & - Entre indivíduos \\
& - Da competência individual à estrutura interna \\
Quanto à direção & - Na estrutura interna à competência individual \\
Quanto aos objetivos & $\bullet$ & Reversa (subsidiária - matriz) \\
\hline
\end{tabular}

Fonte: A autora. 


\subsubsection{As barreiras para a transferência do conhecimento}

A transferência internacional de conhecimento, apesar de relatada como vantajosa, não é livre de custos, e estes devem ser sempre considerados pelas EMNs em sua decisão sobre como transferir conhecimento internacionalmente. Pode-se esperar que as restrições impostas pela distância geográfica, diversidade cultural, diferenças linguísticas e demandas conflitantes dos vários mercados e governos locais tornem a realização das sinergias organizacionais das subsidiárias estrangeiras muito mais desafiadoras do que são no caso das unidades domésticas.

Kogut e Zander (1993), visando defender seu argumento de que as multinacionais são empresas especializadas na transferência e recombinação de conhecimentos, e por isso são mais eficientes do que o mercado nesse quesito, realizaram um estudo cujo resultado permitiu identificar que quanto mais tácito o conhecimento, mais difícil de ser ensinado e imitado, e mais provavelmente a transferência será feita via operações internas à empresa multinacional do que via operações internacionais entre empresas. Entre outros fatores, o custo de transferência entra as unidades da corporação multinacional é mais eficiente do que uma transação via mercado internacional. A transferência internacional possui embutidos mais custos organizacionais, tais como viagens e salários, mas, por outro lado, melhores são as alternativas de custos, de possibilidade de receita e de oportunidades de mercado (HAKANSON; NOBEL, 2000). Segundo Teece (1977) os custos são influenciados por diversos fatores, dentre os quais: a experiência do transmissor com transferências prévias e com a própria tecnologia que está sendo transferida, as habilidades e experiências do receptor e as características da tecnologia.

Embora o uso eficiente e eficaz da transferência de conhecimento possa estar relacionado às vantagens competitivas na EMN, isso não significa que a transferência de conhecimento ocorrerá de forma eficaz e eficiente na rotina da multinacional. Barreiras como a tacitividade e a ambiguidade causal do conhecimento têm sido relatadas como as mais impactantes para a transferência do conhecimento. Barreiras adicionais relacionadas aos fatores motivacionais e à capacidade de absorção do receptor também têm sido relatadas de forma consistente na literatura (GUPTA; GOVINDARAJAN, 2000).

Em seu estudo, Gupta e Govindarajan (2000) adicionam as barreiras da síndrome do "não inventado aqui - NIH" (caracterizada pela rejeição dos receptores do conhecimento que vem de fora da sua empresa), e a falta de riqueza dos canais de transmissão. Outra barreira comumente discutida para a transferência de conhecimento interno é a distância geográfica entre as 
diferentes unidades. Os primeiros estudos de Allen $(1966,1977)$ mostraram que a proximidade física afeta a probabilidade de haver maior comunicação entre o pessoal de P\&D e de outras funções em uma empresa. De Meyer (1991) afirmou: "Um dos mais importantes problemas de produtividade em P\&D é estimular a comunicação entre os pesquisadores e que tal comunicação torna-se mais difícil quando os laboratórios estão dispersos geograficamente" (p. 49). E ainda que este problema tenha sido minimizado com a evolução das tecnologias de comunicação e informação, a distância geográfica ainda é uma barreira para a transferência, pois a troca de conhecimentos ocorre principalmente através de contatos pessoais (face a face) (DE MEYER, 1993).

Um estudo recente envolvendo trinta e cinco das maiores multinacionais suíças assinalou as principais dificuldades relacionadas à transferência reversa de conhecimento, dentre as quais: a alta especificidade do conhecimento estrangeiro; sua relevância para a matriz nem sempre é imediatamente visível; o conhecimento da subsidiária pode ser considerado inferior aos já disponíveis na matriz. Vale observar que a fraqueza da transferência não está, portanto, sempre relacionada com as dificuldades inerentes ao processo de transferência (MICHEL, 2009 apud NARULA, 2010). Davenport e Prusak (1998) destacam alguns fatores culturais que inibem a transferência de conhecimento e suas respectivas soluções, conforme Quadro 9 abaixo:

Quadro 9: Fatores culturais inibidores e soluções da transferência de conhecimento

\begin{tabular}{|l|l|}
\hline \multicolumn{1}{|c|}{ Barreiras } & \multicolumn{1}{c|}{ Solução } \\
\hline Falta de confiança & $\begin{array}{l}\text { Construir relações e confiança por meio de reuniões } \\
\text { pessoais }\end{array}$ \\
\hline $\begin{array}{l}\text { Diferentes culturas, vocabulários e e } \\
\text { quadros de referência }\end{array}$ & $\begin{array}{l}\text { Criar homogeneização por meio de educação, discussão, } \\
\text { publicações, trabalhos em grupo e rotação de } \\
\text { empregados }\end{array}$ \\
\hline $\begin{array}{l}\text { Falta de tempo e de pontos de encontro, } \\
\text { ideia ultrapassada de trabalho produtivo }\end{array}$ & $\begin{array}{l}\text { Estabelecer horários e locais para a transferência de } \\
\text { conhecimento: feiras, salas de conversa, conferências }\end{array}$ \\
\hline $\begin{array}{l}\text { Status e recompensas vão para o dono } \\
\text { do conhecimento }\end{array}$ & Avaliar a performance e dar incentivos baseados na troca \\
\hline $\begin{array}{l}\text { Falta de capacidade de absorção dos } \\
\text { funcionários }\end{array}$ & $\begin{array}{l}\text { Educar os empregados para a flexibilidade; prover tempo } \\
\text { para o aprendizado; contratar pela mente aberta }\end{array}$ \\
\hline $\begin{array}{l}\text { Crença de que o conhecimento é de } \\
\text { grupos particulares }\end{array}$ & $\begin{array}{l}\text { Encorajar uma abordagem não hierárquica para o } \\
\text { conhecimento; qualidade das ideias mais importante que } \\
\text { o status de sua fonte }\end{array}$ \\
\hline
\end{tabular}

FONTE: DAVENPORT; PRUSAK (1998, p. 97).

Em um dos estudos mais reconhecidos sobre as barreiras para a transferência, Szulanski (1996), a partir de uma investigação que apontou as 122 melhores práticas para a transferência de conhecimento em oito EMNs, desenvolveu uma taxonomia para a compreensão das barreiras 
do processo de transferência de conhecimento, classificadas de acordo com quatro elementos do processo de transferência já destacados no modelo analítico preliminar deste estudo, a saber: (i) características do conhecimento transferido - ambiguidade causal; (ii) características dos receptores do conhecimento - falta de motivação, falta de capacidade de absorção e falta de capacidade de retenção; (iii) características do emissor do conhecimento - falta de motivação e de confiança; e (iv) características do contexto organizacional - relações difíceis entre as unidades.

\subsubsection{Transferência reversa do conhecimento na EMN}

Nos estágios iniciais da pesquisa sobre a internacionalização de empresas, muitos autores enfatizavam que a busca de vantagens competitivas das EMNs visava a exploração internacional nos países anfitriões das subsidiárias, portanto a transferência de conhecimento da matriz para a filial (VERNON, 1966, apud AMBOS; AMBOS; SCHLEGELMILCH, 2006). Pouco se falava sobre transferências de conhecimento laterais entre subsidiárias ou mesmo sobre transferência reversa, das subsidiárias para a matriz.

No entanto, alavancar internacionalmente as vantagens do know-how derivado da competência da matriz já não é suficiente para sustentar uma vantagem competitiva da EMN, a menos que a base doméstica continue sendo o único remanescente de novas tecnologias, de competências e de principais clientes (DOZ; SANTOS, 1997). Por isso, estudos recentes, porém bem estabelecidos, têm reforçado a necessidade de as subsidiárias criarem e transferirem conhecimentos dentro da rede corporativa. Entre os mais citados, podem-se elencar: Frost (1998), Gupta e Govindarajan (2000), Hakanson e Nobel (2000, 2001), Zhou e Frost (2003), Frost e Zhou (2005), Ambos, T. Ambos, B. e Schlegelmilch (2006) e Yang, Mudambi e Meyer (2008). Todos esses estudos partem do reconhecimento de que as subsidiárias podem contribuir para a criação de vantagens competitiva para a matriz (AMBOS, T.; AMBOS, B.; SCHLEGELMILCH, 2006), sob a justificativa de que o acesso ao conhecimento local da subsidiária poderia possibilitar à matriz coordenar e aperfeiçoar a estratégia global da corporação, bem como aperfeiçoar o desenvolvimento de produtos, tecnologias ou serviços (Ibid.).

Millar e Choi (2009) definem transferência reversa de conhecimento como sendo "o processo de transferência de conhecimento tácito e explícito de uma subsidiária para sua sede" (Ibid., p. 390). Para Szulanski et al. (2004), a transferência de conhecimento é o processo ou projeto que ocorre em um tempo específico no qual o conhecimento é compartilhado entre agentes distintos, 
como, por exemplo, emissores e receptores, e por meio de mecanismos selecionados. A transferência é tida como uma ação deliberada, ou seja, não se trata de uma difusão involuntária, mas, ao contrário, de um compartilhamento proposital entre as unidades da EMN (CIABUSCHI, 2011a).

Como já mencionado, nem sempre a transferência entre unidades de uma mesma organização é um processo mais fácil de executar do que as transferências entre organizações (KOGUT; ZANDER, 1992; 1993); quando se trata de transferência reversa de conhecimento (subsidiáriamatriz), esse processo pode ficar ainda mais complexo, porque enquanto "[...] a transferência convencional é um processo de ensinar, a transferência reversa é um processo de persuadir" (YANG; MUDAMBI; MEYER, 2008). Nesse caso, o esforço é muito maior porque sua efetividade depende do convencimento da sede (Ibid.).

Com efeito, na transferência convencional a subsidiária é muitas vezes obrigada a replicar o conhecimento gerado na sede por meio de mecanismos de controle (Ibid.). Outro aspecto dificultador é que, muitas vezes, a matriz pode estar interessada na transferência reversa apenas pela perspectiva do autobeneficiamento (GUPTA; GOVINDARAJAN, 2000; KOGUT; ZANDER, 1993). Por outro lado, as subsidiárias, ao transferirem seu conhecimento para a sede, fazem-no com a motivação de fortalecer sua posição estratégica na rede da corporação (GUPTA; GOVINDARAJAN, 2000; MUDAMBI; NAVARRA, 2004). Outros motivadores para a transferência reversa são a economia de custos, a busca de desenvolvimento de novos conhecimentos e a reutilização do conhecimento já desenvolvido em outras partes da corporação (TAVANI, 2010).

No que tange ao sucesso da transferência reversa, autores como Kogut e Zander (1995) e Szulanski (1996) indicam que o processo só é eficiente caso seja realizado com um mínimo de custo e um mínimo de tempo. O custo de transferência é relacionado aos recursos utilizados por ambas as unidades. Quanto menor o tempo de transferência, mais rapidamente o conhecimento será utilizado pelo receptor e mais rapidamente os recursos utilizados em ambas as partes serão realocados em novas atividades.

Transferência reversa de conhecimento pode ser benéfica para a matriz em termos de acesso conhecimento local, de coordenação de uma estratégia global na EMN, de melhoria dos processos, de fornecimento do elo perdido na busca de desenvolver um novo produto ou pode 
resultar em diferentes saberes, como, por exemplo, conhecimentos sobre marketing, compras ou tecnologia (AMBOS, T.; AMBOS, B.; SCHLEGELMILCH, 2006). No entanto, nem toda transferência é igualmente benéfica para o receptor (Ibid.). Algumas transferências de conhecimento podem beneficiar a matriz em um grande negócio, mas algumas só podem ser utilizadas como fonte de informação ou de coordenação e outras podem ser muito custosas para que seja viável sua integração nas operações. Além disso, a matriz pode não reconhecer os benefícios potenciais e, portanto, não tomar as iniciativas adequadas para adotar o conhecimento disponível nas subsidiárias. Essa dificuldade é gerada, sobretudo, pela relação com o agente principal, que implica o fato de que o compromisso de aprendizagem da matriz com o conhecimento advindo da subsidiária é menor do que o compromisso de aprendizagem da subsidiária com o conhecimento originado na matriz (YANG; MUDAMBI; MEYER, 2008). Nesse sentido, Gupta e Govindarajan (2000) ressaltam que há que distinguir os tipos de conhecimento transferidos sob o ponto de vista dos benefícios adicionados à receptora (GUPTA; GOVINDARAJAN, 2000).

Wijk, Jansen e Lyles (2008) realizaram um estudo sobre os antecedentes e as consequências da transferência de conhecimento organizacional interna e externa, por meio de uma meta-análise, nas bases de dados ABI, INFORM, EBSCO, JSTOR, Science Direct e bancos de dados Swetsnet, publicados entre os anos de 1991 e 2005. Como resultado desse apanhado, os autores concluem que a transferência organizacional tem sido associada aos níveis mais elevados de desempenho organizacional e de inovação. A partir desse estudo, as seguintes contribuições são assinaladas:

- Pesquisas anteriores encontram uma relação positiva entre transferência de conhecimento e desempenho organizacional (LYLES; SALK, 1996; STEENSMA; LYLES, 2000);

- Transferência de conhecimento contribui para o desenvolvimento de capacidades organizacionais que são difíceis de imitar e, subsequentemente, leva a um desempenho superior (SZULANSKI, 1996);

- Parceiros de uma joint venture que adquirem e assimilem novos conhecimentos por meio da parceria, acabam aumentando seu desempenho (LANE; SALK; LYLES, 2001); 
- As empresas que são capazes de aprender sobre clientes, concorrentes e reguladores têm uma melhor chance de detectar e adaptar os seus produtos e serviços às necessidades emergentes (DAY, 1994);

- Transferência de conhecimento organizacional permite que uma organização gere novas ideias para o desenvolvimento de novos produtos (POWELL et al., 1996; TSAI, 2001), uma vez que estimula a combinação de conhecimentos pré-existentes com novos conhecimentos e aumenta a capacidade da unidade para fazer novas associações e articulações (JANSEN et al., 2005);

- A acumulação de conhecimento não só permite uma utilização mais eficiente dos recursos relacionados com o conhecimento, mas também permite que as organizações compreendam e avaliem melhor a natureza e o potencial comercial dos avanços tecnológicos (COHEN; LEVINTHAL, 1990).

\subsubsection{Identificação dos fatores determinantes da transferência reversa de conhecimento na EMN}

Comparativamente à transferência tradicional (transferência da matriz para as subsidiárias), o fenômeno da transferência reversa tem sido pouco investigado. Contudo, importantes estudos têm mostrado a importância da transferência reversa como forma de criar vantagem competitiva para a EMN (HAKANSON; NOBEL, 2000; YAMIN; OTTO, 2004; FROST; ZHOU, 2005; TAVANI; GIROUND; SINKOVICS, 2010; RABIOSI, 2008, 2011). Todos esses estudos lançam luz sobre alguns determinantes importantes que contribuem positiva ou negativamente para a transferência reversa.

Conforme mencionado no tópico 2.3 .3 (modelo preliminar da transferência reversa de conhecimento), este estudo utiliza a metáfora desenvolvida por Suzlanski (1996, 2003) e adotada (e aperfeiçoada) por Gupta e Govindarajan (2000), Minbaeva (2007) e Tavani (2010), para classificar a transferência reversa em três grupos: características do conhecimento (mensagem) características do emissor (subsidiária) e características relacionadas à interação emissor/receptor (contexto em que a transferência acontece). Nota-se que as características do receptor (matriz) não serão analisadas neste estudo porque a pesquisa de campo não contemplará o estudo na matriz das EMNs. 
De maneira geral, os estudos têm destacado que a transferência de conhecimento na EMN depende de vários fatores determinantes. No entanto, poucos estudos empíricos têm feito uma investigação que analise os determinantes de forma conjunta em um único modelo. Em geral, os investigadores têm examinado as relações entre dois ou mais determinantes da transferência e seus resultados. Por exemplo, alguns estudos têm-se centrado nas características dos conhecimentos transferidos (ZANDER; KOGUT 1995; SIMONIN, 1999a, 1999b), nas fontes do conhecimento (FOSS; PEDERSEN, 2002), na capacidade de absorção (LYLES; SALK 1996; LANE; LUBATKIN 1998; LANE; SALK; LYLES, 2001; MINBAEVA et al. 2003), e no contexto organizacional em que se dá a transferência (SIMONIN, 1999a, 1999b, BRESMAN, BIRKINSHAW, NOBEL, 1999). Poucos estudos incluem todos os quatro elementos do processo de transferência (SZULANSKI, 1996, GUPTA; GOVINDARAJAN, 2000; MINBAEVA, 2007; TAVANI, 2010). Esta pesquisa identificou apenas quatro estudos que seguem nessa direção, conforme apresentados no quadro a seguir. 
Quadro 10: Modelos de determinantes da transferência de conhecimento

\begin{tabular}{|c|c|c|c|c|c|c|}
\hline Autores & Ideia principal & Contexto & $\begin{array}{l}\text { Características } \\
\text { Conhecimento }\end{array}$ & $\begin{array}{c}\text { Características da } \\
\text { fonte }\end{array}$ & $\begin{array}{l}\text { Características do } \\
\text { receptor }\end{array}$ & $\begin{array}{c}\text { Características do } \\
\text { contexto }\end{array}$ \\
\hline $\begin{array}{l}\text { Szulanksi } \\
\text { (1996) }\end{array}$ & $\begin{array}{l}\text { Faz uma explanação } \\
\text { sobre as barreiras para } \\
\text { a transferência de } \\
\text { conhecimento }\end{array}$ & $\begin{array}{l}122 \text { melhores } \\
\text { práticas de } \\
\text { transferência de } \\
\text { conhecimento em } \\
8 \text { multinacionais }\end{array}$ & $\begin{array}{l}\text { - } \text { ambiguidade }^{\text {causal e }} \\
\text { - } \text { unproveness }^{7}\end{array}$ & $\begin{array}{l}\text { - falta de motivação } \\
\text { e confiabilidade }\end{array}$ & $\begin{array}{l}\text { - falta de motivação } \\
\text { - falta da capacidade } \\
\text { de absorção e } \\
\text { - falta de capacidade } \\
\text { de retenção }\end{array}$ & $\begin{array}{l}\text { contexto } \\
\text { organizacional } \\
\text { árido/difícil e } \\
\text { relacionamentos } \\
\text { difíceis }\end{array}$ \\
\hline $\begin{array}{l}\text { Gupta e } \\
\text { Govindara- } \\
\text { jan (2000) }\end{array}$ & $\begin{array}{l}\text { Define fluxos de } \\
\text { conhecimento (dentro e } \\
\text { fora de uma } \\
\text { subsidiária) como } \\
\text { função do valor de } \\
\text { estoque do } \\
\text { conhecimento da } \\
\text { subsidiária }\end{array}$ & 374 Subsidiárias & $\begin{array}{l}\text { valor do estoque } \\
\text { do conhecimento } \\
\text { da unidade fonte }\end{array}$ & $\begin{array}{l}\text { - } \text { disposição } \\
\text { motivacional }\end{array}$ & $\begin{array}{l}\text { - capacidade de } \\
\text { absorção do } \\
\text { conhecimento pela } \\
\text { unidade receptora }\end{array}$ & $\begin{array}{l}\text { existência de canais de } \\
\text { transmissão ricos } \\
\text { (mecanismos de } \\
\text { socialização) }\end{array}$ \\
\hline $\begin{array}{l}\text { Minbaeva } \\
(2007)\end{array}$ & $\begin{array}{l}\text { Analisa o efeito } \\
\text { conjunto dos quatro } \\
\text { grupos de } \\
\text { determinantes } \\
\text { da transferência de } \\
\text { conhecimento } \\
\text { e as relações entre eles }\end{array}$ & $\begin{array}{l}92 \text { multinacionais } \\
\text { do setor industrial } \\
\text { e de serviços }\end{array}$ & $\begin{array}{l}\text { - } \text { tacitividade } \\
\text { - complexidade } \\
\text { - não } \\
\text { especificidade } \\
\text { - não } \\
\text { disponibilidade }\end{array}$ & $\begin{array}{l}\text { - } \text { habilidade e } \\
\text { motivação }\end{array}$ & $\begin{array}{l}\text { - habilidade e } \\
\text { motivação } \\
\text { - capacidade de } \\
\text { absorver novos } \\
\text { conhecimentos }\end{array}$ & $\begin{array}{l}\text { envolvimento interno } \\
\text { com outras unidades } \\
\text { da rede corporativa }\end{array}$ \\
\hline $\begin{array}{l}\text { Tavani } \\
\text { (2010) }\end{array}$ & $\begin{array}{l}\text { Investiga como três dos } \\
\text { quatro grupos de } \\
\text { determinantes } \\
\text { impactam no grau de } \\
\text { desenvolvimento do } \\
\text { conhecimento e sua } \\
\text { relação com a } \\
\text { transferência. }\end{array}$ & $\begin{array}{l}158 \\
\text { multinacionais } \\
\text { Italianas }\end{array}$ & $\begin{array}{l}\text { - tacitividade e } \\
\text { complexidade }\end{array}$ & $\begin{array}{l}\text { - } \text { motivação } \\
\text { - integração com a } \\
\text { rede externa } \\
\text { - autonomia }\end{array}$ & $\begin{array}{l}\text { - dimensão não } \\
\text { contemplada no } \\
\text { estudo }\end{array}$ & $\begin{array}{l}\text { - integração interna com } \\
\text { subsidiárias pares } \\
\text { - integração interna com } \\
\text { matriz } \\
\text { - mecanismos de } \\
\text { socialização e } \\
\text { - compartilhamento de } \\
\text { valores }\end{array}$ \\
\hline
\end{tabular}

FONTE: Adaptado pela autora.

${ }^{7}$ Conhecimentos cujos resultados não são conhecidos porque nunca foram aplicados (SZULANSKI, 1996). 
Várias medidas foram tomadas para selecionar os determinantes centrais da transferência reversa de conhecimento para este estudo. Em primeiro lugar, seguiram-se as contribuições das teorias que foram base para o estudo: visão baseada em conhecimento e teoria das redes; em segundo lugar, utilizou-se o estudo dos quatro autores adotados como base para este estudo, conforme o Quadro 10; em terceiro lugar, os resultados de outros estudos que consideravam determinantes da transferência de conhecimento individualmente também foram identificados e resumidos, a saber os de: Zander e Kogut (1995), Szulanski (1996), Lyles e Salk (1996), Lane e Lubatkin (1998), Bresman, Birkinshaw e Nobel (1999), Simonin (1999a, 1999b), Lane et al. (2001), Subramaniam e Venkatraman (2001), Foss e Pedersen (2002), Minbaeva et al. (2003), Schulz (2003) e Rabiosi (2008, 2011); em quarto lugar, somente foram considerados nesta pesquisa os determinantes que poderiam ser classificados de acordo com as três categorias de determinantes do estudo: características do conhecimento, características da fonte e características do contexto. É importante notar que o estudo deixou de fora as características do receptor (matriz), tendo em vista que não seria possível entrevistar a matriz das EMNs. Em quinto lugar é necessário informar que este estudo não pretende esgotar todos os fatores influenciadores da transferência reversa de conhecimento.

Finalmente, para cada um dos três grupos de determinantes, foram selecionados os fatores que a literatura apresenta como sendo os mais consistentemente significativos para os resultados de transferência de conhecimento, assim como aqueles sobre os quais foram relatados resultados controversos (MINBAEVA, 2007):

\section{(i) Fatores relacionados às características do conhecimento:}

Dentre os vários aspectos classificados como características do conhecimento, esta pesquisa focaliza apenas os determinantes tacitividade e complexidade, que são identificados por Minbaeva (2007) como sendo os mais destacados na literatura da área.

\section{(ii) Fatores relacionados às características da subsidiária:}

As características do emissor (ou fonte) do conhecimento são um fator amplamente reconhecido na literatura como preponderante para o sucesso da transferência reversa (GUPTA; GOVINDARAJAN, 2000; SZULANSKI, 1996).

Resultados de estudos prévios relacionam aspectos tais como os Ambiente Institucional (AMBOS, T.; AMBOS, B.; SCHLEGELMILCH, 1996; FROST; BIRKINSHAW; ENSIGN, 
2002), os Ambiente competitivo (por exemplo: ANDERSSON; FORSGREN; HOLM, 2002; FROST, 2001, GHOSHAL; NOHRIA, 1989, BIRKINSHAW; HOOD; JONSSON (1998), PORTER (1990) e KOGUT; ZANDER, 1992), o grau de integração externa da subsidiária com universidades, fornecedores, clientes e institutos de pesquisa (ANDERSSON, BJORKMAN; FORSGREN, 2005; HAKANSON; NOBEL, 2001), a autonomia (GUPTA; GOVINDARAJAN, 1991; NOHRIA; GHOSHAL, 1994; BIRKINSHAW; HOOD; JONSSON, 1998), a motivação para a transferência (MINBAEVA, 2007; MINBAEVA; MICHAILOVA, 2004) como fatores fortemente influentes na criação do conhecimento nas subsidiárias.

\section{(iii) Fatores relacionados à interação matriz-subsidiária:}

Outro elemento amplamente citado como influenciador da transferência de conhecimento na EMN é a relação entre fonte e receptor do conhecimento. Laços fortes entre esses parceiros facilitam a transferência de conhecimento, sobretudo quando se trata de um conhecimento de natureza tácita e complexa (SIMONIN, 1999b; ANDERSSON; HOLM; FORSGREN, 2002; FORSGREN; HOLM; JOHANSON, 2006; TAVANI, 2010; GUPTA; GOVINDARAJAN, 2000).

Neste estudo, foram eleitos os seguintes fatores como determinantes da transferência reversa de conhecimento: integração interna - subsidiária com a matriz (ANDERSON; FORSGREN, 1996; ANDERSON; FORSGREN; HOLM; 2001; 2007), semelhança organizacional (AMBOS, T.; AMBOS, B.; SCHLEGELMILCH, 2006; AMBOS, T.; AMBOS, B., 2009; SIMONIN, 1999b), semelhança cultural (AMBOS, T., AMBOS, B. e SCHLEGELMILCH, 2006) e mecanismos de socialização (NOORDEHAVEN; HARZING, 2009, AMBOS, T.; AMBOS, B., 2009, BRESMAN; BIRKINSHAW; NOBEL, 1999; GUPTA; GOVINDARAJAN, 2000; SCHULZ, 2001; TSAI, 2002; RABIOSI, 2006, 2008, 2011).

Os fatores determinantes utilizados neste estudo são apresentados na ilustração a seguir. 

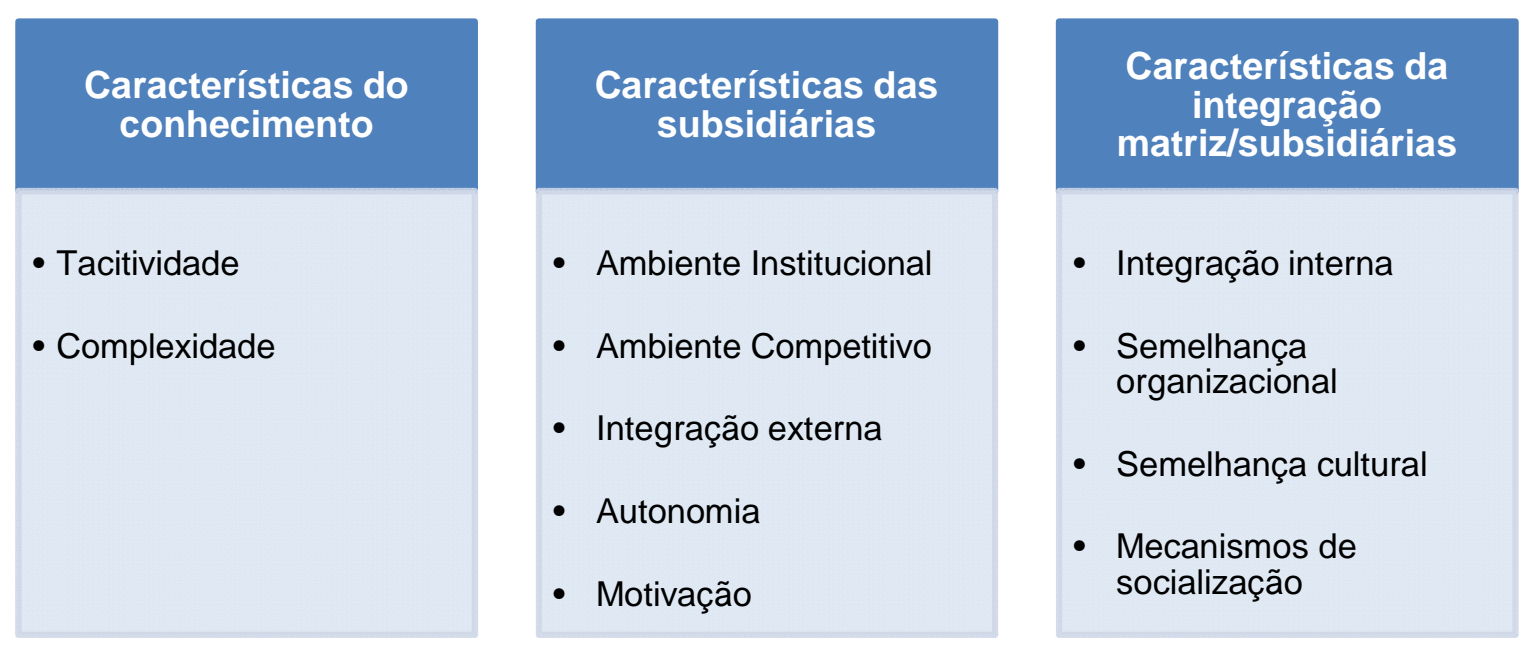

Ilustração 10: Determinantes da transferência classificados por grupos de influência FONTE: A autora.

Nas seções seguintes, cada um dos três fatores determinantes da transferência reversa de conhecimento é conceituado, e hipóteses são desenvolvidas de acordo com seu efeito sobre o grau de transferência reversa de conhecimento.

\subsubsection{Síntese do capítulo de referencial teórico}

Inicialmente, foi discutida a EMN e a sua competência - notadamente superior à dos mercados externos - em transferir conhecimento além das fronteiras internacionais via sua rede interna. A importância crescente do papel das subsidiárias foi explanada, trazendo-se para isso uma visão evolutiva de como esse aspecto tem sido representado na literatura desde o início das discussões do tema sobre negócios internacionais. Com vistas em situar o estudo, foi também apresentado o contexto do crescente peso das EMNEs seguido por uma explanação sobre o processo de internacionalização das EMNBrs. Verificou-se que a internacionalização das empresas brasileiras é recente, tendo ganhado maior impulso a partir dos anos 90 . Verificou-se também que as EMNBrs possuem muitas vantagens comparativas - relacionadas às características do país - e pouco se firmam em vantagens competitivas. Suas subsidiárias inovam pouco, relacionam-se pouco com outras fontes de conhecimento em seus locais de operação e ainda são muito dependentes das determinações e do controle da matriz. Concluiuse, portanto, que, caso as EMNBrs desejem desenhar uma trajetória de internacionalização crescente, é mandatório modificar rapidamente esse quadro de pouca influência das subsidiárias na criação e compartilhamento de conhecimento dentro da corporação.

A seção seguinte desenvolve um modelo analítico com base em algumas correntes de estudo dos negócios internacionais que trazem os subsídios iniciais para a análise e determinação dos 
principais fatores da transferência reversa de conhecimento. Dentre essas correntes, estão: a visão baseada em valor e a teoria das redes. A partir da combinação dessas teorias, um modelo de análise foi desenvolvido para o estudo, que é compreendeu basicamente, as características do emissor (subsidiária), as características do conhecimento e as características do receptor (matriz).

A revisão segue com a seção que explicita as principais definições-chave que permeiam o assunto, dentre elas, a do conhecimento na EMN - que pode ser classificado principalmente quanto à sua dimensão tácita e complexa. Diversas outras classificações sobre os tipos de conhecimento são apresentadas e comparadas com vistas em discutir e especificar os constructos mais adequados a serem utilizados por este estudo. O capítulo segue com a explanação sobre a transferência tradicional de conhecimento (matriz-subsidiária), que empresta muitos de seus conceitos ao entendimento da transferência reversa (subsidiáriamatriz), foco do estudo.

A última seção do capítulo organiza e define, a partir de uma extensa literatura pesquisada, os principais determinantes da transferência reversa de conhecimento na EMN, que são classificados de acordo com o modelo analítico desenvolvido na segunda seção. O objetivo foi construir um modelo parcimonioso, mas que compreendesse os principais determinantes da transferência reversa de conhecimento tecnológico na EMN. A Ilustração 11 apresenta, de forma gráfica, o desenvolvimento da fundamentação teórica. 
A Empresa Multinacional Brasileira

O conhecimento tecnológico na EMN

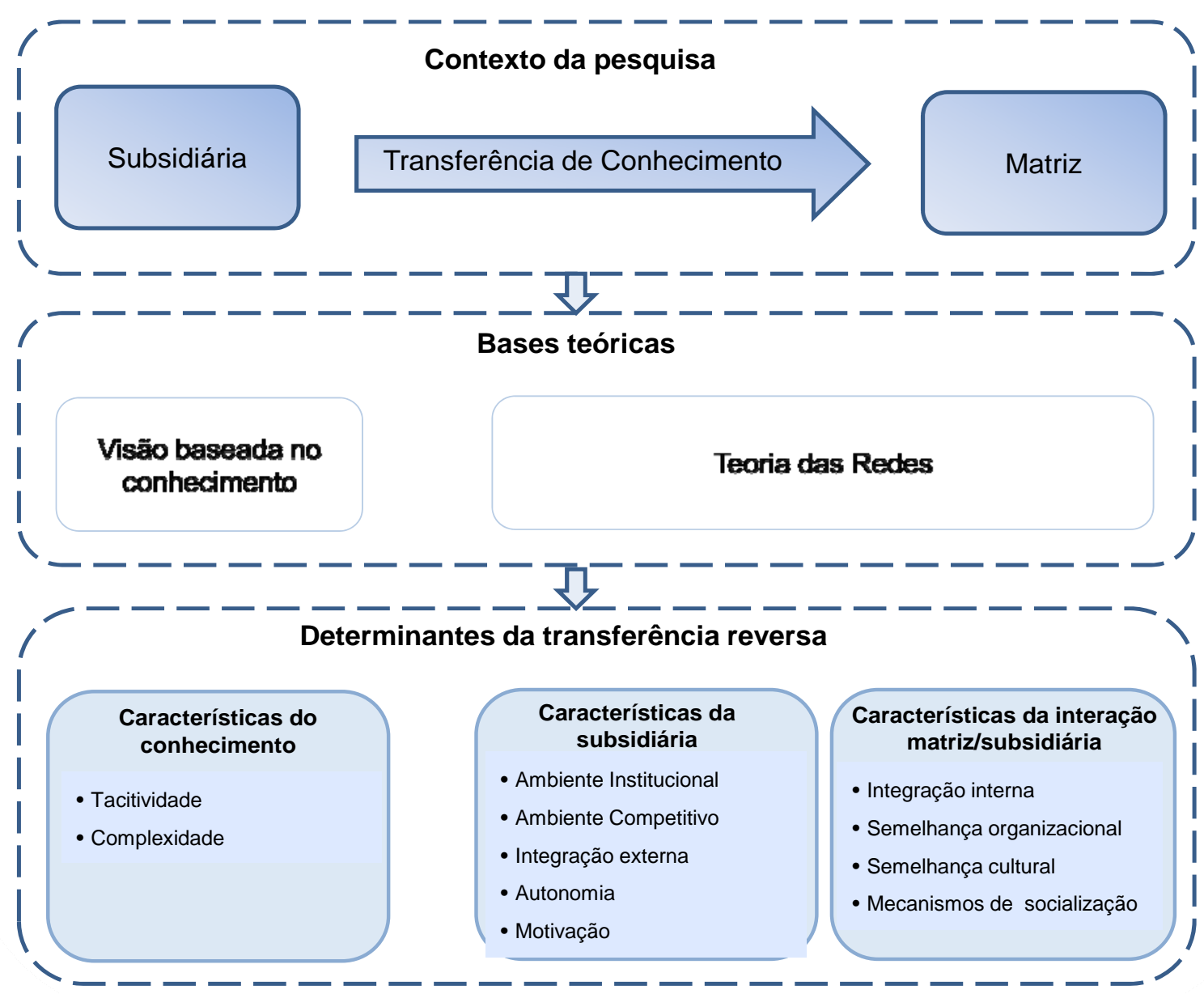

Ilustração 11: Síntese dos principais temas analisados no referencial teórico

FONTE: A autora.

Portanto, com base na revisão da literatura, que procurou abordar e explorar os principais fundamentos teóricos do tema em questão, acredita-se que o conteúdo deste capítulo fornece o suporte teórico suficiente para a elaboração do modelo conceitual utilizado no planejamento desta pesquisa. Além disso, espera-se também que a fundamentação teórica auxilie o pesquisador na interpretação dos resultados e na formulação das recomendações teóricopráticas. 


\section{ESTRUTURA CONCEITUAL E HIPÓTESES}

Nesta seção, cada determinante da transferência reversa de conhecimento tecnológico será apresentado em detalhes e, na sequência, pelo menos uma hipótese será firmada para cada determinante, a fim de testar o modelo conceitual desenvolvido na seção anterior. O conjunto de hipóteses testáveis foi desenvolvido com o intuito de solucionar a questão-chave de pesquisa deste estudo: Quais são os fatores determinantes da transferência reversa de conhecimento tecnológico nas multinacionais brasileiras?

\subsection{Fatores determinantes da transferência reversa do conhecimento em EMNs}

Como já explicado nas seções anteriores, os determinantes estão classificados em três grupos: características do conhecimento, características da subsidiária e características do contexto matriz-subsidiárias.

\subsubsection{Características do conhecimento}

A literatura indica que a ambiguidade do conhecimento é um dos condicionantes mais importantes para a sua transferência (SIMONIN, 1999; SZULANSKI et al., 2004). Essa qualidade se refere às incertezas inerentes tanto à precisão com que se conseguem capturar os componentes subjacentes do conhecimento, quanto à forma como seus agentes (emissor/receptor) interagem. Emerge dos efeitos simultâneos de fatores como especificidade, tacitividade e complexidade do conhecimento (REED; DEFILIPPI, 1990; JANSEN; LYLES, 2008; CIABUSCHI; MARTÍN; 2012).

Por um lado, a ambiguidade do conhecimento proporciona uma barreira para a imitação, mas, por outro lado, também desenvolve barreiras à sua transferência interna (ZANDER; KOGUT, 1995). Esse paradoxo gera três possibilidades, sobretudo para as EMN que precisam compartilhar conhecimento na sua rede dispersa: (i) as empresas passam a transferir apenas o conhecimento que é mais explícito e mais fácil de transmitir (e lidam com o risco de imitação); (ii) as empresas têm que lidar com a codificação e articulação do conhecimento tácito; (iii) as empresas identificam o conhecimento que, apesar de enfrentar problemas de transferência e custos mais elevados, será compensatório para o receptor do conhecimento (CIABUSCHI; 
MARTÍN; 2012). Ressalta-se que a ambiguidade do conhecimento é menos prejudicial no contexto de transferência interna na empresa do que no contexto de transferências entre diferentes organizações (WIJK; JANSEN; LYLES, 2008).

Segundo Minbaeva (2007), os fatores relacionados à ambiguidade foram desenvolvidos e testados empiricamente por diversos estudos anteriores, no entanto, "apenas a 'tacitividade' tem sido relacionada consistentemente a um efeito negativo para a transferência de conhecimento no ambiente da EMN. Já o resultado dos constructos especificidade e complexidade têm variado ao longo dos estudos" (MINBAEVA, 2007, p. 572). Este estudo elegeu os fatores tacitividade e complexidade para trabalhar as características do conhecimento transferido, porque, dentre os três, esses dois são os mais citados, além disso, havia um limite de perguntas adequado no instrumento de coleta.

\subsubsection{Tacitividade}

Subramanian; Meyer e Evans (1998) destacam que quanto maior for o conhecimento tácito em seu domínio, maiores as chances das subsidiárias de participar dos desenvolvimentos tecnológicos.

Como já apresentado na seção 2.4.1 (classificações do conhecimento), é amplamente aceito pela literatura que o conhecimento pode ser dividido em duas categorias: tácito e explícito (POLANY, 1966). O conhecimento explícito "é o saber articulado" e pode ser transferido via formatos tangíveis, como um manual de projeto ou de operação (HOWELLS, 2000). Em contraste, o conhecimento tácito é pessoal, dependente de contexto e, por isso, difícil de articular, e só pode ser adquirido por meio da experiência; é o conhecimento que os indivíduos possuem, mas que não podem explicar ou compreender facilmente (POLANY, 1966). Polany (1962) define o conhecimento tácito como sendo o conhecimento não verbalizado, intuitivo e não articulado. É difícil de articular, formalizar e comunicar, mas pode ser exibido e manifestado por meio das experiências e compartilhado por meio dos processos sociais e engajamentos colaborativos (POLANY, 1966; NONAKA; TAKEUCHI, 1995). Complementarmente, Teece (1985, p. 229) afirma que "é extremamente difícil de realizar a transferência do conhecimento tácito sem ensino, demonstração e participação". Nonaka e Takeuchi (1995) afirmam que o conhecimento tácito só poderia ser aprendido por meio da experiência (NONAKA; TAKEUCHI, 1995), por interações face a face (MUDAMBI, 2002; 
NONAKA; TAKEUCHI; KATSUHIRO, 1996), ou por laços fortes entre emissor e receptor (SZULANSKI, 1996; HANSEN, 1999).

Nonaka e Takeuchi (1995) reiteram que é difícil separar totalmente esses dois tipos de conhecimento, pois, além de ocorrer de forma simultânea nas interações entre as pessoas e grupos, são também complementares. Inkpen e Dinur (1998) apontam que é raro identificar o conhecimento puramente tácito ou o puramente explícito. Em vez de serem apontados como uma dicotomia, esses dois tipos de conhecimento poderiam ser classificados como uma faixa contínua que pode variar entre os dois polos desse espectro.

A partir da Ilustração 12, a organização é vista como um repositório de vários tipos de conhecimento em diferentes níveis da organização. A dimensão a vertical refere-se a tacitividade conhecimento e a dimensão horizontal distingue os níveis em que o conhecimento pode ser armazenado. Nessa ilustração a tacitividade é vista como um continuum na qual o conhecimento explícito tem baixo grau de tacitividade.

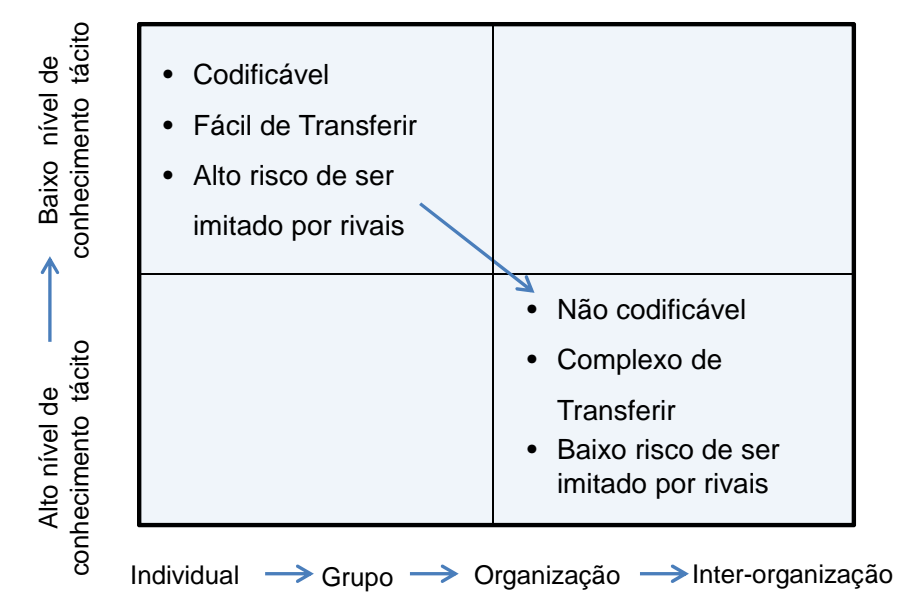

Ilustração 12: classificação da transferência de conhecimento

FONTE: Adaptado de Inpken e Dinur (2008).

Howells (2000) questiona a crença de que a possibilidade de codificar o conhecimento tácito em explícito para realizar o processo de transferência tecnológica é viável. Isso porque, mesmo que a tecnologia em questão esteja madura ou padronizada, nem sempre é possível codificar todo o pacote tecnológico, que inclui implantação e melhorias subsequentes à operação. Seu argumento é baseado na premissa de que "a maior parte do processo de inovação é associada a um alto grau de incerteza, aspectos não codificáveis e atividades de 'tentativa e erro', o que 
resulta em um processo que não pode ser estocado, pelo menos não sem um custo considerável” (Ibid.). Mas, de acordo com Nonaka e Takeuchi (1995), embora haja limites, o conhecimento pode ser convertido de tácito em explícito e vice-versa.

O conceito de conhecimento tácito tem sido fundamental para descrever as características do conhecimento organizacional. Segundo Polanyi (1966), as pessoas sabem mais do que conseguem explicar de forma verbal. Desse ponto de vista, a transferência do conhecimento torna-se um desafio, pois, ao contrário de afirmações de estudos iniciais, como o de Nelson e Winter (1982), nem todo o conhecimento é passível de transferência, mesmo levando-se em consideração a questão do custo de transferência (MINBAEVA, 2007).

Nessa perspectiva, a tacitividade tem sido relacionada a um impacto negativo na transferência de conhecimento, seja porque implica dificuldade de articulação e de codificação do conhecimento por meio de uma linguagem formal ou expressa de forma direta (ZANDER; KOGUT, 1995), seja ainda porque implica ambiguidade de interpretação (SZULANSKI, 1996; SIMONIN, 1999a, 1999b). Em outras palavras, quanto mais tácito o conhecimento, mas difícil de ser transferido de uma empresa para outra. Com base nesses argumentos, a seguinte hipótese é formulada:

H1: Quanto menor a tacitividade do conhecimento da subsidiária, maior o grau de transferência reversa de conhecimento tecnológico.

\subsubsection{Complexidade}

A transferência de conhecimento tem sido reconhecida pelos pesquisadores da área como um fenômeno complexo, constituído por uma sequência de atividades inter-relacionadas (CUSSOMANO, 1992). Simonin (1999b, p. 600) entende complexidade como "um conjunto de competências interdependentes, ligadas por rotinas, indivíduos e recursos vinculados a um conhecimento particular" (ZANDER; KOGUT, 1995). Isso se dá porque a especialização e a sofisticação cada vez maiores de produtos e tecnologias exigem a integração de várias áreas do conhecimento, conduzindo à complexidade de tais elementos. Quanto maior o número de áreas funcionais e disciplinas científicas necessárias para manter e desenvolver o conhecimento, mais complexo ele se torna (CIABUSCHI; MARTÍN, 2012).

Segundo Pringle (1951 apud KOGUT; ZANDER, 1992) complexidade pode ser definida como “o número de parâmetros necessários para definir um sistema”. Simonin (1999a) define 
complexidade do conhecimento como "o número de tecnologias interdependentes, rotinas, indivíduos e recursos vinculados a um determinado conhecimento ou ativo" (SIMONIN, 1999a, p. 600). Um número elevado de elementos únicos aumenta a quantidade de informação que deve ser processada, o que dificulta a compreensão de todo o sistema. Desse modo, saber como um elemento funciona indica muito pouco sobre o conhecimento de todo o sistema. Quanto mais complexo esse sistema, maior a ambiguidade e, por conseguinte, menor a possibilidade de sua replicação, porque o risco de erros aumenta (REED; DEFILLIPPI, 1990).

De acordo Hansen (1999), a complexidade dificulta a transferência de conhecimento porque diminui a capacidade de o receptor identificar, compreender e integrar o conhecimento a ser adquirido; sendo assim, para que a transferência do conhecimento complexo seja viabilizada, o autor conclui que são necessários fortes laços entre as duas partes que compõem a transferência.

Os estudos de Simonin (1999a, 1999b) concluem que a complexidade está negativamente relacionada à transferência de conhecimento: quanto maior o grau de interdependência, menor o grau de transferência de conhecimento. Com base nessas definições, formula-se a seguinte hipótese:

H2: Quanto menor a complexidade do conhecimento da subsidiária, maior o grau de transferência reversa de conhecimento tecnológico.

\subsubsection{Características da subsidiária}

Este estudo explora determinantes como, Ambiente Institucional, Ambiente competitivo, autonomia, inserção da subsidiária nas redes externa de negócios e motivação da subsidiária para transferir conhecimento para a matriz.

\subsection{Ambiente externo}

É amplamente aceito na literatura que a natureza do ambiente local tem uma influência sobre o conhecimento da subsidiária (ANDERSSON; FORSGREN; HOLM, 2002; CANTWELL; MUDAMBI, 2005) e também sobre o papel que a subsidiária desempenha na empresa multinacional (BARTLETT; GHOSHAL, 1986; GHOSHAL; NOHRIA, 1989). 
Um conjunto de características da localização determina o seu alinhamento estratégico com os objetivos da EMN e, consequentemente, a sua importância estratégica dentro da corporação, por conseguinte, quanto maior a importância estratégia da subsidiária, mais fácil para ela "persuadir" a matriz sobre o valor do seu conhecimento (YANG; MUDANBI, 2008). Isto implica que o mesmo nível de conhecimento relevante pode ter um maior ou menor impacto sobre as transferências de conhecimento, dependendo da importância estratégica da localização geográfica da subsidiária (JENSEN; SZULANSKI, 2004). Portanto, espera-se que os efeitos específicos de cada país podem estar associados à relevância do conhecimento, e, por conseguinte, à quantidade e ao tipo de conhecimentos transferidos.

De uma maneira ampla, os aspectos do ambiente externo na qual a subsidiária se instala, pode ser classificado como Ambiente Institucional e Ambiente competitivo. O primeiro abrange as condições (produção, troca e distribuição de bens de uma sociedade) e as vantagens de um país, em outros termos, refere-se às condições e incentivos oferecidos pelo país anfitrião da subsidiária (PENG, 2002). O segundo é caracterizado pela dinâmica dos competidores locais, fornecedores e clientes. Esses dois aspectos do ambiente externo serão detalhados a seguir.

\section{a) Ambiente institucional}

Assim como o país de origem tem sido uma dimensão de análise valiosa para entender uma série de aspectos que rodeiam a EMN, entre os quais, sua estratégia global, estrutura organizacional, sistemas de controle e cultura corporativa interna (BARTLETT; GOSHAL, 1989, GHOSHAL; NOHRIA, 1989), o país anfitrião também tem sido amplamente relacionado a fatores que impactam o desenvolvimento e o posicionamento da subsidiária na corporação (GUPTA; GOVINDARANJAN, 2000) e também à natureza da transferência reversa de conhecimento (YANG; MUDAMBI; MEYER, 2008). Esse argumento tem origem nos pressupostos que indicam que a base de conhecimento da subsidiária é bastante relacionada ao meio no qual ela é desenvolvida (ANDERSSON; FORSGREN; HOLM, 2002; CANTWELL; MUDAMBI, 2005) e que a vantagem competitiva chave da empresa multinacional é sua capacidade de explorar, por meio de suas subsidiárias, conhecimentos existentes em diversos países anfitriões (BARTLETT; GHOSHAL, 1989; SCHLEGELMILCH; CHINI, 2003).

Ao analisar o fluxo de investimento estrangeiro na última década do século XX, Duning (2008) constatou que o estabelecimento de subsidiárias em locais que ofereciam as melhores condições institucionais e econômicas tinha um impacto positivo sobre o investimento. Corroborando a 
literatura de marketing sugere que a imagem da nação tem um significante papel sobre como os consumidores percebem e avaliam a qualidade dos produtos provenientes de países estrangeiros e, portanto, sua propensão para comprar esses produtos (JOHANSSON, 1989). Aplicando um raciocínio semelhante à transferência de conhecimento dentro da EMN, pode-se esperar que a localização de uma subsidiária influencie a forma como os gerentes de outras unidades multinacionais percebem o valor do conhecimento residente nessa subsidiária. Isto implica que, do ponto de vista do receptor, o conhecimento recebido a partir de unidades localizadas em países economicamente e tecnologicamente menos avançados pode - devido a um senso de superioridade ou de etnocentrismo - ser percebido como contextualmente menos sensível e de mais baixo valor comercial. A síndrome do "não inventado aqui”, portanto, tende a ser mais grave quando a subsidiária fonte do conhecimento está localizada em um país economicamente e tecnologicamente menos avançado. Sendo assim, pode-se esperar que a propensão das unidades da EMN em participar na transferência de conhecimento pode variar de acordo com a localização da unidade emissora.

Diversos foram os autores que ressaltaram a importância dos Ambiente Institucional ou ambiente institucional como determinante do estabelecimento das subsidiárias. Segundo Kogut (1991), por exemplo, as capacidades das empresas refletem parcialmente as forças tecnológicas e institucionais do país, tais como fatores legais e institucionais (dentre as quais, políticas de proteção a patentes e incentivos industriais) que garantem a proliferação da inovação. Sob esta ótica, os Ambiente Institucional têm alta relevância para a inovação tecnológica, pois “os tipos de conhecimento, habilidades e aprendizagem que os membros de uma organização vão adquirir refletirão os incentivos embutidos no ambiente institucional” (NORTH, 1990, p. 74 apud BOEHE, 2007). O paradigma eclético de Dunning (2001) ressalta as vantagens que a localização adequada pode oferecer em termos de abundância de recursos naturais, infraestrutura (comunicação, transporte, energia e materiais), instituições (leis e estruturas sociais de gestão pública), fatores de produção, tamanho e dinamismo do mercado, presença de concorrentes ou de clusters, e estabilidade política e econômica.

De acordo com Florida (1997), as nações, e/ou regiões específicas dentro delas, podem ser locais particularmente vantajosos para instalações de $P \& D$ por EMN que buscam aumentar sua base de conhecimento por meio do aproveitamento do conhecimento específico existente em organizações de determinados países, tais como universidades, institutos de pesquisa com financiamento público e concorrentes inovadores. Em consonância com esses autores, Kumar 
(2001) afirma que os recursos oferecidos pelo país anfitrião, tais como: um grande mercado doméstico, abundância de pessoal de P\&D de baixo custo, infraestrutura tecnológica (universidades e institutos de pesquisa) e de comunicações, proteção da propriedade intelectual, políticas de comércio, influenciam o nível de $\mathrm{P} \& \mathrm{D}$ realizado pelas empresas estrangeiras.

Para Boehe (2007), a parceria com universidades e institutos de pesquisa locais pode melhorar a capacidade tecnológica da subsidiária, tornando-a um centro de excelência, cujo conhecimento poderá ser explorado globalmente pelas outras subsidiárias, especialmente em países com as mesmas características culturais, socioeconômicas e climáticas. Frost (2001) aponta que vínculos com instituições nacionais têm um importante efeito no processo e nos mecanismos por meio dos quais o conhecimento viaja dentro das comunicadas técnicas. Gupta e Govindarajan (2000), no contexto do fluxo do conhecimento na empresa multinacional, argumentam que o nível econômico relativo de um país influencia o valor percebido do estoque de conhecimento das subsidiárias no país naquele país.

Em linhas gerais, o argumento é que uma subsidiária pode contribuir de forma mais criativa para a geração de tecnologia na rede corporativa, quanto melhor for a infraestrutura do local no qual ela está situada; isso se dá porque um local com infraestrutura adequada aumentaria suas habilidades potenciais de interação com empresas inovadoras, instituições de pesquisa, etc., o que, subsequentemente, aumentaria o escopo funcional do seu mandato, e ampliaria o seu potencial papel inovador na rede da EMN. Quanto mais madura a subsidiária, mais ela poderia ser estreitamente integrada internacionalmente (CANTWELL; MUDAMBI, 2005).

Várias características são associadas ao local anfitrião da subsidiária, incluindo cultura, instituições, regulamentações governamentais, preferências dos clientes e disponibilidade de trabalho. Esse conjunto de características da localização é que vai determinar o alinhamento estratégico com os objetivos da EMN e, consequentemente, a sua importância estratégica na corporação multinacional; por conseguinte, quanto maior a importância estratégia da subsidiária, mais fácil para ela "persuadir" a matriz sobre o valor do seu conhecimento (YANG; MUDAMBI, 2008). O conhecimento que advém de uma localização com um elevado nível de compatibilidade estratégica com a subsidiária é susceptível de ser visto como estrategicamente importante para toda a corporação. Isto implica que o mesmo nível de conhecimento relevante pode ter maior ou menor impacto sobre as transferências de conhecimento, dependendo da importância estratégica da localização geográfica da subsidiária (JENSEN; SZULANSKI, 2004). 
Isso indica que o desenvolvimento tecnológico de uma corporação está bastante relacionado às oportunidades econômicas e tecnológicas oferecidas no contexto de uma nação. Dessa forma, quanto maior for o desenvolvimento econômico dos países hospedeiros das subsidiárias, maiores os benefícios auferidos pela matriz advindos do conhecimento transferido (AMBOS, T.; AMBOS, B.; SCHLEGELMILCH, 1996; FROST; BIRKINSHAW; ENSIGN, 2002). Essa corrente da literatura pressupõe que os fatores externos desempenham importante papel no desenvolvimento das subsidiárias estrategicamente relevantes e está alinhada com a perspectiva de que os fatores da inovação estão presentes não apenas no ambiente interno à firma, mas também entre consumidores, fornecedores e outras organizações do ambiente externo.

Em termos de vantagens para as multinacionais emergentes, a localização de suas subsidiárias em economias avançadas pode ser bastante benéfica para o aprensizado, já que uma variedade de recursos disponíveis nesses mercados pode ajudar a acelerar e a modernizar a tecnologia das EMNs emergentes (MATHEWS, 2006). Adicionalmente, Aulakh (2007) e Cuervo-Cazurra e Genc (2008) defendem que as EMNs emergentes teriam vantagens decorrentes de operar em condições institucionais similares aos de seus países, nos quais predominam instituições informais que criam maior incerteza, ou como Khanna e Palepu (2006) colocaram, locais onde predominam os "vazios" institucionais.

H3: Quanto mais desenvolvidos os Ambiente Institucional onde a subsidiária está instalada, maior a capacidade da subsidiária de transferir o conhecimento tecnológico.

\section{b) Ambiente competitivo}

É comumente aceito que o desenvolvimento tecnológico dos países é uma importante fonte de vantagem competitiva para as subsidiárias que potencialmente geram inovações com base em estímulos e recursos localizados no país de acolhimento (ANDERSSON; FORSGREN; HOLM, 2002; FROST, 2001). A perspectiva ambiental de Birkinsaw, Hood e Jonsson (1998) e Birkinshaw e Hood (1998), por exemplo, defende que o dinamismo local propicia uma oportunidade latente de aprendizado a partir da rede de negócios local. Destarte, é necessário que a subsidiária tenha capacidade de obter os recursos disponíveis, principalmente, os que se referem a conhecimentos tácitos das redes de negócios (ANDERSSON, FORSGREN, HOLM, 2002; FROST, 2001). 
Segundo Ghoshal e Nohria (1989), o papel de cada subsidiária é influenciado fortemente pelo ambiente de negócios no qual a subsidiária está inserida. Subsidiárias inseridas em um contexto local mais desenvolvido economicamente, ou onde a dinâmica dos competidores locais, fornecedores e clientes seja alta, possivelmente terão acesso a recursos mais sofisticados e, consequentemente, usarão esses recursos como alavanca para inovações globais, conseguindo, dessa forma, um papel mais importante na rede corporativa multinacional (BIRKINSHAW; HOOD; JONSSON, 1998; PORTER, 1990). Em consonância com essa visão, Frost et al. (2002) defendem que as capacidades distintivas das subsidiárias, em muitos casos, são reflexo de suas vantagens regionais.

O modelo de diamante de Porter (1990) oferece um arcabouço para a análise dos Ambiente competitivo. De acordo com o autor, a inovação seria mais viável de ser alcançada por aquelas empresas inseridas em contextos competitivos caracterizados por (i) elevada competitividade as empresas somente construirão inovações se tiverem que deter suas rivais, pois isso desperta maior agressividade e inovação; (ii) demanda aquecida e exigente - a intensidade e a natureza da demanda doméstica fazem com que as empresas percebam com antecedência as necessidades dos compradores; (iii) fornecedores qualificados mundialmente - fornecem insumos com menores custos, maior rapidez e de forma preferencial; e (iv) adequadas condições de infraestrutura física e humana para os negócios. O contexto de intensa competição impactaria a inovação da subsidiária, promovendo a motivação de aprender e de identificar conhecimento local valioso, com vistas em combiná-lo com o seu conhecimento prévio (KOGUT; ZANDER, 1992).

Corroborando essa afirmação, os resultados dos estudos de Birkinshaw, Hood e Jonsson (1998) reforçam que o nível de competição local tem influência positiva sobre a própria competitividade da subsidiária, e, consequentemente, sobre o seu papel contributivo na rede. Frost et al. (2001) mostram a forte associação das características favoráveis do ambiente externo com a criação de inovação (pesquisa e desenvolvimento) em subsidiárias estrangeiras. Kuemmerle (1999) sugere que o tamanho relativo do mercado e a força de sua base científica determinariam a estratégia de investimento em laboratórios de P\&D das EMNs, bem como seu aprendizado de prospecção e/ou exploração. Assim sendo, a proximidade com outros atores detentores de conhecimentos relacionados favorece a complementaridade tecnológica, as interdependências 
socioculturais, o fluxo de informação, o conhecimento e a capacitação tecnológica das empresas.

Segundo Barnard (2010), elementos frequentemente citados como características de um dinamismo ambiental como, por exemplo: consumidores mais sofisticados, forte concorrência, melhor infraestrutura institucional, entre outros (ALMEIDA et al., 2002; PORTER, 1998) não trazem benefícios para as empresas com capacidades básicas mais limitadas ou menos adequadas. Um dos motivos reside no argumento de que EMNs quando jovens, não são ainda susceptíveis de serem capazes de aperfeiçoar diferenças ambientais (BARNARD, 2011). De acordo com Barnard (2010), quando Porter (1998) argumenta que empresas que respondem às pressões competitivas, o fazem muitas vezes por meio do desenvolvimento de soluções inovadoras, ele está analisando os casos de empresas muito compententes no mundo ( $3 \mathrm{M}$ e indústria de flores holandesa, por exemplo). Empresas multinacionais emergentes, geralmente com vantagens e capacidades organizacionais mais fracas, ao sofrer pressões competitivas são mais propensas a ter um efeito negativo. Antes de considerar possíveis benefícios em decorrência da rivalidade, tais empresas precisarão ter vatanges específicas mais robustas para superar a rivalidade. E, na medida em que elas não acumularam experiência suficiente para fazê-lo, tendem a ficar em desvantagem em vez de se favoreceram com a rivalidade (BARNARD, 2010).

Em outras palavras, algum nível de similaridade no contexto de origem e do país anfitrião é importante (BARNARD, 2011). As EMNs emergentes teriam dificuldade em aprender com indústrias mais competitivas por causa de sua defasagem tecnológica. Para suportar seu argumento, o autor coloca luz no caso dos tigres asiáticos, em que EMNs emergentes têm muita dificuldade quando buscam "saltar" em suas tentativas de modernização (HOBDAY, 2000, 1995; SACHWALD, 2001 apud BARNARD, 2011). Sendo assim, é possível que EMNs emergentes possam aprender menos em ambientes com indústrias de ponta no mundo desenvolvido, e, paradoxalmente, aprender mais em ambientes com indústrias menos competitivas, com um menor gap tecnológico e, portanto, com maior similaridade.

Porém, a despeito da advertência de Barnard (2010, 2011), estudos como os de Bonaglia e Goldstein (2007) e Mathews (2006) afirmam que as EMNs emergentes se internacionalizam com a prioridade de buscar novos recursos e de aprender com situações mais competitivas do que aquelas do mercado interno. Alinhado com esses ditames, o estudo de Borini, Fleury, M. E 
Fleury, A. (2013) mostrou que a transferência reversa de competência depende da credibilidade e do dinamismo do contexto competitivo. Sendo assim, postula-se a seguinte hipótese:

H4: Quanto mais desenvolvidos os Ambiente competitivo, maior a capacidade de transferência reversa de conhecimento.

\subsection{Integração externa (com a rede de negócios local)}

A perspectiva da rede de negócios refere-se à inserção das subsidiárias tanto na rede interna quanto na rede externa de negócios (FORSGREN; HOLM; JOHANSON, 2006). Neste tópico, será analisada a inserção das subsidiárias nas redes externas como variável influenciadora da transferência reversa de conhecimento. A integração na rede interna (especificamente com a matriz) será analisada no tópico 3.1.3.1 "características da interação matriz-subsidiárias".

O conceito de enraizamento ou incrustação (embeddedness) foi desenvolvido por Granovetter (1985) e reflete a visão de que "o comportamento econômico está intimamente incrustado em redes de relações interpessoais" (GRANOVETTER, 1985, p. 504). Swedberg (2004, p. 317 apud Machado, 2010) complementa que o conceito de incrustação surge associado a um conjunto de ideias-chave, a saber: todas as ações econômicas estão "incrustadas"; os mercados podem ser conceitualizados como "estruturas sociais"; e as ações econômicas possuem não apenas uma componente racional, como também uma componente sociocultural.

A partir de então, as relações locais têm sido reconhecidas como um recurso estratégico para o desenvolvimento de desempenho e competência em empresas multinacionais, na medida em que elas facilitam o acesso aos recursos e capacidades que se encontram fora da empresa e estão inseridos em um contexto social (ANDERSSON; FORSGREN; HOLM, 2002). A integração da EMN com a rede externa, portanto, é definida como a troca de conhecimento complexo por meio de relacionamento com atores específicos do ambiente (ANDERSON; FORSGREN; HOLM, 2001) e reflete a capacidade da subsidiária de absorver novos conhecimentos com a rede externa (ou rede de negócios local) (ANDERSON; FORSGREN; HOLM, 2002).

Esse conceito é importante para o contexto das EMNs porque elas têm a vantagem de interagir em uma rede de negócios corporativa (distribuída por vários países), composta por diversos 
tipos de parceiros, tais como: fornecedores, compradores, instituições de C\&T, governos, concorrentes, entre outros. Ghoshal e Bartlett (1990) estão entre os primeiros a ressaltar a importância das redes interorganizacionais no contexto da EMN. Para eles, a inserção nas redes externas influencia a posição da subsidiária na rede corporativa, bem como a atribuição dos seus recursos. A inserção nas redes externas viabiliza que as EMNs aproveitem as oportunidades de mercado e promovam o desenvolvimento da competência da subsidiária e seu consequente desempenho no mercado (ANDERSSON; FORSGREN; HOLM, 2002). Em particular, o envolvimento da subsidiária com a rede de negócios local tem sido associado à criação de centros de excelência na subsidiária e ao desenvolvimento desta para a competência da rede da EMN (ANDERSSON; FORSGREN; HOLM, 2002; HOLM; PEDERSEN, 2000).

Resultados de estudos anteriores indicam que o envolvimento da subsidiária com a rede de negócios local reduz o controle da matriz, enquanto aumenta a habilidade da subsidiária em direcionar sua própria estratégia (ANDERSSON; FORSGERN, 1996), e favorece o desenvolvimento das capacidades das subsidiárias por aumentar suas fontes de absorção de novos conhecimentos (ANDERSSON; FORSGREN; HOLM, 2002; ANDERSON, BJöRKMAN; FORSGREN, 2005; HÅKANSON; NOBEL, 2001; BIRKINSHAW; HOOD, 1998). Isso se dá porque, quanto mais vínculos com a rede de negócios local, maiores as possibilidades de troca de informações e de aprendizagem mútua (ANDERSON; BJöRKMAN; FORSGREN, 2005). Mas isso não significa que essas possibilidades de interação levariam as subsidiárias a transferir conhecimentos de forma eficiente e eficaz para o restante da corporação (TEECE, 1981).

A integração externa (com a rede de negócios local) tem sido mensurada pelas relações diretas e indiretas relevantes das subsidiárias com os parceiros de negócios (ATHREYE; BATSAKIS; SINGH, 2013), pela intensidade dos contatos com os parceiros locais (HAKANSON; NOBEL, 2001) ou pela frequência das interações e/ou grau de adaptação mútua de atividades e de recursos (LANE; LUBATKIN, 1998). Nesta perspectiva, o alto enraizamento é o oposto das relações normais de mercado uma vez que subjazem parceiros de confiança (ANDERSSON; FORSGREN; HOLM, 2002; FORSGREN; HOLM; JOHANSON, 2005). Em outras palavras, as relações das subsidiárias baseadas na confiança são classificadas como de alto enraizamento, ao passo que relações baseadas no simples cumprimento de condições normais de concorrência são classificadas como de baixo enraizamento (SANTANGELO, 2009). 
As relações entre parceiros de negócios também são definidas como baseada na confiança, na medida em que dizem respeito à confiabilidade, justiça e boa vontade. Estudos mais amplos relacionam a integração externa com a rede de negócios à capacidade de inovação da empresa. O trabalho de VON HIPPEL, 1988, por exemplo, ressalta a importância de "aprender por meio da interação"; ANDERSSON; FORSGREN; HOLM, 2002, indicam que a capacidade de inovação de uma subsidiária é parcialmente explicada pela sua inserção na rede externa. Hakanson e Nobel (2001) afirmam que subsidiárias que estão fortemente envolvidas no ambiente local e que mantêm frequentes e significativas interações com organizações locais possuem uma posição vantajosa para absorver e combinar novos conhecimentos e tecnologias desses mercados para inovar.

É importante notar que há discordância na literatura quanto aos efeitos da integração da subsidiária com a rede externa na transferência reversa de conhecimento. Schulz (2001) argumenta que, em razão da proximidade geográfica e da similaridade cultural, certos aspectos da transferência de conhecimento podem ocorrer de maneira mais eficaz entre uma subsidiária da EMN e empresas locais do que entre a matriz e suas subsidiárias no exterior. Segundo Yamin e Otto (2004), o envolvimento com a rede de negócios local proporciona, de forma direta, um melhor desempenho da subsidiária e isso, indiretamente, estimula o fluxo de conhecimento entre as unidades da corporação.

Em contraposição, alguns autores arguem que o envolvimento com a rede local, apesar de melhorar a capacidade de absorver conhecimento tácito e complexo, pode voltar as subsidiárias para as demandas e expectativas dos parceiros locais, e isso tenderia a reduzir o nível de integração dela com o resto da multinacional porque poderia gerar um conhecimento muito específico, relacionado ao contexto local (ex.: conhecimento de clientes e fornecedores) e, portanto, difícil de transferir. Isso implicaria menores possibilidades de transferência efetiva de conhecimento na rede, em razão da fraca ligação entre subsidiárias pares e matriz e da diminuição da influência da subsidiária na rede corporativa (ANDERSSON; FORSGREN, 1996). Para Hakanson e Nobel (2001), as subsidiárias não necessariamente enfrentam um tradeoff entre fortes ligações com parceiros locais e forte integração com o resto da EMN. Os resultados de seu estudo sugerem exatamente o oposto: subsidiárias fortemente integradas tendem a manter maior grau de integração com matriz do que as subsidiárias fracamente integradas. 
Em consonância com essa ideia, Luo e Tung (2007) e Mathews (2006) destacam a importância das ligações, oportunidades e conhecimentos potencialmente disponíveis nos mercados anfitriões das subsidiárias. Contudo, para acesso a essa fonte de "vantagens de localização", é preciso que as EMNs emergentes estejam integradas com as instituições detentoras destes conhecimentos (NARULA; ZANFEI, 2005). Ramamurti e Singh (2009, p. 126-127) apontam que as EMNs emergentes podem buscar diversas estratégias distintas, tais como "parceiros de baixo custo", "consolidadores globais" e "first movers globais" pode localizar no mundo desenvolvido. Contudo, independentemente da estratégia utilizada, se integrar a essas redes, além de ser difícil de gerir, também requer consideráveis recursos gerenciais e financeiros. Além disso, quando se trata de subsidiárias localizadas em países em desenvolvimento, as condições institucionais nestes países conduzem à dependência de relações de rede para compensar a insuficiência ou fraqueza de intermediários institucionais (KHANNA; PALEPU, 2000). A partir desses argumentos, coloca-se a seguinte hipótese:

H5a: Quanto maior o envolvimento com a rede externa de fornecedores, maior a
transferência reversa de conhecimento.
H5b: Quanto maior o envolvimento com a rede externa de clientes, maior a transferência
reversa de conhecimento.
H5c: Quanto maior o envolvimento com a rede externa de institutos de ciência e tecnologia,
maior a transferência reversa de conhecimento.

\subsection{Autonomia}

A autonomia é um dos conceitos mais discutidos na literatura sobre EMNs. É definida como a extensão em que uma subsidiária tem permissão para tomar decisões sobre suas principais questões estratégicas (MUDAMBI; NAVARRA, 2004; TAVANI, 2010), mais especificamente, como "a influência que uma subsidiária tem sobre as decisões relativas ao desenvolvimento ou adaptação de produtos, seleção e negociações de preço com fornecedores, e publicidade e política de precificação no mercado local" (NOORDEHAVEN; HARZING, 2009). 
Autonomia está relacionada com a divisão de poder de decisão entre uma organização e suas subunidades. Especificamente, a autonomia da subsidiária está relacionada com a liberdade que a unidade tem para tomar decisões sem a intervenção da matriz (ROTH; MORRISON, 1992). Subsidiárias autônomas são capazes de empregar os recursos de forma independente para resolver seus problemas particulares (GARNIER, 1982). Para Birkinshaw e Morrison (1995), autonomia da subsidiária é entendida como o grau de poder de tomada de decisão autorizado por uma EMN às suas subsidiárias. Quando uma subsidiária toma todas as suas próprias decisões sem consultar a matriz, tem o mais alto nível de autonomia, e quando todas as decisões das subsidiárias devem ser submetidas para aprovação pela matriz, elas têm pouca ou nenhuma autonomia.

Vachani (1999) assinala que existe uma relação inversa entre o grau de controle de uma multinacional sobre as suas filiais e autonomia da subsidiária. Isso se dá porque a matriz procura controlar as atividades das subsidiárias com o intuito de proteger seu investimento no exterior, sobretudo, no que diz respeito ao alinhamento estratégico. A subsidiária, por sua vez, exige maior autonomia para realizar uma administração mais próxima dos imperativos do contexto competitivo local. É nesse ponto que surge o dilema da integração versus autonomia, porque por um lado, com autonomia, a subsidiária pode garantir uma boa aderência ao mercado local, mas por outro lado pode não contribuir para a estratégia do mercado global e do mercado interno no que tange à criação de iniciativas (BORINI, FLEURY, M.; FLEURY, A., 2010).

Birkinshaw e Nobel (1998) pontuam que a autonomia é comumente classificada por duas vertentes: administrativa e de operações. A autonomia administrativa refere-se a fatores como contratação de altos executivos, aprovação do orçamento anual e subcontratação de terceiros para atividades globais (as operações offshoring). A autonomia de operações refere-se às atividades de mercado, como alteração no design de produtos, introdução de novos produtos, entrada em novos mercados, mudanças organizacionais e em processos de produção.

Um alto grau de autonomia tem sido relacionado ao melhor acesso a recursos e a maior propensão à criação de conhecimento na subsidiária (BIRKINSHAW; HOOD; JONSSON, 1998; GUPTA; GOVINDARAJAN, 1991; ANDERSSON; FORSGREN; HOLM, 2002), com base na ideia de que subsidiárias independentes possuem papéis importantes dentro da rede (BIRKINSHAW; HOOD, 1998) e, por conseguinte, responsividade local (BARTLETT; GHOSHAL, 1989). De acordo com Cantwell e Mudambi (2005) e Gupta e Govindarajan (1991), subsidiárias com elevada autonomia, geram conhecimentos que tendem a ser mais 
inovador, complexo e relacionado a um contexto específico. Limitar a autonomia das subsidiárias dificulta seu desenvolvimento porque reduz sua liberdade de experimentar (GHOSHAL; BARTLETT, 1988), de aprender a partir do sistema de inovação dos países anfitriões, e impede que a EMN se beneficie de novos conhecimentos desenvolvidos pelas subsidiárias independentes (FOSS; PEDERSEN, 2002).

A autonomia e os papéis das subsidiárias são fatores complementares e que não podem ser analisados de forma separada quando o intuito for a análise da transferência reversa de conhecimento (RABIOSI, 2008). Em outras palavras, diferentes graus de autonomia das subsidiárias são relacionados aos papéis/importância estratégica da subsidiária (HARZING; NOORDERHAVEN, 2006). Quanto maior a autonomia, mais próxima a subsidiária estaria de um papel inovador (AMBOS; SCHLEGELMILCH, 2007). Gupta e Govindarajan (1991) relacionam a autonomia da subsidiária com a tipologia da subsidiária. De acordo com os autores, o nível de autonomia é alto para subsidiárias cujo papel é de "inovadoras globais" (subsidiárias que desenvolvem produtos para os mercados globais), e baixo para as "implementadoras" (subsidiárias que raramente desenvolvem algum tipo de conhecimento). Um alto grau de autonomia é relacionado com a criação, na subsidiária, de um conhecimento de conteúdo mais tácito e com um ambiente local mais competitivo e turbulento (GUPTA; GOVINDARAJAN, 1991).

O aumento de autonomia da subsidiária favorece sua importância estratégica dentro da corporação (BIRKINSHAW; HOOD, 1998) e, consequentemente, sua independência da matriz. Para lidar com esse desafio, a matriz pode lançar mão de mecanismos de controle para gerenciar a autonomia da subsidiária e assegurar que o conhecimento adquirido possa ser compartilhado com as outras unidades da rede (RABIOSI, 2006). Para Foss e Pedersen (2002), a perda de controle que acompanha o aumento da autonomia da subsidiária seria neutralizada pelo aumento da troca de conhecimento entre as unidades da rede corporativa.

No que tange aos efeitos diretos da autonomia da subsidiária para a transferência reversa de conhecimento, a literatura é ambígua, pois têm sido relatados efeitos neutros (BARTLETT, 1988), positivos (CANTWELL; MUDAMBI, 2005; FOSS; PEDERSEN, 2002; GUPTA; GOVINDARAJAN, 2000; NOBEL; BIRKINSHAW, 1998; TAVANI; GIROUND; SINKOVICS, 2010) e negativos (FORSGREN et al., 2000; ANDERSON; FORSGREN; HOLM, 2002; NOORDEHAVEN; HARZING, 2009; RABIOSI, 2011). A questão central é 
entender como uma subsidiária com competências diferenciadas lida com a contradição inerente entre a autonomia e a integração com seus pares. Exemplificando, quando a subsidiária é exposta a alta competição interna e quando o conhecimento é ativo essencial para a sua diferenciação, a subsidiária pode escolher por reter o conhecimento e se esquivar de transferilo internamente (FOSS; PEDERSEN, 2002; GUPTA; GOVINDARAJAN, 2000).

Gupta e Govindarajan (2000) encontraram uma relação positiva entre a centralização (falta de autonomia) e o fluxo de transferência de conhecimento matriz-subsidiárias. Tavani, Giround e Sinkovics (2010), analisando o contexto de transferência reversa em multinacionais do setor de serviços, também encontraram uma relação positiva entre um alto grau de autonomia e transferência reversa. Entre os autores que encontraram uma relação negativa entre autonomia e transferência de conhecimento, estão Noordehaven e Harzing (2009) que detectaram que um alto grau de atividades autônomas na subsidiária leva a uma menor motivação de compartilhamento de conhecimento; essa afirmação foi confirmada em seu estudo empírico para a relação do fluxo de conhecimento subsidiária-matriz. Andersson, Forsgren e Holm (2002) descobriram que a criação e o desenvolvimento de novos conhecimentos por subsidiárias pode ter por base a troca de informações intensa com organizações locais, que leva a um conhecimento de contexto mais específico e complexo. Sob estas condições, seria mais difícil aplicar tal conhecimento em outras unidades da rede da EMN. Assim, quando um nível muito alto de autonomia é concedido à subsidiária, as conexões e a dependência entre a matriz e a subsidiária podem diminuir, diminuindo, assim, a transferência reversa de conhecimento (FORSGREN et al., 2000).

Rabiosi (2011) concluiu que quando a autonomia da subsidiária é elevada, algumas tensões que implicam a tentativa de ajuste entre o nível de controle versus autonomia podem se manifestar na EMN e, consequentemente, limitar a transferência reversa de conhecimento. Em outras palavras, quando um alto nível de autonomia é concedido a uma subsidiária, mecanismos de coordenação hierárquica, conexões e dependência entre matriz e subsidiárias podem diminuir e, em consequência, diminuir também a confiança recíproca entre as unidades. Nessa situação, é provável haver uma diminuição da transferência de conhecimentos para as outras unidades da EMN (Ibid.). No contexto de EMNs italianas, Rabiosi (2008) relacionou a autonomia das subsidiárias com os mecanismos de socialização (pessoal e eletrônica) e os níveis de transferência reversa de conhecimento. A autora identificou que o aumento do nível de autonomia associado ao aumento da utilização de mecanismos de comunicação pessoal está 
relacionado com níveis mais elevados de transferência reversa de conhecimento, ao passo que o aumento do uso dos meios de comunicação baseados em comunicação eletrônica deve ser conjugado com a diminuição dos níveis de autonomia com o intuito de aumentar a transferência reversa de conhecimento. Em outras palavras, a autora concluiu que a gestão eficaz de transferência reversa de conhecimento a partir de subsidiárias com elevada autonomia requer a utilização de mecanismos de comunicação mais ricos e, nesse caso, as matrizes estariam dispostas "a pagar" o preço em razão da influência positiva que tais transferências poderiam ter na corporação.

No que concerne às subsidiárias de empresas multinacionais emergentes, argumenta-se que, em razão do seu recente avanço no mercado internacional, e, portanto, de sua pouca idade, são fortemente dependentes da matriz para as suas decisões (DUNNING, 1993). Nesse contexto, EMNs emergentes, em grande parte, são muito mais implementadoras de competências da matriz do que inovadoras, em razão do período inicial de sua formação. Contudo, quando se trata de aquisições de empresas internacionais, em geral, os adquirentes de economias emergentes deliberadamente permitem que as empresas adquiridas mantenham sua autonomia e a alta administração intacta, e, só após algum tempo de operação é que gradualmente incentivam a interação entre as duas unidades (BIRKINSHAW et al., 2010, p. 24).

Em síntese, a literatura permite concluir que certo grau de autonomia da subsidiária, aliada à integração interna com a matriz é benéfica para a transferência reversa de conhecimento. Isto posto, coloca-se a seguinte hipótese:

H6: Quanto maior a autonomia da subsidiária, maior a transferência reversa de conhecimento.

\subsubsection{Motivação}

A motivação é definida como a habilidade e a boa vontade do emissor em compartilhar o conhecimento na organização (MINBAEVA, 2007). Minbaeva e Michailova (2004) utilizam a expressão capacidade de disseminação para se referir a esse constructo. De uma maneira geral, a motivação (ou a boa vontade) tem sido relacionada com uma influência positiva na transferência de conhecimento reversa nas EMNs (MINBAEVA, 2007; SZULANSKI, 1996, TAVANI, 2010). 
No contexto de subsidiárias pós-adquiridas, a motivação da fonte do conhecimento pode ser algo mais difícil de alcançar. Em primeiro lugar, porque quando as pessoas de uma corporação não esperam obter muito valor em troca da transferência de conhecimento, elas tendem a ser menos motivadas a compartilhar o seu próprio conhecimento; em segundo lugar, porque a motivação para transferir conhecimentos depende de questões mais complexas como, por exemplo, o estabelecimento de confiança com a outra parte, a percepção da reputação e da imagem da parte receptora do conhecimento (EMPSON, 2001).

Alguns aspectos estimulam a motivação para compartilhar o conhecimento, dentre eles, podese citar a confiança entre os membros, a obrigação de compartilhamento, as normas que incentivam a troca e um senso de identidade do grupo, a percepção clara de benefícios decorrentes do compartilhamento, a percepção de reciprocidade (uma das partes só será motivada a compartilhar o seu conhecimento caso acredite que a outra também está propensa a compartilhar) e os traços de personalidade dos indivíduos - especialmente extroversão, afabilidade, conscienciosidade e abertura (CABRERA, 2003 apud MINBAEVA, 2007). Ainda segundo Cabrera (2003 apud MINBAEVA, 2007), as normas influenciam as intenções de compartilhamento do conhecimento de forma direta, ao passo que os outros aspectos as influenciam de forma indireta, por meio de seu impacto sobre atitudes de partilha do conhecimento.

De acordo com Buckley et al. (2009), fatores como distância geográfica e diferenças culturais e de linguagem aumentam os custos associados com transferência de conhecimento porque aumentam a probabilidade de haver interpretações erradas e mal-entendidos. Numerosos outros estudos argumentam sobre a dificuldade de transferir conhecimento tecnológico por causa de seu componente tácito.

A princípio, parece natural haver uma tendência de acúmulo do conhecimento e, mais do que isso, de que o compartilhamento possa parecer destrutivo para seus detentores, porque a posse de conhecimentos valiosos pode estabelecer uma posição de monopólio e de poder relativo dentro da organização (CYERT, 1995 apud GUPTA; GOVINDARAJAN, 2000). Embora, a partir da perspectiva da organização, o compartilhamento do conhecimento seja sempre desejável, "a decisão de não compartilhar o conhecimento é individual e, frequentemente, racional e bem justificada a partir da perspectiva do emissor” (MINBAEVA, 2007, p. 557). 
Husted e Michailova (2002) apresentam seis razões, do ponto de vista do emissor (no caso, a subsidiária), listadas como possíveis justificativas para o não compartilhamento do conhecimento:

- Potencial perda de valor, de poder de barganha e de proteção da vantagem competitiva individual em razão do sentimento de apropriação pessoal do conhecimento acumulado;

- Relutância em gastar o tempo com o compartilhamento de conhecimento, em detrimento de outras atividades mais produtivas para o indivíduo;

- Receio de hospedar "parasitas do conhecimento". Não agrada a ideia de compartilhar seus conhecimentos com alguém que tenha investido pouco tempo e esforço para o desenvolvimento de seu próprio conhecimento;

- Evitar a exposição. Por não compartilhar o conhecimento, as pessoas se protegem de avaliações externas da qualidade de seus conhecimentos;

- Estratégia contra a incerteza. Em razão da incerteza por parte do receptor, a respeito de seu grau de percepção e de interpretação do conhecimento recebido, os remetentes podem ter a necessidade de agir com cautela ao revelar um conhecimento valioso;

- Respeito pela hierarquia de poder formal. Remetentes podem ser relutantes em compartilhar o conhecimento por receio de perder uma posição de privilégio e superioridade.

Ressalta-se que a motivação para a transferência pode ser consequência da alta capacidade relativa de absorção do receptor e da similaridade dos parceiros em certos atributos, tais como: base de conhecimento e expertise técnica, experiências colaborativas prévias, similaridade tecnológica ou cultural. Quanto mais próximo for o conhecimento especializado dos parceiros, mais fácil estes conseguirão transpor os obstáculos do processo de transferência; ao contrário, quando a similaridade for baixa, os parceiros poderão encontrar dificuldades para resolver os problemas inesperados durante o processo de transferência (YAMIN; TSAI, 2011). 
É preciso apontar que a motivação por parte do receptor também possui barreiras relacionadas. Segundo Gupta e Govindarajan (2000), há pelo menos dois aspectos que podem diminuir ou impedir a motivação do receptor no processo de transferência. O primeiro é a síndrome do "não inventado aqui". O segundo aspecto são as "disputas de poder" dentro da organização, que podem fazer com que gerentes degradem o poder potencial de seus pares ao fingir que o conhecimento gerado por eles não é valioso ou único. Observa-se, no entanto, que neste estudo serão investigadas apenas as motivações da fonte do conhecimento. Por isso, em consonância com a corrente da literatura que destaca a motivação como uma influência positiva na transferência de conhecimento, formula-se a seguinte hipótese:

H7: Quanto maior a motivação da subsidiária, maior a transferência reversa de conhecimento.

\subsubsection{Contexto matriz-subsidiárias}

Nesta pesquisa, a integração interna (com a matriz), semelhança de contexto (cultural e organizacional) e os mecanismos de socialização são considerados componentes da relação entre uma subsidiária e matriz.

\subsubsection{Integração interna (com a matriz)}

Para que a transferência reversa seja efetiva, é preciso um 'envolvimento dual' da subsidiária, tanto com a sua rede de negócios local, como internamente com as outras unidades da multinacional (FROST; BIRKINSHAW; ENSIGN, 2002). De fato, é amplamente aceito na literatura que a existência de fortes vínculos entre subsidiárias e matriz impacta positivamente a transferência de conhecimento interna na EMN. De acordo com Powell et al. (1996) e Dyer e Singh (1998), por exemplo, a integração na rede interna é considerada como um fator crucial para a cooperação e troca de conhecimento. A existência de laços fortes facilita a transferência de conhecimento porque reduz os efeitos de problemas motivacionais e cognitivos (SZULANSKI, 1996); porque diminui os custos associados com a transferência de conhecimento (HÅKANSON; NOBEL, 2001); e porque gera confiança entre os membros (POWELL et al., 1996). 
A integração interna oferece à subsidiária, apoio, recursos e cooperação de outras subsidiárias e da matriz, ao mesmo tempo que facilita à EMN a alavancagem do conhecimento e de capacidades locais, uma vez que estão disponíveis para transferência (ANDERSSON; FORSGREN; HOLM 2002, 2007; RUGMAN; VERBEKE, 2001). Alguns estudos se concentram na dimensão estrutural da integração interna (AMBOS; SCHLEGELMILCH, 2007, por exemplo), contudo, o presente estudo, concentra-se na dimensão relacional da integração (GRANOVETTER, 1985).

Hansen (1999) concluiu que a ausência de relações diretas e de extensiva comunicação entre as pessoas de diferentes departamentos inibe a transferência de conhecimento, ao passo que fortes relações intraunidades a facilitam. Em seu recente trabalho em redes de conhecimento, Bresman, Birkinshaw e Nobel (1999) ressaltam que a integração é um fator ainda mais importante quando o conteúdo do conhecimento a ser transferido é tácito e complexo. É importante salientar que a integração entre matriz e subsidiárias diferencia-se da falta de autonomia e da forte dependência da matriz, pois vai além de medidas de controle de recursos e de tomada de decisão, estando mais relacionada à interdependência entre as duas unidades a qual permite que a matriz compreenda as subsidiárias e vice-versa (NOHRIA; GOSHAL, 1997; RABIOSI, 2011).

A integração indica que grande parte dos recursos e atividades da subsidiária, tais como o conhecimento e a inovação, é realizada via estreitas relações com outras unidades da rede corporativa (CIABUSCHI; DELLESTRAND; MARTÍN, 2011c). Essa interdependência pode assumir diferentes formas de acordo com os atores (ex.: áreas funcionais). Sendo assim, uma subsidiária pode ter um alto grau de imersão no desenvolvimento de produtos, mas ter um relacionamento com laços mais fracos quando se trata de sua comercialização ou distribuição (ANDERSON; FORSGREN, 1996).

A inserção na rede abrange a interdependência e o comprometimento, além de potencializar a capacidade da subsidiária de combinar e usar os recursos dispersos em toda a rede da corporação. Em outras palavras, quanto mais integrada a subsidiária, mais provável que se envolva na troca de recursos intraorganizacional, que assimile competências originadas em outras unidades da rede e que utilize tais competências como input para o desenvolvimento de suas próprias competências (ANDERSON; FORSGREN; HOLM, 2001). Além disso, maior 
envolvimento com a rede interna é positivamente relacionado com maior importância estratégica da subsidiária (ANDERSON; FORSGREN; HOLM, 2007).

EMNs de economias emergentes que têm laços fortes e bem desenvolvidos entre suas unidades (ou seja, fortes normas de relação de confiança e de linguagem comum) pode ter facilitada a cooperação para o desenvolvimento de conhecimento nas subsidiárias e a posterior transferência para seu país de origem (WRIGHT, 2008). No caso das EMNBRs, um estudo recente de Borini et al. (2009) mostrou que as iniciativas das subsidiárias de multinacionais brasileiras estão fortemente correlacionadas com a integração entre a matriz e as subsidiárias. Sendo assim, a transferência reversa de conhecimento "depende da integração, ou do alinhamento estratégico das atividades das subsidiárias com os interesses da matriz bem como da constante troca de informações, conhecimentos e experiências entre subsidiária e matriz." (BORINI et al., 2010). Portanto, pode-se depreender que assim como as multinacionais dos países desenvolvidos, a forte integração entre matriz e subsidiária impulsiona o desenvolvimento dos recursos das EMNs emergentes. Isto posto, sugere-se a seguinte hipótese:

H8: Quanto maior a integração da subsidiária com a rede interna (matriz), maior a transferência reversa de conhecimento.

\subsubsection{Semelhança cultural e organizacional}

Diferenças culturais entre as nações e organizações também podem ser um fator importante que influencia o processo de transferência de conhecimento (CHILD; RODRIGUES, 1996; BHAGAT et al., 2002). Diferenças entre o contexto da matriz e o das subsidiárias podem ser conceituadas em termos de distância cultural e organizacional (AMBOS; AMBOS; SCHLEGELMILCH, 2006). Nesse caso, quanto maior a distância (cultural e organizacional), menor a possibilidade de transferência reversa de conhecimento. Como distância cultural entende-se as diferenças entre as normas, os valores, as crenças e as suposições entre dois países (HOFSTEDE, 2001; KOGUT; SINGH, 1988). Como distância organizacional, entende-se as diferenças de práticas de negócios, de cultura organizacional, de estrutura e de valores das organizações. 
A distância cultural (ou psíquica) também é definida como o resultado vetorial de fatores culturais que impedem o fluxo de informação entre a empresa e seus parceiros ou ambiente (JOHANSON; VAHLNE, 2001); ou pelo sistema de convenções e significados subjacentes e necessários ao entendimento e implementação dos procedimentos entre as unidades da EMN (HOFSTEDE, 2001). No contexto das organizações, isto implica que, quanto maior a distância cultural, maior será a diferença na gestão e nas práticas organizacionais (KOGUT; SINGH, 1988).

Se o compartilhamento entre departamentos ou entre filiais nacionais de uma empresa é difícil, muito provavelmente tais dificuldades aumentam quando os envolvidos são de unidades estrangeiras de uma multinacional. Diferentemente de uma pequena empresa doméstica, é bastante provável que uma grande multinacional, composta de muitas subsidiárias em vários países, tenha práticas de trabalho e culturas diferenciadas. Unidades organizacionais estão fortemente enraizadas nos valores culturais dos seus respectivos países anfitriões, o que sugere que a cultura da matriz e de suas controladas correspondem ao seu respectivo contexto cultural nacional (HARZING; SORGE, 2001). Uma grande distância cultural entre as unidades de uma EMN aumenta a probabilidade de má interpretação, e, por isso, torna mais caro e difícil de interpretar as informações trocadas entre essas unidades (BOYACIGILLER, 1990). Cultura organizacional comum é importante porque conduz a uma efetiva troca de conhecimento e aprendizado como parte da socialização dos membros (HAKANSON; NOBEL, 2001).

De acordo com Simonin (1999b), diferenças organizacionais amplificam a ambiguidade do conhecimento e, consequentemente, geram um impacto negativo na transferência de conhecimento. As diferenças culturais colocam barreiras ao entendimento do parceiro e à aprendizagem com o outro. Uma das principais barreiras para a transferência internacional de conhecimento é a existência de diferenças espaciais, culturais e organizacionais (BRESMAN; BIRKINSHAW; NOBEL, 1999), que pode impactar significativamente no fluxo de informação entre os parceiros (LYLES; SALK, 1996). Datta e Puia (1995), por exemplo, examinaram 112 grandes aquisições internacionais realizadas por empresas norte-americanas no período de 1978 a 1990 e concluíram que quando as diferenças culturais nacionais são grandes, a transferência de conhecimentos entre a aquisição e empresas adquiridas pode ser mais difícil.

Se por um lado contextos culturais e organizacionais diferentes podem gerar desentendimentos e mensagens ambíguas - causadas, por exemplo, pela dificuldade de interpretar uma palavra de 
mesma grafia, mas com sentido diferente - e, consequentemente diminuir a transferência de conhecimento entre as unidades (SIMONIN, 1999b), por outro lado, indivíduos que compartilham de um mesmo senso de identidade ou senso de grupo terão maior possibilidade de trocar e compartilhar conhecimento de forma voluntária com seus pares, embora estejam em unidades estrangeiras da multinacional (BRESMAN; BIRKINSHAW; NOBEL, 1999).

Ambos e Ambos (2009) trazem uma contribuição interessante ao sugerir que mecanismos de socialização pessoal podem inibir a distância cultural e dessa forma facilitar a transferência de conhecimento.

Igualmente às multinacionais tradicionais, a cultura é um dos fatores importantes que influencia o desempenho de EMN emergentes (Shore; Cruz, 2004). Sua justifica reside no fato de que gestores, que foram "educados e treinados" em uma cultura, têm que tomar decisões organizacionais no cenário de outra cultura, tendo em conta não só a sua própria cultura, mas também a cultura estrangeira, juntamente com os fatores subjacentes. E, nesse caso, os gestores das EMNs emergentes precisam atuar de acordo com uma mentalidade global para enfrentar tais desafios.

Essa discussão deixa claro que as características do conhecimento requerem um contexto amplamente compartilhado, além do entendimento profundo entre as partes envolvidas, para que haja sucesso na transferência de conhecimento. Em síntese, a literatura parece evidenciar que a transferência de conhecimento é mais efetiva quando envolve contextos organizacionais e culturais similares. A partir desses argumentos, apresentam-se as seguintes hipóteses:

H9: Quanto maior a semelhança organizacional entre subsidiária e matriz, maior a transferência reversa de conhecimento tecnológico.

H10: Quanto maior a semelhança cultural entre subsidiária e matriz, maior a transferência reversa de conhecimento tecnológico.

\subsubsection{Mecanismos de socialização}

Partindo-se do pressuposto de que o conhecimento é construído socialmente por meio de esforços colaborativos, e que, mais especificamente, "o conhecimento tácito precisa ser 
desincorporado, traduzido, interpretado e integrado para que a aprendizagem ocorra" (BECKER-RITTERSPACH, 2006 apud NOORDEHAVEN; HARZING, 2009), defende-se que o compartilhamento do conhecimento só é possível por meio da interação social entre o emissor e o receptor. Nessa perspectiva, a interação social representa muito mais do que um meio (ou seja, um canal de comunicação), pois, constitui uma condição necessária para viabilizar o compartilhamento do conhecimento na organização (NOORDEHAVEN; HARZING, 2009). Em consonância com esse argumento, de fato a literatura tem defendido que o uso de mecanismos de interação social (ou de socialização) tem um impacto positivo e significativo na transferência de conhecimento entre as unidades da EMN (AMBOS, T.; AMBOS, B., 2009; BRESMAN; BIRKINSHAW; NOBEL, 1999; GHOSHAL et al., 1994; GUPTA; GOVINDARAJAN, 2000; SCHULZ, 2001; TSAI, 2002). Tais mecanismos facilitam o desenvolvimento das relações interpessoais na EMN, que por sua vez pode melhorar a comunicação entre as partes, incluindo a transferência de conhecimento (GUPTA; GOVINDARAJAN, 2000). Os mecanismos de socialização influenciam a entrada e saída de conhecimento, tanto da/para a matriz quanto das/para as subsidiárias da multinacional (GUPTA; GOVINDARAJAN, 2000). Uma vez que um baixo nível de autonomia pode dificultar o desenvolvimento do conhecimento da subsidiária, a matriz, por vezes, utiliza mecanismos de socialização para controlar suas subsidiárias estrangeiras informalmente e indiretamente (HARZING; NOORDERHAVEN, 2006).

Mecanismos de interação social se referem aos mecanismos organizacionais que facilitam o desenvolvimento dos vínculos interpessoais nas organizações. Existem inúmeros mecanismos de socialização, dentre os quais, podem-se citar: visitas frequentes, transferência mútua de funcionários entre as subsidiárias durante um determinado período de tempo, rotatividade dos funcionários entre unidades internacionais, programas de treinamento corporativos, trabalho com equipes temporárias e globais, equipes permanentes que coordenam a comunicação frequente entre as unidades da EMN $\left(\right.$ gatekeepers $^{8}$ ), reuniões anuais com escopo internacional e técnico, atribuição internacional temporária (cessão de pessoal técnico temporariamente a outra unidade da corporação para um projeto específico), uso de sistemas e ferramentas comuns de banco de dados, mecanismos eletrônicos de comunicação (e-mail, videoconferência,

\footnotetext{
${ }^{8}$ Pessoa que tem o papel de conectar os membros das equipes internacionais. O gatekeeper tem o papel de ativar os contatos entre diferentes indivíduos e diferentes grupos, objetivando facilitar o fluxo de comunicação (MEYER, 1991).
} 
mensagens instantâneas) e outros possíveis mecanismos (HAKANSON; NOBEL, 2001; NOORDEHAVEN; HARZING, 2009).

Dentre as principais vantagens da socialização entre as equipes para a transferência de conhecimento na EMN, podem-se citar: a melhor comunicação e aumento nas interações/trocas, como resultado das relações sociais (ENSIGN, 2000), a criação de comunidades sociais e ambiente de apoio, e a diminuição da ansiedade relativa (BRESMAN; BIRKINSHAW, NOBEL, 1999), a criação de confiança e troca mútua de conhecimento Szulanski (1996). Tudo isso porque interações realizadas por meio dos mecanismos de socialização melhoram a "profundidade", a "amplitude" e a eficácia do uso de conhecimento recíproco (TSAI, 2001).

Nota-se também que as trocas tanto podem ocorrer como decorrentes das relações sociais, quanto como antecedentes de tais relações (ENSIGN, 2000). Em seu trabalho, Ghoshal et al. (1994) constataram que o contato direto por meio de trabalho conjunto entre as equipes, forçastarefas, etc. foi o principal determinante da troca de conhecimento nas EMNs. Sendo assim, gerenciar ativamente tais mecanismos de comunicação é essencial para a transferência de conhecimento, pois evidências indicam que a comunicação e a colaboração declinam em razão da distância física entre os agentes (ALLEN, 1977) e das diferentes culturas, diferentes ciências e diferentes níveis de abstração com os quais o conhecimento é transferido (WILLIAMS; GIBSON, 1990 apud ENSIGN, 2009).

Hakanson e Nobel (2001) advertem que a transferência reversa só acontecerá quando o conhecimento e sua disponibilidade forem combinados com a confiança em uma oportunidade lucrativa a ser aplicada no país de origem da multinacional. Assim sendo, a difusão do conhecimento é positivamente relacionada à intensidade de comunicação entre matriz e subsidiária. A interação social torna as unidades organizacionais mais confiantes na previsão dos comportamentos das unidades com as quais concorrem, e isso pode melhorar a motivação para o compartilhamento do conhecimento (TSAI, 2002). O estabelecimento de tais vínculos propicia o aumento da frequência de comunicação e, por conseguinte, a transferência de conhecimento (BJÖRKMAN et al., 2004).

Bresman, Birkinshaw e Nobel (1999) classificam os mecanismos de comunicação ou de socialização em duas categorias: normal, como as interações face a face e outras mídias, e prolongado, como a transferência temporária de pessoas, programas de treinamento conjuntos, 
visitas, entre outros. Outros autores fazem a distinção entre mecanismos baseados em contato pessoal e mecanismos baseados em comunicação eletrônica (AMBOS, T.; AMBOS, B., 2009; HANSEN et al., 1999; RABIOSI, 2006, 2008, 2011). Para Nobel e Birkinshaw (1998), os mecanismos formais de controle e os mecanismos de socialização são complementares. "Socialização é necessária para construir laços entre as unidades, mas, ao mesmo tempo, definições de padrões claros de controle são necessários para assegurar a compatibilidade" (Ibid., 1998, p. 491).

Para que a interação entre as pessoas seja viabilizada, por meio dos mecanismos de socialização eletrônica, é preciso haver uma infraestrutura técnica que permita aos empregados codificar, armazenar e acessar o conhecimento. A infraestrutura deve incluir ferramentas como business inteligence, software de colaboração e aprendizagem e mapeamento dos tipos de conhecimento espalhados na rede da corporação (AMBOS, T.; AMBOS, B., 2009). Além de disponibilizar a infraestrutura, é preciso preparar as pessoas para seu uso, sob pena de ela não ser aceita e/ou utilizada por falta de conhecimento ou habilidade. Evidências empíricas comprovam que empresas com habilidades em utilizar a infraestrutura técnica para a transferência de conhecimento obtiveram bons resultados ao fazê-lo por meio desse tipo de interação (BEZERRA-FERNANDEZ; SABHERWAL, 2001).

Porém, vários outros põem em questão o uso de mecanismos eletrônicos para aproximar equipes distantes e viabilizar o trabalho. De forma específica, Brannen (2004) adverte que a transferência de conhecimento por meio de mecanismos eletrônicos de comunicação pode ser inibida pela distância cultural, pois é dessa forma mais difícil abstrair o contexto para codificar e recuperar as mensagens-chave que são valiosas ao destinatário. Meyer (1991) afirma que compreender a informação recebida depende do compartilhamento do contexto organizacional. Pessoas de diferentes áreas usam linguagem própria e frequentemente têm dificuldades para se compreender. Uma visão compartilhada, a definição de procedimentos comuns e a cooperação de longo prazo tendem a reduzir essas diferenças e, por conseguinte, facilitar a transferência de conhecimento.

Em seu estudo, Meyer (1991) concluiu que a comunicação face a face é um importante recurso da comunicação oral, e que o surgimento de novos tipos de comunicação eletrônica, tais como telefone, tele e videoconferência, entre outros, complementam, mas não substituem a comunicação face a face, que inclui informações sensoriais, sensações, intuição e contexto. $O$ 
autor argumenta ainda que a comunicação eletrônica só pode dar sua contribuição efetiva se nível de confiança já está estabelecido entre os parceiros. Nessa mesma direção, Allen (1977, 2007) estudou os padrões de comunicação em laboratórios de P\&D e constatou que a distância física entre as equipes pode reduzir fortemente a probabilidade de comunicação, ao passo que a proximidade espacial encoraja a colaboração. Mais especificamente, a distância entre o emissor e o receptor é tida como um dos principais fatores de insucesso da transferência do conhecimento (EISENHARDT; SANTOS, 2002).

Para minimizar essas dificuldades decorrentes da comunicação a distância, muitos autores sugerem o uso de mecanismos ricos de comunicação, tais como interações face a face, programas de treinamento, comitês internacionais, força-tarefa ou projetos em conjunto e visitas (KOGUT; ZANDER, 1993; BJÖRKMAN et al., 2004). Complementarmente, Szulanski (1996) e Hansen (1999) afirmam que, quando se trata de transferência de conhecimento tácito, são necessárias intensas e frequentes interações entre os participantes do processo. No entanto, quando se trata de conhecimento explícito, mecanismos de comunicação com baixo grau de riqueza, tais como e-mails, intranet, manuais e base de dados corporativa, podem ser utilizados (TAVANI, 2010).

Outro aspecto que se deve ressaltar, é que frequentes interações, viabilizadas por meio dos mecanismos de socialização, facilitam o desenvolvimento de laços interpessoais porque conseguem criar linguagem comum, visões e normas compartilhadas e confiança entre as partes, que são componentes necessários do aprendizado (MUDAMBI, MUDAMBI, NAVARRA, 2007; BJÖRKMAN; BARNER-RASMUSSEN; LI, 2004). Dessa forma, os mecanismos de socialização, muito mais do que comunicar, conseguem melhorar a qualidade do relacionamento e criar similaridade de contextos entre subsidiárias e matriz (SCHREINER et al., 2009 apud TAVANI, 2010).

O estudo de Ambos, T. e Ambos, B (2009) trata da aplicabilidade dos dois tipos de mecanismos de socialização na transferência de conhecimento. Os resultados indicam haver uma relação negativa entre os mecanismos de comunicação pessoal e a eficácia das transferências de conhecimento para situações de grande distância geográfica linguística e cultural e uma relação favorável para situações de baixa distância geográfica, linguística e cultural. Isso leva a crer que "a infraestrutura técnica desempenha um papel central na transferência de conhecimento intraorganizacional na EMN, uma vez que permite aos funcionários codificar, armazenar e 
acessar o conhecimento.” (Ibid., p. 9). Altos níveis de distância geográfica e linguística podem complicar os processos de compartilhamento de conhecimento via mecanismos de comunicação pessoal em razão dos custos e complexidades inerentes ao conhecimento sobre P\&D (DAFT; LENGEL, 1986; CYERT; MARCH, 1992; HAAS; HANSEN, 2004 apud AMBOS, T.; AMBOS, B., 2009) ao passo que grande distância cultural torna esse processo difícil em razão dos diferentes estilos cognitivos dos indivíduos (GOODALL; ROBERTS, 2003; BHAGAT et al., 2002 apud AMBOS, T.; AMBOS, B., 2009). Já com relação aos mecanismos de comunicação eletrônica, o estudo concluiu que não são dependentes do contexto e, portanto, não são impactados pelas diferentes culturas, de idiomas ou geográficas. Segundo os autores, uma explicação potencial para esse resultado se dá em razão da natureza codificada do conhecimento transferido por meio desses mecanismos eletrônicos. Esses canais, embora sejam menos "ricos", viabilizam o armazenamento e a transferência de comunicação de conhecimentos codificados e facilitam aos usuários de sistemas a escolha das questões e dos formatos de dados para a transferência, que podem ser facilmente descontextualizadas e recontextualizado no novo ambiente (Ibid.).

No contexto das EMNs emergentes, os resultados do estudo de Borini et al. (2010) indicaram que a importância da integração entre matriz e subsidiária para a transferência reversa de conhecimento é expandida. Segundo os autores, nas multinacionais tradicionais, os mecanismos de socialização foram danificados ao longo do tempo pelo controle gerencial feito por meio de orçamentos, relatórios, manuais e inspeções. Só depois de ganhar a confiança nas subsidiárias é que as matrizes dessas empresas diminuíam o controle em favor da integração. Contudo, os autores advertem que as EMNBRs que estão buscando inovação no exterior não tem tempo para ganhar a confiança da subsidiária; para aprender de forma rápida (MATHEWS, 2006), as emergentes precisam fazê-lo por meio de mecanismos de socialização, sobretudo via comunicação pessoal.

Em síntese, se bem coordenados, os mecanismos de comunicação podem diminuir as perdas de entendimento decorrentes da transmissão do conhecimento, especialmente no que se refere ao conhecimento de tipo tácito e complexo (MUDAMBI, 2002). De forma alinhada com essa visão, firmam-se as seguintes hipóteses: 
H11a: Quanto maior a utilização de mecanismos de socialização entre subsidiária e matriz, maior a integração interna com matriz.

H11b: Quanto maior a utilização de mecanismos de socialização entre subsidiária e matriz, maior a semelhança organizacional.

H11c: Quanto maior a utilização de mecanismos de socialização entre subsidiária e matriz, maior a transferência reversa de conhecimento.

Todas as hipóteses deste estudo são sumarizadas no quadro a seguir:

Quadro 11: Hipóteses do estudo

\begin{tabular}{|c|c|c|}
\hline Grupo & & Hipóteses \\
\hline \multirow{2}{*}{$\begin{array}{l}\text { Características do } \\
\text { conhecimento }\end{array}$} & H1: & $\begin{array}{l}\text { Quanto menor a tacitividade do conhecimento da subsidiária, maior o grau } \\
\text { de transferência reversa de conhecimento tecnológico. }\end{array}$ \\
\hline & H2: & $\begin{array}{l}\text { Quanto menor a complexidade do conhecimento da subsidiária, maior o } \\
\text { grau de Transferência reversa de conhecimento tecnológico. }\end{array}$ \\
\hline \multirow{5}{*}{$\begin{array}{c}\text { Características do } \\
\text { conhecimento }\end{array}$} & H3: & $\begin{array}{l}\text { Quanto mais desenvolvidos os Ambiente Institucional, maior a transferência } \\
\text { reversa de conhecimento tecnológico. }\end{array}$ \\
\hline & H4: & $\begin{array}{l}\text { Quanto mais desenvolvidos os Ambiente competitivo, maior a transferência } \\
\text { reversa de conhecimento tecnológico. }\end{array}$ \\
\hline & H5: & $\begin{array}{l}\text { Quanto maior a autonomia da subsidiária, maior a transferência reversa de } \\
\text { conhecimento tecnológico. }\end{array}$ \\
\hline & H6: & $\begin{array}{l}\text { Quanto maior a motivação da subsidiária, maior a transferência reversa de } \\
\text { conhecimento tecnológico. }\end{array}$ \\
\hline & H7a: & $\begin{array}{l}\text { Quanto maior a integração da subsidiária com a rede externa de } \\
\text { fornecedores, maior a transferência reversa de conhecimento tecnológico. } \\
\text { Quanto maior a integração da subsidiária com a rede externa de clientes, } \\
\text { maior a transferência reversa de conhecimento tecnológico. } \\
\text { Quanto maior a integração da subsidiária com a rede externa de instituições } \\
\text { de ciência e tecnologia, maior a transferência reversa de conhecimento } \\
\text { tecnológico. }\end{array}$ \\
\hline \multirow{2}{*}{$\begin{array}{l}\text { Características da } \\
\text { interação } \\
\text { matriz/subsidiária }\end{array}$} & H8: & $\begin{array}{l}\text { Quanto maior a integração da subsidiária com a rede interna (matriz), maior } \\
\text { a transferência reversa de conhecimento tecnológico. }\end{array}$ \\
\hline & H9: & $\begin{array}{l}\text { Quanto maior a semelhança organizacional entre subsidiária e matriz, maior } \\
\text { a motivação da subsidiária. }\end{array}$ \\
\hline
\end{tabular}




\begin{tabular}{|l|l|l|}
\hline H10: & $\begin{array}{l}\text { Quanto maior a semelhança cultural entre subsidiária e matriz, maior a } \\
\text { transferência reversa de conhecimento tecnológico. } \\
\text { Quanto maior a utilização de mecanismos de socialização entre subsidiária } \\
\text { e matriz, maior a similaridade de contexto organizacional entre matriz e } \\
\text { subsidiária. } \\
\text { Quanto maior a utilização de mecanismos de socialização entre subsidiária } \\
\text { e matriz, maior a integração interna entre matriz e subsidiária. } \\
\text { Quanto maior a utilização de mecanismos de socialização entre subsidiária } \\
\text { e matriz, maior a transferência reversa de conhecimento tecnológico. }\end{array}$ \\
\hline
\end{tabular}

FONTE: A autora.

\subsubsection{Os fatores mediadores}

\section{a) Modo de entrada da subsidiária}

Ao decidir operar no mercado internacional, as EMNs tomam decisões quanto à escolha do país, natureza da operação e modo de entrada no exterior. Os modos de entrada podem ser divididos em dois grandes grupos: (i) modalidades acionárias que envolvem as joint ventures e as subsidiárias de propriedade total, aquisições e greenfield: (ii) modalidades não acionárias que envolvem as exportações e os acordos contratuais - licenciamento, franchising, alianças estratégicas e contratos de P\&D (TANURE, DUARTE, 2006).

Apesar de aquisições e joint ventures terem sido tradicionalmente vistas como uma forma comum de as empresas multinacionais acessarem as competências e habilidades dos mercados locais (KOGUT; ZANDER, 1993), estudos empíricos têm indicado que o nível de transferência de tecnologia das subsidiárias para a matriz é maior nas subsidiárias do tipo greenfield do que nas do tipo aquisição (ZHOU, 2002; FROST, 1998; RABIOSI, 2011). Entre outros motivos, porque embora as subsidiárias, integradas à rede por meio de aquisição, estejam tipicamente mais enraizadas no contexto local, elas parecem ser menos integradas à rede corporativa da multinacional, dificultando assim a transferência.

Contudo, há alguns argumentos a favor do modo de entrada de aquisição. Obter acesso a novos conhecimentos, por exemplo, é muitas vezes um importante condutor da decisão de aquisição no exterior, especialmente nos casos em que a empresa-alvo tem um estoque de conhecimento único que é difícil ou demorado para imitar (PRAHALAD; HAMEL, 1990). Contudo, Gupta e 
Govindarajan (2000) afirmam que, embora as subsidiárias adquiridas possuam um estoque de conhecimento maior, se comparado aos estabelecimentos greenfields, tal conhecimento é menos duplicável (ou seja, passível de ser transferida para outra unidade). Ademais, as subsidiárias adquiridas possuem uma capacidade de absorção relativamente menor para o compartilhamento de conhecimento intraunidades na EMN. Outro fator relevante é a velocidade de internacionalização que é muito maior para os casos de aquisição em detrimento do modo de entrada de greenfield (BELDERBOS, 2003). Um estudo mais recente de Brouthers e Brouthers (2009), que utilizou amostras de multinacionais japonesas se estabelecendo na Europa, sugeriu que as organizações que desenvolveram fortes capacidades intangíveis podem alavancar seus conhecimentos de forma mais efetiva dentro da rede se o fizerem por meio do estabelecimento de greenfields investiments.

No tocante ao contexto das multinacionais emergentes, estudos indicam que elas preferem o modo de entrada por aquisições como forma de entrada estratégica (BONAGLIA; GOLDSTEIN, 2007; GUILLÉN; GARCIA-CANAL, 2009; MATHEWS, 2006). No entanto, os estudos citados não demonstram a relação entre o impacto do modo de entrada e a transferência reversa de conhecimento. Para Borini et al. (2010), entrada via greenfield investimentos permite maior alinhamento das atividades da matriz com as atividades das subsidiárias, e isso, ao longo do tempo, possibilita maior integração e criação de recursos inovadores.

\section{b) Idade da subsidiária}

Além de variar de acordo com o modo de entrada, a transferência reversa de conhecimento pode sofrer variações de acordo com o tempo de existência da subsidiária. A literatura relata problemas de transferência de conhecimento interna nas EMNs em subsidiárias adquiridas nos primeiros anos; problemas semelhantes não são relatados sobre investimentos do tipo greenfield.

Estudos prévios afirmam que a habilidade de criar novos conhecimentos depende de experiências prévias com atividades similares (COHEN; LEVINTHAL 1990). Em consonância com esse argumento, Foss e Perdersen (2002) defendem que as subsidiárias mais antigas tendem a ter mais autonomia e ser mais inovadoras. Teoricamente, as subsidiárias mais antigas teriam uma maior probabilidade de desenvolver competências de $\mathrm{P} \& \mathrm{D}$, para não necessitar 
tanto das competências transferidas da matriz. Por outro lado, essa autonomia e independência no desenvolvimento de competências poderiam ser prejudiciais ao reconhecimento de competências por parte da matriz.

Em linhas gerais, a literatura tem se mostrado inconclusiva no que se refere aos efeitos da idade da organização para a transferência do conhecimento. Cyert e March (1963 apud VAN WIJK; JANSEN; LYLES, 2008), argumentam que antigas organizações correm o risco de tornaremse inertes e de possuírem uma capacidade limitada para aprender e adaptar-se as circunstâncias. Seguindo essa linha, Frost et al. (2002) defendem que organizações mais jovens parecem ter vantagens de aprendizagem sobre as mais velhas. E ainda, há outros estudos empíricos sugerem que a idade não tem efeito sobre a extensão da transferência de conhecimento (GRAY; MEISTER; 2004; YLI-RENKO et al., 2001 apud VAN WIJK; JANSEN; LYLES, 2008).

Analisando a transferência reversa de inovação entre as unidades das EMNs, Borini et al (2010) concluíram que quanto maior a idade das subsidiárias, maior a extensão de transferência reversa de inovação. Para os autores, essa questão representa um grande desafio enfrentado pelas EMNBRs dispostas estrategicamente a buscar novos recursos no exterior, "porque o período de existência das subsidiárias de EMNBRs é muito menor quando comparado às subsidiárias de multinacionais tradicionais" (Ibid, p. 227).

\section{c) Importância estratégica da subsidiária}

De acordo com a perspectiva das redes, as subsidiárias podem assumir diferentes papéis dentro da EMN (BIRKINSHAW; HOOD, 1998; GHOSHAL; NOHRIA, 1989). Tais papéis parecem estar associados a diferenças na transferência de conhecimento dentro da EMN (GUPTA; GOVINDARAJAN, 1991; MUDAMBI, R.; MUDAMBI, S.; NAVARRA, 2007; BIRKINSHAW et al., 1998; CANTWELL; MUDAMBI, 2005; RABBIOSI, 2011), bem como à percepção da matriz sobre os benefícios alcançados por meio do conhecimento transferido pela subsidiária (AMBOS, AMBOS, SCHLEGELMILCH, et al., 2006; YANG et al., 2008).

Diversas tipologias têm sido elaboradas para definir o escopo das atividades das subsidiárias. De modo geral, essas tipologias preocupam-se em destacar os fatores que diferenciam as subsidiárias que muito contribuem para a inovação global e as que pouco contribuem. Apesar de terem sido elaboradas com base em dimensões e critérios específicos, até certo ponto podem ser comparáveis. Juntas, essas tipologias ajudam a compreender diversas facetas da 
organização. O Quadro 12 apresenta uma comparação entre algumas das tipologias mais citadas na literatura, bem como o enfoque específico, utilizado por cada autor, para classificar os papéis das subsidiárias. Conhecer várias dessas classificações pode ajudar no entendimento da empresa segundo as diferentes perspectivas apresentadas (OLIVEIRA JÚNIOR; BOEHE; BORINI, 2009).

Quadro 12: Tipologias dos papéis desempenhados pelas subsidiárias

\begin{tabular}{|c|c|c|c|c|}
\hline Tipologia & $\begin{array}{c}\text { Implementadora } \\
\text { Local }\end{array}$ & $\begin{array}{l}\text { Contribuidora } \\
\text { Especializada }\end{array}$ & Mandato Global & Critérios da tipologia \\
\hline $\begin{array}{l}\text { D’Cruz } \\
\text { (1986) }\end{array}$ & Braço da matriz & $\begin{array}{l}\text { Globalmente } \\
\text { racionalizada }\end{array}$ & $\begin{array}{l}\text { Mandato de } \\
\text { produtos mundiais }\end{array}$ & $\begin{array}{l}\text { Autonomia na tomada } \\
\text { de decisão e escopo } \\
\text { geográfico }\end{array}$ \\
\hline $\begin{array}{l}\text { Bartlett e } \\
\text { Ghoshal } \\
(1986)\end{array}$ & Implementadora & Contribuidora & Líder Estratégica & $\begin{array}{l}\text { Importância do local e } \\
\text { complexidade dos } \\
\text { recursos e capacidades }\end{array}$ \\
\hline $\begin{array}{l}\text { Jarillo e } \\
\text { Martinez } \\
(1990)\end{array}$ & Autônoma & Receptiva & Ativa & $\begin{array}{l}\text { Grau de integração } \\
\text { global das atividades da } \\
\text { cadeia de valor }\end{array}$ \\
\hline $\begin{array}{l}\text { Gupta e } \\
\text { Govindarajan } \\
(1991)\end{array}$ & $\begin{array}{l}\text { Inovadora local e } \\
\text { implementadora }\end{array}$ & Inovadora global & Integrada & Fluxo de conhecimento \\
\hline $\begin{array}{l}\text { Roth e } \\
\text { Morrison } \\
(1992)\end{array}$ & & Integrada & $\begin{array}{l}\text { Subsidiária de } \\
\text { mandato global }\end{array}$ & $\begin{array}{l}\text { Grau de centralização e } \\
\text { especialização das } \\
\text { subsidiárias }\end{array}$ \\
\hline
\end{tabular}

FONTE: Adaptado de Birkinshaw e Morrison (1995, p. 729) e Matamouros (2001 apud OLIVEIRA JUNIOR; BOEHE; BORINI, 2009).

De acordo com Ambos e Schlegelmilch (2007), as tipologias parecem convergir para a classificação que, de maneira geral, compreende três principais tipos: a) unidades que adaptam os produtos às necessidades do mercado local; b) unidades que exploram as competências tecnológicas da multinacional de uma forma global; e c) unidades criadas para aumentar ou desenvolver novas tecnologias e competências no exterior. Em suma, os diferentes papéis das subsidiárias sugerem que elas possuem diferentes funções, desde a adaptação, acesso a consumidores e fornecedores-chave, atividades de percepção do mercado e mapeamento de talentos científicos escassos, até funções mais sofisticadas como desenvolvimento de produtos, processos e tecnologias.

A tipologia de Gupta e Govindarajan $(1991,1994)$ é interessante porque os autores elaboraram uma classificação do papel da subsidiária de acordo com o critério de fluxo de conhecimento. Gupta e Govindarajan (1991, 1994) defendem que o papel da subsidiária pode evoluir e, esta, paulatinamente, assumir responsabilidades que ultrapassem as fronteiras do mercado do país 
hospedeiro. Sendo assim, o beneficiamento da matriz pela absorção de conhecimento local das subsidiárias depende do papel que estas possuem dentro da rede multinacional. Segundo eles, os padrões de fluxo de conhecimento podem ser identificados analisando-se a direção (entrada ou saída) e a intensidade com que a subsidiária participa desses fluxos. Com base no padrão do fluxo de conhecimento, os autores classificam as subsidiárias em quatro categorias: i) integrada (alto fluxo de saída e de entrada de conhecimento); ii) inovadora global (alto fluxo de saída e baixo fluxo de entrada), implementadora (baixo fluxo de saída e alto fluxo de entrada), e inovadora local (baixo fluxo de saída e entrada).

Embora os limites de cada papel não possam ser claramente demarcados, é possível distinguir as principais características de cada um deles (CIABUSCHI; DELLESTRAND; MARTÍN, 2011c). As subsidiárias Integradas e as Inovadoras Globais são as líderes na criação do conhecimento de autovalor para a organização. Envolvem-se no desenvolvimento de novos produtos e tecnologias e descobrem novas práticas de negócio (BARTLETT; GHOSHAL, 1989). Além disso, engajam-se na transferência desse conhecimento para as outras unidades da corporação. As subsidiárias Integradas baseiam-se na absorção do conhecimento originado na sede ou nas subsidiárias pares e muitas vezes trabalham para gerar conhecimento expressamente destinado aos mercados estrangeiros. A criação e desenvolvimento de novos conhecimentos pelas subsidiárias inovadoras é muitas vezes baseada em informações e conhecimento intensivo adquiridos por meio do intercâmbio com organizações locais, o que leva a conhecimentos mais específicos do contexto local (ANDERSSON; FORSGREN; HOLM, 2002). O papel de Inovadora Local implica que a subsidiária desenvolve recursos críticos, mas muito relacionados ao seu contexto local, razão pela qual é pouco provável que sejam transferidos para as outras unidades. O papel de Implementador diz respeito ao tipo de subsidiárias que são dependentes de fluxos de conhecimento originados na sede ou em outras subsidiárias e que raramente possuem e/ou fornecem conhecimentos relevantes às outras unidades da EMNs (GUPTA; GOVINDARAJAN, 1994).

Uma classificação recente do papel da subsidiária e de sua relação com a transferência de conhecimento dentro da EMN é desenvolvida por Meyer, Mudambi e Navarra (2011), como segue:

1) Subsidiárias com papel tradicional (caracterizadas pelo conhecimento top-down, ou seja, apenas recebe influxos da matriz): 
- Operação "chave de fenda": neste nível mais baixo de transferência de conhecimento, a subsidiária monta ou entrega e mantém produtos e serviços fornecidos pela matriz.

2) Subsidiárias com papéis mais criativos (caracterizadas por fluxo de conhecimento reverso - conhecimentos que fluem das subsidiárias em direção à matriz):

- Posto de escuta: neste nível a subsidiária tem a função de receber o conhecimento, filtrálo e transmiti-lo de volta para a matriz. Ao longo do tempo, pode evoluir para centro regional ou mesmo centro de excelência da rede corporativa.

- Competência de exploração: a fim de gerar fluxos reversos de conhecimento, a subsidiária deve ser capaz de acessar os conhecimentos externos (da rede de negócios local) e, em seguida, transferi-los internamente na EMN. A subsidiária deve acessar essa rede de empresas e instituições locais a fim de aprender sobre os clientes e tecnologias, e, assim, capturar o conhecimento local.

- Competência de criação: neste nível, a subsidiária deve usar sua conectividade dual (com a rede da EMN e com a rede de negócios locais) e transferir para a EMN o conhecimento adquirido no local.

O resumo da taxonomia de Meyer, Mudambi e Navarra (2011) é apresentado a seguir.

Quadro 13: Taxonomia do conhecimento segundo o papel da subsidiária

\begin{tabular}{|l|l|l|c|}
\hline \multicolumn{2}{|c|}{} & \multicolumn{2}{c|}{ Direção do fluxo do conhecimento } \\
\cline { 3 - 4 } & \multicolumn{1}{|c|}{ Inflow } & Outflow \\
\hline $\begin{array}{l}\text { Atividades de } \\
\text { conhecimento }\end{array}$ & Transferência & Operação “chave-de fenda” & Posto de escuta \\
\cline { 2 - 3 } & Integração & Competência de exploração & Competência de criação \\
\hline
\end{tabular}

FONTE: MEYER; MUDAMBI; NAVARRA (2011).

A ideia subjacente em todas essas classificações, segundo a importância da subsidiária, é que subsidiárias associadas com papéis mais importantes na corporação estão mais aptas a transferir conhecimento para a matriz

A ilustração a seguir apresenta o relacionamento das hipóteses que formam o modelo do estudo. 


\section{Fatores Relacionados à Subsidiária}

Fatores relacionados às características do conhecimento

\begin{tabular}{|c|}
\hline Ambiente Institucional \\
\hline Ambiente Competitivo \\
\hline Integração externa \\
\hline \hline Autonomia \\
\hline \hline Motivação \\
\hline
\end{tabular}

$\mathrm{H} 3+$
$\mathrm{H} 4+$
$\mathrm{H} 5+$
$\mathrm{H} 6+$
$\mathrm{H} 7+$

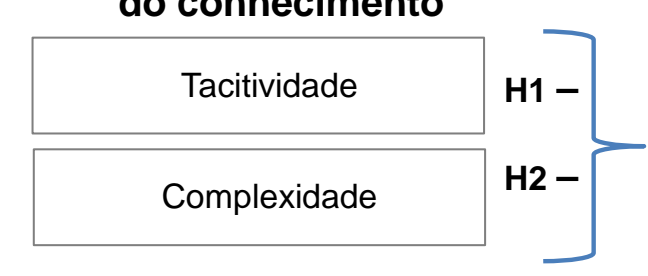

Fatores Relacionados à Matriz-Subsidiária

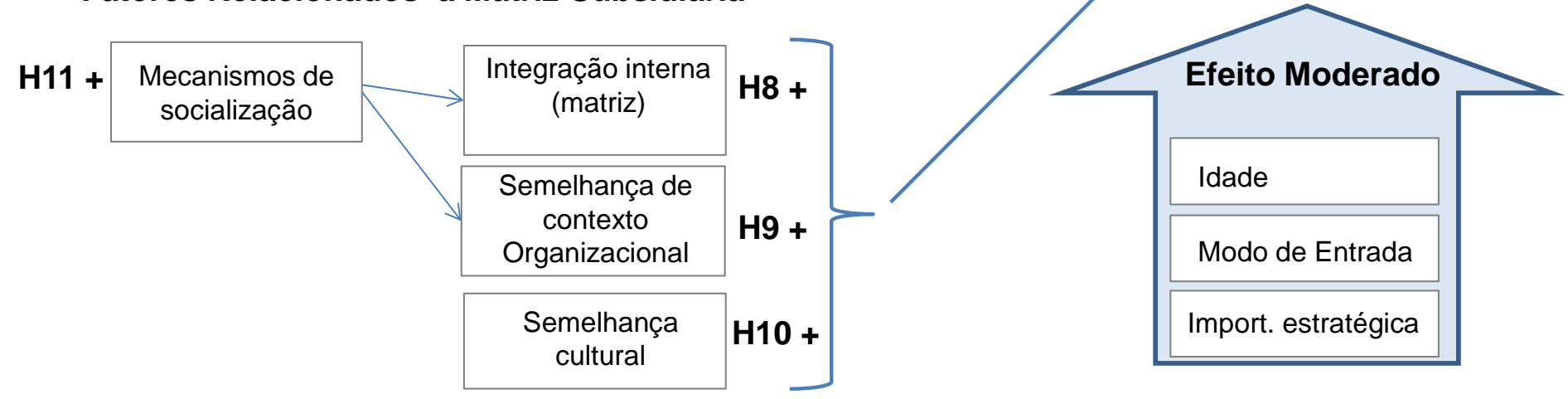

Ilustração 13: Modelo do estudo 


\section{METODOLOGIA}

\subsection{Delineamento da pesquisa}

Esta pesquisa é de natureza descritiva e correlacional. Descritiva, porque descreve as características da situação-problema deste objeto, que, neste caso, é a identificação dos fatores determinantes da transferência reversa do conhecimento em subsidiárias das EMNs brasileiras. Correlacional, porque investigar as relações existentes entre as variáveis, resultando em uma descrição de nível mais acurado, porém sem intervenção do pesquisador na realidade investigada (TRIVIÑOS, 1987).

A pesquisa correlacional não implica uma relação de causa e efeito; em outras palavras, "correlação não implica causação" (SELLTIZ, et al., 1987), ao contrário, investiga especificamente as associações entre as variáveis. "A correlação, nesse caso, significa que há uma covariância entre duas ou mais variáveis, ou seja, que há uma tendência de que certos valores ou níveis de uma variável ocorram junto com determinados valores ou níveis da outra variável" (SELLTIZ et al., 1987). A dificuldade de interpretar os resultados de comparação com um grupo estático (variável dependente) está na possibilidade de haver outras variáveis externas ao escopo do estudo que também podem estar afetando o fenômeno (Ibid.).

A análise emprega o estudo quantitativo com o uso de técnicas estatísticas que envolvem a coleta, classificação, sumarização, organização, análise e interpretação dos dados (MARTINS; THEÓPHILO, 2007), e o método de coleta aplicado foi o survey eletrônico.

Os surveys são utilizados quando o pesquisador busca explicar as fontes dos eventos, bem como suas características e correlações (Ibid.). Aplicam-se a coletar dados quantitativos de um número maior de indivíduos de uma maneira relativamente rápida e conveniente. No entanto, por serem constituídos de perguntas fechadas, recaem no problema de mensuração das ciências sociais, já que tentam representar, por meio de dados quantitativos, aspectos como crenças, opiniões, atitudes e experiências em geral de um indivíduo ou grupo. Outro problema é que, diferentemente do método de observação, o entrevistado saberá claramente que estão sendo 
coletadas informações sobre seu comportamento, o que pode influenciar nas suas respostas (HAIR et al., 2005).

Em vez de se realizar a medição do estudo em diversos períodos no tempo, a coleta dos dados foi realizada em uma única oportunidade (espaço-tempo), o que caracteriza este estudo como transversal. Foi expost facto, porque analisa os dados de campo depois de eles terem ocorrido na prática das empresas e sem interferências deste estudo (HAIR et al., 2005).

\subsubsection{Unidade de análise}

Os estudos que tratam da transferência de conhecimento muitas vezes não deixam claro sua unidade de análise (MINBAEVA, 2007). O autor argui que essa especificação é fundamental para esse tipo de estudo, já que o fluxo de conhecimento pode ocorrer em várias direções. Uma categorização esclarecedora das possíveis unidades de análise sobre o tema é feita por Gupta e Govindarajan (2000). De acordo com os autores, é possível operacionalizar as pesquisas em pelo menos três níveis:

- Nodal - quando a análise incide sobre o comportamento individual de um tipo de unidade da EMN (emissor ou receptor do conhecimento);

- Dual - quando a análise incide sobre o comportamento conjunto das unidades pares (emissor e receptor);

- Sistêmica - quando a análise incide sobre o comportamento de toda a rede da multinacional.

Dada a escassez relativa de trabalhos empíricos anteriores sobre o assunto, Gupta e Govindarajan (2000) decidem limitar sua investigação ao nível nodal de análise, com o argumento de que seria útil primeiramente concentrar-se no nível mais simples e, posteriormente, investigar o nível dual e sistêmico. Este estudo adota uma abordagem semelhante e seleciona as subsidiárias das multinacionais brasileiras como o nível de análise (nodal), para o entendimento do grau de transferência reversa de conhecimento. 


\subsection{Modelo conceitual e operacionalização das variáveis}

Neste estudo, a situação-problema circunscreve-se ao entendimento dos fatores condicionantes da transferência reversa de conhecimento tecnológico em multinacionais brasileiras com subsidiárias manufatureiras no exterior (GINEBRA, 2010).

As variáveis são um símbolo atribuído a um objeto ou evento que o numera ou valora (COOPER; SCHINDLER, 1998). Segundo Lakatos e Marconi (2001, p. 137-154), uma pesquisa possui diversos tipos de variáveis, dentre as quais "variáveis independentes, dependentes, moderadoras, de controle, extrínsecas, componentes, intervenientes e antecedentes." Este estudo adota as variáveis independentes, dependentes e moderadoras.

A variável independente é aquela que pode influenciar ou prever as variáveis dependentes. "É aquela que influencia, determina ou afeta outra variável; é fator determinante, condição ou causa para determinado resultado, efeito ou consequência” (MARCONI; LAKATOS, 2007, p. 140). A variável dependente é aquela que os pesquisadores tentam compreender, explicar ou prever; ou seja, ela representa resultados ou consequências: "Consistem naqueles valores (fenômenos, fatores) a serem explicados ou descobertos, em virtude de serem influenciados, determinados ou afetados pela variável independente" (Ibid.). Ao contrário das variáveis supracitadas, as variáveis moderadoras não podem ser mensuradas, observadas ou manipuladas; a despeito disso, podem afetar o fenômeno em estudo (COOPER; SCHINDLER, 2003).

No modelo conceitual adotado, a variável dependente é a transferência reversa de conhecimento tecnológico. As variáveis independentes correspondem aos vários fatores encontrados na literatura que podem afetar de forma positiva ou negativa a transferência reversa de conhecimento. Tais fatores são classificados em três blocos: a) relacionados à natureza do conhecimento, b) relacionados às características das subsidiárias e c) relacionados às características do relacionamento matriz/subsidiária. As variáveis moderadoras consideradas são: os modos de entrada no mercado estrangeiro (aquisição e greenfield investments), idade e a importância estratégica das subsidiárias (implementadora, contribuidora e inovadora).

Com o objetivo de integrar a literatura revisada, a Ilustração 11 descreve o modelo conceitual proposto, que serviu de base para organizar a análise do fluxo de transferência reversa de 
conhecimento na EMN. Cada um dos elementos componentes do modelo será definido operacionalmente a seguir.

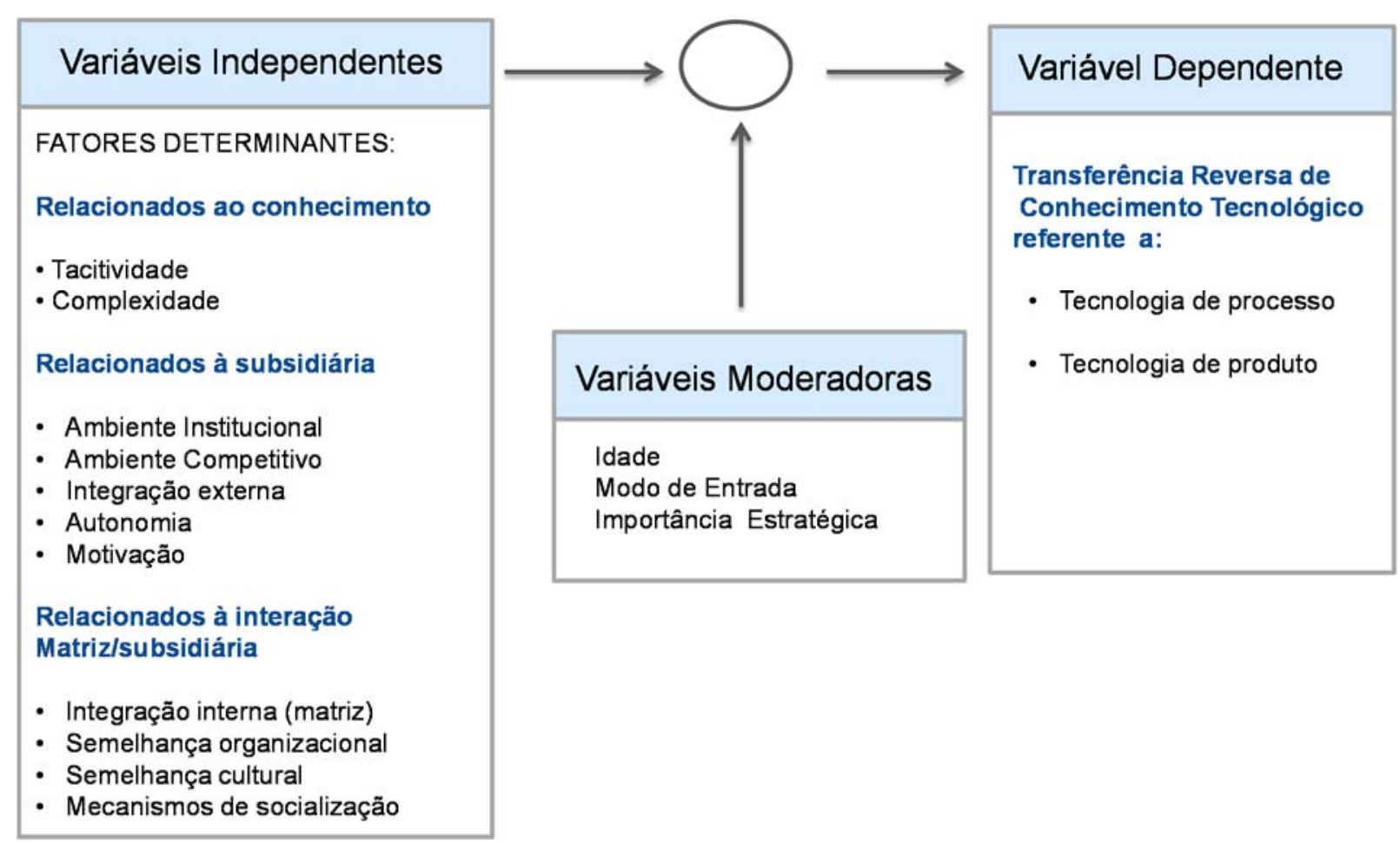

Ilustração 14: Modelo conceitual do estudo

\subsubsection{Operacionalização das variáveis}

Há dois tipos de definição operacional das variáveis: constitutiva e operacional. A definição constitutiva é a que define os termos com a aplicação de novos termos (ou palavras); em outras palavras, é a definição apresentada nos dicionários. Tal definição, apesar de ser a mais utilizada, é insuficiente para os propósitos científicos. Nesse caso, é preciso efetuar as definições operacionais, que são "a ponte entre os conceitos e as observações" (KERLINGER, 1979). Nesse sentido, definição operacional "atribui significado a um constructo ou variável especificando as atividades ou 'operações' necessárias para medi-lo ou manipulá-lo [...] é como um manual de instruções para o pesquisador.” (KERLINGER, 1979).

Os tópicos abaixo descrevem a operacionalização de cada uma das três categorias de variáveis constituintes deste estudo: dependentes, moderadoras e independentes. Nota-se que a definição das variáveis é de extrema importância para a validade dos resultados, sobretudo quando se levam em conta os argumentos de Minbaeva (2007), que advoga ser a variação que se encontra nas definições operacionais dos estudos da área um dos principais motivos para os resultados controversos e a falta de consistência. 


\subsubsection{Variável dependente}

\subsubsection{Transferência reversa de conhecimento tecnológico}

Transferência reversa de conhecimento tecnológico é definida como "o grau com que o conhecimento (tecnológico) desenvolvido na subsidiária é utilizado pela matriz da corporação multinacional" (MINBAEVA et al., 2007). De fato, "o elemento fundamental na transferência de conhecimento não é o conhecimento (original) subjacente, mas sim o grau com que o receptor adquire potencialmente o conhecimento útil e o utiliza em operações próprias" (MINBAEVA et al., 2003, p. 587).

Este estudo adota a definição apresentada por Gupta e Govindarajan (1991) que definem fluxo de conhecimento como a transferência de qualquer expertise (ex.: habilidades e capacidades) ou know-how de valor estratégico sobre o mercado externo. É importante notar que o fluxo de conhecimento não engloba a transferência de informações administrativas internas (ex.: troca de dados financeiros mensais).

A fim de detalhar os tipos de conteúdo tecnológico, utilizou-se a classificação de capacidades tecnológicas desenvolvidas por Lall (1992), Bell e Pavitt (1995) apresentada no tópico 2.2.2 a inovação das subsidiárias e o desenvolvimento de suas capacidades tecnológicas. Adicionalmente, utilizou-se a classificação detatalhada das capacidades tecnológicas desenvolvidas por Iammarino, Padilla-Pérez e Tunzelmann (2008) com base nos estudos de Lall (1992), Bell e Pavitt (1995) e Ariffin e Figueiredo (2003). A partir do cruzamento desses dois estudos, conseguiu-se chegar aos indicadores de mensuração da variável dependente deste estudo, conforme $\mathrm{O}$ quadro a seguir:

Quadro 14: Detalhamento dos tipos de conhecimento tecnológico com base no nível das capacidades tecnológicas

\begin{tabular}{|c|c|c|}
\hline $\begin{array}{c}\text { Nível de } \\
\text { Capacidade } \\
\text { Tecnológica }\end{array}$ & Orientada a Produto & Orientada a Processo \\
\hline & $\begin{array}{l}\text { Pequenas adaptações na tecnologia de } \\
\text { produtos existentes (impulsionadas por }\end{array}$ & Montagem de componentes e produtos finais \\
\hline
\end{tabular}




\begin{tabular}{|c|c|c|}
\hline \multirow[t]{5}{*}{ Básica } & $\begin{array}{l}\text { necessidades de mercado ou de } \\
\text { produção) }\end{array}$ & \\
\hline & $\begin{array}{l}\text { Rotinas de controle de qualidade para } \\
\text { manter padrões e especificações de } \\
\text { produtos existentes }\end{array}$ & Planejamento e controle da produção (PCP) \\
\hline & & $\begin{array}{l}\text { Pequenas mudanças na tecnologia de } \\
\text { processo }\end{array}$ \\
\hline & & $\begin{array}{l}\text { Melhoria significativa no processo de } \\
\text { produção (aprimoramento de layout, fluxo de } \\
\text { materiais e processos, automação de linhas, } \\
\text { e/ou eliminação de gargalos) }\end{array}$ \\
\hline & & Manutenção de máquinas e equipamentos \\
\hline \multirow{6}{*}{ Intermediária } & $\begin{array}{l}\text { Melhoria significativa em produtos } \\
\text { existentes (especificações, funções e } \\
\text { características) }\end{array}$ & $\begin{array}{l}\text { Pequenas adaptações na tecnologia de } \\
\text { produtos existentes (impulsionadas por } \\
\text { necessidades de mercado ou de produção) }\end{array}$ \\
\hline & Desenvolvimento de novos protótipos & $\begin{array}{l}\text { Rotinas de controle de qualidade para manter } \\
\text { padrões e especificações de produtos } \\
\text { existentes }\end{array}$ \\
\hline & Testes de novos produtos & $\begin{array}{l}\text { Desenvolvimento de novos equipamentos e/ } \\
\text { ou ferramentas }\end{array}$ \\
\hline & & Processos de automação \\
\hline & & Fabricação de novos componentes \\
\hline & & $\begin{array}{l}\text { Técnicas de organização da produção (ex.: } \\
\text { just in time, controle da qualidade total) }\end{array}$ \\
\hline \multirow{3}{*}{ Avançada } & $\begin{array}{l}\text { Know-how e experiência técnica na } \\
\text { forma de planos, modelos, instruções, } \\
\text { guias, fórmulas, especificações, projetos, } \\
\text { plantas, desenhos técnicos, e / ou } \\
\text { protótipos para projetar novos produtos }\end{array}$ & Projeto (design) próprio de fabricação \\
\hline & $\begin{array}{l}\text { Resultados de pesquisa sobre novos } \\
\text { materiais e novas especificações }\end{array}$ & $\begin{array}{l}\text { Desenvolvimento de novos processos de } \\
\text { produção }\end{array}$ \\
\hline & $\begin{array}{l}\text { Resultados de pesquisa e } \\
\text { desenvolvimento sobre nova geração de } \\
\text { produtos }\end{array}$ & \\
\hline
\end{tabular}

Fonte: Adaptado de Lall (1992), Bell e Pavitt (1995), Ari n e Figueiredo (2003) e Iammarino, Padilla-Peréz e Tunzelmann (2008)

Os respondentes das subsidiárias foram solicitados a avaliar "em que medida, durante os últimos três anos, a subsidiária transferiu para a matriz, conhecimentos tecnológicos referentes 
a [...]". Essa pergunta foi apresentada para cada um dos conhecimentos tecnológicos supracitados. Os indicadores foram mensurados por uma escala de cinco pontos, variando de 1= "nunca" a 5= "muitíssimo". O constructo "transferência de conhecimento tecnológico" foi calculado como a média relatada pelos entrevistados de todos esses indicadores de tipo de transferência de conhecimento relatados acima.

\subsubsection{Variáveis independentes}

As variáveis independentes estão classificadas em três grupos: fatores relacionados às características do conhecimento, das subsidiárias e da interação matriz/subsidiárias. Cada um dos grupos é classificado por constructos mensuráveis por meio de vários indicadores, conforme detalhado a seguir.

\subsubsection{Fatores relacionados às características do conhecimento}

As principais fontes de inspiração para a definição da mensuração das características do conhecimento foram a taxonomia desenvolvida por Winter (1987) e os estudos posteriores de Kogut e Zander (1992), Zander e Kogut (1995), Minbaeva (2007) e Tavani (2010).

\section{a) Tacitividade}

Kogut e Zander (1992, p. 386) definem conhecimento tácito como sendo “[...] as habilidades práticas ou expertises acumuladas que permitem a alguém fazer algo de maneira fácil e eficiente." Essa definição de tacitividade foi adotada por Simonin (2004), Zander e Kogut (1995), Minbaeva (2007) e Tavani (2010). O constructo tacitividade será mensurado pela média de três indicadores aferidos por meio das seguintes afirmações:

- O conhecimento da subsidiária pode ser facilmente documentado (em instruções, manuais, relatórios);

- O conhecimento da subsidiária pode ser facilmente aprendido;

- O conhecimento da subsidiária é mais explícito do que tácito.

A mensuração utilizou uma escala do tipo Likert de 5 pontos, que variou de $1=$ "discordo totalmente" a 5= "concordo totalmente". O resultado do constructo foi a média dos três tipos de conhecimento. Os indicadores foram desenvolvidos de forma reversa. Para que esses 
indicadores correspondessem ao constructo tacitividade, sua pontuação foi invertida na análise dos dados.

\section{b) Complexidade}

A complexidade do conhecimento é definida pela "quantidade de tecnologias, rotinas, recursos e indivíduos interdependentes ligados a um conhecimento ou ativo" (SIMONIN, 1999, p. 600). O constructo complexidade utilizará os critérios adotados por Simonin (2004), Zander e Kogut (1995) e Tavani (2010) e será mensurado pela média de quatro indicadores aferidos por meio das seguintes afirmações:

Nosso conhecimento tecnológico:

- Seu entendimento requer um aprendizado prévio sobre outros conhecimentos tecnológicos relacionados;

- É produto de muitos rotinas interdependentes, indivíduos e recursos;

- Inclui muitas habilidades ou competências distintas;

- É tecnologicamente sofisticado e difícil de implantar;

- É complexo (vs. simples).

A mensuração utilizou uma escala do tipo Likert de 5 pontos, que variou de $1=$ "discordo totalmente" a 5= "concordo totalmente". O resultado do constructo foi a média dos cinco indicadores relatados.

\subsubsection{Fatores relacionados às características das subsidiárias}

\section{a) Ambiente institucional}

A literatura tem destacado que uma subsidiária pode contribuir de forma mais criativa para a geração de tecnologia dentro da rede corporativa, dependendo das características do local em que a subsidiária está situada (CANTWEL; MUDAMBI, 2005; FROST 2001; NELSON, 1993 apud FROST, 2001). Essas características gerais são importantes determinantes da natureza das transferências de conhecimento intrarrede multinacional (YANG; MUDAMBI; MEYER, 2008). Em uma região com boa infraestrutura local, relevante base científica e uma força de trabalho mais qualificada, as subsidiárias são mais propensas a explorar novos conhecimentos (CANTWEL; MUDAMBI, 2005) e a explorá-los dentro da corporação multinacional. O 
constructo foi desenvolvido pela autora deste estudo com base nas contribuições de Cantwel e Mudambi (2005) e Frost (2001) e foi aferido por meio das seguintes afirmações:

- Existem importantes centros de pesquisa (externos à empresa) que colaboram com os negócios da subsidiária;

- Há boas instituições de suporte aos negócios;

- A infraestrutura no país (disponibilidade de energia, transporte, telecomunicações, logística) é adequada;

- O governo dá apoio à inovação;

- O ambiente legal é favorável (regulamentação).

A mensuração utilizou uma escala do tipo Likert de 5 pontos, que variou de $1=$ "discordo totalmente" a 5= "concordo totalmente". A mensuração foi feita pela média dos cinco indicadores.

\section{b) Ambiente competitivo}

Importantes estudos na área de negócios internacionais (FROST; BIRKINSHAW; ENSIGN, 2002; BIRKINSHAW; HOOD; JONSSON, 1998) decidiram decompor esta variável de acordo com as características tratadas no Modelo Diamante da Vantagem Competitiva Nacional (PORTER, 1990), para apresentar a influência dos Ambiente competitivo sobre as estratégias de subsidiárias em outros países.

Estudos anteriores indicaram que o conhecimento é mais facilmente encontrado em locais onde a indústria é mais desenvolvida (KUEMMERLE, 1999). Espera-se, portanto, que subsidiárias localizadas nessas regiões contribuam de maneira mais significativa para a transferência reversa do conhecimento (AMBOS, T.; AMBOS, B.; SCHLEGELMILCH, 2006).

Este constructo adotou os critérios utilizados pelo estudo de Birkinshaw, Hood e Jonsson (1998) o qual utilizou um instrumento de pesquisa para medir a percepção da concorrência global em termos de intensidade e frequência de iniciativas da concorrência. Tal constructo também foi utilizado no contexto sobre EMNs brasileiras no estudo dos autores Borini e Renel (2008). Sendo assim, os Ambiente competitivo foram mensurados pela média de seis indicadores a seguir: 
- A demanda de mercado está crescendo no setor da subsidiária;

- Os consumidores locais exigem padrões elevados de qualidade e funcionalidades em produtos/serviços;

- A competição no país é intensa;

- A velocidade da inovação dos competidores é alta;

- As capacidades e qualidades dos fornecedores são elevadas;

- A mão de obra é qualificada e especializada.

A mensuração do constructo utilizou uma escala do tipo Likert de 5 pontos, que variou de $1=$ "discordo totalmente" a 5= "concordo totalmente".

\section{c) Integração externa (com a rede de negócios)}

Pesquisas mostraram que ao serem incorporadas em redes locais, subsidiárias ficam expostas a novos conhecimentos, ideias e oportunidades (ANDERSSON; FORSGREN; HOLM, 2002; FORSGREN et al., 2005). Por meio de uma estreita colaboração das subsidiárias com empresas na rede externa, uma inovação pode ser parcialmente desenvolvida dentro das instalações de tais parceiros (DELLESTRAND, 2010), o que pode, consequentemente, conduzir a uma posterior transferência de conhecimento para a sede.

Este constructo foi desenvolvido com base Andersson et al., (2005) e Dellestrand (2010), sendo mensurado da seguinte forma:

- Este parceiro tem participado intensamente do desenvolvimento do conhecimento tecnológico na subsidiária;

- Este parceiro teve importantes iniciativas para o desenvolvimento do conhecimento tecnológico na subsidiária;

- Este parceiro atendeu aos seus interesses ao desenvolver o conhecimento tecnológico na subsidiária;

- O conhecimento tecnológico da subsidiária foi parcialmente desenvolvido dentro das instalações deste parceiro;

- A cooperação com este parceiro tem sido caracterizada por frequentes interações.

Os indicadores acima foram utilizados para cada um dos seguintes atores da rede externa:

- Clientes; 
- Fornecedores;

- Institutos de ciência e tecnologia (C\&T).

A mensuração do constructo utilizou uma escala do tipo Likert de 5 pontos, que variou de $1=$ "discordo totalmente" a 5= "concordo totalmente". O resultado representou a média dos cinco indicadores observados para cada um dos atores citados.

\section{d) Autonomia}

Indica a extensão em que uma subsidiária tem permissão para tomar decisões sobre suas principais questões estratégicas (TAVANI, 2010). O constructo foi desenvolvido com base em Ghoshal e Nohria (1989), Birkinshaw, Hood e Jonsson (1998) e Rabiosi (2011). A mensuração teve o intuito de verificar o grau de autonomia da subsidiária na realização das seguintes atividades:

- Realização de mudanças nos produtos e serviços;

- Desenvolvimento de novos produtos e serviços;

- Realização de mudanças nos processos de produção;

- Entrada de novos mercados no país;

- Desenvolvimento de novos fornecedores e parceiros;

- Gestão de compras e da cadeia de suprimentos;

- Contratação e demissão da força de trabalho.

Foi utilizada uma escala do tipo Likert, onde 1= "a matriz decide sozinha", 2 = "a matriz decide, mas considera as sugestões das subsidiarias"; 3= "ambas têm igual influência sobre as decisões"; 4= "a subsidiária decide, mas considera as sugestões da matriz" e 5= "a subsidiária decide sozinha" (RABIOSI, 2011). A mensuração final da autonomia da subsidiária foi feita com base na média dos sete indicadores observados.

\section{e) Motivação}

É definida como a habilidade e boa vontade do emissor em compartilhar o conhecimento (MINBAEVA, 2007). Este constructo possui uma limitação inerente, uma vez que é pouco provável que a subsidiária opine de forma sincera caso tenha uma postura relutante em relação 
a transferir o conhecimento para a matriz (MINBAEVA, 2007; TAVANI, 2010). O constructo foi desenvolvido com base nas contribuições de Gupta e Govindarajan (2000), Szulanski (1996) e Tavani (2010). O entrevistado foi solicitado a indicar se:

- A subsidiária percebe claramente os benefícios em compartilhar seu conhecimento com a matriz;

- A matriz motiva/incentiva (financeira ou emocionalmente) a subsidiária a transferir seu conhecimento;

- A subsidiária compromete recursos físicos, financeiros, organizacionais e logísticos para transferir seu conhecimento à matriz.

A mensuração foi realizada com base em uma escala do tipo Likert, que variou de 1= "discordo totalmente" a 5= "concordo totalmente". O resultado refletiu a média dos três indicadores observados.

\subsubsection{Fatores relacionados às características da interação matriz/subsidiária}

\section{a) Integração interna (com a matriz)}

Integração interna com a matriz reflete a capacidade da subsidiária de realizar adaptações com base no relacionamento com as outras subsidiárias. Este constructo é operacionalizado do mesmo modo como o é o envolvimento externo (FORSGREN et al., 2005) e segue as contribuições de Andersson et al. (2005) e Dellestrand (2010). Os entrevistados foram solicitados a responder as seguintes afirmações:

- A matriz tem participado intensamente do desenvolvimento do conhecimento tecnológico na subsidiária;

- A matriz teve importantes iniciativas para o desenvolvimento do conhecimento tecnológico na subsidiária;

- A matriz atendeu aos seus interesses ao desenvolver o conhecimento tecnológico na subsidiária;

- O conhecimento tecnológico da subsidiária foi parcialmente desenvolvido dentro das instalações da matriz;

- A cooperação com a matriz tem sido caracterizada por frequentes interações. 
A mensuração deste constructo utilizou uma escala do tipo Likert de 5 pontos, que variou de $1=$ "discordo totalmente" a 5= "concordo totalmente". A mensuração final deste constructo refletiu a média dos cinco indicadores observados.

\section{c) Semelhança organizacional}

O constructo semelhança cultural procura capturar o grau de similaridade entre as práticas de negócios, heranças institucionais e cultura organizacional entre uma subsidiária e outra unidade da EMN (SIMONIN, 1999b). Os entrevistados foram solicitados a responder às seguintes afirmações:

- As bases do conhecimento tecnológico da subsidiária e da matriz são muito semelhantes;

- As práticas de negócios e os mecanismos operacionais são muito semelhantes entre subsidiária e matriz;

- O estilo gerencial é muito semelhante entre subsidiária e matriz;

- A cultura organizacional é muito semelhante entre subsidiária e matriz.

A mensuração dos dois constructos teve por base uma escala do tipo Likert, que variou de $1=$ "discordo totalmente" a 5= "concordo totalmente". A mensuração deste constructo foi feito com base na média dos quatro indicadores observados.

\section{d) Semelhança cultural}

O constructo semelhança cultural é definido como o resultado vetorial de fatores baseados na cultura que impedem o fluxo de informação entre as unidades da EMN (JOHANSON; VAHLNE, 1977; SIMONIN, 1999b). Os entrevistados foram solicitados a indicar seu grau de concordância sobre a seguinte declaração:

- A cultura dos países-sede da matriz e da subsidiária influencia fortemente o modo de fazer negócio;

- Muitos desentendimentos e conflitos culturais emergem da transferência de conhecimento entre subsidiária e matriz;

- As diferenças de idioma são os principais obstáculos na comunicação e compreensão entre subsidiária e matriz. 
A mensuração dos dois constructos teve por base uma escala do tipo Likert, que variou de 1= "discordo totalmente" a 5= "concordo totalmente". A mensuração final deste constructo foi feita com base na média dos três indicadores supracitados. A pontuação dos indicadores foi invertida para corresponder ao constructo semelhança cultural.

\section{d) Mecanismos de socialização}

A mensuração deste constructo foi adaptada das contribuições de Ambos, T. e Ambos, B. (2009) e Rabiosi (2011) que classificam os mecanismos de socialização como mecanismos baseados e em mecanismos baseados comunicação eletrônica. Argumenta-se que os dois tipos de mecanismos são complementares e necessários para que a transferência reversa de conhecimento seja efetivada (AMBOS, T.; AMBOS, B., 2009).

Os respondentes foram convidados a indicar a frequência com que utilizam os seguintes mecanismos.

a) Mecanismos socialização baseados em comunicação eletrônica:

- Compartilhamento de documentos, tais como manuais, projetos e bases de dados;

- Instrumentos baseados em internet, como fóruns, e-mails, mensagens instantâneas, etc.;

- Repositores de informação, melhores práticas e lições aprendidas;

- Mapeamento de tipos de conhecimentos específicos (incorporados em indivíduos, sistemas específicos ou bases de dados).

b) Mecanismos socialização baseados em interação pessoal:

- Encontros entre pessoas da matriz e das subsidiárias para transferência de conhecimento;

- Constituição de equipe de trabalho envolvendo pessoas tanto da subsidiária como da matriz;

- Transferência temporária (de curto prazo) de gerentes da subsidiária para a matriz e viceversa;

- Transferência temporária (de curto prazo) de staff científico e técnico (pesquisadores, engenheiros) da subsidiária para a matriz e vice-versa;

- Treinamentos conjuntos envolvendo pessoas tanto da subsidiária como da matriz.

A mensuração dos dois tipos de mecanismos de socialização tomou por base uma escala do tipo Likert, que variou de $1=$ "muito raramente" a 5= "muito frequentemente". O resultado deste constructo representou a média dos nove indicadores observados. 


\subsubsection{Variáveis moderadoras}

\section{a) Modo de entrada da subsidiária}

A fim de capturar os efeitos do modo de entrada sobre os níveis de transferência reversa de conhecimento, decidiu-se inserir esta variável como moderadora do modelo. Os entrevistados foram solicitados a indicar, a forma pela qual a subsidiária foi formada:

- Uma companhia local foi adquirida pela multinacional brasileira;

- Greenfield operation (nova empresa criada).

Para mensuração do constructo modo de entrada foi aplicada uma variável dicotômica na qual a opção "aquisição" correspondeu ao valor (0) e a opção "Greenfield operation” correspondeu ao valor (1).

\section{b) Tempo de existência da subsidiária}

O período de existência da subsidiária também foi considerado como uma variável moderadora e foi medido pela diferença entre o ano de criação da subsidiária no exterior e o ano de realização da pesquisa de campo (2013). A mensuração dessa variável seguiu as contribuições de Foss e Pedersen (2002): foi feita pelo cálculo da idade média das subsidiárias respondentes, e, a partir disso, uma variável dicotômica foi estipulada para as subsidiárias mais jovens (0) e as mais antigas (1).

\section{c) Importância estratégica da subsidiária}

A aplicação desta variável moderadora foi feita com base na pesquisa de Ambos e Schlegelmilch (2007) e de Rabiosi (2011) que classificaram as subsidiárias de acordo com sua importância estratégica: "subsidiárias implementadoras", "subsidiárias contribuintes" e "subsidiárias inovadoras". Os autores defendem que sua aplicação deve seguir uma heurística relativamente simples, que toma por base a natureza das atividades da subsidiária. Especificamente, os entrevistados foram convidados a indicar se a subsidiária é dedicada a atividades voltadas para a criação de novos produtos e/ou novas tecnologias (capacidade de criar) ou a atividades voltadas para a melhoria do produto ou do processo (capacidade de explorar atividades desenvolvidas por outras unidades). A questão foi formulada da seguinte forma: 
- Sua subsidiária se dedica a atividades voltadas para a criação de novos; produtos/serviços e/ou novas tecnologias;

- Sua subsidiária se dedica a atividades voltadas para a melhoria de produtos/serviços e processos.

As subsidiárias que não têm nem capacidade de criar nem de explorar (aperfeiçoar) atividades de produtos/serviços desenvolvidas em outras subsidiárias foram chamadas de implementadoras; as subsidiárias que têm capacidade de explorar, mas não têm capacidade de criar foram chamadas de contribuintes; aquelas que possuem simultaneamente a capacidade de explorar e de criar foram chamadas de inovadoras (RABIOSI, 2011). Essa variável moderadora age como um proxy da real influência que as subsidiárias têm na criação de valor para a EMN. A operacionalização das variáveis supracitadas está resumida nos três quadros apresentados a seguir.

O Quadro 15 apresenta a operacionalização da variável dependente, qual seja, a transferência reversa de conhecimento tecnológico, seus indicadores e rótulos, a referência teórica e a forma pela qual cada indicador foi medido.

Quadro 15: Definição operacional da variável dependente

\begin{tabular}{|c|c|c|c|}
\hline Variável & Rótulo & Indicadores & Autor (es) \\
\hline \multirow{14}{*}{$\begin{array}{l}\text { TRANSFERENCI } \\
\text { A REVERSA DE } \\
\text { CONHECIMENT } \\
\text { O } \\
\text { TECNOLÓGICO }\end{array}$} & TRCT1 & $\begin{array}{l}\text { Técnicas de organização da produção (ex.: just in time, } \\
\text { controle da qualidade total) }\end{array}$ & \multirow{14}{*}{$\begin{array}{l}\text { Proposto pelo } \\
\text { autor com base } \\
\text { nas } \\
\text { contribuições } \\
\text { de: } \\
\text { Lall (1992); } \\
\text { Bell e Pavitt } \\
\text { (1995); } \\
\text { Iammarino, } \\
\text { Padilla-Pérez e } \\
\text { Tunzelmann } \\
\text { (2008). }\end{array}$} \\
\hline & TRCT2 & Planejamento e controle da produção (PCP) & \\
\hline & TRCT3 & Processos de automação & \\
\hline & TRCT4 & Desenvolvimento de novos processos de produção & \\
\hline & TRCT5 & $\begin{array}{l}\text { Pequenas mudanças na tecnologia de processo para } \\
\text { adaptá-lo a condições locais }\end{array}$ & \\
\hline & TRCT6 & $\begin{array}{l}\text { Melhoria significativa no processo de produção } \\
\text { (aprimoramento de layout, fluxo de materiais e processos, } \\
\text { automação de linhas e/ou eliminação de gargalos) }\end{array}$ & \\
\hline & TRCT7 & Projeto (design) próprio de fabricação & \\
\hline & TRCT8 & $\begin{array}{l}\text { Desenvolvimento de novos equipamentos e/ou } \\
\text { ferramentas }\end{array}$ & \\
\hline & TRCT9 & Fabricação de novos componentes & \\
\hline & TRCT10 & Montagem de componentes e produtos finais & \\
\hline & TRCT11 & Manutenção de máquinas e equipamentos & \\
\hline & TRCT12 & $\begin{array}{l}\text { Pequenas adaptações na tecnologia de produtos existentes } \\
\text { (impulsionadas por necessidades de mercado ou de } \\
\text { produção) }\end{array}$ & \\
\hline & TRCT13 & $\begin{array}{l}\text { Melhoria significativa em produtos existentes } \\
\text { (especificações, funções e características) }\end{array}$ & \\
\hline & TRCT14 & Desenvolvimento de novos produtos & \\
\hline
\end{tabular}




\begin{tabular}{|l|l|l|l|} 
TRCT15 & $\begin{array}{l}\text { Rotinas de controle de qualidade para manter padrões e } \\
\text { especificações de produtos existentes } \\
\text { TRCT16 } \\
\text { DRCT17 }\end{array}$ & $\begin{array}{l}\text { Testes de novos produtos protótipos } \\
\text { Know-how e experiência técnica na forma de planos, } \\
\text { modelos, instruções, guias, fórmulas, projetos, plantas, } \\
\text { desenhos técnicos e/ou protótipos para projetar novos } \\
\text { produtos } \\
\text { Resultados de pesquisa sobre novos materiais e } \\
\text { TRCTas especificações } \\
\text { Resultados de pesquisa e desenvolvimento sobre nova } \\
\text { geração de produtos }\end{array}$ & TRCT19 \\
\hline
\end{tabular}

O Quadro 16 apresenta a operacionalização das variáveis independentes, quais sejam: tacitividade, complexidade, Ambiente Institucional, Ambiente competitivo, rede externa (com clientes, fornecedores e instituições de C\&T, autonomia, motivação, rede interna, contexto organizacional, contexto cultural, mecanismos de socialização).

Quadro 16: Definição operacional das variáveis independentes

\begin{tabular}{|c|c|c|c|}
\hline Variável & Rótulo & Indicadores & Autor (es) \\
\hline \multirow{3}{*}{$\begin{array}{l}\text { TACITIVIDADE } \\
\text { Mensuração } \\
\text { escala de } 5 \\
\text { pontos: } \\
\text { 1= discordo } \\
\text { totalmente } \\
\text { 5=concordo } \\
\text { totalmente }\end{array}$} & TACIT1 & $\begin{array}{l}\text { O conhecimento da subsidiária pode ser facilmente } \\
\text { documentado (em instruções, manuais, relatórios) }\end{array}$ & \multirow{3}{*}{$\begin{array}{l}\text { Simonin } \\
\text { (2004); Zander } \\
\text { e Kogut } \\
\text { (1995); } \\
\text { Minbaeva } \\
(2007) \text {; Tavani } \\
(2010)\end{array}$} \\
\hline & TACIT2 & $\begin{array}{l}\text { O conhecimento da subsidiária pode ser facilmente } \\
\text { aprendido }\end{array}$ & \\
\hline & TACIT3 & $\begin{array}{l}\text { O conhecimento da subsidiária é mais explícito do que } \\
\text { tácito }\end{array}$ & \\
\hline \multirow{5}{*}{\begin{tabular}{l} 
COMPLEXIDA- \\
\multicolumn{1}{c}{ DE } \\
Mensuração \\
escala de 5 \\
pontos: \\
$1=$ discordo \\
totalmente \\
$5=$ concordo \\
totalmente
\end{tabular}} & COMPLX1 & $\begin{array}{l}\text { Seu entendimento requer um aprendizado prévio de } \\
\text { outros conhecimentos tecnológicos relacionados }\end{array}$ & \multirow{5}{*}{$\begin{array}{l}\text { Simonin } \\
(2004) \text {; Zander } \\
\text { e Kogut } \\
(1995)\end{array}$} \\
\hline & COMPLX2 & $\begin{array}{l}\text { É produto de muitas rotinas interdependentes, } \\
\text { indivíduos e recursos }\end{array}$ & \\
\hline & COMPLX3 & Inclui muitas habilidades ou competências distintas & \\
\hline & COMPLX4 & É tecnologicamente sofisticado e difícil de implantação & \\
\hline & COMPLX5 & É complexo (vs. simples) & \\
\hline \multirow{5}{*}{\begin{tabular}{l}
\multicolumn{1}{c}{ AMBIENTE } \\
INSTITUCIONAL \\
Mensuração \\
escala de 5 \\
pontos: \\
$1=$ discordo \\
totalmente \\
$5=$ concordo \\
totalmente
\end{tabular}} & AINST1 & $\begin{array}{l}\text { Existem importantes centros de pesquisa (externos à } \\
\text { empresa) que colaboram com os negócios da subsidiária }\end{array}$ & \multirow{5}{*}{$\begin{array}{l}\text { Proposta do } \\
\text { autor com base } \\
\text { nos trabalhos } \\
\text { de Cantwel e } \\
\text { Mudambi } \\
\text { (2005) e de } \\
\text { Frost (2001) }\end{array}$} \\
\hline & AINST2 & Há boas instituições de suporte aos negócios & \\
\hline & AINST3 & $\begin{array}{l}\text { A infraestrutura no país (disponibilidade de energia, } \\
\text { transporte, telecomunicações, logística) é adequada }\end{array}$ & \\
\hline & AINST4 & O governo dá apoio à inovação & \\
\hline & AINST5 & O ambiente legal é favorável (regulamentação) & \\
\hline
\end{tabular}




\begin{tabular}{|c|c|c|c|}
\hline AIMBIENIE & ACOMP1 & $\begin{array}{l}\text { A demanda de mercado está crescendo no setor da } \\
\text { subsidiária }\end{array}$ & \multirow{6}{*}{$\begin{array}{l}\text { Birkinshaw, } \\
\text { Hood e } \\
\text { Jonsson } \\
\text { (1998); Borini } \\
\text { e Renel (2008) }\end{array}$} \\
\hline \multirow{5}{*}{$\begin{array}{l}\text { Mensuração } \\
\text { escala de } 5 \\
\text { pontos: } \\
1=\text { discordo } \\
\text { totalmente } \\
5=\text { concordo } \\
\text { totalmente }\end{array}$} & ACOMP2 & $\begin{array}{l}\text { Os consumidores locais exigem padrões elevados de } \\
\text { qualidade e funcionalidades em produtos/serviços }\end{array}$ & \\
\hline & ACOMP3 & A competição no país é intensa & \\
\hline & ACOMP4 & A velocidade da inovação dos competidores é alta & \\
\hline & ACOMP5 & $\begin{array}{l}\text { As capacidades e qualidades dos fornecedores são } \\
\text { elevadas }\end{array}$ & \\
\hline & ACOMP6 & A mão de obra é qualificada e especializada & \\
\hline $\begin{array}{l}\text { REDE EXTERNA } \\
\text { (COM } \\
\text { CLIENTES, }\end{array}$ & $\begin{array}{l}\text { RCLI1/ } \\
\text { RFOR1/ } \\
\text { RC\&T1 }\end{array}$ & $\begin{array}{lrll}\text { Este parceiro tem } & \text { participado intensamente } & \text { do } \\
\text { desenvolvimento do conhecimento tecnológico na } \\
\text { subsidiária }\end{array}$ & \multirow{5}{*}{$\begin{array}{l}\text { Anderson, } \\
\text { Bjorkman e } \\
\text { Holm }(2005) \text { e } \\
\text { Dellestrand } \\
(2010)\end{array}$} \\
\hline $\begin{array}{l}\text { FORNECEDORE } \\
\text { S E } \\
\text { INSTITUIÇÕES }\end{array}$ & $\begin{array}{l}\text { RCLI2/ } \\
\text { RFOR2/ } \\
\text { RC\&T2 }\end{array}$ & $\begin{array}{l}\text { Este parceiro teve importantes iniciativas para o } \\
\text { desenvolvimento do conhecimento tecnológico na } \\
\text { subsidiária }\end{array}$ & \\
\hline DE C\&T) & $\begin{array}{l}\text { RCLI3/ } \\
\text { RFOR3/ }\end{array}$ & $\begin{array}{l}\text { Este parceiro atendeu aos seus interesses ao } \\
\text { desenvolver o conhecimento tecnológico na subsidiária }\end{array}$ & \\
\hline \multirow{2}{*}{$\begin{array}{l}\text { Mensuração } \\
\text { escala de } 5 \\
\text { pontos: } \\
1=\text { discordo } \\
\text { totalmente } \\
5=\text { concordo } \\
\text { totalmente }\end{array}$} & $\begin{array}{l}\text { RC\&T3/ } \\
\text { RCLI4/ } \\
\text { RFOR4/ } \\
\text { RC\&T4 }\end{array}$ & $\begin{array}{l}\text { O conhecimento tecnológico da subsidiária foi } \\
\text { parcialmente desenvolvido dentro das instalações deste } \\
\text { parceiro }\end{array}$ & \\
\hline & $\begin{array}{l}\text { RCLI5/ } \\
\text { RFOR5/ } \\
\text { RC\&T5 }\end{array}$ & $\begin{array}{l}\text { A cooperação com este parceiro tem sido caracterizada } \\
\text { por frequentes interações. }\end{array}$ & \\
\hline \multirow{7}{*}{ AUTONOMIA } & AUTO1 & Real & \multirow{7}{*}{$\begin{array}{l}\text { Ghoshal e } \\
\text { Nohria (1989); } \\
\text { Birkinshaw, } \\
\text { Hood e } \\
\text { Jonsson } \\
\text { (1998); } \\
\text { Rabiosi (2011) }\end{array}$} \\
\hline & AUTO2 & Desenvolvimento de novos produtos & \\
\hline & AUTO3 & Realização de mudanças nos processos de produção & \\
\hline & AUTO4 & Entrada em novos mercados no país & \\
\hline & AUTO5 & Desenvolvimento de novos fornecedores e parceiros & \\
\hline & AUTO6 & Gestão de compras e da cadeia de suprimentos & \\
\hline & AUTO7 & Contratação e demissão da força de trabalho & \\
\hline MOTIVAÇÃO & MOTIV1 & $\begin{array}{l}\text { A subsidiária percebe claramente os benefícios em } \\
\text { compartilhar seu conhecimento com a matriz }\end{array}$ & \\
\hline $\begin{array}{l}\text { Mensuração } \\
\text { escala de } 5 \\
\text { pontos: }\end{array}$ & MOTIV2 & $\begin{array}{l}\text { A matriz motiva/incentiva } \text { (financeira } \\
\text { emocionalmente) a subsidiária para transferir } \\
\text { conhecimento }\end{array}$ & $\begin{array}{l}\text { Gupta e } \\
\text { Govindarajan } \\
(2000) \text {; } \\
\text { Szulanski }\end{array}$ \\
\hline $\begin{array}{l}1=\text { discordo } \\
\text { totalmente } \\
5=\text { concordo } \\
\text { totalmente }\end{array}$ & MOTIV3 & $\begin{array}{l}\text { A subsidiária compromete recursos físicos, financeiros, } \\
\text { organizacionais e logísticos para transferir seu } \\
\text { conhecimento para a matriz }\end{array}$ & $\begin{array}{l}\text { (1996); Tavani } \\
(2010)\end{array}$ \\
\hline REDE INTERNA & RMAT1 & $\begin{array}{l}\text { A matriz tem participado intensamente do } \\
\text { desenvolvimento do conhecimento tecnológico na } \\
\text { subsidiária }\end{array}$ & \\
\hline Mensuração & RMAT2 & $\begin{array}{l}\text { A matriz teve importantes iniciativas para o } \\
\text { desenvolvimento do conhecimento tecnológico na } \\
\text { subsidiária }\end{array}$ & $\begin{array}{l}\text { Andersson, } \\
\text { Bjorkman e }\end{array}$ \\
\hline pontos: & RMAT3 & $\begin{array}{l}\text { A matriz atendeu aos seus interesses ao desenvolver o } \\
\text { conhecimento tecnológico na subsidiária }\end{array}$ & $\begin{array}{l}\text { Holm, (2005); } \\
\text { Dellestrand }\end{array}$ \\
\hline $\begin{array}{l}1=\text { alscordo } \\
\text { totalmente } \\
5=\text { concordo }\end{array}$ & TMAT4 & $\begin{array}{l}\text { O conhecimento tecnológico da subsidiária foi } \\
\text { parcialmente desenvolvido dentro das instalações da } \\
\text { matriz }\end{array}$ & $(2010)$ \\
\hline & RMAT5 & $\begin{array}{l}\text { A cooperação com a matriz tem sido caracterizada por } \\
\text { frequentes interações }\end{array}$ & \\
\hline
\end{tabular}




\begin{tabular}{|c|c|c|c|}
\hline $\begin{array}{l}\text { SEMELHANÇA } \\
\text { ORGANIZACIO- }\end{array}$ & SORG1 & As bases do conhecimento tecnológico da subsidiária e & \multirow{4}{*}{$\begin{array}{l}\text { Tsai e Ghoshal } \\
\text { (1998); } \\
\text { Simonin } \\
\text { (1999b); Chini } \\
\text { (2002) }\end{array}$} \\
\hline \multirow{3}{*}{$\begin{array}{l}\text { Mensuração } \\
\text { escala de } 5 \\
\text { pontos: } \\
1=\text { discordo } \\
\text { totalmente } \\
5=\text { concordo } \\
\text { totalmente }\end{array}$} & SORG2 & $\begin{array}{l}\text { As práticas de negócios e os mecanismos operacionais } \\
\text { são muito semelhantes entre subsidiária e matriz }\end{array}$ & \\
\hline & SORG3 & $\begin{array}{l}\text { O estilo gerencial é muito semelhante entre subsidiária } \\
\text { e matriz }\end{array}$ & \\
\hline & SORG4 & $\begin{array}{l}\text { A cultura organizacional é muito semelhante entre } \\
\text { subsidiária e matriz }\end{array}$ & \\
\hline $\begin{array}{l}\text { CONTEXTO } \\
\text { CULTURAL }\end{array}$ & SCULT1 & $\begin{array}{l}\text { A cultura dos países-sede da matriz e da subsidiária } \\
\text { influencia fortemente o modo de fazer negócio }\end{array}$ & \\
\hline $\begin{array}{l}\text { Mensuração } \\
\text { escala de } 5 \\
\text { pontos: } \\
1=\text { discordo }\end{array}$ & SCULT2 & $\begin{array}{l}\text { Muitos desentendimentos e conflitos culturais emergem } \\
\text { da transferência de conhecimento entre subsidiária e } \\
\text { matriz }\end{array}$ & $\begin{array}{l}\text { Tsai e Ghoshal } \\
\text { (1998); } \\
\text { Simonin } \\
\text { (1999b); Chini }\end{array}$ \\
\hline $\begin{array}{l}\text { totalmente } \\
5=\text { concordo } \\
\text { totalmente }\end{array}$ & SCUT3 & $\begin{array}{l}\text { As diferenças de idioma são os principais obstáculos na } \\
\text { comunicação e compreensão entre subsidiária e matriz }\end{array}$ & $(2002)$ \\
\hline & SOC1 & $\begin{array}{l}\text { Compartilhamento de documentos, tais como manuais, } \\
\text { projetos e bases de dados }\end{array}$ & \\
\hline & SOC2 & $\begin{array}{l}\text { Instrumentos baseados em internet, como fóruns, } e \text { - } \\
\text { mails, mensagens instantâneas, etc. }\end{array}$ & \\
\hline $\begin{array}{l}\text { MECANISMOS } \\
\text { DE }\end{array}$ & SOC3 & $\begin{array}{l}\text { Repositores de informação, melhores práticas e lições } \\
\text { aprendidas }\end{array}$ & \\
\hline SUCIALIZAÇAU & SOC4 & $\begin{array}{l}\text { Mapeamento de tipos de conhecimentos específicos } \\
\text { (incorporados em indivíduos, sistemas específicos ou } \\
\text { bases de dados) }\end{array}$ & $\begin{array}{l}\text { Ambos, T. e } \\
\text { Ambos, B. } \\
\text { (2009); }\end{array}$ \\
\hline Mensuração & SOC5 & $\begin{array}{l}\text { Encontros entre pessoas da matriz e das subsidiárias } \\
\text { para transferência de conhecimento }\end{array}$ & $\begin{array}{l}\text { Rabiosi } \\
(2011)\end{array}$ \\
\hline pontos: & SOC6 & $\begin{array}{l}\text { Constituição de equipe de trabalho envolvendo pessoas } \\
\text { tanto da subsidiária como da matriz }\end{array}$ & $\begin{array}{l}\text { Barnard } \\
(2011)\end{array}$ \\
\hline $\begin{array}{l}1=\text { discordo } \\
\text { totalmente }\end{array}$ & SOC7 & $\begin{array}{l}\text { Transferência temporária (de curto prazo) de gerentes da } \\
\text { subsidiária para a matriz e vice-versa }\end{array}$ & \\
\hline $\begin{array}{l}5=\text { concordo } \\
\text { totalmente }\end{array}$ & SOC8 & $\begin{array}{l}\text { Transferência temporária (de curto prazo) de staff } \\
\text { científico e técnico (pesquisadores, engenheiros) da } \\
\text { subsidiária para a matriz e vice-versa }\end{array}$ & \\
\hline & SOC9 & $\begin{array}{l}\text { Treinamentos conjuntos envolvendo pessoas tanto da } \\
\text { subsidiária como da matriz }\end{array}$ & \\
\hline
\end{tabular}

O Quadro 17 apresenta a definição operacional das variáveis moderadoras, quais sejam: modo de entrada, tempo de existência da subsidiária e importância estratégica da subsidiárias.

Quadro 17: Definição operacional das variáveis moderadoras

\begin{tabular}{|c|c|c|c|}
\hline Variável & Rótulo & Indicadores & Autor (es) \\
\hline $\begin{array}{l}\text { MODO DE } \\
\text { ENTRADA }\end{array}$ & ME1 & $\begin{array}{l}\text { Uma companhia local foi adquirida pela } \\
\text { multinacional brasileira }\end{array}$ & Frost (1998) \\
\hline $\begin{array}{l}\text { Dummy: } \\
\text { Aquisição (0) } \\
\text { Greenfield (1) }\end{array}$ & ME2 & $\begin{array}{l}\text { Investimento direto - greenfield operation (ex. nova } \\
\text { empresa criada) }\end{array}$ & $\begin{array}{l}\text { Frost e Zhou } \\
(2005)\end{array}$ \\
\hline $\begin{array}{l}\text { TEMPO DE } \\
\text { EXISTÊNCIA }\end{array}$ & JOVENS & $\begin{array}{l}\text { Subsidiárias mais jovens (que ficaram abaixo da idade } \\
\text { média) }\end{array}$ & $\begin{array}{l}\text { Foss e } \\
\text { Perdersen } \\
(2002)\end{array}$ \\
\hline
\end{tabular}




\begin{tabular}{|c|c|c|c|}
\hline $\begin{array}{l}\text { Dummy: } \\
\text { mais jovens }(0) \\
\text { mais antigas }(1)\end{array}$ & ANTIGAS & $\begin{array}{l}\text { Subsidiárias mais antigas (que ficaram abaixo da idade } \\
\text { média) }\end{array}$ & \\
\hline \multirow{2}{*}{$\begin{array}{l}\text { IMPORTÂNCIA } \\
\text { ESTRATÉGICA } \\
\text { DA } \\
\text { SUBSIDIÁRIA }\end{array}$} & $\begin{array}{l}\text { INOVADO- } \\
\text { RAS }\end{array}$ & $\begin{array}{l}\text { A subsidiária se dedica a atividades voltadas para a } \\
\text { criação de novos produtos/serviços e/ou novas } \\
\text { tecnologias; }\end{array}$ & \multirow{2}{*}{$\begin{array}{l}\text { Ambos e } \\
\text { Schlegelmilch } \\
\text { (2007) e } \\
\text { Rabiosi (2011) }\end{array}$} \\
\hline & $\begin{array}{l}\text { CONTRIBU- } \\
\text { INTES }\end{array}$ & $\begin{array}{l}\text { A subsidiária se dedica a atividades voltadas para a } \\
\text { melhoria de produtos/serviços e processos }\end{array}$ & \\
\hline
\end{tabular}

\subsection{Caracterização do universo e seleção da amostra}

O universo se refere ao conjunto de dados que contempla todos os elementos possíveis sobre os quais se deseja inferir algo (COOPER; SCHINDLER, 2003). Para fins desta pesquisa, definiu-se Multinacional Brasileira como a empresa brasileira que gerencia ativamente uma ou mais operações produtivas no exterior. Isso inclui empresas com subsidiárias manufatureiras e/ou laboratórios de pesquisa e desenvolvimento no exterior. Essa escolha exclui da análise representações comerciais, lojas ou postos de distribuição no exterior e empresas de serviços. A justificativa para excluir essas empresas da pesquisa é a de que o questionário é voltado à transferência reversa sobre conhecimento de produto e processo.

O universo da pesquisa foi representado por 95 EMNBrs industriais, comerciais e prestadoras de serviço com unidades produtivas ou comerciais no exterior, identificadas mediante fontes secundárias de evidências, tais como o Projeto GINEBRA, a pesquisa anual da Fundação Dom Cabral, o Valor Econômico, os levantamentos feitos pela SOBEET $^{9}$ e dados do Observatório de internacionalização da ESPM (Apêndice II - Quadro 1). A partir desse universo realizou-se uma estratificação para atender ao escopo da tese e, dessa forma, identificar as subsidiárias industriais e que detinham fábricas ou laboratórios de P\&D internacionais das EMNBrs. Para realizar essa estratificação foram estabelecidos contatos telefônicos com os responsáveis pelas áreas de negócios internacionais, $\mathrm{P} \& \mathrm{D}$ ou Engenharia; além disso, recorreu-se às informações dos websites institucionais das EMNBrs e aos Relatórios Anuais da Administração das EMNBrs disponíveis nos websites das empresas. A estratificação resultou em 63 EMNBrs industriais e manufatureiras ou com operação de P\&D no exterior (Apêndice II - Quadro 2).

\subsection{Procedimentos de campo}

\footnotetext{
${ }^{9}$ Sociedade Brasileira de Estudos das Empresas Transnacionais e de Globalização Econômica.
} 


\subsubsection{Instrumento de coleta de dados}

O instrumento de coleta de dados é um questionário eletrônico com perguntas fechadas aplicado por meio do método survey eletrônico. O questionário foi elaborado com o apoio do software Survey Monkey. Esse software organiza a base de dados iniciais dos questionários respondidos, é bastante flexível e possui uma variedade de possibilidades de personalização para a realização de análises de estatística descritiva.

A coleta de dados por meio do método survey eletrônico possui pontos positivos e negativos. As principais vantagens envolvem o alcance global dos respondentes, a flexibilidade na aplicação, a conveniência para os respondentes, a otimização do tempo para resposta, a facilidade de preenchimento e de análise dos dados coletados, o reduzido custo de aplicação e a facilidade de acompanhamento; as principais desvantagens contemplam a representatividade da amostra, as diferenças tecnológicas, a impessoalidade, os aspectos de privacidade e segurança e a reduzida taxa de resposta (EVANS; MATHUR, 2005). Com vistas em diminuir o impacto das desvantagens e otimizar as vantagens, Vasconcellos e Guedes (2007) elaboram algumas recomendações, tais como: pesquisar pessoas que têm acesso à internet, utilizar endereços eletrônicos confiáveis, usar uma formatação amigável para o questionário, incentivar a resposta e disponibilizar atendimento para esclarecer dúvidas.

\subsubsection{Pré-teste}

A fim de identificar possíveis problemas com o instrumento de pesquisa foi conduzido, antes da aplicação oficial do questionário, um pré-teste com colegas pesquisadores da área (COOPER; SCHINDLER, 2003). De acordo com Malhotra (2001, p. 290), “[...] o pré-teste se refere ao teste do questionário em uma pequena amostra de entrevistados, com o objetivo de identificar e eliminar problemas potenciais.” Diversas modalidades de pré-teste são possíveis. Uma delas consiste em realizar o pré-teste com pessoas que possuem características semelhantes às das pessoas que responderão o questionário definitivo (COOPER; SCHINDLER, 2003). Uma segunda opção é o pré-teste do pesquisador, situação em que colegas professores e pesquisadores realizam um teste informal do instrumento (COOPER; SCHINDLER, 2003). Neste estudo, o pré-teste foi realizado por três colegas professores doutores, e, em seguida, o questionário foi enviado para três profissionais da área de engenharia e desenvolvimento de produto. Os pré-testes foram realizados com o questionário em papel, como proposto por Cooper e Schindler (2003). 
A finalidade dos pré-testes foi identificar pontos no questionário que poderiam comprometer o bom resultado do estudo, tais como: problemas de significado advindos da tradução de idioma, questões ambíguas, falta de clareza, duplicação de questões, fluidez e continuidade do tema, indicadores que não capturem constructos para os quais foram projetados, entre outros problemas (Ibid.). Com a aplicação do pré-teste, pretendeu-se garantir a confiabilidade e validade do estudo. Confiabilidade se refere a "medir ou descrever de forma precisa o que se pretende de fato". Validade diz respeito a "garantir que serão obtidos os mesmos resultados se forem aplicados aos mesmos respondentes.” (MARTINS; THEÓPHILO, 2007).

Nessa fase, algumas dificuldades de compreensão e repetições foram identificadas, e, para melhorar o entendimento do entrevistado e alguns indicadores adicionados, alguns termos foram modificados. Em seguida, o questionário foi transformado em formato on-line, no sistema survey monkey. Logo após a estruturação do questionário on-line, um novo pré-teste foi realizado com um pesquisador doutor especialista na área de negócios internacionais, que concordou com a facilidade e agilidade do meio de coleta de dados e sugeriu algumas modificações de formato. Depois desse pré-teste final, o questionário foi concluído e disponibilizado para o início da pesquisa de campo. Os respondentes levaram cerca de 20 minutos para responder ao questionário. A versão final do questionário é apresentada no Apêndice I.

\subsubsection{Procedimentos para a coleta de dados}

Inicialmente, foi feita uma pesquisa nos websites das 63 empresas selecionadas, especificamente na área responsável pelas relações com investidores da empresa, para identificar e-mails e/ou telefones dos diretores e gerentes de cada subsidiária. Na sequência, foi feito um contato telefônico com cada uma das subsidiárias da amostra, para que fosse identificada a pessoa considerada a mais qualificada para responder ao questionário. O cargo do respondente foi identificado de acordo com a conveniência e aplicabilidade de cada empresa. Os cargos mais indicados eram:

- CEO da subsidiária;

- Diretor de negócios internacionais da subsidiária;

- Gestor de P\&D;

- Gestor responsável pelos negócios de interação matriz-subsidiária. 
Após a identificação do respondente, efetuava-se um contato por telefone e, em caso de resposta positiva do respondente, enviava-se um e-mail com uma carta de apresentação e o link para que respondesse ao questionário. Foram previstos três follow-ups com um intervalo de 15 dias a contar da data de envio do link do questionário, para assegurar o recebimento do questionário e esclarecer eventuais dúvidas do respondente. A intenção foi estimular o recebimento dos questionários de forma ativa por pelo menos dois meses após a data do primeiro envio. $\mathrm{O}$ período total de coleta de dados foi de seis meses: de setembro de 2012 a fevereiro de 2013. A Ilustração 15 resume o fluxo dos procedimentos de coleta de dados.

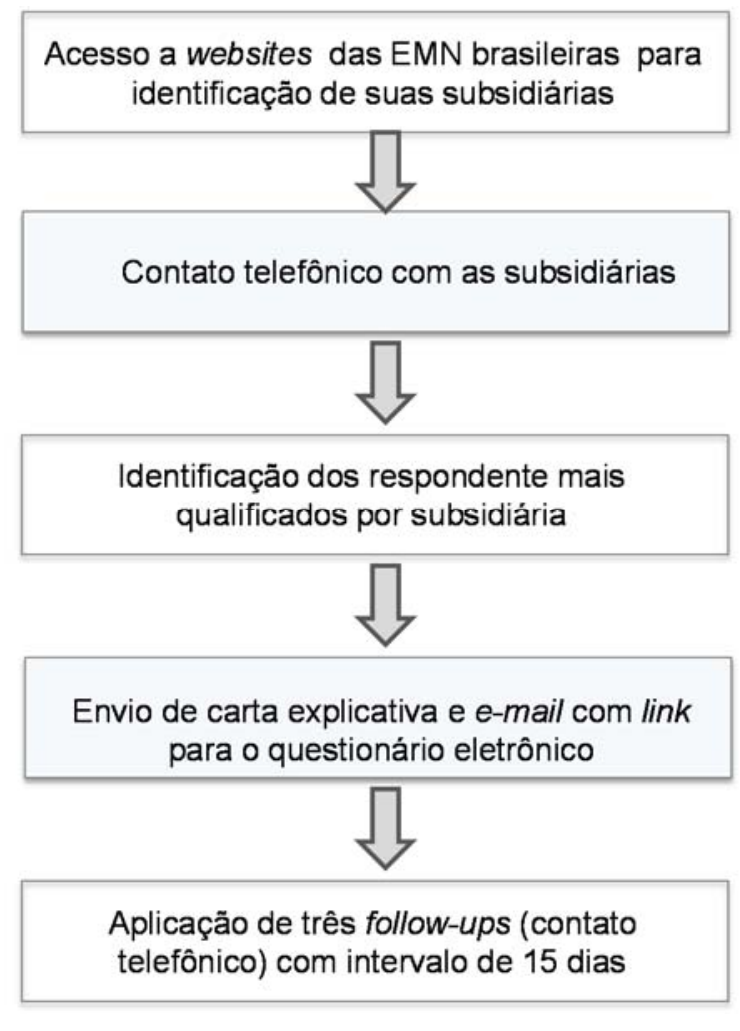

Ilustração 15: Procedimentos de coleta de dados

\subsubsection{Perfil das empresas pesquisadas}

Partindo-se da lista de 63 matrizes identificadas como o universo do estudo, conseguiu-se identificar 240 subsidiárias com operações fabris ou de $\mathrm{P} \& \mathrm{D}$, das quais 78 aceitaram responder à pesquisa. Em outros termos, conseguiu-se resposta de $32 \%$ das subsidiárias identificadas. $\mathrm{O}$ quadro a seguir apresenta as 63 subsidiárias respondentes de acordo com seu setor de atuação.

Quadro 18: Multinacionais que participaram da pesquisa e as subsidiárias respondentes 


\begin{tabular}{|c|c|c|}
\hline Empresas & $\begin{array}{l}\text { Subsidiárias } \\
\text { Respondentes }\end{array}$ & Setor \\
\hline Petrobras & 6 & Baseado em recursos naturais \\
\hline Artecola & 5 & Insumos Básicos \\
\hline Alpargatas & 4 & Bens de consumo \\
\hline Brasil Foods & 4 & Bens de consumo \\
\hline Iochpe-Maxion & 4 & Partes, componentes e Subsistemas \\
\hline Tigre & 4 & Insumos para a construção civil \\
\hline Weg & 4 & Partes, componentes e Subsistemas \\
\hline Braskem & 3 & Insumos Básicos \\
\hline Embraco & 3 & Partes, componentes e Subsistemas \\
\hline Eurofarma & 3 & Bens de consumo \\
\hline Gerdau & 3 & Insumos Básicos \\
\hline Metalfrio & 3 & Montadora de sistemas - bens duráveis \\
\hline CCX (EBX) & 2 & Insumos Básicos \\
\hline Estre & 2 & Insumos Básicos \\
\hline Marfrig & 2 & Baseado em recursos naturais \\
\hline Oxiteno & 2 & Insumos Básicos \\
\hline Penalty & 2 & Bens de consumo \\
\hline Agrale & 1 & Montadora de sistemas - CoPS \\
\hline Bematech & 1 & Montadora de sistemas - bens duráveis \\
\hline Bio Embryo & 1 & Insumos Básicos \\
\hline CGX (EBX) & 1 & Insumos Básicos \\
\hline Cia providência & 1 & Insumos Básicos \\
\hline Cinex & 1 & Insumos para a construção civil \\
\hline Embraer & 1 & Montadora de sistemas - CoPS \\
\hline Forjas Taurus & 1 & Bens de consumo \\
\hline Fras-le (Randon) & 1 & Montadora de sistemas - bens duráveis \\
\hline Gauss & 1 & Partes, componentes e Subsistemas \\
\hline Gautom & 1 & Partes, componentes e Subsistemas \\
\hline Haco Etiquetas & 1 & Insumos Básicos \\
\hline JBS-Friboi & 1 & Baseado em recursos naturais \\
\hline Lupatech & 1 & Partes, componentes e Subsistemas \\
\hline Magnesita & 1 & Insumos Básicos \\
\hline Marcopolo & 1 & Montadora de sistemas - CoPS \\
\hline Master (Randon) & 1 & Partes, componentes e Subsistemas \\
\hline Natura & 1 & Bens de consumo \\
\hline Paquetá & 1 & Insumos Básicos \\
\hline Vulcabrás & 1 & Bens de consumo \\
\hline Votorantim Cimentos & 1 & Insumos Básicos \\
\hline
\end{tabular}




\begin{tabular}{lcc}
\hline Votorantim Siderurgia & 1 & Insumos Básicos \\
Total & $\mathbf{7 8}$ & \\
\hline
\end{tabular}

As empresas foram classificadas de acordo com as posições que ocupam em redes globais de produção; de montante para jusante: indústrias baseadas em recursos naturais, produtoras de insumos básicos, de materiais para construção, de bens de consumo, de componentes e subsistemas e montadoras de sistemas. Embora este sistema de classificação privilegie o posicionamento de cada empresa nas redes globais de produção, possui correspondência com outras classificações nacionais e internacionais utilizadas em análises econômicas.

\subsubsection{Comparação das matrizes que compõem o universo deste estudo e as matrizes com subsidiárias respondentes}

As 63 matrizes de multinacionais brasileiras foram convidadas a participar da pesquisa; 39 matrizes das multinacionais tiveram alguma subsidiária que respondeu ao questionário. Isso representou um percentual de $64 \%$ do total das subsidiárias que compõem o universo desta pesquisa. Observa-se, a partir da ilustração abaixo, que se obteve a participação das multinacionais em todos os setores da economia.

Das 39 matrizes que participaram da pesquisa por meio de suas subsidiárias, conseguiu-se um resultado de 78 subsidiárias. A Ilustração 16 apresenta a distribuição das 78 subsidiárias respondentes por setor da economia. 


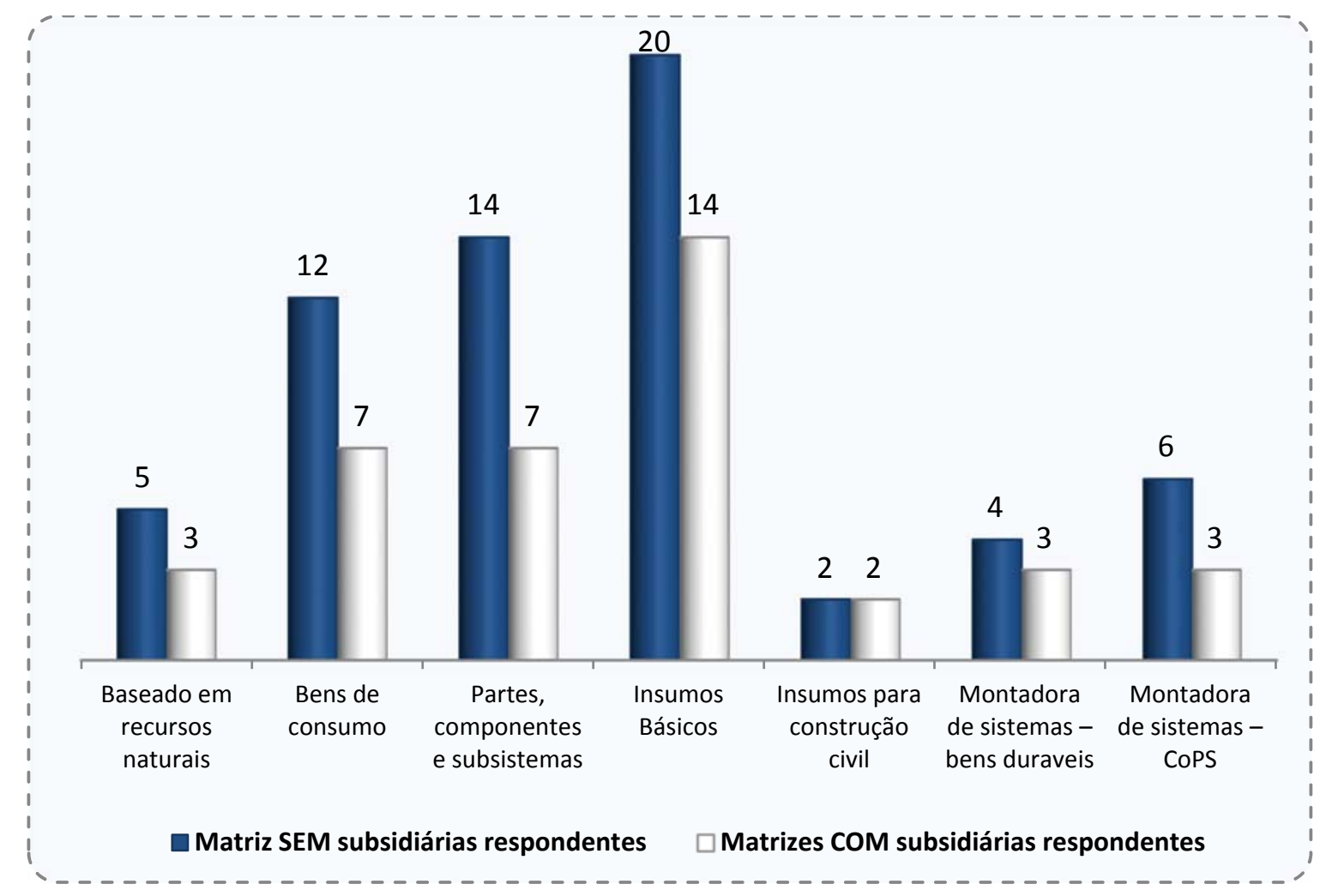

Ilustração 16: Universo das Multinacionais - Comparação por setor entre as matrizes respondentes e as não respondentes

\subsubsection{Setor das subsidiárias respondentes}

A amostra (78 subsidiárias respondentes) é composta de fabricantes de Insumos Básicos (32\%), fabricantes de partes, componentes e subsistemas (19\%), bens de consumo (21\%), empresas baseadas em recursos naturais $(12 \%)$, montadoras de sistemas - bens duráveis $(6 \%)$, insumos para a construção civil $(6 \%)$ e montadoras de Sistemas - CoPS, que ficaram com a menor parcela (4\%). Detalhes na ilustração a seguir. 


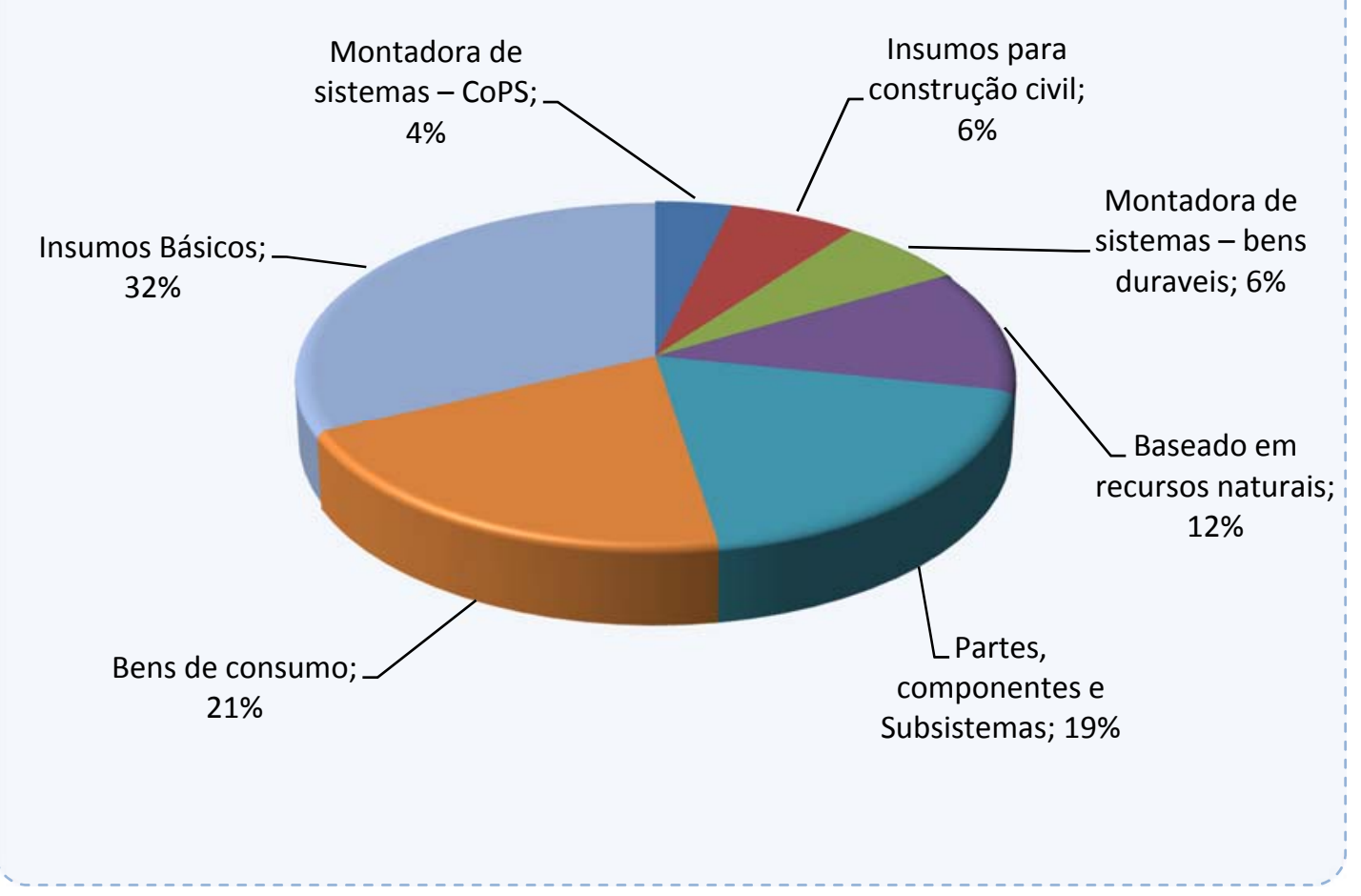

Ilustração 17: Subsidiárias respondentes por setor

\subsubsection{Localização das subsidiárias respondentes}

As 78 subsidiárias das EMNBRs estão localizadas principalmente na América Latina (42\%), seguidas das da América do Norte (24\%), Ásia (14\%) e União Europeia (13\%). Essas 4 regiões representam $93 \%$ da distribuição geográfica das subsidiárias respondentes.

Entre as empresas pesquisadas, o destino principal dos investimentos, a América Latina, continua sendo o preferido (FLEURY, A.; FLEURY, M., 2013). Uma mudança em relação às pesquisas anteriores é que, nestas, as subsidiárias geralmente ficavam mais concentradas na América Latina, América do Norte e União Europeia. Desta vez, a Ásia aparece com maior número de subsidiárias do que a União Europeia. Detalhes na ilustração a seguir. 


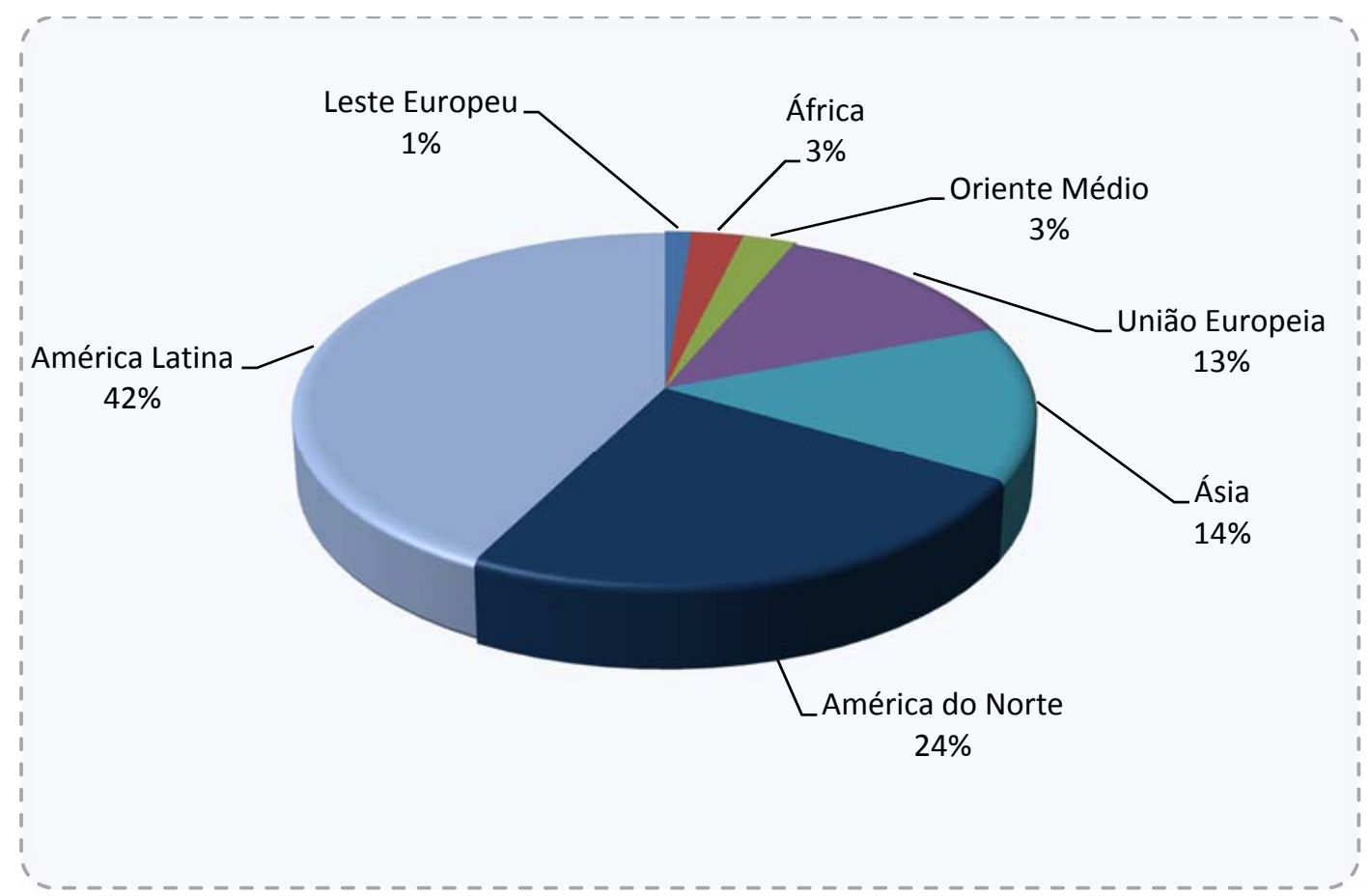

Ilustração 18: Localização das subsidiárias da amostra

\subsubsection{Porte das subsidiárias respondentes}

A Ilustração 19 mostra que as subsidiárias, em sua maioria, são empresas de médio porte em seus países de atuação; 29\% possuem menos de 100 funcionários. Esse dado é interessante, pois um grande número de subsidiárias de pequeno porte poderia comprometer a análise pretendida neste estudo. A faixa de 100 a 1.000 funcionários ficou com um porcentual relevante, 56\%, seguido por $14 \%$ das subsidiárias com mais de 1.000 funcionários. Isso mostra que um porcentual relativo de subsidiárias é de empresas consolidados no exterior.

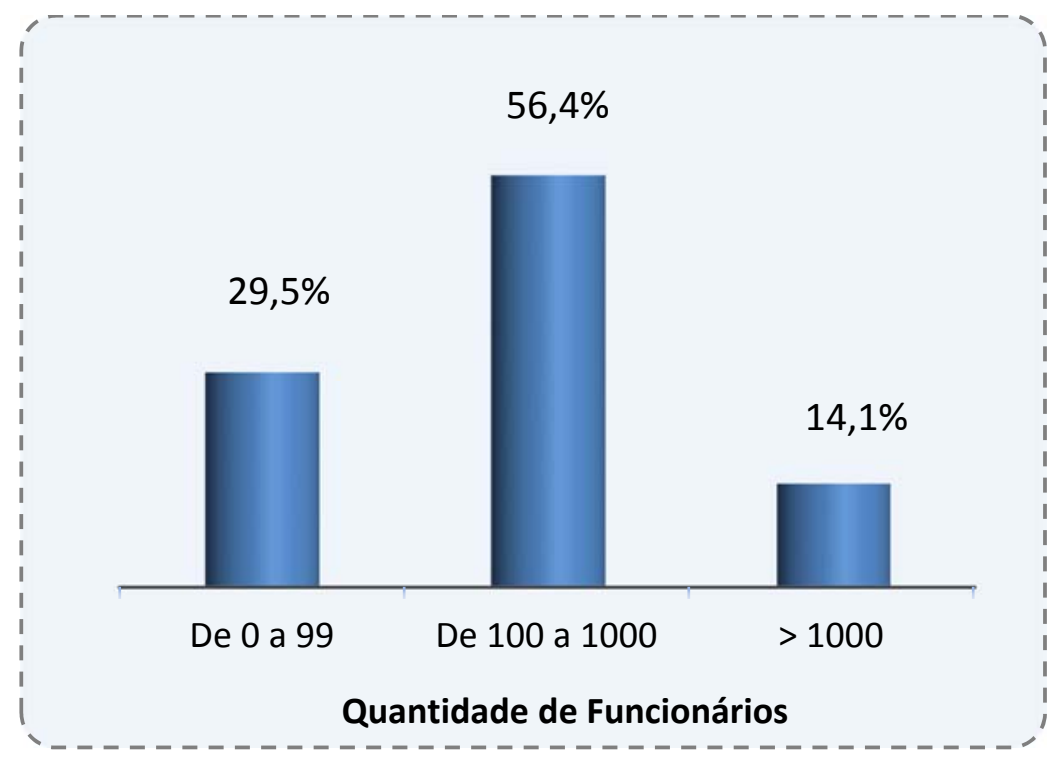




\subsubsection{Faturamento das subsidiárias respondentes}

Conforme a Ilustração 20, a contribuição das operações internacionais para as receitas da multinacional é significativa: $53 \%$ das empresas possuem um faturamento acima de US\$ 50 milhões. Porcentual bastante significativo se comparado aos resultados das pesquisas realizadas pelo GINEBRA (2006; 2010) e FDC (2010). Esse faturamento mais alto é observado pelo fato de esta pesquisa considerar apenas subsidiárias manufatureiras e de $\mathrm{P} \& \mathrm{D}$, que, em geral, possuem um resultado financeiro maior do que as subsidiárias que prestam serviços.

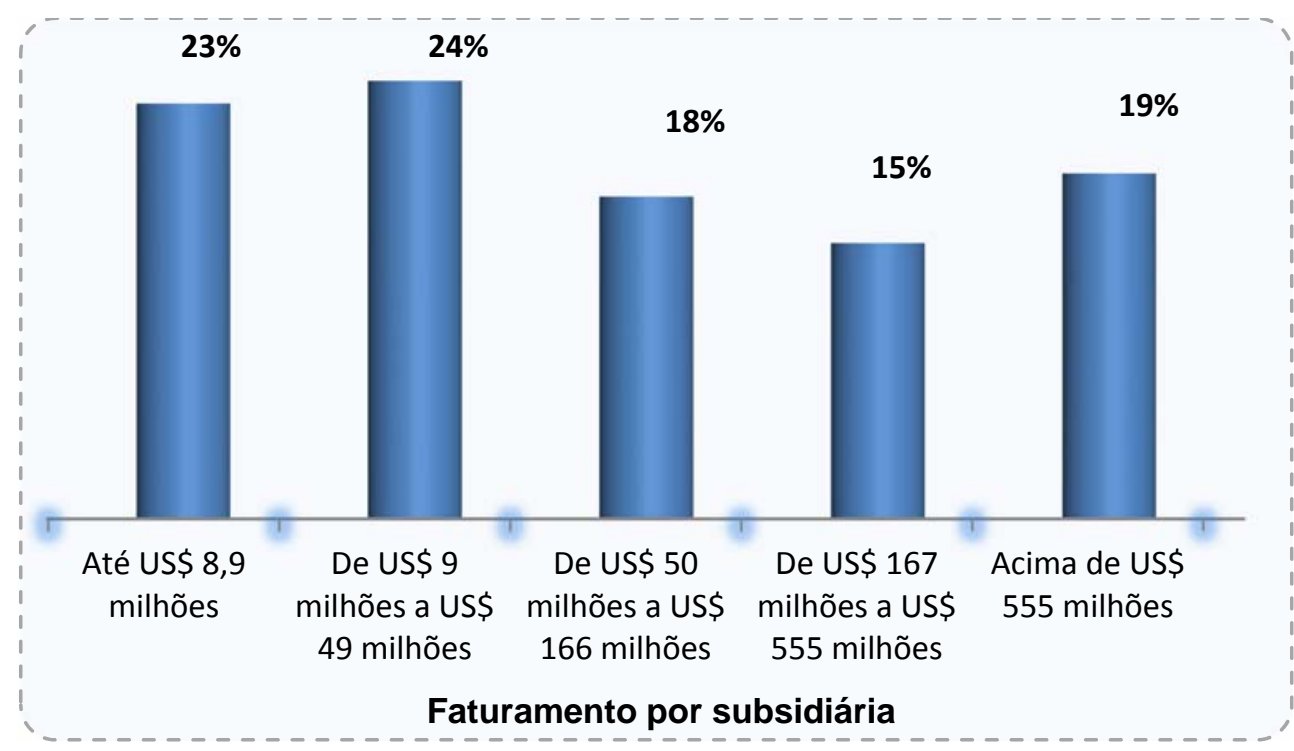

Ilustração 20: Subsidiárias por faturamento

\subsubsection{Tempo de existência das subsidiárias respondentes}

No que se refere à idade das subsidiárias, a grande maioria delas, $69 \%$, possui menos de dez anos de existência, $22 \%$ possuem entre dez e dezenove anos, e apenas $9 \%$ delas têm idade maior que 20 anos. Isso reforça o que já se sabe: as multinacionais brasileiras são, em sua grande maioria, empresas jovens, se comparadas às multinacionais com origem em países desenvolvidos. Detalhes estão na ilustração abaixo. 


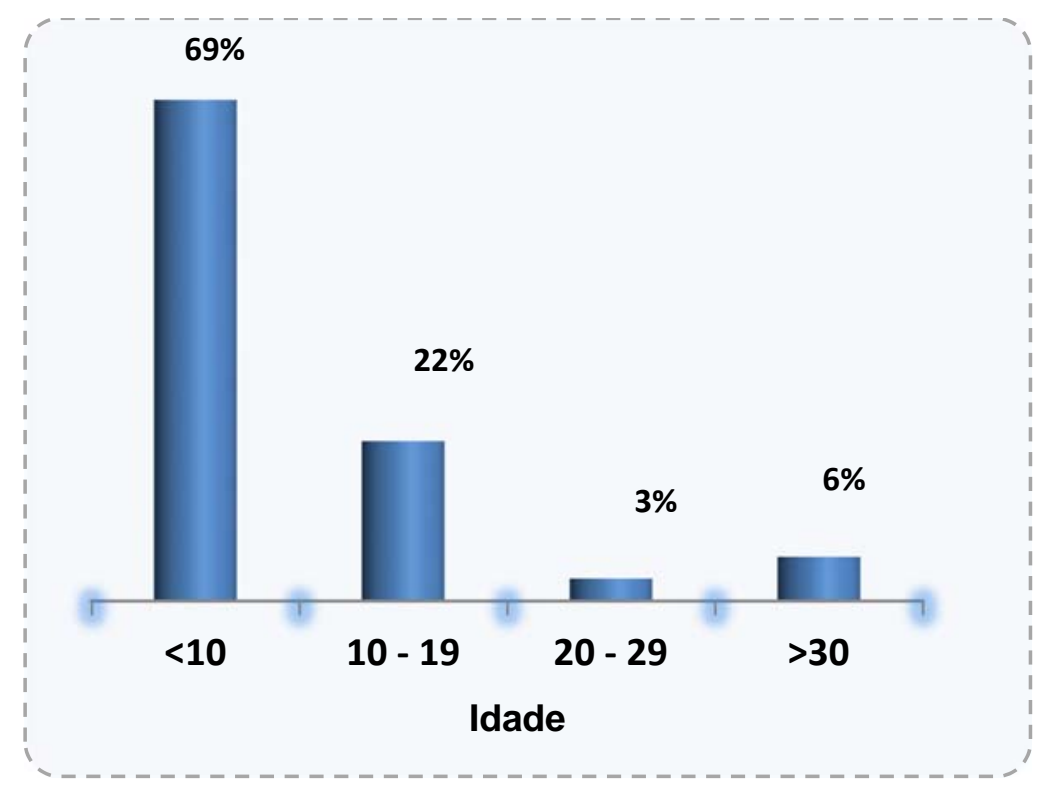

Ilustração 21: Subsidiárias por idade

\subsubsection{Tipos de subsidiárias}

Do conjunto de subsidiárias estudadas, $77 \%$ foram formadas por aquisições e joint ventures e $23 \%$ foram formadas por instalações novas (greenfields), conforme a Ilustração 22.

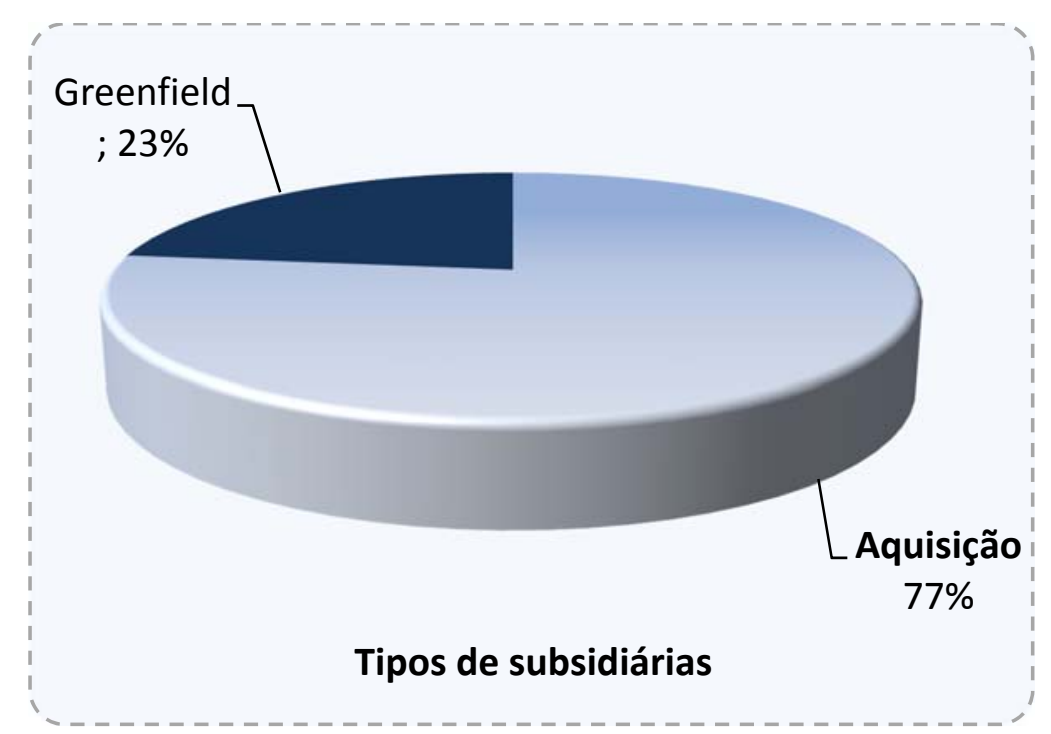

Ilustração 22: Subsidiárias por modo de entrada no exterior

\subsection{Seleção da técnica e do modelo da análise de dados}

Após a finalização da coleta, os dados foram organizados, codificados e processados com o auxílio do software estatístico SPSS (Statistical Package for the Social Sciences). Na sequência, foi conduzida a estatística descritiva para cada variável, com a finalidade de melhor organizar os dados e de identificar o tipo de distribuição das variáveis, a relação de linearidade entre elas 
e as medidas aleatórias de erros (VELDE; JANSEN; ANDERSON, 2004). Depois desse processo, o passo seguinte foi definir a técnica multivariada de análise dos dados.

De acordo com Hair et al. (2005), há um modelo de decisão para a escolha adequada da técnica multivariada, conforme a Ilustração 23.

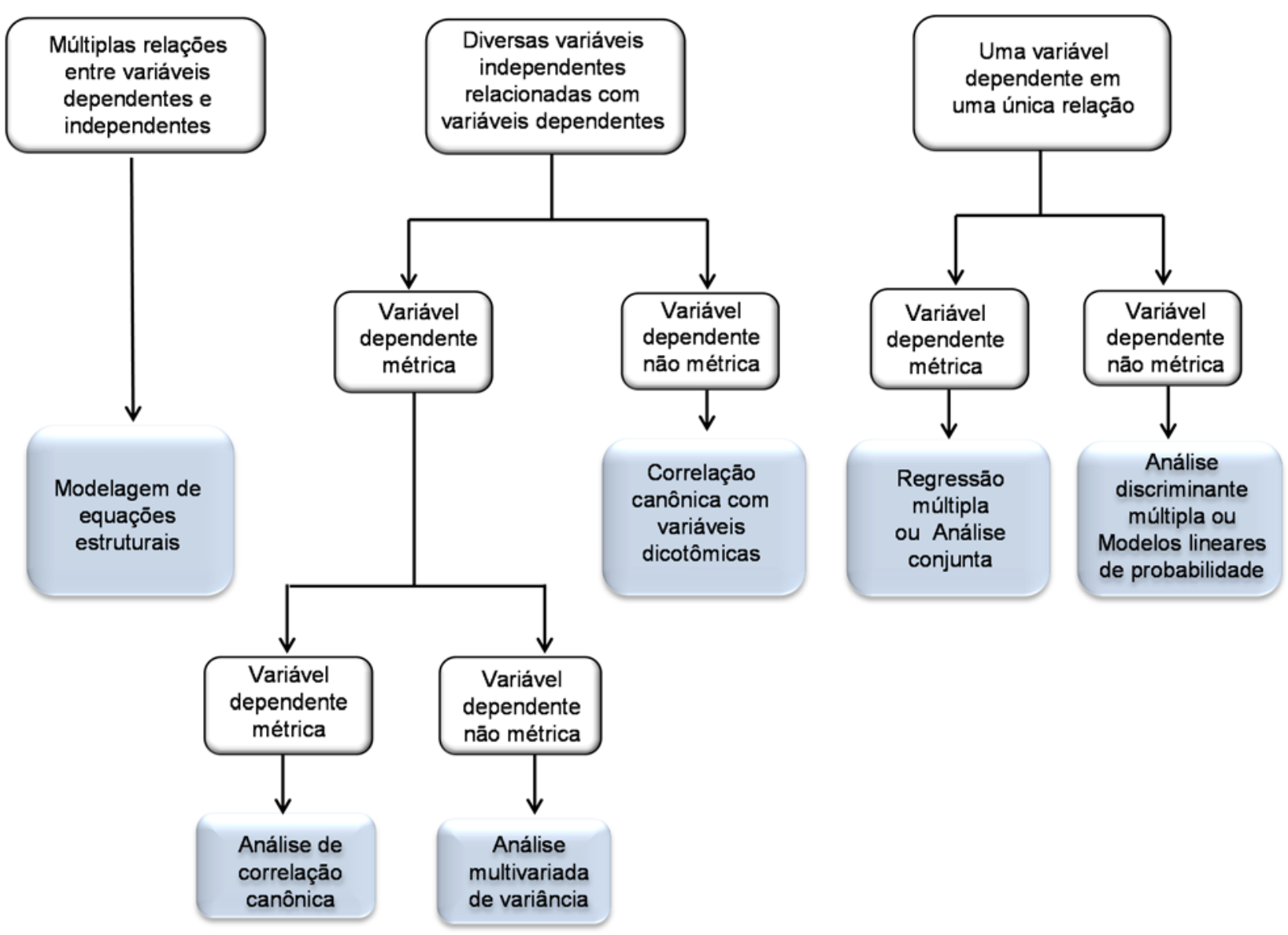

Ilustração 23: Seleção de uma técnica multivariada

Fonte: HAIR et al. (2005, p. 30).

O modelo conceitual proposto envolve o estudo estatístico de múltiplas variáveis associadas ao constructo transferência reversa de conhecimento tecnológico. Algumas dessas variáveis possuem múltiplas relações e, por isso, podem ser classificadas como dependentes em alguns relacionamentos e independentes em outros. Considerando-se esse aspecto, a técnica mais apropriada para este estudo são as equações estruturais (chamadas de técnicas de segunda geração), as quais viabilizam a modelagem de relações entre construções latentes múltiplas simultaneamente. Essa capacidade para análises simultâneas difere muito das técnicas baseadas em modelos de regressão, como a Regressão Linear, a ANOVA e a MANOVA (chamadas de técnicas de primeira geração), pois estas podem analisar apenas uma camada de ligações entre variáveis dependentes e independentes de cada vez (HAIR et al., 2005). 


\subsubsection{Técnica de análise de equações estruturais}

As técnicas estatísticas multivariadas permitem múltiplas variáveis dependentes. Já a análise multivariada de variância e a correlação canônica permitem apenas uma relação entre o bloco de variáveis dependentes e o de independentes. A abordagem de equações estruturais é a técnica estatística mais indicada para análises que envolvem variáveis latentes com múltiplos indicadores, conforme apresentado na Ilustração 23. Hair et al. (2005) destacam que as relações propostas entre as variáveis são traduzidas em uma série de equações estruturais (parecidas com as equações de regressão) para cada variável dependente.

A modelagem de equações estruturais pode ser desenvolvida por meio de um processo de sete estágios: a) desenvolvimento de um modelo teórico fundamentado em revisão bibliográfica robusta; b) construção de um diagrama de caminhos e relações causais (ou influenciadoras); c) conversão do diagrama de caminhos em um conjunto de modelos estruturais e de mensuração (usando um software); d) escolha do tipo de matriz de entrada e estimação apropriada para estimar o modelo proposto; e) avaliação da identificação do modelo estrutural; f) avaliação dos critérios de qualidade do modelo de ajuste; e g) interpretação e modificação do modelo (CHIN, 1998, 2004; CHIN et al., 1999; HAIR et al., 2005).

$\mathrm{Na}$ linguagem das equações estruturais, variáveis latentes são constructos teóricos (ex.: complexidade) que não podem ser medidos diretamente, mas por meio de características atribuídas a eles, denominadas de indicadores ou variáveis manifestas. Variáveis manifestas, ou indicadores, são variáveis consideradas detentoras de informações sobre o comportamento das variáveis latentes, ou conceitos teóricos, que não são diretamente observáveis. As variáveis latentes ou constructos devem ser definidos com base na teoria, assim como seus indicadores, que são avaliados por meio de escalas, normalmente mediante de um questionário.

A modelagem de equações estruturais (doravante denominada MEE) refere-se a um conjunto de técnicas estatísticas que permite a estimativa de uma rede teórica de relacionamentos causais, associando conceitos complexos latentes que são medidos por meio de um conjunto de indicadores observáveis. A MEE é uma técnica de análise confirmatória, razão pela qual seu modelo deve ser desenvolvido antes da coleta de dados e tem como questionamento se os dados confirmam ou não o modelo. Além disso, a MEE pode ser utilizada também para testar modelos alternativos ou para gerar outros modelos (HAIR et al., 2010). 
As técnicas da MEE integram as medições do modelo por meio do modelo de mensuração (indicadores ou variáveis medidos diretamente) e do modelo estrutural, por meio do qual se estabelecem as relações causais propostas entre os constructos ou variáveis latentes, de acordo com as hipóteses propostas. A junção do modelo de mensuração com o modelo estrutural viabiliza a apresentação dos resultados em um modelo único, permitindo uma melhor estimativa das relações e hipóteses do modelo (Ibid.).

Há dois tipos de abordagem para as equações estruturais: $\mathrm{MEEBC}^{10}$ (técnica de MEE baseada em covariância) e MEEPLS ${ }^{11}$ (técnica de modelagem de equações estruturais baseada em variância e em estimativa via método dos mínimos quadrados) (HENSELER; RINGLE; SINKOVICS, 2009; ZWICKER, SOUZA; BIDO, 2008). A MEEBC é a técnica mais comumente utilizada e foi inicialmente desenvolvida pelos criadores do software LISREL (por isso, a MEEBC tem sido chamada de "modelo LISREL"). Já a MEEPLS é considerado uma abordagem baseada em componentes, uma vez que sua técnica de estimação é semelhante à da análise de componentes principais associada à regressão múltipla, na qual o conceito de causalidade é formulado em termos de uma expectativa de combinação linear de variáveis (FORNELL; BOOKSTEIN, 1982). Apesar de ser contemporânea à MEEBC, só mais recentemente a MEEPLS tem recebido maior destaque na literatura acadêmica (HSU et al., 2006 apud ZWICKER; SOUZA; BIDO, 2008).

Apesar das vantagens de utilização, é importante lembrar que técnicas MEEBC somente podem ser utilizadas se for cumprida uma série de definições prévias referentes aos dados, à teoria e à operacionalização de variáveis latentes. Essas especificações refletem as hipóteses do pesquisador e, em seu conjunto, compõem o modelo a ser avaliado, ou seja, o modelo de mensuração e o modelo estrutural. Uma das principais restrições ao uso da MEEBC é o fato de a estimação mais comum ser feita por máxima verossimilhança; no entanto, tal estimação só é eficiente e sem vieses quando for verdadeira a premissa de normalidade multivariada. Outra restrição é que o tamanho da amostra pode interferir nos resultados, razão pela qual são exigidas amostras de tamanho relativamente grande, variando de 5 a 10 observações por parâmetro

\footnotetext{
${ }^{10}$ Covariance Based Structural Equation Modeling.

${ }^{11}$ Partial Least Squares. Detalhes disponíveis em: <http://www.smartpls.de>. Acesso em: 09 de maio de 2013.
} 
informado (indicador), o que gera um tamanho de amostra recomendado, variando de 150 a 400 (HAIR et al., 2010).

Como alternativa à MEEBC, em alguns casos tem sido recomendada a utilização da MEEPLS. Esse método é baseado no estudo de um sistema de relações lineares entre variáveis latentes que é resolvido por partes (combinações de constructos teóricos e medidas), uma de cada vez (por isso o partial - parcial), pelo uso de regressões interdependentes. O diagrama como um todo é repartido em blocos e uma estimativa inicial da variável latente é estabelecida de modo que os escores tenham variância unitária, diferentemente da estimação pela $\mathrm{MEEBC}$, que não exige esse cálculo (ZWICKER; SOUZA; BIDO, 2008).

A MEEPLS foi desenvolvida por Wold (1982 apud ZWICKER; SOUZA; BIDO, 2008) como uma alternativa à MEEBC, cuja principal característica é o cálculo das estimativas com base no critério estatístico de máxima verossimilhança (maximum likelihood). Wold (1982) introduziu o conceito de "soft modeling" ao apresentar o PLS, em razão da habilidade característica da técnica de proporcionar grande flexibilidade na manipulação de problemas em situações nas quais é difícil ou impossível atender às restrições requeridas pelas demais técnicas de estatística multivariada. O termo "soft" é atribuído somente às exigências de distribuição da amostra e não ao rigor ou validade dos modelos e à precisão das técnicas de estimação. O PLS tem como objetivo a busca de relacionamentos lineares o mais aderentes possível em vez da buscar de mecanismos causais, privilegiando um processo de testes de hipóteses orientado à predição. Dessa forma, o método PLS demanda significativamente menos requisitos e premissas se comparado com outras técnicas que se baseiam em estruturas de covariâncias, porém gera resultados consistentes (WOLD, 1982 apud ZWICKER; SOUZA; BIDO, 2008).

Em síntese, cada técnica é apropriada para um determinado tipo de pesquisa, por isso, essas duas técnicas são muito mais complementares do que concorrentes (HAIR et al., 2013). O Quadro 19 apresenta as principais diferenças entre MEEPLS e MEEBC. 
Quadro 19: Diferenças entre MEEPLS e MEEBC (LISREL)

\begin{tabular}{|c|c|c|}
\hline CRITÉRIO & MEEPLS - soft modeling & MEEBC (LISREL) - Hard modeling \\
\hline Objetivo & Predição. & Explicação: modelos causais, teste de teoria. \\
\hline Abordagem & Baseado na variância. & Baseado na covariância. \\
\hline Precisão & $\begin{array}{l}\text { Consistente conforme o tamanho da } \\
\text { amostra (consistency) e a quantidade de } \\
\text { indicadores aumentam (consistency at } \\
\text { large). }\end{array}$ & Ótimo para amostras grandes. \\
\hline $\begin{array}{l}\text { Variáveis } \\
\text { latentes (VL) }\end{array}$ & $\begin{array}{l}\text { As VL são combinações lineares dos } \\
\text { indicadores; os escores fatoriais são } \\
\text { estimados explicitamente. }\end{array}$ & $\begin{array}{l}\text { Indeterminância fatorial: diversos modelos } \\
\text { podem reproduzir a matriz de covariâncias. }\end{array}$ \\
\hline $\begin{array}{l}\text { Modelo de } \\
\text { mensuração }\end{array}$ & $\begin{array}{l}\text { Pode haver indicadores formativos ou } \\
\text { reflexivos. }\end{array}$ & $\begin{array}{l}\text { Apenas indicadores reflexivos. Para modelar } \\
\text { a VL com indicadores formativos usa-se a } \\
\text { abordagem MIMIC (múltiplos indicadores e } \\
\text { múltiplas causas). }\end{array}$ \\
\hline $\begin{array}{l}\text { Requisitos } \\
\text { quanto à teoria }\end{array}$ & $\begin{array}{l}\text { Mais flexível, contexto mais } \\
\text { exploratório. }\end{array}$ & Fortemente dependente da teoria. \\
\hline $\begin{array}{l}\text { Distribuição dos } \\
\text { dados }\end{array}$ & $\begin{array}{l}\text { Não há suposições, por isso, diz-se que é } \\
\text { soft. }\end{array}$ & $\begin{array}{l}\text { Dependendo do método de estimação, as } \\
\text { variáveis deveriam apresentar distribuição } \\
\text { normal multivariada. }\end{array}$ \\
\hline $\begin{array}{l}\text { Tamanho da } \\
\text { amostra }\end{array}$ & $\begin{array}{l}\text { Análise do poder estatístico com a } \\
\text { porção do modelo que possui o maior } \\
\text { número de preditores ou } 10 \text { vezes o } \\
\text { maior número de preditores (indicadores } \\
\text { formativos ou setas estruturais chegando } \\
\text { à VL, o que for maior). O mínimo } \\
\text { recomendado é de } 100 \text { casos. }\end{array}$ & $\begin{array}{l}\text { Idealmente baseado na análise do poder } \\
\text { estatístico: sendo o mínimo recomendado é } \\
\text { da ordem de } 200 \text { casos. }\end{array}$ \\
\hline $\begin{array}{l}\text { Identificação } \\
\text { (estimação } \\
\text { única dos } \\
\text { parâmetros) }\end{array}$ & $\begin{array}{l}\text { Para modelo recursivos é sempre } \\
\text { identificado. }\end{array}$ & $\begin{array}{l}\text { Depende do modelo e deve ter pelo menos } 4 \\
\text { indicadores por VL. Necessário impor } \\
\text { restrições aos parâmetros. Três problemas: } \\
\text { às vezes o modelo não converge, soluções } \\
\text { impróprias e indeterminância fatorial. }\end{array}$ \\
\hline $\begin{array}{l}\text { Significância } \\
\text { dos Parâmetros }\end{array}$ & $\begin{array}{l}\text { Estimada por métodos não paramétricos, } \\
\text { como o bootstrap. }\end{array}$ & $\begin{array}{l}\text { Geralmente estimada por métodos } \\
\text { paramétricos, mas o bootstrap é uma opção. }\end{array}$ \\
\hline Complexidade & $\begin{array}{l}\text { Capaz de lidar com modelos complexos } \\
\text { (100 constructos e } 1000 \text { indicadores). }\end{array}$ & $\begin{array}{l}\text { Complexidade de média a moderada (menos } \\
\text { de } 100 \text { indicadores). }\end{array}$ \\
\hline $\begin{array}{l}\text { Inclusão de } \\
\text { restrições nos } \\
\text { parâmetros do } \\
\text { modelo }\end{array}$ & $\begin{array}{l}\text { Mesmo que não haja seta entre as VL, é } \\
\text { suposto que elas tenham correlação entre } \\
\text { si (não se usam setas bidirecionais na } \\
\text { MEEPLS). }\end{array}$ & $\begin{array}{l}\text { Se não houver setas entre as VL (uni ou } \\
\text { bidirecionais), é suposto que a correlação } \\
\text { entre elas seja zero (restrição implícita). }\end{array}$ \\
\hline
\end{tabular}




\begin{tabular}{|l|l|l|}
\hline & $\begin{array}{l}\text { É possível impor restrições em qualquer } \\
\text { Não é possível impor restrições aos } \\
\text { parâmetros do modelo, como, por } \\
\text { exemplo, forçando que a correlação } \\
\text { entre duas VL seja igual a 1 no teste de } \\
\text { validade discriminante. }\end{array}$ & $\begin{array}{l}\text { parâmetro = valor fixo; parâmetro 1 } \\
\text { parâmetro 2; parâmetro 1 do grupo } 1= \\
\text { parâmetro 1 do grupo 2; ou maior do que; } \\
\text { ou menor do que, e outras menos usadas, } \\
\text { como restrições de proporcionalidade e de } \\
\text { não linearidade (KLINE, 2005, p. 102). }\end{array}$ \\
\hline
\end{tabular}

FONTE: HAIR et al., (2013); FORNELL; BOOKSTEIN (1982, p. 450); JÖRESKOG; WOLD (1982, p. 266269 apud ZWICKER; SOUZA; BIDO (2008).

Para este estudo, especificamente, optou-se pela utilização do método MEEPLS em razão dos seguintes critérios:

- Precisão: mostra consistência nas condições de amostras pequenas e muitos indicadores;

- Requisitos quanto à teoria: a pesquisa de multinacionais brasileiras ainda é restrita e, por isso, são necessários modelos estatísticos mais flexíveis e exploratórios;

- A distribuição dos dados deste estudo não é normal, exigindo, portanto, a análise via MEEPLS;

- Tamanho da amostra: a amostra de 78 é considerada pequena para ser utilizada em LISREL, cuja indicação é de no mínimo 100 casos;

- Complexidade: o estudo traz um grande número de constructos (16) e de indicadores (88).

Nos próximos tópicos serão apresentados os passos para avaliar a técnica PLS.

\subsubsection{Avaliação da qualidade do modelo estimado via técnica PLS}

A avaliação pode ser separada em duas partes: a) avaliação do modelo de mensuração; b) avaliação do modelo estrutural. O modelo de mensuração consiste no relacionamento entre as variáveis latentes (variáveis não observáveis) e seus indicadores correspondentes (variáveis observáveis), e o modelo estrutural especifica relacionamentos entre as variáveis latentes.

Um modelo de mensuração pode ser formado por constructos com indicadores reflexivos ou formativos. Constructos reflexivos compartilham um tema comum e podem ser vistos como amostra representativa de todos os itens possíveis e disponíveis do conceito que formam o constructo. Já os constructos formativos não precisam conter conteúdo similar e são baseados 
na suposição de que os indicadores causam o constructo e representam o censo. A especificação depende da conceitualização do constructo e dos objetivos do estudo.

A avaliação do modelo de mensuração preocupa-se com a validade e a confiabilidade dos constructos: análise de cargas e pesos, confiabilidade composta, variância média extraída, cargas cruzadas e correlação entre as variáveis latentes. A análise do modelo estrutural preocupa-se com o relacionamento entre as variáveis latentes do modelo: $\mathrm{R}^{2}$, coeficientes de caminho e suas significâncias por meio do recurso bootstrapping.

\subsubsection{Avaliação do modelo de mensuração (outer model)}

Existem alguns passos necessários para a realização do modelo de mensuração no PLS, a saber:

A confiabilidade do constructo possui dois tipos de mensuração: confiabilidade do indicador e pela confiabilidade compósita (CC).

- Confiabilidade do indicador (Alpha de Cronbach) - especifica a parcela da variância dos indicadores que pode ser explicada pela variável latente subjacente. Um critério comum de aceite é que mais de $50 \%$ da variância de um indicador deve ser explicada pelo constructo latente. Isso implica dizer que uma carga fatorial maior que 0,70 é aceitável. No tocante à decisão de manter ou excluir um indicador, Hair et al. (2013, p. 103) ressaltam que "indicadores com cargas entre 0,40 e 0,70 deverão ser mantidos no constructo apenas nos casos em que a exclusão do indicador conduzir a um aumento na confiabilidade compósita ou na AVE". Outra consideração sobre a decisão de manter ou não indicadores com cargas menores que 0,7 é de que sua retirada afeta a validade do conteúdo. Com relação aos indicadores com cargas muito baixas $(<0,40)$, devem sempre ser eliminados do modelo de mensuração (HAIR et al., 2013, p. 103). Os indicadores devem ter cargas com significância estatística em suas relações com as variáveis latentes: significante a $1 \%(\mathrm{p}<0.01)$, estatística $t$ superior a 2.5857 ou significante a $5 \%(\mathrm{p}<0.05)$, estatística $t$ superior a 1.9647. A estatística $t$ é gerada por meio da técnica de bootstrapping, detalhada a seguir. 
É importante notar que, no software SmartPLS, a análise das cargas refere-se aos indicadores reflexivos; já a análise dos pesos segue o mesmo raciocínio de significância das cargas, mas é destinada aos indicadores formativos.

- Confiabilidade Compósita - representa a confiabilidade e a consistência interna da variável latente com seus indicadores. Hair et al. (2005) a consideram um indicador de confiabilidade melhor do que o alpha, que tende a ser subestimado. Para esses autores, valores da confiabilidade composta acima de 0,6 são adequados.

A validade de constructo é a correspondência entre os indicadores coletados, de natureza observável, e seus constructos, de natureza não observável, em nível conceitual. A validação de constructos é classificada em dois tipos: validade convergente e validade discriminante.

- A validade convergente verifica se o instrumento mede aquilo que se propõe medir, ou seja, verifica a extensão em que os indicadores são capazes de medir uma variável latente (constructo). Como critério para avaliar a validade convergente, utiliza-se a average variance extracted - AVE (variância média extraída): quanto maior a variância extraída, mais representativos são os indicadores do constructo. Hair, et al. (2005) e Chin (1998, p. 321) sugerem um índice superior a 0,50. Isso significa que uma variável latente está apta a explicar mais da metade da variância de seus indicadores, em média (Hair et al., 2013).

- A validade discriminante é definida como uma medida da não similaridade entre as mensurações de diferentes constructos do modelo; os indicadores de constructos diferentes não devem ser tão altamente correlacionados para se concluir que eles não medem a mesma ideia. Se isso ocorrer, o modelo deverá ser reavaliado. A validade discriminante pode ser medida de duas formas. Primeiro podem-se comparar os valores da correlação entre os constructos com a raiz quadrada da variância extraída (AVE), ou seja, a AVE de cada constructo deveria ser maior do que as correlações quadradas com todos os outros constructos do modelo. Outra forma de medir essa correlação é por meio do critério de carga cruzada (cross loadings), ou seja, a carga de cada indicador deve ser maior do que todas as suas cargas cruzadas (FORNELL; LARCKER, 1981). 
Após a realização e comprovação da validade discriminante, o processo de validação do modelo de mensuração para variáveis reflexivas ${ }^{12}$ está finalizado. O Quadro 20 apresenta o resumo dos parâmetros de aceitação do modelo de mensuração do PLS.

Quadro 20: Critérios para avaliação do modelo de mensuração (outer model)

\begin{tabular}{|c|c|c|c|c|}
\hline Avaliação & Critérios & Descrição & Mensuração & Autor (es) \\
\hline Validade & De conteúdo e face. & $\begin{array}{l}\text { Verificação de adequação teórica dos } \\
\text { constructos, indicadores, modelo e } \\
\text { instrumento de pesquisa. }\end{array}$ & $\begin{array}{l}\text { Validação por } \\
\text { professores, } \\
\text { especialistas e } \\
\text { executivos }\end{array}$ & $\begin{array}{l}\text { Bido } \\
(2008)\end{array}$ \\
\hline \multirow{2}{*}{$\begin{array}{l}\text { Confiabili- } \\
\text { dade do } \\
\text { constructo }\end{array}$} & $\begin{array}{l}\text { Confiabilidade do } \\
\text { indicador (alpha de } \\
\text { Cronbach) (Indicator } \\
\text { reliability). }\end{array}$ & $\begin{array}{l}\text { Teste de confiabilidade da escala dos } \\
\text { constructos. }\end{array}$ & $\begin{array}{l}\alpha \text { Cronbach }> \\
0,5, \text { não } \\
\text { podendo ser }< \\
0,4\end{array}$ & $\begin{array}{l}\text { Hair et al. } \\
(2013)\end{array}$ \\
\hline & $\begin{array}{l}\text { Confiabilidade do } \\
\text { compósito } \\
\text { (Composity } \\
\text { reliability). }\end{array}$ & $\begin{array}{l}\text { A confiabilidade do compósito é a } \\
\text { medida de consistência interna do } \\
\text { modelo. É o grau de inter-relação } \\
\text { entre os itens de uma escala. }\end{array}$ & $\mathrm{CC}>0,7$ & $\begin{array}{l}\text { Hair et al. } \\
(2013)\end{array}$ \\
\hline \multirow{3}{*}{$\begin{array}{l}\text { Validade de } \\
\text { constructo }\end{array}$} & $\begin{array}{l}\text { Validade convergente } \\
\text { Variância Média } \\
\text { Extraída (AVE) } \\
\text { (Average variance } \\
\text { extrated) }\end{array}$ & $\begin{array}{l}\text { Grau em que um conjunto de } \\
\text { indicadores representa um constructo } \\
\text { subjacente. É demonstrado por sua } \\
\text { unidimensionalidade. }\end{array}$ & $\begin{array}{l}\text { A AVE deve ser } \\
>0,5\end{array}$ & $\begin{array}{l}\text { Hair et al. } \\
(2013)\end{array}$ \\
\hline & $\begin{array}{l}\text { Validade } \\
\text { Discriminante } \\
\text { Critério de Fornell- } \\
\text { Larcker } \\
\text { (Fornell-Larcker } \\
\text { criterion). }\end{array}$ & $\begin{array}{l}\text { Grau de correlação de uma medida } \\
\text { em relação à outra da qual deveria } \\
\text { divergir. }\end{array}$ & \multirow{2}{*}{$\begin{array}{l}\text { Correlação entre } \\
\text { as variáveis } \\
\text { latentes e as } \\
\text { demais deve ser } \\
\text { menor do que o } \\
\text { valor da AVE. }\end{array}$} & $\begin{array}{l}\text { Hair et al. } \\
(2013)\end{array}$ \\
\hline & $\begin{array}{l}\text { Cargas cruzadas } \\
\text { (Cross-loadings). }\end{array}$ & $\begin{array}{l}\text { Outra maneira de verificar a validade } \\
\text { discriminante do modelo. Se um } \\
\text { indicador apresentar uma correlação } \\
\text { com outra variável latente maior do } \\
\text { que com sua própria VL o modelo } \\
\text { deverá ser reconsiderado. }\end{array}$ & & $\begin{array}{l}\text { Hair et al. } \\
(2013)\end{array}$ \\
\hline
\end{tabular}

FONTE: Adaptado pela autora.

\subsubsection{Avaliação do modelo estrutural (inner model)}

O modelo estrutural é representado pelos relacionamentos entre os constructos definidos no modelo conceitual formando o diagrama que ilustra os constructos - que vem a ser o conceito teórico - e as setas utilizadas para representar as relações específicas entre eles. Esse diagrama

\footnotetext{
${ }^{12} \mathrm{O}$ modelo estrutural pode ser formado de variáveis reflexivas e/ou formativas. Variáveis formativas são um tipo de modelo em que as setas possuem sentido contrário se comparadas às setas do modelo reflexivo, ou seja, saem da variável dependente e chegam à variável independente. Isso supõe que os indicadores são as causas das variáveis na mensuração do constructo (variável dependente) (HAIR et al., 2013).
} 
é geralmente chamado de path analysis. "Ambos são críticos para a construção da modelagem porque representam as hipóteses e sua relação com a teoria que está sendo testada" (HAIR et al., 2013, p. 33).

A sequência é apresentada da esquerda para a direita, com constructos independentes (preditores) na esquerda e dependentes (resultados) na direita. Constructos que agem apenas como variáveis independentes são chamados de "variáveis latentes exógenas", não são ocasionados ou previstos por qualquer outra variável no modelo e não possuem setas apontadas para eles (KLINE, 2005, p. 67). Os constructos que agem como variáveis latentes endógenas ficam à direita no modelo estrutural e são previstos por um ou mais constructos. Constructos que operam como ambos, independentes e dependentes variáveis, também são considerados como endógenos e geralmente aparecem no meio do diagrama. Como no caso da regressão, a diferenciação entre constructo exógenos e endógenos é determinada exclusivamente pelo pesquisador (HAIR et al., 2005, p. 478; 2013, p. 34).

Os critérios para avaliação do modelo estrutural são: determinação do $\mathrm{R}^{2}$ e coeficientes de caminho, conforme descrição a seguir.

O Coeficiente de determinação $\left(\mathbf{R}^{2}\right)$ pode ser interpretado como os coeficientes beta padronizados das regressões com a técnica dos quadrados mínimos ordinários (HENSELER; RINGLE; SINKOVICS, 2009). É uma métrica lógica para julgar o modelo estrutural no que se refere às variáveis endógenas. Reflete o porcentual de variação na variável exógena que é explicado pelas variáveis endógenas. $\mathrm{O}$ valor do $\mathrm{R}^{2}$ é normalizado e assume valores entre $0 \mathrm{e}$ 1, e quanto maior o valor de $\left(\mathrm{R}^{2}\right)$, maior o porcentual de variância explicada (Hair et al., 2009).

Associado a esse coeficiente, encontra-se o $\mathrm{R}^{2}$ ajustado, que considera o fato de que o $\mathrm{R}^{2}$ tende a superestimar a quantidade atual de variação contabilizada para a população. Também é fato que a inclusão de muitos termos no modelo de regressão aumenta substancialmente o valor de $\mathrm{R}^{2}$. Se o modelo receber fatores adicionais desnecessários, haverá um incremento em $\mathrm{R}^{2}$, sem haver, necessariamente, melhoria de informação na resposta. É por esse motivo que o valor de $\mathrm{R}^{2}$ ajustado é mais apropriado para comparar modelos com diferentes quantidades de termos. Embora não haja um limite mínimo aceitável, nas ciências sociais é comum considerar os valores para $\mathrm{R}^{2}$ de $0,20,13$ ou 0,26 como sendo, respectivamente, substancial, moderado ou fraco (COHEN, 1977, p. 413 apud BIDO et al., 2010). 
Hair et al. (2009) não apresentam uma classificação, porém sugerem que seja avaliada a significância prática. Dessa maneira, os resultados do coeficiente de determinação devem ser analisados à luz da razão. Assim, mesmo que um coeficiente de correlação seja extremamente significativo estatisticamente, pode não o ser na prática.

O Quadro 21 apresenta uma síntese dos critérios de avaliação do modelo estrutural da técnica PLS.

Coeficientes de caminho (path coefficients). O principal critério de avaliação é o coeficiente de determinação $\left(\mathrm{R}^{2}\right)$ da variável latente endógena (HENSELER; RINGLE; SINKOVICS, 2009). Com relação ao poder de explicação do $R^{2}$, coloca-se o seguinte argumento de Cohen (1977, p. 78):

[...] o fato é que o estado de desenvolvimento de muito da ciência comportamental é tal que não muito da variância da variável dependente é explicável (predictable). Isto é essencialmente outro modo de dizer o óbvio: que a ciência comportamental, coletivamente, não é tão avançada como as ciências físicas. $\mathrm{Na}$ última, nós podemos frequentemente explicar mais de $90 \%$ da variância da variável dependente, por exemplo, na mecânica clássica.

O coeficiente de caminho (path coefficients) indica a força estatística entre as variáveis latentes do modelo e pode ser expresso na forma padronizada, permitindo a comparação relativa entre as forças de cada coeficiente apresentadas no modelo estudado. Os coeficientes possuem valores padronizados entre -1 e +1 . Estimativas de coeficiente de caminho próximas a +1 refletem uma forte relação positiva entre os constructos e vice-versa. Quanto mais próximos de zero ficarem os coeficientes estimados, mas fraca a relação entre as variáveis. Os valores dos coeficientes são utilizados para aceitar ou rejeitar as hipóteses (HAIR et al., 2013).

Um indicador pode ser irrelevante para a construção do constructo, por duas principais razões. A primeira, por não ter um impacto significativo sobre o índice de formação; a segunda porque exibe alta multicolinearidade ${ }^{13}$, o que pode significar que a informação do indicador é de ordem redundante. A verificação da significância do indicador é determinada por meio da técnica

\footnotetext{
13 Multicolinearidade é definida como a dependência linear entre duas ou mais variáveis. A presença da multicolinearidade dificulta a separação dos efeitos preditivos das variáveis, resultando em estimativas instáveis.
} 
bootstrapping (CHIN, 1998; TENENHAUSETAL, 2005 apud HENSELER; RINGLE; SINKOVICS, 2009).

A técnica de reamostragem chamada de bootstrapping é uma técnica na qual os dados originais são repetidamente amostrados com substituição, para a estimação do modelo (HAIR et al., 2005, p. 466). O modelo é reestimado para cada amostra e as estimativas dos parâmetros são calculadas como a média das estimativas em todas as amostras (Ibid.).

O erro-padrão do bootstrap permite calcular o valor empírico do $t$ de student. De acordo com a distribuição do $t$ de student, pode-se definir se os coeficientes padronizados (path coefficients) são significantes. Utiliza-se comumente o valor crítico para testes bicaudais de 1,65 (nível de significância de 10\%), 1,96 (nível de significância de 5\%) e 2,57 (nível de significância de 1\%) (HAIR et al., 2013 p. 171). Em outros termos, $t$ de student superior a 1,96 indica que há menos de $5 \%$ de risco de rejeitar H0. Quanto maior o $t$, menor o risco de rejeitar H0, e, portanto, com H0 rejeitada, a correlação é significante (BAGOZZI et al., 1991). Para Henseler Ringle e Sinkovics (2009, p. 305), a abordagem bootstrapping trata a amostra observada como se esta representasse uma população, criando as bases para a inferência estatística. O Quadro 21 a seguir apresenta o resumo dos parâmetros de aceitação do modelo estrutural da técnica PLS.

Quadro 21: Critérios de avaliação do modelo estrutural

\begin{tabular}{|c|c|c|c|}
\hline Critérios & Descrição & Mensuração & Autor (es) \\
\hline $\begin{array}{l}\text { Coeficiente de } \\
\text { determinação } \\
\text { (R2) das variáveis } \\
\text { latentes } \\
\text { endógenas }\end{array}$ & $\begin{array}{l}\text { É uma métrica lógica para } \\
\text { julgar o modelo estrutural } \\
\text { no que se refere às variáveis } \\
\text { endógenas. }\end{array}$ & $\begin{array}{l}\text { Avaliada pelo valor de R2. Os valores de } \\
2 \%, 13 \% \text { ou } 26 \% \text { são considerados } \\
\text { respectivamente como substancial, } \\
\text { moderado e fraco. }\end{array}$ & $\begin{array}{l}\text { Cohen } \\
(1977, \mathrm{p} \text {. } \\
413)\end{array}$ \\
\hline $\begin{array}{l}\text { Tamanho e } \\
\text { significância dos } \\
\text { coeficientes de } \\
\text { caminho (path } \\
\text { coefficients) }\end{array}$ & $\begin{array}{l}\text { Indica a força estatística } \\
\text { entre as variáveis latentes. } \\
\text { É uma técnica na qual os } \\
\text { dados originais são } \\
\text { repetidamente amostrados } \\
\text { para estimação do modelo, e } \\
\text { o erro-padrão do bootstrap }\end{array}$ & $\begin{array}{l}\text { Os valores estimados para os coeficientes } \\
\text { de caminho dentro do modelo estrutural } \\
\text { devem ser avaliados em termos de sinal, } \\
\text { magnitude e significância via } \\
\text { boostrapping. } \\
\text { Bootstrapping } \\
\text { Testes de duas caldas: } \\
\text { 1,65 (nível de significância }=10 \% \text { ) } \\
\text { 1,96 (nível de significância }=5 \% \text { ) } \\
2,57 \text { (nível de significância }=1 \% \text { ) }\end{array}$ & $\begin{array}{l}\text { Hair, et al. } \\
(2013, \text { p. } \\
171)\end{array}$ \\
\hline
\end{tabular}




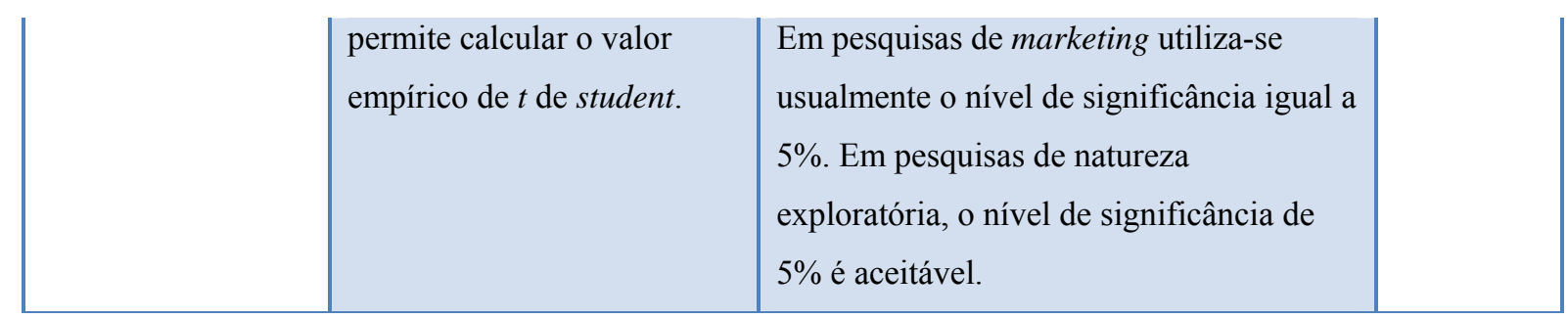

FONTE: adaptado pela autora.

\section{Análise do poder estatístico e tamanho do efeito}

Outro aspecto importante diz respeito ao tamanho da amostra. A especificação do tamanho da amostra pode ser medida por meio da técnica da análise do poder estatístico, que significa a probabilidade de rejeição da hipótese nula, dado que esta é falsa. A análise do poder estatístico depende de três classes de parâmetros: o nível de significância (probabilidade do erro tipo I), o tamanho da amostra utilizada e o tamanho do efeito.

Segundo Faul et al. (2009), há cinco diferentes tipos de análise do poder estatístico, quais sejam: análise do poder a priori, análise do poder a posteriore, análise do poder ajustado, análise de sensibilidade e análise de critério. A escolha dependerá dos recursos disponíveis e da etapa do processo de pesquisa. Para este estudo, utilizou-se a análise de sensibilidade, que calcula a amostra como função do nível de significância $(\alpha)$, tamanho do efeito a ser detectado como probabilidade $(1-\beta)$.

Para efetuar o cálculo do poder estatístico, utiliza-se o software G*Power 3.1.7, que, segundo Faul et al. (2007) envolve as seguintes etapas: (i) seleção do teste estatístico apropriado para o problema; (ii) escolha de um dos cinco tipos de análise de poder; (iii) indicação dos parâmetros de entradas necessários para a análise; (iv) obtenção dos resultados. Esse software traz a facilidade de se calcularem os tamanhos da amostra de acordo com a potência desejada. Segundo Cohen (1988 apud FAUL et al., 2007, p. 180), tamanhos de efeito de "0,02", "0,15" e " 0,35 " são considerados, respectivamente, como pequenos, médios e grandes. Além disso, Hair et al. (2009) recomendam que estudos devem ser planejados para terem níveis de alpha de, pelo menos, 0,05, com níveis de poder de 80\% (COHEN, 1988 apud HAIR et al., 2009, p. 28). 


\subsection{Limitações metodológicas}

As limitações relativas a este estudo são classificadas de acordo com os seguintes aspectos: amostra, unidade de medida, respondentes, instrumento de coleta de dados, escalas de mensuração, representatividade e confiabilidade dos dados, emprego das técnicas e das ferramentas estatísticas e interpretação do pesquisador.

- As dificuldades verificadas na definição da população, pelo fato de não existir um banco de dados ou listagem oficial que contemple os principais dados relativos às EMNBRs, pode prejudicar a seleção da amostra, mesmo que o processo siga todos os procedimentos recomendados. Além disso, o limitado número de EMNs brasileiras e das respectivas subsidiárias dificulta o uso de amostragens probabilísticas e, por conseguinte, impede generalizações;

- A unidade de medida definida para o estudo - subsidiária da EMN - pode representar uma limitação. Tal escolha trará luz ao entendimento da transferência do conhecimento a partir da visão do gerador e transmissor do conhecimento. Reconhece-se a limitação de não incluir a visão e o contexto do receptor (matriz), como indicam os autores Minbaeva (2007) e Szulanski (1996). É que isso dificultaria a coleta e análise das informações, sendo o entendimento do contexto e características do receptor um importante passo para a compreensão do fenômeno que se deseja investigar, conforme justifica Gupta e Govindarajan (2000);

- O respondente-alvo pode representar outra limitação do estudo. Inicialmente, por causa da dificuldade de identificar e acessar o respondente mais adequado por subsidiária. Outro ponto é a utilização de um único entrevistado por subsidiária. Há muitas vulnerabilidades ocasionadas por tal fator, dentre elas: a avaliação da percepção do respondente pode ser condicionada pelo cargo, por sua experiência na área, bem como por seus valores individuais; é possível que ele não consiga responder com propriedade a todas as questões levantadas no questionário, mas nem por isso sinta necessidade de manifestar sua dificuldade, respondendo às questões de forma superficial e sem esforços analíticos suficientes; 
- O instrumento de coleta de dados, mesmo que tome por base estudos anteriores e siga as recomendações gerais para sua elaboração, pode não conseguir replicar de forma adequada todos os constructos, ainda que estes tenham sido previamente definidos no texto. Ademais, por ser apresentado em forma eletrônica por mais simples que possa parecer, pode gerar dificuldades ao entrevistado no momento de seu manuseio;

- O survey eletrônico, utilizado como método de coleta de dados, possui algumas desvantagens inerentes (VASCONCELLOS; GUEDES, 2007), tais como: impessoalidade, respondentes podem considerar a mensagem de e-mail como invasão de privacidade, baixo índice de resposta, baixa confiabilidade dos dados, e-mails com o questionário eletrônico direcionados diretamente para o "lixo eletrônico", entre outras desvantagens. Contudo, tendo em vista que a população-alvo deste estudo está localizada em outros países a maneira mais rápida e econômica de acessá-la seria por meio da utilização de um web-survey. Além disso, tomaram-se alguns cuidados para aumentar a eficácia desse método de coleta, tais como: contato com o respondente por telefone antes de enviar o link do questionário por $e$ mail, cuidado extremo na elaboração do questionário no que diz respeito ao layout e à formatação, inclusão de explicação sobre termos-chave da pesquisa e estratégia de followups quinzenais para aumentar a taxa de resposta.

- A estratégia de avaliação do modelo deste estudo possui natureza quantitativa, que fornece subsídios para o entendimento das relações de correlação, bem como de suas intensidades, dentro do modelo de pesquisa formulado. Todavia, as análises de determinadas relações poderiam ser aprofundadas por meio de técnicas de avaliação qualitativa, como entrevistas em profundidade com algumas das subsidiárias da amostra, ou seja, uma estratégia de triangulação dos dados poderia fornecer mais elementos para o entendimento de fatores não observados pela técnica estatística de MEEPLS.

\subsection{Síntese dos procedimentos metodológicos}

Este capítulo explicou a metodologia adotada no estudo, em suas várias dimensões classificações metodológicas e conceituais, procedimentos amostrais, procedimentos de coleta 
de dados, informantes-chave, forma de tratamento e análise dos dados -, além de evidenciar as limitações. O Quadro 22 faz uma síntese de todas as especificidades metodológicas utilizadas.

Quadro 22: Delineamento do estudo

\begin{tabular}{|c|c|}
\hline Perspectiva do Estudo & Classificação do estudo \\
\hline Natureza da Pesquisa & Descritiva e correlacional \\
\hline Abordagem & Quantitativa \\
\hline Método & Survey eletrônico \\
\hline Tipo de pesquisa & Estudo de campo \\
\hline Dimensão temporal & Estudo cross-sectional \\
\hline $\begin{array}{l}\text { Poder do pesquisador para afetar as } \\
\text { variáveis }\end{array}$ & Estudo ex post facto \\
\hline Unidade de análise & Subsidiária da EMN \\
\hline Tamanho da amostra & 78 subsidiárias estrangeiras de EMNs \\
\hline Informantes-chave & $\begin{array}{l}\text { - CEO da subsidiária; } \\
\text { - Diretor de negócios internacionais da } \\
\text { subsidiária; } \\
\text { - Gestor de P\&D da subsidiária; } \\
\text { - Gestor responsável pelos negócios de } \\
\text { interação matriz-subsidiária }\end{array}$ \\
\hline Tratamento dos dados & $\begin{array}{l}\text { Técnica estatística multivariada: } \\
\text { modelagem de equações estruturais com } \\
\text { estimação Partial Least Square } \\
\text { (MEEPLS) }\end{array}$ \\
\hline
\end{tabular}

FONTE: Adaptado pela autora. 


\section{APRESENTAÇÃO E ANÁLISE DOS RESULTADOS}

Este capítulo está estruturado em quatro tópicos, que abordam os procedimentos de preparação dos dados para que possíveis violações não comprometam a interpretação e a análise dos resultados, a análise descritiva e a análise da modelagem de equações estruturais com a estimação partial least square e testes das hipóteses. Essas análises foram conduzidas com a finalidade de encontrar resultados que ajudem a responder à questão-chave de pesquisa apresentada no capítulo introdutório deste estudo.

\subsection{Preparação dos dados}

Antes de iniciar a análise multivariada, fez-se necessário um exame dos dados com o objetivo de um conhecimento preliminar para averiguar os dados perdidos, conforme as recomendações de Hair et al. (2005, p. 49) “o exame dos dados é um passo que consome tempo, mas necessário, que às vezes é ignorado por pesquisadores".

A primeira etapa envolveu a análise dos dados faltantes ou ausentes (missing values). Concluiuse que esse problema foi razoavelmente minimizado, uma vez que o instrumento de coleta de dados utilizado não permitia que a maioria dos itens questionados fosse deixada sem preenchimento. Isso possibilitou a substituição desses dados ausentes pela média do item. Esse é um dos métodos mais amplamente utilizados em pesquisa e tem a vantagem tanto de ser fácil de implantar quanto de fornecer todos os casos com informação completa (HAIR et al., 2005, p. 63). Quanto aos outliers (dados extremos) univariados, esses não excederam a referência proposta por Hair et al. (2005) e, por este motivo, optou-se por mantê-los no banco de dados.

Após essa fase de limpeza dos dados, foi feita a análise da natureza dos dados, para verificação de adequação do(s) tipo(s) de testes estatísticos que seriam empregados. Para Corrar, Paulo e Dias Filho (2009, p. 41), testes gráficos e estatísticos devem ser sempre usados pelo pesquisador “para avaliar o real grau de desvio da normalidade”. Seguindo essas orientações foi realizada uma inspeção visual a partir da análise dos histogramas e do teste de Kolmogorov-Smirnov. O resultado mostra que, em todos os construtos o teste de Kolgomorov-Smirnov constatou a não 
normalidade da distribuição dos dados. Considerando-se ser esta uma pesquisa de opinião onde utilizamos uma escala progressiva, é plausível que os dados não se distribuam normalmente, e até mesmo que as respostas se concentrem mais em uma extremidade da curva de distribuição. Sendo assim, seguiu-se a aplicação da modelagem de equações estruturais com estimativa Partial Least Square que não exige normalidade dos dados para seu emprego.

Após a conclusão dessa fase de preparação, será apresentada a validação da amostra do estudo.

\subsection{Verificação do tamanho do efeito (effect-size)}

Para testar a sensibilidade da amostra e detectar qual o $\mathrm{R}^{2}$ mínimo para se inferir que há relacionamento estatisticamente significante entre as variáveis, utilizou-se o software G*Power 3.1.7 (FAUL et al., 2007, p. 181). Esse software mensura o valor de $\mathrm{R}^{2}$ de referência a partir do valor do efeito do tamanho $\left(\mathrm{f}^{2}\right)$. Para realizar o teste, adotou-se o poder de $80 \%$ (power $=0,8$ ), confiança de $95 \%(\alpha=0,05)$, amostra de 78 unidades e 11 preditores (quantidade de setas que chegam ao constructo principal). Com essas premissas chegou-se a um tamanho de efeito ( $\left.\mathrm{f}^{2}\right)$ $=0,2483810$, conforme demonstrado na Ilustração 24 a seguir.

Portanto, um $\mathrm{f}^{2}$ igual ou superior a 0,2483810 já seria suficiente para detectar como significante a regressão. Convertendo o $\mathrm{f}^{2} \mathrm{em} \mathrm{R}^{2}$, significa dizer que, se na população houver um $\mathrm{R}^{2}$ (para a transferência reversa de conhecimento tecnológico) igual ou superior a 19,89\%, o tamanho da amostra será tido como significante. 


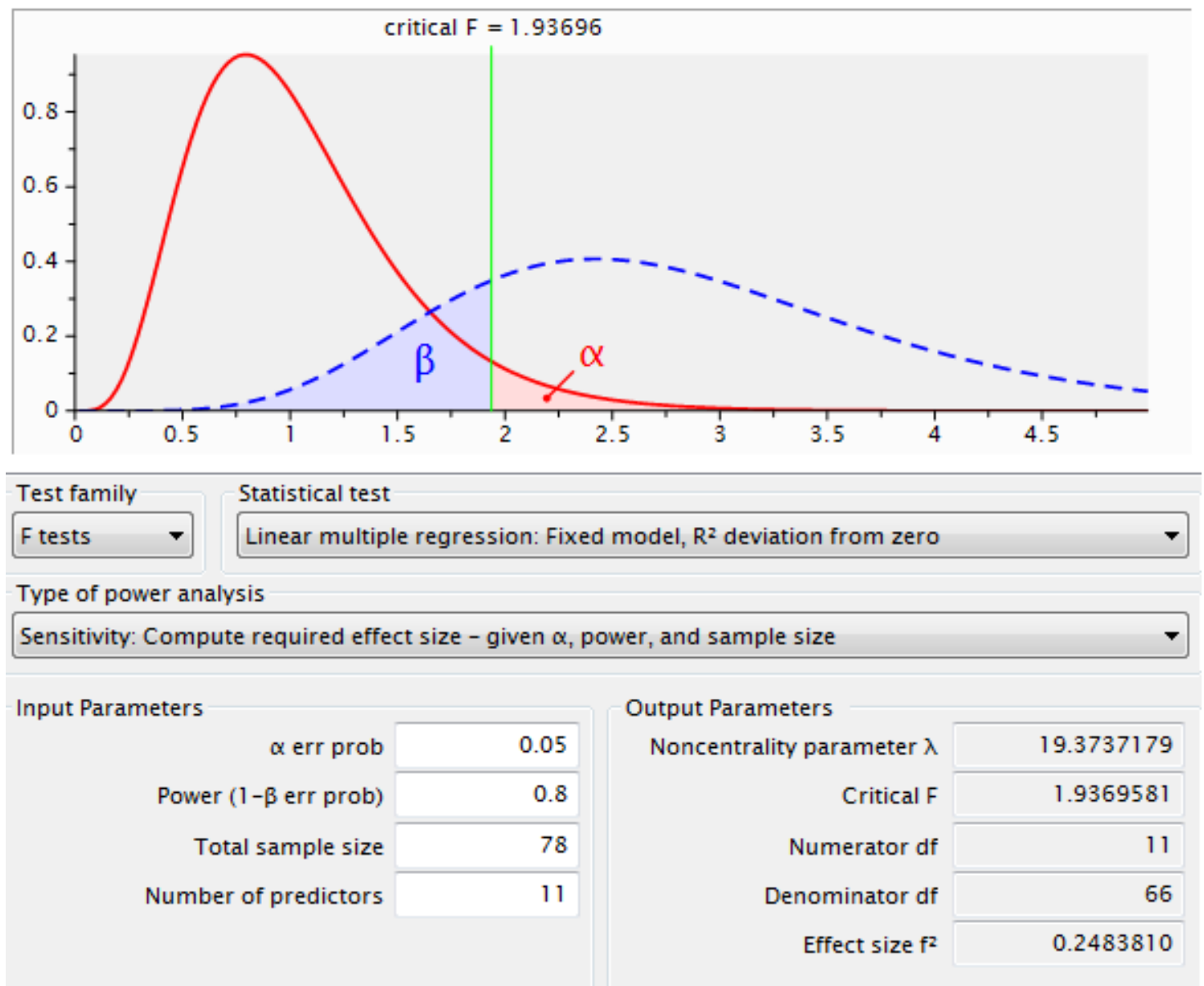

Ilustração 24: Análise de sensibilidade da amostra

FONTE: G*Power 3.1.7.

\subsection{Análise univariada}

A análise descritiva foi conduzida com o propósito de descrever e organizar os dados coletados. Nesta seção, as variáveis dependente (transferência reversa de conhecimento tecnológico) e independente (determinantes da transferência reversa de conhecimento tecnológico), bem como seus respectivos indicadores, são avaliadas uma a uma, sem a pretensão de se estabelecerem relações entre elas. A ênfase recai, portanto, no conteúdo dos dados e não nas análises das hipóteses de pesquisa. Para tanto, foram consideradas as medidas estatísticas de média, mediana e desvio-padrão e, para obter mais detalhes, análises descritivas foram adicionadas a cada constructo.

Essa seção está classificada por transferência reversa de conhecimento tecnológico, características do conhecimento, características da subsidiária e características da interação matriz/subsidiárias. 


\subsubsection{Transferência reversa de conhecimento tecnológico}

Neste tópico é avaliado o constructo transferência reversa de conhecimento tecnológico, cujas definições foram apresentadas no capítulo dedicado à metodologia. A Tabela 2 apresenta os dados obtidos.

Tabela 2: Distribuição de frequências da transferência reversa de conhecimento tecnológico

\begin{tabular}{|c|c|c|c|c|c|}
\hline Transferência reversa de conhecimento tecnológico & Mínimo & Máximo & Média & Mediana & $\begin{array}{l}\text { Desvio- } \\
\text { Padrão }\end{array}$ \\
\hline $\begin{array}{l}\text { Técnicas de organização da produção (ex.: just in time, } \\
\text { controle da qualidade total) }\end{array}$ & - & 5 & 2,4 & 2 & 1,2 \\
\hline Planejamento e controle da produção (PCP) & - & 5 & 2,5 & 2 & 1,2 \\
\hline Processos de automação & - & 5 & 2,4 & 2 & 1,2 \\
\hline Desenvolvimento de novos processos de produção & - & 5 & 2,5 & 2 & 1,1 \\
\hline Pequenas mudanças na tecnologia de processo & - & 5 & 2,8 & 3 & 1,0 \\
\hline Melhoria significativa no processo de produção & - & 5 & 2,5 & 2 & 1,1 \\
\hline Projeto (design) próprio de fabricação & - & 5 & 2,4 & 2 & 1,2 \\
\hline $\begin{array}{l}\text { Desenvolvimento de novos equipamentos e/ou } \\
\text { ferramentas }\end{array}$ & - & 5 & 2,0 & 2 & 1,1 \\
\hline Fabricação de novos componentes & - & 4 & 2,2 & 2 & 1,1 \\
\hline Montagem de componentes e produtos finais & - & 5 & 2,2 & 2 & 1,2 \\
\hline Manutenção de máquinas e equipamentos & - & 5 & 2,0 & 2 & 1,2 \\
\hline $\begin{array}{l}\text { Pequenas adaptações na tecnologia de produtos } \\
\text { existentes }\end{array}$ & - & 5 & 2,7 & 3 & 1,2 \\
\hline Melhoria significativa em produtos existentes & - & 5 & 2,7 & 3 & 1,2 \\
\hline Desenvolvimento de novos produtos & - & 5 & 2,7 & 3 & 1,3 \\
\hline Rotinas de controle de qualidade & - & 5 & 2,4 & 2 & 1,3 \\
\hline Desenvolvimento de novos protótipos & - & 5 & 2,2 & 2 & 1,2 \\
\hline Testes de novos produtos & - & 5 & 2,6 & 3 & 1,3 \\
\hline Know-how para projetar novos produtos & - & 5 & 2,6 & 3 & 1,2 \\
\hline $\begin{array}{l}\text { Resultados de pesquisa sobre novos materiais e novas } \\
\text { especificações }\end{array}$ & - & 5 & 2,5 & 2 & 1,4 \\
\hline
\end{tabular}

Legenda: NA = não se aplica; DP = desvio-padrão; $\mathrm{M}$ = média; MD = mediana *Escala utilizada: 1 para transfere nada e 5 para transfere muitíssimo.

O Gráfico 1, a seguir, demonstra que o valor médio da pontuação deste constructo varia de 2 a 2,8, em média. Os indicadores com maior média, ou seja, os mais passíveis de transferência da subsidiária para a matriz são: "pequenas mudanças na tecnologia de processo", "melhoria significativa em produtos existentes", "pequenas adaptações na tecnologia de produtos existentes", "desenvolvimento de novos produtos", "know-how para projetar novos produtos" e "testes de novos produtos". Isso indica que os tipos de conhecimento tecnológico mais transferidos de forma reversa nas EMNs brasileiras são os relacionados ao desenvolvimento de produto, pois, dos seis itens mais transferidos, cinco são referentes a produto e um a processo.

Já os tipos de conhecimento tecnológico menos transferidos da subsidiária para a matriz, em ordem decrescente, foram: "manutenção de máquinas e equipamentos", "desenvolvimento de 
novos equipamentos", "montagem de componentes e produtos finais", "fabricação de novos componentes" e "desenvolvimento de novos protótipos". Pode-se perceber que, com exceção do indicador desenvolvimento de protótipos, todos os outros são relacionados ao trabalho com componentes e equipamentos.

Em resumo, o resultado do estudo permite concluir que, em primeiro lugar, as subsidiárias, ainda que com pouca extensão, transferem conhecimentos relacionados a produto, seguidos dos conhecimentos relacionados a processos. Em segundo lugar, que os tipos de conhecimento menos transferidos (e, em alguns casos, não transferidos) são os relacionados aos componentes de produtos e equipamentos e/ou ferramentas para o processo de produção. 


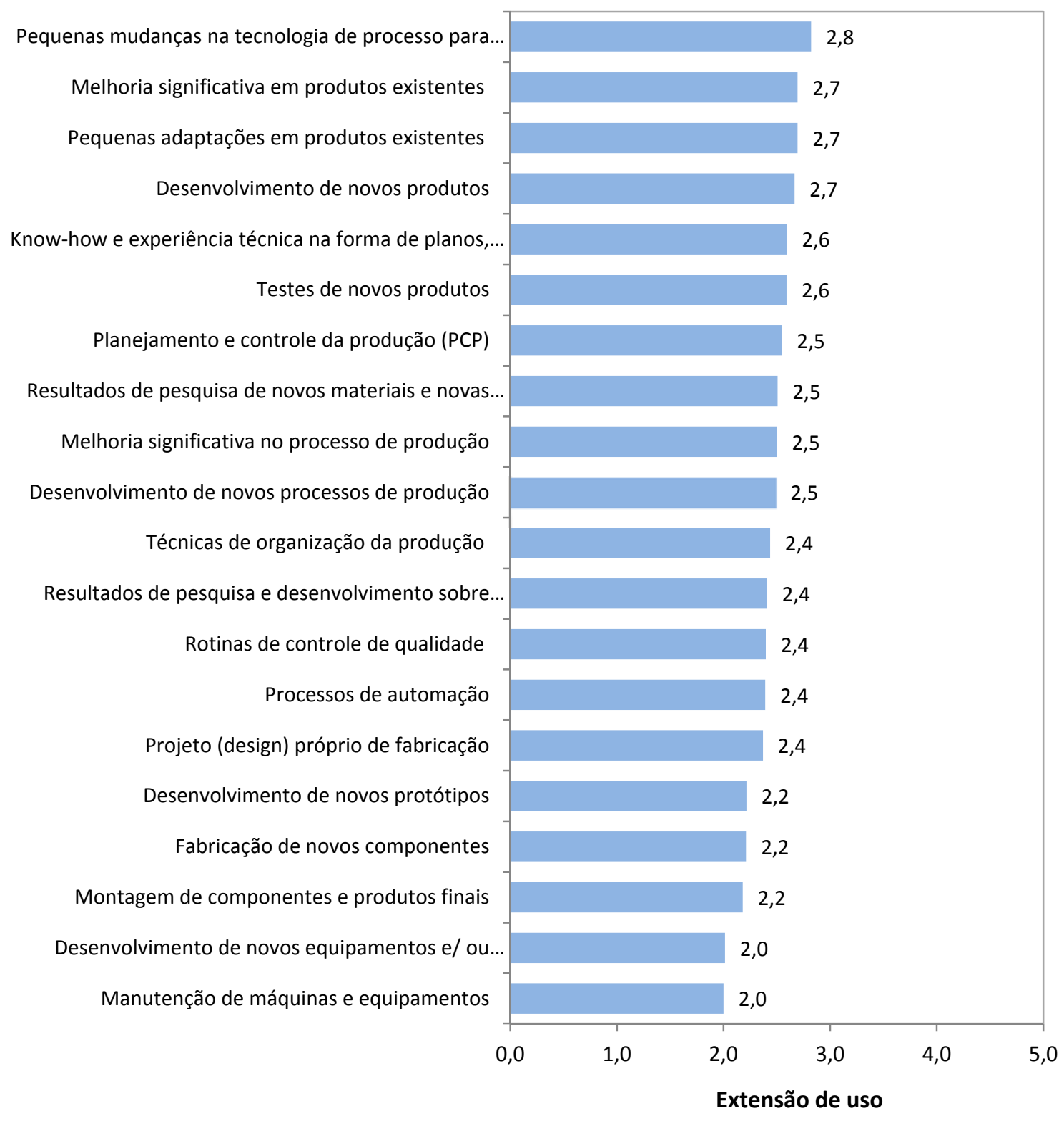

Gráfico 1: Distribuição da frequência de respostas ao constructo transferência reversa de conhecimento tecnológico

\subsubsection{Determinantes da transferência reversa de conhecimento tecnológico}

Neste tópico é apresentada a análise univariada de todos os determinantes da transferência reversa de conhecimento tecnológico que estão classificados em: características do conhecimento tecnológico, características da subsidiária e características da interação matriz/subsidiária. 


\subsubsection{Características do conhecimento tecnológico}

Neste tópico são avaliados os constructos referentes às características do conhecimento tecnológico: tacitividade e complexidade. A Tabela 3 apresenta os dados obtidos.

Tabela 3: Distribuição de frequências das características do conhecimento tecnológico

\begin{tabular}{|c|c|c|c|c|c|}
\hline Tacitividade & Mínimo & Máximo & Média & Mediana & $\begin{array}{l}\text { Desvio- } \\
\text { Padrão }\end{array}$ \\
\hline $\begin{array}{l}\text { É fácil de documentar em manuais, relatórios e } \\
\text { imagens }\end{array}$ & 1 & 5 & 4 & 3,8 & 0,9 \\
\hline $\begin{array}{l}\text { É fácil de compreender por meio de documentos } \\
\text { escritos }\end{array}$ & 2 & 5 & 4 & 3,8 & 0,7 \\
\hline $\begin{array}{l}\text { É mais explícito do que tácito (difícil de documentar, } \\
\text { imitar e aprender) }\end{array}$ & 2 & 5 & 2 & 2,7 & 1,0 \\
\hline Complexidade & Mínimo & Máximo & Média & Mediana & $\begin{array}{l}\text { Desvio- } \\
\text { Padrão }\end{array}$ \\
\hline $\begin{array}{l}\text { Seu entendimento requer um aprendizado prévio de } \\
\text { outros conhecimentos tecnológicos relacionados }\end{array}$ & 1 & 5 & 4 & 3,5 & 1,1 \\
\hline $\begin{array}{l}\text { Seu entendimento requer uma grande quantidade de } \\
\text { informação }\end{array}$ & 1 & 5 & 4 & 3,4 & 1,1 \\
\hline $\begin{array}{l}\text { É produto de muitas rotinas interdependentes, } \\
\text { indivíduos e recursos }\end{array}$ & 1 & 5 & 4 & 3,5 & 1,1 \\
\hline Inclui muitas novas habilidades ou competências & 1 & 5 & 4 & 3,4 & 1,0 \\
\hline É tecnologicamente sofisticado e difícil de implantar & 1 & 5 & 3 & 2,6 & 0,9 \\
\hline É complexo (vs. simples) & 1 & 5 & 3 & 3,1 & 1,1 \\
\hline
\end{tabular}

Legenda: $1=$ discordo totalmente, até $5=$ concordo totalmente.

\section{a) Tacitividade}

De acordo com o Gráfico 2, a maioria das subsidiárias respondentes concorda que o conhecimento tecnológico das subsidiárias é de fácil documentação em manuais, relatórios e imagens e de fácil compreensão por meio de documentos escritos. Ao analisar o resultado dessas duas assertivas, subentende-se que o conhecimento nas subsidiárias seria mais próximo de ser explícito do que tácito. No entanto, com relação ao constructo "conhecimento explícito", os gerentes das subsidiárias discordaram dessa afirmativa, o que indica uma pequena inclinação para a existência de conhecimento tácito, em vez de explícito. A partir da análise univariada deste constructo, pode-se concluir que o conhecimento da subsidiária é fácil de entender e de documentar, muito embora, os respondentes tenham indicado de forma contraditória, que o conteúdo é mais tácito do que explícito. 


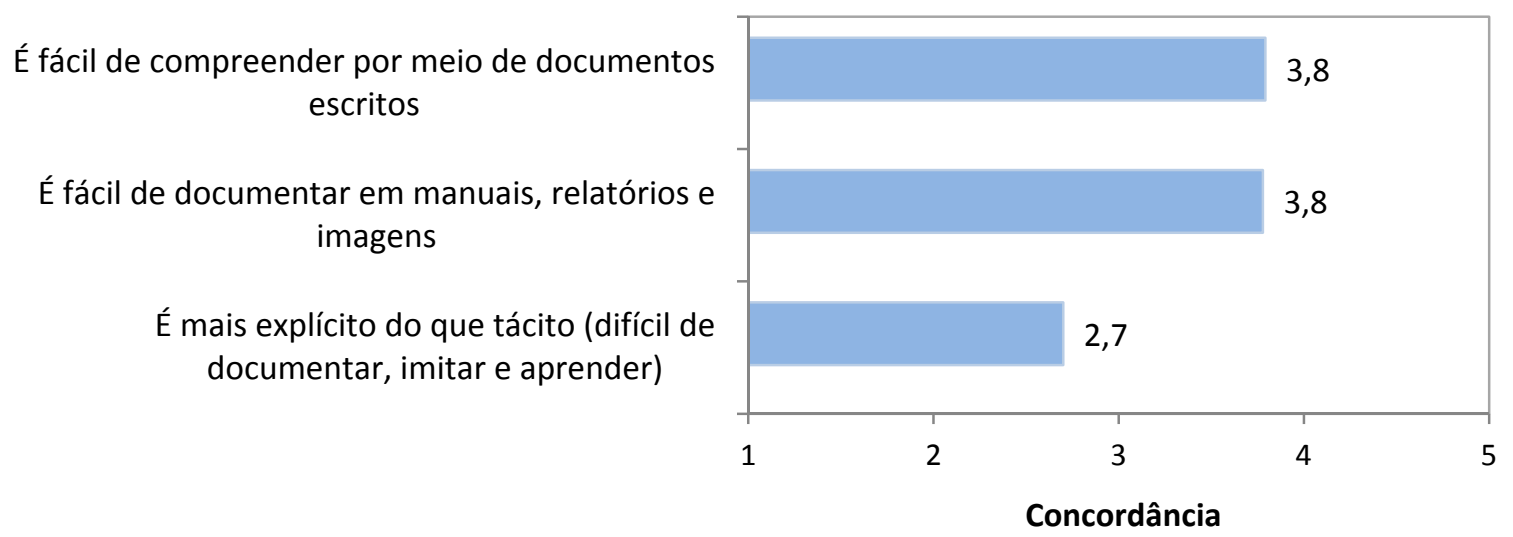

Gráfico 2: Distribuição da frequência de resposta ao constructo tacitividade

\section{b) Complexidade}

De acordo com o Gráfico 3, os gerentes das subsidiárias pesquisadas tendem a concordar com a maioria dos indicadores que compõem o constructo complexidade do conhecimento, com exceção do indicador "é tecnologicamente sofisticado e difícil de implantar", cuja resposta leva a uma discordância com essa afirmação. Isso leva a crer que os respondentes, apesar de considerarem o conhecimento da subsidiária complexo, não acreditam que sua implantação seja difícil. Portanto, ainda que com pouca intensidade, os gerentes das subsidiárias consideram que o conhecimento desenvolvido em suas subsidiárias tem características complexas (média em torno de 3,4).

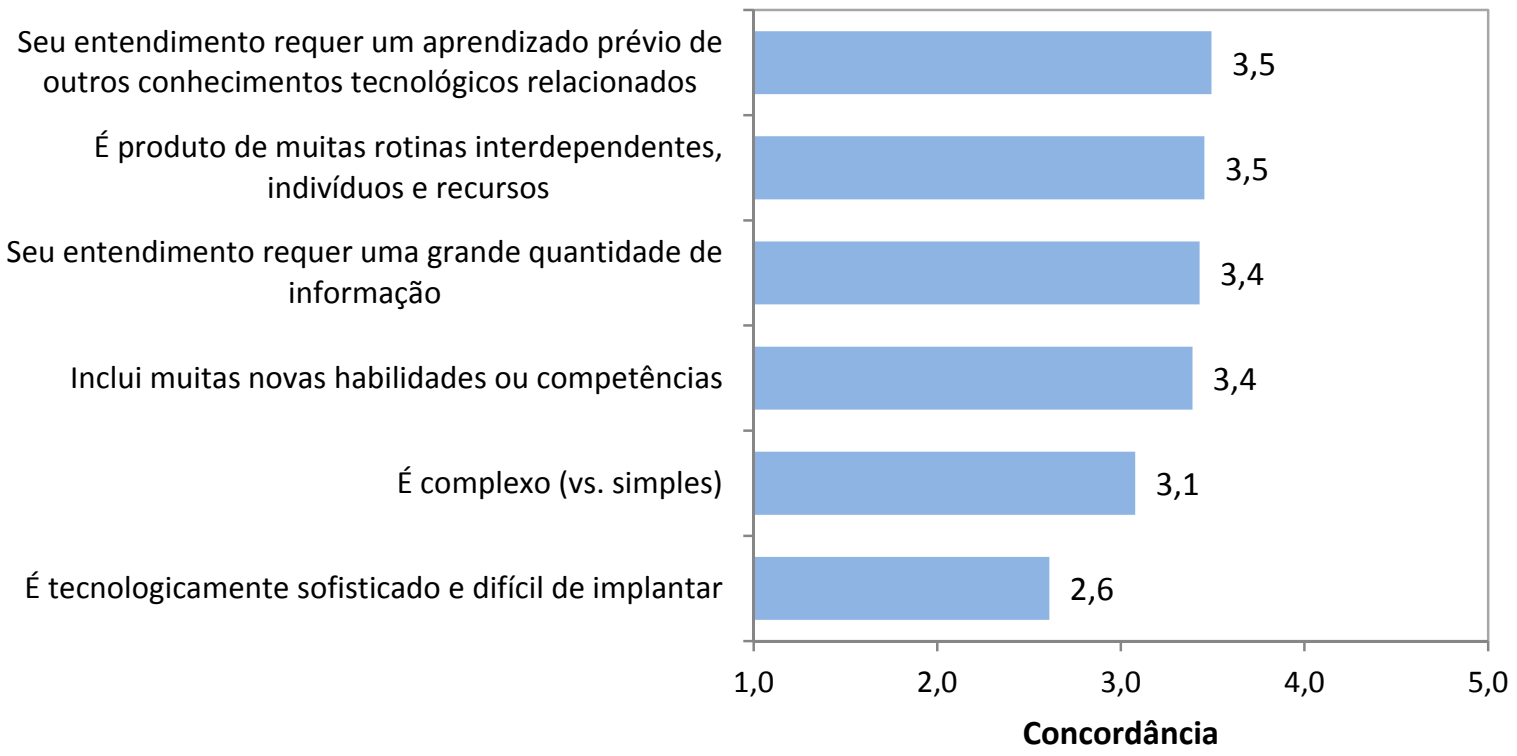

Gráfico 3: Distribuição da frequência de resposta ao constructo complexidade 


\subsubsection{Características das subsidiárias}

Neste tópico são avaliados os constructos referentes às características das subsidiárias: Ambiente Institucional, Ambiente competitivo, integração externa com a rede de fornecedores, clientes e instituições de C\&T, autonomia e motivação. A Tabela 4 apresenta os dados obtidos.

Tabela 4: Distribuição de frequências das características das subsidiárias respondentes

\begin{tabular}{|c|c|c|c|c|c|}
\hline Ambiente Institucional & Mínimo & Máximo & Média & Mediana & $\begin{array}{l}\text { Desvio- } \\
\text { Padrão }\end{array}$ \\
\hline $\begin{array}{l}\text { Existem importantes centros de pesquisa (externos à } \\
\text { empresa) que colaboram com os negócios da subsidiária }\end{array}$ & 1 & 5 & 3 & 2,6 & 1,0 \\
\hline Há boas instituições de suporte aos negócios & 1 & 5 & 3 & 3,2 & 0,9 \\
\hline $\begin{array}{l}\text { A infraestrutura no país (disponibilidade de energia, } \\
\text { transporte, telecomunicações, logística) é adequada }\end{array}$ & 1 & 5 & 3 & 3,5 & 1,1 \\
\hline O governo dá apoio à inovação & 1 & 5 & 4 & 3,2 & 1,1 \\
\hline O ambiente legal é favorável (regulamentação) & 1 & 5 & 3 & 3,2 & 1,2 \\
\hline Ambiente competitivo & Mínimo & Máximo & Média & Mediana & $\begin{array}{l}\text { Desvio- } \\
\text { Padrão }\end{array}$ \\
\hline $\begin{array}{l}\text { A demanda de mercado está crescendo no setor da } \\
\text { subsidiária }\end{array}$ & 1 & 5 & 4 & 3,6 & 1,1 \\
\hline $\begin{array}{l}\text { Os consumidores locais exigem padrões elevados de } \\
\text { qualidade e funcionalidades em produtos/serviços }\end{array}$ & 1 & 5 & 4 & 3,8 & 1,0 \\
\hline A competição no país é intensa & 1 & 5 & 4 & 4,1 & 1,0 \\
\hline A velocidade da inovação dos competidores é alta & 1 & 5 & 4 & 3,6 & 1,0 \\
\hline $\begin{array}{l}\text { As capacidades e qualidades dos fornecedores são } \\
\text { elevadas }\end{array}$ & 2 & 5 & 4 & 3,5 & 0,9 \\
\hline A mão de obra é qualificada e especializada & 1 & 5 & 4 & 3,3 & 1,0 \\
\hline Rede externa com fornecedores & Mínimo & Máximo & Média & Mediana & $\begin{array}{l}\text { Desvio- } \\
\text { Padrão }\end{array}$ \\
\hline $\begin{array}{l}\text { Este parceiro tem participado intensamente do } \\
\text { desenvolvimento do conhecimento tecnológico na } \\
\text { subsidiária }\end{array}$ & 1 & 5 & 3 & 3,1 & 1,0 \\
\hline $\begin{array}{l}\text { Este parceiro teve importantes iniciativas para o } \\
\text { desenvolvimento do conhecimento tecnológico na } \\
\text { subsidiária }\end{array}$ & 1 & 5 & 3 & 2,9 & 1,0 \\
\hline $\begin{array}{l}\text { Este parceiro atendeu aos seus interesses ao } \\
\text { desenvolver o conhecimento tecnológico na subsidiária }\end{array}$ & 1 & 5 & 3 & 3,1 & 1,0 \\
\hline $\begin{array}{l}\text { a conhecimento tecnologico da subsidiarıa fô } \\
\text { parcialmente desenvolvido dentro das instalações deste } \\
\text { parceiro }\end{array}$ & 1 & 5 & 2,5 & 2,6 & 1,2 \\
\hline $\begin{array}{l}\text { A cooperação com este parceiro tem sido caracterizada } \\
\text { por frequentes interações }\end{array}$ & 1 & 5 & 3 & 3,3 & 0,9 \\
\hline Rede Externa com clientes & Mínimo & Máximo & Média & Mediana & $\begin{array}{l}\text { Desvio- } \\
\text { Padrão }\end{array}$ \\
\hline $\begin{array}{l}\text { Este parceiro tem participado intensamente do } \\
\text { desenvolvimento do conhecimento tecnológico na } \\
\text { subsidiária }\end{array}$ & 1 & 5 & 3 & 3,1 & 1,1 \\
\hline $\begin{array}{l}\text { Este parceiro teve importantes iniciativas para o } \\
\text { desenvolvimento do conhecimento tecnológico na } \\
\text { subsidiária }\end{array}$ & 1 & 5 & 3 & 3,0 & 1,0 \\
\hline $\begin{array}{l}\text { Este parceiro atendeu aos seus interesses ao } \\
\text { desenvolver o conhecimento tecnológico na subsidiária } \\
\text { O conhecimento tecnológico da subsidiária foi } \\
\text { parcialmente desenvolvido dentro das instalações deste } \\
\text { parceiro }\end{array}$ & 1 & 5 & 3 & 2,9 & 1,1 \\
\hline
\end{tabular}




\begin{tabular}{|c|c|c|c|c|c|}
\hline $\begin{array}{l}\text { A cooperação com este parceiro tem sido caracterizada } \\
\text { por frequentes interações }\end{array}$ & 1 & 5 & 3 & 3,1 & 1,3 \\
\hline Rede externa com instituições de C\&T & Mínimo & Máximo & Média & Mediana & $\begin{array}{l}\text { Desvio- } \\
\text { Padrão }\end{array}$ \\
\hline $\begin{array}{l}\text { Este parceiro tem participado intensamente do } \\
\text { desenvolvimento do conhecimento tecnológico na } \\
\text { subsidiária }\end{array}$ & 1 & 4 & 2 & 2,1 & 1,1 \\
\hline $\begin{array}{l}\text { Este parceiro teve importantes iniciativas para o } \\
\text { desenvolvimento do conhecimento tecnológico na } \\
\text { subsidiária }\end{array}$ & 1 & 5 & 2 & 2,0 & 1,1 \\
\hline $\begin{array}{l}\text { Este parceiro atendeu aos seus interesses ao } \\
\text { desenvolver o conhecimento tecnológico na subsidiária }\end{array}$ & 1 & 4 & 2 & 2,0 & 1,1 \\
\hline $\begin{array}{l}\text { O conhecimento tecnológico da subsidiária foi } \\
\text { parcialmente desenvolvido dentro das instalações deste } \\
\text { parceiro }\end{array}$ & 1 & 5 & 2 & 2,0 & 1,0 \\
\hline $\begin{array}{l}\text { A cooperação com este parceiro tem sido caracterizada } \\
\text { por frequentes interações }\end{array}$ & 1 & 4 & 2 & 1,9 & 1,0 \\
\hline Autonomia & Mínimo & Máximo & Média & Mediana & $\begin{array}{l}\text { Desvio- } \\
\text { Padrão }\end{array}$ \\
\hline Realização de mudanças em produtos e serviços & 1 & 5 & 3 & 3,5 & 1,1 \\
\hline Desenvolvimento de novos produtos/serviços & 1 & 5 & 3 & 3,3 & 1,2 \\
\hline Realização de mudanças nos processos de produção & 1 & 5 & 4 & 3,6 & 1,1 \\
\hline Entrada em novos mercados do país & 1 & 5 & 4 & 3,5 & 1,3 \\
\hline Desenvolvimento de novos fornecedores e parceiros & 1 & 5 & 4 & 3,7 & 1,1 \\
\hline Gestão de compras e da cadeia de suprimentos & 1 & 5 & 4 & 3,7 & 1,0 \\
\hline $\begin{array}{l}\text { Contratação e demissão da força de trabalho da } \\
\text { subsidiária }\end{array}$ & 1 & 5 & 4 & 4,1 & 0,9 \\
\hline Motivação & Mínimo & Máximo & Média & Mediana & $\begin{array}{l}\text { Desvio- } \\
\text { Padrão }\end{array}$ \\
\hline $\begin{array}{l}\text { Sua subsidiária percebe claramente os benefícios em } \\
\text { compartilhar seu conhecimento com a matriz }\end{array}$ & 2 & 5 & 4 & 4,2 & 0,9 \\
\hline $\begin{array}{l}\text { A matriz motiva/incentiva sua subsidiária a transferir } \\
\text { seu conhecimento }\end{array}$ & 2 & 5 & 4 & 3,9 & 0,9 \\
\hline $\begin{array}{l}\text { Sua subsidiária compromete recursos físicos, } \\
\text { financeiros, organizacionais e logísticos para transferir } \\
\text { seu conhecimento para a matriz }\end{array}$ & 2 & 5 & 4 & 3,6 & 0,9 \\
\hline
\end{tabular}

\section{a) Ambiente Institucional}

De acordo com o Gráfico 4, observa-se maior grau de concordância para o indicador "a infraestrutura no país é adequada". Já em relação aos constructos, "há boas instituições de suporte aos negócios", "o ambiente legal é favorável” e "o governo dá apoio à inovação", os resultados indicam que, apesar de ter havido concordância com esses três indicadores, há muitos respondentes que discordaram das afirmativas, já que a pontuação média ficou muito perto do limite mínimo para a concordância. Os informantes consideraram também que não existem centros de pesquisas que colaboram com os negócios das subsidiárias. De maneira geral, os gerentes das subsidiárias entendem que os Ambiente Institucional no qual as subsidiárias estão hospedadas são levemente propícios. 


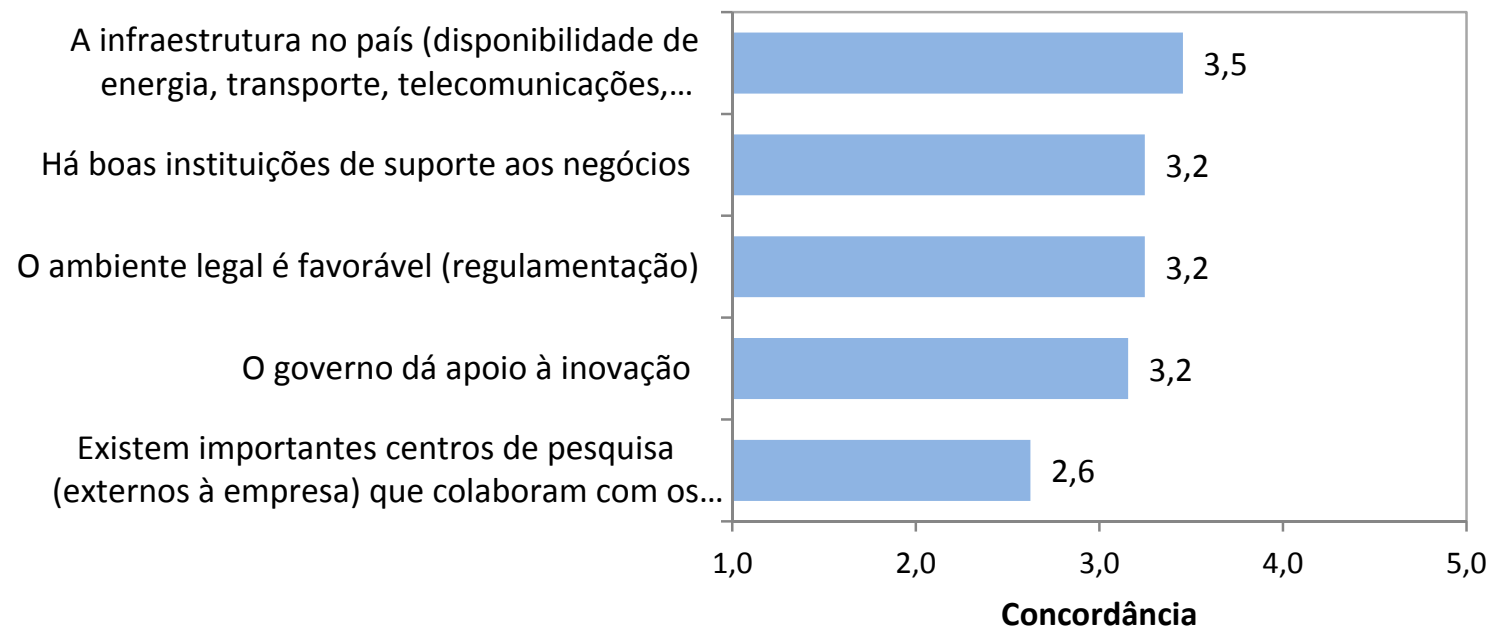

Gráfico 4: Distribuição da frequência de resposta ao constructo Ambiente Institucional

\section{b) Ambiente competitivo}

De forma geral, os sete indicadores do constructo Ambiente competitivo tiveram valores positivos para a concordância (detalhes no Gráfico 5). A partir dos resultados, percebe-se uma clara concordância com os seis indicadores que compõem este constructo. Os dois indicadores com concordância mais relevantes são "a competição no país é intensa" e "os consumidores locais exigem padrões elevados...". O indicador com menor concordância foi "mão de obra qualificada e especializada”. De maneira geral, os gerentes entendem que o ambiente no qual as subsidiárias estão inseridas é competitivo.

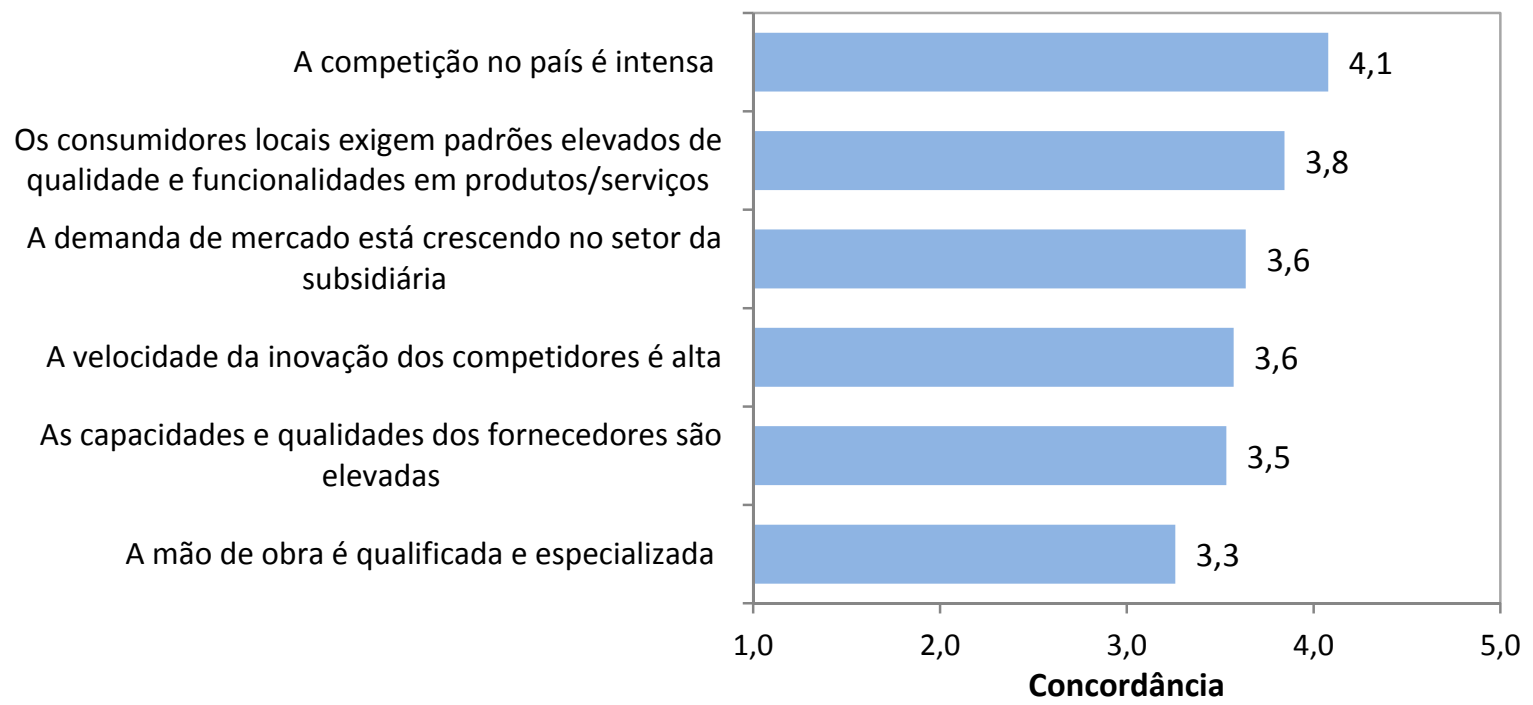

Gráfico 5: Distribuição da frequência de resposta ao constructo Ambiente competitivo

\section{c) Integração externa (com a rede de negócios)}


Este constructo visa mensurar o grau de integração entre a subsidiária e os seguintes parceiros: fornecedores, clientes e instituições de ciência e tecnologia, conforme apresentado no Gráfico 6. Os resultados para o aspecto sob análise denotam que existe uma tendência para uma pequena inserção na rede externa por uma maior parte das subsidiárias para os parceiros fornecedores e clientes, com exceção do indicador 'conhecimento tecnológico teria sido desenvolvido nas dependências dos parceiros (fornecedores e clientes)'. Quanto às instituições de C\&T, não foram consideradas como integradas às subsidiárias (pontuação média abaixo do limite mínimo de concordância, 3).

Pode-se concluir, portanto, que de modo geral é fraca a inserção das subsidiárias em redes de negócio no exterior. 


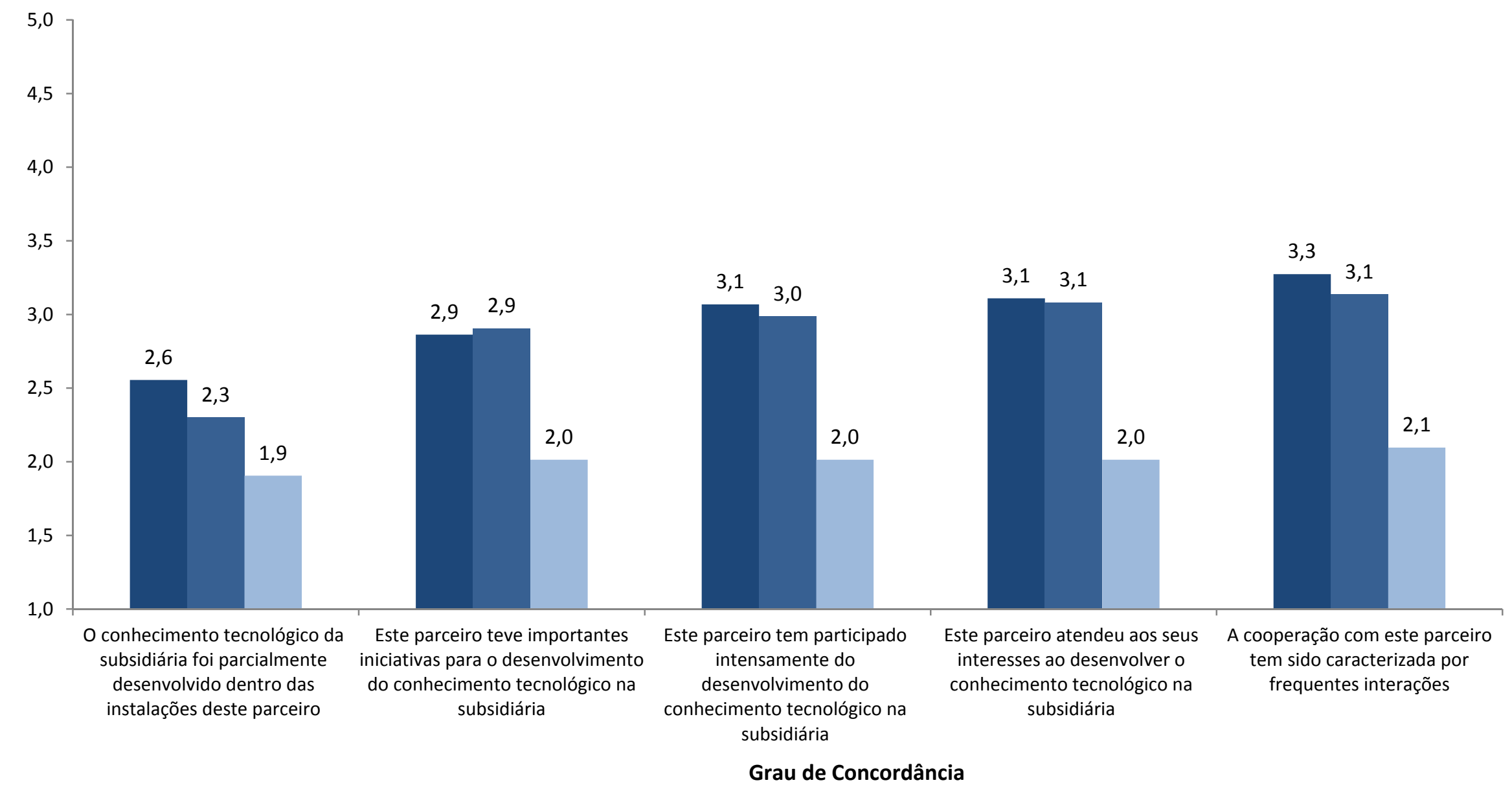

$\square$ FORNECEDORES $\square$ CLIENTES INST. PRIVADAS C\&T

Gráfico 6: Distribuição da frequência de resposta aos constructos de rede externa 


\section{d) Autonomia}

As respostas dadas à questão referente às variáveis que integram o constructo autonomia encontram-se no Gráfico 7, que mostra os escores médios de cada indicador do constructo. Para a mensuração desse constructo, foi utilizada uma escala de 5 pontos no qual 1 foi considerado como "a matriz decide sozinha", 2 "matriz decide, mas considera a opinião da subsidiária", 3 "(matriz e subsidiária têm autonomia para decidir)", 4 "subsidiária decide, mas considera sugestões da matriz" e 5 "subsidiária decide sozinha".

Os resultados denotam que as subsidiárias tendem a decidir sozinhas em três dos sete indicadores, quais sejam: "contratação e demissão da fora de trabalho", "gestão de compras", "desenvolvimento de novos fornecedores" e "realização de mudanças no processo de produção". Quanto aos indicadores 'entrada em novos mercados' e 'realização de mudanças em produtos e serviços e desenvolvimento de novos produtos', o resultado indica uma decisão compartilhada, ou seja, ambas (matriz e subsidiárias) têm igual influência nas decisões. A atividade que mais tende à centralização (ou seja, na qual ambas - subsidiárias e matriz - podem decidir) refere-se à assertiva sobre "desenvolvimento de produtos/serviços".

Esses resultados indicam que a subsidiária tem autonomia para desempenhar funções mais corriqueiras da gestão da empresa, tais como gestão de recursos humanos, de compras, de fornecedores, e até realização de melhorias nos processos de produção. Decisões um pouco mais estratégicas, como sobre o "desenvolvimento de novos produtos", são compartilhadas entre subsidiária e matriz. Outro aspecto importante a ser notado é que em nenhum dos indicadores a subsidiária possui autonomia total para decidir; ao contrário, ela sempre deve considerar a opinião da matriz.

Portanto, pode-se concluir que a subsidiária possui uma autonomia parcial para tomar decisões por conta própria, porém sempre sob o crivo da matriz. 


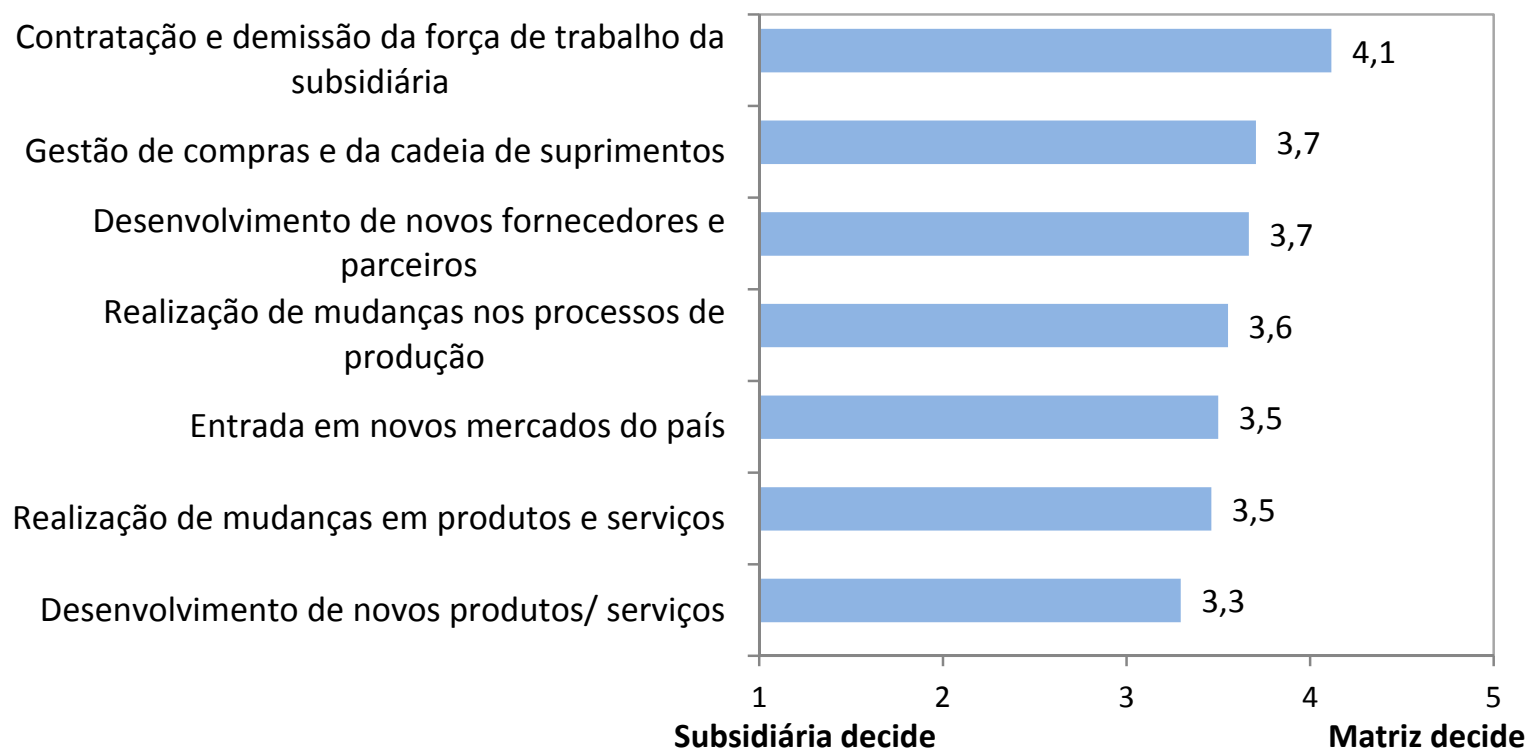

\section{Gráfico 7: Distribuição da frequência de resposta ao constructo autonomia}

\section{e) Motivação}

De acordo com o Gráfico 8, os resultados mostraram que a subsidiária percebe claramente os benefícios em compartilhar conhecimento com a matriz. Com um pouco menos de concordância, as subsidiárias afirmaram que a matriz motiva/incentiva a subsidiária a transferir seu conhecimento. $\mathrm{O}$ indicador com menor concordância foi "a subsidiária compromete recursos físicos, financeiros organizacionais e logísticos para transferir seu conhecimento"; mostrando que, embora haja uma concordância, essa assertiva fica com a menor concordância em relação às demais no constructo.

Portanto, conclui-se que a subsidiária possui motivação para transferir conhecimento para a matriz, muito embora o comprometimento dos recursos físicos e financeiros, apesar de positivo, tenha sido declarado como tímido.

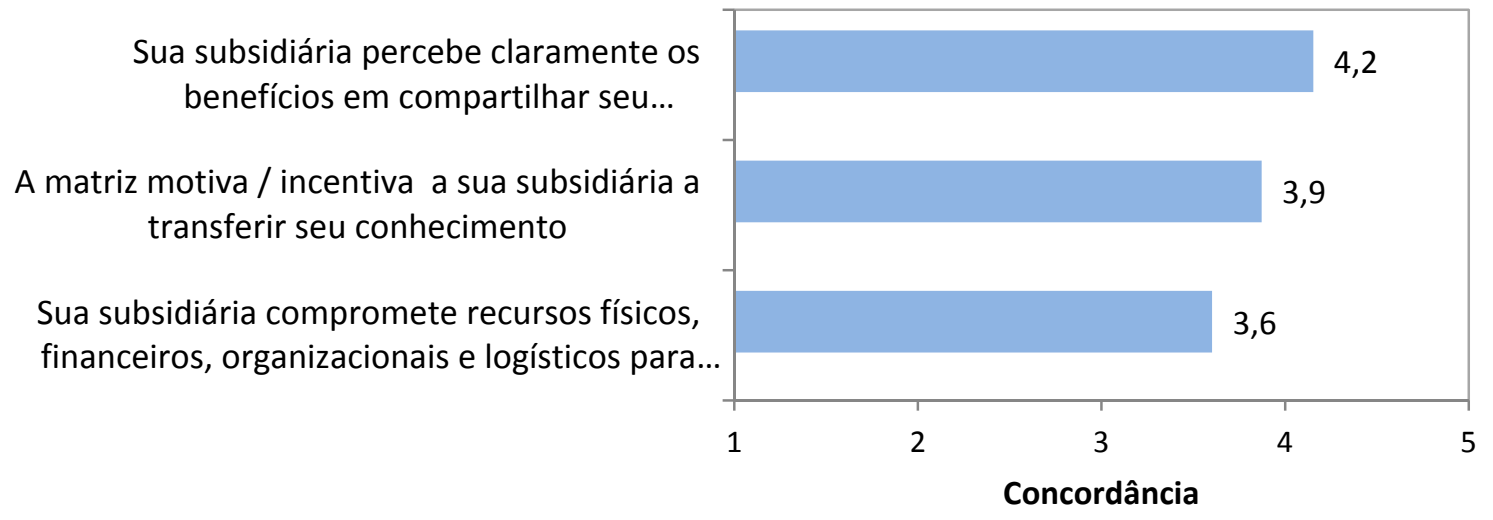

Gráfico 8: Distribuição da frequência de resposta ao constructo motivação 


\subsubsection{Características da interação matriz/subsidiárias}

Neste tópico são avaliados os constructos referentes às características da interação entre $\mathrm{s}$ subsidiárias e matriz: integração interna (com a matriz), semelhança organizacional, semelhança cultural e mecanismos de socialização. A Tabela 5 apresenta os dados obtidos.

Tabela 5: Distribuição de frequências das características da interação subsidiária/matriz

\begin{tabular}{|c|c|c|c|c|c|}
\hline Integração Interna (com a matriz) & Mínimo & Máximo & Média & Mediana & $\begin{array}{l}\text { Desvio- } \\
\text { Padrão }\end{array}$ \\
\hline $\begin{array}{l}\text { A demanda de mercado está crescendo no setor da } \\
\text { subsidiária }\end{array}$ & 1 & 5 & 4 & 3,8 & 1,2 \\
\hline $\begin{array}{l}\text { Os consumidores locais exigem padrões elevados } \\
\text { de qualidade e funcionalidades em } \\
\text { produtos/serviços }\end{array}$ & 1 & 5 & 4 & 4,1 & 1,0 \\
\hline A competição no país é intensa & 1 & 5 & 4 & 3,9 & 1,2 \\
\hline \multirow{2}{*}{$\begin{array}{l}\text { A velocidade da inovação dos competidores é alta } \\
\text { As capacidades e qualidades dos fornecedores são } \\
\text { elevadas }\end{array}$} & 1 & 5 & 4 & 3,3 & 1,3 \\
\hline & 1 & 5 & 4 & 4,0 & 1,0 \\
\hline Semelhança Organizacional & Mínimo & Máximo & Média & Mediana & $\begin{array}{l}\text { Desvio- } \\
\text { Padrão }\end{array}$ \\
\hline $\begin{array}{l}\text { As bases do conhecimento tecnológico da } \\
\text { subsidiária e da matriz são muito semelhantes }\end{array}$ & 1 & 5 & 3,5 & 3,3 & 1,1 \\
\hline $\begin{array}{l}\text { As práticas de negócio e os mecanismos } \\
\text { operacionais são muito semelhantes entre } \\
\text { subsidiária e matriz }\end{array}$ & 1 & 5 & 4 & 3,5 & 0,9 \\
\hline $\begin{array}{l}\text { O estilo gerencial é muito semelhante entre } \\
\text { subsidiária e matriz }\end{array}$ & 1 & 5 & 4 & 3,5 & 0,9 \\
\hline $\begin{array}{l}\text { A cultura organizacional é muito semelhante entre } \\
\text { subsidiária e matriz }\end{array}$ & 1 & 5 & 3 & 3,2 & 1,1 \\
\hline Semelhança Cultural & Mínimo & Máximo & Média & Mediana & $\begin{array}{l}\text { Desvio- } \\
\text { Padrão }\end{array}$ \\
\hline $\begin{array}{l}\text { A cultura dos países-sede da matriz e da subsidiária } \\
\text { influencia fortemente o modo de fazer negócio }\end{array}$ & 1 & 5 & 3,9 & 4 & 1,0 \\
\hline $\begin{array}{l}\text { Muitos desentendimentos e conflitos culturais } \\
\text { emergem da transferência de conhecimento entre } \\
\text { subsidiária e matriz }\end{array}$ & 1 & 5 & 2,7 & 3 & 1,1 \\
\hline $\begin{array}{l}\text { As diferenças de idioma são os principais } \\
\text { obstáculos na comunicação e compreensão entre } \\
\text { subsidiária e matriz }\end{array}$ & 1 & 5 & 2,5 & 2 & 1,1 \\
\hline
\end{tabular}

\begin{tabular}{|c|c|c|c|c|c|}
\hline Mecanismos de Socialização & Mínimo & Máximo & Média & Mediana & $\begin{array}{l}\text { Desvio- } \\
\text { Padrão }\end{array}$ \\
\hline \multirow{2}{*}{$\begin{array}{l}\text { Compartilhamento de documentos com a matriz } \\
\text { Instrumentos de comunicação baseados em internet, } \\
\text { como fóruns, e-mails, etc. }\end{array}$} & 2 & 5 & 4 & 4,0 & 0,9 \\
\hline & 2 & 5 & 4 & 4,3 & 0,7 \\
\hline $\begin{array}{l}\text { Repositores (banco de dados) de informação, } \\
\text { melhores práticas e lições aprendidas }\end{array}$ & 1 & 5 & 4 & 3,5 & 0,9 \\
\hline $\begin{array}{l}\text { Mapeamento de tipos de conhecimento específico } \\
\text { (incorporados em indivíduos, sistemas específicos } \\
\text { ou base de dados) }\end{array}$ & 1 & 5 & 3 & 3,3 & 0,9 \\
\hline Encontros entre pessoas da matriz e subsidiárias & 2 & 5 & 4 & 3,9 & 0,7 \\
\hline $\begin{array}{l}\text { Constituição de equipe de trabalho envolvendo } \\
\text { pessoas tanto da subsidiária como da matriz }\end{array}$ & 2 & 5 & 4 & 3,6 & 0,9 \\
\hline $\begin{array}{l}\text { Transferência temporária (de curto prazo) de } \\
\text { gerentes da sua subsidiária para a matriz e vice-versa }\end{array}$ & 1 & 5 & 3 & 2,9 & 1,1 \\
\hline
\end{tabular}


Transferência temporária (de curto prazo) de staff científico e técnico (pesquisadores, engenheiros) da subsidiária para a matriz e vice-versa

Treinamentos conjuntos envolvendo pessoas da subsidiária e da matriz

\section{a) Integração interna (com a matriz)}

Os resultados apresentados no Gráfico 9 denotam que "a matriz teve importantes inciativas para o desenvolvimento tecnológico na subsidiária", que "a cooperação entre matriz e subsidiária é frequente", que "a matriz atendeu aos seus interesses ao cooperar para o desenvolvimento tecnológico na subsidiária" e que "a matriz tem participado intensamente do desenvolvimento tecnológico na subsidiária". A afirmação de que "o conhecimento tecnológico da subsidiária foi parcialmente desenvolvido dentro das instalações da matriz" obteve uma concordância fraca $(3,3)$, ou seja, no limite do escore que indica discordância (nesse caso, 3).

Portanto, conclui-se que a maioria das subsidiárias tem uma forte integração com a matriz que colabora para o desenvolvimento do seu conhecimento, sobretudo no que se refere à iniciativa da matriz e à cooperação frequente.

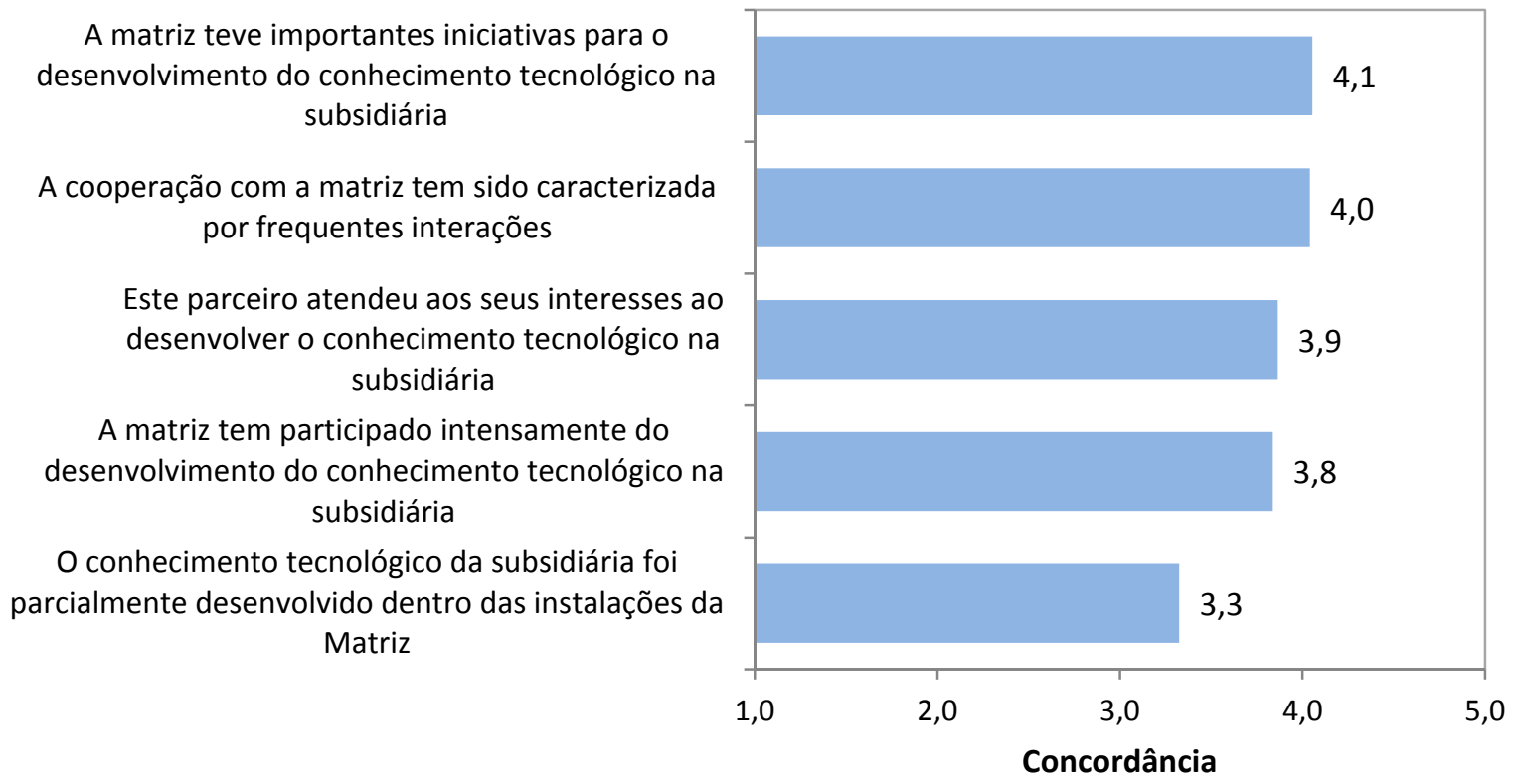

Gráfico 9: Distribuição da frequência de resposta do constructo rede interna (matriz)

\section{b) Semelhança organizacional}


Práticas de negócios e os mecanismos operacionais e o estilo gerencial são os aspectos organizacionais mais semelhantes entre subsidiária e matriz. O conhecimento tecnológico e a cultura corporativa, ainda que de forma moderada, também foram considerados aspectos semelhantes entre matriz e subsidiárias, conforme distribuição de frequência apresentada no Gráfico 10 .

Conclui-se, portanto, que há uma razoável similaridade de contexto organizacional entre matriz e subsidiária.

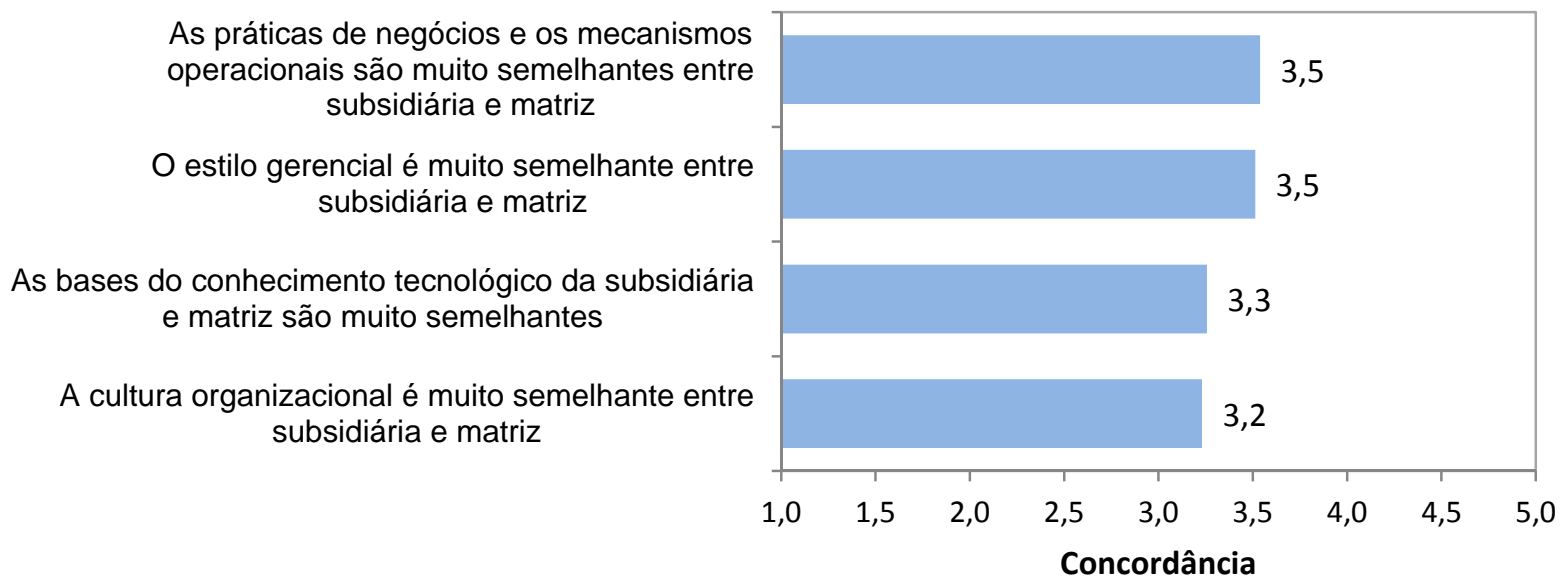

Gráfico 10: Distribuição da frequência de resposta ao constructo semelhança organizacional

\section{c) Semelhança cultural}

De acordo com os gestores entrevistados (Gráfico 11), a cultura nacional influencia fortemente a maneira de fazer negócios, mas eles não acreditam que os mal-entendidos e os conflitos culturais impeçam de alguma maneira a transferência reversa de conhecimento entre as unidades em diferentes países. Além disso, diferenças linguísticas também não parecem ser grandes obstáculos. Esses resultados podem ser devidos ao background dos entrevistados. Todos eles possuem posições de gestão e é muito provável que todos, pelo menos em alguma extensão, tenham sido envolvidos em operações internacionais. Isso pode ser comprovado na análise dos mecanismos de socialização, na qual se observa que muitos dos entrevistados participaram de trabalhos no exterior. 


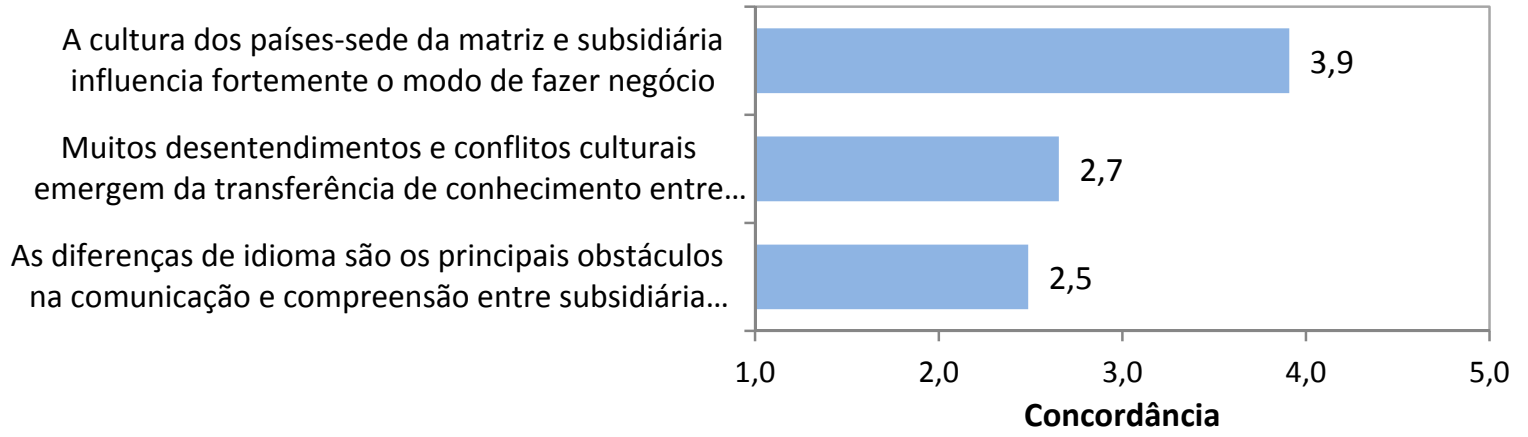

Gráfico 11: Distribuição da frequência de resposta do constructo semelhança cultural

\section{d) Mecanismos de socialização}

A mensuração do constructo mecanismos de socialização incluiu a frequência de utilização de diferentes mecanismos classificados de acordo com os mecanismos de comunicação eletrônica e comunicação pessoal (Gráfico 12 e Gráfico 13). Gestores foram convidados a indicar em uma escala de 1 (muito raramente) a 5 (muito frequentemente), o uso e a frequência de diferentes mecanismos de socialização. Os resultados permitem notar que há frequência de uso da maioria dos mecanismos de socialização.

Os mecanismos mais utilizados, em ordem decrescente, foram: "instrumentos de comunicação baseados em internet, como fóruns, e-mails, etc.", "compartilhamento de documentos com a matriz, tais como manuais, projetos e bases de dados", "encontros entre pessoas da matriz e subsidiárias para transferência de conhecimento", "constituição de equipe de trabalho envolvendo pessoas tanto da subsidiária como da matriz" e "repositores (banco de dados) de informação, melhores práticas e lições aprendidas". Os mecanismos menos utilizados (média < 3,2) foram "transferência temporária (de curto prazo) de gerentes de sua subsidiária para a matriz e vice-versa" e "transferência temporária (de curto prazo) de staff científico e técnico da subsidiária para a matriz e vice-versa”.

$\mathrm{Na}$ comparação entre os grupos, verifica-se que os dois grupos (comunicação eletrônica e pessoal) são utilizados de forma frequente. Esses resultados indicam que a socialização entre subsidiária e matriz ocorre frequentemente tanto por meio de comunicação pessoal, como os encontros face a face, constituição de equipes de trabalho, etc., quanto por meio de comunicação eletrônica, como o compartilhamento de documentos via internet, os repositores de informação e a constituição de equipes de trabalho à distância. O destaque, como já era de esperar, fica por conta dos instrumentos de comunicação baseados em internet. 
O Gráfico 12 apresenta a frequência de utilização dos mecanismos de socialização por meio de comunicação eletrônica.

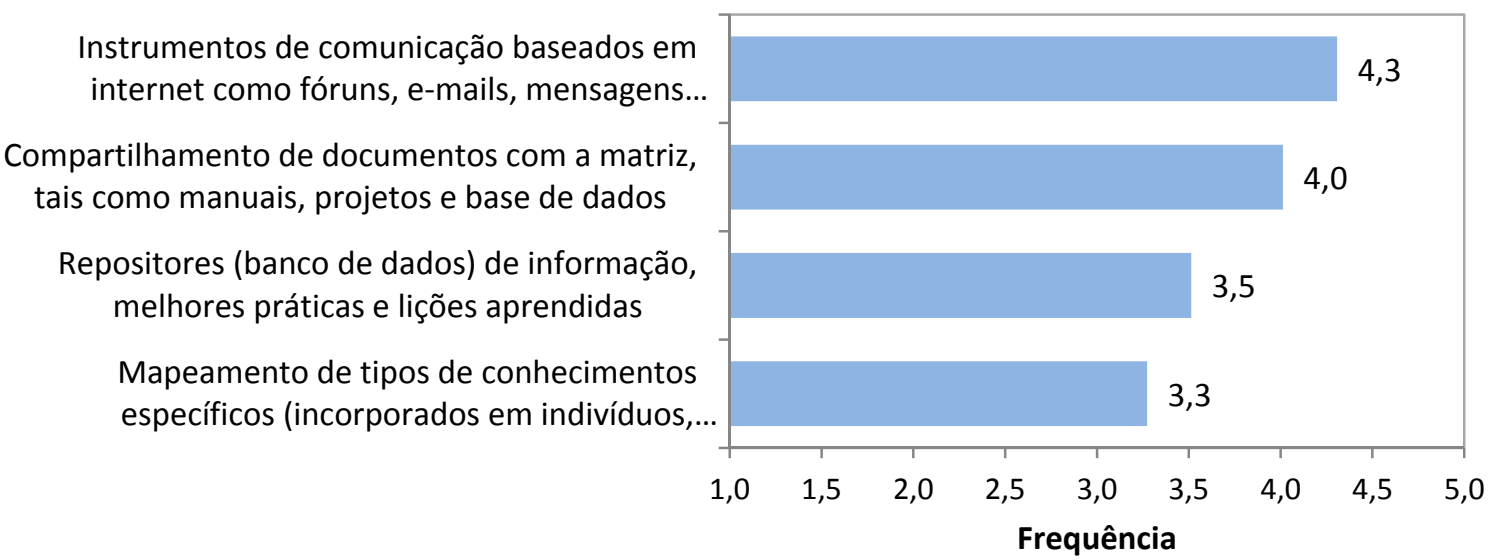

Gráfico 12: Distribuição da frequência de resposta do constructo mecanismos de socialização comunicação eletrônica

O Gráfico 13 apresenta a frequência de utilização dos mecanismos de socialização por meio de contatos pessoais.

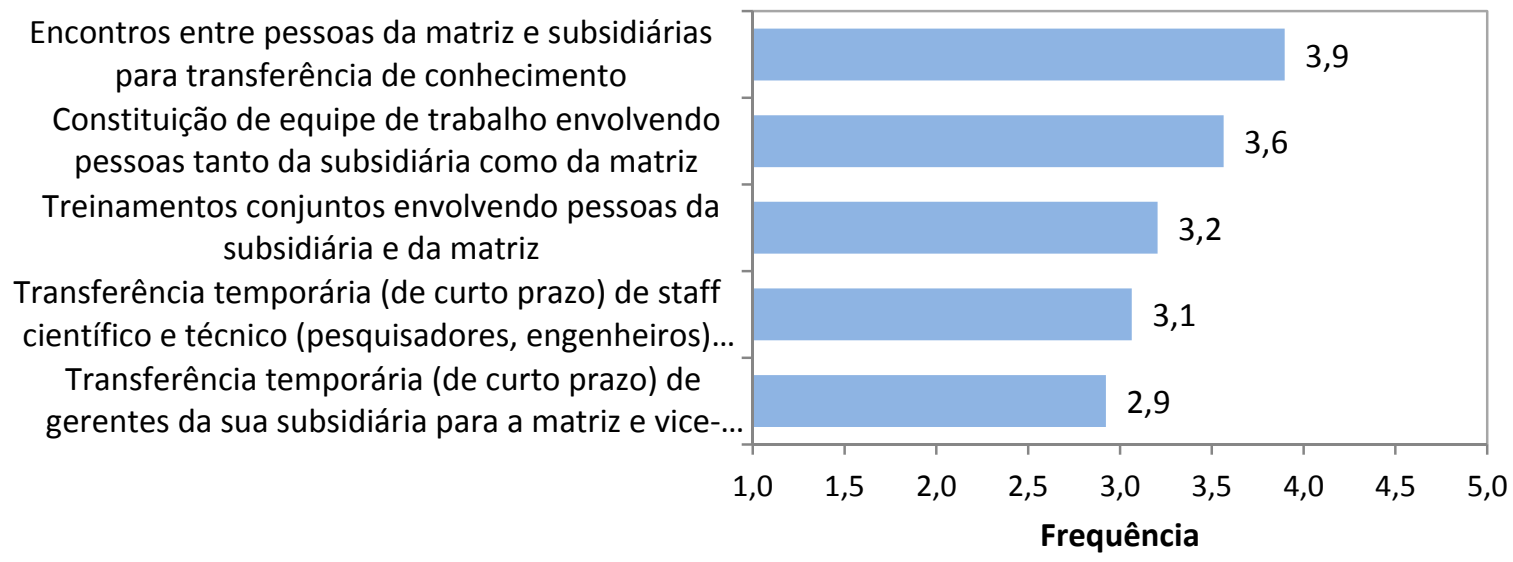

Gráfico 13: Distribuição da frequência de resposta do constructo mecanismos de socialização comunicação pessoal

\subsubsection{Síntese da análise descritiva dos constructos do estudo}

Em termos de contexto externo, os Ambiente Institucional foram destacados como razoavelmente adequados em termos de infraestrutura, boas instituições de negócios, regulamentação e apoio do governo. A existência de centros de pesquisa colaborativos foi relatada como insuficiente. O dinamismo dos Ambiente competitivo, concluiu-se que tende a ser positivo, uma vez que quase dois terços das subsidiárias avaliou positivamente o contexto competitivo em relação à demanda aquecida, à competitividade intensa e aos consumidores exigentes. 
No tocante à autonomia concedida às subsidiárias, destaca-se que elas começam a tomar decisões operacionais sozinhas. O destaque é que elas também começam a decidir, embora que com auxílio da matriz, questões estratégicas relativas, por exemplo, à entrada em novos mercados no país, modificação e desenvolvimento de novos produtos.

Em termos de motivação para transferir conhecimento para a matriz, mais da metade das subsidiárias percebe claramente os benefícios de compartilhar conhecimento e concordam que a matriz as incentiva, contudo, a grande maioria não compromete seus recursos para esse procedimento.

Percebe-se que há bastante semelhança entre os contextos cultural e organizacional da subsidiária e matriz, e que as dificuldades e/ou desentendimentos provenientes das diferentes culturas nacionais não são obstáculos para a transferência reversa de conhecimento.

A integração entre matriz e subsidiária foi o aspecto melhor avaliado pelos respondentes indicando que a matriz coopera frequentemente e que teve importantes iniciativas para o desenvolvimento tecnológico das subsidiárias. Essa relação positiva já não acontece para a integração com os parceiros externos. De maneira geral, existe uma baixa inserção das subsidiárias na rede externa para todos os parceiros de negócios avaliados (clientes, fornecedores e instituições de P\&D) no que se refere a iniciativas e participação desses atores em atividades de desenvolvimento de conhecimento tecnológico nas subsidiárias. Contudo, quando se trata de cooperação frequente, é razoavelmente positiva a interação das subsidiárias com os clientes e os fornecedores.

Os mecanismos de socialização com a matriz, por meio de comunicação eltrônica, são utilizados de forma frequente. Com exceção das trasnferências temporárias de gerentes entre as unidades, os mecanismos de socialização via interação pessoal também são utilizados de forma frequente pela subsidiária, embora que com uma frequência levemente menor se comparado aos mecanismos de comunicação eletrônica.

O conhecimento da subsidiária foi identificado como pouco tácito, tendendo à explítico, mas muito complexo. E no que diz respeito à transferência reversa de conhecimento tecnológico, identificou-se uma razoável transferência de conhecimento sobre produtos, especificamente no que se refere a pequenas mudanças tecnológicas (impulsiondas por necessidades de mercado), 
ou melhorias mais significativas motivadas por especificações técnicas. Também foi identificada uma pequena extensão de transferência reversa de desenvolvimento de novos produtos e know-how para planejar novos produtos. O Quadro 23: a seguir apresenta os prinicpais achados da análise univarida dos dados.

Quadro 23: Síntese dos resultados da análise descritiva

\begin{tabular}{|c|c|}
\hline Indicador & Síntese dos resultados da análise univariada \\
\hline Tacitividade & Fraca tacitividade tendendo a explícito \\
\hline Complexidade & Razoável tendendo a complexo \\
\hline Ambiente Institucional & Razoável ambiente institucional \\
\hline Ambiente competitivo & Razoável tendendo a competitivo \\
\hline Rede externa & $\begin{array}{l}\text { Fraca integração externa com a rede de negócios, especialmente } \\
\text { com os institutos de ciência e tecnologia }\end{array}$ \\
\hline Autonomia & $\begin{array}{l}\text { Forte autonomia para atividades operacionais } \\
\text { Razoável autonomia para atividades estratégicas }\end{array}$ \\
\hline Rede interna & Forte integração entre matriz e subsidiária \\
\hline Motivação & Razoável motivação \\
\hline Semelhança organizacional & Razoável similaridade de contexto organizacional \\
\hline Semelhança cultural & Razoável semelhança cultural \\
\hline Mecanismos de socialização & $\begin{array}{l}\text { Razoável frequência de socialização por meio de comunicação } \\
\text { pessoal e eletrônica }\end{array}$ \\
\hline $\begin{array}{l}\text { Transferência reversa de } \\
\text { conhecimento tecnológico }\end{array}$ & $\begin{array}{l}\text { Razoável transferência de conhecimento sobre produtos } \\
\text { Não há transferência reversa sobre processos e componentes }\end{array}$ \\
\hline
\end{tabular}

FONTE: A autora.

\subsection{Análise multivariada}

Antes de aplicar a MEEPLS, foi aplicada a Análise Fatorial Confirmatória (AFC), por meio do software LISREL para avaliar a adequacidade dos indicadores que medem cada constructo. Com isso, a AFC eliminou alguns indicadores, o que, por conseguinte, aprimorou os dados de entrada na MEEPLS. Nas seções a seguir serão apresentados a metodologia e os resultados de análise de cada procedimento.

\subsubsection{Análise Fatorial Combinatória (AFC)}

A AFC tem o objetivo de verificar qual o conjunto de assertivas realmente mede o constructo analisado. Ou seja, no modelo de mensuração são definidas as relações entre as variáveis observadas (os indicadores) e as variáveis latentes (constructos teóricos), uma vez que estes não podem ser medidas diretamente (SILVA, 2006; HAIR et al., 2005). 
Assim, neste tópico serão apresentados os modelos de mensuração dos constructos e indicadores do instrumento de pesquisa. Os cálculos e análises foram realizados de forma independente para cada questão, em razão do número reduzido de sujeitos e para tentar garantir um mínimo de 4 a 5 sujeitos por indicador (assertiva) na aplicação do modelo. Todos os parâmetros foram estimados por meio do Método dos Mínimos Quadrados não Ponderados (Unweighted Least Squares - ULS).

A validação foi analisada mediante a observação de 4 características: confiabilidade, validade convergente, ajuste do modelo global e unidimensionalidade dos constructos.

A validade verifica se o instrumento mede aquilo que se propõe medir. Uma das formas de validade é a convergente, por meio da qual se verifica a extensão em que os indicadores são capazes de medir um constructo. Sua constatação foi feita observando-se as cargas fatoriais padronizadas. Foram consideradas aceitas como grandes e significativas aquelas que apresentaram significância no teste $t$ inferior a 0,10 (PASQUALI, 2003; IM et al., 1998).

Já a confiabilidade de cada constructo é uma medida da consistência interna de seus indicadores e mostra a adequacidade das escalas para medi-lo. Para a avaliação da confiabilidade foi adotado o alpha de Cronbach. Segundo Hair et al. (2005), um valor de alpha acima de 0,6 é indicativo da adequacidade dos indicadores para medir o constructo.

Para verificar o ajuste do modelo global, utilizaram-se dois tipos de medidas: as medidas de ajuste absolutas, que comparam a matriz de entrada com aquela predita pelo modelo proposto e as medidas de ajuste incrementais, que comparam o modelo proposto, com um modelo nulo. Dentre as medidas de ajuste absolutas, utilizou-se o Qui-quadrado ponderado ( $\chi 2 /$ graus de liberdade), o Goodness-of-fit (GFI) e o Root Mean Square Error of Approximation (RMSEA). O valor do qui-quadrado ponderado deve estar abaixo de 3; o RMSEA, abaixo de 0,08; e o GFI, acima de 0,9 (HAIR et al., 2005). Já dentre as medidas de ajuste incrementais, utilizou-se o Normed fit index (NFI), o Non-Normed Fit Index (NNFI), o Ajusted Goodness-of-Fit Index (AGFI) e o Comparative fit index (CFI). Para todas essas medidas aceitou-se somente valores iguais ou superiores a 0,9 (HAIR et al., 2005). 
A unidimensionalidade dos constructos consiste em verificar se os indicadores estabelecidos representam de fato um único constructo (HAIR et al., 2005), ou seja, cada indicador deve estar associado fortemente a uma única variável latente. Para avaliar a unidimensionalidade dos constructos, observou-se se cada valor da matriz de resíduos normalizados de cada constructo era pequeno (menor que 2,58, a um nível de significância de 5\%).

A seguir, são apresentados os resultados da AFC para cada constructo do modelo deste estudo. No que se refere à avaliação sobre a validade e confiabilidade dos constructos, estão apresentados na Tabela 6. A validade é apresentada por meio dos valores de carga fatorial e de sua significância avaliada ( $p$-value). A confiabilidade é apresentada por meio dos resultados do alpha de Cronbach.

Tabela 6: Modelo de mensuração da AFC - Cargas fatoriais dos constructos e códigos dos indicadores

\begin{tabular}{|c|c|c|c|c|}
\hline Constructo & Indicadores & Código & $\begin{array}{c}\text { Carga } \\
\text { fatorial }\end{array}$ & p-value \\
\hline $\begin{array}{l}\text { Transferência de } \\
\text { Tecnologia de } \\
\text { processos } \\
\text { Alpha }=0,926\end{array}$ & $\begin{array}{l}\text { - Técnicas de organização da produção (ex.: just in } \\
\text { time, controle da qualidade total) } \\
\text { - Planejamento e controle da produção (PCP) } \\
\text { - Processos de automação } \\
\text { - Desenvolvimento de novos processos de produção } \\
\text { - Pequenas mudanças na tecnologia de processo para } \\
\text { adaptá-lo a condições locais } \\
\text { - Melhoria significativa no processo de produção } \\
\text { - Projeto (design) próprio de fabricação } \\
\text { - Desenvolvimento de novos equipamentos e/ou } \\
\text { - ferramentas } \\
\text { - Mabricação de novos componentes } \\
\text { - Mantagem de componentes e produtos finais }\end{array}$ & \begin{tabular}{|c|} 
TTPROC1 \\
TTPROC2 \\
TTPROC3 \\
TTPROC4 \\
TTPROC5 \\
TTPROC6 \\
TTPROC7 \\
TTPROC8 \\
TTPROC9 \\
TTPROC10 \\
TTPROC11
\end{tabular} & $\begin{array}{l}0,783 \\
0,674 \\
0,835 \\
0,853 \\
0,708 \\
0,835 \\
0,693 \\
0,611 \\
0,747 \\
0,723 \\
0,617 \\
\end{array}$ & $\begin{array}{l}0,044 \\
0,044 \\
0,045 \\
0,045 \\
0,044 \\
0,045 \\
0,043 \\
0,043 \\
0,044 \\
0,044 \\
0,043 \\
\end{array}$ \\
\hline $\begin{array}{l}\text { Transferência de } \\
\text { Tecnologia de } \\
\text { produtos } \\
\text { Alpha }=0,895\end{array}$ & $\begin{array}{l}\text { - Pequenas adaptações na tecnologia de produtos } \\
\text { existentes (impulsionadas por necessidades de } \\
\text { mercado ou de produção) } \\
\text { - Melhoria significativa em produtos existentes } \\
\text { - Desenvolvimento de novos produtos } \\
\text { - Rotinas de controle de qualidade } \\
\text { - Desenvolvimento de novos protótipos } \\
\text { - Testes de novos produtos } \\
\text { - Know-how e experiência técnica na forma de planos, } \\
\text { modelos, instruções, fórmulas, especificações, para } \\
\text { projetar novos produtos } \\
\text { - Resultados de pesquisa sobre novos materiais e novas } \\
\text { especificações } \\
\text { - Resultados de pesquisa e desenvolvimento sobre } \\
\text { nova geração de produtos }\end{array}$ & $\begin{array}{l}\text { TTPROD12 } \\
\text { TTPROD13 } \\
\text { TTPROD14 } \\
\text { TTPROD15 } \\
\text { TTPROD16 } \\
\text { TTPROD17 } \\
\text { TTPROD18 }\end{array}$ & $\begin{array}{l}0,788 \\
0,837 \\
0,778 \\
0,773 \\
0,682 \\
0,503 \\
0,507 \\
0,614 \\
0,729\end{array}$ & $\begin{array}{l}0,047 \\
0,048 \\
0,048 \\
0,047 \\
0,047 \\
0,046 \\
0,046 \\
0,047 \\
0,048\end{array}$ \\
\hline $\begin{array}{l}\text { Tacitividade } \\
\text { conhecimento } \\
\text { tecnológico } \\
\text { Alpha }=0,812 \\
\end{array}$ & $\begin{array}{l}\text { - É fácil de documentar em manuais, relatórios e } \\
\text { imagens } \\
\text { - É fácil de compreender por meio de documentos } \\
\text { escritos }\end{array}$ & $\begin{array}{l}\text { TACIT1 } \\
\text { TACIT2 }\end{array}$ & $\begin{array}{l}0,872 \\
0,504\end{array}$ & $\begin{array}{l}0,092 \\
0,053\end{array}$ \\
\hline
\end{tabular}




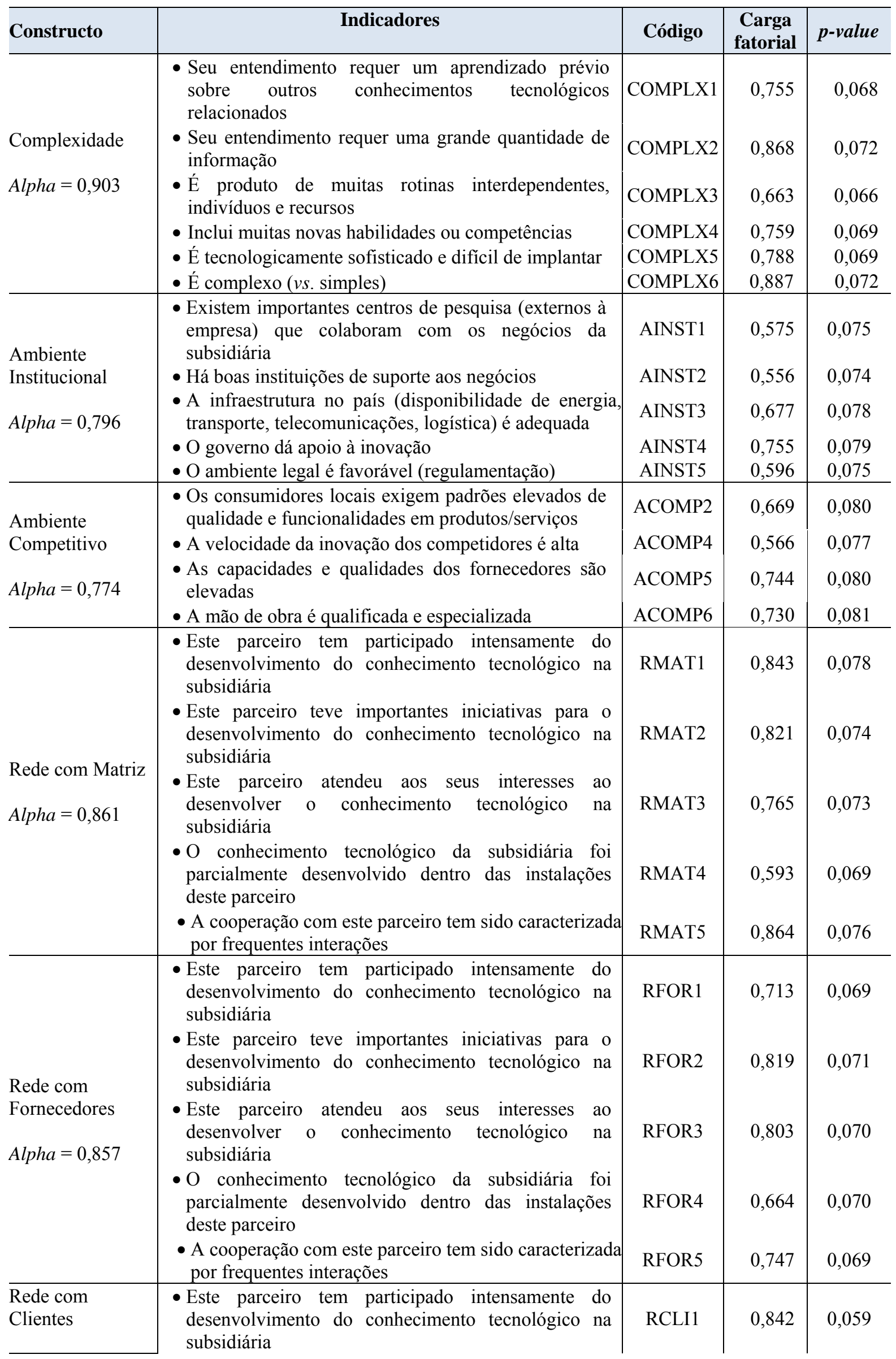




\begin{tabular}{|c|c|c|c|c|}
\hline Constructo & Indicadores & Código & $\begin{array}{c}\text { Carga } \\
\text { fatorial }\end{array}$ & p-value \\
\hline Alpha $=0,914$ & $\begin{array}{l}\text { - Este parceiro teve importantes iniciativas para o } \\
\text { desenvolvimento do conhecimento tecnológico na } \\
\text { subsidiária } \\
\text { - Este parceiro atendeu aos seus interesses ao } \\
\text { desenvolver o conhecimento tecnológico na } \\
\text { subsidiária } \\
\text { - O conhecimento tecnológico da subsidiária foi } \\
\text { parcialmente desenvolvido dentro das instalações } \\
\text { deste parceiro } \\
\text { - A cooperação com este parceiro tem sido caracterizada } \\
\text { por frequentes interações }\end{array}$ & $\begin{array}{l}\text { RCLI4 } \\
\text { RCLI5 }\end{array}$ & $\begin{array}{l}0,837 \\
0,809\end{array}$ & $\begin{array}{l}0,058 \\
0,058\end{array}$ \\
\hline $\begin{array}{l}\text { Rede com } \\
\text { Instituições de } \\
\text { C\&T }\end{array}$ & $\begin{array}{l}\text { - Este parceiro tem participado intensamente do } \\
\text { desenvolvimento do conhecimento tecnológico na } \\
\text { subsidiária } \\
\text { - Este parceiro teve importantes iniciativas para o } \\
\text { desenvolvimento do conhecimento tecnológico na } \\
\text { subsidiária } \\
\text { - Este parceiro atendeu aos seus interesses ao } \\
\text { desenvolver o conhecimento tecnológico na } \\
\text { subsidiária } \\
\text { - O conhecimento tecnológico da subsidiária foi } \\
\text { parcialmente desenvolvido dentro das instalações } \\
\text { deste parceiro } \\
\text { - A cooperação com este parceiro tem sido caracterizada } \\
\text { por frequentes interações }\end{array}$ & RC\&T4 & $\begin{array}{l}0,917 \\
0,929\end{array}$ & $\begin{array}{l}0,046 \\
0,046\end{array}$ \\
\hline $\begin{array}{l}\text { Autonomia } \\
\text { Alpha }=0,867\end{array}$ & $\begin{array}{l}\text { - Realização de mudanças em produtos e serviços } \\
\text { - Desenvolvimento de novos produtos/ serviços } \\
\text { - Realização de mudanças nos processos de produção } \\
\text { - Entrada em novos mercados do país } \\
\text { - Desenvolvimento de novos fornecedores e parceiros } \\
\text { - Gestão de compras e da cadeia de suprimentos } \\
\text { - Contratação e demissão da força de trabalho da } \\
\text { subsidiária }\end{array}$ & $\begin{array}{l}\text { AUTO1 } \\
\text { AUTO2 } \\
\text { AUTO3 } \\
\text { AUTO4 } \\
\text { AUTO5 } \\
\text { AUTO6 } \\
\text { AUTO7 }\end{array}$ & $\begin{array}{l}0,775 \\
0,677 \\
0,800 \\
0,723 \\
0,729 \\
0,691 \\
0,511\end{array}$ & $\begin{array}{l}0,073 \\
0,070 \\
0,072 \\
0,070 \\
0,070 \\
0,072 \\
0,067\end{array}$ \\
\hline $\begin{array}{l}\text { Motivação } \\
\text { Alpha }=0,795\end{array}$ & $\begin{array}{l}\text { - Sua subsidiária percebe claramente os benefícios em } \\
\text { compartilhar seu conhecimento com a matriz } \\
\text { - A matriz motiva/incentiva sua subsidiária a transferir } \\
\text { seu conhecimento } \\
\text { - Sua subsidiária compromete recursos físicos, } \\
\text { financeiros, organizacionais e logísticos para } \\
\text { transferir seu conhecimento para a matriz }\end{array}$ & $\begin{array}{l}\text { MOTIV1 } \\
\text { MOTIV2 } \\
\text { MOTIV3 }\end{array}$ & 0,675 & $\begin{array}{l}0,013 \\
0,018 \\
0,012\end{array}$ \\
\hline $\begin{array}{l}\text { Semelhança } \\
\text { Organizacional } \\
\text { Alpha }=0,724\end{array}$ & $\begin{array}{l}\text { - As bases do conhecimento tecnológico da subsidiária } \\
\text { e matriz são muito semelhantes } \\
\text { - As práticas de negócios e os mecanismos operacionais } \\
\text { são muito semelhantes entre subsidiária e matriz } \\
\text { - O estilo gerencial é muito semelhante entre } \\
\text { subsidiária e matriz } \\
\text { - A cultura organizacional é muito semelhante entre } \\
\text { subsidiária e matriz }\end{array}$ & $\begin{array}{l}\text { SORG2 } \\
\text { SORG3 } \\
\text { SORG4 }\end{array}$ & $\begin{array}{l}0,567 \\
0,810 \\
0,697\end{array}$ & $\begin{array}{l}0,108 \\
0,112 \\
0,014 \\
0,120\end{array}$ \\
\hline $\begin{array}{l}\text { Mecanismo de } \\
\text { Socialização }\end{array}$ & $\begin{array}{l}\text { - Compartilhamento de documentos com a matriz, tais } \\
\text { como manuais, projetos e bases de dados } \\
\text { - Instrumentos de comunicação baseados em internet, } \\
\text { como fóruns, e-mails, mensagens instantâneas, etc. } \\
\text { - Repositores (banco de dados) de informação, } \\
\text { melhores práticas e lições aprendidas }\end{array}$ & $\begin{array}{l}\text { SOC1 } \\
\text { SOC2 } \\
\text { SOC3 }\end{array}$ & $\begin{array}{l}0,592 \\
0,591 \\
0,866\end{array}$ & $\begin{array}{l}0,072 \\
0,072 \\
0,078\end{array}$ \\
\hline
\end{tabular}




\begin{tabular}{|c|c|c|c|c|}
\hline Constructo & Indicadores & Código & $\begin{array}{c}\text { Carga } \\
\text { fatorial }\end{array}$ & p-value \\
\hline & $\begin{array}{l}\text { - Mapeamento de tipos de conhecimento específico } \\
\text { (incorporados em indivíduos, sistemas específicos ou } \\
\text { bases de dados) }\end{array}$ & SOC4 & 0,776 & 0,076 \\
\hline & $\begin{array}{l}\text { - Encontros entre pessoas da matriz e das subsidiárias } \\
\text { para transferência de conhecimento }\end{array}$ & SOC5 & 0,626 & 0,071 \\
\hline & $\begin{array}{l}\text { - Constituição de equipe de trabalho envolvendo } \\
\text { pessoas tanto da subsidiária como da matriz }\end{array}$ & SOC6 & 0,670 & 0,071 \\
\hline & $\begin{array}{l}\text { - Transferência temporária (de curto prazo) de gerentes } \\
\text { da sua subsidiária para a matriz e vice-versa }\end{array}$ & SOC7 & 0,672 & 0,071 \\
\hline & $\begin{array}{l}\text { - Transferência temporária (de curto prazo) de staff } \\
\text { científico e técnico (pesquisadores, engenheiros) da } \\
\text { subsidiária para a matriz e vice-versa }\end{array}$ & SOC8 & 0,557 & 0,070 \\
\hline & $\begin{array}{l}\text { - Treinamentos conjuntos envolvendo pessoas da } \\
\text { subsidiária e da matriz }\end{array}$ & SOC9 & 0,672 & 0,070 \\
\hline
\end{tabular}

A partir da análise dos dados apresentados na Tabela 6 , discute-se a validade por meio da significância do test $t$ e a confiabilidade, por meio do alpha de Cronbach para os resultados da análise fatorial combinatória (AFC).

\section{a) Validade (significância do test t)}

Conforme apresentado na Tabela 6, optou-se por classificar o constructo "transferência reversa de conhecimento tecnológico" em apenas dois subgrupos: transferência de processos e de produtos, em vez de classificá-lo de acordo com os três tipos de níveis de capacidade tecnológica, de acordo com Iammarino, Padilla-Pérez e Tunzelmann (2008), Lall (1992), Bell e Pavitt (1995) e Ariffin e Figueiredo (2003). Isso se deu porque essa classificação foi a que apresentou melhor ajuste, tanto em termos de validade (carga fatorial), como em termos das medidas de ajuste global.

Os resultados da AFC apontam valores de significância do teste $t$ abaixo de 0,10 para todos os indicadores dos constructos avaliados. Isso indica uma boa validade convergente para esses constructos, ou seja, os indicadores são capazes de medir cada um dos constructos avaliados, com exceção de um caso específico:

- Nenhum dos indicadores do constructo "contexto cultural" - SCUL1 (a cultura dos países sede da matriz e da subsidiária influenciam fortemente o modo de fazer negócio), SCULT2 (muitos desentendimentos e conflitos culturais emergem da transferência de conhecimento entre subsidiária e matriz) e SCULT3 (as diferenças de idioma são os 
principais obstáculos na comunicação e compreensão entre subsidiária e matriz) apontou cargas fatoriais significantes; o valor de alpha de todos ficou em 0,362. Dessa forma, não se pode dizer que os indicadores medem esta ideia e, portanto, este constructo foi excluído do modelo.

\section{b) Confiabilidade (alpha de Cronbach)}

A confiabilidade (mensurada pelo alpha de Cronbach) ficou acima de 0,6 para cada um dos constructos avaliados, indicando boa adequação do modelo de mensuração. Importante ressaltar que, para chegar a um alpha de Cronbach adequado, ou seja, maior que 0,6, foi preciso eliminar alguns indicadores que não mostravam aderência aos seus respectivos constructos, quais sejam:

- Tacitividade: TACIT3 (é mais explícito do que tácito - difícil de documentar, imitar e aprender).

- Ambiente competitivo: ACOMP1 (a demanda do mercado está crescendo no setor da subsidiária) e ACOMP3 (a competição no país é intensa).

- Semelhança cultural: é importante ressaltar que esse constructo, mensurados pelos indicadores SCULT5 a SCULT7 não apontou cargas fatoriais significantes e seu valor de alpha ficou em 0,362. Dessa forma, não se pode dizer que os indicadores medem esta ideia, e o constructo foi excluído do modelo.

Sendo assim, os 86 indicadores iniciais foram reduzidos a 80 indicadores após a análise de AFC.

A Tabela 7 apresenta os dados sobre o ajuste do modelo global - representado pelas medidas: Qui-quadrado, RMSEA, GFI, AGFI, NFI e NNFI - e a unidimensionalidade dos constructos - representado CFI. 
Tabela 7: Modelo de mensuração global para todos os constructos

\begin{tabular}{|c|c|c|c|c|c|c|c|c|c|c|}
\hline Avaliação & $\begin{array}{l}\text { Valores de } \\
\text { Referência }\end{array}$ & $\begin{array}{c}\text { Transferência } \\
\text { de } \\
\text { conhecimento }\end{array}$ & Tacitividade & Complexidade & $\begin{array}{c}\text { Fatores } \\
\text { específ. País e } \\
\text { Indústria }\end{array}$ & $\begin{array}{c}\text { Rede Interna/ } \\
\text { Externa }\end{array}$ & Autonomia & Motivação & $\begin{array}{c}\text { Semelhança } \\
\text { organizacional } \\
\text { e cultural }\end{array}$ & $\begin{array}{c}\text { Mecanismos } \\
\text { de } \\
\text { socialização }\end{array}$ \\
\hline Qui-quadrado & $<3,0$ & 3,306 & $<0,001$ & 1,986 & 2,176 & 2,811 & 4,290 & $<0,001$ & 5,826 & 4,895 \\
\hline RMSEA & $<0,08$ & 0,178 & $<0,001$ & 0,114 & 0,124 & 0,160 & 0,209 & $<0,001$ & 0,252 & 0,226 \\
\hline GFI & $>0,9$ & 0,938 & $>0,999$ & 0,996 & 0,971 & 0,938 & 0,975 & $>0,999$ & 0,981 & 0,969 \\
\hline AGFI & $>0,9$ & 0,923 & $>0,999$ & 0,992 & 0,950 & 0,927 & 0,950 & $>0,999$ & 0,906 & 0,939 \\
\hline NFI & $>0,9$ & 0,923 & $>0,999$ & 0,995 & 0,945 & 0,923 & 0,959 & $>0,999$ & 0,949 & 0,946 \\
\hline NNFI & $>0,9$ & 0,976 & $>0,999$ & $>0,999$ & $>0,999$ & $>0,999$ & 0,989 & $>0,999$ & 0,908 & 0,978 \\
\hline CFI & $>0,9$ & 0,979 & 1,000 & 1,000 & 1,000 & 1,000 & 0,993 & 1,000 & 0,969 & 0,985 \\
\hline
\end{tabular}

Legenda: Para as medidas de ajuste absolutas, o Qui-quadrado ponderado deve estar abaixo de 3; o RMSEA, abaixo de 0,08; e o GFI, acima de 0,9 (HAIR et al., 2005).

Para as medidas de ajuste incrementais, utilizou-se Ajusted Goodness-of-Fit Index (AGFI), Normed fit index (NFI), Non-Normed Fit Iindex (NNFI) e Comparative fit index (CFI). Para todas estas medidas foram aceitos somente valores iguais ou superiores a 0,9 (HAIR et al., 2005).

A partir da análise dos dados apresentados na Tabela 7, avalia-se o ajuste do modelo global e a unidimensionalidade dos constructos para os resultados da análise fatorial combinatória (AFC). 


\section{c) Ajuste do modelo global e unidimensionalidade}

De acordo com a tabela acima, podem-se fazer as seguintes análises com base nos resultados dos testes da AFC.

Transferência de conhecimento tecnológico: todas as medidas de ajuste se mostraram adequadas, exceto o qui-quadrado e o RMSEA. No entanto, Hair et al. (2005, p. 523) afirmam que o RMSEA é mais adequado para uso em amostras maiores, de forma que o não ajuste desta medida pode ser devido ao baixo número de respondentes desta pesquisa. Para avaliar a unidimensionalidade dos constructos, observou-se se cada valor da matriz de resíduos normalizados de cada constructo era pequeno (menor que 2,58, a um nível de significância de $5 \%)$. Ao se analisar o valor do CFI, verificou-se que apenas 2,1\% (1-0,979) dos resíduos possuíam valor acima de 2,58, o que é considerado adequado.

- Tacitividade, complexidade, Ambiente Institucional e da indústria, rede interna e externa e motivação: observou-se que todas as medidas de ajuste se mostraram adequadas. Com relação ao valor do CFI, verificou-se que nenhum dos resíduos possuía valor acima de 2,58, o que é considerado adequado.

- Autonomia: observou-se que todas as medidas de ajuste se mostraram adequadas, exceto o RMSEA e o qui-quadrado ponderado. Para avaliar a unidimensionalidade dos constructos, verificou-se se cada valor da matriz de resíduos normalizados de cada constructo era pequeno (menor que 2,58, a um nível de significância de 5\%). Quanto ao valor do CFI, observou-se que apenas $0,7 \%(1-0,993)$ dos resíduos possuía valor acima de 2,58, o que é considerado adequado.

- Semelhança cultural: é importante ressaltar que este constructo, mensurado pelos indicadores 16.5 a 16.7, não apontou cargas fatoriais significantes, e que seu valor de alpha ficou em 0,362. Dessa forma, não se pode dizer que os indicadores medem esta ideia, razão pela qual ela foi excluída do modelo.

- Semelhança organizacional: observou-se que todas as medidas de ajuste se mostraram adequadas, exceto o RMSEA e o qui-quadrado ponderado. Para avaliar a 
unidimensionalidade dos constructos, observou-se o CFI e verificou-se que apenas 3,1\% (1-0,969) dos resíduos possuía valor acima de 2,58, o que é considerado adequado.

- Mecanismos de Socialização: observou-se que todas as medidas de ajuste se mostraram adequadas, exceto o RMSEA e o qui-quadrado ponderado. Para avaliar a unidimensionalidade dos constructos, verificou-se o CFI e constatou-se que apenas $1,5 \%(1-0,985)$ dos resíduos possuía valor acima de 2,58 , o que é considerado adequado.

Na seção a seguir serão apresentados os resultados da modelagem de equações estruturais com Partial Least Square (MEEPLS). Cabe ressaltar que os dados de entrada para o processamento da MEEPLS atingiu o número de 78 indicadores, já que os 84 indicadores iniciais do estudo foram reduzidos para 78 com a exclusão de 6 indicadores na AFC.

\subsubsection{Modelagem de equações estruturais - partial least square (MEEPL)}

A modelagem de equações estruturais foi realizada em duas etapas. A primeira foi a avaliação do modelo de mensuração e a segunda foi a avalição do modelo estrutural. Nos tópicos seguintes, a avaliação dois modelos será apresentada.

\subsubsection{Avaliação do modelo de mensuração}

Primeiramente, por meio do software Smart PLS 3.0, testou-se novamente a adequacidade dos indicadores para medir cada um dos constructos, utilizando-se como input os indicadores apontados pelo LISREL como significativos. Esta etapa foi importante para corroborar (ou não) os modelos obtidos pelo LISREL. Em seguida, procedeu-se à avaliação do modelo de mensuração. A avaliação do modelo de mensuração foi feita por meio das análises relacionadas à validade e confiabilidade dos constructos. A confiabilidade dos constructos foi analisada por meio do alpha de Cronbach (medido pelas cargas dos coeficientes de caminho) e da confiabilidade do compósito. A validade dos constructos foi medida pela variância média extraída AVE (validade convergente), pelas cargas cruzadas e pelo critério de Fornell-Larcker (validade discriminante).

\subsection{Confiabilidade do indicador (alpha de Cronbach)}


A confiabilidade do indicador especifica qual parte da variância do indicador pode ser explicada pela variável latente subjacente. Para analisar a confiabilidade de um indicador utiliza-se sua carga fatorial.

Buscando aperfeiçoar o modelo, a cada processamento foi retirado de cada constructo, no máximo um indicador com carga fatorial inferior a 0,7 , conforme detalhado na Tabela 8 , pois este acarreta baixa validade e confiabilidade para o modelo de mensuração. O novo modelo formado foi processado, obtendo-se, assim, outros valores para as cargas fatoriais. Esse processo foi repetido até se obterem cargas fatoriais aceitáveis, ou seja, valores preferencialmente maiores que 0,7 (FORNELL; LARCKER, 1981; CHIN, 1998) para todas as variáveis. Cabe salientar, no entanto, que cargas menores, de 0,6 ou de 0,7 , podem ser aceitas (até o limite de 0,41 ), dependendo dos outros indicadores do constructo, como forma de manter a validade de conteúdo (HAIR, et al., 2013, p. 103). A Tabela a seguir apresenta os indicadores excluídos do modelo por apresentaram carga fatorial menor que 0,7 .

Tabela 8: Indicadores excluídos do modelo por apresentarem carga fatorial menor que 0,7

\begin{tabular}{|c|c|c|}
\hline Constructos & $\begin{array}{c}\text { Constructos de } 1^{\mathrm{a}} \\
\text { Ordem }\end{array}$ & $\begin{array}{c}\text { Constructos de } 2 \mathrm{a} \\
\text { e 3a ordem }\end{array}$ \\
\hline Ambiente Competitivo & $\begin{array}{l}\text { ACOMP5 } \\
\text { ACOMP6 }\end{array}$ & \\
\hline Ambiente Isntitucional & AINST10 & \\
\hline Complexidade & COMPLX1 & \\
\hline Semelhança Organizacional & $\begin{array}{l}\text { SORG3 } \\
\text { SORG4 }\end{array}$ & \\
\hline Mecanismos de Socialização & $\begin{array}{l}\text { SOC1 } \\
\text { SOC4 } \\
\text { SOC5 } \\
\text { SOC6 }\end{array}$ & \\
\hline Motivação & & MOTIV1 \\
\hline Transferência de conhecimento tecnológico de processo & & $\begin{array}{l}\text { TPROC8 } \\
\text { TPROC10 } \\
\text { TPROC } 11\end{array}$ \\
\hline Transferência de conhecimento tecnológico de produto & & $\begin{array}{l}\text { TPROD13 } \\
\text { TPROD15 } \\
\text { TPROD17 } \\
\text { TPROD18 }\end{array}$ \\
\hline
\end{tabular}

Após as várias estimações do modelo de mensuração, os 78 indicadores iniciais resultantes do modelo de AFC foram reduzidos a 60 indicadores, já que a análise de confiabilidade do indicador eliminou 18 deles do modelo.

Com relação aos constructos, tacitividade, rede com matriz, rede com fornecedores, rede com clientes, rede com instituições privadas de C\&T e autonomia, destaca-se que todos obtiveram 
cargas fatoriais acima de 0,7. Em outros termos, os índices de confiabilidade foram aceitos sem que fosse necessário excluir nenhum indicador.

Já para o constructo "Ambiente competitivo" foi necessário excluir o indicador ACOMP5 (as capacidades e qualidades dos fornecedores são elevadas) e ACOMP6 (a mão de obra é qualificada e especializada). Para esse constructo, a confiabilidade de compósito não alcançou o valor recomendado de 0,7 (ficou com 0,69), mas como a AVE ficou acima de 0,5, e o alpha de cronbach acima de 0,7 optou-se por não excluir outros indicadores do constructo, sob pena de prejudicar a validade de conteúdo do constructo.

Também foi necessário a exclusão do indicador AINST10 (o ambiente legal é favorável) do constructo "Ambiente Institucional”, pois a confiabilidade de compósito não alcançou o valor recomendado de 0,7 .

Da mesma forma aconteceu com o constructo "semelhança organizacional", no qual foi excluído o indicador SORG3 (o estilo gerencial é muito semelhante entre subsidiária e matriz) e o SORG4 (a cultura organizacional é muito semelhante entre subsidiária e matriz). Ao final, esse constructo apresentou uma carga fatorial abaixo de 0,7 , mas obteve AVE e confiabilidade compósita acima do recomendado (HAIR et al., 2013).

Quanto ao constructo motivação, foi excluído o indicador MOTIV1 (a subsidiária percebe claramente os benefícios em compartilhar seu conhecimento com a matriz). Depois dessa exclusão, esse constructo apresentou carga fatorial acima de 0,739 e AVE acima de 0,791, atendendo assim, aos critérios de aceitação recomendados por (HAIR et al., 2013).

No que se refere ao constructo "mecanismos de socialização", foram excluídos os indicadores: SOC1 (compartilhamento de documentos com a matriz, tais como manuais, projetos e bases de dados), SOC4 (mapeamento dos tipos de conhecimentos específicos), SOC5 (encontros entre pessoas da matriz e das subsidiárias para transferência de conhecimento) e SOC6 (constituição de equipe de trabalho envolvendo pessoas da matriz e da subsidiária). Após essa exclusão o constructo mecanismos de socialização passou a ser mensurado com sete indicadores com carga fatorial acima de 0,67 . 
As cargas finais por constructo estão detalhadas na Erro! Fonte de referência não encontrada. que apresenta as cargas cruzadas por indicadores do modelo.

\subsection{Análise da Confiabilidade Compósita (CC)}

No que se refere à confiabilidade compósita, observa-se que todos os constructos alcançaram o valor acima de 0,7 (Tabela 9).

\subsection{Análise da Variância Extraída (AVE)}

Após a exclusão das variáveis com cargas fatoriais menores que 0,7 , ou seja, considerando-se o modelo final de estimação (Tabela 9), observa-se que os valores da average variance extracted - AVE (variância média extraída) em todos os constructos do modelo são iguais ou superiores a 0,5 , condição mínima exigida para que o modelo tenha validade convergente (HAIR et al., 2005). Logo, a validade convergente do modelo é satisfeita, conforme apresentado na Tabela 9.

Tabela 9: Avaliação do modelo de mensuração

\begin{tabular}{lcccc}
\hline \multicolumn{1}{c}{ Constructos } & Ordem & AVE & $\begin{array}{c}\text { Confiabilidade } \\
\text { compósita }\end{array}$ & $\begin{array}{c}\text { Alpha de } \\
\text { Cronbach }\end{array}$ \\
\hline Ambiente Institucional & $1^{\text {a }}$ & 0,502 & 0,799 & 0,691 \\
\hline Ambiente Competitivo & $1^{\text {a }}$ & 0,537 & 0,656 & 0,711 \\
\hline Tacitividade & $1^{\text {a }}$ & 0,652 & 0,778 & 0,819 \\
\hline Complexidade & $1^{\text {a }}$ & 0,617 & 0,888 & 0,891 \\
\hline Autonomia & $1^{\text {a }}$ & 0,582 & 0,893 & 0,867 \\
\hline Motivação & $1^{\text {a }}$ & 0,791 & 0,883 & 0,739 \\
\hline Rede com Fornecedor & $1^{\text {a }}$ & 0,639 & 0,838 & 0,758 \\
\hline Rede com Instituições de C\&T & $1^{\text {a }}$ & 0,797 & 0,952 & 0,937 \\
\hline Rede com Matriz & $2^{\text {a }}$ & 0,667 & 0,857 & 0,748 \\
\hline Semelhança Organizacional & $2^{\text {a }}$ & 0,708 & 0,829 & 0,587 \\
\hline Mecanismos de Socialização & $1^{\text {a }}$ & 0,624 & 0,832 & 0,701 \\
\hline Tecnologia de Processo & $1^{\text {a }}$ & 0,692 & 0,940 & 0,925 \\
\hline Tecnologia de Produto & $1^{\text {a }}$ & 0,657 & 0,905 & 0,869 \\
\hline Transferência de conhecimento & $3^{\text {a }}$ & 0,504 & 0,923 & 0,908 \\
\hline \hline Valores de referência & & $>\mathbf{0 , 5}$ & $>\mathbf{0 , 7}$ & $>\mathbf{0 , 6}$ \\
\hline
\end{tabular}




\subsection{Análise das Cargas Cruzadas (cross loading)}

A análise de cargas cruzadas (ou validade discriminante) representa o grau em que os constructos, assim como as escalas concebidas para medir constructos diferentes, são adequados para esse fim. Quando duas escalas não apresentam validade discriminante, pode-se dizer que existe redundância entre suas medidas, em razão de não ter ocorrido distinção entre as perguntas sob a ótica dos respondentes nas mensurações, ou de os respondentes compreenderem as questões como sendo um conjunto uniforme de perguntas (NETEMEYER et al., 2003).

Ao se elaborar a análise de validade discriminante por meio das cargas cruzadas (cross loadings), verificou-se que alguns fatores ainda possuíam problemas de cargas altas $(>0,5) \mathrm{em}$ outras variáveis latentes, conforme especificado no quadro a seguir.

Quadro 24: Indicadores que apresentaram problemas de cargas cruzadas

\begin{tabular}{|l|l|}
\hline \multicolumn{1}{|c|}{ Constructos } & \multicolumn{1}{c|}{ Problema de cargas cruzadas } \\
\hline Rede externa com fornecedores & RFOR2; RFOR3 \\
Rede externa com clientes & RCLI1; RCLI2; RCLI3; RCLI4; RCLI5 \\
Rede interna com matriz & RMAT2; RMAT5 \\
Mecanismos de socialização & SOC2; SOC3 \\
Transferência de conhecimento tecnológico & TPROC9 \\
de processo & \\
\hline
\end{tabular}

Para eliminar qualquer tipo de cargas cruzadas, retiraram-se 12 indicadores (conforme quando acima) que apresentaram cargas fatoriais maiores do que 0,5 em outros constructos. Dessa forma, o modelo final passou a ser composto por 48 indicadores. Após esses ajustes finais, todos os constructos (variáveis latentes) ficaram com cargas maiores nas suas respectivas variáveis latentes (VL) do que em qualquer outra VL.

A análise final das cargas cruzadas é apresentada na Tabela 10. Por meio das cargas cruzadas pode-se constatar que os valores em azul (cargas dos indicadores em seus fatores) são superiores às suas cargas cruzadas, o que mostra que o modelo possui boa validade discriminante. 
Tabela 10: Resultado da análise de cargas cruzadas (cross loading)

\begin{tabular}{|c|c|c|c|c|c|c|c|c|c|c|c|c|c|}
\hline Indicador & Jто & ORG & MPLX & ACOMP & AINST & IOTIV & RFORN & C\&T & MAT & CIAL & TACIT & Roc & TPROD \\
\hline JTO1 & 1 & 0,004 & $-0,053$ & $-0,015$ & 0,061 & 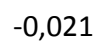 & $-0,144$ & 0,129 & $-0,063$ & 020 & ,148 & 021 & 230 \\
\hline JTO2 & 68 & 0,053 & 5 & $-c$ & 0 & 5 & $-c$ & 55 & 1 &, 016 & 54 & 4 & 3 \\
\hline AUTO3 & 0,736 & 0,183 & 0,032 & $-0,161$ & $-0,032$ & $-0,097$ & $-0,191$ & $-0,066$ & $-0,064$ & 97 & 0,074 & 078 & $-0,015$ \\
\hline AUTO4 & 0,757 & 0,184 & $-0,036$ & $-0,245$ & $-0,167$ & $-0,116$ & $-0,214$ & $-0,079$ & $-0,102$ & 0,010 & $-0,044$ & 13 & 0,088 \\
\hline AUTO5 & 0,863 & $-0,091$ & 0,023 & $-0,169$ & $-0,003$ & $-0,158$ & $-0,273$ & $-0,092$ & 0,039 & 0,033 & 0,079 & 0,101 & 0,360 \\
\hline AUTO6 & 0,771 & $-0,036$ & 0,204 & $-0,248$ & $-0,253$ & $-0,056$ & $-0,117$ & $-0,304$ & 0,036 & 019 & 0,171 & 0,138 & 0,139 \\
\hline SORG1 & 0,173 & 0,850 & 0,136 & $-0,063$ & $-0,048$ & 0,211 & 0,097 & 0,111 & $-0,111$ & 0,182 & $-0,293$ & 0,102 & 0,021 \\
\hline SORG2 & $-0,158$ & 0,832 & 0,094 & $-0,111$ & $-0,190$ & 0,108 & 0,119 & 0,101 & 0,051 & 0,192 & $-0,343$ & $-0,040$ & 0,016 \\
\hline COMPLX2 & 0,048 & 0,189 & 0,896 & 0,031 & $-0,028$ & 0,195 & 0,083 & $-0,174$ & 0,253 & 0,049 & $-0,027$ & 0,275 & 0,126 \\
\hline COMPLX3 & 0,092 & 0,044 & 0,861 & 0,067 & 0,063 & 0,252 & 0,012 & $-0,262$ & 0,182 & 0,061 & 0,119 & 0,291 & 0,155 \\
\hline COMPLX4 & $-0,006$ & 0,132 & 0,745 & $-0,031$ & 0,057 & 0,157 & 0,093 & 0,020 & $-0,003$ & $-0,009$ & $-0,160$ & 0,120 & 0,140 \\
\hline COMPLX5 & $-0,085$ & 0,115 & 0,614 & 0,072 & 0,044 & 0,148 & 0,156 & $-0,023$ & 0,170 & $-0,028$ & $-0,037$ & $-0,145$ & $-0,038$ \\
\hline COMPLX6 & $-0,132$ & 0,132 & 0,780 & 0,027 & $-0,030$ & 0,162 & $-0,002$ & $-0,052$ & 0,171 & 0,043 & $-0,022$ & 0,164 & 0,008 \\
\hline ACOMP7 & $-0,057$ & $-0,059$ & $-0,022$ & 0,337 & 0,677 & 0,007 & 0,151 & 0,467 & $-0,105$ & 0,074 & $-0,233$ & 0,002 & 0,267 \\
\hline ACOMP8 & $-0,026$ & 0,030 & 0,119 & 0,202 & 0,607 & $-0,045$ & $-0,010$ & 0,214 & $-0,156$ & 0,173 & $-0,098$ & $-0,044$ & 0,179 \\
\hline ACOMP9 & $-0,078$ & $-0,181$ & 0,010 & 0,276 & 0,857 & 0,002 & $-0,134$ & 0,070 & 0,001 & $-0,091$ & $-0,076$ & 0,035 & 0,333 \\
\hline ACOMP11 & $-0,070$ & $-0,086$ & 0,002 & 0,439 & 0,669 & $-0,094$ & $-0,085$ & 0,028 & $-0,023$ & $-0,062$ & $-0,130$ & $-0,006$ & 0,149 \\
\hline AINST2 & $-0,222$ & $-0,102$ & $-0,002$ & 0,974 & 0,452 & 0,063 & 0,208 & 0,194 & 0,120 & 0,013 & $-0,255$ & 0,093 & 0,181 \\
\hline AINST3 & $-0,166$ & $-0,047$ & $-0,114$ & 0,350 & 0,328 & 0,094 & 0,142 & 0,110 & $-0,011$ & $-0,244$ & $-0,285$ & $-0,102$ & 0,072 \\
\hline MOTIV2 & $-0,136$ & 0,181 & 0,181 & 0,045 & $-0,032$ & 0,863 & 0,057 & $-0,062$ & 0,552 & 0,230 & $-0,098$ & 0,119 & 0,021 \\
\hline мотIV3 & $-0,079$ & 0,162 & 0,243 & 0,036 & $-0,012$ & 0,915 & 0,156 & 0,078 & 0,291 & 0,241 & $-0,038$ & 0,107 & 0,092 \\
\hline RFORN2 & $-0,185$ & 0,260 & 0,046 & 0,189 & $-0,101$ & 0,050 & 0,892 & 0,254 & 0,146 & 0,211 & -0 , & 0,342 & 0,107 \\
\hline RFORN4 & $-0,128$ & 0,176 & 0,004 & 0,135 & $-0,064$ & 0,117 & 0,945 & 0,233 & 0,109 & 0,046 & $-0,191$ & 0,178 & 0,200 \\
\hline RFORN5 & $-0,092$ & 0,110 & $-0,029$ & 0,180 & $-0,143$ & 0,206 & 0,796 & 0,129 & 0,154 & 0,042 & $-0,117$ & 0,136 & 0,169 \\
\hline RISTC\&T1 & $-0,126$ & 0,060 & $-0,224$ & 0,171 & 0,270 & 0,008 & 0,182 & 0,934 & 0,072 & 0,055 & $-0,208$ & $-0,152$ & $-0,091$ \\
\hline RISTC\&T2 & $-0,151$ & 0,212 & $-0,025$ & 0,128 & 0,285 & 0,011 & 0,125 & 0,885 & $-0,072$ & 0,180 & $-0,267$ & $-0,121$ & $-0,135$ \\
\hline RISTC\&T3 & 0,002 & 0,273 & $-0,180$ & 0,101 & 0,122 & $-0,006$ & 0,199 & 0,895 & 0,097 & 0,172 & $-0,242$ & $-0,130$ & $-0,088$ \\
\hline RISTC\&T4 & $-0,092$ & 0,058 & $-0,235$ & 0,208 & 0,246 & 0,009 & 0,118 & 0,916 & 0,067 & 0,126 & $-0,196$ & $-0,162$ & $-0,109$ \\
\hline RISTC\&T5 & $-0,006$ & $-0,059$ & $-0,193$ & 0,257 & 0,312 & 0,084 & 0,088 & 0,831 & 0,139 & 0,171 & $-0,161$ & $-0,083$ & $-0,055$ \\
\hline RMAT1 & $-0,108$ & $-0,251$ & 0,148 & 0,214 & 0,049 & 0,399 & 0,058 & $-0,034$ & 0,834 & 0,183 & 0,240 & 0,196 & 0,067 \\
\hline RMAT3 & 0,022 & 0,058 & 0,030 & 0,105 & $-0,072$ & 0,344 & 0,086 & 0,109 & 0,817 & 0,257 & 0,150 & 0,124 & 0,014 \\
\hline RMAT4 & $-0,153$ & 0,103 & 0,225 & 0,025 & $-0,120$ & 0,271 & 0,236 & 0,077 & 0,717 & 0,161 & $-0,026$ & 0,268 & 0,053 \\
\hline SOCIAL7 & 0,089 & 0,154 & 0,042 & 0,066 & 0,145 & 0,127 & 0,058 & 0,247 & 0,162 & 0,743 & $-0,223$ & 0,149 & 0,067 \\
\hline SOCIAL8 & $-0,080$ & 0,143 & 0,047 & 0,157 & 0,042 & 0,288 & $-0,018$ & 0,047 & 0,156 & 0,775 & $-0,050$ & 0,199 & $-0,022$ \\
\hline SOCIAL9 & $-0,006$ & 0,216 & 0,054 & $-0,002$ & $-0,143$ & 0,217 & 0,120 & 0,075 & 0,270 & 0,845 & 0,028 & 39 & $-0,122$ \\
\hline TACTIV1 & 14 & $-0,391$ & 0,000 & $-0,227$ & $-0,198$ & $-0,092$ & $-0,144$ & 39 & 20 & $-0,100$ & 3 & 34 & $-0,056$ \\
\hline TACTIV2 & 85 & $-0,337$ & $-0,040$ & $-0,249$ & $-0,230$ & $-0,174$ & $-0,072$ & $-0,142$ & 38 & 38 & 0,600 & 30 & $-0,015$ \\
\hline TPROC1 & 0,014 & 0,064 & 0,397 & 0,198 & 0,123 & 0,223 & 0,347 & $-0,102$ & 0,200 & 0,270 & $-0,145$ & 0,816 & 0,364 \\
\hline TPROC2 & 0,099 & 0,117 & 0,268 & 0,166 & $-0,035$ & 0,183 & 0,206 & $-0,057$ & 0,142 & 0,072 & $-0,103$ & 0,770 & 0,344 \\
\hline TPROC3 & 0,077 & 0,038 & 0,263 & 0,170 & 0,152 & 0,061 & 0,304 & 0,004 & 0,113 & 0,316 & $-0,066$ & 0,888 & 0,425 \\
\hline TPROC4 & 0,113 & 0,093 & 0,289 & 0,188 & 0,104 & 0,145 & 0,234 & $-0,238$ & 0,166 & 0,236 & $-0,124$ & 0,873 & 0,459 \\
\hline TPROC5 & 0,189 & $-0,047$ & 0,281 & $-0,139$ & $-0,218$ & $-0,048$ & 0,177 & $-0,332$ & 0,172 & 0,110 & 0,212 & 0,804 & 0,320 \\
\hline TPROC6 & 0,134 & $-0,027$ & 0,182 & 0,064 & 0,000 & 0,001 & 0,202 & $-0,058$ & 0,204 & 0,255 & 0,036 & 0,906 & 0,386 \\
\hline TPROC7 & 0,025 & $-0,014$ & 0,322 & 0,102 & $-0,101$ & 0,177 & 0,354 & $-0,111$ & 0,247 & 0,181 & $-0,045$ & 0,751 & 0,396 \\
\hline TPROD1 & 0,269 & $-0,148$ & 0,108 & 0,036 & 0,081 & 0,041 & 0,035 & $-0,275$ & 0,185 & 0,070 & 0,131 & 0,489 & 0,738 \\
\hline TPROD3 & 0,287 & $-0,018$ & 0,095 & 0,066 & 0,287 & 0,069 & 0,202 & $-0,130$ & 0,060 & $-0,070$ & $-0,005$ & 0,447 & 0,848 \\
\hline TPROD5 & 0,140 & 0,141 & 0,134 & 0,133 & 0,157 & 0,020 & 0,406 & 0,014 & 0,022 & $-0,092$ & $-0,187$ & 0,331 & 0,795 \\
\hline TPROD8 & 0,132 & 0,062 & 0,187 & 0,286 & 0,447 & 0,153 & 0,166 & $-0,057$ & 0,047 & $-0,094$ & $-0,111$ & 0,244 & 0,786 \\
\hline TPROD9 & 0,200 & 0,081 & 0,171 & 0,257 & 0,504 & 0,006 & 0,184 & 0,031 & $-0,007$ & $-0,016$ & $-0,105$ & 0,332 & 0,879 \\
\hline
\end{tabular}




\subsection{Análise do critério de Fornell-Larcker}

Outra forma de analisar a validade discriminante do modelo é a análise dos critérios, também conhecida por Fornell-Larcker, que consiste em comparar a variância média extraída dos indicadores dos constructos com a variância compartilhada entre os constructos teóricos $\left(\mathrm{R}^{2}\right.$ obtido por meio da correlação dos escores estimados no PLS). Quando as escalas de um constructo apresentam mais variância compartilhada entre si do que com seus próprios indicadores, pode-se dizer que houve uma violação da validade discriminante. O resultado da análise de critério de Fornell-Larcker é apresentado na Tabela 11. Na diagonal desta tabela (começando no canto superior esquerdo e terminando no canto inferior direito), vê-se a raiz quadrada da variância média extraída (AVE); nos demais campos, a correlação entre as variáveis latentes. 
Tabela 11: Análise de Fornell-Larker

\begin{tabular}{|c|c|c|c|c|c|c|c|c|c|c|c|}
\hline Var. Latente (1a Ordem) & AUTO & COMPLX & ACOMP & AINST & MOTIV & RFORN & RIC\&T & SOCIAL & TACIT & TPROC & TPROD \\
\hline Autonomia & 0,763 & & & & & & & & & & \\
\hline Complexidade & 0,051 & 0,785 & & & & & & & & & \\
\hline Ambiente Competitivo & $-0,205$ & 0,028 & 0,733 & & & & & & & & \\
\hline Ambiente Institucional & $-0,086$ & 0,018 & 0,419 & 0,709 & & & & & & & \\
\hline Motivação & $-0,117$ & 0,242 & 0,045 & $-0,024$ & 0,889 & & & & & & \\
\hline Rede com Fornecedor & $-0,289$ & 0,032 & 0,179 & 0,009 & 0,172 & 0,799 & & & & & \\
\hline Rede com Instituições C\&T & $-0,092$ & $-0,196$ & 0,189 & 0,271 & 0,018 & 0,161 & 0,893 & & & & \\
\hline Mecanismos de Socialização & 0,002 & 0,061 & 0,082 & 0,002 & 0,265 & $-0,028$ & 0,151 & 0,790 & & & \\
\hline Tacitividade & 0,113 & 0,006 & $-0,210$ & $-0,182$ & $-0,073$ & $-0,089$ & $-0,241$ & $-0,092$ & 0,821 & & \\
\hline Tecnologia de Processo & 0,112 & 0,341 & 0,132 & 0,012 & 0,126 & 0,279 & $-0,151$ & 0,252 & $-0,043$ & 0,832 & \\
\hline Tecnologia de Produto & 0,261 & 0,168 & 0,183 & 0,357 & 0,068 & 0,278 & $-0,110$ & $-0,043$ & $-0,060$ & 0,465 & 0,810 \\
\hline & \multicolumn{5}{|c|}{ Var. Latente (2 e 3a Ordem) } & RMAT & SORG & TRCT & & & \\
\hline & \multicolumn{5}{|c|}{ Rede Matriz } & 0,816 & & & & & \\
\hline & \multirow{2}{*}{\multicolumn{5}{|c|}{$\begin{array}{l}\text { Semelhança Organizacional } \\
\text { Transferência Reversa de conhecimento } \\
\text { tecnológico }\end{array}$}} & 0,014 & 0,841 & & & & \\
\hline & & & & & & 0,192 & 0,041 & 0,710 & & & \\
\hline
\end{tabular}

Nota: Os valores na diagonal principal correspondem à variância média extraída dos constructos. Os valores abaixo da diagonal correspondem ao quadrado do coeficiente de correlação entre os valores fatoriais da amostra, estimados no PLS. 
A Ilustração 25 representa o modelo de mensuração final, após várias estimações. Os números nas setas representam os coeficientes de caminho (path coefficients) e também a contribuição positiva $(+)$ ou negativa $(-)$ para o efeito da variável endógena (transferência reversa de conhecimento).

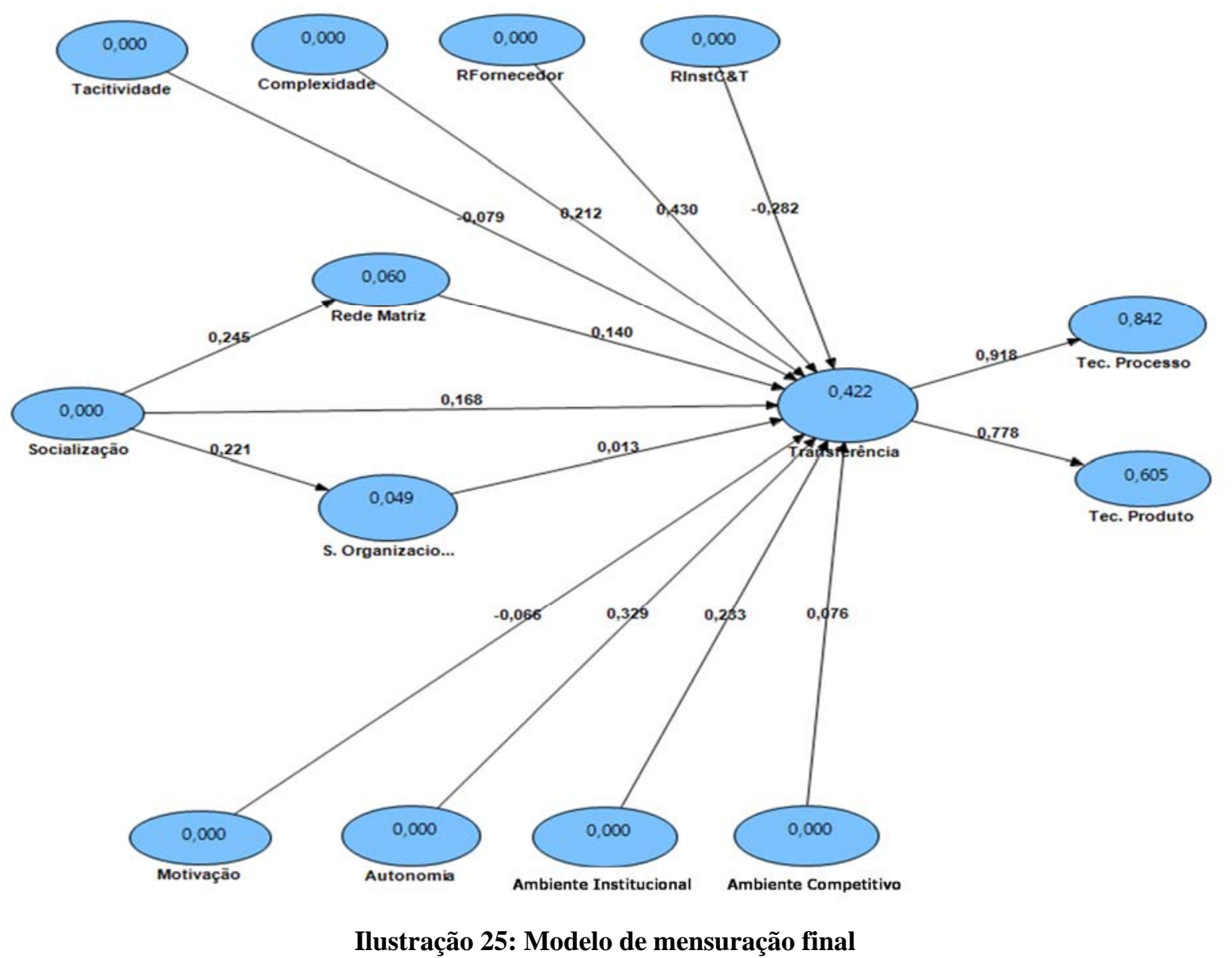

Nota: Os indicadores não foram incluídos nesta figura apenas por questão estética, mas as cargas fatoriais de cada um dos constructos são apresentadas na Tabela 14. Além disso, uma ilustração completa do modelo de mensuração final pode ser visualizada no Apêndice III.

Na seção seguinte será avaliado o modelo estrutural que visa verificar a significância dos constructos.

\subsubsection{Avaliação do modelo estrutural}

A elaboração do modelo estrutural passa pelas seguintes etapas (HAIR et al., 2013): avaliação do nível de $\mathrm{R}^{2}$ e avaliação da significância e relevância das relações do modelo estrutural.

\subsection{Avaliação do coeficiente de determinação (R2)}

A medida mais comum de adequação de um modelo é o coeficiente de determinação $\left(\mathrm{R}^{2}\right)$. $\mathrm{O}$ coeficiente de determinação $\mathrm{R}^{2}$ das variáveis latentes endógenas mede a variância explicada em 
relação ao seu total. Em outros termos, quanto maior coeficiente, melhor o modelo. Considerando a área de ciências sociais e do comportamento, Cohen (1977) sugere a seguinte classificação para o coeficiente de determinação: $\mathrm{R}^{2}=0,02$ (pequeno); $\mathrm{R}^{2}=0,13$ (médio) e $\mathrm{R}^{2}$ $=0,26$ (grande).

A Tabela 12 mostra as hipóteses do modelo testadas, com seus respectivos pesos obtidos no modelo estrutural (PLS). Os valores padronizados ( $t$ statistics) podem ser usados para interpretar quais constructos independentes têm maior relação com os constructos dependentes, bastando para isso avaliar o tamanho absoluto dos valores padronizados. Uma interpretação possível dos valores padronizados é considerá-los como o grau de variação no constructo dependente, com a variação de uma unidade no constructo independente.

De acordo com a Tabela 12, o valor ajustado obteve um valor consideravelmente menor para o constructo transferência reversa de conhecimento em razão da grande quantidade de variáveis preditoras (11). No entanto, ainda assim pode-se considerar que o modelo explica uma boa parcela da variabilidade da transferência reversa de conhecimento tecnológico $\left(\mathrm{R}^{2}=0,326\right)$ e que o número de subsidiárias, embora reduzido, foi suficiente para validar o modelo de pesquisa. Os resultados mostram que os onze constructos explicam 33\% do modelo de transferência reversa. Além disso, $92 \%$ da tecnologia de processo transferida de forma reversa é explicada pelo constructo de transferência reversa. Do mesmo modo, $78 \%$ da tecnologia de produto é explicada pelo constructo de transferência reversa.

Tabela 12: Análise dos coeficientes de determinação das variáveis endógenas

\begin{tabular}{c|ccc}
\hline Constructos & R2 & R2 ajustado & Explicação \\
\hline TRCT & 0,422 & 0,326 & Substancial \\
RMAT & 0,060 & 0,048 & Pequeno \\
SORG & 0,049 & 0,036 & Pequeno \\
TPROC & 0,842 & 0,917 & Substancial \\
TPROD & 0,605 & 0,775 & Substancial \\
\hline
\end{tabular}

Nota: Valores de referência substancial $(0,26)$, médio $(0,13)$ e pequeno $(0,02)$.

Em relação ao efeito do tamanho da amostra analisada (78 subsidiárias respondentes), conforme apresentado no capítulo de metodologia, para que houvesse significância para o estudo, o $\mathrm{R}^{2}$ deveria ser superior a 19,89\% (informação retirada do software $\mathrm{G}^{*}$ Power 3.1.7).

\subsection{Avaliação dos coeficientes do caminho e significâncias}

A avaliação dos coeficientes do caminho no modelo estrutural do PLS-PM deve considerar o sinal, a grandeza e a significância das relações entre as variáveis latentes. Se o sinal for contrário 
ao estabelecido pela hipótese, esta então não é suportada, apontam Urbach e Ahlemann (2010); a grandeza, por sua vez, indica a força da relação entre as variáveis e deve ser avaliada em conjunto com sua significância por meio de reamostragem bootstraping (HAIR et al., 2013).

Analisando-se o resultado dos coeficientes de determinação, observa-se que quatro dos sinais das relações entre as variáveis latentes foram negativos. Um deles está de acordo com a hipótese colocada (tacitividade), mas os outros três são contrários às hipóteses colocadas (competitividade, motivação e rede com institutos de C\&T).

A significância foi estimada por meio da técnica bootstraping com 78 casos e 300 amostragens aleatórias (repetições) e opção Individual changes, obtendo-se os valores $t$ de student. Para 78 graus de liberdade, e um intervalo de confiança de 95\%, tem-se o valor crítico t de student de 1,965. O teste $t$ de student testa a hipótese de que os coeficientes de correlação/regressão sejam iguais a zero - caso o resultado seja igual ou superior a 1,965, a hipótese é rejeitada, o que significa que a correlação/regressão é significativa (HAIR, et al., 2009). A Tabela 13 apresenta os resultados dos coeficientes de determinação, sinal e significâncias de cada caminho entre os constructos. No Apêndice IV, estão detalhadas as significâncias por indicador.

Por meio da Tabela 13, observa-se que, dos constructos com efeitos direitos sobre a transferência reversa, a rede com fornecedores $(4,54, p<0,01)$ foi o que exerceu maior influência sobre o constructo transferência reversa de conhecimento tecnológico, seguido pelo constructo autonomia $(2,77, \mathrm{p}<0,01)$, pelo constructo Ambiente Institucional $(2,09, \mathrm{p}<0,05)$ e pelo constructo complexidade do conhecimento $(2,01, \mathrm{p}<0,05)$. Ressalta-se que os constructos rede interna (com a matriz) possui uma relação marginal com a transferência reversa $(1,75, p<0,10)$. No caso do constructo mecanismos de socialização, percebe-se que obteve uma relação direta marginal com a transferência reversa de conhecimento tecnológico $(1,70, p<0,10)$, mas se somado a relação indireta por meio dos constructos rede interna e semelhança organizacional, essa relação passa a ser significativa $(1,96, \mathrm{p}<0,05)$.

Com relação à influência negativa e significante sobre o constructo transferência reversa de conhecimento tecnológico, destaca-se o constructo rede externa com institutos de C\&T $(2,62$, $\mathrm{p}<0,10$ ). Além disso, observa-se que os constructos tecnologia de processo e tecnologia de produtos foram altamente significantes. 
Tabela 13: Análise dos coeficientes do caminho e significâncias

\begin{tabular}{|c|c|c|c|c|c|}
\hline \multicolumn{2}{|l|}{ Caminho } & \multirow{2}{*}{$\begin{array}{c}\text { Coeficiente } \\
\text { de } \\
\text { Caminho }\end{array}$} & \multirow{2}{*}{$\begin{array}{l}\text { Sinal do } \\
\text { caminho }\end{array}$} & \multirow{2}{*}{$\begin{array}{c}\text { Valor } \\
\mathbf{t}\end{array}$} & \multirow[b]{2}{*}{ Significância } \\
\hline $\begin{array}{c}\text { Constructo de } \\
\text { Origem }\end{array}$ & $\begin{array}{c}\text { Constructo de } \\
\text { destino }\end{array}$ & & & & \\
\hline Autonomia & TRCT & 0,329 & + & 2,767 & $* * *$ \\
\hline Ambiente Institucional & TRCT & 0,233 & + & 2,094 & ** \\
\hline Ambiente Competitivo & TRCT & 0,077 & + & 0,897 & n.s. \\
\hline Complexidade & TRCT & 0,212 & + & 2,014 & $* *$ \\
\hline Semelhança Organizacional & TRCT & 0,013 & + & 0,196 & n.s. \\
\hline Rede com Fornecedores & TRCT & 0,431 & + & 4,542 & $* * *$ \\
\hline Motivação & TRCT & $-0,066$ & - & 1,030 & n.s. \\
\hline Rede com Institutos de C\&T & TRCT & $-0,282$ & - & 2,620 & $* *$ \\
\hline Rede com Matriz & TRCT & 0,140 & + & 1,755 & $*$ \\
\hline Mecanismos de Socialização & TRCT & 0,168 & + & 1,709 & n.s. \\
\hline Tacitividade & TRCT & $-0,079$ & - & 0,865 & n.s. \\
\hline Mecanismos de Socialização & SORG & 0,221 & + & 2,080 & $* *$ \\
\hline Mecanismos de Socialização & RMAT & 0,245 & + & 2,038 & $* *$ \\
\hline $\begin{array}{l}\text { Transferência reversa de } \\
\text { conhecimento }\end{array}$ & TPROC & 0,918 & + & 36,20 & $* * *$ \\
\hline $\begin{array}{l}\text { Transferência reversa de } \\
\text { conhecimento }\end{array}$ & TPROD & 0,778 & + & 11,55 & $* * *$ \\
\hline
\end{tabular}

Legenda: $* * *$ Significante a $0,001, * *$ Significante a 0,005 e * Significante a 0,010 .

\subsubsection{Teste de hipóteses}

A Ilustração 26 apresenta o resultado dos testes de hipóteses. Todas as linhas pontilhadas na ilustração são hipóteses não suportadas estatisticamente. Os resultados do modelo PLS serão apresentados com base na classificação das características do conhecimento, da subsidiária e do relacionamento matriz-subsidiária. 


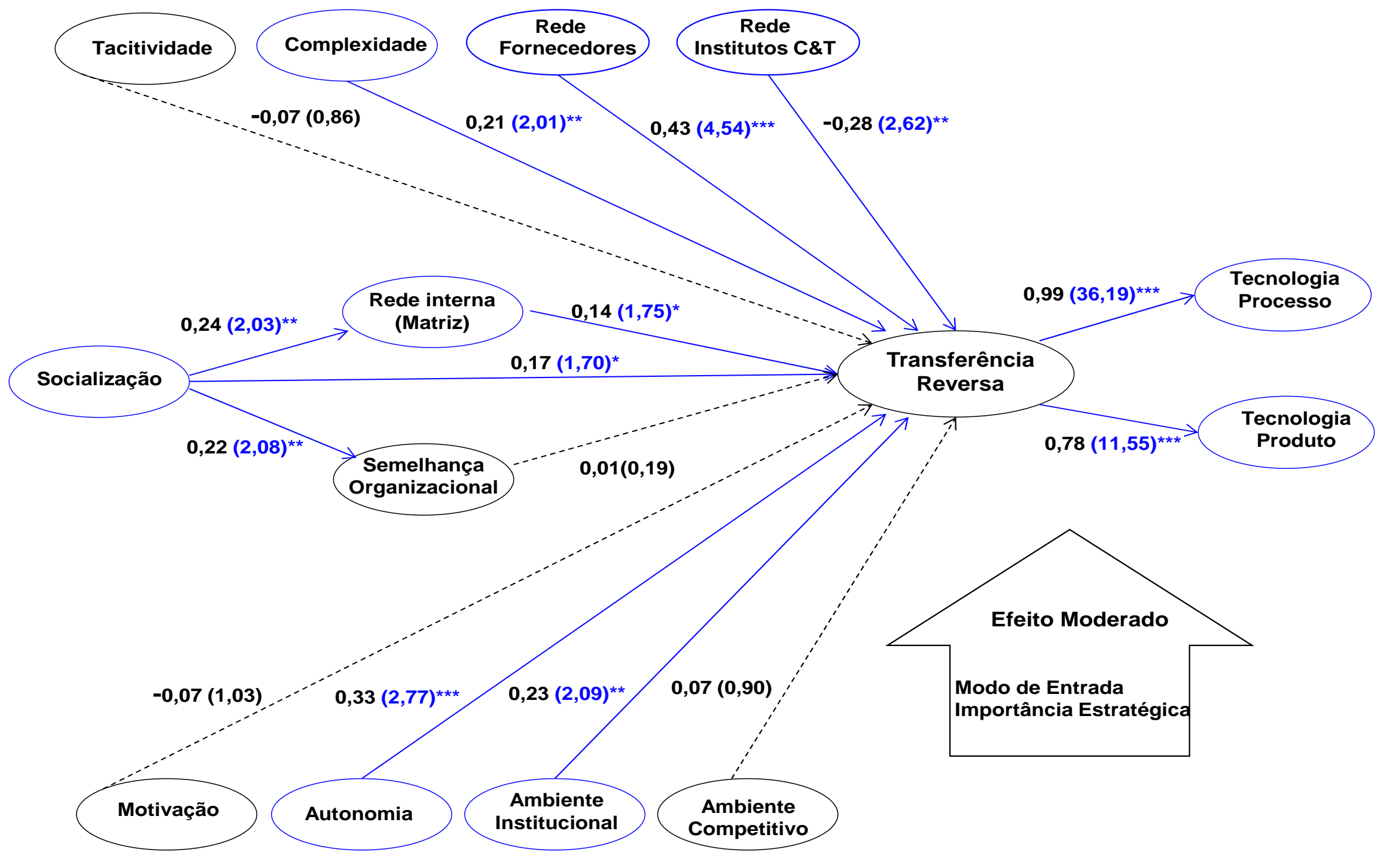

Nota: * Significante a 0,10, ${ }^{* \star}$ Significante a 0,05 e ${ }^{\star \star \star}$ Significante a 0,01 Linhas tracejadas representam relações não significantes

Ilustração 26: Resultado do teste de hipóteses 


\subsubsection{Relação entre as características do conhecimento e a transferência reversa do conhecimento tecnológico}

Cada relação contém informação sobre a estimativa do parâmetro e valor t. As características do conhecimento foram avaliadas por meio dos constructos tacitividade e complexidade do conhecimento. O principal objetivo foi compreender como as características e a complexidade do conhecimento impactam a extensão da transferência reversa do conhecimento. Nesse sentido, duas hipóteses foram desenvolvidas. A Hipótese 1 indica que a tacitividade influencia negativamente a transferência de conhecimento, contudo, o resultado do PLS não confirmou essa hipótese, pois o valor do t-value foi 0,86 , o que mostra que a relação, apesar de negativa é insignificante. A Hipótese 1, portanto, não foi suportada.

A Hipótese 2 predizia um impacto negativo da complexidade sobre a transferência reversa de conhecimento. Ao contrário disso, os resultados mostram que há um impacto significativamente positivo na interação entre as duas variáveis. O t-value para esta hipótese foi 2,01; assim, a Hipótese 2 é invertida.

\subsubsection{Relação entre as características das subsidiárias e a transferência reversa do conhecimento tecnológico}

Tal como acontece em relação à transferência de competências da matriz para as subsidiárias, a transferência reversa depende dos Ambiente Institucional no qual está localizada a subsidiária. A institucionalização e a credibilidade de locais com contextos competitivos dinâmicos são uma importante razão tanto para a matriz transferir recursos como para buscar recursos nas subsidiárias (BORINI, 2008).

De acordo com os resultados, há forte relação entre os ambiente institucional e a transferência reversa de conhecimento (valor estimado do bootstrapping é de t-value 2,09, com uma probabilidade de 0,05 para a hipótese nula); portanto, a Hipótese 3 é suportada.

De acordo com a Hipótese 4, quanto mais desenvolvidos os ambiente competitivo, maior a capacidade de transferir o conhecimento de forma reversa. Ao contrário do que foi hipotetizado, a relação entre essas duas variáveis obteve resultado positivo, no entanto, o resultado não se mostrou significativo ( $t$-value 0,9 ). Dessa forma, a Hipótese 4 não foi suportada. 
A hipótese rede externa foi testada por meio da rede com fornecedores, rede com clientes e rede com instituições de C\&T. De acordo com os resultados, existe uma relação negativa entre a transferência reversa de conhecimento e a rede com instituições de C\&T (t-value 2,62); sendo assim, pode-se afirmar que o resultado para a Hipótese 5a é invertido. Com relação à hipótese sobre a rede com fornecedores, os resultados apresentaram uma forte relação positiva com a transferência reversa de conhecimento (t-value 4,54), o que leva a aceitar a Hipótese 5b. A relação positiva entre transferência reversa e rede com clientes, apresentada pela Hipótese 5c, não foi suportada ${ }^{14}$.

A Hipótese 6 previa que a autonomia é relacionada de forma positiva com a transferência reversa de conhecimento, e os resultados corroboraram essa hipótese ( $t$-value 2,77), indicando que a Hipótese 6 é suportada. Com relação à hipótese sobre motivação, os resultados indicam existir uma correlação negativa, mas não significativa, entre esse constructo e a transferência reversa de conhecimento tecnológico (t-value 1,03), o que levou a não suportar a Hipótese 7.

\subsubsection{Relação entre as características da relação entre matriz e subsidiárias e a transferência reversa do conhecimento tecnológico}

As características da relação entre matriz e subsidiárias foram divididas em três categorias. A primeira variável do grupo de características da relação matriz-subsidiária é a integração com rede interna (matriz), cujos resultados indicam que há uma relação positiva entre este constructo e a extensão com que a subsidiária transfere conhecimento para a matriz. Essa hipótese é marginalmente confirmada tendo em vista que o t-value foi 1,75; dessa forma a Hipótese 8 é suportada, com uma significância de $90 \%$ (probabilidade de hipótese nula 0,10 ).

De acordo com segunda variável desse grupo, há uma associação positiva entre a semelhança organizacional e a transferência reversa de conhecimento. No entanto, essa relação não apresentou significância ( $t$-value 0,20), o que significa que a Hipótese 9 não foi suportada. A hipótese 10 predizia uma relação positiva entre semelhança cultural e transferência reversa de conhecimento. Contudo, esse constructo foi eliminado na avaliação da AFC porque seus indicadores não apresentaram cargas fatoriais significantes. Dessa forma, a Hipótese 10 não foi suportada.

\footnotetext{
${ }^{14} \mathrm{O}$ constructo integração externa com os clientes foi excluído na etapa de análise das cargas cruzadas (item 5.4.2.1.4). Dessa forma, o teste de hipótese nem chegou a ser realizado para este constructo.
} 
A terceira variável trata dos mecanismos de socialização (hipótese 11). A hipótese 11a predizia que os mecanismos de socialização relacionavam-se positivamente com a rede interna com a matriz ( $t$-value 2,04). Com esse resultado a Hipótese 11a foi suportada, mesmo que de forma marginal. Há também uma relação positiva entre mecanismos de socialização e semelhança organizacional (t-value 2,08) o que leva a suportar a Hipótese 11b. No que se refere à relação entre os mecanismos de socialização e a transferência reversa de conhecimento (Hipótese 11c), os resultados indicam que, há uma relação positiva entre mecanismos de socialização e transferência reversa de conhecimento, embora que de forma marginal (t-value 1,71), o que leva a suportar a hipótese 11c (com uma significância de 90\% - probabilidade de hipótese nula 0,10$)$.

Em resumo, o modelo mostra que a transferência de conhecimento é positivamente influenciada pelos fatores:

- Complexidade do conhecimento;

- Ambiente institucional;

- Autonomia;

- Integração externa com fornecedores;

- Integração interna com a matriz;

- Mecanismos de socialização via comunicação pessoal.

E é negativamente influenciada pela:

- Integração externa com instituições de ciência e tecnologia.

O Quadro 25 apresenta o resultado da análise das hipóteses firmadas neste estudo.

Quadro 25: Análises das hipóteses do modelo

\begin{tabular}{|c|l|l|c|}
\hline Grupo & & \multicolumn{1}{|c|}{ Hipóteses } & Resultado \\
\hline $\begin{array}{c}\text { Características } \\
\text { do } \\
\text { conhecimento }\end{array}$ & H1: & $\begin{array}{l}\text { Quanto maior a tacitividade do conhecimento da } \\
\text { subsidiária, menor a extensão da transferência reversa } \\
\text { de conhecimento tecnológico. } \\
\text { Quanto maior a complexidade do conhecimento da } \\
\text { subsidiária, menor a extensão da transferência reversa } \\
\text { de conhecimento tecnológico. }\end{array}$ & $\begin{array}{c}\text { Rejeitada } \\
\text { (porém a } \\
\text { relação inversa } \\
\text { é significante) }\end{array}$ \\
\hline $\begin{array}{c}\text { Características } \\
\text { do } \\
\text { conhecimento }\end{array}$ & H3: & $\begin{array}{l}\text { Quanto mais desenvolvidos os ambiente institucional } \\
\text { onde a subsidiária está localizada, maior a transferência } \\
\text { reversa de conhecimento tecnológico. }\end{array}$ & Suportada \\
\hline
\end{tabular}




\begin{tabular}{|c|c|c|c|}
\hline & H4: & $\begin{array}{l}\text { Quanto mais desenvolvidos os ambiente competitivo, } \\
\text { maior a transferência reversa de conhecimento } \\
\text { tecnológico. }\end{array}$ & $\begin{array}{l}\text { Rejeitada } \\
\text { (porém a } \\
\text { relação inversa } \\
\text { é significante) }\end{array}$ \\
\hline & H5b: & $\begin{array}{l}\text { Quanto maior a integração da subsidiária com a rede } \\
\text { externa de fornecedores, maior a transferência reversa } \\
\text { de conhecimento tecnológico. } \\
\text { Quanto maior a integração da subsidiária com a rede } \\
\text { externa de clientes, maior a transferência reversa de } \\
\text { conhecimento tecnológico. } \\
\text { Quanto maior a integração da subsidiária com a rede } \\
\text { externa de instituições de ciência e tecnologia, maior a } \\
\text { transferência reversa de conhecimento tecnológico. }\end{array}$ & $\begin{array}{c}\text { Não } \\
\text { suportada } \\
\text { Rejeitada } \\
\text { (porém a } \\
\text { relação inversa } \\
\text { é significante) }\end{array}$ \\
\hline & H6: & $\begin{array}{l}\text { Quanto maior a autonomia da subsidiária, maior a } \\
\text { transferência reversa de conhecimento tecnológico. }\end{array}$ & Suportada \\
\hline & H7: & $\begin{array}{l}\text { Quanto maior a motivação da subsidiária, maior a } \\
\text { transferência reversa de conhecimento tecnológico. }\end{array}$ & $\begin{array}{l}\text { Não } \\
\text { suportada }\end{array}$ \\
\hline \multirow{4}{*}{$\begin{array}{l}\text { Características } \\
\text { da interação } \\
\text { matriz/subsidiária }\end{array}$} & H8: & $\begin{array}{l}\text { Quanto maior a integração da subsidiária com a rede } \\
\text { interna (matriz), maior a transferência reversa de } \\
\text { conhecimento tecnológico. }\end{array}$ & Suportada \\
\hline & H9: & $\begin{array}{l}\text { Quanto maior a semelhança organizacional entre } \\
\text { subsidiária e matriz, maior a transferência reversa de } \\
\text { conhecimento tecnológico. }\end{array}$ & $\begin{array}{c}\text { Não } \\
\text { suportada }\end{array}$ \\
\hline & H10: & $\begin{array}{l}\text { Quanto maior a semelhança cultural entre subsidiária e } \\
\text { matriz, maior a transferência reversa de conhecimento } \\
\text { tecnológico. }\end{array}$ & $\begin{array}{c}\text { Não } \\
\text { suportada }\end{array}$ \\
\hline & H11a: & $\begin{array}{l}\text { Quanto maior a utilização de mecanismos de } \\
\text { socialização entre subsidiária e matriz, maior a } \\
\text { integração da subsidiária com a rede interna (matriz). } \\
\text { Quanto maior a utilização de mecanismos de } \\
\text { socialização entre subsidiária e matriz, maior a } \\
\text { semelhança organizacional entre matriz e subsidiária. } \\
\text { Quanto maior a utilização de mecanismos de } \\
\text { socialização entre subsidiária e matriz, maior a } \\
\text { transferência reversa de conhecimento tecnológico. }\end{array}$ & Suportada \\
\hline
\end{tabular}

\subsubsection{A influência das variáveis moderadoras: idade, modo de entrada e importância estratégica das subsidiárias}

Além de testar a relação entre as variáveis, a pesquisa está interessada em comparar os resultados, classificando-os em diferentes grupos, para saber se há ou não alguma diferença significativa entre os mesmos. Especificamente, as subsidiárias foram classificadas por idade, modo de entrada e importância estratégica. Quanto à idade, as subsidiárias foram classificadas como subsidiárias jovens ( 5 anos ou menos) e subsidiárias maduras ( 5 anos ou mais). Quanto ao tipo, foram classificadas em aquisição e greenfield e quanto à importância estratégica, foram classificadas como inovadores, contribuidoras e implementadoras. A finalidade da comparação entre os resultados da amostra é permitir que o pesquisador faça afirmações sobre a população 
maior da qual a amostra foi extraída. Este tipo de análise é chamado de estatística inferencial ou inferência estatística.

O teste de Mann-Whitney é utilizado para duas amostras independentes e compara o número de vezes em que um escore de uma das amostras é maior que o valor obtido no escore da outra amostra. Os resultados produzidos por um teste Mann-Whitney por meio do aplicativo estatístico SPSS apresentam o valor de U de Mann-Whitney, o valor W de Wilcoxon, a estatística $\mathrm{Z}$ e o nível de significância. Para avaliação das diferenças entre as duas amostras independentes, utiliza-se o valor da estatística $Z$ e seu nível de significância, sendo que valores de $\mathrm{p}<0,05$ indicam que há diferença nas respostas das variáveis (BRYMAN; CRAMER, 2005, p. 169).

\subsubsection{Análises multigrupo (MGA - Multigroup Analysis)}

A melhor forma de realizar uma comparação multigrupo em um modelo de PLS é por meio da análise multigrupo (MGA - Multigroup Analysis) quando as variáveis que se quer investigar possuem escalas ordinais (HENSELER; RINGLE; SINKOVICS, 2009; HAIR et al., 2013). Contudo, para efetuar esse procedimento é necessário que amostra seja grande o suficiente para que, mesmo que dividida, consiga alcançar os critérios de tamanho exigidos pelo método. A amostra deste estudo não atende aos critérios de tamanho mínimo para realizar a análise de MGA. Uma alternativa, quando isso acontece, é fazer a análise multigrupo por meio do teste Mann-Whitney. Esse teste é usado para testar se duas amostras independentes foram retiradas de populações com médias iguais; esse é um dos testes paramétricos mais poderosos e pode substituir o teste paramétrico $t$ quando as amostras forem pequenas e/ou quando não houver normalidade nos dados. A única exigência deste teste é que a variável seja medida em escala ordinal ou quantitativa (FÁVERO et al., 2009, p. 163).

\subsection{Comparação dos grupos por tipo de subsidiária (aquisição e greenfield)}

Na Tabela 14 apresenta-se o resultado do processamento do teste Mann-Whitney para o tipo de empresa.

Tabela 14: Comparação do grupo Tipo de empresa

\begin{tabular}{|c|c|c|c|}
\hline Constructos & $\begin{array}{c}\text { Aquisição } \\
\text { Média (DP) }\end{array}$ & $\begin{array}{c}\text { Greenfield } \\
\text { Média (DP) }\end{array}$ & $p$-value ${ }^{1}$ \\
\hline Tecnologia de processos & $2,43(1,07)$ & $2,07(1,06)$ & 0,416 \\
\hline Tecnologia de produtos & $2,35(1,03)$ & $2,34(1,33)$ & 0,991 \\
\hline Tacitividade & $2,26(0,78)$ & $2,17(0,82)$ & 0,553 \\
\hline
\end{tabular}




\begin{tabular}{lccc}
\hline \multirow{2}{*}{ Constructos } & Aquisição & Greenfield & \multirow{2}{*}{ p-value $^{\mathbf{1}}$} \\
\cline { 2 - 3 } & Média (DP) & Média (DP) & \\
\hline Complexidade & $3,15(0,87)$ & $3,48(0,85)$ & 0,361 \\
Ambiente competitivo & $3,48(0,74)$ & $3,48(0,85)$ & 0,854 \\
Ambiente institucional & $3,15(0,79)$ & $3,19(0,76)$ & 0,868 \\
Rede externa com matriz & $3,65(0,96)$ & $3,82(0,99)$ & 0,422 \\
Rede externa com fornecedores & $2,86(0,81)$ & $3,49(0,63)$ & $0,004^{* *}$ \\
Rede externa com instituições de C\&T & $2,04(0,91)$ & $1,89(0,92)$ & 0,502 \\
Autonomia & $3,70(0,80)$ & $3,00(0,93)$ & $0,008^{* *}$ \\
Motivação & $3,59(0,74)$ & $4,22(0,81)$ & $0,001^{* * *}$ \\
Semelhança Organizacional & $3,37(0,76)$ & $3,67(0,69)$ & 0,071 \\
Mecanismos de Socialização & $3,22(0,76)$ & $3,52(0,67)$ & 0,075 \\
\hline 1 Teste de Mann-Whitney, ** Significante a 0,01 e ** Significante a $0,01$. & & &
\end{tabular}

Legenda: DP= desvio-padrão.

A partir da tabela acima, observam-se diferenças estatisticamente significantes para os constructos rede externa com fornecedores e motivação - o grupo "greenfield" apresentou escores mais elevados em rede externa com fornecedores e motivação, enquanto o grupo "aquisição" apresentou escore mais elevado em autonomia.

Esses resultados indicam que subsidiárias formadas por meio de greenfield são mais motivadas e mais integradas com as redes externas de fornecedores. Já as subsidiárias formadas por meio de aquisição, como já era previsto, possuem mais autonomia. Ressalta-se que não houve distinção do modo de entrada com a extensão com que o conhecimento é transferido. Esse resultado discorda dos achados dos diversos autores que encontraram relação positiva entre esses dois constructos (ZHOU, 2002; FROST, 1998; RABIOSI, 2011). Ao contrário do que se esperava, a integração com a matriz não se mostrou diferente para os dois modos de formação das subsidiárias. Geralmente, a integração interna (matriz/subsidiárias) para subsidiárias pósadquiridas é menor do que a integração com subsidiárias estabelecidas por greenfield (HAKANSON; NOBEL, 2001).

\subsection{Comparação dos grupos por tempo de existência da subsidiária}

A partir da Tabela 15, apresenta-se o resultado do processamento do teste Mann-Whitney para a idade da empresa.

Tabela 15: Comparação do grupo Idade da empresa

\begin{tabular}{lccc}
\hline \multirow{2}{*}{ Constructos } & Idade $<=5$ anos & Idade $>$ 5 anos & \multirow{2}{*}{ p-value $^{\mathbf{1}}$} \\
\cline { 2 - 3 } & Média (DP) & Média (DP) & \\
\hline Tecnologia de processos & $2,38(1,05)$ & $2,27(1,13)$ & 0,845 \\
Tecnologia de produtos & $2,43(1,08)$ & $2,16(1,15)$ & 0,369 \\
Tacitividade - invertido & $2,28(0,80)$ & $2,14(0,75)$ & 0,505 \\
Complexidade & $3,20(0,87)$ & $3,28(0,89)$ & 0,816 \\
Ambiente Competitivo & $3,48(0,72)$ & $3,49(0,84)$ & 0,961 \\
\hline
\end{tabular}




\begin{tabular}{lccc}
\hline \multirow{2}{*}{ Constructos } & Idade <= 5 anos & Idade $>$ 5 anos & \multirow{2}{*}{-value $^{\mathbf{1}}$} \\
\cline { 2 - 3 } & Média (DP) & Média (DP) & 0,481 \\
\hline Ambiente institucional & $3,20(0,82)$ & $3,07(0,69)$ & 0,143 \\
Rede externa com matriz & $3,60(0,97)$ & $3,90(0,93)$ & 0,733 \\
Rede externa com fornecedores & $3,00(0,82)$ & $3,02(0,82)$ & 0,699 \\
Rede externa com institutos de C\&T & $2,01(0,96)$ & $2,00(0,80)$ & 0,176 \\
Autonomia & $3,64(0,94)$ & $3,30(0,67)$ & 0,588 \\
Motivação & $3,70(0,80)$ & $3,81(0,79)$ & 0,845 \\
Semelhança organizacional & $3,45(0,74)$ & $3,40(0,79)$ & 0,944 \\
\hline Mecanismos de socialização & $3,28(0,72)$ & $3,31(0,83)$ & \\
\hline
\end{tabular}

1 Teste de Mann-Whitney.

Legenda: DP = desvio-padrão.

De acordo com a Tabela 15, não há diferenças estatisticamente significantes do constructo idade da subsidiária em relação à transferência reversa de conhecimento tecnológico. Em outros termos, diferentemente dos resultados do estudo de Foss e Perdersen (2002) que concluiu que as subsidiárias mais antigas tendem a ter mais autonomia e ser mais inovadoras, este estudo alinha-se aos trabalhos de Gray e Meister (2004) e Yli-Renko et al., (2001 apud VAN WIJK; JANSEN; LYLES, 2008) que também concluíram que o constructo idade da subsidiária não interfere na transferência de conhecimento.

\subsection{Comparação dos grupos por papel da subsidiária}

A partir da Tabela 16, apresenta o resultado do processamento do teste Mann-Whitney para a importância estratégica da subsidiária.

Tabela 16: Comparação do grupo Importância estratégica da subsidiária

\begin{tabular}{|c|c|c|c|c|c|}
\hline \multirow[t]{2}{*}{ Constructos } & $\begin{array}{c}(1) \\
\begin{array}{c}\text { Implementa- } \\
\text { doras }\end{array} \\
\end{array}$ & $\begin{array}{c}\text { (2) } \\
\begin{array}{c}\text { Contribuido- } \\
\text { ras }\end{array} \\
\end{array}$ & $\begin{array}{c}(3) \\
\text { Inovadoras }\end{array}$ & \multirow[t]{2}{*}{ p-value ${ }^{1}$} & \multirow[t]{2}{*}{ Diferenças ${ }^{2}$} \\
\hline & Média (DP) & Média (DP) & Média (DP) & & \\
\hline Tecnologia de processos & $2,03(1,06)$ & $2,56(1,32)$ & $2,28(0,90)$ & 0,527 & \\
\hline Tecnologia de produtos & $1,50(1,17)$ & $2,05(1,10)$ & $2,67(0,97)$ & $0,004 * *$ & $\begin{array}{l}1 \text { e } 3 * \\
2 \text { e } 3 * *\end{array}$ \\
\hline Tacitividade - invertido & $2,50(0,53)$ & $2,36(0,86)$ & $2,12(0,77)$ & 0,226 & \\
\hline Complexidade & $3,75(0,61)$ & $3,09(0,97)$ & $3,21(0,83)$ & 0,116 & \\
\hline Ambiente Competitivo & $3,15(0,69)$ & $3,27(0,77)$ & $3,66(0,72)$ & 0,080 & \\
\hline Ambiente institucional & $2,91(0,71)$ & $2,82(0,81)$ & $3,41(0,69)$ & $0,006 * *$ & 1 e $3 * *$ \\
\hline Rede externa com matriz & $3,68(1,40)$ & $3,99(1,14)$ & $3,52(0,70)$ & $0,029 *$ & 1 e $3 * *$ \\
\hline Rede externa com fornecedores & $2,64(0,93)$ & $3,19(0,70)$ & $2,96(0,84)$ & 0,449 & \\
\hline $\begin{array}{l}\text { Rede externa com institutos de } \\
\text { C\&T }\end{array}$ & $1,80(0,91)$ & $1,77(0,84)$ & $2,18(0,93)$ & 0,170 & \\
\hline Autonomia & $3,08(0,70)$ & $3,11(0,68)$ & $3,88(0,88)$ & $<0,001 * * *$ & $\begin{array}{l}1 \text { e } 3 * * * \\
2 \text { e } 3 * *\end{array}$ \\
\hline Motivação & $3,44(0,56)$ & $3,74(0,89)$ & $3,78(0,77)$ & 0,599 & \\
\hline Semelhança organizacional & $3,41(0,51)$ & $3,50(0,72)$ & $3,41(0,81)$ & 0,878 & \\
\hline Mecanismos de socialização & $3,34(0,56)$ & $3,50(0,81)$ & $3,16(0,73)$ & 0,147 & \\
\hline
\end{tabular}


De acordo com a Tabela 16 há diferenças estatisticamente significantes para os constructos tecnologia de produtos, Ambiente Institucional, integração interna (com a matriz) e autonomia.

Pode-se dizer que as subsidiárias do tipo inovadoras transferem com maior extensão, conhecimento tecnológico de produtos, se comparadas às subsidiárias implementadoras e contribuidoras. As subsidiárias inovadoras são o tipo que possui maior autonomia se comparada às subsidiárias implementadoras e contribuidoras. Além disso, pode-se afirmar que as subsidiárias inovadoras estão localizadas em ambientes com fatores institucionais mais adequados se comparadas às subsidiárias contribuidoras. Porém são menos integradas na rede interna se comparadas às subsidiárias contribuidoras.

Esses resultados positivos de transferência partindo de subsidiárias do tipo inovadoras estão em linha com os preceitos de Ambos, T.; Ambos, B. e Schlegelmilch (2006) que afirmam que a transferência reversa de conhecimento dependerá da importância estratégica da unidade de origem (subsidiária). Isso se justifica porque subsidiárias inovadoras se engajam no desenvolvimento de novos produtos e tecnologias, e, sendo assim, descobrem novos gostos ou práticas de negócios (RABIOSI, 2011).

No que concerne aos resultados para as subsidiárias contribuidoras constatou-se que elas estão mais integradas com a matriz, argumenta-se que esse tipo de subsidiária é caracterizado por se envolver em melhorias tecnológicas de produtos e serviços para adaptá-la aos mercados locais ou mesmo, para mercados estrangeiros. Para desempenhar essa atividade, é preciso que estejam estreitamente alinhadas com as estratégias da matriz (RABIOSI, 2011; KUEMMERLE, 1999). E finalmente, subsidiárias implementadoras geralmente executam as estratégias corporativas e, sendo assim, não se envolvem com a criação de conhecimento e raramente possuem conhecimento relevante para transferir para a rede corporativa da EMN (AMBOS, T.; AMBOS, B.; SCHLEGELMILCH, 2006; RABIOSI, 2011). 


\subsection{Síntese e discussão dos resultados}

A discussão dos resultados está estruturada em três tópicos que abordam a relação entre a transferência reversa e as características do conhecimento, características das subsidiárias e as características da interação entre matriz e subsidiária.

\subsubsection{Transferência reversa do conhecimento e características do conhecimento}

De acordo com Winter (1987) e outros autores, a complexidade possui uma relação negativa com a transferência de conhecimento. Isso se dá, na maioria dos casos, porque uma vez que um conhecimento complexo se baseia em vários tipos de competências interrelacionadas, tende a gerar tecnologias independentes, rotinas individuais e recursos específicos. Hipoteticamente, a tacitividade e a complexidade dificultam a transferência reversa de conhecimento por meio de dois aspectos. Por um lado, a complexidade torna a atividade de transferência demandante de tempo e consumidora de recursos; sendo assim, a subsidiária, muitas vezes, reluta em se envolver com atividades de compartilhamento de conhecimento. Por outro lado, a tacitividade e a complexidade diminuem a habilidade da matriz em compreender e valorizar o conhecimento recebido; em outros termos, tais características diminuem a capacidade de absorção por parte da receptora do conhecimento (neste caso, matriz) (WINTER, 1987; TAVANI, 2010).

Corroborando a hipótese firmada neste estudo, os resultados mostram que a tacitividade influencia negativamente a transferência reversa de conhecimento, mas apesar disso, o resultado não apresentou significância estatística. O estudo de Minbaeva (2007) também não apresentou significância estatística para este constructo. A partir desse resultado, o autor argumenta que a ausência dos resultados sobre as características de conhecimento está em linha com sugestões recentes nas quais as características do conhecimento enquanto são determinantes importantes do conhecimento transferência não são necessariamente as únicas a interferirem no processo de trasnferência. De fato, muitos pesquisadores têm dado excessiva importância às características do conhecimento e pouca atenção aos outros determinantes do processo de transferência de conhecimento. Corroborando esse argumento, Szulanski e Cappetta (2003, p. 528) defendem que nem sempre as características do conhecimento são os determinantes mais impactantes da transferência de conhecimento. Ao contrário, também é preciso ampliar o escopo de análise e avaliar as empresas que buscam informações e as que são provedoras de informação. 
Em síntese, a falta de apoio para a relação entre tacitividade e transferência reversa de conhecimento pode ter se dado por duas razões: em primeiro lugar, a importância desta variável pode ser compensada por outros constructos; em segundo lugar, a falta de significância pode ser o resultado de limitações na operacionalização do constructo tacitividade.

Ao contrário da maioria dos estudos, os resultados deste estudo mostraram que há uma influência positiva e significativa da complexidade na transferência reversa de conhecimento tecnológico. Uma das razões desse resultado intrigante pode estar relacionada com o paradoxo da complexidade. Ou seja, ao mesmo tempo em que o conhecimento complexo enfrenta problemas de transferência e custos mais elevados, é o tipo de conhecimento mais compensatório para o receptor do conhecimento, no caso a matriz (CIABUSCHI; MARTÍN, 2012). Além disso, cabe ressaltar que apenas a tacitividade do conhecimento tem sido relacionada consistentemente a um efeito negativo para a transferência de conhecimento no ambiente da EMN. "O resultado do constructo complexidade tem variado ao longo dos estudos" (MINBAEVA, 2007, p. 572).

Conforme já referenciado, os estudo de Li (2007) e Wu e Li (2008) realizados com EMNs de Taiwan e da China constataram que a tacitividade e a complexidade, dentro de um nível crítico, resulta em maior capacidade dos funcionários da subsidiária em solucionar de problemas e, portanto, aumenta a implementação de transferência reversa de conhecimento, ao mesmo tempo em que aumenta a aceitação por parte do destinatário em receber o conhecimento que está sendo transferido. Evidentemente, após ultrapassar um nível crítico, o excesso de dificuldade começa a declinar a extensão com que a transferência de conhecimento é realizada. Em resumo, níveis moderados de tacitividade e complexidade resultam em grande extensão de transferência reversa de conhecimento tecnológico, ao passo que altos níveis de tacitividade e complexidade, resultam em uma diminuição dessa transferência.

Outra possível explicação para esse resultado reside na análise integrada das variáveis constantes no modelo deste estudo, como por exemplo, a variável complexidade com a variável rede interna. Segundo Winter (1987), quanto maior o grau de integração (relações estreitas) entre a unidade que transfere e a que recebe o conhecimento, maior é a possibilidade de que haja transferência de conhecimento complexo. Como o resultado da variável integração entre matriz e subsidiária é positivo e significante, isso pode ser uma das razões de a complexidade do conhecimento contribuir positivamente para a transferência reversa de conhecimento. Outro 
aspecto que pode ter contribuído para a relação positiva entre complexidade e transferência reversa de conhecimento é a interação da complexidade com a variável mecanismos de socialização (que de forma indireta apresentou um resultado positivo e significante), sobretudo os relacionados aos mecanismos de comunicação pessoal. De acordo com Mudambi (2002), mecanismos de socialização, como interação face a face, programa de formação conjunta, trabalho em equipe, entre outros, minimizam substancialmente a perda de conhecimento que geralmente acontece durante a transferência de conhecimento complexo.

Em relação à análise de comparação entre grupos para os constructos tacitividade e complexidade, nenhuma diferença significativa foi encontrada entre os subgrupos analisados (aquisição vs. greenfield; maduras vs. jovens; inovadora vs. implementadora vs. inovadora). O Quadro 26 apresenta as principais conclusões com relação à associação entre características do conhecimento e transferência reversa de conhecimento.

Quadro 26: Conclusões sobre a associação entre às características do conhecimento e a transferência reversa de conhecimento tecnológico

\begin{tabular}{|l|l|}
\hline Conceito chave & $\begin{array}{l}\text { Características do conhecimento influenciam a transferência reversa de } \\
\text { conhecimento tecnológico. }\end{array}$ \\
\hline \multirow{2}{*}{ Resultados chave } & $\begin{array}{l}\text { A complexidade do conhecimento aumenta a transferência reversa de } \\
\text { conhecimento tecnológico de forma significante. } \\
\text { A tacitividade do conhecimento não foi indicada como um item influenciador } \\
\text { da transferência de conhecimento tecnológico da subsidiária para a matriz. }\end{array}$ \\
\hline
\end{tabular}

\subsubsection{Transferência reversa do conhecimento e características das subsidiárias}

\subsubsection{Ambiente institucional}

A literatura destaca que a localização da subsidiária, entre outros fatores, tem impacto sobre a propensão das subsidiárias para inovar (CANTWELL; IAMMARINO, 1998, CANTWEL; MUDAMBI, 2008) e se envolver em transferências de conhecimento intrarrede (GUPTA; GOVINDARAJAN, 2000; YANG et al., 2008). Fatores institucionais dos países de acolhimento podem ser cruciais na determinação das características gerais das subsidiárias em cada local. 
De acordo com a Hipótese 3, quanto mais desenvolvidos os Ambiente institucional, maior a transferência reversa de conhecimento tecnológico. Isto está em consonância com diversas contribuições da literatura que argumentam que nações e/ou regiões específicas podem ser locais particularmente vantajosos para instalações de EMNs que buscam aumentar sua base de conhecimento por meio do aproveitando do conhecimento específico existente nas organizações desses países ou regiões (CANTWELL, 1989; FLORIDA, 1997). Autores como Gupta e Govindarajan (2000); Yang et al. (2008) e Cantwell e Mudambi (2008) concluíram que a intensidade de P\&D comandada pelas subsidiárias depende, em grande parte, das características da localização. Fatores institucionais dos países anfitriões, podem, portanto, influenciar na determinação das características gerais das subsidiárias em cada local. Tais características, por sua vez, podem determinar a natureza das transferências de conhecimento intrarrede (MEYER, 2007; YANG et al., 2008).

Considerando-se esse resultado, é importante retomar duas importantes correntes da literatura sobre EMNEs sobre os efeitos da localização. A primeira, liderada por Guillén e García-Canal (2009) e Ramamurti (2009a; 2009b), Khanna, Musacchio e Reisen de Pinho (2010), entre outros, defende que as EMNs emergentes, por terem operado em ambientes com condições difíceis, tais como, infraestrutura física pouco desenvolvida, burocracias corruptas, instituições educacionais fracas e governos instáveis, possuem as "vantagens da adversidade" e, sendo assim, estariam melhor preparadas para ter sucesso em países com um fraco ambiente institucional. Na segunda corrente, autores como Mathews (2006) e Child e Rodrigues (2005) arguem que as EMNEs localizam suas subsidiárias em países desenvolvidos como uma forma de alavancar sua eficiência produtiva, tecnológica e de marketing, seguindo uma estratégia de asset-seeking $^{15}$, a fim de aumentar a suas vantagens competitivas. As preferências das EMNBRs por mercados instáveis como alguns países da África e América Latina exemplificam sua tendência de explorarem os "vazios institucionais". Porém, quando se trata de subsidiárias que transferem conhecimento de forma reversa, nota-se que estão instaladas em países com melhores condições de infraestrutura, instituições de suporte aos negócios e ambiente legal favorável. Logo, pode-se inferir que as EMNBrs se adaptam mais facilmente a mercados estrangeiros com ambientes institucionais fracos, contudo, parecem ter a capacidade dinâmica

15 Strategic asset seeking é, segundo Dunning (1988), um dos quatro diferentes tipos de atividades que caracterizam o porquê da atuação da empresa multinacional e que constituem os principais motivadores do investimento direto externo. Especificamente, a estratégia de asset-seeking se dá quando uma empresa se internacionaliza com o objetivo proteger e aumentar suas vantagens específicas ou reduzir a dos seus competidores. 
de se moldarem em ambientes institucionais mais desenvolvidos afim de aprender e transferir conhecimentos para a matriz.

Os resultados da análise de grupo apresentam diferenças significativas para o constructo Ambiente institucional quando associado ao papel inovador da subsidiária. Esse resultado corrobora o estudo de Frost (2001), que afirma que as capacidades técnicas distintas das subsidiárias estão relacionadas positivamente com as vantagens dos países anfitrião, tais como: clientes locais importantes, recursos humanos com habilidades técnicas distintas e instituições avançadas de tecnologias.

\subsubsection{Ambiente competitivo}

Um ambiente altamente competitivo propicia as condições essenciais para que as subsidiárias localizadas naqueles mercados sejam susceptíveis de receber recursos e apoio da corporação para melhorar seus processos de desenvolvimento de conhecimento na subsidiária. Uma vez fazendo parte de ambientes dinâmicos, as subsidiárias podem ter acesso a ideias de inovação, talentos e conhecimentos específicos (BARTLETT; GHOSHAL, 1992; PORTER, 1990). De acordo com Mudambi e Navarra (2004), grandes subsidiárias estabelecidas em grandes mercados podem exercer maior poder de barganha intrafirma. A partir desse argumento, Yang et al. (2008) advogam que subsidiárias estabelecidas em grandes mercados podem achar mais fácil transferir conhecimento de volta para seus países, mesmo que o nível de relevância desse conhecimento seja baixo. Além disso, a falta de dinamismo do mercado freia o comprometimento da multinacional no exterior, uma vez que a matriz pode delegar a subsidiárias estabelecidas nesses mercados, um papel periférico focado apenas em explorar em detrimento de inovar (BORINI, 2008).

No contexto de EMNs emergentes, Guillén e García-Canal (2009) argumentam que tais empresas deveriam estabelecer suas subsidiárias em locais onde possam tirar proveito do ambiente competitivo e aprender com as condições dos fatores, demanda local e competição acirrada (PORTER, 1990). Tal aprendizagem resultaria em vantagens competitivas. É válido ressaltar, porém, que pesquisas realizadas no contexto das EMNs emergentes indicaram dificuldades dessas empresas em aprender com indústrias mais competitivas por causa da defasagem tecnológica. Para suportar seu argumento, o autor coloca luz ao caso dos tigres asiáticos em que EMNs emergentes têm muitam dificuldade quando tentam "dar saltos" em 
suas tentativas de modernização (HOBDAY, 2000, 1995; SACHWALD, 2001 apud BARNARD, 2011). Em outras palavras, é possível que EMNs emergentes possam aprender menos em ambientes com indústrias de ponta nos países desenvolvidos, e, paradoxalmente, aprender mais em ambientes com indústrias menos competitivas, com menor defasagem tecnológica e, portanto, com maior similaridade. Independentemente dos argumentos sobre o dinamismo do ambiente externo para as EMNs tradicionais e emergentges, a Hipótese H4 não apresentou evidências estatística significativas.

Em relação à análise de comparação entre grupos, não apresentou nenhuma diferença significativa entre os subgrupos para o constructo ambiente competitivo.

\subsubsection{Integração externa (com a rede de negócios)}

A Hipótese H5 procurou verificar a relação entre a inserção na rede externa e a extensão da transferência reversa de conhecimento. O resultado do modelo PLS está em linha com esta hipótese no que se refere aos fornecedores e clientes. Ou seja, há uma relação positiva e significativa entre integração com fornecedores e clientes e a extensão da transferência reversa de conhecimento.

Em contraposição, no que se refere às instituições de $C \& T$, a relação encontrada no modelo PLS foi negativa e significativa. Uma provável explicação para esse resultado pode ser o fato de a integração com instituições de C\&T estar possivelmente relacionada à criação de conhecimento muito específico, relacionado ao contexto local, não sendo passível, portanto, de transferência para outras unidades da EMN.

É interessante notar que há discordância na literatura quanto à contribuição da integração externa com a rede de negócios local para a transferência reversa de conhecimento. Alguns autores arguem que integração com os atores locais serve de dispositivo de aquisição de conhecimentos que aumenta a capacidade da empresa de desenvolver o conhecimento. Contribuições anteriores também suportam essa conclusão (BIRKINSHAW, 1996; HÅKANSON; NOBEL, 2001; ALMEIDA; ANUPAMA, 2004). Andersson, Forsgren e Holm. (2005) e Håkanson e Nobel (2001) mostram que o grau de enraizamento com os atores locais de fato impacta positivamente na capacidade de inovação da subsidiária. Birkinshaw (1996) descobriu que os atores locais são uma das principais fontes de vantagem competitiva para as 
subsidiárias. Por outro lado, Andersson, Forsgren e Holm (2007), por exemplo, defendem que o envolvimento com a rede local, apesar de melhorar a capacidade de absorver conhecimento tácito e complexo, focaliza a demanda e as expectativas dos parceiros locais (HAKANSON; NOBEL, 2001) e, por isso, tenderia a reduzir o nível de integração da subsidiária com as outras unidades da multinacional por gerar um conhecimento muito específico, relacionado ao contexto local e, portanto, difícil de transferir.

Com relação à comparação entre grupos, os resultados apontaram uma diferença significativa para o tipo de empresa. O envolvimento das subsidiárias com os fornecedores resultou numa associação mais forte para o grupo greenfield. Esse resultado é diferente do esperado, pois, de maneira geral, os estudos indicam que as subsidiárias adquiridas possuem maior envolvimento com a rede externa (por exemplo, Tavani (2010)). De acordo com Hakanson e Nobel (2001), uma vez que as elas já tiveram tempo para estabelecerem-se em redes de locais, unidades adquiridas tendem a ser mais profundamente enraizada se comparadas às unidades do tipo greenfield no momento da criação. No entanto, na sequência da aquisição, o nível de enraizamento pode diminuir inicialmente, como resultado do redirecionamento estratégico das atividades e prioridades por parte do novo proprietário, ou até mesmo por causa da incerteza do novo proprietário sobre a capacidade e confiabilidade da rede local. Com o aumento da idade, porém, as condições que determinam o grau de incrustação local tornam-se semelhantes às das unidades greenfield. Em outros termos, o enraizamento local das unidades greenfield tende a subir ao longo do tempo. No caso das unidades adquiridas, pode-se esperar uma relação curvilínea, em forma de U, ao longo do tempo. Como, neste estudo, não foi feito o cruzamento entre os constructos rede com fornecedores, tipo de subsidiária e tempo de existência, não se pode afirmar que as suposições de Hakanson e Nobel (2001) se confirmaram neste estudo; ao contrário, pode-se apenas especular com base nas suposições do referido autor que subsidiárias adquiridas tendem a ser mais integradas com a rede externa com o passar do tempo.

\subsubsection{Autonomia}

De acordo com a Hipótese 6, quanto maior a autonomia da subsidiária, maior a extensão da transferência reversa de conhecimento. Os resultados apoiaram fortemente esta hipótese. A literatura também destaca a importância da autonomia da subsidiária para a transferência reversa de conhecimento (por exemplo, CANTWELL; MUDAMBI, 2005; NOBEL; BIRKINSHAW, 1998). Foss e Pedersen (2002) argumentam que as subsidiárias altamente 
autônomas adquirem liberdade para explorar o conhecimento e, portanto, envolver-se em mais transferência de conhecimento.

A comparação entre os grupos apresentou diferença significativa para os grupos tipo de empresa (aquisição e greenfield) e papel da subsidiária (implementadora, contribuidora e inovadora). Com relação ao tipo de empresa, o constructo autonomia apresentou um escore mais elevado para o contexto de subsidiárias adquiridas. Uma provável explicação para esse resultado são as diferenças entre esses tipos de subsidiárias. Subsidiárias estabelecidas por meio de greenfield são formadas a partir do zero em termos de estrutura e de operação, sendo natural, portanto, que a matriz estruture a nova unidade de acordo com seu próprio funcionamento (HAKANSON; NOBEL, 2001). Tais subsidiárias são significativamente dependentes do conhecimento de sua empresa matriz, e não do conhecimento do mercado. Por outro lado, dado que as subsidiárias adquiridas já operavam no mercado anteriormente, elas podem estar mais aptas e interessadas em perseguir seus próprios objetivos, além de possuir culturas organizacionais muitas vezes bem distintas da cultura da matriz. Nesse contexto, conceder maior grau de autonomia para a empresa adquirida pode aliviar as tensões, facilitar interações e, consequentemente, aumentar o fluxo de conhecimento entre as duas organizações. No entanto, é preciso sempre buscar o equilíbrio entre autonomia e integração, tendo em vista que a concessão demasiada de autonomia para empresas adquiridas pode impedir sinergias internas na rede corporativa (MARTINKENAITE, 2012).

Com relação ao papel da subsidiária, a comparação entre grupos confirma que subsidiárias com um papel mais estratégico (inovador) são propensas a ter altos níveis de autonomia (NOBEL; BIRKINSHAW, 1998; RABIOSI, 2011). Conclui-se, portanto, que diferentes graus de autonomia da subsidiária estão intimamente relacionados aos papéis das subsidiárias (HARZING; NOORDERHAVEN, 2006) e a seu modo de entrada (HAKANSON; NOBEL, 2001).

\subsubsection{Motivação}

De acordo com a Hipótese 7, um alto nível de motivação estaria relacionado com o aumento da extensão com que o conhecimento é transferido de forma reversa entre matriz e subsidiária. Em contraste com isso, os testes estatísticos aplicados ao modelo apresentaram uma relação 
negativa entre a motivação e a transferência reversa de conhecimento tecnológico. No entanto, a relação não apresentou significância.

$\mathrm{Na}$ literatura, encontra-se constatações opostas. Contribuições como as Minbaeva (2007) e Inkpen (2000) têm destacado o importante papel da motivação para a transferência de conhecimentos. Contudo, estudos de igual importância como os de Gupta e Govindarajan (2000) não encontrou suporte para essa hipótese. Esses autores justificam que a motivação da unidade recebedora do conhecimento pode ser muito mais importante do que a motivação da unidade fonte para o processo de transferência de conhecimento. O estudo de Szulanski (1996) também constatou que os fatores motivacionais têm, relativamente, menor importância para a compreensão da eficiência da transferência do conhecimento.

Com relação à comparação entre grupos, o resultado permitiu concluir que o constructo motivação é mais fortemente associado com subsidiárias estabelecidas por meio de greenfield. De acordo com Szulanski (1996), um clima social marcado por confiança, cooperação e compartilhamento de códigos e linguagem, limita a competição entre os empregados e os encoraja a compartilhar seus conhecimentos com outras unidades da rede. No que tange aos processos de aquisição, sabe-se que por vezes, são marcados por barreiras culturais e dificuldades de integração. Logo, isso pode diminuir a vontade de compartilhar conhecimento na EMN. Assim sendo, conclui-se que unidades estabelecidas por meio de greenfield possivelmente teriam maior motivação inicial para transferir conhecimento intrarrede.

O Quadro 27 apresenta uma síntese dos resultados da associação entre as características da subsidiária e a transferência reversa de conhecimento.

Quadro 27: Conclusões sobre a associação entre às características das subsidiárias e a transferência reversa de conhecimento tecnológico

\begin{tabular}{|l|l|}
\hline Conceito chave & $\begin{array}{l}\text { Características das subsidiárias influenciam a transferência reversa de } \\
\text { conhecimento tecnológico. }\end{array}$ \\
\hline Resultados chave & $\begin{array}{l}\text { Ambiente institucional, Rede externa com fornecedores e Autonomia são } \\
\text { facilitadores da transferência reversa de conhecimento. }\end{array}$ \\
- Ambiente competitivo não foram indicados como influenciadores da \\
transferência reversa de conhecimento.
\end{tabular}




\subsubsection{Transferência reversa do conhecimento e características da interação subsidiárias/matriz}

\subsubsection{Integração interna (com a matriz)}

De acordo com a Hipótese 8, a integração interna (subsidiária-matriz) é relacionada positivamente com a transferência reversa de conhecimento. Esta hipótese foi confirmada, ainda que de forma marginal ( $p$-value 0,10). A literatura tem destacado, de forma consistente, a relação entre matriz e subsidiária como benéfica para a transferência de conhecimento (por exemplo, SZULANSKI, 1996; KOGUT; ZANDER, 1993). Foss e Perdensen (2000) concluíram que quanto maior a interdependência entre a unidade que transfere o conhecimento e a unidade que recebe o conhecimento, mas bem-sucedida será a transferência de conhecimento. De forma mais específica aos objetivos deste estudo, Hakanson e Nobel (2001) concluíram que a integração entre matriz e subsidiária é positivamente associada à transferência reversa de conhecimento.

A comparação entre grupos para o constructo integração interna não apresentou nenhuma diferença significativa. Em outras palavras, independentemente dos subgrupos modo de entrada, idade ou importância estratégica, a integração interna é considerada um fator determinante para a transferência reversa de conhecimento.

\subsubsection{Semelhança organizacional}

Os resultados das contribuições anteriores (KOGUT; ZANDER, 1992), sobre o processo de transferência do conhecimento internacional, mostram que a existência de valores compartilhados facilita as atividades de compartilhamento de conhecimento por meio da criação de confiança e entendimento compartilhado. Em contraste com estes resultados, nem o resultado do modelo PLS nem o resultado da comparação entre os grupos apoiam essa associação (Hipótese 9). Na literatura existente, alguns estudos (ZHOU; FROST, 2003; AMBOS; AMBOS; SCHLEGELMILCH, 2006; TAVANI, 2007) também não conseguiram encontrar qualquer conexão entre a semelhança organizacional e a transferência reversa de conhecimento. 
A comparação entre grupos para o constructo semelhança organizacional não apresentou nenhuma diferença significativa. Em outras palavras, independentemente dos subgrupos modo de entrada, idade e importância estratégica, a semelhança organizacional não é considerada um fator determinante para a transferência reversa de conhecimento neste estudo.

\subsubsection{Mecanismos de socialização e integração interna (com a matriz)}

Pesquisas empíricas sugerem que os mecanismos de socialização nas EMNs facilitam o desenvolvimento de laços interpessoais (MUDAMBI; MUDAMBI; NAVARRA, 2007; BJÖRKMAN; BARNER-RASMUSSEN; LI, 2004) (e, por conseguinte, a existência de redes interpessoais facilita a difusão e criação de novos conhecimentos em todas as unidades dentro de uma corporação) (TSAI; GOSHAL, 1998; TSAI; 2001). Alinhada com esses achados, a Hipótese 11a, estabelece que quanto mais frequentes os mecanismos de socialização, maior a integração com a matriz. Os resultados indicaram uma positiva e significante relação entre esses dois fatores.

A comparação entre grupos em relação ao constructo mecanismos de socialização não apresentou nenhuma diferença significativa. Em outras palavras, independentemente dos subgrupos analisados, os mecanismos de socialização são considerados um fator determinante para a transferência reversa de conhecimento neste estudo.

\subsubsection{Mecanismos de socialização e semelhança organizacional}

Além de desenvolverem laços fortes entre os interlocutores, os mecanismos de socialização também têm sido destacados como um modo de estabelecer compartilhamento de valores, objetivos, crenças, senso de missão e cultura corporativa unitária entre os atores das unidades das EMNs (NOHRIA; GHOSHAL, 1994). Os estudos de Dyer e Nobeoka (2000) e Tavani (2010) constataram haver uma relação positiva entre mecanismos de socialização e semelhança organizacional (similarmente ao postulado na hipótese 11b). Os resultados desta pesquisa confirmaram essa hipótese, já que apresentaram uma positiva e significante relação entre esses dois fatores. 
A comparação entre grupos realizada para o constructo mecanismos de socialização também não apresentou diferença significativa, indicando que esse constructo, em todos os subgrupos analisados, é um fator positivo e significante para o constructo semelhança organizacional.

\subsubsection{Mecanismos de socialização e transferência reversa de conhecimento}

Os mecanismos de socialização entre unidades da rede corporativa da EMN têm sido relacionados positivamente com a transferência reversa de conhecimento (BJÖRKMAN; BARNER-RASMUSSEN; LI, 2004; BRESMAN; BIRKINSHAW; NOBEL, 1999, SCHULZ, 2003). Estudos prévios relacionaram os canais ricos ${ }^{16}$ de comunicação com a difusão da inovação intrarrede (GHOSHAL; BARTLETT, 1988). Szulanski (1996) indica que, na ausência de relações preexistentes entre unidades da EMN, os mecanismos de socialização agem como um fator de criação de "aderência" para o compartilhamento do conhecimento. Isto se dá principalmente porque os mecanismos de socialização melhoram a profundidade e a extensão do uso de conhecimento recíproco (TSAI, 2001).

Da mesma forma, Tsai (2001) argumenta que a transferência de conhecimento interunidade em multinacionais ocorre por meio de um contexto social compartilhado no qual diferentes unidades são ligadas umas às outras. Para Bjorkman Barner-Rasmussen e Li (2004), laços interpessoais entre as unidades de multinacionais fornecem canais por meio dos quais a informação e o fluxo de recursos podem ser intercambiados de uma unidade à outra.

Em aderência às contribuições da literatura, a Hipótese 11c, a qual indicava haver uma relação positiva entre mecanismos de socialização e transferência reversa de conhecimento foi confirmada. Além disso, as Hipóteses 11a e 11b também indicaram haver uma relação indireta dos mecanismos de socialização mediados pela integração interna e semelhança organizacional, respectivamente. Destarte, pode-se concluir que a existência de mecanismos de socialização, além de criar laços mais fortes entre subsidiária e matriz, também possibilita construir contextos organizacionais semelhantes entre as unidades de uma EMN.

Com relação ao tipo de mecanismos de socialização, este estudo traz uma contribuição interessante. As evidências positivas desse constructo na transferência reversa de conhecimento

\footnotetext{
${ }^{16}$ Comunicação face a face.
} 
tecnológico só foram encontradas para os mecanismos de socialização do tipo pessoal. Para os mecanismos de socialização formais não foram encontradas nenhuma evidência. Esse resultado vai de encontro às explicações sugeridas pelos estudos anteriores, como, por exemplo, Bartlett e Ghoshal (1989) que lançaram luz sobre o papel dos mecanismos formais de integração. Contudo, autores como Piscitello e Rabiosi (2006) concluem que nos casos de subsidiárias com papel inovador, o impacto dos fluxos de conhecimento de inovação reversa é maior nos casos em que os mecanismos de socialização baseados em pessoas são mais utilizados do que os mecanismos baseados em comunicação formal (ou eletrônica).

Com o intuito de entender esse resultado, levantam-se algumas suposições. A primeira reside no fato de que os gestores enfrentam diversas dificuldades na transferência de conhecimento de contexto específico e tácito por meio de mecanismos de coordenação baseados em comunicação eletrônica (PEDERSEN et al., 2003). E, além disso, sabe-se que os mecanismos de socialização via comunicação pessoal, diminuem as incertezas sobre a amplitude e a difusão do conhecimento ambíguo (SCHREINER; KALE; CORSTEN, 2009 apud ROWEL et al., 2013). A segunda suposição reside no fato de que a relação da matriz e suas controladas é hierarquizada e, nesta situação, mecanismos coercitivos e formalizados aplicados pela matriz poderia induzir a antagonismos das controladas e, posteriormente, gerar um efeito negativo sobre o fluxo de conhecimento partindo das subsidiárias; ao passo que os mecanismos de socialização mediados por comunicação pessoal são representados por pressupostos colaborativos e, por isso, podem render um melhor resultado no compartilhamento do conhecimentos por meio da construção de relação de confiança entre as subsidiárias e matriz (PARK; GHAURI, 2011 apud ROWEL et al., 2013).

A comparação entre grupos realizada para o constructo mecanismos de socialização não apresentou nenhuma diferença significativa.

O

Quadro 28 apresenta uma síntese dos resultados da associação entre as características da interação matriz/subsidiária e a transferência reversa de conhecimento. 
Quadro 28: Conclusões sobre a associação entre às características da interação entre matriz/subsidiárias e a transferência reversa de conhecimento tecnológico

\begin{tabular}{|l|l|}
\hline Conceito chave & $\begin{array}{l}\text { Características da interação entre matriz/subsidiárias influenciam a transferência } \\
\text { reversa de conhecimento tecnológico. }\end{array}$ \\
\hline Resultados chave & $\begin{array}{l}\text { Integração interna (com a matriz) tem uma influência positiva na } \\
\text { transferência reversa de conhecimento. }\end{array}$ \\
- $\begin{array}{l}\text { Semelhança organizacional não foi detectada estatisticamente como } \\
\text { influenciadora da transferência reversa de conhecimento. }\end{array}$ \\
$\begin{array}{l}\text { Mecanismos de socialização possuem uma positiva influência na } \\
\text { transferência reversa de conhecimento. Adicionalmente, por meio da } \\
\text { integração interna, esse fator influencia positivamente a transferência } \\
\text { reversa de conhecimento. }\end{array}$ \\
\hline
\end{tabular}

\subsubsection{Visão integrada da transferência reversa de conhecimento tecnológico}

A Ilustração 27 apresenta as associações entre transferência reversa de conhecimento e seus antecedentes. Ressalta-se que só estão apresentados nessa ilustração os antecedentes que se mostraram significantes a partir do presente estudo.

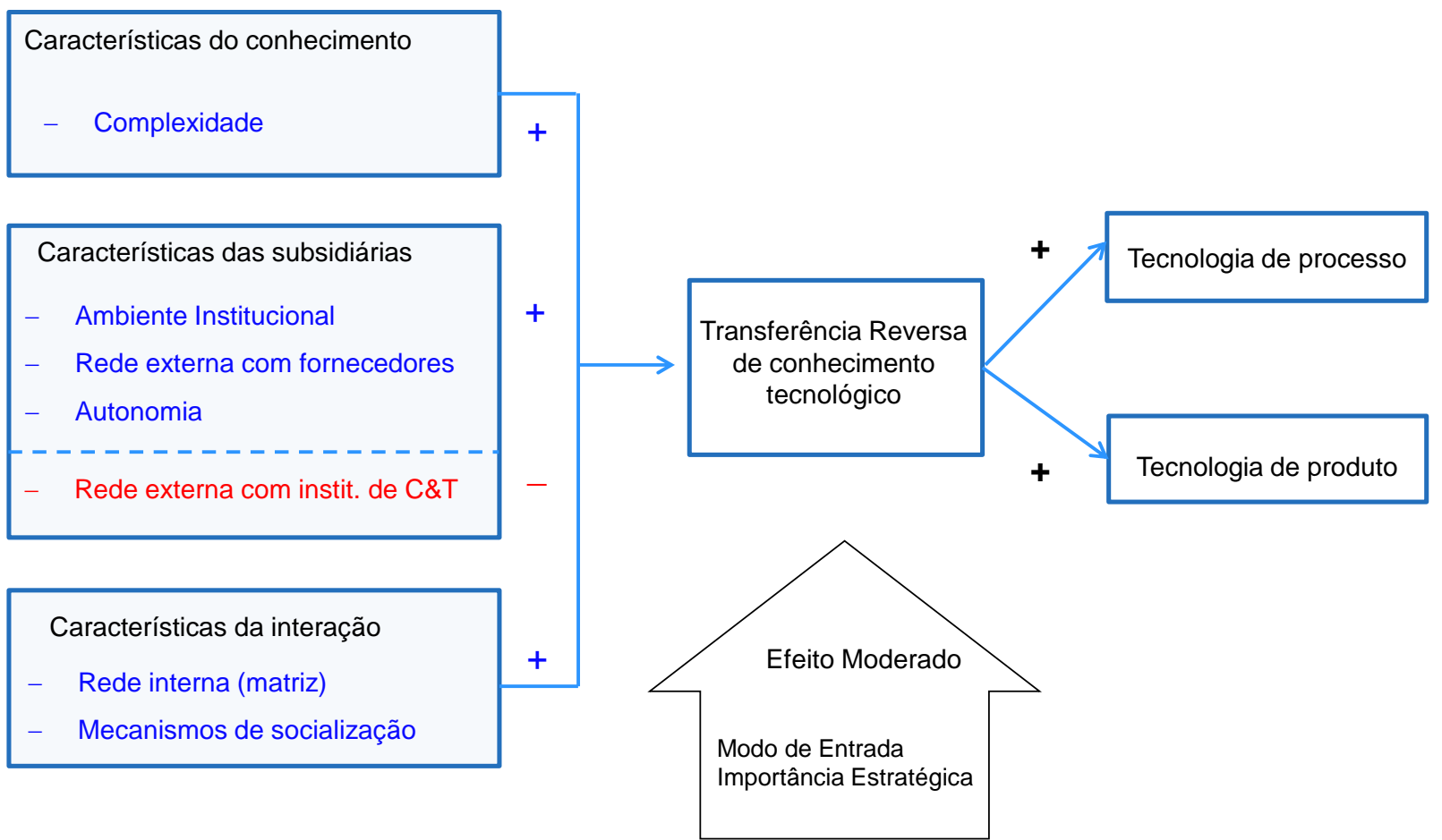

Ilustração 27: Facilitadores e dificultadores da transferência reversa de conhecimento tecnológico segundo a pesquisa realizada 


\section{CONCLUSÕES E RECOMENDAÇÕES}

Este capítulo está estruturado em três seções. A primeira sintetiza as conclusões sobre os resultados obtidos pelo estudo. A segunda firma as implicações teóricas e gerenciais com base nesses resultados. A terceira seção discute as limitações e faz as recomendações para futuras direções de pesquisa.

\subsection{Conclusões}

A importância da transferência do conhecimento na EMN é indiscutível e pode afetar criticamente a estrutura organizacional e a configuração estratégica desta. Atualmente, muitos autores têm abordado o tema da transferência do conhecimento interna na EMN, mas poucos são os estudos que abordam essa temática analisando o fluxo de conhecimento da subsidiária para a matriz. Ainda que trabalhos mais recentes abordem esse tema, fornecendo uma visão valiosa, muitos são fragmentados e assumem diversas perspectivas. Vários ainda são limitados ao menos em duas perspectivas teóricas. Partem, sobretudo, do contexto de EMNs provenientes de países desenvolvidos. Não está claro que as descobertas de estudos anteriores em EMNs tradicionais sejam generalizáveis para as EMNs de países emergentes e, em particular, às EMNs brasileiras.

Sendo assim, o estudo em questão tomou por base o framework ancorado nos preceitos da visão baseada no conhecimento $(\mathrm{KBV})$ e da teoria das redes, que ressaltam a importância da integração dual, ou seja, a integração com os parceiros internos e externos à EMN como promovedora da transferência de conhecimento da subsidiária para a matriz (TAVANI, 2010; MU et al., 2007). Argumentou-se que, o aumento da importância da subsidiária ao longo de sua evolução, potencializou a capacidade das unidades periféricas da EMN de transferir conhecimento de forma reversa, ressaltando-se a premissa inicial deste estudo de que as EMNs têm habilidade superior em transferir inovações internamente (KOGUT; ZANDER, 1992, 1993; ZANDER; KOGUT, 1995, 1996).

Foi a partir desse ponto da literatura que este trabalho se propôs a verificar quais os principais determinantes da transferência reversa de conhecimento tecnológico nas empresas multinacionais brasileiras distinguindo tais determinantes em características do 
conhecimento, características das subsidiárias e características da interação matriz/subsidiária. Além disso, avaliaram-se os efeitos moderadores, nessa relação, do modo de entrada, do tempo de existência e da importância estratégia da subsidiária.

Para tanto, realizou-se um survey com 78 subsidiárias de multinacionais brasileiras. Empregouse o método de modelagem de equações estruturais - Partial Least Square (MEEPLS) - e procedeu-se à análise dos resultados, que consistiu em duas fases sequenciais: a análise descritiva e a análise de PLS. A análise descritiva permitiu a identificação das frequências de respostas dos respondentes relativamente a todos os constructos presentes no instrumento de pesquisa. A análise PLS foi conduzida com a finalidade de identificar quais seriam as correlações entre os determinantes e a transferência reversa de conhecimento do tipo tecnológico nas empresas multinacionais brasileiras pesquisadas. A seguir, serão evidenciadas, a partir dessa análise, as condições prioritárias para que a transferência reversa aconteça nas multinacionais brasileiras.

Várias conclusões podem ser traçadas. Em primeiro lugar, os resultados mostram que as subsidiárias das EMNs brasileiras, transferem seus conhecimentos tecnológicos para a matriz, ainda que em média extensão. Entre os vários tipos de conhecimento tecnológico mensurados, listam-se os seis que apresentaram um grau razoável de transferência, por ordem decrescente: (i) pequenas mudanças na tecnologia de processo; (ii) melhoria significativa em produtos existentes; (iii) pequenas adaptações na tecnologia de produtos existentes; (iv) desenvolvimento de novos produtos; (v) know-how para projetar novos produtos; e (vi) testes de novos produtos. Como se pode observar, apenas o primeiro item é relacionado à inovação em processo. Logo, pode-se afirmar que há maior extensão de transferência reversa nas EMNs brasileiras relacionada a melhorias e desenvolvimento de novos produtos. A partir desse novo resultado e tomando-se por base os estudos de Fleury, A. e Fleury, M. (2013), desenvolvidos nos anos de 2006 e 2010, pode-se traçar uma análise evolutiva das transferências reversas nas EMNs brasileiras. Os resultados do primeiro levantamento feito por Fleury, A. e Fleury, M. (2013) constataram que no ano de 2006 não havia transferência de competências da subsidiária para a matriz em nenhum dos aspectos pesquisados: produção, marketing, desenvolvimento de produtos e serviços e gerenciamento de recursos humanos e financeiros. O segundo levantamento, realizado entre 2010 e 2011, indicou ter havido um acréscimo significante de transferência referente a competências de produção. Adicionando-se aos estudos de Fleury, A. e Fleury, M., os resultados deste estudo parecem confirmar que, finalmente, as EMNs 
brasileiras começam a se mover na direção de criar e compartilhar conhecimento em sua rede dispersa.

Na sequência, são apresentados os resultados sobre os determinantes que influenciam positiva e negativamente a transferência reversa do conhecimento, de acordo com o modelo conceitual delineado e as hipóteses subjacentes.

Do ponto de vista das características do conhecimento, foi possível inferir que os níveis de complexidade, contrariamente ao que se postulou, têm um impacto positivo sobre a extensão da transferência reversa de conhecimento. Uma das possíveis explicações para esse resultado intrigante pode ser o nível de complexidade aceito por quem deseja transferir o conhecimento. De acordo com Li (2007) e Wu e Li (2008), níveis moderados de tacitividade, complexidade e especificidade do conhecimento podem aumentar a transferência reversa de conhecimento tecnológico porque aumentam a capacidade dos funcionários de resolver problemas e de se envolver no processo de transferência. Só após ultrapassarem um nível crítico é que as dificuldades causadas pela complexidade resultariam numa diminuição da transferência reversa de conhecimento tecnológico.

Pode-se inferir, a partir desse pressuposto, que a complexidade do conhecimento tecnológico no contexto das EMNs brasileiras ainda não chegou a um nível crítico que impeça a ocorrência de transferência reversa de conhecimento tecnológico. Isso pode ser atestado pelo grau de complexidade da tecnologia que está sendo transferida, pois de acordo com a classificação de Lall (1992), adaptações e melhorias de produto estão em um grau intermediário de complexidade tecnológica. A partir desses resultados, sugere-se que o conhecimento complexo, apesar de ser considerado mais abstrato, não verbalizável, intuitivo, embutido, mais difícil de compreender e ensinar e mais demandante de tempo, dinheiro e esforços para ser transferido, pode ter seu lado positivo até que não ultrapasse certo limite de dificuldade aceito pela fonte desse conhecimento. Nesse caso, é preciso que a matriz, como beneficiária direta desse conhecimento, esteja atenta para acionar um alerta e atuar na melhoria desse processo quando as dificuldades relativas ao conhecimento de natureza ambígua não puderem mais ser superadas pela fonte (JENSEN; SZULANSKI, 2004).

Quanto aos resultados para o grupo de determinantes classificados como características das subsidiárias, destacam-se incialmente os ambiente institucional, também chamados de 
determinantes do local. Os resultados desse constructo apresentaram uma relação positiva com a transferência reversa de conhecimento tecnológico. Como outros autores têm apontado, os determinantes do local "têm um importante efeito no processo e nos mecanismos através dos quais o conhecimento viaja dentro das comunidades técnicas." (NELSON, 1993 apud FROST, 2001).

Em seu estudo sobre as EMNs emergentes, Mathews (2006) e Child e Rodrigues (2005) argumentam que países desenvolvidos atenderiam melhor à busca das EMNs por ativos estratégicos que impulsionem sua eficiência produtiva, tecnológica e de mercado. A partir dos resultados deste estudo, fica claro que as EMNs brasileiras contribuem mais criativamente para a geração e transferência de tecnologia quanto melhor e mais favoráveis são os determinantes do país no qual a subsidiária está instalada. Ademais, alguns autores ressaltam que, dependendo da importância estratégica da localização geográfica da subsidiária, um conhecimento relevante pode ter maior ou menor impacto sobre as transferências de conhecimento (JENSEN; SZULANSKI, 2004). Além disso, os resultados permitem verificar que as multinacionais provenientes de mercados emergentes, especificamente as brasileiras, estão lançando mão de estratégias ambidestras no que se refere à localização. Isso significa que, de um lado, instalam suas operações em países com os chamados "vazios institucionais" (KHANNA; MUSACCHIO; REISEN DE PINHO, 2010), para usufruir de sua vantagem de saber operar em ambientes menos desenvolvidos e com economias menos estáveis; de outro, procuram estabelecer suas unidades em países com ambientes institucionais estruturados, com vistas em se apropriar das facilidades e dos novos conhecimentos existentes nesses mercados.

No tocante aos ambiente competitivo, a despeito de o resultado deste estudo ter apontado uma relação positiva destes com a transferência reversa de conhecimento tecnológico, não foram encontradas evidências estatísticas. Estudos em subsidiárias estrangeiras de países desenvolvidos (FROST, 2001; FROST et al., 2002), mostram que as subsidiárias estrangeiras instaladas em contextos competitivos são beneficiadas pelos atributos positivos do ambiente e os usam como alavanca para inovações globais (GUILLÉN; GARCIA CANAL, 2009). Contudo, resultados de estudos anteriores sobre o contexto das EMNEs indicaram dificuldades dessas empresas em aprender com indústrias mais competitivas por causa de sua defasagem tecnológica (HOBDAY, 2000, 1995; SACHWALD, 2001 apud BARNARD, 2011), enquanto em mercados menos competitivos seria mais fácil para elas obter vantagens competitivas (WELLS, 1983). Independentemente da falta de evidências relativas a esse constructo, é 
importante ressaltar que, apesar da grande importância dada aos benefícios de um contexto competitivo este tem menor poder de explicação do que a integração externa com a rede de negócios local no que concerne à criação e transferência de conhecimento e competências (BORINI; FLEURY, 2011).

Os resultados para o constructo integração externa com a rede de negócios apresentaram algumas facetas. Foi analisada, especificamente, a integração com três parceiros do ambiente local: fornecedores, clientes e instituições de C\&T. A integração com fornecedores resultou no principal determinante positivo da transferência reversa de conhecimento tecnológico, mas a integração com instituições de C\&T, surpreendentemente, resultou em um impacto negativo na transferência reversa de conhecimento tecnológico. Quanto à integração com os clientes, não houve resultado significante.

A integração positiva com os fornecedores está em consonância com os autores que arguem que quanto mais a subsidiária se encontra enraizada nas redes de negócios, maior a possibilidade de ganhar acesso a novos conhecimentos, que podem, subsequentemente, ser transferidos para a EMN (ANDERSSON; FORSGREN; HOLM, 2002). Ao interagir com os fornecedores, a subsidiária aprende sobre problemas específicos e novas possibilidades tecnológicas, e cria oportunidades para encontrar novas soluções e conhecimentos. Já a relação negativa das instituições de C\&T com a transferência reversa de conhecimento tecnológico, pode ter-se dado porque a integração externa com a rede local, apesar de melhorar a capacidade de absorver conhecimento tácito e complexo, foca a demanda e expectativas dos parceiros locais (HAKANSON; NOBEL, 2001); por isso, tenderia a gerar um conhecimento muito específico, relacionado ao contexto local e, nesse caso, de difícil aderência às necessidades de outras unidades da corporação. Logo, pode-se depreender que uma aproximação das subsidiárias estrangeiras com os fornecedores gera um conhecimento de conteúdo não local ${ }^{17}$, e, por isso, possível de ser transferido para o resto da corporação, ao passo que a integração com os centros de C\&T pode influenciar negativamente a transferência reversa de

17 De acordo com Rugman e Verbeke (2001) competências "não locais" são aquelas provenientes das vantagens de propriedade de uma unidade da empresa multinacional (matriz ou subsidiária) que são possíveis de ser transferidas para as demais empresas do grupo. Essa nomenclatura foi cunhada, porque nem todas as competências desenvolvidas podem ser transferidas, em razão de serem são úteis apenas para garantir a competitividade num determinado país em que a competência foi desenvolvida e, portanto, são exclusivas de um único mercado. Essas são chamadas de competências "locais". 
conhecimento tecnológico porque propicia um conhecimento do contexto específico do local, que não se aplica a outros contextos da corporação.

Independentemente das relações encontradas entre os determinantes da rede de negócios local e a transferência reversa de conhecimento tecnológico, o estudo também constata que continua pífia a integração das subsidiárias brasileiras com os parceiros das redes de negócios local. Estudos anteriores também chegaram à mesma constatação (BORINI, 2008; OLIVEIRA JÚNIOR; BORINI, 2009; BORINI; FLEURY, 2011). Fazer parte dessas redes é essencial para o desenvolvimento de conhecimentos distintivos na subsidiária. Sem essa conexão com parceiros locais, é provável que as subsidiárias tenham atribuições circunscritas apenas à adaptação de produtos e processos da sede para o mercado local, o que, evidentemente, não permite desenvolver competências capazes de fornecer à multinacional uma vantagem competitiva global.

No tocante ao constructo autonomia, a despeito de evidências ambíguas sobre o efeito da autonomia na extensão da transferência reversa de conhecimento tecnológico, este estudo confirmou que um alto grau de autonomia da subsidiária é mais capaz de transferir, de forma reversa, conhecimento tecnológico. Subsidiárias adquiridas obtêm um grau mais elevado de autonomia do que as subsidiárias do tipo greenfield (BIRKINSHAW et al., 2010). O argumento mais comumente citado sobre o efeito positivo da autonomia na transferência reversa de conhecimento tecnológico baseia-se na ideia de que a independência das subsidiárias lhes possibilita maior acesso às bases dos conhecimentos locais, levando-as a aprender com os parceiros locais e conduzindo-as ao desenvolvimento de inovações (ANDERSSON; FORSGREN; HOLM, 2002; CANTWELL, 1995; 1999; CANTWELL; MUDAMBI, 2005; CIABUSCHI; MARTIN, 2011; GUPTA; GOVINDARAJAN, 1991), que posteriormente seriam compartilhadas com a rede interna na EMN. Quanto à concessão de um grau mais elevado de autonomia às empresas adquiridas, essa possibilidade fundamenta-se no pressuposto de que a empresa adquirida possui um estoque de conhecimento tácito, complexo e, muitas vezes, valioso (de difícil imitação). O fato é que, independentemente do tipo de subsidiária (adquirida ou greenfield), delegar às subsidiárias a competência para desenvolver suas próprias oportunidades de negócios com maior independência condiz com os preceitos das multinacionais emergentes, que têm suas fontes de vantagem competitiva não só na matriz, mas também nas subsidiárias inovadoras. Portanto, essa parece ser condição necessária neste momento em que as subsidiárias precisam de diferenciação. Por fim, tomando-se em 
consideração que as multinacionais brasileiras ainda estão em um estágio inicial de desenvolvimento no exterior, é uma novidade a constatação de que as subsidiárias parecem caminhar em busca da descentralização.

Contudo, o dilema da autonomia permanece, uma vez que um maior grau de autonomia pode diminuir ou eliminar a integração e a recombinação de diferentes conjuntos de conhecimentos essenciais para a transferência reversa de conhecimento tecnológico. Como forma de ficar atentas a essa tensão entre autonomia e integração, as multinacionais devem controlar o grau de empreendedorismo das subsidiárias e evitar discrepâncias nas capacidades das subsidiárias afetadas por sua autonomia. Corroborando isso, Rabiosi (2008) propõe que altos níveis de autonomia sejam associados com o uso de mecanismos de comunicação baseados nas pessoas. Segundo a autora, altos níveis de socialização estimulam a formação de interesses convergentes e de normas e valores compartilhados entre os gestores das diferentes unidades da EMN.

Quanto ao constructo motivação, não foram constatadas evidências que confirmassem a importância da motivação para a transferência reversa de conhecimento tecnológico. Contudo, esse determinante apresentou uma relação positiva com a transferência reversa de conhecimento tecnológico quando se analisou somente o grupo de empresas greenfield. Esse resultado se justifica tendo em vista que o ambiente de operações pós-aquisição frequentemente é caracterizado por incertezas e ambiguidades entre as partes (EISENHARDT, 1985, 1989). No contexto de subsidiárias pós-adquiridas, a motivação da fonte do conhecimento pode ser algo mais difícil de alcançar. Em primeiro lugar, porque quando as pessoas de uma corporação não esperam obter muito valor em troca da transferência de conhecimento, elas tendem a se sentir menos motivadas a compartilhar seu próprio conhecimento; em segundo lugar, a motivação para transferir conhecimentos também depende de questões mais complexas, como o estabelecimento de confiança com a outra parte e a forma pela qual a fonte percebe a reputação e a imagem da parte receptora (EMPSON, 2001).

Além disso, talvez seja importante lançar mão do argumento de Szulanski (1996), segundo o qual os fatores motivacionais possuem relativamente menor importância para o entendimento da transferência reversa de conhecimento se comparados aos outros determinantes comumente citados. No contexto deste estudo, verifica-se que as empresas fonte de conhecimento, apesar de perceberem os benefícios em compartilhar seu conhecimento com a matriz, parecem não estar dispostas a comprometer recursos físicos e financeiros para transferir seu conhecimento 
para a ela. Por outro lado, também ficou claro que não há um forte incentivo por parte da receptora (matriz).

Quanto às características da interação matriz/subsidiárias, destacam-se, inicialmente, os resultados do constructo integração interna com a matriz. Em concordância com as contribuições da literatura sobre EMNBRs (BORINI et al., 2009, por exemplo), os resultados confirmam que a integração entre matriz e subsidiária é positivamente associada à transferência reversa de conhecimento tecnológico. Esse constructo aparece na literatura como indissociável da autonomia, pois, enquanto a autonomia possibilita a captura de conhecimento dos parceiros das redes locais, o enraizamento interno potencialmente dá apoio e os recursos à subsidiária para que esta compartilhe com outras unidades da empresa suas capacidades e conhecimentos (ANDERSSON; FORSGREN; HOLM, 2002, 2007; RUGMAN; VERBEKE, 2001). Ressaltase que a autonomia é importante no início da história de uma subsidiária, mas, depois de algum tempo, é a integração entre matriz e subsidiária que se torna mais relevante (BORINI; FLEURY, 2009), porque cria vínculos e facilita a compreensão das operações de diferentes subsidiárias.

No tocante à semelhança organizacional, a literatura tem defendido que as facetas do isomorfismo organizacional supostamente impactam a estrutura e o processo de conhecimento (ASAKAWA, 1995). Logo, a falta de isomorfismo entre duas unidades da EMN poderia levar a uma distância organizacional e, consequentemente, prejudicar as transferências intraorganizacionais de conhecimento. Neste estudo, a distância organizacional é vista como as diferenças de estruturas, processos e valores entre unidades organizacionais. Contudo, não foi possível constatar uma relação positiva entre similaridade organizacional e transferência reversa de conhecimento tecnológico. Note-se que outros estudos empíricos também não encontraram suporte para essa relação. Um exemplo disso é o estudo de Simonin (1999b), cujo resultado não evidenciou um impacto da distância organizacional na transferência de conhecimento e revelou que funções de marketing (foco do estudo) são relativamente homogêneas em diferentes contextos. A falta de evidências para a distância organizacional e cultural pode ser relacionada à discussão sobre se a distância ainda prevalece (GHEMAWAT, 2001) ou se a globalização tem diminuído as barreiras das operações internacionais.

Quanto aos mecanismos de socialização, encontraram-se evidências, ainda que de forma marginal, sobre o efeito direto desse constructo na transferência reversa de conhecimento 
tecnológico. Além disso, encontraram-se fortes evidências do efeito indireto desse constructo na transferência reversa de conhecimento tecnológico, mediado pelos constructos integração com a matriz e semelhança organizacional. Os resultados também comprovaram que os mecanismos formais de socialização não provocaram nenhum impacto na transferência reversa de conhecimento tecnológico. Isso implica dizer que transferir conhecimento tácito e complexo pode exigir comunicação rica e não rotineira entre a unidade fonte e a receptora na EMN, como a transferência temporária de pessoas para a unidade receptora do conhecimento a fim de formar equipes envolvendo pessoal de ambas as unidades e/ou realizar job rotation, treinamentos conjuntos, para uma transferência bem-sucedida. Assim, pode-se inferir que as EMNs devem investir em mecanismos de socialização e também em mecanismos de integração formal; contudo, é preciso garantir que o processo de codificação seja feito de modo a permitir a recuperação desse conhecimento via mecanismos de comunicação formal e/ou eletrônica.

Em síntese, os resultados destacam que o caráter de complexidade do conhecimento é determinante para a transferência reversa de conhecimento. Com relação à capacidade da subsidiária de transferir conhecimento para a sede, o principal facilitador é a integração externa com os fornecedores. Outro fator que se mostrou determinante para a transferência reversa de conhecimento tecnológico foram as condições adequadas da localização da subsidiária. Aspectos da organização da subsidiária também aparecem como preponderantes para a transferência reversa de conhecimento tecnológico, tais como a autonomia da subsidiária e a integração com a matriz. No que concerne à integração entre matriz e subsidiárias, destaca-se a influência positiva dos mecanismos de socialização, especificamente os de comunicação pessoal, que se mostraram preponderantes para a viabilização das transferências, não apenas por seu efeito direto, mas também porque reforçam os laços da integração com a matriz e diminuem as diferenças entre as estruturas organizacionais das unidades envolvidas com a transferência. Ressalta-se que a integração não é aqui definida em termos de estrutura de controle; pelo contrário, está associada à aproximação com a matriz a fim de desenvolver novos conhecimentos estratégicos para a matriz e a própria subsidiária (BORINI et al., 2010).

No que concerne aos fatores mediadores, concluiu-se que as subsidiárias inovadoras transferem, em maior extensão, conhecimentos tecnológicos referentes a produtos, se comparadas às subsidiárias implementadoras e contribuidoras. Em relação ao fator tipo de subsidiárias, não foram encontradas diferenças significativas para a transferência reversa de conhecimento tecnológico. Entretanto, pôde-se constatar que subsidiárias do tipo greenfield são mais 
integradas às redes externas de fornecedores e mais motivadas a transferir conhecimento de forma reversa. No que concerne à idade da subsidiária, não foi encontrada nenhuma diferença entre subsidiárias mais jovens e mais maduras, isso reforça os resultados de outros estudos que também concluíram que o constructo idade não interfere na transferência de conhecimento (GRAY; MEISTER, 2004; YLI-RENKO et al., 2001 apud VAN WIJK; JANSEN; LYLES, 2008).

Finalmente, embora nem todas as hipóteses tenham sido apoiadas, os resultados forneceram conclusões que, em sua maioria, estão de acordo com os preceitos clássicos da literatura. Também foram obtidos resultados intrigantes, cuja explicação pode residir no fato de se estar analisando o contexto das empresas multinacionais emergentes, em especial as multinacionais brasileiras.

\subsection{Contribuições teóricas e práticas}

O argumento central deste estudo é que EMNs, sobretudo as emergentes, devem se engajar na transferência reversa de conhecimento para criar diferenciação sustentável. Contudo, em razão dos fatores dificultadores desse processo, a realidade raramente faz jus a tais expectativas.

Uma das principais contribuições do estudo foi colaborar para o enriquecimento da literatura acadêmica em construção sobre as subsidiárias de multinacionais brasileiras, principalmente no que se refere à transferência reversa de conhecimento tecnológico que está em linha com os preceitos da visão evolutiva da subsidiária e da teoria sobre as empresas multinacionais emergentes. A literatura até então existente se concentra principalmente na transferência de conhecimento da sede para a subsidiária, deixando inexplorados, portanto, o processo de transferência reversa de conhecimento e seus determinantes.

A combinação das perspectivas teóricas da visão baseada no conhecimento e da teoria das redes resultou num arcabouço rico e amplo para o entendimento dos fatores internos e externos do processo de transferência reversa, uma vez que o foco da visão baseada em valor são os recursos internos do conhecimento e o foco da teoria das redes é a busca de integração com os atores externos detentores de novos conhecimentos. Essa associação se revela positiva na medida em 
que o resultado traz determinantes importantes, para a transferência reversa do conhecimento tecnológico, baseados nos ditames dessas duas perspectivas abordadas.

Enquanto a literatura sobre a transferência tradicional de conhecimento destaca constantemente a importância de alguns fatores tais como ambiguidade e motivação, entre outros, há poucos estudos que investigam vários fatores de maneira associada - este estudo analisou o efeito de onze fatores associados. Essa taxonomia abrangente dos facilitadores e das barreiras da transferência reversa de conhecimento tecnológico oferece a oportunidade para especificar os determinantes mais influentes desse processo.

Ao comparar os resultados deste estudo (contexto de empresas multinacionais emergentes) com os resultados de estudos sobre empresas multinacionais tradicionais, não se pode afirmar que há grandes diferenças no processo de transferência reversa de conhecimento tecnológico no que se refere ao contexto desses dois grupos de EMNs. Contudo, algumas peculiaridades relativas, podem ser destacadas:

- As subsidiárias de EMNBRs transferem, em média extensão, conhecimentos sobre produtos com um nível de capacidade tecnológica básica e intermediária (LALL, 1992; BELL; PAVIT, 1995; ARIFFIN; FIGUEIREDO (2003); IAMMARINO; PADILLAPÉREZ; TUNZELMANN, 2008). Já as subsidiárias de EMNs tradicionais, transferem, de forma reversa, conhecimentos de capacidade tecnológica também do tipo avançada. Percebe-se que esse aspecto traz uma diferença entre a transferência reversa de conhecimento realizada por EMNs tradicionais e emergentes;

- As subsidiárias que transferem conhecimento para a matriz, possuem um razoável grau de autonomia que vai desde o aperfeiçoamento e desenvolvimento de novos produtos, passando por gestão da cadeia de suprimentos, desenvolvimento de fornecedores até a decisão de entrada em novos países. Sabe-se que as subsidiárias das EMNs tradicionais, sobretudo as mais maduras, também já operam com certa autonomia. Logo, percebe-se que o determinante automia é importante para a transferência reversa de conhecimento, independetemente se o contexto em que esta é realizada é o de EMNs tradicionais ou emergentes; 
- As subsidiárias que transferem conhecimento para a matriz, estão localizadas em ambientes institucionais mais desenvolvidos em termos de infraestrutura do país, ambiente legal, apoio governamental e instituições de suporte aos negócios. Esse resultado também ocorre, de forma similar, no contexto das EMNs tradicionais, portanto, pode-se dizer que o determinante ambiente institucional adequado facilita a transferência tanto para o caso de EMNs tradicionais quanto emergentes;

- As subsidiárias que transferem conhecimento para a matriz são mais integradas com sua rede de fornecedores em termos de cooperação para desenvolvimento de conhecimento tecnológico. De maneira geral, subsidiárias mais integradas com a rede externa de negócios conseguem criar e transferir conhecimento internamente em maior extensão. Pode-se afirmar, portanto, que esse resultado não é específico do contexto das EMNs emergentes e que ocorre de igual forma para as EMNs tradicionais;

- As subsidiárias que transferem conhecimento para a matriz não possuem integração com institutos de Ciência e Tecnologia. Ao contrário, as que possuem integração com tais institutos, não transferem conhecimento tecnológico para a matriz. De maneira geral, a literatura tem afirmado que a integração com institutos de C\&T pode gerar conhecimento com alto grau de especificidade ao contexto local e isso inviabilizaria sua transferência para outras unidades da corporação multinacional (ANDERSSON; FORSGREN, 1996). Conclui-se, portanto, que esse achado também não é específíco das multinacionais de mercados emergentes;

- As subsidiárias que transferem conhecimento para a matriz, utilizam muito frequentemente mecanismos de comunicação pessoal, tais como: transferências temporárias de staff científico, técnico e de gestores, encontros interunidades com o objetivo de transferência de conhecimento, equipes de trabalhos com pessoal das subsidiárias e matriz, treinamentos conjuntos, entre outros. O resultado desse constructo especificamente, pode trazer uma diferenciação no processo de transferência reversa de conhecimento tecnológico entre EMNs tradicionais e emergentes. Ou seja, para que a interação entre as pessoas seja viabilizada por meio dos mecanismos de socialização eletrônica é preciso que as empresas disponibilizem e construam habilidades para trabalhar com infraestrutura técnica que permita aos empregados codificar, armazenar e acessar o conhecimento (AMBOS, T.; AMBOS, B., 2009). Estudos recentes indicaram que algumas das grandes EMNBRs ainda 
não utilizavam uma das ferramentas mais básicas para o compartilhamento de dados entre as unidades de uma multinacional que é um banco de dados (SILVEIRA, SBRAGIA, 2010). O que induz a fazer o seguinte questionamento: Será que as EMNs emergentes e, sobretudo, as EMNBRs possuem infraestrutura técnica e habilidades suficientes que as permitam compartilhar conhecimento internamente de uma forma eficaz? No que conserne as EMNs tradicionais, ainda que não se possa generalizar, sabe-se que muitas já trabalham com sofisticados mecanismos de comunicação eletrônica que as possibilita compartilhar internamente esse ativo tão valioso que é o conhecimento tecnológico.

No que tange às implicações para as empresas, os resultados obtidos permitem que se identifiquem algumas sugestões para a atuação das multinacionais brasileiras no contexto internacional.

Primeiro, as subsidiárias que tiveram acesso ao conhecimento institucional local estarão em melhor posição para responder às mudanças do contexto institucional, aumentando dessa forma sua legitimidade local. Com isso, sugere-se que as subsidiárias tenham incentivos suficientes para gerenciar fatores relacionados aos seus ambientes institucionais, incluindo ações como aumento do conhecimento institucional para reduzir a incerteza institucional local e o aperfeiçoamento das interações empresa-governo, por meio, por exemplo, de colaboração institucional e de cocriação.

Segundo, apesar de o enraizamento com os fornecedores locais ter sido indicado como o mais importante determinante da transferência reversa de conhecimento tecnológico, fica claro que as subsidiárias estão muito aquém de um nível razoável de integração com esse parceiro e outros atores locais. Sendo assim, sugere-se que as subsidiárias sejam encorajadas pela matriz a estabelecer estreitas relações com os parceiros locais para que obtenham acesso a conhecimentos valiosos e consigam compreender rápida e claramente suas tendências. $\mathrm{O}$ estabelecimento de relações com os atores externos é, sem dúvida, demorado e dispendioso, e, por isso, uma posição mais proativa no sentido de construir relações sociais estreitas com os diversos atores locais é urgente. É preciso encontrar maneiras de a subsidiária se envolver em inovações localizadas que acontecem nessas redes. Fazendo isso, a subsidiária estará se apropriando de um dos principais benefícios da multinacional - a presença no país de 
acolhimento para gerar estoque de conhecimento que, subsequentemente, será compartilhado com as outras unidades da EMN.

Terceiro, os resultados também indicaram que as subsidiárias são incorporadas mais internamente (com a matriz) do que localmente (com os parceiros externos). Esse é outro indicativo de que é urgente o trabalho da matriz de incentivar as subsidiárias a perseguir conscientemente as informações advindas do enraizamento com clientes, fornecedores locais, institutos de pesquisa e até mesmo com os concorrentes. Estudos são claros em constatar que as subsidiárias ganham novas perspectivas e inovam por meio de suas interações sociais com os clientes locais e fornecedores, e que os atores locais devem fazer o mesmo.

Quarto, quanto ao trade-off entre autonomia e integração, sugere-se que um grau relativo de autonomia seja autorizado às subsidiárias, para que elas possam tomar decisões rapidamente e aproveitar as oportunidades. Por sua vez, a interdependência da subsidiária com a matriz deve ser sempre cultivada, pois isso está diretamente vinculado à condição da subsidiária de compartilhar com a rede o valor adicionado da inovação. Uma das formas de se viabilizar essa integração são os mecanismos de socialização. De acordo com a percepção dos entrevistados, as subsidiárias já possuem infraestrutura técnica e vários mecanismos e de integração interna. Esses mecanismos e infraestrutura de socialização e de integração podem ser usados de forma mais eficaz para construir maior enraizamento internamente. Essa forte integração é importante porque diminui o tempo, o custo e os esforços no sentido de convencer a matriz sobre a relevância do conhecimento proveniente das controladas.

Finalmente, quanto aos mecanismos de comunicação, recorda-se que os associados positivamente à transferência reversa de conhecimento tecnológico foram os que envolvem a comunicação pessoal. Em geral, esses mecanismos de socialização são custosos para serem mantidos, e isso indica que sua utilização deve ser justificada e aplicada somente se comprovada sua necessidade. Como sugere Rabiosi (2011), esses canais ricos de comunicação poderiam ser utilizados, por exemplo, para transferências de conhecimento (de contexto mais específico) das subsidiárias do tipo inovadoras. Ao mesmo tempo, os mecanismos de comunicação eletrônica devem ser adequados, para melhor apoiar as transferências de conhecimento. Caso contrário, muitos conhecimentos serão perdidos durante a transferência. 
Em síntese, indica-se que a matriz talvez precise repensar sua estratégia de compartilhamento de conhecimento interno, a fim de motivar e incentivar de forma deliberada o fluxo do conhecimento gerado nas subsidiárias. No tocante às subsidiárias, consistentemente com os comentários de Szulanski (1996), elas devem tornar claro aos seus empregados os benefícios de melhorar a eficácia da transferência de conhecimento para melhorar até mesmo seu posicionamento estratégico dentro da rede multinacional.

\subsection{Limitações e recomendações para futuros estudos}

Esta última seção aponta as limitações do estudo e apresenta sugestões para futuras pesquisas, decorrentes das próprias limitações do trabalho.

Em primeiro lugar, esta pesquisa circunscreve-se ao contexto restrito das empresas multinacionais brasileiras, o que, portanto, impõe limites à generalização dos resultados aqui apresentados a outras amostras de grupos de empresas advindas de países emergentes. Assim, sugere-se que investigações futuras utilizem o modelo de investigação elaborado por este estudo, a fim de testá-lo em outros contextos de multinacionais emergentes, tais como o dos BRICs. Além disso, embora haja diferentes tipos de conhecimento, apenas um foi alvo deste estudo: o conhecimento tecnológico. O objetivo foi focalizar a capacidade de inovação tecnológica da EMN por meio de suas subsidiárias. Contudo, novos estudos abrangendo áreas de igual importância, como as de produção, marketing e gerenciamento de recursos humanos e tecnológicos, ampliariam a visão sobre a importância das subsidiárias na geração de valor para a rede no contexto das multinacionais emergentes.

Em segundo lugar, o método de pesquisa utilizado, um survey com as subsidiárias estrangeiras, é de grande importância para traçar um panorama geral do comportamento das subsidiárias estrangeiras. Contudo, esse tipo de pesquisa apresenta limitações no que concerne ao método, que se refletem nos resultados apresentados. A estratificação das subsidiárias realizada no estudo apresenta uma fotografia estática que permite algumas inferências sobre a transferência reversa de conhecimento tecnológico realizada pelas subsidiárias. Estudos de caso, entretanto, embora menos abrangentes que um survey, têm a vantagem de analisar de maneira longitudinal o processo de transferência de conhecimento em multinacionais brasileiras, bem como identificar com mais profundidade as características desse processo. Além disso, uma vez que 
foi solicitado aos entrevistados que respondessem sobre questões tão amplas das organizações, reconhece-se ser bastante possível a presença de viés do método. A fim de evitar tal problema sugere-se incorporar em novos estudos, dados e informações objetivas, como por exemplo, os de fonte secundária. Outra restrição metodológica diz respeito ao fato de a amostra não ter sido probabilística, em razão da própria dificuldade de identificar as empresas multinacionais brasileiras. Ou seja, a população não é totalmente conhecida. Assim, embora as empresas participantes tenham uma boa representatividade, não se pode dizer que os resultados aqui alcançados podem ser generalizados.

Em terceiro lugar, esta pesquisa investiga o processo de transferência reversa de conhecimento apenas a partir do ponto de vista da fonte, no caso, a subsidiária. De acordo com Gupta e Govindarajan (2000), no entanto, a realização de pesquisas em nível diádico (envolvendo fonte e receptor do conhecimento) aumentaria a compreensão sobre a transferência do conhecimento internacional. Dessa forma, reconhece-se que a perspectiva de díade é altamente importante, uma vez que oferece a oportunidade de investigar as implicações recíprocas no processo de transferência reversa de conhecimento tecnológico. Portanto, investigar a transferência reversa de conhecimentos em nível diádico é um tema promissor para futuros estudos, pois revelará uma visão compartilhada e menos tendenciosa, já que a investigação em unidades diferentes da mesma corporação permite contrabalançar as perspectivas por vezes enviesadas dos respondentes. 


\section{REFERÊNCIAS}

AGMON, T.; GLINOW, M. A. Y. V. Technology transfer in international business. University of Southern California, 1991.

ALAVI, M., LEIDNER, D. E. Knowledge management and knowledge management systems: Conceptual foundations and research n.s. MIS Quarterly. v. 25 n. 1, p. 107-136, 2001.

ALLEN, T. J. Architecture and communication among product development engineers, California Management Review, v. 49, n. 2, p. 23-41, 2007.

ALLEN, T. J. Managing the flow of technology: technology transfer and the dissemination of technological information within the R\&D organization. Cambridge: The MIT Press, 1977.

ALLEN, T. J. Performance of information channels in the transfer of technology. Industrial Management Review, v. 8, n. 1, p. 87-98, Fall, 1966.

ALMEIDA, P. Knowledge sourcing by foreign multinationals: Patent citation analysis in the US semiconductor industry. Strategic Management Journal, v. 17, Winter Special N., p. 155165,1996

ALMEIDA, P.; ANUPAMA, P. Subsidiaries and Knowledge Creation: The Influence of the MNC and Host Country on Innovation, Strategic Management Journal, v. 25, n. 8-9, p. 847864, 2004.

AMALIA, M.; NUGROHO, Y. An innovation perspective of knowledge management in a multinational subsidiary. Journal of Knowledge Management, v. 15, n. 1, p. 71-87, 2011.

AMATUCCI, M.; BERNARDES, R. C.. O Novo Papel das Subsidiárias de Países Emergentes na Inovação em Empresas Multinacionais o caso da General Motors do Brasil. RAI: Revista de Administração e Inovação, v. 4, p. 5-16, 2007.

AMBOS, B., SCHLEGELMILCH, B. B. Innovation and control in the Multinational firm: A comparison of political and contingency approaches. Strategic Management Journal, v. 28, n. 5, p. 473-486, 2007.

AMBOS, T., AMBOS, B.; SCHLEGELMILCH, B. Learning from foreign subsidiaries: An empirical investigation of headquarters benefits from reverse knowledge transfers. International Business Review, v. 15, n. 3, p. 294-312, 2006.

AMIT, R.; SCHOEMAKER, P. Strategic assets and organizational rent. Strategic Management Journal, v. 14, n. 1, p. 33-46, 1993.

ANDERSSON, U., MUDAMBI, R.; PERSSON, M. Unpacking inter-unit knowledge transfer in multinational corporations, Journal of International Business Studies, p. 08-25, 2011. 
ANDERSSON, U., FORSGREN, M.; HOLM, U.. Balancing Subsidiary Influence in the Federative MNC: A Business Network View. Journal of International Business Studies, v. 38, p. 802-818, 2007.

ANDERSSON, U.; BJöRKMAN, I.; FORSGREN, M. Managing Subsidiary Knowledge Creation: The Effect of Control Mechanisms on Subsidiary Local Embeddedness. International Business Review, 14, 521-538, 2005.

ANDERSSON, U., FORSGREN, M.; HOLM, U., The strategic impact of external networks: subsidiary performance and competence development in the multinational corporation. Strategic Management Journal, v. 23, n. 11, p. 979-996, 2002.

ANDERSSON, U; FORSGREN, M. In Search of Centre of Excellence: network embeddedness and subsidiary roles in multinational corporations. Management International Review, v. 40, p. 329-350, 2000.

ANDERSSON, U., FORSGREN, M.; HOLM, U. Subsidiary Embeddedness and Competence Development in MNCs A Multi-Level Analysis. Organization Studies, v. 22, p. 1013-1034, 2001.

ANDERSSON, U.; FORSGREN, M. Subsidiary Embeddedness and control in the multinational corporation. International Business Review, v.5, p.487-508, 1996.

ARIFFIN, N.; FIGUEIREDO, P. Internationalization of innovative capabilities: Counterevidence from the electronics industry in Malaysia and Brazil. In Paper for DRUID Summer Conference, Copenhagen, June, p. 12-14, 2003.

ASAKAWA, K. Managing knowledge conversion processes across boarders: toward a framework of international knowledge management. INSEAD working paper series v. 95/91/OB. Fontainbleau, 1995.

ATHREYE, S.; BATSAKIS, G.; SINGH, S. Subsidiary Embeddedness is a Strategic Choice: Complementarity and the factors associated with different types of embeddedness. Working paper. DRUID (The full text of this publication is not available from this repository), 2013.

AULAKH P.S. Emerging multinationals from developing economies: motivations, paths and performance. Journal of International Management, v. 13, n. 3, p. 235-240, 2007.

AVELLAR, A. P. Relatório final DPP-FINEP para o setor de bens de capital. Araraquara: Faculdade de Ciências e Letras, UNESP, 2004.

BAGOZZI, R. P.; Gopinath, M.; N.; Prashanth U. The Role of Emotions in Marketing. Journal of The Academy of Marketing Science, Spring, v. 27, n. 2, p. 184, 1999.

BARNARD, H. Emerging multinationals benefiting from subsidiaries located in more developed countries: drivers for the sharing of capabilities. Innovation and Development. v. 1, n. 2, 2011. 
BARNARD, H. Overcoming the liability of foreignness without strong firm capabilities - the value of market-based resources. Journal of International Management, v. 16, n. 2, p. 165$176,2010$.

BARNEY, J. B. Firm Resources and Sustained Competitive Advantage. Journal of Management, v. 17, p. 99-120, 1991.

BARTLETT, C. A.; GHOSHAL, S. Managing Across Borders. The Transnational Solution, Boston ,MA., Harvard Business School Press., 1989.

BARTLETT, C.; GHOSHAL, S.. Managing across borders: New Strategic Requirements, 1998.

BELDERBOS, R. Antidumping and Tariff Jumping Divestment, Review of World Economics, v. 139, n. 1, p. 131-160, 2003.

BELL, M., PAVITT, K., The development of technological capabilities. In: Trade, technology and international competitiveness. 1st ed. World Bank, Washington, DC., 1995.

BEZERRA-FERNANDEZ, I.; SABHERWAL, R. Organizational knowledge managment: a contigency perspective. Journal of Managment Information System, v. 18, n. 1., p. 23-55, 2001.

BHAGAT, R. S.; KEDIA, B.L.; HARVESTON, P. D.; TRIANDIS, H. C. Cultural variations in the cross-border transfer of organizational knowledge: An integrative framework, Academy of Management Review, v. 27, n. 2, p. 204-221, 2002.

BIDO, D. S.; GODOY, A. S.; ARAUJO, B. F. V. B.; LOUBACK, J. C. Articulação entre as aprendizagens individual, grupal e organizacional: um estudo no ambiente industrial. Revista de Administração Mackenzie, v. 11, n. 2, mar./abr. 2010.

BIRKINSHAW, J.; PEDERSEN, T. Strategy and Management in MNE subsidiaries. In. A. Rugman ; T. Brewer (Eds) Oxford handbook of international business. Oxford University Press, 2009.

BIRKINSHAW, J., BRESMAN, H.; NOBEL, R. Knowledge transfer in international acquisitions: a retrospective. Journal of International Business Studies, 41, 21-6, 2010.

BIRKINSHAW, J. Strategy and Management in MNE subsidiaries. In Rugman, A; Brewer, T. (Eds) Oxford Handbook of International Business. Oxford University Press, 2001.

BIRKINSHAW, J, HOOD, N. Characteristics of foreign subsidiaries in industry clusters. Journal of International Business Studies. v. 31, n. 1, p. 141-154, 2000.

BIRKINSHAW, J. Entrepreneurship in Multinational Corporations: The Characteristics of Subsidiary Initiatives, Strategic Management Journal, V. 18, No. 3, p. 207-229, 1997. 
BIRKINSHAW, J. M.: MORRISON, A. J. Configurations of strategy and structure in subsidiaries of multinational corporations. Journal of International Business Studies, v. 26, p. 729-753, 1995.

BIRKINSHAW, J. Tap your subsidiaries for global reach. Harvard Business Review, 1986.

BIRKINSHAW, J.; FRY, N. Subsidiary initiatives to develop new markets. Sloan Management Review, v. 39, nº 3, p. 51-61, 1998.

BIRKINSHAW, J.; HOOD, N.; JONSSON, Building Firm-Specific Advantages in Multinational Corporations: The Role of Subsidiary Initiative. Strategic Management Journal, v. 19, p. 221-241, 1998.

BIRKINSHAW, J; HOOD, N. Multinational subsidiary evolution: Capability and charter change in foreign-owed subsidiaries companies. Academy of Management Review, v. 23, n.4, p.773-795, 1998.

BJORKMAN, I.; BARNER-RASMUSSEN, W.; LI, L. Managing knowledge transfer in EMNs: the impact of headquarters control mechanisms. Journal of International Business Studies, v. 35, p. 443-455, 2004.

BOEHE, D. Os papéis de subsidiárias brasileiras na estratégia de inovação de empresas multinacionais estrangeiras. RAUSP. Revista de Administração, São Paulo, v. 42, p. 5-18, 2007.

BOHN, R. E. Measuring and managing technological knowledge. Sloan Management Review, v. 36, n. 1, p. 61-73, fall, 1994.

BONACHE, J.; ZÁRRAGA-OBERTY, C. Determinants of the success of international assignees as knowledge transferors: a theoretical framework. The International Journal of Human Resource Management. v. 19, n. 1, p. 1-18, 2008

BONAGLIA, F.; GOLDSTEIN, A. Strengthening Productive Capacities in Emerging Economies through Internationalisation: Evidence from the Apliance Industry. OECD Development Centre Working Papers 262, OECD Publishing, 2007.

BORINI, F. M.; OLIVEIRA JÚNIOR, M. M. ; SILVEIRA, F. F.; CONCER, R. O. The Reverse Transfer of Innovation of Foreign Subsidiaries of Brazilian Multinationals. European Management Journal (Cessou em u992), v. 30, p. 219-231, 2012.

BORINI, F. M.; FLEURY, M. T. L. Development of non-local competences in foreign subsidiaries of Brazilian multinationals. European Business Review, v. 23, p. 106-119, 2011.

BORINI, F. M.; FLEURY, M. T. L.; FLEURY, A. C. Transferência, Desenvolvimento e Reconhecimento de Competências Organizacionais em Subsidiárias de Empresas Multinacionais Brasileiras. Economia Global e Gestão, v. 14, p. 31-54, 2010. 
BORINI, F. M.; Oliveira Jr, M. M. The Relationship between Subsidiaries Initiatives and Subsidiaries Roles in Emerging Markets. Espacios (Caracas), v. 31, p. 9-12, 2010.

BORINI, F. M.; FLEURY, M. T. L.; FLEURY, A. C. C.; OLIVEIRA JR., M. M. The relevance of subsidiary initiatives for brazilian multinationals. Revista de Administração Eletrônica, n. 3, v. 49, p. 253-265, jul./set, 2009.

BORINI, F. M.; FLEURY, M. T. L.; FLEURY, A. C.. Corporate Competences in Subsidiaries of Brazilian Multinationals. Latin American Business Review (Binghamton), v. 10, p. 161$185,2009$.

BORINI, F. M. Transferência, desenvolvimento e reconhecimento de Competências organizacionais em subsidiárias estrangeiras de Empresas multinacionais brasileiras. Ribeirão Preto. 132 p., 2007. Tese (Doutorado em Administração) - Faculdade de Economia, Administração e Contabilidade da Universidade de São Paulo, 2007.

BOYACIGILLER, N. The role of expatriates in the management of interdependence, complexity and risk in multinational corporations, Journal of International Business Studies, v. 21, n. 3, p. 357-81, 1990.

BRESMAN, H.; BIRKINSHAW, J. NOBEL, R. Knowledge transfer in international acquisitions. Journal of International Business Studies, v. 30, p. 439-462, 1999.

BROUTHERS, K.D.; BROUTHERS, L.E. Why Service and manufacturing Entry Mode Choices Differ: The influence of transaction cost factors, risk and trust. Journal of Management Studies, v. 40, n.5, p. 1179-1204, 2003.

BRYMAN, A.; CRAMER, D. Quantitative Data Analysis with SPSS 12 and 13: A Guide for Social Scientists, Routledge, 2005.

BUCKLEY, P. J.; GLAISTER, K.W.; KLIJN, E.; TAN, H. Knowledge Accession and Knowledge Acquisition in Strategic Alliances: The Impact of Sup.lementary and Complementary Dimensions. British Journal of Management, v. 20, p. 598-609, 2009.

BUCKLEY, P.J.; CASSON, M.C. The Future of the Multinational Enterprise, Homes. Meier: London, 1976.

CANTWELL, J., DUNNING, J. H. ; LUNDAN, S. M. An Evolutionary Ap.roach to Understanding International Business Activity: The Co-Evolution of MNEs and the Institutional Environment. Journal of International Business Studies, v. 41, p. 567-586, 2010 .

CANTWELL, J.; MUDAMBI, R. MNE competence-creating subsidiary mandates. Strategic Management Journal, v. 26, p. 1109-1128, 2005. 
CANTWELL, J.; PISCITELLO, L. The Emergence of Corporate International Networks for the Accumulation of Dispersed Technological Competences. Management International Review, 39, 123-147, 1999.

CAVUSGIL, S. T., CALANTONE, R. J.; ZHAO, Y. 2003. Tacit Knowledge Transfer and Firm Innovation Capability. Journal of Business and Industrial Marketing, v. 18, p. 6-21, 2003.

CHIESA, V. Managing the internationalization of R\&D activities. IEEE Transactions on Engineering Management, v. 43, p. 7-23, 1996.

CHILD, J.; RODRIGUEZ, S. B. The Internationalization of Chinese Firms: A Case for Theoretical Extension? Management and Organization Review, v. 1, n. 3, p. 381-410, 2005.

CHIN, W. W. The partial least squares aproach for structural equation modeling. in G. A. Marcoulides (Ed.), Modern methods for business research. p. 295-236. London: Lawrence Erlbaum Associates. 1998.

CHINI, T. C. Effective knowledge transfer in multinational corporations. New York: Palgrave Mcmillan, 2008.

CIABUSCHI, F.; MARTÍN, O. Knowledge ambiguity, innovation and subsidiary performance. Baltic Journal of Management. v. 7, n. 2, p. 143-167, 2012.

CIABUSCHI, F.; DELLESTRAND, H.; MARTÍN, N. O. Internal embeddedness, headquarters involvement, and innovation importance in multinational enterprises. Journal of Management Studies, v. 48, n. 7, nov., 2011.

COHEN, W. M.; LEVINTHAL, D. A. 1990. Absorptive capacity: A New Perspective on Learning and Innovation. Administrative Science Quarterly, v. 35, p. 128-152, 1990.

CONSONI, F. L.; QUADROS, R.. Between Centralisation and Decentralisation of Product Development in Multinational Corporations: recent trajectories in Brazilian Subsidiaries of Car Assemblers. Faces (FACE/FUMEC), Belo Horizonte: MG, v. 3, n. 1., p. 18-30, 2005.

COOPER, D. R.; SCHINDLER, P. S. Métodos de pesquisa em administração. Porto Alegre: Bookman, 2003.

CORRAR, L. J.; PAULO, EDILSON; DIAS FILHO, J. M.; (Coordenadores). Análise multivariada: para os cursos de administração, ciências contábeis e economia. São Paulo: Atlas, 2009.

CRISOULO, P. Inter-firm reverse technology transfer: the home country effect of R\&D internationalization, Industrial and Corporate Change, v. 18, n, 5, p. 869-899, 2005.

CUERVO-CAZURRA, A. The multinationalization of developing country EMNEs: the case of Multilatinas. Journal of International Management, 14, p. 138-154, 2008. 
CUERVO-CAZURRA, A.; GENGC, M. Transforming disadvantages into advantages: Developing country MNEs in the least developed countries. Journal of International Business Studies, v. 39. p. 957-979, 2008.

CUSUMANO, M. A.; ELENKOV, D. Linking international technology transfer with strategy and management: a literature commentary. Research Policy, v. 23, n. 2, p. 195-215 ,1994.

CYERT, R. M.; MARCH, J. G. A Behavioral Theory of the Firm. Englewood Cliffs, N. J., Prentice-Hall, 1963.

CYRINO, A. B.; BARCELLOS, P. E. Estratégias de Internacionalização: Evidências e reflexões sobre as empresas brasileiras. In: Betania Tanure; Roberto Gonzalez Duarte. (Org.). Gestão Internacional. São Paulo: Saraiva, v. 1, p. 221-246, 2006.

DATTA, D. K.; PUIA, G. Cross-border acquisitions: An examination of the influence of relatedness and cultural fit on shareholder value creation in U.S. acquiring firms. Management of International review, v. 35, n.4, p. 337-359, 1995.

DAVENPORT, T. H.; PRUSAK, L. Conhecimento empresarial: como as organizações gerenciam seu capital intelectual. Rio de Janeiro: Campus, 1998.

DAY, G. The capabilities of market-driven organizations. Journal of Marketing, v.58, p. 37$52,1994$.

De MEYER A. Internationalizing research-and-development improves a firms technical learning. Research-Technology Management, v. 36, n. 4, p. 42-49, jul./aug. 1993.

De MEYER, A. Tech talk: how managers are stimulating global R\&D communication. Sloan Management Review, v. 32, p. 49-59, Spring 1991.

DELLESTRAND, H. Orchestrating Innovation in the Multinational Enterprise: Headquarters Involvement in Innovation Transfer Projects. Thesis, 2010.

DENG, P. Investing for strategic resources and its rationale: The case of outward FDI from Chinese companies. Business Horizons, v. 50, p. 1-81, 2007.

DENG, P. Why do Chinese Firms Tend to Acquire Strategic Assets in International Expansion?, Journal of World Business, v. 44, n. 1, p. 74-84, 2009.

DIAS, A. V. C. Produto mundial, engenharia brasileira: integração de subsidiárias no desenvolvimento de produtos globais na indústria automobilística. 2003. 303 p. Tese (Doutorado em Engenharia) - Escola Politécnica, Universidade de São Paulo, São Paulo, 2003.

DIEZ, J. R.; BERGER M. Technological capabilities and innovation in Southeast Asia: empirical evidence from Singapore, Penang (Malaysia) and Bangkok (Thailand). In: DRUID 
SUMMER CONFERENCE 2003 - On creating, sharing and transferring knowledge. Copenhagen, Jun. 2003.

DOZ, Y., SANTOS, J.; WILLIAMSON, P. From global to metanational: how companies win in the knowledge economy. Boston: Harvard Press, 2001.

DOZ, Y.; SANTOS, J. On the management of knowledge: From the transparency of collocation and co-setting to the quandary of dispersion and differentiation. INSEAD working paper series, 1997.

DUNNING, J. H. ; LUNDAN, S. M. 2008. Multinational Enterprises and the Global Economy. Cheltenham, Edward Elgar Publishing Limited, 2008.

DUNNING, J. The eclectic (OLI) paradigm of international production: past, present and future. International Journal of the Economics of Business, Abingdon, v. 8, n. 2, p. 173190, 2001.

DUNNING, J. H.; LUNDAN, S. M. The Geographic Sources of Competitiveness of Firms: An Economic Analysis. International Business Review. v. 7, p. 115-133, 1998.

DYER, J.; NOBEOKA, K. Creating and managing a high performance knowledge-sharing network: The Toyota case. Strategic Management Journal. V. 21, p. 345-367, 2000.

EISENHARDT, K.; SANTOS, F. Knowledge-Base View: A New Theory of Strategy? In Pettigrew, A., Thomas, H. and Whittington, R. (Eds), Handbook of Strategy and Management. Thousand Oaks, CA: Sage, 2002.

EMPSON, L. Fear of exploitation and fear of contamination: Impediments to knowledge transfer in mergers between professional service firms. Human Relations, v. 54, p.7, p. 839$862,2001$.

ENRIGHT, M. J.; SUBRAMANIAN, V. An organizing framework for MNC subsidiary typologies. Management International Review, v. 47, p. 895 - 924, 2007.

ENSIGN, P. C.; HÉBERT, L. Competing explanations for knowledge exchange: Technology sharing within the globally dispersed R\&D of the multinational enterprise. Journal of High Technology Management Research, v. 20, p. 75-85, 2009.

ENSIGN, P. C. innovation in the multinational firm with globally dispersed R\&D: technological knowledge utilization and accumulation. Journal of High Technology Management Research, v. 10, n. 2, p. 203-221, 2000.

EVANS, J. R.; MATHUR, A. The value of online surveys, Internet Research, v. 15, n. 2, p. $195-219,2005$. 
FAUL F.; ERDFELDER E.; LANG A.-G., BUCHNER A. G*Power 3: a flexible statistical power analysis program for the social, behavioral, and biomedical sciences. Behavior Research Methods. v. 39, p. 175-191, 2007.

FÁVERO, L. P.; BELFIORE, P.; SILVA, F. L.; CHAN, B. L. Análise de Dados: Modelagem Multivariada para Tomada de Decisões. 5 ed. Editora Campus, 2009.

FIGUEIREDO, P. N.; BRITO, K. N. MNE-subsidiaries innovation capability building and learning in emerging economies: firm-level evidence from the ICT industry in Brazil. International Journal of Innovation and Learning, v. 11, p. 12-43, 2012.

FIGUEIREDO, P.N.; BRITO, K. N. The innovation performance of MNE subsidiaries and local embeddedness: evidence from an emerging economy. Journal of Evolutionary Economics, v. 21, n. 1, 2011.

FIGUEREIDO, P. N. Learning processes features and technological capability-accumulation: explaining inter-firm difference. Technovation, v. 22, p. 685-698, 2002.

FILATOTCHEV, I; STRANGE, R; PIESSE, J; LIEN, Y-C. FDI by firms from newly industrialized economies in emerging markets: corporate governance, entry mode and location. Journal of International Business Studies, v. 38, p. 556-572, 2007.

FLEURY, A. C.; FLEURY, M. T. L.; BORINI, F. M. Value-chain configurations of Brazilian EMNEs. In: WILLIANSON, P. J.; RAMAMURTI, R.; FLEURY, A.; FLEURY, M. T. L. (Org.). The Competitive Advantage of Emerging Market Multinationals. 1 ed. Cambridge: Cambridge Press, v. 1, p. 97-117, 2013.

FLEURY, A; FLEURY, M. Brazilian multinationals. Competences for internationalization. Cambridge, 2011.

FLEURY, A.; FLEURY, M. T. L.; BORINI, F.; OLIVEIRA JR. SILVEIRA, F. Resultado Survey Gestão Internacional das Empresas Brasileiras - GINEBRA, FGV/FEA-USP. (Relatório interno), 2010.

FLEURY, A.; FLEURY, M. T. L. Internacionalização das empresas brasileiras: em busca de uma abordagem teórica para os late movers. In: FLEURY, A.; FLEURY, M. T. L (Org). Internacionalização e os países emergentes, São Paulo, Atlas, 2007.

FLORIDA, R. The globalization of R\&D: results of a survey of foreign-affiliated R\&D laboratories in the USA, Research Policy. v. 26, n. 1, p. 85-103, 1997.

FORNELL, C.; BOOKSTEIN, F. L. Two structural equation models: LISREL and PLS ap.lied to consumer exit-voice theory. Journal of Marketing Research, v. 19, p. 440-452, 1982.

FORNELL, C.; D. LARCKER. Evaluating Structural Equation Models with Unobservable Variables and Measurement Error, Journal of Marketing Research, v. 18, n. 1, p. 39-50, 1981. 
FORSGREN, M., HOLM, U.; JOHANSON, J. Managing the Embedded Multinational: A Business Network View, Cheltenham, Edward Elgar Publishing, 2006.

FOSS, N. J.; Knowledge and organization in the theory of the multinational corporation: some foundational n.s. Journal of Management and Governance, v. 10, n. 3, 2006.

FOSS, N. J.; PEDERSEN, T. Transferring knowledge in EMNs: The role of sources of subsidiary knowledge and organization context. Journal of International Management, $\mathrm{v} 8$, p. 49-67, 2002.

FROST, T. S.; ZHOU, C.. R\&D Co-Practice and Reverse Knowledge Integration in Multinational Firms. Journal of International Business Studies, v. 36, p. 676-687, 2005.

FROST, T.; BIRKINSHAW, J.; ENSIGN, P. Centers of Excellence in Multinational Corporations. Strategic Management Journal, v. 23, p. 997-1018, 2002.

GALINA, S. Relatório final DP.-FINEP para o setor de Equipamentos para Telecomunicações. Araraquara: Faculdade de Ciências e Letras, UNESP, 2004. Mimeografado

GALINA, S. V. R. Desenvolvimento global de produtos: o papel das subsidiárias brasileiras de fornecedores de equipamentos do setor de telecomunicações. 2006. 311 p. Tese (Doutorado). Escola Politécnica; Universidade de São Paulo. São Paulo; 2003.

GAMMELGAARD, J.; HOBDARI, B. FDI Strategies of Emerging Economy Multinationals: Firm-Level Antecedents and Consequences. Proceedings presented at the Third Copenhagen Conference on Emerging Multinationals: Outward Investment from Emerging Economies, Copenhagen, Denmark, p. 25-26, Oct., 2012.

GAMMELTOFT, P, J. P; GOLDSTEIN, A. Emerging multinationals: Home and host country determinants and outcomes. International Journal of Emerging Markets, v. 5, p. 254-265, 2010 .

GAMMELTOFT, P. Emerging multinationals: outward FDI from the BRICS countries». International. Journal of Technology and Globalization, v. 4, n. ${ }^{\circ}$ 1., 2007.

GAMMELTOFT, P. Internationalization of R\&D: trends; drivers and managerial challenges. In: DRUID SUMMER CONFERENCE ON DYNAMICS OF INDUSTRY AND INNOVATION: ORGANIZATIONS; NETWORKS AND SYSTEM, 10., 2005; Copenhagen. Proceedings... Copenhagen: DRUID, 2005.

GARNIER, G. H. et al. Autonomy of the Mexican affiliates of U.S. multinational corporations, in: Columbia Journal of World Business, v. 14, n. 1, p. 78-90, 1979.

GARUD, R.; NAYYAR, P. R. Transformative capacity: Continual structuring by Intertemporal technology transfer, Strategic Management Journal., v. 15, n. 5, p. 365-385, 1994. 
GHEMAWAT, P. Distance still matters: the hard reality of global expansion, Harvard Business Review v. 79, n.8, p. 137-147, 2001.

GHOSHAL, S.; BARTLETT, C. A. Creation, Adoption, And DiffusionOf Innovations By Subsidiaries Of Multinational Corporations. Journal of International Business Studies, v. 19, p. 365-388, 1988.

GHOSHAL, S.; BARTLETT, C. A. 1990. The Multinational Corporation as an Interorganizational Network. The Academy of Management Review, v. 15, p. 603-625, 1990.

GINEBRA, Relatório survey com multinacionais brasileiras - matriz e subsidiárias. São Paulo, FEA-USP, 2006.

GINEBRA. Relatório survey com multinacionais brasileiras - matriz e subsidiárias, São Paulo, FEA-USP, 2011.

GNYAWALI, D., R.; SINGAL, M.; MU, S. C. Knowledge ties among subsidiaries in MNCs: A multi-level conceptual model, 387-400. In: Journal of International Management. v. 15, n. 4, 2009.

GOMES, R.; CONSONI, F. L.; GALINA, S. V. R.. P\&D em filiais de empresas multinacionais instaladas no Brasil. Pretexto (Belo Horizonte), v. 11, p. 23-40, 2010.

GOMES, R. Empresas transnacionais e internacionalização da P\&D. Revista Economia Política, v.28, n.2, São Paulo: Unesp, apr./june, 2006.

GOMES, R. O papel das subsidiárias e a internacionalização das atividades tecnológicas pelas empresas transnacionais (ETNs). Gestão e Produção, v. 10, n. 3, p. 267-281, 2003.

GOPALAKRISHNAN, S.; SANTORO, M.D. Distinguishing between knowledge transfer and technology activities: the role of key organizational factors; IEEE Transactions on Engineering Management. v. 51, n. 1, p. 57- 69, 2004.

GORMAN, M. E. Types of knowledge and their roles in technology transfer. Journal of Technology Transfer, v. 27, p. 219-231, 2002.

GRANOVETTER, M. 1985. Economic Action and Social Structure: The Problem of Embeddedness. American Journal of Sociology, v. 91, p. 481-510, 1985.

GRANT, R. M. Toward the Knowledge-Based Theory of the Firm. Strategic Management Journal, v. 17, p. 109-122, 1996.

GUBBI, S. R., AULAKH, P. S., RAY, S., SARKAR, M. B. and CHITTOOR, R. Do international acquisitions by emerging-economy firms create shareholder value? The case of India firms. Journal of International Business Studies, v. 41, p. 397-418, 2010. 
GUILLÉN, M. F.; GARCÍA-CANAL. The American model of the multinational firm and the new multinationals from emerging economies. Academy of Management Perspectives, v. 23, p. 23-35, 2009.

GUPTA, A. K. GOVINDARAJAN, V. Knowledge Flows within the Multinational Corporation', Strategic Management Journal, v. 21, p. 473-496, 2000.

GUPTA, A.; GOVINDARAJAN, V. Organizing for Knowledge Flows within EMNs, International Business Review, v. 3, n. 4, p. 443-457, 1994.

GUPTA, A.; GOVINDARAJAN, V. Knowledge flows and the structure of control within multinational corporations. Academy of Management Review, v. 16, n. 4, p. 768-792, 1991.

HAIR, J. F., ANDERSON, R.; TATHAM, R. L.; BLACK, W. C. Análise multivariada de dados. São Paulo: $5^{\mathrm{a}}$ ed, 2005.

HAKANSON, L.; NOBEL, R. Organizational Characteristics and Reverse Technology Transfer. Management International Review, v. 41, n. 4, p. 395- 420, 2001.

HåKANSON, L.; NOBEL, R. 2000. Technology Characteristics and Reverse Technology Transfer. Management International Review, p. 29-48, 2000.

HANSEN, M. T. The Search-Transfer Problem: The Role of Weak Ties in Sharing Knowledge across Organization Subunits. Administrative Science Quarterly, v. 44, p. 82-111, 1999.

HANSEN, M. T., NOHRIA, N.; TIERNEY, T. Whats your strategy for managing knowledge? Harvard Business Review, March-April, p. 106-16, 1999.

HARZING, A.-W. ; NOORDERHAVEN, N. Knowledge flows in MNCs: An Empirical Test and Extension of Gupta and Govindarajans Typology of Subsidiary Roles. International Business Review, v.15, p. 195-214, 2006.

HARZING, A.W.; SORGE, A. The relative impact of country of origin and universal contingencies on internationalization strategies and corporate control in multinational enterprises: Worldwide and European perspectives, Organization Studies, v. 24, n. 2, p. 187 214, 2003.

HEDLUND G.; NONAKA, I. Models of knowledge management in the West and Japan, In P. Lorange, B. Chakravarthy, J. Roos, et A. van de Ven (Eds.), Implementing Strategic Processes: change, learning and co-operation, Blackwell, London, 1993.

HEDLUND, G. The hypermodern MNC: A heterarchy? Human Resource Management, Spring, p. 9-35, 1986.

HEDLUND, G. The Intensity and Extensity of Knowledge: Implications for Possible Futures of the Global Firm. CEMS. Business Review, v. 1, p. 111-126, 1996. 
HENSELER, J.; RINGLE, C. M.; SINKOVICS, R. R. The use of partial least squares path modeling in international marketing. In: SINKOVICS, R. R.; GHAURI, P. N. (Org.), New Challenges to International Marketing, 277-319 (Advances in International Marketing, 20). Disponível em: <http://www.emeraldinsight.com/10.1108/S1474-7979(2009) 0000020014>. Acesso em 05/06/2009, 2009.

HERSCHBACH, D. R. Technology as Knowledge: Implications for Instruction. Journal of Technology Education. v. 7, n. 1, fall, 1995.

HOFSTEDE, G. Masculinity and Femininity: The Taboo Dimension of National Cultures. 2nd Edition, Thousand Oaks CA: Sage Publications, 2001.

HOLM, U.; PERDERSEN, T. The Dilemma of Centres of Excellence - Contextual Creation of Knowledge versus Global Transfer Knowledge. Working Paper Disponível em: http://web.cbs.dk/departments/int/publications/wp_2000/wp8-2000 tp.pdf. 2000.

HOWELLS, J. International coordination of technology flows and knowledge activity in innovation. International Journal of Technology Management, v. 19, n. 7/8, 2000.

HUSTED, K.; MICHAILOVA, S. Diagnosing and fighting knowledge sharing hostility. Organizational Dynamics, v. 31, p. 60-73, 2002.

HYMER, S. H. The International Operations of National Firms: A study of foreign direct investment. The MIT Press: Cambridge, MA. (1960 doctoral thesis submitted posthumously for publication by Charles P. Kindleberger, 1976.

IAMMARINO, S.; PADILLA-PÉREZ, R.; VON TUNZELMANN, N. Technological capabilities and global-local interactions. The electronics industry in two Mexican regions. World Development, v. 36, n. 10. p. 1980-2003, 2008.

INKPEN, A. C. Learning Through Joint Ventures: A Framework of Knowledge Acquisition. Journal of Management Studies, v. 37, p. 1019-1044, 2000.

INPKEN, A. C.; DINUR, A. Knowledge management processes and international joint venture. Organization Science. V. 9, n. 4, p. 454-68, 1998.

JANSEN, J. J. P.; VAN DEN BOSCH, F. A. J.; VOLBERDA, H. W. Managing potential and realized absorptive capacity: how do organizational antecedents matter? Academy of Management Journal, v. 48, p. 999-1015, 2005.

JENSEN, R.; SZULANSKI, G. Stickiness and the adaptation of organizational practices in cross-border knowledge transfers, Journal of International Business Studies, v. 35, p. 508$523,2004$.

JOHANSON, J.; VAHLNE, J. E. The mechanism of internationalization. International Marketing Review, v. 7, n. 4, p. 11-24, 2001. 
JOHANSSON, J. K. Determinants and Effects of the Use of Made in Labels. International Marketing Review. v. 6, n. 1, p. 47-58, 1989.

KERLINGER, F. N. Metodologia da pesquisa em ciências sociais. São Paulo: Editora Pedagógica e Universitária, 1979.

KHANNA T, MUSACCHIO A, REISEN DE PINHO R. Vale: Global Expansion in the Chall enging World of Mining. Harvard Business School Case. v. 9, p. 710-054, 2010.

KHANNA, T.; PALEPU, K. Emerging giants: building world-class companies in developing countries. Harvard Business Review, v. 84, n. 10, p. 60-69, 2006.

KHANNA, T.; PALEPU, K. The future of business groups in emerging markets: Long-run evidence from Chile. Academy of Management Journal, v. 43, n. 3, p. 268-285, 2000.

KOGUT, B.; ZANDER, U. Knowledge of the firm and the evolutionary theory of the multinational corporation. Journal of International Business Studies, v. 24, n. 4, p. 625-645, 1993.

KOGUT, B.; ZANDER, U. Knowledge of the firm, combinative capabilities, and the replication of technology. Organization Science, v. 3, n. 3, 1992.

KOGUT, B.; ZANDER, U., Knowledge of the firm and the evolutionary theory of the multinational corporation. Journal of International Business Studies, v. 25, n. 4, 1995.

KOSTOVA, T. Transnational Transfer of Strategic Organizational Practices: A Contextual Perspective. Academy of Management Review, v. 24, p. 308-324, 1999.

KOTABE, M., DUNLAP-HINKLER, D., PARENTE, R.; MISHRA, H., A. Determinants of Cross-National Knowledge Transfer and its Effect on Firm Innovation. Journal of International Business Studies, v. 38, p. 259-282, 2007.

KROG, G. V.; GRAND, S. From economic Theory toward a knowledge-based theory of the firm - Conceptual Building Blocks. In: CHOO, C. W.; BONITS, N. (Ed.) The strategic management intellectual capital and organization knowledge, New York: Oxford University Press, 2002.

KUEMMERLE, W. Home base and knowledge management in international ventures. Journal of Business Venturing, v. 17, n.2, p. 99-122, 2002.

KUEMMERLE, W. The Drivers of foreign direct investment into research and development: An empirical investigation. Journal of International Business Studies, v. 30, n. 1, p. 1-24. 2001. 
KUEMMERLE, W. Foreign direct investment in industrial research in the pharmaceutical; electronic industries - results from a survey of multinational firms. Research Policy, v. 28, n. 2-3: p. 179-193, 1999.

KUEMMERLE, W. Building effective R\&D capabilities abroad. Harvard Business Review, v. 75, n. 2 , p. 61-70, 1997.

KUMAR, J. A.; GANESHI, L. S. Research on knowledge transfer in organizations: a morphology. Journal Of Knowledge Management, v. 13, n. 4, p. 161-174, 2009.

KUMAR, N. Determinants of Location of Overseas R\&D Activity of Multinational Enterprises: The Case of US and Japanese Corporations, Research Policy, v. 30, p. 159-174, 2001.

LALL, S. (Ed.) The New Multinationals: The Spread of Third World Enterprises. New York: John Wiley, Sons, 1983.

LANE P., SALK, J.; LYLES, M. Absorptive Capacity, Learning and Performance in International Joint Ventures, Strategic Management Journal. v. 22, p. 1139-1161, 2001.

LANE, P., J.; LUBATKIN, M. 1998. Relative Absorptive Capacity and Interorganizational Learning. Strategic Management Journal, v. 19, p. 461-477, 1998.

LATTIN, J.; CARROLL, J. D.; GREEN, P. E. Análise de dados multivariados, Cenage Learning: São Paulo, 2011.

LEVINTHAL, D. A.; MARCH, J. G. The myopia of learning. Strategic Management Journal, v. 14, p. 95-112, 1993.

LI, L., BARNER-RASMUSSEN, W.; BJöRKMAN, I. What Difference Does the Location Make?: A Social Capital Perspective on Transfer of Knowledge from Multinational Corporation Subsidiaries Located in China and Finland. Asia Pacific Business Review, v. 13, p. 233-249, 2007.

LINDSAY, V., CHADEE, D., MATTSSON, J., JOHNSTON, R.; MILLETT, B. Relationships, the Role of Individuals and Knowledge Flows in the Internationalisation of Service Firms. International Journal of Service Industry Management, v. 14, p. 7-35, 2003.

LUBATKIN, M. H., SIMSEK, Z.; LING, Y. V., J., F. Ambidexterity and Performance in Small to Medium-Size Firms: The Pivotal Role of Top Management Team Behavioral Integration. Journal of Management. v. 32, p. 646-672. 2006.

LUO, Y.; RUI, H. An Ambidexterity Perspective Toward Multinational Enterprises from Emerging Economies Academy of Management Perspective. v. 23, n. 4, p. 49-70. 2009.

LUO, Y; TUNG, R. International expansion of emerging market enterprises. Journal of International Business Studies, v. 38, n. 4, p. 481-498, 2007. 
LYLES, M. A.; SALK, J. E. Knowledge Acquisition from Foreign Parents in International Joint Ventures: An Empirical Examination in the Hungarian Context. Journal of International Business Studies, v. 27, p. 877- 903, 1996.

MACHADO, N. Karl Polanyi e a Nova Sociologia Económica: Notas sobre o conceito de (dis)embeddedness. Revista Crítica de Ciências Sociais. n. 90, p. 71, set., 2010.

MAJCHRZAK, A.; COOPER, L. P.; NEECE, O. E. Knowledge reuse for innovation. Management Science, v. 50, n. 2, p. 174-188, 2004.

MALHOTRA, N.K. Pesquisa de marketing: uma orientação aplicada. 3.ed. Porto Alegre: Bookman, 2001.

MALIK, K. Aiding the Technology Manager: a conceptual model for intra-firm technology transfer. Technovation. v. 22, n. 7, p. 427-436, 2002.

MANSFIELD, E.; ROMEO, A.; SCHWARTZ, M.; TEECE, D.; WAGNER, S.; BRACH, P. New Findings in Technology Transfer, Productivity and Development. Research Management, March-April, p. 11-20, 1983.

MARCH, J. G. Exploration and Exploitation in Organizational Learning, Organization Science. v. 2, n. 1, February, p. 71-87, 1991.

MARCONI, M. A.; LAKATOS, E. M. Fundamentos de metodologia científica. $6^{\text {a }}$ ed. São Paulo: Atlas; 2007.

MARTINKENAITE, I. Antecedents of knowledge transfer in acquisitions. Baltic Journal of Management. v. 7, n. 2, p. 167-184, 2012.

MARTINS, G. A.; THEÓPHILO, C. R. Metodologia da investigação científica para ciências sociais aplicadas. São Paulo: Editora Atlas, 2007.

MATHEWS, J. Dragon Multinationals: New Players in the 21 st Century. Asia-Pacific Journal of Management, 23: 2-27, 2006.

MATHEWS, J. A. Dragon Multinationals: A New Model for Global Growth. New York: Oxford University Press, 2002.

MENZLER-HOKKANEN, I. Multinational enterprises and technology transfer. International Journal of Technology Management, 10(2-3), 293-310, 1995.

MILLAR, C.; CHOI, C. Reverse Knowledge and Technology Transfer: Imbalances Caused by Cognitive Barriers in Asymmetric Relationships. International Journal of Technology Management, v. 48, 2009. 
MINBAEVA, D. HRM Practices affecting extrinsic and intrinsic motivation of knowledge receivers and their effect on intra-EMN knowledge transfer. International Business Review, v. 17. n. 6, p. 703-713, 2008.

MINBAEVA, D. B. Knowledge Transfer in Multinational Corporations. Management International Review, v. 47, p. 567-593, 2007.

MINBAEVA, D., PEDERSEN, T., BJÖRKMAN, I., FEY, C. PARK, H.J. EMN Knowledge transfer, subsidiary absorptive capacity and HRM. Journal of International Business Studies, v. 34, p. 586-99, 2003.

MONTEIRO, L. F., ARVIDSSON, N.; BIRKINSHAW, J. Knowledge flows within multinational corporations: explaining subsidiary isolation and its performance implications. Organization Science, v. 19, p. 90-107, 2008.

MOURA, P. G. DA. S. O processo de internacionalização do desenvolvimento de produtos em empresas multinacionais brasileiras. Ribeirão Preto. 132 p., 2007. Dissertação (Mestrado em Administração) - Faculdade de Economia, Administração e Contabilidade de Ribeirão Preto da Universidade de São Paulo.

MUDAMBI, R., MUDAMBI, S. M.; NAVARRA, P. Global Innovation in MNCs: The Effects of Subsidiary Self-Determination and Teamwork. Journal of Product Innovation Management, v. 24, p. 442-455, 2007.

MUDAMBI, R. Knowledge Management in Multinational Firms. Journal of International Management. v. 8, p. 1-9, 2002.

MUDAMBI; NAVARRA, P. Is knowledge power? Knowledge flows, subsidiary power and rent-seeking within EMNs. Journal of International Business Studies, v. 35, n.5, p.385-406, 2004.

NARULA, R. AND A. ZANFEI, 2005, Globalization of Innovation: The Role of Multinational Enterprises. In: Fagerberg, J., D. Mowery and R.R. Nelson, (eds.) The Oxford Handbook of Innovation, Oxford: Oxford University Press, 2005.

NELSON, R.R.; WINTER, S.G. An evolutionary theory of economic change. Cambridge, MA: Harvard University Press, 1982.

NOHRIA, N.; GHOSHAL, S. The Differentiated Network: Organizing Multinational Corporations for Value Creation. San Francisco: Jossey-Bass Publishers, 1997.

NONAKA, I. A Dynamic Theory of Organizational Knowledge Creation. Organization Science. v. 5, p. 14-37, 1994.

NONAKA, I., TAKEUCHI, H.; KATSUHIRO, U. A Theory of Organizational Knowledge Creation. International Journal of Technology Management. v, 11, p. 833-846, 1996. 
NONAKA, I.; TAKEUCHI, H. The knowledge creating company: how japanese companies create the dynamics of innovation, New York: Oxford University Press, 1995.

NOORDERHAVEN, N.; HARZING, A.W. Knowledge-Sharing and Social Interaction within EMNEs. Journal of International Business Studies, v. 40, p. 719-741, 2009.

NORTH, D. Institutions, institutional change and economic performance. Cambridge: Cambridge University Press, 1990.

OECD. Manual de Oslo: diretrtizes para a coleta e interpretação de dados sobre inovação tecnológica. Publicado pela FINEP (Financiadora de Estudos e Projetos), $3^{\mathrm{a}}$ edição, 2006.

OLIVEIRA JÚNIOR, M. M.; BORINI, F. M.; FLEURY, A. C. Innovation by Brazilian EMNEs. In: WILLIANSON, P. J.; RAMAMURTI, R.; FLEURY, A.; FLEURY, M. T. L. (Org.). The Competitive Advantage of Emerging Market Multinationals. 1 ed. Cambridge: Cambridge Press, v. 1, p. 11-28, 2013.

OLIVEIRA JÚNIOR, M. M.; BORINI, F. M. Subsidiaries of Brazilian Multinational Corporations: How manage them? Anais. In: Encontro da ANPAD, 2010, Rio de Janeiro. Encontro da ANPAD, 2010. v. XXXIV. p. 1-16, 2010.

OLIVEIRA JÚNIOR, M. M.; BORINI, F. M. Gestão de Subsdiárias. GV Executivo, v. 8, p. 18-21, 2009.

OLIVEIRA JÚNIOR, M. M.; BORINI, F. M.; GUEVARA, A. J. H. The strategic relevance of Brazilian subsidiaries of multinational corporations. Revista de Administração (FEA-USP), v. 44, p. 285-298, 2009.

OSULLIVAN, A. Dispersed collaboration in a multi-firm, multi-team product development project. Journal of Engineering and Technology Management, v. 20, n.1, p. 93-116, 2003.

PATERSON, S. L; BROCK; D. M. The development of subsidiary-management research: review and theoretical analysis. International Business Review, v. 11, p-139-163, 2002.

PEARCE, R., PAPANASTASSIOU, M., Overseas R\&D and the strategic evolution of EMNEs: evidence from laboratories in the UK. Research Policy, n. 28, p. 23-41, 1999.

PENG, M. W. 2002. Towards an institution-based view of business strategy. Asia Pacific Journal of Management. v. 19, p. 251-267, 2002.

POLANYI, M. The Growth of Science in Society. Minerva 5(4): 533-545, 1967.

POLANYI, M. The Republic of Science: Its Political and Economic Theory, Minerva. v. 1, n. 1, p. 54-73, 1962.

PORTER, M. E. 1990. The Competitive Advantage of Nations, New York, Free Press, 1990. 
PORTER, M. E. Competition in global industries: A conceptual framework. In M. E. Porter (Ed.), Competition in global industries: 15-60. Boston: Harvard Business School Press, 1986.

PORTO, G.; GALINA, S.; COSTA, P. R.; MOURA, P.; MATA, R. Gestão de P\&D de empresas multinacionais brasileiras. In: FLEURY, A. (Org.). Gestão empresarial para a internacionalização das empresas brasileiras, São Paulo: Atlas, 2010.

POWELL, W. W., KOPUT, K. W.; SMITH-DOERR, L. 1996. Interorganizational Collaboration and the Locus of Innovation: Networks of Learning in Biotechnology. Administrative Science Quarterly. v. 41, p. 116-145, 1996.

PRAHALAD, C. K.; DOZ, Y. The multinational mission: balancing local demands and global vision. Free Press, Macmillan, New York, 1987.

RABIOSI, L. Subsidiary roles and reverse knowledge transfer: An investigation of the effects of coordination mechanisms. Journal of International Management, v. 17, p. 97-113, 2011.

RABIOSI, L.; SANTANGELO, G. D. Parent company benefits from reverse knowledge transfer: The role of the liability of newness in MNEs. In: Proceeedings of DRUID 2011, Copenhagen Business School, Denmark, 2011.

RABIOSI, L. The Impact of Subsidiary Autonomy on Reverse Knowledge Transfer: Moving from Single to Interdependent Explanations. Working Paper. Copenhagen Business School, Center for Strategic Management and Globalization, 2008.

RAMAMURTI, R. What have we learn about emerging-market MNEs? In: RAMAMURTI, R.; SINGH, J. (Ed). Emerging multinationals in emerging markets. Oxford: Oxford University Press, p.399-426. 2009a.

RAMAMURTI, R. Why study emerging-market multinationals? In: RAMAMURTI, R.; SINGH, J. (Ed). Emerging multinationals in emerging markets. Oxford: Oxford University Press, p. 3-22, $2009 b$.

REED, R.; DEFILLIP.I, R. J. Causal Ambiguity, Barriers to Imitation, and Sustainable Competitive Advantage. Academy of Management Review, v. 15, p. 88-102, 1990.

RENZL, B. Trust in management and knowledge sharing: The mediating effects of fear and knowledge documentation. Omega, v. 36, n. 2, p. 206-220, 2008.

ROCHA, A.; SILVA, J. F. e CARNEIRO, J. Expansão internacional das empresas brasileiras: revisão e síntese. In: FLEURY, A.; FLEURY, M. T. L. (Org.), internacionalização e os países emergentes. Atlas, São Paulo, p. 183-197, 2007.

ROGERS, E.; VALENTE, T. Technology transfer in high-technology industries, In: AGMON T.; GLINOW, M. V. (Eds.), Technology transfer in international business. Oxford University Press, Oxford, 1991. 
ROTH, K., MORRISON, A. J. Implementing Global Strategy. Characteristics of Global Subsidiary Mandates. Journal of International Business Studies. v. 23, n. 4, p. 715-735, 1992.

RUGMAN A.; VERBEKE, A. Subsidiary Specific Advantages in Multinational Enterprises. Strategic Management Journal, v. 22, p. 237-250, 2001.

SANTANGELO, G. D. MNCs and linkages creation: Evidence from a peripheral area Journal of World Business, v. 44, n. 2, p. 192-205, 2009.

SCHULZ, M.. Pathways of relevance: exploring inflows of knowledge into subunits of multinational corporations. Organization Science, v. 14, n. 4, p. 440-459, 2003.

SCHULZ, M. The uncertain relevance of newness: organizational learning and knowledge flows. Academy of Management Journal, v. 44, p. 661-681, 2001.

SELLTIZ, C.; WRIGHTSMAN, L. S.; COOK, S. W. Métodos de pesquisa nas relações sociais. São Paulo: EPU, 1987.

SHIN, M., HOLDEN, T.; SCHMIDT, R. A. From knowledge theory to management practice: towards an integrated aproach. Information Processing and Management. v. 37, p. 335-355, 2001.

SILVA, N.; FLEURY, M. Estratégias de transferência de conhecimento em multinacionais brasileiras: Estudo comparativo entre as subsidiárias adquiridas e as greenfield. Internext Revista Eletrônica de Negócios Internacionais da ESPM, v. 7, n. 1, p. 1-33, 2012.

SIMONIN, B. L. An empirical investigation of the process of knowledge transfer in international strategic alliances. Journal of International Business Studies, v. 35, p. 407-427, 2004.

SIMONIN, B. L. Transfer of marketing know-how in international strategic alliances: an empirical investigation of the role and antecedents of knowledge ambiguity. Journal of International Business Studies, v. 30, p. 463-490, $1999 \mathrm{~b}$.

SIMONIN, B., L. Ambiguity and the process of knowledge transfer in strategic alliances. Strategic Management Journal, v. 20, p. 595-623, 1999a.

SOBEET. Internacionalização das Empresas Brasileiras. CLIO Editora, São Paulo, 2011.

STAL, E. CAMPANÁRIO, M. A. Empresas multinacionais de países emergentes. O crescimento das multilatinas, Economia Global e Gestão, abr. 2010, v. 15, n. 1, p. 55-73, 2010.

STEENSMA, H. K.; LYLES, M.A. Explaining IJV survival in a transitional economy through social exchange and knowledge-based perspectives, Strategic Management Journal. v. 21, p. 831-851, 2000. 
SUBRAMANIAM, M. AND VENKATRAMAN, N. Determinants of transnational new product development capability: Testing the influence of transferring and deploying tacit overseas knowledge. Strategic Management Journal. v. 22, n. 4, p. 359-378. 2001

SUBRAMANIAN, V., B. MEYER AND EVANS, G.S. The murine Cdx1 gene product localises to the proliferative compartment in the developing and regenerating intestinal epithelium. Differentiation. v. 64, p. 11-18, 1998.

SULL, D. N.; ESCOBARI, M. Sucesso Made in Brazil. 3ed. Elsevier, Rio de Janeiro, 2004.

SVEIBY, K. E. A knowledge-based theory of the firm to guide in strategy formulation, Journal of Intellectual Capital. v. 2 n. 4, p. $344-358,2001$.

SZULANSKI, G.; JENSEN, R., J. 2006. Presumptive Adaptation and the Effectiveness of Knowledge Transfer. Strategic Management Journal, 27, 937-957, 2006.

SZULANSKI G.; CAPETTA R. Stickiness: Conceptualising Measuring and Predicting Difficulties in the Transfer of Knowledge Within Organisations, in M Easterby-Smith and MA Lyles (eds.), The Blackwell handbook of organisational learning and knowledge management, Malden, MA, Blackwell Publishing. 2003.

SZULANSKI, G. Exploring internal stickiness: impediments to the transfer of best practice within the firm. Strategic Management Journal, v. 17, p. 27-43, 1996.

TANURE, B.; DUARTE, R. G. (Org.). (2006) Gestão Internacional. São Paulo: Saraiva, 2006.

TAVANI, Z. N.; GIROUD, A., ANDERSSON, U. The Interplay of Networking Activities and Internal Knowledge Actions for Subsidiary Influence within MNCs. Journal of World Business. 2013.

TAVANI, N. H., GIROUD, A.; SINKOVICS, R., Mediating effects in Reverse Knowledge Transfer Processes: The Case of Knowledge-Intensive Services in the U.K., Proceedings of the 54rd Annual Meeting of the Academy of International Business. Presented at 7th JIBS workshop development, Rio de Janeiro, Brazil, 2010.

TAVANI, Z. N. Mediating effects in reverse knowledge transfer processes: the case of knowledge-intensive services in the U.K. PhD Thesis, Manchester Business School Marketing, International and Business Strategy, 2010.

TEECE, D. J.; PISANO, G.; SHUEN, A. Dynamic capabilities and strategic management. Strategic Management Journal, v. 18, n. 7, p. 509-533, 1997.

TEECE, D. J. Multinational Enterprise, Internal governance and Industrial Organization. American Economic Review of World Economics. v. 75, p. 233-238, 1985. 
TEECE, D. J. The Market for Know-How and the Efficient International Transfer of Technology. The ANNALS of the American Academy of Political and Social Science, v. 458, p. 81-96, 1981.

TEECE, D. Technology transfer by multinational firms: The resource cost of transferring technological know-how, The Economic Journal, 87 (June):242-261, 1977.

TRIVIÑOS, A. N. S. Introdução à pesquisa em ciências sociais: a pesquisa qualitativa em educação. São Paulo: Atlas, 1987.

TSAI, W., Knowledge transfer in inter-organizational networks: Effects of network position and absorptive capacity on business unit innovation and performance. Academy of Management Journal. v. 44, n. 5, p. 996-1004, 2001.

TSAI, W. Social capital, strategic relatedness, and the formation of intra-organizational linkages. Strategic Management Journal. v.21, p. 925-939, 2000.

TSOUKAS $\mathrm{H}$. The firm as a distributed knowledge system: a constructionist ap.roach. Strategic Management Journal. v. 17, winter special issue, p. 11-25, 1996.

UNCTAD. FDI policies for development: national and international perspectives. World Investment Report. New York: United Nation, 2005.

URBACH, N.; F. AHLEMANN. Structural Equation Modeling in Information Systems Research Using Partial Least Squares. Journal of Information Technology Theory and Application, v. 11, n. 2, p. 5-40, june, 2010.

VACHANI, S. Global diversifications effect on multinational subsidiaries autonomy. International Business Review, v. 8, n. 5, p. 535-560, 1999.

VAN DE VEN, A.H. 1986. Central problems in the management of innovation. Management Science. v. 32, n. 5, p. 590-607, 1986.

VAN DER VELDE, M.; JANSEN, P.; ANDERSON, N. Guide to Management Research Methods. Oxford: Blackwell Publishing, 2004.

VAN WIJK, R.; JANSEN, J. J. P.; LYLES, M. A. Inter- and intra-organizational knowledge transfer: a meta-analytic review and assessment of its antecedents and consequences. Journal of Management Studies, v. 45, n. 4, 2008.

VON HIPEL, E. Sticky Information and the Locus of Problem Solving: Implications for Innovation. Management Science, 40, 429-439, 1994.

WANG, L. The liability of foreignness: Chinese investment in Australia, international conference transnational corporations and China, Wuhan, November, Proceedings, p. 281-324, 2012. 
WIJK, R. V.; JANSEN, J. J. P.; LYLES, M. Inter- and intra-organizational knowledge transfer: a meta-analytic review and assessment of its antecedents and consequences. Journal of Management Studies. v. 45, n. 4, p. 830-853, 2008.

WINTER, S. G. 1987. Knowledge and competence as strategic assets. In D.J. Teece (Ed.), The competitive challenge: Strategies for industrial innovation and renewal. Cambridge, MA: Ballinger Publishing, 1987.

WRIGHT, M., FILATOTCHEV, I., HOSKISSON, R. E.; PENG, M. W. Strategy research in emerging economies: challenging the conventional wisdom. Journal of Management Studies, v. 42, p. 1-33, 2005.

YAMAKAWA, Y., PENG, M. W.; DEEDS, D. What drives new ventures to internationalize from emerging to developed economies? Entrepreneurship Theory and Practice, v. 32, n.2, p. 59-82, 2008.

YAMIN M.; TSAI, H. S.; HOLM, U. The performance effects of headquarters involvement in lateral innovation transfers in multinational corporations. Management International Review, v. 51, p. 157-177, 2011.

YAMIN, M.; OTTO, J. Patterns of Knowledge Flows and MNE Innovative Performance. Journal of International Management, v. 10, p. 239-258, 2004.

YANG, Q., MUDAMBI, R.; MEYER, K.E. Convention and reverse knowledge flows in multinational corporations. Journal of Management, v. 34, n. 5, p. 882-903, 2008.

ZACK, M. H. Managing codified knowledge. Sloan Management Review. v. 40, n. 4, p. 45$58,1999$.

ZANDER, I., Technological diversification in the multinational corporation-historical evolution and future prospects. Research Policy, n. 26, p. 209-227, 1997.

ZANDER, U.; KOGUT, B. Knowledge and the speed of the transfer and imitation of organizational capabilities: an empirical test. Organization Science, v. 6, n.1, p. 76-92, 1995.

ZHAO, H.; LUO, Y. Antecedents of knowledge sharing with peer subsidiaries in other countries: A perspective from subsidiary managers in a foreign emerging market. Management International Review, v. 45, n.1, p. 71-97, 2005.

ZHOU, C.; FROST, T. Centrifugal Forces, R\&D Co-practice, and Reverse Knowledge Flows in Multinational Firms. Proceedings of AIB annual meeting, 2003.

ZWICKER, R., SOUZA, C. A. E BIDO, D. S. Uma revisão do modelo do grau de informatização de empresas: novas propostas de estimação e modelagem usando PLS (partial least squares). Anais... Encontro da Associação Nacional de Pós- Graduação e Pesquisa em Administração - ENANPAD, 32, 2008. 


\section{APÊNDICE I}

Instrumento de pesquisa - Questionário com perguntas fechadas

\section{Transferência Reversa de Conhecimento Tecnológico da Subsidiária para a Matriz em Multinacionais Brasileiras}

Bem vindo e obrigado por aceitar participar de nossa pesquisa.

Esta pesquisa investiga como as subsidiárias das multinacionais brasileiras podem melhor contribuir para a base de conhecimento tecnológico da matriz. Mais especificamente, o estudo objetiva verificar em qual extensão as subsidiárias estão transferindo seu conhecimento do tipo tecnológico para a sede da corporação. A experiência que a sua empresa já acumulou pode trazer grandes contribuições para um melhor entendimento dessa questão ao mesmo tempo em que os resultados da pesquisa podem ajudá-lo a entender os fatores, que se empregados, podem melhorar a posição estratégica da sua subsidiária.

Nós entendemos plenamente a sua limitação de tempo e ficaremos muito agradecidos se você puder dedicar 15 minutos para responder este questionário. Em troca, teremos o prazer de enviar o resumo executivo dos resultados. Por favor, note que não há respostas certas e erradas, é a sua opinião pessoal que é importante para nós.

Todos os dados serão tratados de maneira estritamente confidencial. Para tanto, os resultados da pesquisa serão apresentados somente de forma agregada.

Agradecemos a sua contribuição.

Coordenadores da pesquisa:

Profa. Franciane Freitas Silveira

Doutoranda de administração na Universidade de São Paulo - USP

\section{Prof. Dr. Roberto Sbragia}

Professor, Titular da Universidade de São Paulo - USP 


\section{QUESTIONÁRIO}

\section{Instruções:}

O foco dessa pesquisa é discutir os fatores determinantes da transferência reversa de conhecimento tecnológico da subsidiária para a matriz em empresas multinacionais brasileiras. O questionário compreende 1 página com 19 questões. Seu preenchimento levará cerca de 20 minutos. Todos os dados serão tratados de maneira confidencial, e só serão apresentados de forma agregada.

As questões marcadas com asterisco $\left(^{*}\right)$ requerem uma resposta para que se possa prosseguir.

Transferência reversa de conhecimento tecnológico: "é a transferência de informações, know-how e conhecimento técnico incorporada em produtos, processos e gestão tecnológica."

\section{PARTE 1}

As perguntas desta parte do questionário dizem respeito às características gerais da sua subsidiária.

1. Nome da Empresa

2. Função atual na empresa:

3. Em que país sua subsidiária está localizada?

4. Quantos empregados há em sua subsidiária?

5. Em que ano a sua subsidiária iniciou as operações?

6. Como a sua subsidiária foi formada? (marque um " $\mathrm{X}$ ")

\begin{tabular}{|l|l|}
\hline & Uma companhia local foi adquirida pela multinacional brasileira \\
\hline & $\begin{array}{l}\text { Investimento direto - greenfield operation (ex. uma nova subsidiária foi } \\
\text { criada) }\end{array}$ \\
\hline Alianças e Joint-Ventures
\end{tabular}

7. Qual o percentual de vendas da sua subsidiária do total da corporação, aproximadamente? 


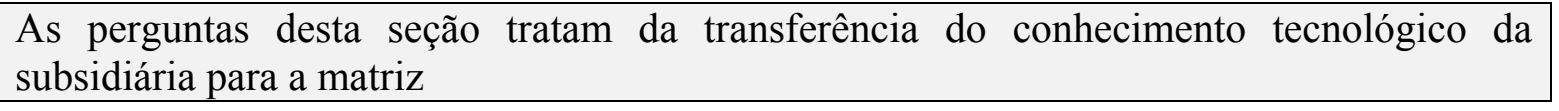

1) Com que extensão, durante os últimos três anos, sua subsidiária transferiu para a matriz, conhecimentos referentes a:

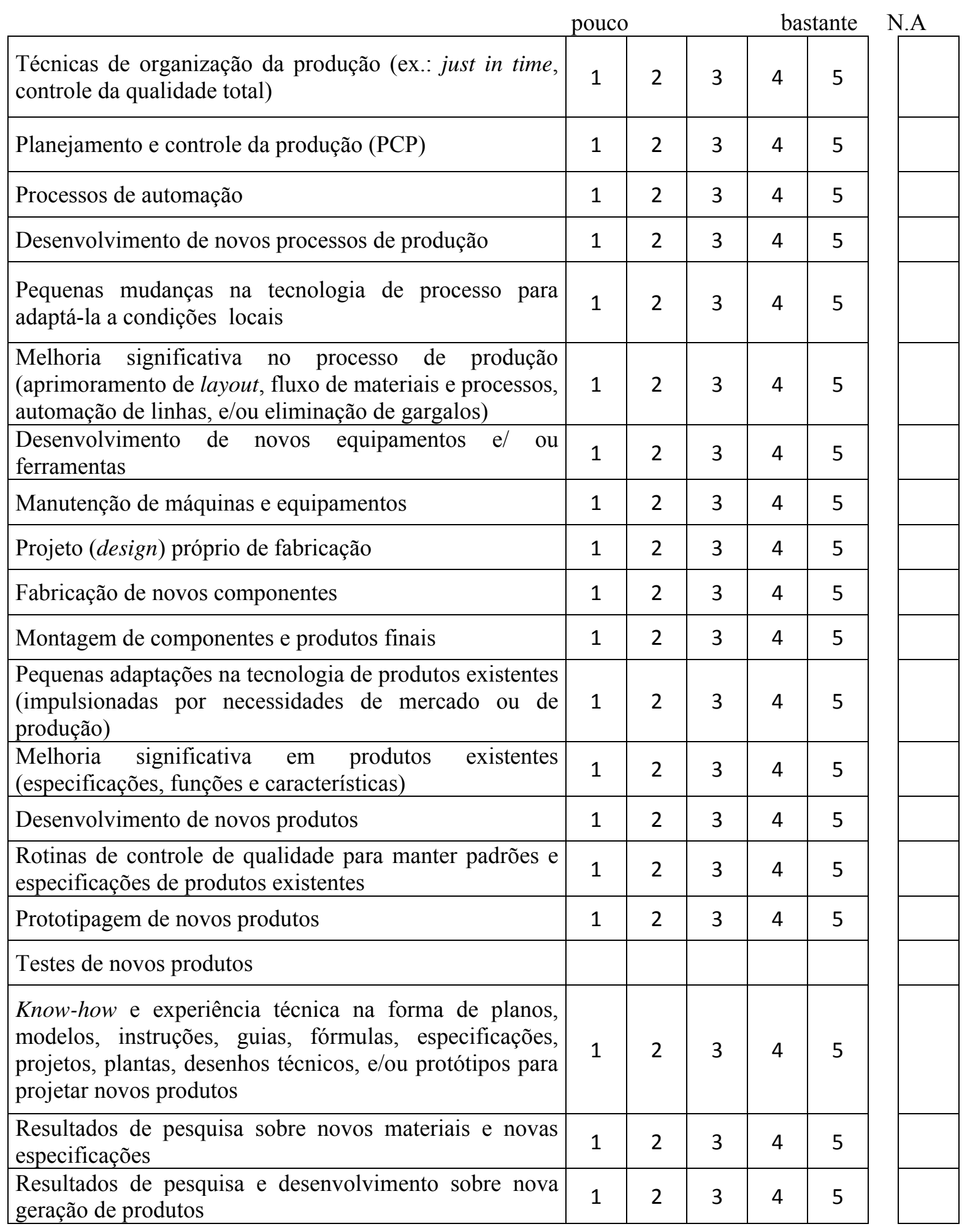


As perguntas desta seção tratam da característica do conhecimento tecnológico e das características da subsidiária

1) Indique seu grau de concordância em relação às características do conhecimento tecnológico da sua subsidiária.

\begin{tabular}{|l}
\multicolumn{4}{c}{$\begin{array}{c}\text { Discordo } \\
\text { Totalmente }\end{array}$} \\
\begin{tabular}{|l|c|c|c|c|c|}
\hline É fácil de documentar em manuais, relatórios e imagens & 1 & 2 & 3 & 4 & 5 \\
\hline É fácil de compreender por meio de documentos escritos & 1 & 2 & 3 & 4 & 5 \\
\hline $\begin{array}{l}\text { É mais explícito do que tácito (difícil de documentar, imitar } \\
\text { e aprender) }\end{array}$ & 1 & 2 & 3 & 4 & 5 \\
\hline
\end{tabular}
\end{tabular}

2) Indique seu grau de concordância em relação a complexidade do conhecimento tecnológico da sua subsidiária.

\begin{tabular}{|c|c|c|c|c|c|}
\hline \multicolumn{4}{|c|}{$\begin{array}{l}\text { Discordo } \\
\text { Totalmente }\end{array}$} & \multicolumn{2}{|c|}{$\begin{array}{l}\text { Concordo } \\
\text { Totalmente }\end{array}$} \\
\hline $\begin{array}{l}\text { Seu entendimento requer um aprendizado prévio de outros } \\
\text { conhecimentos tecnológicos relacionados }\end{array}$ & 1 & 2 & 3 & 4 & 5 \\
\hline $\begin{array}{l}\text { Seu entendimento requer uma grande quantidade de } \\
\text { informação }\end{array}$ & 1 & 2 & 3 & 4 & 5 \\
\hline $\begin{array}{l}\text { É produto de muitas rotinas interdependentes, indivíduos e } \\
\text { recursos }\end{array}$ & 1 & 2 & 3 & 4 & 5 \\
\hline Inclui muitas novas habilidades ou competências & 1 & 2 & 3 & 4 & 5 \\
\hline É tecnologicamente sofisticado e difícil de implantar & 1 & 2 & 3 & 4 & 5 \\
\hline É complexo (vs. simples) & 1 & 2 & 3 & 4 & 5 \\
\hline
\end{tabular}

3) A sua subsidiária é dedicada a atividades voltadas a:

\begin{tabular}{|l|r|r|}
\multicolumn{2}{c|}{ Sim } & Não \\
\hline Criação de novos produtos/serviços e/ou novas tecnologias & 1 & 2 \\
\hline Adaptação e melhoria de produtos/serviços e/ou processos & 1 & 2 \\
\hline
\end{tabular}

4) Indique seu grau de concordância com as considerações a respeito do ambiente de negócios no país em que a sua subsidiária atua, em relação ao ambiente da matriz. 


\begin{tabular}{|c|c|c|c|c|c|}
\hline \multicolumn{4}{|c|}{ Totalmente } & \multicolumn{2}{|c|}{ Totalmente } \\
\hline $\begin{array}{l}\text { A demanda de mercado está crescendo no setor da } \\
\text { subsidiária }\end{array}$ & 1 & 2 & 3 & 4 & 5 \\
\hline $\begin{array}{l}\text { Os consumidores locais exigem padrões elevados de } \\
\text { qualidade e funcionalidades }\end{array}$ & 1 & 2 & 3 & 4 & 5 \\
\hline A competição no país é intensa & 1 & 2 & 3 & 4 & 5 \\
\hline A velocidade da inovação dos competidores é alta & 1 & 2 & 3 & 4 & 5 \\
\hline As capacidades e qualidades dos fornecedores são elevadas & 1 & 2 & 3 & 4 & 5 \\
\hline A mão de obra é qualificada e especializada & 1 & 2 & 3 & 4 & 5 \\
\hline $\begin{array}{l}\text { Existem importantes centros de pesquisa (externos à } \\
\text { empresa) que colaboram com os negócios da subsidiária }\end{array}$ & 1 & 2 & 3 & 4 & 5 \\
\hline Há boas instituições de suporte aos negócios & 1 & 2 & 3 & 4 & 5 \\
\hline $\begin{array}{l}\text { A infraestrutura no país (disponibilidade de energia, } \\
\text { transporte, telecomunicações, logística) é adequada }\end{array}$ & 1 & 2 & 3 & 4 & 5 \\
\hline O governo dá apoio à inovação & 1 & 2 & 3 & 4 & 5 \\
\hline O ambiente legal é favorável (regulamentação) & 1 & 2 & 3 & 4 & 5 \\
\hline
\end{tabular}

5) Indique o grau de relacionamento da sua subsidiária com os clientes (ou algum cliente específico) do ambiente local:

\begin{tabular}{|l|r|r|r|r|r|}
\hline $\begin{array}{l}\text { Os clientes têm participado intensamente do } \\
\text { desenvolvimento do conhecimento tecnológico na } \\
\text { subsidiária }\end{array}$ & 1 & 2 & 3 & 4 & 5 \\
\hline $\begin{array}{l}\text { Os clientes tiveram importantes iniciativas para o } \\
\text { desenvolvimento do conhecimento tecnológico na } \\
\text { subsidiária }\end{array}$ & 1 & 2 & 3 & 4 & 5 \\
\hline $\begin{array}{l}\text { Os clientes atenderam aos seus interesses ao desenvolver o } \\
\text { conhecimento tecnológico na subsidiária }\end{array}$ & 1 & 2 & 3 & 4 & 5 \\
\hline $\begin{array}{l}\text { O conhecimento tecnológico da subsidiária foi } \\
\text { parcialmente desenvolvido dentro das } \\
\text { instalações dos clientes }\end{array}$ & 1 & 2 & 3 & 4 & 5 \\
\hline $\begin{array}{l}\text { A cooperação com os clientes tem sido caracterizada por } \\
\text { frequentes interações }\end{array}$ & 1 & 2 & 3 & 4 & 5 \\
\hline
\end{tabular}

6) Indique o grau de relacionamento da sua subsidiária com fornecedores do ambiente local: 


\begin{tabular}{|c|c|c|c|c|c|}
\hline $\begin{array}{l}\text { Os fornecedores têm participado intensamente do } \\
\text { desenvolvimento do conhecimento tecnológico na } \\
\text { subsidiária }\end{array}$ & 1 & 2 & 3 & 4 & 5 \\
\hline $\begin{array}{l}\text { Os fornecedores tiveram importantes iniciativas para o } \\
\text { desenvolvimento do conhecimento tecnológico na } \\
\text { subsidiária }\end{array}$ & 1 & 2 & 3 & 4 & 5 \\
\hline $\begin{array}{l}\text { Os fornecedores atenderam aos seus interesses ao } \\
\text { desenvolver o conhecimento tecnológico na subsidiária }\end{array}$ & 1 & 2 & 3 & 4 & 5 \\
\hline $\begin{array}{l}\text { O conhecimento tecnológico da subsidiária foi } \\
\text { parcialmente desenvolvido dentro das } \\
\text { instalações dos fornecedores }\end{array}$ & 1 & 2 & 3 & 4 & 5 \\
\hline $\begin{array}{l}\text { A cooperação com os fornecedores tem sido caracterizada } \\
\text { por frequentes interações }\end{array}$ & 1 & 2 & 3 & 4 & 5 \\
\hline
\end{tabular}

7) Indique o grau de relacionamento da sua subsidiária com instituições de ciência e tecnologia (C\&T) do ambiente local:

\begin{tabular}{|l|r|r|r|r|r|}
\multicolumn{2}{|c|}{ Fraco } & Forte \\
\hline $\begin{array}{l}\text { As instituições de C\&T têm participado intensamente do } \\
\text { desenvolvimento do conhecimento tecnológico na } \\
\text { subsidiária }\end{array}$ & 1 & 2 & 3 & 4 & 5 \\
\hline $\begin{array}{l}\text { As instituições de C\&T tiveram importantes iniciativas } \\
\text { para o desenvolvimento do conhecimento tecnológico na } \\
\text { subsidiária }\end{array}$ & 1 & 2 & 3 & 4 & 5 \\
\hline $\begin{array}{l}\text { As instituições de C\&T atenderam aos seus interesses ao } \\
\text { desenvolver o conhecimento tecnológico na subsidiária }\end{array}$ & 1 & 2 & 3 & 4 & 5 \\
\hline $\begin{array}{l}\text { O conhecimento tecnológico da subsidiária foi } \\
\text { parcialmente desenvolvido dentro das } \\
\text { instalações das instituições de C\&T }\end{array}$ & 1 & 2 & 3 & 4 & 5 \\
\hline $\begin{array}{l}\text { A cooperação com as instituições de C\&T tem sido } \\
\text { caracterizada por frequentes interações }\end{array}$ & 1 & 2 & 3 & 4 & 5 \\
\hline
\end{tabular}

8. Indique o grau de integração da sua subsidiária com a matriz.

\begin{tabular}{|c|c|c|c|c|c|}
\hline \multicolumn{4}{|c|}{$\begin{array}{l}\text { Discordo } \\
\text { Fortemente }\end{array}$} & \multicolumn{2}{|c|}{$\begin{array}{l}\text { Concordo } \\
\text { Fortemente }\end{array}$} \\
\hline $\begin{array}{l}\text { A matriz tem participado intensamente do } \\
\text { desenvolvimento do conhecimento tecnológico na } \\
\text { subsidiária }\end{array}$ & 1 & 2 & 3 & 4 & 5 \\
\hline $\begin{array}{l}\text { A matriz teve importantes iniciativas para o } \\
\text { desenvolvimento do conhecimento tecnológico na } \\
\text { subsidiária }\end{array}$ & 1 & 2 & 3 & 4 & 5 \\
\hline $\begin{array}{l}\text { A matriz atendeu aos seus interesses ao desenvolver o } \\
\text { conhecimento tecnológico na subsidiária }\end{array}$ & 1 & 2 & 3 & 4 & 5 \\
\hline $\begin{array}{l}\text { O conhecimento tecnológico da subsidiária foi } \\
\text { parcialmente desenvolvido dentro das } \\
\text { instalações da matriz }\end{array}$ & 1 & 2 & 3 & 4 & 5 \\
\hline $\begin{array}{l}\text { A cooperação com a matriz tem sido caracterizada por } \\
\text { frequentes interações }\end{array}$ & 1 & 2 & 3 & 4 & 5 \\
\hline
\end{tabular}


8) Qual grau de autonomia sua subsidiária tem para realizar as seguintes atividades:

\section{Assinale:}

$1=$ Matriz decide sozinha

2= A Matriz decide, mas considera as sugestões da subsidiaria

$3=$ Ambas têm igual influência sobre as decisões

4= A subsidiária decide, mas considera as sugestões da matriz

$5=$ A subsidiária decide sozinha

\begin{tabular}{|l|r|r|r|r|r|}
\hline Definição de projetos, plano e recursos para P\&D & 1 & 2 & 3 & 4 & 5 \\
\hline Introdução de novas tecnologias & 1 & 2 & 3 & 4 & 5 \\
\hline Realização de mudanças em produtos e serviços & 1 & 2 & 3 & 4 & 5 \\
\hline Alteração dos processos de produção & 1 & 2 & 3 & 4 & 5 \\
\hline Desenvolvimento de novos fornecedores e parceiros & 1 & 2 & 3 & 4 & 5 \\
\hline Realização de compras para a matriz e outras subsidiárias & 1 & 2 & 3 & 4 & 5 \\
\hline Contratação e demissão da força de trabalho & 1 & 2 & 3 & 4 & 5 \\
\hline
\end{tabular}

9) Indique seu grau de concordância no que se refere às motivações da sua subsidiária para a transferência de conhecimento tecnológico:

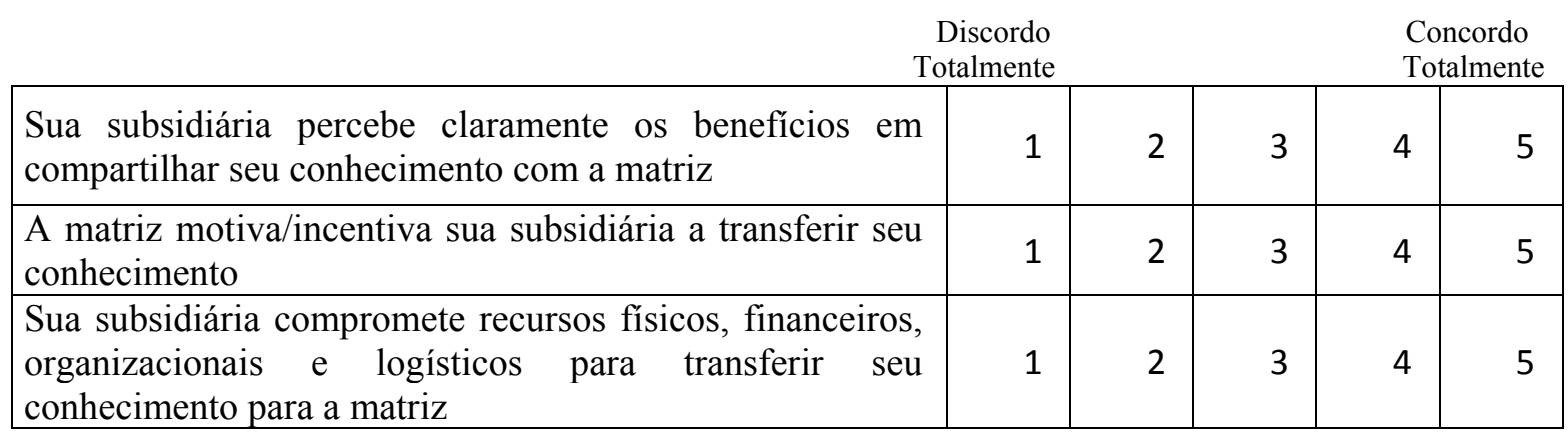

10) Indique seu grau de concordância no que tange às semelhanças organizacionais existentes entre a matriz e subsidiária: 


\begin{tabular}{|c|c|c|c|c|c|}
\hline \multicolumn{4}{|c|}{$\begin{array}{c}\text { Discordo } \\
\text { Totalmente }\end{array}$} & \multicolumn{2}{|c|}{$\begin{array}{r}\text { Concordo } \\
\text { Totalmente } \\
\end{array}$} \\
\hline $\begin{array}{l}\text { As bases do conhecimento tecnológico da subsidiária e } \\
\text { matriz são muito semelhantes }\end{array}$ & 1 & 2 & 3 & 4 & 5 \\
\hline $\begin{array}{l}\text { As práticas de negócios e os mecanismos operacionais são } \\
\text { muito semelhantes entre subsidiária e matriz }\end{array}$ & 1 & 2 & 3 & 4 & 5 \\
\hline $\begin{array}{l}\text { O estilo gerencial é muito semelhante entre subsidiária e } \\
\text { matriz }\end{array}$ & 1 & 2 & 3 & 4 & 5 \\
\hline $\begin{array}{l}\text { A cultura organizacional é muito semelhante entre } \\
\text { subsidiária e matriz }\end{array}$ & 1 & 2 & 3 & 4 & 5 \\
\hline
\end{tabular}

11) Indique seu grau de concordância no que tange às semelhanças culturais existentes entre a matriz e subsidiária:

\begin{tabular}{|l|r|r|r|r|r|}
\hline $\begin{array}{l}\text { A cultura dos países sede da matriz e subsidiária } \\
\text { influenciam fortemente o modo de fazer negócio }\end{array}$ & 1 & 2 & 3 & 4 & 5 \\
\hline $\begin{array}{l}\text { Muitos desentendimentos e conflitos culturais emergem } \\
\text { da transferência de conhecimento entre subsidiária e } \\
\text { matriz }\end{array}$ & 1 & 2 & 3 & 4 & 5 \\
\hline $\begin{array}{l}\text { As diferenças de idioma são os principais obstáculos na } \\
\text { comunicação e compreensão entre subsidiária e matriz }\end{array}$ & 1 & 2 & 3 & 4 & 5 \\
\hline
\end{tabular}

12) Indique com que frequência cada um dos seguintes processos e ferramentas de gestão do conhecimento são utilizados na subsidiária. Se um destes não existe na sua subsidiária, por favor, escolha a opção 'Não aplicável - NA':

\begin{tabular}{|c|c|c|c|c|c|}
\hline \multicolumn{4}{|c|}{$\begin{array}{l}\text { Muito } \\
\text { raramente }\end{array}$} & \multicolumn{2}{|c|}{$\begin{array}{l}\text { Muito } \\
\text { frequentemente }\end{array}$} \\
\hline $\begin{array}{l}\text { Compartilhamento de documentos com a matriz, tais como } \\
\text { manuais, projetos e base de dados }\end{array}$ & 1 & 2 & 3 & 4 & 5 \\
\hline $\begin{array}{l}\text { Instrumentos de comunicação baseados em internet como } \\
\text { fóruns, e-mails, mensagens instantâneas, etc. }\end{array}$ & 1 & 2 & 3 & 4 & 5 \\
\hline $\begin{array}{l}\text { Repositores (banco de dados) de informação, melhores } \\
\text { práticas e lições aprendidas }\end{array}$ & 1 & 2 & 3 & 4 & 5 \\
\hline $\begin{array}{l}\text { Mapeamento de tipos de conhecimentos específicos } \\
\text { (incorporados em indivíduos, sistemas específicos ou base } \\
\text { de dados) }\end{array}$ & 1 & 2 & 3 & 4 & 5 \\
\hline $\begin{array}{l}\text { Encontros entre pessoas da matriz e subsidiárias para } \\
\text { resolução de problemas }\end{array}$ & 1 & 2 & 3 & 4 & 5 \\
\hline $\begin{array}{l}\text { Constituição de equipe de trabalho envolvendo pessoas } \\
\text { tanto da subsidiária como da matriz }\end{array}$ & 1 & 2 & 3 & 4 & 5 \\
\hline $\begin{array}{l}\text { Transferência temporária (de curto prazo) de gerentes da } \\
\text { sua subsidiária para a matriz e vice-versa }\end{array}$ & 1 & 2 & 3 & 4 & 5 \\
\hline $\begin{array}{l}\text { Transferência temporária (de curto prazo) de staff científico } \\
\text { e técnico (pesquisadores, engenheiros) da subsidiária para } \\
\text { matriz e vice-versa }\end{array}$ & 1 & 2 & 3 & 4 & 5 \\
\hline
\end{tabular}




\section{OBRIGADA POR SUA COLABORAÇÃO!}




\section{APÊNDICE II}

Quadro 1 - Multinacionais Brasileiras com subsidiárias no exterior (indústria e serviços)

\begin{tabular}{|c|c|c|c|}
\hline & Empresa & Setor & Segmento Produtivo \\
\hline 1 & Marfrig & Alimentício & Baseado em recursos naturais \\
\hline 2 & JBS-Friboi & Alimentício & Baseado em recursos naturais \\
\hline 3 & CBMM & Mineração & Baseado em recursos naturais \\
\hline 4 & Vale & Mineração & Baseado em recursos naturais \\
\hline 5 & Petrobras & Petróleo e Gás & Baseado em recursos naturais \\
\hline 6 & Citrosuco & Sucos a granel & Insumos básicos \\
\hline 7 & Cutrale & Sucos a granel & Insumos básicos \\
\hline 8 & Duas Rodas & Alimentício & Insumos básicos \\
\hline 9 & Artecola & Química & Insumos Básicos \\
\hline 10 & Cia. Providência & Não-tecidos & Insumos Básicos \\
\hline 11 & Gerdau & Siderurgia & Insumos Básicos \\
\hline 12 & Santista & Têxtil & Insumos Básicos \\
\hline 13 & Klabin & Papel e celulose & Insumos Básicos \\
\hline 14 & $\mathrm{CSN}$ & Siderurgia & Insumos Básicos \\
\hline 15 & Votorantim Cimentos & Cimento & Insumos Básicos \\
\hline 16 & Votorantim Sider. & Siderurgia & Insumos Básicos \\
\hline 17 & Votorantim Metais & Metais & Insumos Básicos \\
\hline 18 & Camargo Corrêa Cim. & Cimento & Insumos Básicos \\
\hline 19 & Oxiteno & Químico & Insumos Básicos \\
\hline 20 & Mextra & Siderurgia & Insumos Básicos \\
\hline 21 & Braskem & Químico & Insumos Básicos \\
\hline 22 & FFS Filmes & Química e petroquímica & Insumos Básicos \\
\hline 23 & Inplac & Embalagens & Insumos Básicos \\
\hline 24 & Magnesita & Produção de Refratários & Insumos Básicos \\
\hline 25 & Portobello & Cerâmica & Insumos Básicos \\
\hline 26 & Suzano & Papel e celulose & Insumos Básicos \\
\hline 27 & Eucatex & Madeira & Insumos para construção civil \\
\hline 28 & Cinex & Moveleiro & Insumos para construção civil \\
\hline 29 & Duratex & Insumos para a Construção Civil & Insumos para construção civil \\
\hline 30 & Tigre & Material de Construção & Insumos para construção civil \\
\hline 31 & Tupy & Autopeças & Partes, componentes e subsistemas \\
\hline 32 & Metagal & Autopeças & Partes, componentes e Subsistemas \\
\hline 33 & Embraco & Máquinas e Materiais Elétricos & Partes, componentes e Subsistemas \\
\hline 34 & Moura & Autopeças & Partes, componentes e Subsistemas \\
\hline 35 & Iochpe-Maxion & Autopeças & Partes, componentes e Subsistemas \\
\hline
\end{tabular}




\begin{tabular}{|c|c|c|c|}
\hline 36 & DHB & Autopeças & Partes, componentes e Subsistemas \\
\hline 37 & Grupo Brasil & Veículos/ peças & Partes, componentes e Subsistemas \\
\hline 38 & Lupatech & Máquinas e Materiais Elétricos & Partes, componentes e Subsistemas \\
\hline 39 & Riffel & Peças de motos & Partes, componentes e Subsistemas \\
\hline 40 & Sabó & Autopeças & Partes, componentes e Subsistemas \\
\hline 41 & Weg & Máquinas e Materiais Elétricos & Partes, componentes e Subsistemas \\
\hline 42 & Jacto & Máquinas e Materiais Elétricos & Montadora de sistemas - Bens duráveis \\
\hline 43 & Metalfrio & Máquinas e Materiais Elétricos & Montadora de sistemas - Bens duráveis \\
\hline 44 & Randon & Implementos Rodoviários & Montadora de sistemas - Bens duráveis \\
\hline 45 & Guerra & Implementos Rodoviários & Montadora de sistemas - Bens duráveis \\
\hline 46 & Itautec & Computadores & Montadora de sistemas - Bens duráveis \\
\hline 47 & Bematech & TI - hardware & Montadora de sistemas - Bens duráveis \\
\hline 48 & Alpargatas & Calçadista & Bens de consumo \\
\hline 49 & Brasil Foods & Alimentício & Bens de consumo \\
\hline 50 & Coteminas & Têxtil & Bens de consumo \\
\hline 51 & Azaléia & Produtora de calçados & Bens de consumo \\
\hline 52 & Hstern & Jóias & Bens de consumo \\
\hline 53 & Eurofarma & Farmacêutica & Bens de consumo \\
\hline 54 & Minerva & Alimentício & Bens de consumo \\
\hline 55 & Ambev & Bebidas & Bens de consumo \\
\hline 56 & Natura & Cosméticos e Higiene Pessoal & Bens de consumo \\
\hline 57 & Forjas Taurus & Armamentos & Bens de consumo \\
\hline 58 & Romi & Bens de capital & Montadora de sistemas - CoPS \\
\hline 59 & Agrale & Veículos/ peças & Montadora de sistemas - CoPS \\
\hline 60 & Marcopolo & Indústria Automotiva & Montadora de sistemas - CoPS \\
\hline 61 & SMAR & Automação Industrial & Montadora de sistemas - CoPS \\
\hline 62 & Embraer & Aeronaves & Montadora de sistemas - CoPS \\
\hline 63 & Busscar & Indústria Automotiva & Montadora de sistemas - CoPS \\
\hline 64 & Neogrid & TI - software & Serviços técnicos TI \\
\hline 65 & Móvile & Serviços de TI & Serviços técnicos TI \\
\hline 66 & Fujitec & TI - software & Serviços técnicos TI \\
\hline 67 & Xseed & TI - software & Serviços técnicos TI \\
\hline 68 & Stefanini & TI - software & Serviços técnicos TI \\
\hline 69 & CI\&T & TI - software & Serviços técnicos TI \\
\hline 70 & Totvs & TI - software & Serviços técnicos TI \\
\hline 71 & Politec & TI - software & Serviços técnicos TI \\
\hline 72 & Spring Wireless & TI - software & Serviços técnicos TI \\
\hline 73 & Atech & TI - software & Serviços técnicos TI \\
\hline 74 & Nexxera & TI - software & Serviços técnicos TI \\
\hline
\end{tabular}




\begin{tabular}{|c|c|c|c|}
\hline 75 & $\begin{array}{l}\text { Camargo Corrêa } \\
\text { Const. }\end{array}$ & Engenharia e Construção & Serviços técnicos engenharia \\
\hline 76 & Odebrecht & Engenharia e Construção & Serviços técnicos engenharia \\
\hline 77 & Andrade Gutierrez & Engenharia e Construção & Serviços técnicos engenharia \\
\hline 78 & Alusa & Engenharia e Construção & Serviços técnicos engenharia \\
\hline 79 & Totalcom & Serviços Téc. Especializados & Serviços técnicos especializados \\
\hline 80 & ALL América & Logística e Transporte & Serviços técnicos especializados \\
\hline 81 & SOAP & Serviços Téc. Especializados & Serviços técnicos especializados \\
\hline 82 & IBOPE & Serviços Téc. Especializados & Serviços técnicos especializados \\
\hline 83 & Griaule Biometrics & Tecnologia da Informação & Serviços técnicos especializados \\
\hline 84 & PromonLogicalis & Tecnologia da Informação & Serviços técnicos especializados \\
\hline 85 & Fogo-de-chao & Alimentício & Operadora de serviços - Varejo \\
\hline 86 & Arezzo & Varejista de calçados & Operadora de serviços - Varejo \\
\hline 87 & Bob's & Alimentício & Operadora de serviços - Varejo \\
\hline 88 & Gran Sapore & Serviços de restaurante & Operadora de serviços - Varejo \\
\hline 89 & Track \& Field & Roupas e Acessórios & Operadora de serviços - Varejo \\
\hline 90 & Osklen & Acessórios & Operadora de serviços - Varejo \\
\hline 91 & Artefacto & Roupas e Acessórios & Operadora de serviços - Varejo \\
\hline 92 & Giraffas & Alimentício & Operadora de serviços - Varejo \\
\hline 93 & Café do Centro & Alimentício & Operadora de serviços - Varejo \\
\hline 94 & Porto Seguro & Seguros & Operadora de serviços - Varejo \\
\hline 95 & Ivia & Operadora de turismo & Operadora de serviços - Varejo \\
\hline
\end{tabular}

FONTE: GINEBRA, 2010; FUNDAÇÃO DOM CABRAL, SOBEET e autor 
Quadro 2 - Multinacionais Brasileiras com unidades fabris e/ou de P\&D no exterior (indústria)

\begin{tabular}{|c|c|c|}
\hline Empresa & Indústria & Segmento Produtivo \\
\hline Agrale & Veículos/ peças & Montadora de sistemas - CoPS \\
\hline Alpargatas & Calçadista & Bens de consumo \\
\hline Artecola & Química & Insumos Básicos \\
\hline Bematech & TI - hardware & Montadora de sistemas - bens duráveis \\
\hline Bio Embryo & Químico & Insumos Básicos \\
\hline Braskem & Químico & Insumos Básicos \\
\hline Brasil Foods & Alimentício & Bens de consumo \\
\hline Camil & Alimentício & Bens de consumo \\
\hline Camargo Corrêa & Cimento & Insumos Básicos \\
\hline CCX (EBX) & Mineração & Insumos Básicos \\
\hline CGX (EBX) & Energia e Gás & Insumos Básicos \\
\hline Cia providência & Não-tecidos & Insumos Básicos \\
\hline Cinex & Moveleiro & Insumos para construção civil \\
\hline Citrosuco & Sucos a granel & Insumos Básicos \\
\hline CRW Plásticos & Máquinas e Moldes & Partes, componentes e subsistemas \\
\hline CSN & Siderurgia & Insumos Básicos \\
\hline Dass & Calçados e couros & Bens de consumo \\
\hline Duas Rodas & Alimentício & Insumos básicos \\
\hline Embraco & Máquinas e Materiais Elétricos & Partes, componentes e Subsistemas \\
\hline EMS & Farmacêutica & Bens de consumo \\
\hline Embraer & Aeronaves & Montadora de sistemas - CoPS \\
\hline Eurofarma & Farmacêutica & Bens de consumo \\
\hline Estre & Reciclagem de Resíduos & Insumos Básicos \\
\hline Fanem & Equip. Médicos e Laboratoriais & Partes, componentes e Subsistemas \\
\hline Forjas Taurus & Armamentos & Bens de consumo \\
\hline Fras-le (Randon) & Implementos Rodoviários & Montadora de sistemas - bens duráveis \\
\hline Gauss & Autopeças & Partes, componentes e Subsistemas \\
\hline Gautom & Automação Industrial & Montadora de sistemas - CoPS \\
\hline Gerdau & Siderurgia & Insumos Básicos \\
\hline Haco Etiquetas & Textil & Insumos Básicos \\
\hline Iochpe-Maxion & Autopeças & Partes, componentes e Subsistemas \\
\hline Jacto & Máquinas e Materiais Elétricos & Montadora de sistemas - bens duraveis \\
\hline JBS-Friboi & Alimentício & Baseado em recursos naturais \\
\hline Lupatech & Máquinas e Materiais Elétricos & Partes, componentes e Subsistemas \\
\hline Magnesita & Produção de Refratários & Insumos Básicos \\
\hline Marcopolo & Indústria Automotiva & Montadora de sistemas - CoPS \\
\hline Marfrig & Alimentício & Baseado em recursos naturais \\
\hline
\end{tabular}




\begin{tabular}{|c|c|c|}
\hline Master (Randon) & Autopeças & Partes, componentes e Subsistemas \\
\hline Metagal & Autopeças & Partes, componentes e Subsistemas \\
\hline Metalfrio & Máquinas e Materiais Elétricos & Montadora de sistemas - bens duráveis \\
\hline Minerva & Alimentício & Bens de consumo \\
\hline Moura & Autopeças & Partes, componentes e Subsistemas \\
\hline Natura & Cosméticos e Higiene Pessoal & Bens de consumo \\
\hline OGX (EBX) & Petróleo e Gás & Baseado em recursos naturais \\
\hline Oxiteno & Químico & Insumos Básicos \\
\hline Paquetá & Calçados e couros & Insumos Básicos \\
\hline Petrobras & Petróleo e Gás & Baseado em recursos naturais \\
\hline Penalty & Calçados e couros & Bens de consumo \\
\hline Riffel & Peças de motos & Partes, componentes e Subsistemas \\
\hline Romi & Bens de capital & Montadora de sistemas - CoPS \\
\hline Sabó & Autopeças & Partes, componentes e Subsistemas \\
\hline Santana Têxtil & Têxtil & Insumos Básicos \\
\hline Smar & Automação Industrial & Montadora de sistemas - CoPS \\
\hline Sifco (Grupo Brasil) & Autopeças & Partes, componentes e Subsistemas \\
\hline Tavex (Santista) & Têxtil & Insumos Básicos \\
\hline Tigre & Material de Construção & Insumos para construção civil \\
\hline Tupy & Autopeças & Partes, componentes e subsistemas \\
\hline Vale & Mineração & Baseado em recursos naturais \\
\hline Vicunha & Têxtil & Insumos Básicos \\
\hline Votorantim Cimentos & Cimento & Insumos Básicos \\
\hline $\begin{array}{l}\text { Votorantim } \\
\text { Siderurgia }\end{array}$ & Siderurgia & Insumos Básicos \\
\hline Vulcabrás & Calçados e couros & Bens de consumo \\
\hline Weg & Máquinas e Materiais Elétricos & Partes, componentes e Subsistemas \\
\hline
\end{tabular}


APÊNDICE III

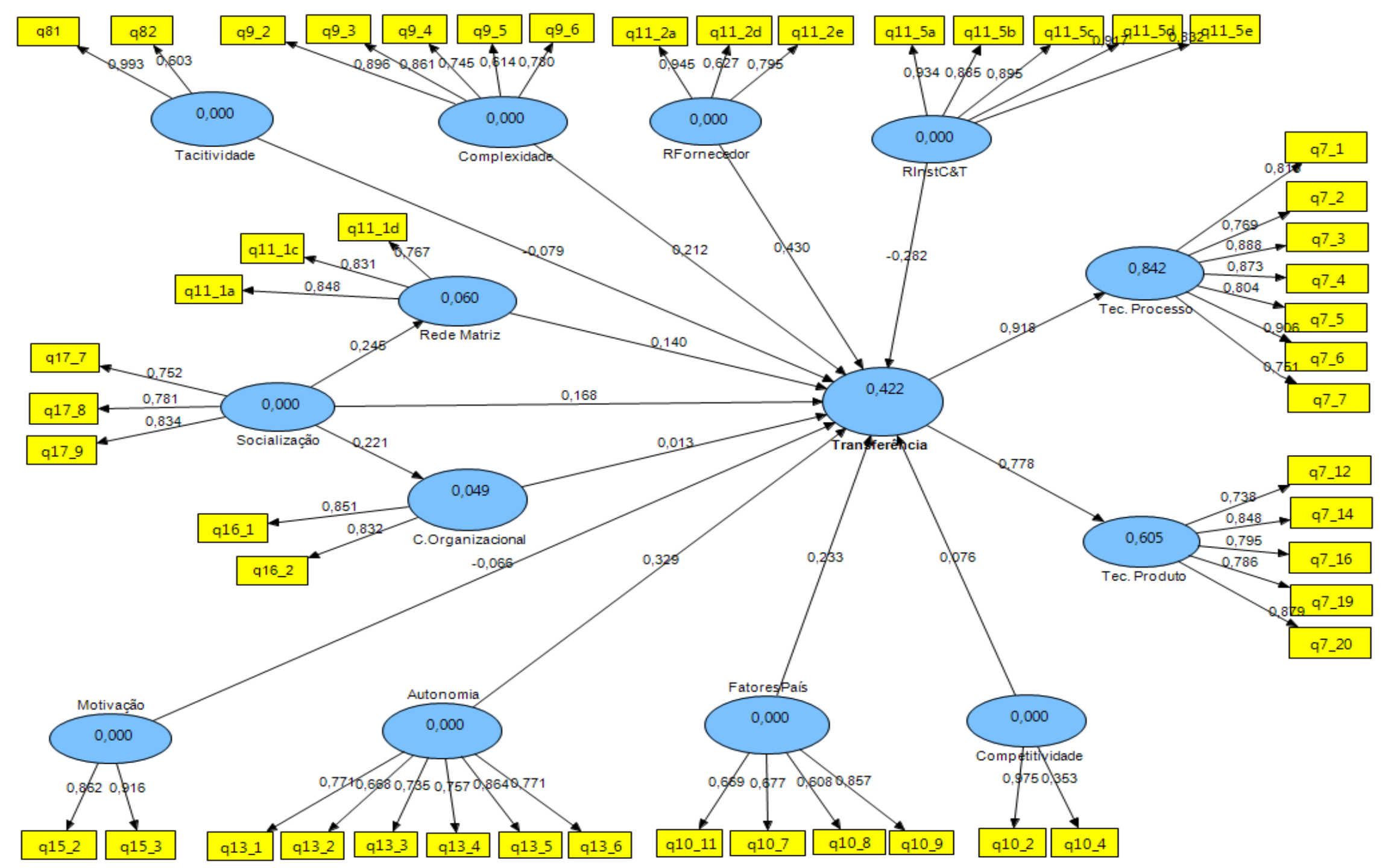

Ilustração 1: Modelo de mensuração completo 


\section{APÊNDICE IV}

Tabela 1: Teste de significância para todos os indicadores de cada constructo

\begin{tabular}{|c|c|c|c|c|c|c|c|c|}
\hline Constructos & Indicador & $\begin{array}{l}\text { Carga } \\
\text { Fatorial } \\
\text { Original }\end{array}$ & $\begin{array}{c}\text { Carga } \\
\text { Fatorial } \\
\text { (Bootstrap) }\end{array}$ & $\begin{array}{c}\text { Standard } \\
\text { Deviation } \\
\text { (STDEV) }\end{array}$ & $\begin{array}{l}\text { Standard } \\
\text { Error } \\
\text { (STERR) }\end{array}$ & $\begin{array}{c}\text { t } \\
\text { Student }\end{array}$ & teste $-p$ & Sig. \\
\hline \multirow{4}{*}{$\begin{array}{c}\text { Ambiente } \\
\text { Institucional }\end{array}$} & AINST11 & 0,669 & 0,567 & 0,225 & 0,225 & 2,979 & 0,003 & $* *$ \\
\hline & AINST7 & 0,677 & 0,616 & 0,228 & 0,228 & 2,976 & 0,003 & $* *$ \\
\hline & AINST8 & 0,608 & 0,562 & 0,223 & 0,223 & 2,922 & 0,004 & $* *$ \\
\hline & AINST9 & 0,857 & 0,706 & 0,223 & 0,223 & 3,844 & 0,000 & $* * * *$ \\
\hline \multirow{2}{*}{$\begin{array}{l}\text { Ambiente } \\
\text { competitivo }\end{array}$} & ACOMP2 & 0,975 & 0,783 & 0,276 & 0,276 & 3,538 & 0,000 & $* * * *$ \\
\hline & ACOMP4 & 0,353 & 0,616 & 0,281 & 0,281 & 2,853 & 0,005 & $*$ \\
\hline \multirow{3}{*}{$\begin{array}{l}\text { Rede interna } \\
\text { (Matriz) }\end{array}$} & RMAT1 & 0,848 & 0,821 & 0,111 & 0,111 & 7,673 & 0,000 & $* * * * *$ \\
\hline & RMAT3 & 0,831 & 0,819 & 0,104 & 0,104 & 8,006 & 0,000 & $* * * * *$ \\
\hline & RMAT4 & 0,767 & 0,724 & 0,153 & 0,153 & 5,002 & 0,000 & $* * * * *$ \\
\hline \multirow{3}{*}{$\begin{array}{c}\text { Rede externa } \\
\text { com } \\
\text { Fornecedos }\end{array}$} & RFOR1 & 0,945 & 0,933 & 0,050 & 0,050 & 18,806 & 0,000 & $* * * * *$ \\
\hline & RFOR4 & 0,627 & 0,587 & 0,173 & 0,173 & 3,623 & 0,000 & $* * * *$ \\
\hline & RFOR5 & 0,795 & 0,743 & 0,145 & 0,145 & 5,468 & 0,000 & $* * * * *$ \\
\hline \multirow{5}{*}{$\begin{array}{l}\text { Rede externa } \\
\text { com } \\
\text { Instituições de } \\
\text { C\&T }\end{array}$} & RIC\&T1 & 0,934 & 0,899 & 0,109 & 0,109 & 8,600 & 0,000 & $* * * * *$ \\
\hline & RIC\&T2 & 0,885 & 0,862 & 0,115 & 0,115 & 7,695 & 0,000 & $* * * * *$ \\
\hline & RIC\&T3 & 0,895 & 0,870 & 0,110 & 0,110 & 8,103 & 0,000 & $* * * * *$ \\
\hline & RIC\&T4 & 0,917 & 0,871 & 0,141 & 0,141 & 6,501 & 0,000 & $* * * * *$ \\
\hline & RIC\&T5 & 0,832 & 0,799 & 0,148 & 0,148 & 5,610 & 0,000 & $* * * * *$ \\
\hline \multirow{6}{*}{ Autonomia } & AUTO1 & 0,771 & 0,696 & 0,203 & 0,203 & 3,801 & 0,000 & $* * * *$ \\
\hline & AUTO2 & 0,668 & 0,622 & 0,194 & 0,194 & 3,451 & 0,001 & $* * *$ \\
\hline & AUTO3 & 0,735 & 0,644 & 0,198 & 0,198 & 3,708 & 0,000 & $* * * *$ \\
\hline & AUTO4 & 0,757 & 0,677 & 0,196 & 0,196 & 3,856 & 0,000 & $* * * *$ \\
\hline & AUTO5 & 0,864 & 0,785 & 0,166 & 0,166 & 5,190 & 0,000 & $* * * * *$ \\
\hline & AUTO6 & 0,771 & 0,680 & 0,193 & 0,193 & 3,997 & 0,000 & $* * * *$ \\
\hline \multirow{2}{*}{ Motivação } & Мот2 & 0,862 & 0,806 & 0,191 & 0,191 & 4,515 & 0,000 & $* * * * *$ \\
\hline & MOT3 & 0,916 & 0,837 & 0,194 & 0,194 & 4,724 & 0,000 & $* * * * *$ \\
\hline \multirow{2}{*}{$\begin{array}{c}\text { Semelhança } \\
\text { Organizacional }\end{array}$} & SORG1 & 0,851 & 0,815 & 0,151 & 0,151 & 5,651 & 0,000 & $* * * * *$ \\
\hline & SORG2 & 0,832 & 0,801 & 0,162 & 0,162 & 5,122 & 0,000 & $* * * * *$ \\
\hline \multirow{3}{*}{$\begin{array}{l}\text { Mecanismos } \\
\text { de } \\
\text { Socialização }\end{array}$} & SOC7 & 0,752 & 0,716 & 0,155 & 0,155 & 4,857 & 0,000 & $* * * * *$ \\
\hline & SOC8 & 0,781 & 0,771 & 0,107 & 0,107 & 7,303 & 0,000 & $* * * * *$ \\
\hline & SOC9 & 0,834 & 0,813 & 0,116 & 0,116 & 7,173 & 0,000 & $* * * * *$ \\
\hline \multirow{6}{*}{$\begin{array}{c}\text { Tecnologia de } \\
\text { Processo }\end{array}$} & TPROC1 & 0,816 & 0,811 & 0,057 & 0,057 & 14,438 & 0,000 & $* * * * *$ \\
\hline & TPROC2 & 0,769 & 0,760 & 0,094 & 0,094 & 8,200 & 0,000 & $* * * * *$ \\
\hline & TPROC3 & 0,888 & 0,888 & 0,024 & 0,024 & 37,749 & 0,000 & $* * * * *$ \\
\hline & TPROC4 & 0,873 & 0,871 & 0,028 & 0,028 & 31,758 & 0,000 & $* * * * *$ \\
\hline & TPROC5 & 0,804 & 0,801 & 0,050 & 0,050 & 15,934 & 0,000 & $* * * * *$ \\
\hline & TPROC6 & 0,906 & 0,902 & 0,029 & 0,029 & 31,354 & 0,000 & $* * * * *$ \\
\hline
\end{tabular}




\begin{tabular}{|c|c|c|c|c|c|c|c|c|}
\hline & TPROC7 & 0,751 & 0,738 & 0,072 & 0,072 & 10,371 & 0,000 & $* * * * *$ \\
\hline \multirow{5}{*}{$\begin{array}{c}\text { Tecnologia de } \\
\text { Produto }\end{array}$} & TPROD12 & 0,738 & 0,741 & 0,062 & 0,062 & 11,938 & 0,000 & $* * * * *$ \\
\hline & TPROD14 & 0,848 & 0,850 & 0,041 & 0,041 & 20,628 & 0,000 & $* * * * *$ \\
\hline & TPROD16 & 0,795 & 0,790 & 0,059 & 0,059 & 13,375 & 0,000 & $* * * * *$ \\
\hline & TPROD19 & 0,786 & 0,775 & 0,087 & 0,087 & 9,074 & 0,000 & $* * * * *$ \\
\hline & TPROD20 & 0,879 & 0,876 & 0,035 & 0,035 & 25,172 & 0,000 & $* * * * *$ \\
\hline \multirow{12}{*}{$\begin{array}{l}\text { Transferência } \\
\text { Reversa de } \\
\text { Conhecimento } \\
\text { Tecnológico }\end{array}$} & TRCT1 & 0,748 & 0,742 & 0,062 & 0,062 & 12,014 & 0,000 & $* * * * *$ \\
\hline & TRCT2 & 0,701 & 0,691 & 0,087 & 0,087 & 8,075 & 0,000 & $* * * * *$ \\
\hline & TRCT3 & 0,821 & 0,821 & 0,036 & 0,036 & 22,581 & 0,000 & $* * * * *$ \\
\hline & TRCT4 & 0,828 & 0,825 & 0,039 & 0,039 & 21,184 & 0,000 & $* * * * *$ \\
\hline & TRCT5 & 0,708 & 0,709 & 0,081 & 0,081 & 8,693 & 0,000 & $* * * * *$ \\
\hline & TRCT6 & 0,813 & 0,810 & 0,057 & 0,057 & 14,237 & 0,000 & $* * * * *$ \\
\hline & TRCT7 & 0,711 & 0,702 & 0,086 & 0,086 & 8,276 & 0,000 & $* * * * *$ \\
\hline & TRCT12 & 0,672 & 0,669 & 0,074 & 0,074 & 9,095 & 0,000 & $* * * * *$ \\
\hline & TRCT14 & 0,695 & 0,693 & 0,074 & 0,074 & 9,387 & 0,000 & $* * * * *$ \\
\hline & TRCT16 & 0,592 & 0,591 & 0,108 & 0,108 & 5,472 & 0,000 & $* * * * *$ \\
\hline & TRCT19 & 0,531 & 0,519 & 0,139 & 0,139 & 3,817 & 0,000 & $* * * * *$ \\
\hline & TRCT20 & 0,632 & 0,629 & 0,110 & 0,110 & 5,755 & 0,000 & $* * * * *$ \\
\hline \multirow{2}{*}{ Tacitividade } & TACIT1 & 0,993 & 0,837 & 0,221 & 0,221 & 4,499 & 0,000 & $* * * * *$ \\
\hline & TACIT2 & 0,603 & 0,792 & 0,234 & 0,234 & 2,879 & 0,004 & $*$ \\
\hline \multirow{5}{*}{ Complexidade } & COMPLX2 & 0,896 & 0,787 & 0,210 & 0,210 & 4,273 & 0,000 & $* * * * *$ \\
\hline & COMPLX3 & 0,861 & 0,791 & 0,173 & 0,173 & 4,989 & 0,000 & $* * * * *$ \\
\hline & COMPLX4 & 0,745 & 0,648 & 0,214 & 0,214 & 3,483 & 0,001 & $* * *$ \\
\hline & COMPLX5 & 0,614 & 0,560 & 0,211 & 0,211 & 2,912 & 0,004 & $*$ \\
\hline & COMPLX6 & 0,780 & 0,676 & 0,222 & 0,222 & 3,510 & 0,001 & $* * *$ \\
\hline
\end{tabular}

Legenda: *significante a 0,$5 ; * *$ significante a 0,$2 ; * * *$ significante a 0,$1 ; * * * *$ significante a 0,05 ; $* * * * *$ significante a 0,01 .

Nota: Carga Fatorial Original: peso padronizado obtido para amostra completa; Carga Fatorial (bootstrapping): peso médio obtido na população; STDEV: desvio padrão da estimativa; STERR: erro estimado da estimativa; t-student: valor t e a razão entre o peso não padronizado pelo seu erro padrão. 